\title{
Kansanvalta, ikä, vero-oikeus
}


Esko Linnakangas

\section{Kansanvalta, ikä, \\ vero-oikeus}


Copyright (C) 2020 Esko Linnakangas

ISBN 978-952-69372-0-5

Kansi ja sivunvalmistus: NotePad

Kirjapaino: Grano Oy

Helsinki 2020 


\section{Vanhoista, demokratiasta ja veroista}

"Vanha on aina parempi kuin uusi", sanotaan usein, kun puhutaan veroista. Olen työskennellyt koko aikuisikäni verojen parissa, 1970-luvun alusta hallintotuomioistuimissa ja vuodesta 1984 lähtien yliopistoissa. Kokemukseni mukaan väite vanhan veron erinomaisuudesta ei yleensä pidä paikkaansa.

Tämä kirja ei ole muistokirjoitus, muistokirja eikä muistelmateos, vaikka se jotenkin muistuttaa niitä. Verohistorian osalta olen eniten hyödyntänyt professori Leila Juannon kanssa laatimaani teosta Verojen historia (2016) ja siinä mainittua lähdeaineistoa. Käsillä olevaan kirjaan on lisäksi kerätty ja muokattu sellaista uudempaa aineistoa, jonka haluan säilyvän muuallakin kuin tietokoneeni muistissa.

Kirjan alkujakso (luku 1) "Yhdenvertaisuus tuloverotuksessa perustuslakikysymyksenä" pohjautuu pitkäaikaisen ystäväni ja kollegani Matti Myrskyn muistoseminaarissa Joensuussa 24.3.2017 pitämääni esitelmään, joka koski mm. eläkeläisten verotusta. Lasten ja nuorten kohtelua tarkastellaan seuraavassa luvussa (luku 2), jossa verokysymysten lisäksi käsitellään nuorille tarkoitettuja ns. kevyt- eli hidasautoja koskevaa EU-oikeudellisesti kummallista lainsäädäntöhanketta.

"Perintöverokarhun peijaiset" (luku 3) pohjautuu pitkälti vanhoihin perintöverokriittisiin kirjoituksiini ja uudempaan aineistoon USA:sta. Kirjassa käsitellään myös varallisuusveroja (luku 4) ja varainsiirtoveroa (luku 5), ja nuokin luvut perustuvat paljolti aikaisempiin kirjoituksiini. Selvitettävänä on myös vanha veronkiertämisen problematiikka (luku 6) - mutta osittain uudesta näkökulmasta. 
Kirjan laajimman jakson (luku 7) teema on minulle uusi. Siinä selvitetään, onko kansalaisaloitteinen verotus viihdettä vai demokratiaa. Idean tuohon kirjoitukseen sain, kun eduskunnan valtiovarainvaliokunta enemmistöpäätöksellä kieltäytyi kirjoittamasta mietintöä kansalaisaloitteesta, joka koski perintö- ja lahjaveron kumoamista. Kiinnostustani lisäsi lentoverosta tehty kansalaisaloite, joka voimakkaan loppukiihdytyksen jälkeen saavutti 50000 kannattajan rajan ja eteni eduskunnan käsittelyyn.

Seuraavassa luvussa (luku 8) analysoidaan rahalla vaientamisen verokohtelua ja tuloverojulkisuuden kehitystä ja uudistustarvetta. Ajankohtaisia virikkeitä teeman käsittelyyn olen saanut sekä Atlantin takaa että kotimaasta.

Tämän jälkeen (luku 9) tarkastellaan kehitystä sotaveroista soteveroihin. Teema on nyt erityisen ajankohtainen sosiaali- ja terveydenhuollon hallinnon ja rahoituksen uudistamishankkeen vuoksi.

Seuraavaksi (luku 10) esitellään kahta suunniteltua uutta veroa: robottiveroa ja digiveroa. Kirjan lopussa olevan Suomen verotohtoreita koskevan jakson (luku 11) perustana on vuonna 2010 tekemäni laajempi analyysi, jota on täydennetty myöhemmällä kehityksellä.

Ikääntyminen on kirjan keskeisiä teemoja, ja siksi teos oli tarkoitus julkistaa virallisesti vanhojenpäivänä. Koska vanhojenpäivää kuitenkin näkyy vietettävän helmikuussa eri kouluissa eri aikaan, kirja julkaistaan jo tammikuussa 2020.

Kielen- ja mielenhuollosta kiitän jälleen Taija Haapaniemeä, joka on myös ottanut kansikuvan ja jolta olen saanut virikkeitä mm. lapsilukuun ja verokarhun rooliin naamiaisissa. - Kansikuvassa on erilaisia ajoneuvoja sastamalalaisen koulun parkkipaikalla kuuman kevyt- eli hidasautokeskustelun aikoihin syksyllä 2019.

Karkussa (Sastamala) talvipäivän seisahtuessa 22.12.2019

\section{Esko Linnakangas}

finanssioikeuden emeritusprofessori esko.linnakangas@professori.fi 


\section{Sisällys}

Vanhoista, demokratiasta ja veroista ......................... 5

Lyhenteitä ..................................................................... 19

\section{YHDENVERTAISUUS TULOVEROTUKSESSA} PERUSTUSLAKIKYSYYMYKSENÄ ................................. 21

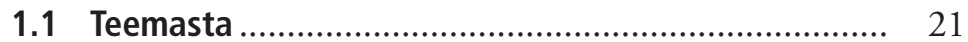

1.2 Omaisuustulovähennyksestä ennen 1980-luvun lopun kokonaisverouudistusta ....................................... 22

1.3 Osinkotulojen täysi ja osittainen verovapaus nykyisin .............................................................. 23

1.4 Yrittäjävähennys ................................................... 24

1.5 Kokonaan tai osittain verovapaat luovutusvoitot...... 24

1.6 Metsälahjavähennys................................................ 25

1.7 Kokonaan tai osittain verovapaita ansiotuloja .......... 27

1.8 Ansiotulovähennys ja työtulovähennys..................... 28

1.9 Merimiesten erityiskohtelu verotuksessa .................. 29

1.10 Lähdeverotus eräistä tuloista ................................. 30

1.11 Pienten eläkkeiden eläketulovähennykset................. 31

1.12 Eläketulon lisävero.................................................... 31

1.13 Johtopäätökset ....................................................... 35 


\section{LAPSET JA NUORET VERO- JA} LIIKENNEOIKEUDESSA …..................................... 37

2.1 Henkiverosta yleisradioveroon ................................. 37

2.2 Tuloverotus, perintöverotus ja varainsiirtoverotus .... 38

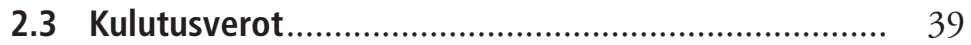

2.3.1 Arvonlisäverotus .............................................. 39

2.3.2 Koiravero ......................................................... 40

2.3.3 Matkustaja- ja lentoverot ................................... 40

2.3.4 Sänkyverot .................................................. 41

2.4 Alaikäiset autonkuljettajat - EU-oikeus..................... 41

2.4 .1 Ns. kevytautot .............................................. 41

$2.4 .2 \quad 17$-vuotiaiden poikkeusluvat.............................. $\quad 50$

3 PERINTÖVEROKARHUN PEIJAISET? ......................... 53

3.1 Varhaisimmat perintöverotukset................................ 53

3.2 Perintöverotus keskiajalta Suomen itsenäistymiseen ................................................... 54

3.2.1 Keskiaika ja kirkon vaatimukset ......................... 54

3.2.2 1600-luvulta Ruotsin vallan loppuun .................. 54

3.2.3 Suomen autonomian aika ................................. 55

3.3 Kehitys itsenäisessä Suomessa................................ 56

3.3.1 1920- ja 1930-luvut .......................................... 56

3.3.2 1940-luvun alusta 1970-luvun lopulle................ 57

3.3.3 1970-luvun lopulta 2000-luvulle ........................ 58

3.4 Kansainvälistä vertailua ............................................ 59

3.4.1 Tilanne 1800- ja 1900-lukujen vaihteessa........... 59

3.4.2 Tilanne 2000-luvun alun Euroopassa .................. 60

3.4.2.1 Ruotsi ja muut Pohjoismaat ................. 60

3.4.2.2 Viro ja Venäjä....................................... 60

3.4.2.3 Muu Eurooppa.................................. 61

3.5 Perintöveron puoltajat ja vastustajat ......................... 62

\subsection{Perintöveron puolesta ja sitä vastaan esitetyt}

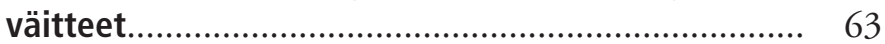

3.6.1 Tutkimuskirjallisuudesta..................................... 63

3.6.2 Perintöveron puolesta......................................... 63 
3.6.2.1 Pitkä historia - hieno perine.................. 63

3.6.2.2 Valtion yliomistusoikeus ...................... 64

3.6.2.3 Valtion varaintarpeen tyydyttäminen ..... 64

3.6.2.4 Maksukyvyn verottaminen .................... 65

3.6.2.5 Oikeudenmukaisuus .......................... 65

3.6.2.6 Varallisuuden uusjako .......................... 66

3.6.2.7 Tuloveron täydentäminen ..................... 66

3.6.2.8 Varallisuusveron täydentäminen ........... 67

3.6.2.9 Varainsiirtoveron täydentäminen ........... 68

3.6.2.10 Psykologinen tekijä.............................. 68

3.6.2.11 Perunkirjoituksen varmistaminen ......... 69

3.6.3 Perintöveroa vastaan.......................................... 69

3.6.3.1 Kaksinkertainen verotus tuloveron kanssa ................................................ 69

3.6.3.2 Pääoman muodostumisen estäminen kansantaloudessa ................................. 69

3.6.3.3 Omaisuus ei todellisuudessa lisäänny ..... $\quad 70$

3.6.3.4 Yritysten sukupolvenvaihdosten vaikeutuminen ..................................... 71

3.6.3.5 Laajat välttämismahdollisuudet ............. 71

3.6.3.6 Kansainvälinen kilpailu ja veropako....... 72

3.6.3.7 Yhdenvertaisuuspuutteet....................... 73

3.6.3.8 Vähäinen tuotto .................................. 73

3.6.3.9 Verotuskustannukset............................. 73

3.6.4 Pisteet, korvauspalikat ja vaihtoehtoiset mallit ..... 74

3.7 USA:n perintöverouudistus ...................................... 75

3.7.1 USA:n perintöverotuksen kehitys....................... 75

3.7.2 Lahjaverotus USA:ssa ....................................... 77

3.7.3 Perintö- ja lahjasaannot USA:n tuloverotuksessa .. 78

3.7.4 Esikuvaksi Suomeen?......................................... 78

4 VARALLISUUSVERON REINKARNAATIO?................ 81

4.1 Varallisuusveron synty, kehitys, hiipuminen ja kuolema ........................................................... 81

4.2 Varallisuuden verottamistavoista ............................. 82

4.3 Varallisuusveron paluusta ....................................... 84 


\section{VARAINSIIRTOVERON MENNEISYYS JA}

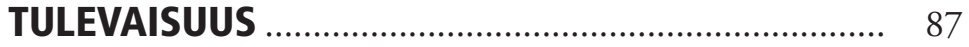

5.1 Varainsiirtoveron tarkoitus ja fiskaalinen merkitys ... 87

5.2 Varainsiirtoveron kielteiset vaikutukset asumiseen ja työllisyyteen ................................................... 88

5.3 Leimaverotuksen keksiminen .................................. 88

5.4 Leimaverotus Ruotsin vallan aikana ......................... 89

5.5 Leimaverotus Suomen autonomian aikana ............... 90

5.6 Kiinteistöjen leimavero/varainsiirtovero itsenäisessä Suomessa ......................................................... 90

5.7 Osakeantileimavero ................................................. 91

5.8 Obligaatioiden leimavero........................................... 91

5.9 Arvopaperien siirtovero .......................................... 92

5.10 Finanssitransaktioverot............................................ 94

5.11 Kiinteistöveron korottaminen tai asuntotuloveron palauttaminen varainsiirtoveron tilalle ................... 95

5.12 Muita vaihtoehtoja ................................................... 96

6 VEROKARHUN ROOLI NAAMIAISISSA ..................... 99

6.1 Verosuunnittelun, veron kiertämisen ja verovilpin käsitteistä ....................................................... 99

6.2 Yleiset veronkiertämissäännökset ........................... 99

6.3 Veronkiertämissäännöksen tyyppitilanteet ja soveltaminen verovelvollisen eduksi ....................... 101

6.4 Verosuunnitteluksi naamioidut tasa-arvon

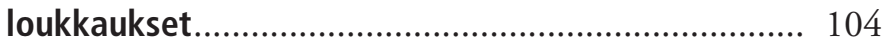

\section{KANSALAISALOITTEINEN VEROTUS - VIIHDETTÄ} VAI DEMOKRATIAA? ............................................ 107

7.1 Veroista säätämisestä ja kansalaisvaikuttamisesta ... 107

7.1.1 Säätyvaltiopäivien aika ...................................... 107

7.1.2 Eduskuntauudistus 1906 ja Suomen itsenäistyminen 1917 
7.1.3 Vaatimuksia kansalaisaloitejärjestelmäksi Suomessa 1900-luvulla ................................... 112

7.2 Ulkomaisia kansalaisaloitejärjestelmiä...................... 114

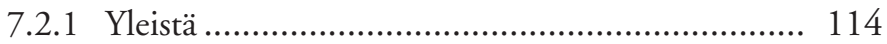

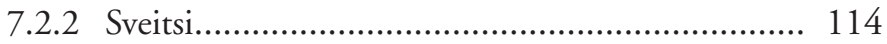

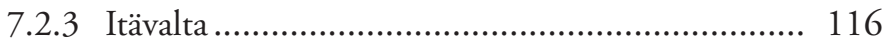

7.2.4 Alankomaat .................................................. 117

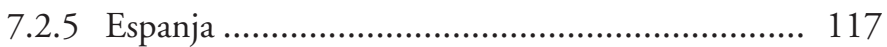

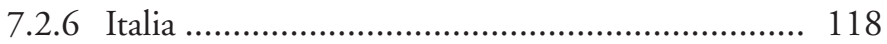

7.2.7 Portugali ............................................................ 119

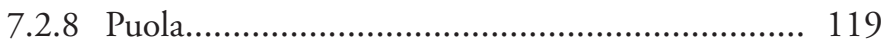

7.2.9 Unkari, Slovakia ja Liettua................................ 120

7.3 Kansalaisaloite Suomen perustuslakiin ja kansalaisaloitelain säätäminen 2010-luvulla ........... 121

7.3.1 Perustuslain muutos ........................................ 121

7.3.2 Kansalaisaloitelaki.......................................... 122

7.4 Verotusta koskevat kansalaisaloitteet ..................... 126

7.4.1 Määrä ja verolajeittainen jakautuminen ............... 126

7.4.2 Vireillepanijoista, kannattajista ja kommenteista.. 128

7.4.3 Verotusaiheisten aloitteiden teemat ja sisällöt....... 129

7.4.3.1 Verotus yleensä..................................... 129

7.4.3.1.1 Verot vapaaehtoisiksi ............ 129

7.4.3.1.2 Valintamahdollisuus veron käyttötarkoitukseen ............. 130

7.4.3.1.3 Äänioikeus veronmaksun mukaan ............................... 131

7.4.3.1.4 Verolotto ja nollaverokorttiarpajaiset ....... 133

7.4.3.1.5 Veronpalautukselle ulosmittauskielto.................. 136

7.4.3.1.6 Kansanäänestys veronkorotuksista ja säästöistä....... 137

7.4.3.2 Tuloverotus ...................................... 138

7.4.3.2.1 Perheverotus ........................ 138

a. Yhteisverotus perheenjäsenille ............................ 138 
Sisällys

b. Lapsettomille naisille lisävero

c. Sinkuille tasavertainen asema verovähennyksissä .. 140

d. Lasten päivähoitomaksut vähennyskelpoisiksi.......... 143

7.4.3.2.2 Harrastusmenot vähennyskelpoisiksi

7.4.3.2.3 Kotitalousvähennys suuremmaksi ja laajaalaisemmaksi

7.4.3.2.4 Omaishoidon tuki kokonaan tai osaksi verovapaaksi

7.4.3.2.5 Eläkkeiden verotusta kevennettävä

7.4.3.2.6 Lääkekaton vuosiomavastuuosuus verovähennyskelpoiseksi osittain tai kokonaan

7.4.3.2.7 Polkupyörävähennys kilometriperusteiseksi

7.4.3.2.8 Ilmastonmuutoksen torjuntaan lahjoitusvähennys

7.4.3.2.9 Talkoiden ja vaihtotyön esteet poistettava

7.4.3.2.10 Osinko- ja vuokratuloille verovapaa määrä

7.4.3.2.11 Työmarkkinajärjestöjen tuloverotusta tiukennettava .. 163

7.4.3.2.12 Työmarkkinajärjestöjen jäsenmaksujen verovähennys poistettava 164

7.4.3.2.13 Viron malli yhteisöverotukseen 166 
Sisällys

7.4.3.2.14 Työurien pidentäminen sekä yrittäjyyden ja työllisyyden edistäminen yhteisöverotusta muuttamalla ..................... 167

7.4.3.2.15 Osinkotulojen verotus yhdenmukaistettava............. 171

7.4.3.2.16 Vakuutuskuorien veroedut poistettava .

7.4.3.2.17 Korkojen vähentämistä rajattava yritysverotuksessa ja Suomen verotusoikeus turvattava

7.4.3.2.18 Halpatyövoimalle maahantuontivero.

7.4.3.2.19 Ylimääräinen verovähennys yhdistystoiminnan sponsoroimiseksi

7.4.3.3 Yleisradiovero kumottava 176

7.4.3.4 Kirkollisvero 180

7.4.3.4.1 Kirkollisvero poistettava yhteisöiltä

7.4.3.4.2 Kirkollisvero korvattava henkisen hyvinvoinnin verolla

7.4.3.5 Kunnallisvero

7.4.3.5.1 Työssäkäyntikunnalle verosta osa

7.4.3.5.2 Kunnan vähimmäisveroprosentiksi $22 \%$

7.4.3.6 Perintö- ja lahjavero kumottava 183

7.4.3.7 Asunnon varainsiirtoveron poistaminen tai muuttaminen määräsuuruiseksi

7.4.3.8 Kiinteistöveron kohtuullistaminen, järkiperäistäminen tai poistaminen

7.4.3.9 Kaivosvero säädettävä 193

7.4.3.10 Alkoholiverotusta vähennettävä 
Sisällys

7.4.3.11 Elintarvikeverotusta muutettava ..................... 199

7.4.3.12 Arvonlisäverotus .............................. 207

7.4.3.12.1 Arvonlisävero poistettava palveluilta ja alkutuotannolta...................... 207

7.4.3.12.2 Pienyrittäjien arvonlisäverovapautta laajennettava ......... 208

7.4.3.12.3 Kampaamo- ja parturipalvelujen arvonlisäverokantaa alennettava.............. 211

7.4.3.12.4 E-kirjojen arvonlisävero painettujen kirjojen veron tasolle.

7.4.3.12.5 Tekstiilialan arvonlisäverokantaa alennettava.............. 213

7.4.3.12.6 Eläinlääkäripalvelujen arvonlisäverotusta kevennettävä..... 216

7.4.3.12.7 Kuukautissuojien verokantaa alennettava ...................... 218

7.4.3.12.8 Uusiutuviin luonnonvaroihin perustuvan energian arvonlisäverokantaa alennettava.... 222

7.4.3.12.9 Aurinkosähkön arvonlisäveroa alennettava ...................... 225

7.4.3.12.10 Verosta maksettava arvonlisävero poistettava..... 226

7.4.3.13 Tieliikenteen verot........................... 227

7.4.3.13.1 Autovero on poistettava tai sitä on alennettava.............. 227

7.4.3.13.2 Ajoneuvoveron perusvero on poistettava tai sitä on muutettava 233

7.4.3.13.3 Käyttövoimavero poistettava dieselautoilta..................... 240

7.4.3.13.4 Polttoaineveroa alennettava... 242 
Sisällys

7.4.3.13.5 Uusiutuvan dieselin polttoaineveroa alennettava... 243

7.4.3.13.6 Käyttövoimavero poistettava kaasuautoilta....................... 246

7.4.3.13.7 Autojen käyttövoiman muuttamista tuettava ........... 246

7.4.3.13.8 Sähköautoilun tukeminen kiellettävä .......................... 247

7.4.3.13.9 Ulkomaisille ajoneuvoille tienkäyttömaksu .................. 248

7.4.3.14 Vene-, traktori- yms. verot..................... 250

7.4.3.15 Lentovero säädettävä............................. 251

7.4.3.16 Kiinteistöjen lämmitysöljyn veroa korotettava ...................................... 256

7.4.3.17 Tekstiiliveron säätäminen ...................... 257

7.4.4 Veroaloitteiden arviointia .................................. 258

7.4.4.1 Esitysten erilaisuus ja samanlaisuus ........ 258

7.4.4.2 Verotuksen alentaminen vai lisääminen? ........................................ 259

7.4.4.3 Kellojen siirtäminen taaksepäin taantumukselliset vai edistykselliset aloitteet? ............................................ 260

7.4.4.4 Suhde perustuslakiin ja EU-oikeuteen.... 262

7.4.4.5 Aloitteiden toteuttamiskelpoisuus.......... 263

\subsection{Kansalaisaloitejärjestelmän merkitys ....................... 265}

7.5.1 Kansalaisaloitejärjestelmän tavoite, aloitteiden kannatus ja taloudellinen tuki........................... 265

7.5.2 Vertailua kansanedustajien aloitteisiin ................ 268

7.5.3 Hallituksen kokoonpanon tärkeys....................... 270

7.5.4 Kansalaisaloitejärjestelmän muutostarve?............ 270

\section{RAHALLA VAIENTAMISEN VEROKOHTELU JA TULOVEROTIETOJEN JULKISUUS ….......................... 273}

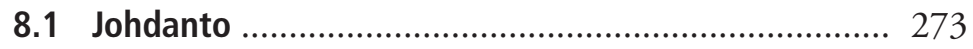

\subsection{Sananvapaus, yksityiselämän suoja ja seksuaalinen} itsemääräämisoikeus. 


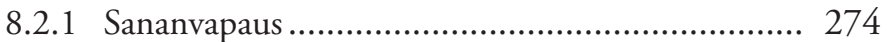

8.2.2 Kunnianloukkaus............................................ 275

8.2.3 Yksityiselämän suoja ...................................... 275

8.2.4 Yksityiselämää loukkaava tiedon levittäminen ...... 276

8.2.5 Tiettyjen alojen lakisääteinen vaitiolovelvollisuus .. 277

8.2.6 Vaitiolovelvollisuus sopimuksissa........................ 278

8.2.7 Kiristäminen ja lahjonta .................................... 278

8.2.8 Seksuaalirikokset........................................... 279

8.3 Vaitiolokorvaukset verotuksessa .............................. 280

8.3.1 Laaja veronalaisuus lähtökohtana ........................ 280

8.3.2 Rikoksella saadun hyödyn verokohtelu ................ 281

8.3.3 Saadun vahingonkorvauksen verovapaus ja vaitiolokorvauksen veronalaisuus....................... 282

8.3.4 Sanktionluonteisten maksuseuraamusten vähentämiskielto verotuksessa ........................... 283

8.3.5 Lahjusten vähentämiskielto .............................. 284

8.3.6 Vahingonkorvaukset ja sopimussakot menoina

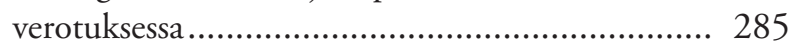

8.3.7 Seksipalvelun osto ja vaikenemiskorvaus.............. 285

8.4 Vihjepalkkioiden verokohtelu ................................. 286

8.5 Tuloverotietojen julkisuus ..................................... 288

8.5.1 Verotietojen julkisuuden kehitys Suomessa

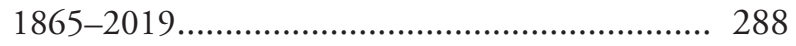

8.5.1.1 Tuloverotuksen synty .......................... 288

8.5.1.2 Julkisuus kunnallisverotuksessa ja valtionverotuksessa ............................. 289

8.5.1.3 Nykyinen sääntely ............................... 290

8.5.2 Julkisuuden rajaaminen suurituloisiin ilman vastustamisoikeutta?........................................... 292

9 SOTAVEROISTA SOTE-VEROIHIN.............................. 295

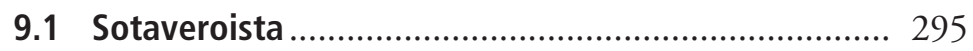

9.2 Sosiaaliturvan kehitys .............................................. 296

9.2.1 Keskiajalta 1800-luvun puoliväliin ..................... 296

9.2.2 1860-luvulta 1930-luvun puoliväliin................... 298 
9.2.3 1930-luvun loppupuolelta 1950-luvun loppupuolelle.................................................... 299

9.2.4 1950- ja 1960-lukujen vaihteesta 2010-luvulle..... 300

9.3 Itsenäisen Suomen valtion menorakenteen kehitys... 301

9.4 Kokonaisveroaste ................................................... 303

9.5 Aikaisempia maakuntahallintoehdotuksia................ 305

9.6 Nykyisen hallituksen sote-ohjelma .......................... 307

9.7 Maakuntavero perustuslain kannalta ....................... 309

10ROBOTTIVERO JA DIGIVERO .................................... 311

10.1 Uusista veroista...................................................... 311

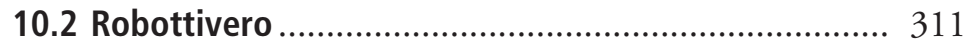

10.2.1 Robottiverokeskustelu Suomen eduskunnassa 1985-2014....................................................... 311

10.2.2 Robottiveroehdotukset 2010-luvun lopulla.......... 320

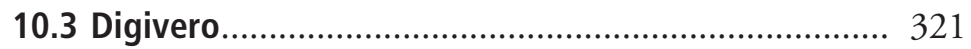

10.3.1 Digitaalisen toiminnan kansainvälinen tuloverotus nykyisin ....................................... 321

10.3.2 OECD:n hanke ............................................. 322

10.3.3 EU:n direktiiviehdotukset ................................. 323

10.3.4 Vähimmäisverot................................................ 333

11 SUOMEN VEROTOHTORIT ....................................... 335

11.1 Vero-oikeudelliset väitöskirjat .................................. 335

11.2 Väitöskirjan koko .................................................... 341

11.3 Väittelijän sukupuoli ja väitöskirjan kieli.................. 341

11.4 Ikä ja työ ............................................................... 342

11.5 Verotohtorit veronmaksajina ................................... 343

Jälkipuhetta kirjan arvosta ...................................... 345

Asiahakemisto .......................................................... 347 


\section{Lyhenteitä}

$\mathrm{EK}=$ Elinkeinoelämän keskusliitto

ETLA $=$ Elinkeinoelämän tutkimuslaitos

EVL = laki elinkeinotulon verottamisesta

JFT = Tidskrift utgiven av Juridiska Föreningen i Finland

$\mathrm{HE}=$ hallituksen esitys

$\mathrm{KHO}=$ korkein hallinto-oikeus

$\mathrm{KKO}=$ korkein oikeus

$\mathrm{LM}=$ Lakimies (lehti)

PeVL = perintö- ja lahjaverolaki

SAK = Suomen Ammattiliittojen Keskusjärjestö

TVL = tuloverolaki

VATT $=$ Valtion taloudellinen tutkimuskeskus

$\mathrm{VML}=$ laki verotusmenettelystä

VSVL $=$ varainsiirtoverolaki 


\section{1 \\ Yhdenvertaisuus tuloverotuksessa perustuslaki- kysymyksenä ${ }^{1}$}

\subsection{Teemasta}

"Ketään ei saa ilman hyväksyttävää perustetta asettaa eri asemaan sukupuolen, iän, alkuperän, kielen, uskonnon, vakaumuksen, mielipiteen, terveydentilan, vammaisuuden tai muun henkilöön liittyvän syyn perusteella." (Perustuslain 6.2\$)

"Tässä yleissopimuksessa tunnustetuista oikeuksista ja vapauksista nauttiminen taataan ilman minkäänlaista sukupuoleen, rotuun, ihonväriin, kieleen, uskontoon, poliittisiin tai muihin mielipiteisiin, kansalliseen tai yhteiskunnalliseen alkuperä̈n, kansalliseen vähemmistöön kuulumiseen, varallisuuteen, syntyperä̈̈n tai muubun asemaan perustuvaa syrjintää." (Euroopan ihmisoikeussopimuksen 14 artikla) ${ }^{2}$

1 Tämä kirjoitus pohjautuu huomattavalta osin esitelmääni Itä-Suomen yliopiston vero-oikeuden professorin Matti Myrskyn (1953-2016) muistoseminaarissa 24.3.2017.

2 Ihmisoikeussopimuksen syrjintäkieltoartiklassa ei mainita nimenomaisesti ikäsyrjintää, mutta siinä mainitaan varallisuussyrjintä. Tuskin kuitenkaan ihmisoikeussopimukseen vetoamalla voidaan puoltaa ikäsyrjintää ja vastustaa varallisuusveroa. Ihmisoikeussopimuksen omaisuudensuoja-artiklan (1 artikla) 
Maksukyky, yhdenvertaisuus ja neutraalius olivat arvoja, joita professori Matti Myrsky korosti tieteellisessä tuotannossaan. Hän oli kiinnostunut myös perustuslain merkityksestä verotuksessa. Mainittakoon vain seuraavat Myrskyn kirjat ja artikkelit:

Progressiosta verotuksessa (1997)

Oikeudenmukaisuus ja verotus, LM 2009 s. 739 ss.

Veronmaksukykyperiaatteesta verotuksen perusperiaatteena,

Verotus 1998 s. 136 ss.

Perustuslain merkityksestä verotuksen kannalta, Verotus 2005 s. 27 ss.

Jatkan tässä samaa teemaa. Aluksi selvitän sellaisia lainkohtia, joissa tietyn tulon verotus on säädetty yleistä tasoa lievemmäksi. Sen jälkeen tarkastelen ainoaa lainkohtaa, jossa tietynlaista tuloa verotetaan yleistä verokantaa ankarammin. Lopussa esitän johtopäätökset yhdenvertaisuusperiaatteen vaikutuksesta verolainsäätäjän toimivaltaan ja verolain tulkintaan.

\subsection{Omaisuustulovähennyksestä ennen 1980-luvun lopun kokonaisverouudistusta}

Tuloverotuksessamme oli 1980-luvun alkuun asti osinkotulovähennys, jonka tarkoituksena oli lieventää osinkotulojen verotusta. Tämä tapahtui siten, että osinkotuloista sallittiin tehdä vähennys, joka oli yhtä suuri kuin osinkotulojen määrä mutta enintään 500 markkaa. Näin arveltiin edistettävän pienosakesäästämistä. Vähennykseen olivat oikeutettuja luonnollinen henkilö ja kuolinpesä.

Vuonna 1981 vähennys muuttui omaisuustulovähennykseksi ja vähennys saatiin tehdä osinkojen lisäksi asunnon vuokratuloista ja veronalaisista korkotuloista. Verotuksen lievennys tapahtui siten, että

mukaan sopimuksen määräykset eivät saa millään tavoin heikentää valtioiden oikeutta saattaa voimaan lakeja, jotka ne katsovat välttämättömiksi omaisuuden käytön valvomiseksi yleisen edun nimissä taikka taatakseen verojen tai muiden maksujen tai sakkojen maksamisen. 
näistä tuloista sallittiin tehdä vähennys, joka oli yhtä suuri kuin noiden tulojen määrä mutta enintään 2500 markkaa.

Vähennyksen piirin laajentamisella pyrittiin saattamaan erilaiset veronalaiset pääomatulot keskenään tasapuolisempaan asemaan. Asuntojen vuokratulojen osalta pidettiin silmällä yksityisten vuokranantajien raskasta verotusta ja näiden vuokra-asuntojen määrän jatkuvaa laskua, joka ainakin osittain johtui verotuksesta.

Omaisuustulovähennyksen enimmäismäärä korotettiin myöhemmin 6000 markaksi, johon sai sisältyä enintään 3800 markkaa muita kuin vuokratuloja. Vähennyksen määrä oli 1990-luvun alussa 2000 markkaa lisättynä $50 \%$ :lla ylimenevästä osasta; enimmäismäärä oli 20000 markkaa. Vähennyksen enimmäismäärään oikeuttava tulo oli siis 38000 markkaa.

Vuoden 1993 alussa voimaan tulleeseen tuloverolakiin ei sisällytetty omaisuustulovähennystä. Siirryttiin eriytettyyn tuloverotukseen, jossa pääomatulot verotetaan oman erillisen veroprosentin mukaan. Pääomatulojen veroprosentti oli aluksi $25 \%$. Nykyisin se on tulojen suuruudesta riippuen $30-34 \%$.

\subsection{Osinkotulojen täysi ja osittainen verovapaus nykyisin}

Osakeyhtiöiden ja muiden yhteisöjen saamien osinkojen täydestä ja osittaisesta verovapaudesta säädetään EVL 6a \$:ssä. Siinä on kysymys ketjuverotuksen torjumisesta.

Tuloverolain mukaan verotettavien luonnollisten henkilöiden osinkoverotuksesta säädetään TVL 33a ja 33b §:ssä. TVL 33a \$:ssä säädetään julkisesti noteeratusta yhtiöstä saadusta osingosta. Julkisesti noteeratusta yhtiöstä saadusta osingosta $85 \%$ on pääomatuloa ja $15 \%$ verovapaata tuloa (TVL 33a \$).

Muusta kuin julkisesti noteeratusta yhtiöstä saadusta osingosta on TVL 33b \$:n mukaan $25 \%$ veronalaista pääomatuloa ja 75 \% verovapaata tuloa siihen määrän saakka, joka vastaa varojen arvostamisesta verotuksessa annetussa laissa tarkoitetulle osakkeen verovuoden matemaattiselle arvolle laskettua $8 \%$ :n vuotuista tuottoa. Siltä osin kuin verovelvollisen saamien tällaisten osinkojen määrä ylittää 150000 
euroa, osingoista $85 \%$ on pääomatuloa ja $15 \%$ verovapaata tuloa. Vuotuisen tuoton ylittävältä osalta osingosta $75 \%$ on ansiotuloa ja $25 \%$ verovapaata tuloa. Peitellystä osingosta $75 \%$ on ansiotuloa ja $25 \%$ verovapaata tuloa (TVL 33d \$).

\subsection{Yrittäjävähennys}

Tuloverolakiin on vuoden 2017 alussa lisätty säännös (30a \$) yrittäjävähennyksestä. Lakia muutettiin siten, että elinkeinotoiminnan, maatalouden, metsätalouden ja porotalouden tuloksesta vähennetään verotuksessa $5 \%$, kun tulos otetaan huomioon luonnollisen henkilön tai kuolinpesän verotuksessa. Samalla yhteismetsän ja muun yhteisetuuden verokanta on alennettu 26,5\%:ksi. Yhteisöjen verokanta on nykyisin $20 \%$.

\subsection{Kokonaan tai osittain verovapaat luovutusvoitot}

TVL 48 \$:ssä mainitaan verovapaat luovutusvoitot. Niistä tärkein on luovutusvoitto vähintään kaksi vuotta omistetusta omana asuntona käytetystä asunnosta. Verovapaita ovat myös omassa käytössä olleesta tavanomaisesta koti-irtaimistosta verovuonna saadut luovutusvoitot yhteensä 5000 euroon saakka. Samoin verovapaita ovat tietyin edellytyksin sukupolvenvaihdosluovutukset, kun omaisuus on omistettu yli 10 vuotta, sekä kiinteän omaisuuden luovutus valtiolle luonnonsuojelualueeksi.

TVL 49 §:ssä säädetään osittain verovapaista kiinteistöjen luovutusvoitoista. Tässä osittainen verovapaus toteutetaan siten, että luovutushinnasta vähennetään voittoa laskettaessa aina vähintään $80 \%$ hankintamenona, kun hankintameno-olettama yleensä on omistusajasta riippuen 20 tai $50 \%$. Säännös koskee lähinnä pakkolunastuksia sekä luovutuksia valtiolle ja kunnalle.

Elinkeinoverolaissa on verovapaiksi säädetty tietyin edellytyksin vuoden omistusajan jälkeen konserniyhteisön käyttöomaisuusosakkeiden luovutukset (EVL 6b $\$$ ). 


\subsection{Metsälahjavähennys}

Tuloverolakiin on otettu vuoden 2017 alusta säännökset metsätilan sukupolvenvaihdoksen johdosta suoritettavan lahjaveron perusteella myönnettävästä metsälahjavähennyksestä. Vähennys tehdään metsätalouden puhtaasta pääomatulosta. Tavoitteena on edistää metsätilojen sukupolvenvaihdoksia, kasvattaa metsätilakokoa, edistää yrittäjämäistä metsätaloutta ja lisätä puun tarjontaa.

Metsälahjavähennyssäännös perustuu hallituksen esitykseen 158/2016, joka muuttui eduskunnassa vain teknisissä yksityiskohdissa. Tästä esityksestä hankittiin perustuslakivaliokunnan lausunto. Valiokunnan kuulemien asiantuntijoiden käsitykset esityksen perustuslainmukaisuudesta jakaantuivat, mutta enemmistö asiantuntijoista ei katsonut esitystä perustuslain vastaiseksi. Enemmistöön kuuluivat ministeriön lisäksi Mikael Hidén, Heikki Niskakangas, Teuvo Pohjolainen, Pekka Viljanen ja Matti Urpilainen. Vähemmistössä olivat Juha Lavapuro, Tuomas Ojanen ja Esko Linnakangas. Hallituksen olisi mielestäni ollut syytä peruuttaa esityksensä, asettaa toimikunta selvittämään mahdollisuutta luopua koko perintö- ja lahjaverotuksesta ja korvata sen verotuotto muuta pääomaverotusta kehittämällä. ${ }^{3}$ Luovutusvoittoverotuksen tiukentaminen ei suinkaan ole ainoa vaihtoehto perintö- ja lahjaverosta luopumiselle. ${ }^{4}$

Marraskuun 18. päivänä 2016 antamassaan lausunnossa (PeVL 52/2016) perustuslakivaliokunta totesi, että metsälahjavähennyksen ehdotuksen vaikutukset ja soveltuvuus tavoitteiden saavuttamisen kannalta näyttivät olevan ainakin osaksi epäselviä ja kiistanalaisia, mikä horjutti hyväksyttävyyden ohella ehdotuksen oikeasuhtaisuutta, etenkin kun samalla otettiin huomioon huojennuksen suu-

Hallitus antoi 6.10.2016 eduskunnalle esityksen 175/2006, jossa ehdotettiin sukupolvenvaihdosten helpottamiseksi perintöverosäännöksiä muutettavaksi siten, että alaikäisen perillisen kohdalla voidaan yritystoiminnan jatkamisen arvioinnissa perillisen jatkamisena pitää myös edunvalvojan toimintaa osakeyhtiössä. Hallituksen mielestä ehdotus oli ongelmaton perustuslain yhdenvertaisuusvaatimuksen kannalta. Kuitenkin 17.11.2016 hallitus poisti esityksestään tuon kohdan, koska muuten olisi vaarannettu eräiden muidenkin perintöverolain muutosten saaminen voimaan vuoden 2017 alusta (HE 245/2016).

4 Esim. Esko Linnakangas - Leila Juanto, Verojen historia. Synty, kehitys, kuolema, ylösnousemus, reinkarnaatio (2016) s. 81-109. 
ruus. Perustuslakivaliokunnan mielestä esityksen elinkeinopoliittiset tavoitteet olivat kuitenkin verotuksellisten ratkaisujen yhteydessä osin hyväksyttäviä ja lähtökohtaisesti lainsäätäjän harkintamarginaaliin kuuluvia. Tällaisia olivat metsätalouden harjoittamisen edellytyksien parantamiseen sekä metsäteollisuuden puun saannin turvaamiseen liittyvät perusteet. Esitys myös vaikutti suoraan tai välillisesti työllisyyteen ja investointeihin. Jonkin henkilöryhmän suosiminen ehdotetulla tavalla ei perustuslakivaliokunnan mielestä muodostunut mielivaltaiseksi tai kohtuuttomaksi. Perustuslakivaliokunta otti arvioinnissaan huomioon myös sen, että verotuksessa on jo nykyisin runsaasti huojennussäännöksiä. Valiokunnan mielestä metsälahjavähennystä koskeva sääntely muodostui kuitenkin varsin pistemäiseksi, mikä ei perustuslain yhdenvertaisuussäännöstenkään näkökulmasta ollut täysin asianmukaista.

Vaikka vähennysjärjestelmä poikkesi muodollisesta yhdenvertaisesta kohtelusta, ehdotus kuului perustuslakivaliokunnan mielestä lainsäätäjän harkintavallan piiriin. Koska yhdenvertaisuudesta ei valiokunnan vakiintuneen kannan mukaan voi koitua tiukkoja rajoja lainsäätäjän harkinnalle pyrittäessä kulloisenkin yhteiskuntakehityksen vaatimaan sääntelyyn, kynnys todeta tietty verolaki perustuslain yhdenvertaisuussääntelyn vastaiseksi on korkea.

Valtiosääntöoikeudellisesti perustuslakivaliokunnan aiempaa veronhuojennuksia koskevaa tulkintakäytäntöä vasten ei kuitenkaan ole täysin ongelmatonta se, ettei huojennuksen tavoitteena ole kohtuuttomien veroseuraamusten välttäminen. Päinvastoin, metsälahjavähennyksestä saatava veroetu on hyvin merkittävä. Perustuslakivaliokunta toi lausunnossaan esille hallituksen mainitseman esimerkkitilanteen, jossa verokustannus alenisi jopa $56 \%$. Tämä tarkoitti perustuslakivaliokunnan mielestä voimakasta yhden elinkeinonharjoittajien ryhmän verotuksellista suosintaa.

Perustuslakivaliokunta otti huomioon verojärjestelmän kokonaisuutena sekä sen, että verotuksessa eri tulolajeja, tulolähteitä ja omaisuuslajeja kohdellaan eri tavoin ja menojen vähennyskelpoisuus vaihtelee eri tilanteissa. Samoin perustuslakivaliokunnan lausunnossa todettiin, että verotus on harvoin neutraalia ja verotuksella on fiskaalisen tavoitteen lisäksi muita tavoitteita, kuten käsillä olevassa hallituksen esityksessä olevia elinkeinopoliittisia tavoitteita, joiden 
saavuttamiseksi verotuksellisten kannusteiden tulee olla riittäviä. Huolimatta veroedun merkittävyydestä perustuslakivaliokunta ei pitänyt edellä todettujen näkökohtien vuoksi ehdotettua sääntelyä oikeasuhtaisuudenkaan näkökulmasta niin ongelmallisena, että ehdotus olisi ollut perustuslain vastainen.

\subsection{Kokonaan tai osittain verovapaita ansiotuloja}

Tasavallan presidentin palkkio ja eläke ovat verovapaita (TVL 87 §). Kysymys tuskin on verokannustimesta vaan nykyjärjestelmään huonosti soveltuvasta historiallisesta jäänteestä.

Kansanedustajien palkkiotkin olivat ennen vuotta 1947 verovapaita; sen jälkeen niistä oli verovapaata puolet, mutta palkkion verovapaus kumottiin 1950-luvun puolivälissä (kansanedustajan nykyisistä verovapaista kulukorvauksista ks. TVL 70 \$).

Verovapaita ovat tiettyjen kerättyjen luonnontuotteiden sekä äidinmaidon luovutuksesta saadut tulot (TVL 89 \$). Tässä on kysymys verokannustimesta. Äidin verottamiseen hänen tuottamastaan maidosta liittyisi myös vaikeuksia tuotantokustannusten määrän laskemisessa.

Myös lapsen elatusapu ja puolison saama toistuvaisavustus ovat verovapaita (TVL 90-91 \$).

Verovapaaksi on säädetty päivää kohden enintään 16 euron lakkoavustus (TVL 88 \$). TVL 92 \$:ssä luetellaan runsaat 20 verovapaata sosiaalietuutta (mm. äitiysavustus, hautausavustus, lapsilisä, elatustuki, sotilasavustus, asumistuki, toimeentulotuki). TVL 92a \$:ssä säädetään verovapaaksi rakennusperinnön hoitoon saatu avustus, 92b §:ssä todistelu- ja vihjepalkkiot ja 92c \$:ssä rikoksen hyvittäminen työsuorituksella. Vihjepalkkioiden verovapaudella pyritään suojelemaan vihjeen antajaa eikä varsinaisesti kannustamaan taloudellisesti ilmiantojen tekemistä.

Veronalaisiksi tuloiksi ei tietyin edellytyksin katsota myöskään TVL 69 \$:ssä mainittuja tavanomaisia ja kohtuullisia henkilökuntaetuja (terveydenhuolto, henkilökunta-alennukset, muuna kuin rahana saadut merkkipäivälahjat ja vähäiset muut lahjat, virkistys- ja harrastus- 
toiminta, yhteiskuljetus, sairaan lapsen hoito, tietoliikenneyhteydet). Työsuhdelainan verovapauden edellytykset säädetään TVL 67 §:ssä. Henkilöstörahastosta saadusta rahasto-osuudesta ja ylijäämästä $80 \%$ on veronalaista ansiotuloa; muilta osin tulo on verosta vapaa (TVL $65 \$)$.

Apurahoista ja tunnustuspalkinnoista säädetään TVL 82 §:ssä. Veronalaista tuloa ei ole stipendi tai muu apuraha, joka on saatu opintoja tai tieteellistä tutkimusta tahi taiteellista toimintaa varten. Veronalainen ei ole myöskään tieteellisen, taiteellisen tai yleishyödyllisen toiminnan tunnustukseksi saatu palkinto eikä valtion varoista huippu-urheilijalle maksettava valmennus- ja harjoitteluapuraha. Muulta kuin valtiolta, kunnalta tai muulta julkisyhteisöltä saadut stipendit, opintorahat ja muut apurahat sekä palkinnot ovat kuitenkin veronalaista tuloa siltä osin kuin niiden sekä julkisyhteisöiltä saatujen stipendien, muiden apurahojen, opintorahojen ja palkintojen yhteenlaskettu määrä tulon hankkimisesta ja säilyttämisestä johtuneiden menojen vähentämisen jälkeen verovuonna ylittää valtion taiteilijaapurahan vuotuisen määrän. Valtiovarainministeriö voi hakemuksesta päättää, että edellä tarkoitettu tieteellisen, taiteellisen tai yleishyödyllisen toiminnan tunnustuksena saatu palkinto on koko määrältään verosta vapaata tuloa.

Laissa säädetään verovapaiksi myös tietyt taidekilpailupalkinnot (TVL $83 \$$ ) ja koululaiskilpailupalkinnot (TVL $84 \$$ ). Tuloverotuksessa verovapaita ovat lotto- ja muut arpajaisvoitot (TVL $85 \$$ ), joihin sovelletaan arpajaisverolakia.

Laissa on säännöksiä myös verovapaista kulukorvauksista, vahingonkorvauksista ja vakuutuskorvauksista.

\subsection{Ansiotulovähennys ja työtulovähennys}

Ansiotulovähennys ja työtulovähennys ovat sellaisia vähennyksiä, jotka liittyvät vain tiettyjen ansiotulojen verotukseen. Eläketuloista ei noita vähennyksiä saa.

Taloudelliseen lamaan liittyvien järjestelyjen yhteydessä säädettiin 1990-luvun alkupuolella kunnallisverotukseen puhtaasta ansiotulosta 
tehtävä ansiotulovähennys. Vähennystä on sittemmin korotettu, ja sen merkitys on kasvanut. Tarkoituksena on kannustaa pienituloisia hakeutumaan työhön ja hankkimaan lisätuloja. Nykyisin vähennyksestä säädetään TVL 105a §:ssä. Tämä vähennys lasketaan verovelvollisen ansaitsemien veronalaisten palkkatulojen, muusta toiselle suoritetusta työstä, tehtävästä tai palveluksesta saatujen ansiotulojen, ansiotulona pidettävien käyttökorvausten, ansiotulona verotettavan osingon, jaettavan yritystulon ansiotulo-osuuden sekä yhtymän osakkaan elinkeinotoiminnan tai maatalouden ansiotulo-osuuden perusteella.

TVL 125 \$:ssä säädetään työtulovähennyksestä, joka tehdään ensisijaisesti ansiotulosta valtiolle suoritettavasta tuloverosta. Siltä osin kuin vähennys ylittää ansiotulosta valtiolle suoritettavan tuloveron määrän, se tehdään kunnallisverosta, sairausvakuutuksen sairaanhoitomaksusta ja kirkollisverosta näiden verojen suhteessa. Työtulovähennys muistuttaa kunnallisverotuksen ansiotulovähennystä, mutta se tehdään verosta eikä tulosta.

\subsection{Merimiesten erityiskohtelu verotuksessa}

Merimiehet ovat eri miehiä verotuksessakin. Vuonna 1958 Suomessa säädettiin merimiesverolaki. Sen mukaan merimiestuloa ei luettu tuloksi tuloverotuksessa vaan vero suoritettiin siten, että laivanisäntä pidätti palkanmaksun yhteydessä merimiesverotaulukon mukaisen veron. Merimiesverotuksen toimeenpanoa ja valvontaa varten oli merimiesverolautakunta.

Merimiesverolaki kumottiin vuoden 1986 alusta, ja merimiesten verotus siirrettiin muun tuloverotuksen yhteyteen. Samalla katsottiin kuitenkin tarpeelliseksi edelleen ottaa huomioon merimiesammatin erityisolosuhteet siten, että merillä saadusta palkkatulosta saadaan tehdä palkkatuloon yleensä kohdistuvien vähennysten lisäksi erityinen vain merityötuloon kohdistuva vähennys. Nämä säännökset ovat nykyisin TVL 97 §:ssä.

Merityötuloa saanut merimies saa sekä valtion- että kunnallisverotuksessa tehdä puhtaasta ansiotulostaan merityötulovähennyksen. 
Sen määrä vuodesta 2016 alkaen sekä valtionverotuksessa että kunnallisverotuksessa on $20 \%$ merityötulon kokonaismäärästä, kuitenkin enintään 7000 euroa. Verovelvollisen merityötulon kokonaismäärän ylittäessä 50000 euroa merityötulovähennyksen määrä pienenee.

\subsection{Lähdeverotus eräistä tuloista}

Ulkomailta Suomeen muuttavien suurituloisten palkansaajien verotusta varten on ollut 1990-luvun puolivälistä alkaen määräaikainen erityislaki. Sen 3 \$:n mukaan tällaisten ns. avainhenkilöiden palkkatulon vero on ollut $35 \%$, mutta vuodesta 2020 alkaen vero alenee $32 \%: k s i$ ja laista tulee pysyvä.

Rajoitetusti verovelvollisen eli ulkomailla asuvan tulon verottamisesta annetussa laissa on erisuuruisia veroprosentteja erilaisille tuloille. Tämän lain 7 \$:n mukaan ulkomailla asuvan vero Suomesta saadusta tulosta määräytyy seuraavasti:

- $35 \%$ palkasta, työkorvauksesta ja peitellystä osingosta kuten myös muusta TVL:n mukaan ansiotulona verotettavasta suorituksesta

- $30 \%$ tietyistä yhteisöille maksettavista osingoista, koroista, rojalteista, vakuutussuorituksista yms.

- $20 \%$ muusta yhteisölle maksettavasta osingosta, korosta ja rojaltista yms.

- $15 \%$ osingosta tietyin edellytyksin, kun osinkoa jakavan yhteisön osakkeet kuuluvat osingon saajan sijoitusomaisuuteen

- $15 \%$ taiteilijan tai urheilijan toimintaan perustuvasta korvauksesta

- $13 \%$ yhteisölle, yhteisetuudelle ja yhtymälle maksettavasta muusta kuin taiteilijan ja urheilijan toimintaan perustuvasta työkorvauksesta.

Korkotulon lähdeverosta annetun lain 6 \$:n mukaan korkotulon lähdevero on $30 \%$ talletukselle tai joukkovelkakirjalainalle maksetusta korosta. Tällainen korkotulo ei ole tuloverotuksessa veronalaista tuloa. 


\subsection{Pienten eläkkeiden eläketulovähennykset}

Aikoinaan monet eläkkeet olivat verovapaita. Kansaneläkeuudistukseen ja siihen liittyvään kansaneläkkeiden säätämiseen veronalaiseksi tuloksi perustui eläketulovähennysten käyttöönotto vuodesta 1983 alkaen. Eläketuloja varten on eläketulovähennykset. Eläketulovähennysten tarkoituksena on varmistaa, ettei pienituloinen eläkeläinen joudu maksamaan valtion- eikä kunnallisveroa. Nämä vähennykset sisältyvät TVL 100 \$:ään (valtionverotuksen eläketulovähennys) ja 101 §:ään (kunnallisverotuksen eläketulovähennys), ja ne tehdään verovelvollisen puhtaasta ansiotulosta.

Eläketulovähennyksiä säädettäessä käytiin melkoinen poliittinen taistelu. Erimielisyyttä oli erityisesti siitä, voitiinko ja oliko syytä kytkeä nämä vähennykset indeksiin, vaikka muita TVL:n vähennyksiä ei indeksiin kytketty. Kytkennän puoltajat katsoivat, että vain kytkennällä voitiin välttää kansaneläkkeiden joutuminen uudistuksen periaatteiden vastaisesti tulevina vuosina verotuksen kohteeksi sen vuoksi, ettei vähennyksiä koroteta indeksin nousua vastaavasti. Kiistan ratkaisuksi muodostui se, että vähennyksen määrä kytkettiin täyden kansaneläkkeen määrän. Koska tämä puolestaan on sidottu elinkustannusindeksiin, voidaan sanoa, että eläketulovähennyksetkin tulivat välillisesti sidotuiksi indeksiin. ${ }^{5}$

\subsection{Eläketulon lisävero ${ }^{6}$}

Kaikissa edellä mainituissa lainkohdissa on kysymys siitä, että jotakin tiettyä tuloa verotetaan normaalia kevyemmin. Olen etsinyt myös lainkohtia, joissa jotakin tiettyä tuloa verotettaisiin normaalia ankarammin. Ainoa tällainen lainkohta, jonka olen löytänyt, on eläketulon lisävero.

5 Edward Andersson - Esko Linnakangas - Joakim Frände, Tuloverotus (2016) s. 413 ss.

6 Eläkkeistä, erityisesti lisäverosta, on tehty useita kansalaisaloitteita. Ks. niistä jäljempänä luku 7.4.3.2.5. 
Eläketulon lisäveroa on kannettu vuoden 2013 alusta alkaen suurista eläkkeistä. Vuosina 2013-2016 lisäveron määrä oli $6 \%$ siltä osin kuin eläketulo verovuonna ylitti 45000 euroa. Vuodesta 2017 alkaen lisävero on 5,85 \% siltä osin kuin eläketulo ylittää 47000 euroa.

Hallituksen esityksen perustelujen mukaan eläketulon lisäverolla on tarkoitus ensinnäkin kerätä verotuloja niiltä, joiden veronmaksukyky on korkealla tasolla. Yhdenvertaisuusperiaatteen vastaista on lähtökohtaisesti mielestäni kuitenkin lisätä ainoastaan eläketulon veroa, koska muidenkin suurituloisten veronmaksukyky on korkealla tasolla. Yhdenvertaisuusperiaatteen mukaista olisi lisätä kaikkien suurituloisten verorasitusta ankaroittamalla tuloveroasteikkojen yläpäitä.

Hallitus katsoi eläkkeitä verotettavan liian kevyesti verrattuna palkkatuloon. Sen mielestä lakisääteiset työntekijämaksut piti veronluonteisina maksuina ottaa tässä vertailussa huomioon, koska ne vähentävät verovelvolliselle verojen ja maksujen jälkeen jäävää tuloa. Tällä tavalla ei kuitenkaan nähdäkseni saisi tehdä, koska näin itse asiassa perittäisiin eläketulon saajilta työntekijämaksuja, jotka eivät heidän maksettavakseen kuulu.

Hallitus totesi, että eläketulon lisäveroa maksetaan kaikkien eläketulojen perusteella eikä pelkästään esimerkiksi vanhuuseläkkeen perusteella ja että säännöksen soveltaminen perustuu siihen, minkä tyyppisestä ansiotulosta on kyse, eikä eläketulon saajan henkilöön liittyvillä ominaisuuksilla ole merkitystä säännöksen soveltumiseen. Tässäkin kohtaa esitys on mielestäni altis kritiikille. Koska eläkkeiden maksaminen perustuu verovelvollisen ikään, sairauteen tai muuhun henkilökohtaiseen seikkaan, myös eläketulon lisävero on tosiasiassa sidoksissa ikään tai muuhun henkilökohtaiseen syyhyn. ${ }^{7}$

Eläketulon lisäveron suhteesta perustuslakiin saatiin 15.11.2016 korkeimman hallinto-oikeuden päätös (KHO 2016:180), jossa katsottiin, että eläketulon lisävero perustui vähintäänkin välillisesti henkilön ikään. KHO totesi, että lainsäätäjän oli katsottava ensisijaisesti kohdentaneen verorasituksen veronmaksukyvyn perusteella suuritu-

Kansantaloustieteen professori Matti Tuomala esitti 2010-luvun alussa, että keski-ikäisten tuloverotuksen tulisi olla kireämpää kuin muiden ja että tämän pitäisi koskea myös pääomatuloja. Tämä erikoiselta tuntunut ehdotus sai melkoista huomiota mutta ei johtanut lainmuutoksiin. Minäkin vastustin sitä perustuslakiimme viitaten. 
loisiin eläkkeensaajiin veropoliittisten tavoitteiden saavuttamiseksi. Eläketulon lisäveron ensisijaiseksi tarkoitukseksi esitetty veronmaksukykyä koskeva peruste vastasi niitä tavoitteita, joita Suomen tuloverojärjestelmään on yleisesti liitetty, ja kuului sellaisenaan lainsäätäjän yhteiskuntapoliittisen harkintavallan piiriin. Valittajan voitiin katsoa kuuluvan sellaisten eläkkeensaajien joukkoon, joiden maksukyky oli lain esitöissä tarkoitetulla tavalla korkealla tasolla. Valittajan veroaste oli hänen eläketulostaan kannettavan lisäveron myötä muodostunut palkansaajan veroastetta korkeammaksi riippumatta siitä, luettiinko palkansaajien veroasteeseen palkansaajamaksut. Lain esitöissä mainittua työelämässä jatkamista koskevaa tavoitetta ei voitu enää pitää ajankohtaisena verovuonna 65 vuotta täyttäneen verovelvollisen tilanteessa. Kaikesta huolimatta eläketulon lisäveroa koskevan sääntelyn soveltaminen ei ollut KHO:n mielestä verovelvollisen veronmaksukyky ja sääntelyn kannalta hyväksyttävät tavoitteet huomioon ottaen perustuslain 6 \$:n mukaisen yhdenvertaisuussääntelyn kannalta arvioiden tai muutoinkaan perustuslain $106 \$$ :ssä tarkoitetulla tavalla ilmeisessä ristiriidassa perustuslain kanssa.

KHO:n päätös ei ollut yllätys. Jotta tuomioistuin voisi jättää eduskuntalain säännöksen soveltamatta, vaaditaan, että laki on ilmeisessä, siis ilmiselvässä, ristiriidassa perustuslain kanssa. Nyt kysymys ei ollut selvästä perustuslain loukkaamisesta vaan rajatapauksesta, josta ei ollut perustuslakivaliokunnan kannanottoa ja jossa asiantuntijoidenkin käsitykset poikkesivat toisistaan.

Eläketulon lisäveron perustuslainmukaisuutta käsiteltiin perustuslakivaliokunnassa ensi kerran syksyllä 2016, kun eduskuntaan annettiin hallituksen esitys (HE 135/2016) eläketulon lisäveron alentamisesta. Valiokunnan kuulemien asiantuntijoiden mielipiteet jakaantuivat. Enemmistö piti eläketulon lisäveroa perustuslain mukaisena. Enemmistöön kuuluivat ministeriön lisäksi tässäkin asiassa Mikael Hidén, Heikki Niskakangas, Teuvo Pohjolainen, Pekka Viljanen ja Matti Urpilainen. Vähemmistössä olivat Juha Lavapuro, Tuomas Ojanen ja Esko Linnakangas. Eläketulon lisäverosta olisi mielestäni ollut luovuttava; tavoiteltu verotuotto olisi ollut kerättävä valtion yleisten tuloveroasteikkojen yläpäitä lievästi ankaroittamalla.

Perustuslakivaliokunnan kannanotto saatiin kohta KHO:n päätöksen jälkeen 18.11.2016 (PeVL 53/2016). Valiokunta totesi verotuk- 
sessa olevan tyypillistä, että eri tulolajeja (pääomatuloja ja ansiotuloja) ja tulolähteitä (elinkeinotoiminta, maatilatalous ja muu toiminta) sekä omaisuuslajeja kohdellaan eri tavoin ja että menojen vähennyskelpoisuus on säännelty erikseen ja se vaihtelee eri tilanteissa. Vaikka verotuksen ensisijainen tehtävä on tuottaa julkiselle sektorille tuloja niin paljon, että ne riittävät kattamaan julkisen sektorin menot, verotusta on perinteisesti käytetty myös muiden yhteiskunnallisten tavoitteiden toteuttamisvälineenä. Perustuslakivaliokunnan mielestä hallituksen esityksessä mainittuja ihmisten välisten keskinäisten tuloerojen tasaamista ja heidän kannustamistaan työnteon jatkamiseen eläkkeelle jäämisen sijasta voidaan sinänsä pitää hyväksyttävinä verolainsäädännön tavoitteina.

Oikeasuhtaisuusvaatimuksen kannalta perustuslakivaliokunta totesi, että tietyn veron kohdistaminen yksinomaan eläketuloon voisi merkitä yhdenvertaisuuden loukkausta vain, jos se samalla saattaisi eläkkeensaajat merkittävästi heikompaan asemaan. Hallituksen esityksessä tehdyt vertailut palkansaajien ja eläkkeensaajien kokonaisverorasituksen osalta osoittivat valiokunnan mielestä sen, etteivät eläkkeensaajat ole verotuksen kokonaisuuden kannalta yleisesti palkansaajia heikommassa asemassa. Esitettyjen laskelmien perusteella eläketulojen veroaste on vastaavaa palkkatulon veroasetetta korkeampi vasta hyvin suurien, 118000 euroa vuodessa ylittävien eläketulojen kohdalla. Tällöinkään veroaste ei ole merkittävässä epäsuhteessa vastaavan suuruisten palkkatulojen veroasteen kanssa, eikä sen voi katsoa olevan verovelvollisten kannalta kohtuuton, kun otetaan huomioon myös heidän veronmaksukykynsä.

Perustuslakivaliokunta katsoi, että hallituksen ehdotukselle oli esitetty hyväksyttävä peruste, eikä ehdotus johtanut tietyn ryhmän asettamiseen merkittävästi muita heikompaan asemaan. Säännös eläketulon lisäverosta ei siten valiokunnan mielestä muodostunut perustuslain $6 \$$ :ssä säädetyn yleisen yhdenvertaisuuden taikka syrjinnän kiellon vastaiseksi. 


\subsection{Johtopäätökset}

Perustuslakivaliokunnan marraskuussa 2016 antamat kannanotot metsälahjavähennyksestä ja eläketulon lisäverosta ovat erittäin tärkeitä valtiosääntöoikeudellisia linjauksia. Niiden vuoksi yhdenvertaisuusperiaate ei käytännössä rajoita merkittävästi enemmistöhallituksen ja verolainsäätäjän toimintavapautta.

Perustuslakivaliokunnan lausunnon hankkiminen veroasioissa on ollut harvinaista ja voi jatkossa harvinaistua entisestään, vaikka monet ovatkin arvostelleet hallitusta perustuslakiongelmien sivuuttamisesta tai vähättelystä lainvalmistelussa. Vielä harvemmin saataneen sellaisia korkeimman hallinto-oikeuden päätöksiä, joissa tuomioistuin jättäisi selvän verosäännöksen soveltamatta ilmeisesti perustuslain vastaisena.

Kaikesta huolimatta yhdenvertaisuuskysymystä on pidettävä lainvalmistelussa vahvasti esillä. Tulkinnallisesti epäselviä verosäännöksiä sovellettaessa voidaan ja pitääkin pyrkiä yhdenvertaisuusperiaatetta kunnioittaviin ratkaisuihin. 


\section{2 \\ Lapset ja nuoret vero- ja liikenneoikeudessa}

\subsection{Henkiverosta yleisradioveroon}

Henkiraha eli henkivero otettiin meillä käyttöön 1600-luvulla. Henkiverona tuli jokaisen aatelittoman täysi-ikäisen kruunun alamaisen maksaa vuosittain kruunulle könttäsumma, joka oli riippumaton henkilön tuloista ja omaisuudesta. Henkirahaa maksoivat 1920-luvun alussa miehet ja naiset viisi markkaa vuodessa. Tästä verosta oli vapautettu alle 18-vuotiaat ja vähintään 65-vuotiaat.

Vuodesta 2013 alkaen kannettu yleisradiovero, joka on pitkälti tasavero, muistuttaa muinaista henkiveroa. Yleisradioveroakaan eivät maksa alle 18-vuotiaat. Sitä vanhemmilta - myös 65 vuotta täyttäneiltä - sitä sen sijaan peritään (jos tulot eivät ole todella pienet), vaikka heillä ei olisi radiota eikä televisiota taikka terveydellisistä tai muista syistä edes mahdollisuutta niiden kuunteluun tai katseluun. ${ }^{8}$

8 Yleisradioverosta tarkemmin kirjoitukseni Verotus 2012 s. 352 ss. 


\subsection{Tuloverotus, perintöverotus ja varainsiirtoverotus}

Unkarin pääministeri Viktor Orban herätti helmikuussa 2019 Suomessakin keskustelua, kun hän sanoi haluavansa antaa verovapauden kaikille äideille, joilla on vähintään neljä lasta; neljännen lapsen saamisen jälkeen äidin ei enää elinikänään tarvitsisi maksaa tuloveroja. ${ }^{9}$ Orbanin mielestä kaikkialla Euroopassa syntyy yhä vähemmän lapsia, ja lännen vastaus tähän on maahanmuutto. Mutta Orbanin mukaan unkarilaiset haluavat unkarilaisia lapsia, ja maahanmuutto olisi antautumista. ${ }^{10}$

Ihmisten kannustamista lisääntymään voidaan arvostella ekologisista syistä: maapallolla on kestävään kehitykseen tarpeeksi ja liikaakin väkeä. ${ }^{11}$ Mooseksen kirjan viides päiväkäsky "Olkaa hedelmälliset ja lisääntykää ja täyttäkää maa" on jo täytetty.

Tasa-arvo ja lapsiperheiden maksukyky on kuitenkin syytä huomioida myös verojärjestelmässä. Valtion tuloverotuksessa sovellettiin Suomessa 1970-luvulle asti järjestelmää, joka perustui pitkälti puo-

9 Suomessa perussuomalaisten eduskuntaryhmän puheenjohtajan Ville Tavion mukaan kolme lasta synnyttäneet naiset voisi vapauttaa kokonaan tuloverosta (Uusi Suomi 17.10.2019).

10 Puolassa hallitseva Laki ja Oikeus -puolue on lupaillut lainmuutosta, jonka mukaan ne alle 26-vuotiaat, jotka ovat vakituisessa työsuhteessa, saisivat palkkansa verottomina (YLE uutiset 17.9.2019). Iltalehden pääkirjoituksen 14.10.2019 mukaan alle 26-vuotiailta on jo poistettu tuloverot 20000 euron vuosituloihin saakka. - Voimakas ikäperusteinen veroetu saatettaisiin katsoa Suomessa perustuslain $6 \$$ :n vastaiseksi. Vrt. myös EU:n perustamissopimuksen 21 artikla, jonka mukaan kiellettyä on kaikenlainen syrjintä, joka perustuu mm. ikään.

11 Lundin yliopiston tutkimuksessa vuodelta 2017 todetaan lapsen tekemättä jättämisen olevan merkittävin yksilötason ekoteko. Ks. myös Tieteen Kuvalehti 13/2019 s. 28-31, jonka mukaan yksi lapsi vähemmän perheessä johtaa keskimäärin 58,6 tonnin CO2-päästöleikkaukseen vuodessa, kun esimerkiksi autottomuudella voi pienentää vuotuisia CO2-päästöjään 2,4 tonnilla ja maan pinnalla pysymällä 1,6 tonnilla.

Ekologian professori Janne Kotiahon mielestä synnytystalkoisiin kannustaminen on perverssiä. Hän on pohtinut, voisiko lapsettomia ja lapsen hankintaa lykkääviä jopa palkita rahallisesti (Helsingin Sanomat 16.3.2019 s. D2). Samansuuntainen vaihtoehto voisi olla isien ja äitien lapsiluvun mukaan nouseva verotus. Olen nähnyt myös ehdotuksen, että lapsettomuuden takia taloudellisesti syrjityille olisi maksettava taannehtivat verottomat korvaukset valtion varoista. 
lisoiden ja heidän alaikäisten lastensa yhteisverotukseen. ${ }^{12}$ Erilaiset veroluokat ja vähennykset kuitenkin tasasivat veroseuraamuksia.

Suomen nykyistä tuloverojärjestelmää voidaan pitää perhepoliittisesti varsin neutraalina. Yhteisverotusta ei enää ole, ja vähennyksiä on suuresti karsittu. Alaikäisellä tarkoitetaan tuloverolain 8 \$:n mukaan lasta, joka ennen verovuoden alkua ei ole täyttänyt 17 vuotta.

Perintöverotuksessa hyvin merkittävä on perintö- ja lahjaverolain 12 §:ssä säädetty 60000 euron alaikäisyysvähennys. Sen saa sellainen perinnönjättäjän suoraan alenevassa polvessa oleva perillinen, jolla perinnönjättäjän kuolinhetkellä lähinnä oli oikeus periä perinnönjättäjä ja joka tuolloin ei ollut täyttänyt 18 vuotta.

Varainsiirtoverotuksessa verovelvollisen iällä on merkitystä ensiasunnon verovapaudessa (VSVL $11 \$, 25 \$)$. Verovapauden voi saada, jos ennen luovutuskirjan allekirjoitusta on täyttänyt 18 mutta ei 40 vuotta.

\subsection{Kulutusverot}

\subsubsection{Arvonlisäverotus}

Suomen arvonlisäverolaissa ihmisen ikärajasta ei löydy mainintaa. Sellainen on kuitenkin ollut vuoden 2018 loppuun asti laissa vaikeavammaisille yrittäjille myönnettävistä veronhuojennuksista. Tuon lain mukainen huojennus edellytti, että henkilö ei käyttänyt apulaisina muita kuin aviopuolisoa tai alle 18-vuotiaita jälkeläisiään ja enintään yhtä muuta henkilöä.

Joissakin maissa vauvanruuilla ja lastenvaatteilla on hyvin edullinen arvonlisäverokohtelu. Näin on varsinkin Isossa-Britanniassa ja Irlannissa. ${ }^{13}$ Veroedun vuoksi useat verkkokaupat ovat sijoittaneet varastonsa Isoon-Britanniaan. Vaate- ja jalkinekauppiaiden etujärjestö esitti eduskuntavaalien 2011 alla, että Suomessa lupaukset lapsiperheiden taloudellisesta tukemisesta voitaisiin lunastaa alentamalla lastenvaatteiden ja -jalkineiden arvonlisäveroa tai poistamalla se kokonaan.

12 Ks. myös jäljempänä kansalaisaloitteita koskeva luku 7.4.3.2.

13 Näissä maissa elintarvikkeidenkin arvonlisäverokantasääntely on poikkeuksellisen monimutkainen. Ks. kirjani Verokarhun keitto- ja drinkkikirja - Terve elintarvikeverotus (2019), erityisesti sen liite. 
2 Lapset ja nuoret vero- ja liikenneoikeudessa

\subsubsection{Koiravero}

1800-luvun alussa oli käytössä valtiolle maksettava ylellisyysveroluonteinen koiravero. Ensimmäinen kunnalle suoritettava koiraveromme säädettiin vuonna 1878. Lakia perusteltiin terveyspoliittisilla ja taloudellisilla syillä. Koiraverolaki oli voimassa vuoteen 2018 saakka, mutta sitä ennen jo lähes kaikki kunnat olivat luopuneet sen kannosta.

Koiraveroa ei ollut suoritettava koirasta, joka verovuoden päättyessä oli viittä kuukautta nuorempi. Komiteanmietintöön vuonna 1973 liitetyssä eriävässä mielipiteessä oli vaadittu koiran ikärajaksi kuutta kuukautta. Siinä todettiin, että koiran biologista ikää verrattaessa ihmisen ikään käytettiin yleensä kerrointa 7 , ja kuuden kuukauden ikä vastasi ihmislapsen 3,5 vuoden ikää. ${ }^{14}$

\subsubsection{Matkustaja- ja lentoverot}

Suomessa perittiin 1990-luvun alussa erityistä kulutusveroa laivalla ja lentokoneella tehdyistä ulkomaanmatkoista. Näitä veroja ei suoritettu alle 12-vuotiaista lapsista. Ruotsi on vuonna 2018 palauttanut verojärjestelmäänsä lentoveron. Samantapaista veroa ovat monet ehdottaneet Suomeenkin (ks. esim. jäljempänä luku 7.4.3.15, jossa selostetaan eduskunnan käsittelyyn päässyttä kansalaisaloitetta).

Nykyisin lentoverosta on tavallisesti vapautettu alle 2-vuotiaat lapset, ainakin jos he ovat ilman omaa istumapaikkaa. Isossa-Britanniassa ikäraja on perheiden aseman helpottamiseksi nostettu ensin 12 ja sitten 16 vuoteen, kun matkustetaan säästöluokassa.

Perustuslakimme 6 \$:n mukaan ketään ei saa ilman hyväksyttävää perustetta asettaa eri asemaan iän perusteella. Sille, että alle 2-vuotiaat vapautettaisiin lentoverosta, hyväksyttävä syy lienee jo tällaisen lapsen pieni paino. ${ }^{15}$

14 Uusi kaava koiran iän laskemiseksi ihmisiässä ei ole yhtä helppo kuin seitsemällä kertominen. Kaavassa koiran iän luonnollinen logaritmi kerrotaan luvulla 16 ja saatuun lukuun lisätään 31. Ks. Helsingin Sanomat (HS.fi) 22.11.2019, jossa on myös laskuri tätä varten.

15 Esko Linnakangas - Leila Juanto, Lentoveron ylösnousu? Ilma- ja avaruusliikenteen verotus (2018) s. 118. 


\subsubsection{Sänkyverot}

Suomessa ei koiraveron kumoamisen jälkeen ole alueellisia kulutusveroja. Ulkomailla sen sijaan useissa kaupungeissa ja kohteissa turisteilta peritään yöpymisen yhteydessä alueellista veroa, jonka määrä riippuu majoituksen tasosta ja oleskelun pituudesta. ${ }^{16}$ Saksassa puhutaan yleisesti sänkyverosta (Bettensteuer). ${ }^{17}$ Monin paikoin tästä verosta on vapautettu tiettyä ikää nuoremmat lapset, mutta ikärajat vaihtelevat. Esimerkkeinä voidaan mainita seuraavat:

18 vuotta: Milano, Malta, Nizza

16 vuotta: Barcelona

15 vuotta: Verona ${ }^{18}$

14 vuotta: Bologna

12 vuotta: Pariisi

11 vuotta: Rooma

2 vuotta: Firenze

10 vuotta: Venetsia.

\subsection{Alaikäiset autonkuljettajat - EU-oikeus}

\subsubsection{Ns. kevytautot}

Hallitus antoi 3.10.2018 eduskunnalle esityksen (173/2018), jolla ehdotettiin muutettavaksi ajoneuvolakia, ajokorttilakia, tieliikennelakia, ajoneuvoverolakia, autoverolakia, polttoaineen maksusta

16 Veron nimenä voi olla esim. turistivero tai kaupunkivero.

17 Suomessa aikoinaan kannettu "hetekavero" ei ollut kulutusvero vaan omaisuudenluovutusveroksi kutsuttu omaisuusvero. Omaisuudenluovutusverot olivat 1940-luvun ylimääräisiä omaisuusveroja, joilla Suomen valtio keräsi varoja maksaakseen siirtoväelle korvauksia Neuvostoliitolle luovutetuille alueille jääneestä omaisuudesta. Hetekaverosta puhuminen selittyy hetekoiden silloisella yleisyydellä ja sillä, että omaisuudenluovutusverotuksessa veronalaiseen ja verolomakkeella ilmoitettavaan omaisuuteen kuuluivat myös huonekalut ja muukin sellainen irtaimisto, joka oli säädetty vapaaksi normaalista omaisuusverosta. Ks. kirjoitukseni Korvamerkkiverot, vapaaehtoiset verot ja veron kirnuaminen, Defensor Legis 4/2018 s. 656 ss.

18 Veronassa veronalaisia eivät ole myöskään 75 vuotta täyttäneet. 
annettua lakia, arvonlisäverolakia ja rikoslakia. Esityksellä ehdotettiin otettavaksi käyttöön uusi kansallinen T-ajoneuvoluokan ajoneuvoryhmä "kevytauto", johon kuuluisivat henkilöautosta muunnetut, nopeudeltaan enintään 45 kilometriin tunnissa rajoitetut omamassaltaan enintään $1500 \mathrm{~kg}: n$ ajoneuvot. ${ }^{19}$ Vaatimuksena oli, että ajoneuvo oli muutettu aiemmin Suomessa käyttöönotetusta M1-luokan ajoneuvosta, jonka ensimmäisen käyttöönottovuoden päättymisestä oli kulunut enintään 10 vuotta, kuitenkin niin, että ensimmäinen käyttöönotto oli 1.1.2015 tai sen jälkeen.

Kevytauton kuljettaminen edellytti esityksen mukaan mopoautosäännöksiä vastaavasti AM-luokan ajo-oikeutta. Tavoitteena oli mahdollistaa uusi liikkumisen muoto erityisesti nuorille, 15-17-vuotiaille. Nuoret liikkuvat paljon, ja liikkumiseen he käyttävät usein mopoa tai mopoautoa. Kevytauto toisi näiden rinnalle uuden vaihtoehdon. Esityksen tavoitteena oli lisäksi parantaa erityisesti nuorten liikenneturvallisuutta. Lait ehdotettiin tuleviksi voimaan 1.11.2019. Hallituksen esityksessä todettiin EU-oikeudellisista ongelmista seuraavaa:

"Esitysluonnos on ilmoitettu komissiolle direktiivin (EU 2015/1535) mukaisesti teknisenä määräyksenä. Direktiivin (EU) 2015/1535 mukaan jäsenvaltioiden on toimitettava komissiolle teknisiä määräyksiä koskevat ehdotukset ja jäsenvaltioiden on lykättävä teknistä määräystä koskevan ehdotuksen hyväksymistä kolmella kuukaudella siitä päivästä alkaen, jona komissio on saanut ilmoituksen (odotusaika). Komissio ja jäsenval-

19 Nelipyörät ja kevytautot tuovat mieleen entisaikojen trillat (eli rillat) ja linjaalirattaat. Wikisanakirjan mukaan trillat ovat "kevyet nelipyöräiset hevosajopelit". Ruotsin sanakirjoissa todetaan mm.: "trillor (åld.) fjädervagn med två säten" tai ”öppen fyrhjulig lantlig fjädervagn med ett fram- o. ett baksäte." Linjaalirattaat, joita leikillisesti myös viivoitinrattaiksi on kutsuttu, taisivat ainakin kuvista päätellen olla useimmiten kaksipyöräisiä hevosajopelejä. Niitä käytettiin aikoinaan $\mathrm{mm}$. kyytilaitoksessa, siis linja-ajoissa. Kyytilaitosta varten rakennetut huoneet oli pidettävä kunnossa kyytilaitoksen isännän kustannuksella sitten kun ne täysin valmiina oli annettu hänen haltuunsa. Kestikievaritalossa piti matkustajien tarpeiksi aina olla varalla siistit ja lämpimät ilmanvaihtolaitoksilla varustetut huoneet, sänkyjä makuuvaatteineen, liinavaatteita ja pöytäkaluja ynnä muita tarvittavia talouskaluja, ruoka-aineita, kynttilöitä ja polttopuita, kauroja tai ohria ja olkia sekä talli ja kalustovaja. Kyyditsevillä tuli kyyditysten toimittamista varten olla tarvittava määrä kelvollisia linjaalirattaita, tyynyjä ja jalkapeitteitä, rekiä lämpimine vällyineen sekä muita ajokaluja ja, silloin kuin venekyytiä tehtiin, kelvollisia veneitä. 
tiot voivat esittää teknistä määräystä koskevan ehdotuksen toimittaneelle jäsenvaltiolle huomautuksia; tämän jäsenvaltion on otettava esitetyt huomautukset myöhemmässä teknisen määräyksen valmistelussa mahdollisuuksien mukaan huomioon. Edellä mainittuna kolmen kuukauden odotusaikana komissio on esittänyt esitysluonnoksesta huomautuksensa.

Komissio on muun muassa huomauttanut, että jotta kevytautot kuuluisivat EU:n traktoriluokkaan (T-luokka), niillä pitäisi näin ollen olla teknisiä ominaisuuksia, joiden ansiosta niillä pystyisi vetämään, työntämään, kuljettamaan ja käyttämään tiettyjä vaihdettavissa olevia laitteita, kuten vetokoukku ja mukautetut puskurit. Lakiluonnoksessa säädetään, että uusi ajoneuvoryhmä luotaisiin EU:n luokituksen mukaiseen luokkaan T1. Asetuksen (EU) N:o 167/2013 4 artiklassa säädetään, että T1-luokkaan kuuluvien traktoreiden painon on oltava yli 600 kilogrammaa, mutta tätä vaatimusta ei mainita lakiluonnoksessa.

Komissio on myös huomauttanut, että alkuperäisen ajoneuvon valmistaja ei olisi enää vastuussa siitä hetkestä alkaen, jona ajoneuvo muunnettiin kevytautoksi, vaikka se palautettaisiin alkuperäiseen tilaansa M1-luokan ajoneuvoksi.

Lisäksi komissio on kiinnittänyt huomiota esityksen turvallisuus- ja ympäristöongelmiin, joita ajoneuvon muuttamisesta saattaisi aiheutua. Huomautuksen mukaan M1-luokan ajoneuvojen vääntömomentti saattaa aiheuttaa turvallisuusongelmia, jos sitä ei mukauteta muunnetuille kevytautoille sopivaksi. Nopeudenrajoittimen virittämistä koskevaa riskiä, jolloin "traktorilla" ajettaisiin suurella nopeudella, ei myöskään voida sulkea pois. Komission mukaan ehdotettu ratkaisu, jossa henkilöautoon (M1) asennettaisiin nopeudenrajoitin, merkitsisi, että muunnetun ajoneuvon nopeus olisi rajoitettu nopeuteen, jolla sitä ei ole suunniteltu ajettavaksi koko sen käyttöiän ajan. Tämä aiheuttaa komission mukaan epävarmuutta ajoneuvojen päästöistä sekä muunnettujen dieselautojen pakokaasujen jälkikäsittelyjärjestelmän tehokkuudesta.

Komissio on myös ollut huolissaan mahdollisesta EU:n luokituksen mukaisten luokkien L1e-B (mopo) ja L6e-B (mopoauto) ajoneuvojen markkinoiden vääristymisestä. Näiden ajoneuvojen valmistajat, jotka ovat pääasiassa eurooppalaisia, joutuisivat epäedulliseen asemaan EU:n markkinoilla muihin L-luokan ajoneuvoihin verrattuna.

Komission mukaan yksittäishyväksynnällä ei saisi vääristää EU:n tyyppihyväksyntää koskevalla lainsäädännöllä säädettyjä tasapuolisia toimintaedellytyksiä.

Komission huomautuksessa on ajoneuvoteknisten harmonisointia koskevien kysymysten lisäksi kiinnittänytetty huomiota esityksen ajokorttidirektiivin mukaisuuteen. Ajokorttidirektiivin mukainen AM-luokan ajokortti antaa luvan asetuksen (EU) N:o 168/2013 1 artiklan 2 kohdan $\mathrm{f}$ alakohdassa määritettyjen kevyiden nelipyörien ajamiseen. Komissio on todennut, että ilmoitusluonnoksella luotava uusi T1-luokkaan kuu- 
luva ajoneuvoryhmä ei ole kyseisessä asetuksessa säädettyjen "kevyiden nelipyörien" (luokka L6e) yhteisten luokitusperusteiden mukainen eikä ajokorttidirektiivissä tarkoitetulla AM-luokan ajokortilla voi ajaa ilmoitusluonnoksessa tarkoitettuja T1-luokkaan kuuluvia uuden ajoneuvoryhmän ajoneuvoja.

Lopuksi komission huomautuksessa todetaan, että ilmoitetun esitysluonnoksen T1-luokkaan kuuluvat uuden ajoneuvoryhmän ajoneuvot eivät ole ajokorttidirektiivin 4 artiklan 4 kohdassa säädetyn "maataloustai metsätraktorin" määritelmän mukaisia, minkä vuoksi ne katsotaan kuuluviksi "moottoriajoneuvoihin". Direktiivissä olevan traktoreiden määritelmän mukaisesti matkustajien tai tavaroiden kuljettaminen tiellä on traktoreiden toissijainen tarkoitus, kun taas ilmoitusluonnoksessa kaavaillut, T1-luokkaan kuuluvan uuden ajoneuvoryhmän ajoneuvot on tarkoitettu ensisijaisesti henkilöiden kuljettamiseen. Komissio on sen vuoksi katsonut, että ilmoitusluonnos olisi saatettava direktiivin ajokorttidirektiivin 2006/126/EY mukaiseksi.

Esitysluonnosta ei ole muutettu komission huomautusten perusteella. Ehdotusluonnoksen mukaan kevytauto kuuluisi T1-luokkaan, johon kuuluvat 14 \$:n mukaan maa- ja metsätaloudessa käytettäväksi tarkoitetut pyörillä tai telaketjuilla varustetut ajoneuvot, joiden pienin raideväli on vähintään 1150 millimetriä ja omamassa ajokuntoisena yli 600 kiloa. Näin ollen ajoneuvon omamassan tulee ajokuntoisena olla komission huomautuksessa esitetyn mukaisesti yli 600 kiloa, kuten maa- ja metsätaloudessa käytettävien ajoneuvojen hyväksynnästä ja markkinavalvonnasta annetussa Euroopan parlamentin ja neuvoston asetuksessa (EU) 167/2013 edellytetään. Vetokoukkuvaatimusta tai muita T1-luokan teknisiä vaatimuksia ei ole esitykseen lisätty, koska ehdotettavien kevytautojen tarkoitettu käyttö ei sitä edellytä eikä mainittu EU:n asetus (EU) 167/2013 sitä nimenomaisesti edellytä. Mainitun asetuksen ja ajokorttidirektiivin mukaan traktorit on tarkoitettu erityisesti vetämään, työntämään, kuljettamaan tai käyttämään tiettyjä työkaluja, koneita tai perävaunuja, joita käytetään maa- tai metsätaloustöissä ja joita vain toissijaisesti käytetään matkustajien tai tavaroiden kuljettamiseen tiellä taikka matkustajien tai tavaroiden kuljettamiseen käytettyjen ajoneuvojen vetämiseen tiellä. Muun muassa ajoneuvon rakennetta ja ominaisuuksia koskevia tarkempia teknisiä vaatimuksia voidaan ajoneuvolain 27a \$:n 2 momentin nojalla antaa Liikenteen turvallisuusviraston määräyksellä.

Maa- ja metsätaloudessa käytettävien ajoneuvojen hyväksynnästä ja markkinavalvonnasta annetun Euroopan parlamentin ja neuvoston asetuksen (EU) 167/2013 mukaisiin tyyppihyväksyttyihin T-luokan ajoneuvoihin kuuluu ajoneuvoja, joita voidaan katsoa ominaisuuksiensa perusteella käytettävän ensisijaisesti matkustajien tai tavaroiden kuljettamiseen tiellä. Nämä ajoneuvot on katsottu T-luokkaan kuuluviksi sillä perusteella, että ne täyttävät traktoreita koskevat tekniset vaatimukset. 
Liikenne- ja viestintäministeriön näkemyksen mukaan kevytautot täyttävät T-luokkaa koskevat tekniset vaatimukset, jolloin niihin ei sovelleta ajokorttidirektiiviä. T-luokkaa koskevat ajokorttivaatimukset voidaan asettaa kansallisessa lainsäädännössä. Ehdotuksen mukaan T1-luokkaan kuuluvan kevytauton kuljettamiseen vaadittaisiin AM-luokan ajokortti. Myös Ruotsissa henkilöautoista muutetun A-traktorin kuljettaminen on sallittua AM-luokan ajokortilla.

Kevytautojen ei katsota myöskään vääristävän markkinoita, koska kevytautot ovat henkilöautoista muutettuja ajoneuvoja ja niiden määrän ei arvioida olevan merkittävä.

Myös muut komission esittämät huomautukset on tiedostettu valmistelussa, mutta esityksen tavoitteiden saavuttamiseksi ehdotetut muutokset on arvioitu tarkoituksenmukaisimmaksi ja Euroopan unionin lainsäädännön mukaiseksi toteuttamistavaksi siitä huolimatta, että ehdotetut lainmuutokset eivät komission huomautuksessaan esittämän näkemyksen mukaisesti täyttäisi unionin lainsäädännön vaatimuksia. Esityksen tavoitteena on mahdollistaa uusi liikkumisen muoto nuorille, 15-17-vuotiaille, sallimalla nopeusrajoitettu henkilöauto nuorten käyttöön. Henkilöauto tarjoaisi rakenteeltaan modernin ja vankemman vaihtoehdon mopoautoille nuorten liikkumisen tukemiseksi Suomen olosuhteissa. Esityksen tavoitteena on parantaa erityisesti nuorten liikenneturvallisuutta. Nuoret liikkuvat paljon mopoilla ja mopoautoilla, joista varsinkin mopojen turvallisuus onnettomuustilanteissa on henkilöautoa heikompi."

Nuorten ajopeleiksi maanteillä tarkoitettuja nopeusrajoitettuja henkilöautoja ei voida katsoa sellaisiksi ajoneuvoiksi, joita direktiivin määritelmän mukaan "käytetään maa- tai metsätaloustöissä ja joita vain toissijaisesti käytetään matkustajien tai tavaroiden kuljettamiseen tiellä taikka matkustajien tai tavaroiden kuljettamiseen käytettyjen ajoneuvojen vetämiseen tiellä”. Ensisijaisesti matkustajien kuljettamiseen tiellä tarkoitetut ajoneuvot eivät edes väljästi ja hyväntahtoisesti tulkiten sovi traktori-määritelmään, joten kansallista sääntelyä voidaan pitää EU-oikeuden vastaisena; tässä vaadittaisiin direktiivin muuttamista.

Hankkeen puolustajat ovat maininneet Ruotsissa 1930-luvulta asti käytössä olleet EPA-traktorit ja niiden tilalle tulleet A-traktorit. A-traktori on kaksipaikkainen vetokoukullinen ajoneuvo, jonka tavaratilaa ei ole katettu. Tällaisen ajoneuvon omamassan pitää olla ainakin $2000 \mathrm{~kg}$ (tai perävaunun vetokyvyn vähintään $1000 \mathrm{~kg}$ ). Kysymyksessä on siis varsin raskas ajoneuvo, jonka suurin rakenteel- 
linen nopeus on vain $30 \mathrm{~km} / \mathrm{h}$; näitä ajoneuvoja on kuitenkin yleisesti mutta luvattomasti muutettu niin, että niillä pääsee selvästi kovempaa. Muualla kuin Ruotsissa ei tällaisia ajoneuvoja liene käytössä.

Suomessakin olisi voitu ottaa käyttöön myös raskasta nelipyörää eli "kevytautoa" (ajoneuvoluokka L7e) kuljettamaan oikeuttava B1-ajokortti, jossa ajajan alaikäraja olisi 16 vuotta. Tuollaisen ajoneuvon enimmäisnopeus olisi mahdollista rajoittaa esimerkiksi niin, että se olisi 60 km/h. Raskaan nelipyörän maksimaalinen omamassa on kuitenkin niin alhainen, ettei henkilöautoa käytännössä voi muuttaa raskaaksi nelipyöräksi. Kevyimpienkin henkilöautojen massa on satoja kiloja suurempi kuin raskaitten nelipyörien sallittu massa.

Valiokunta muutti kevytauton määritelmää siten, että kevytauton suurin rakenteellinen nopeus rajoitettiin 60 kilometriin tunnissa hallituksen esityksessä ehdotetun 45 kilometrin sijasta. Valiokunnan mukaan muutoksella oli merkittäviä liikenteen sujuvuutta edistäviä vaikutuksia ja positiivisia vaikutuksia myös ympäristön kannalta. Valiokunta myös korotti kevytautona pidettävän sähköauton enimmäispainon 1800 kiloon.

Liikenne- ja viestintävaliokunnass $\mathrm{a}^{20}$ kiinnitettiin myös huomiota esityksen ongelmallisuuteen EU-oikeuden kannalta. Valiokunta totesi mietinnössään (LiVM 33/2018):

"Valiokunnan saaman selvityksen mukaan liikenne- ja viestintäministeriö on käynyt Euroopan unionin komission kanssa keskusteluja esityksen suhteesta EU-lainsäädäntöön komission ehdotuksesta antaman huomautuksen jälkeen. Saadun selvityksen mukaan ajokorttidirektiiviä tullaan arvioimaan uudelleen ns. kolmannen liikkuvuuspaketin yhteydessä, missä yhteydessä voidaan ottaa huomioon erilaisia vaihtoehtoja. Ministeriön käytyjen keskustelujen pohjalta tekemän arvion ja valiokunnan ministeriöltä saaman selvityksen mukaan esitys voidaan tässä vaiheessa hyväksyä esitetyssä T-ajoneuvoluokkaan ja AM-luokan ajo-oikeuteen perustuvassa muodossa."

Laki säädettiin äänin 167-12 valiokunnan esittämässä muodossa, ja sen oli tarkoitus tulla voimaan 1.11.2019. ${ }^{21}$ Euroopan komissio

20 Jyrki Kasvi (vihr) ja Satu Taavitsainen (sd) jättivät mietintöön vastalauseen. He olisivat hylänneet hallituksen esityksen.

21 Vihreät (11) ja yksi sosialidemokraatti äänestivät vastaan. 
lähetti kuitenkin elokuun alussa 2019 Suomen ulkoministerille kirjeen, josta ilmeni, että komissio ei hyväksy Suomen säätämää lakia. Hallituksen esityksessä 21/2019 lain voimaantuloa ehdotettiin lykättäväksi vuodella toivoen, että sinä aikana Suomen ja EU:n säännökset voidaan sovittaa yhteen.

Perussuomalaiset, kokoomuslaiset ja kristillisdemokraatit vaativat eduskunnassa perustuslakivaliokunnan lausunnon hankkimista asiasta, mutta he hävisivät äänestyksessä. ${ }^{22}$ Liikenne- ja viestintävaliokunnan enemmistö puolsi hallituksen esityksen hyväksymistä; vastaan äänestivät vain perussuomalaiset. ${ }^{23}$ Eduskunta hyväksyi hallituksen esityksen äänin 105-35 (poissa 59). Vastaan äänestivät perussuomalaiset, kristillisdemokraatit ja osa kokoomuslaisista.

Suomen säännösten ja EU:n säännösten yhteen sovittaminen vaatisi varmaankin EU-direktiivin muuttamista sellaiseksi, että Suomessa sallittaisiin alaikäisten kuljetettavaksi tällaiset ajopelit. ${ }^{24}$ Ei tavalliseen henkilökuljetukseen maantiellä tarkoitettu auto muutu pääasiassa maa- ja metsätaloustöihin käytettäväksi traktoriksi esimerkiksi rajoittamalla sen nopeutta, asentamalla vetokoukku ja poistamalla takapenkki. ${ }^{25}$

22 Perustuslakivaliokunnan lausunnon hankkiminen olisi ollut asian käsittelyn tarpeetonta hidastamista. Omaisuudensuojan tai muunkaan perusoikeuden vastaisena ei kukaan valtiosääntöoikeuden asiantuntija voine pitää sitä, että eduskunta lykkää säätämänsä lain voimaantuloa, kun pyrkimyksenä on saada laki Suomea sitovien EU-säädösten mukaiseksi.

23 Perussuomalaiset vastustivat lain voimaantulon lykkäystä, koska lykkäys vaikuttaa negatiivisesti monen PK-yrittäjän arkeen myös Suomessa. Muutoinkin perussuomalaiset ilmaisivat vastustavansa lainvalmistelua, jossa avataan eduskunnan jo hyväksymä lakipaketti.

24 Eurooppaoikeuden professori Juha Raitio totesi 27.9.2019 Yle Uutisissa, että kevytautolait tulisi kumota. Hän ei muista vastaavaa tapausta, jossa Suomi olisi jatkanut lakien eteenpäin viemistä saatuaan komissiolta yhtä selvän tyrmäyksen niitä vastaan. Raitio kummastelee, että Suomi selvittelee sitä, miten komission kannan voisi kiertää. Hänen mukaansa säädöksiä tulisi muuttaa EU-tasolla, koska tulkintaa ohjaa keskeisesti EU:n ajokorttidirektiivi.

25 Varustelukysymys tuo mieleen maastoautot, joilla aikoinaan oli edullinen verokohtelu. Tuollaisia autoja väitettiin käytettävän varsinkin metsätaloudessa työautoina. Esimerkiksi vuonna 1961 säädetyssä autoverolaissa maastoautoksi määriteltiin "sellainen henkilöauto, jossa oli maastossa kulkemista varten nelipyöräveto, maastovaihdelaatikko ja erityinen voimansiirtoakseli työkoneiden käyttämistä varten”. Ks. tarkemmin Esko Linnakangas - Leila Juanto, Tieliikenneverot (2000) s. 59 ss. 
Direktiivin muuttaminen ei välttämättä onnistu Suomen haluamalla tavalla liikenneturvallisuuteen ja pitkälle edenneeseen valmisteluun viittaamalla. Vilpittömään mieleen vetoaminenkaan tuskin vakuuttaa, kun Suomi on varoituksista välittämättä ottanut tietoisen riskin. Onkin hyvin mahdollista, että kevytautosäännöksemme kumotaan ennemmin tai myöhemmin, viimeistään EU-tuomioistuimen tuomion jälkeen. ${ }^{26}$ Jos nopeusrajoitettuja autoja koskeva sääntely joskus tulee voimaan, olisi syytä muuttaa näiden ajoneuvojen nimeksi esimerkiksi "hidasautot", jota termiä STT ryhtyi syyskuun lopulla 2019 käyttämään uutisoinnissaan. Kysymyksessä ovat hitaat mutta eivät erityisen kevyet autot.

Kevytautolakien kumoamiseksi on tehty myös kansalaisaloite ${ }^{27}$ 30.11.2019 (Maria Granskog, Anders Granskog, Alex Johansson, Pia Rouhiainen ja Rauno Niemenkari). Siinä esitetään lukuisia muita kuin EU-oikeudellisia perusteita kevytautolainsäädäntöä vastaan.

Kansalaisloitteessa todetaan, että kevytautot lisäävät nuorten kuljettajien aiheuttamia henkilövahinkoihin johtavia onnettomuuksia, vaarantavat kaikkien tienkäyttäjäryhmien turvallisuutta ja lisäävät yksityisautoilun aiheuttamia liikenteen päästöjä.

Kevytauto on normaalirakenteinen henkilöauto, jonka enimmäisnopeudeksi on rajoitettu $60 \mathrm{~km} / \mathrm{h}$. Kevytautolla saa vetää perävaunua, ja se voi olla rekisteröity 9:lle henkilölle. Lisäksi kevytauto voi olla jopa painavampi kuin monet tavalliset henkilöautot, sillä kevytauton painorajaksi on asetettu $1500 \mathrm{~kg}$ vaikka keskimääräinen liikenteessä oleva henkilöauto painaa vain $1372 \mathrm{~kg}$.

Kevytauto on tarkoitettu 15 vuotta täyttäneille eli peruskoulun 8.-9.-luokkalaisille nuorille vapaa-ajan liikkumista varten. Heiltä ei vaadita henkilöauton ajokorttia, sillä henkilöauton ajokorttia ei voida myöntää 15-vuotiaalle. Kevytautoa saa kuljettaa mopoauton (AM121) ajokortilla eikä autokoulua tarvitse käydä, sillä AM-kortin suorittamiseen ei liity laisinkaan pakollista ajo-opetusta.

Nuoret kuljettajat ovat liikenteen merkittävin riskiryhmä. Heidän kohdallaan loukkaantumisten ja liikennekuolemien lukumärä on erityisen korkealla nimenomaan 15-vuotiaana mopoilun alkaessa sekä 18-vuotiaana henkilöautolla ajamisen alkaessa. Liikenneonnettomuus on 15-19-vuotiaiden yleisin kuolinsyy. Syynä nuorten kuljettajien henkilö-

26 Ks. myös netissä olevat lausuntoni liikenne- ja viestintäministeriölle.

27 Kansalaisaloitejärjestelmästä ks. jäljempänä luku 7. 
vahinkojen huippulukemiin ei tutkimusten mukaan ole kokemattomuus, vaan kuljettajien nuori ikä. Sosiaalinen paine vaikuttaa ajokäyttäytymiseen haitallisesti erityisesti nuorten kuljettajien kohdalla. Riskinotto ja vaarallinen ajotapa lisääntyvät heidän kohdallaan voimakkaasti juuri silloin kun auto on täynnä muita nuoria. Heidän lisäkseen osallisiksi onnettomuuksiin saattavat joutua myös kaiken ikäiset muut ihmiset, eivät ainoastaan kevytauton sisällä matkustavat ja sitä itse kuljettavat nuoret.

Kevytautot painavat saman verran kuin tavalliset henkilöautot, eikä niiden kiihtyvyyttä ole rajoitettu. 2010-luvulla käyttöön otettujen henkilöautojen keskiteho on 132 hv. Se on vaarallinen määrä hevosvoimia 15-vuotiaalle kuljettajalle. Kun tällaisella autolla törmätään esimerkiksi jalankulkijaan tai pyöräilijään, ovat seuraukset usein hyvin vakavia. Onnettomuustilanteessa liike-energian määrä on suoraan verrannollinen törmäävän ajoneuvon massaan. Nykyiset mopoautot eivät vastaavissa törmäystilanteissa ole läheskään yhtä vaarallisia kuin tulevat kevytautot, sillä törmäyksessä kevyttä liikennettä kohtaan niiden tuhovoima on pienempi, mikä suoraan alentaa kuolemanriskiä.

Kevytautoksi rekisteröity henkilöauto, jonka nopeus on $60 \mathrm{~km} / \mathrm{h}$, on varsinkin raskaalle liikenteelle vaikea ohitettava. Suomen tieliikenteessä kuolemaan johtaneet onnettomuudet tapahtuvat yleisimmin joko törmäyksissä raskaan ajoneuvon kanssa tai kohtaamisonnettomuuksissa, toisin sanoen maantieliikenteen ohitustilanteissa. Kevytauton korirakenne ei näissä tilanteissa riitä pelastamaan ihmishenkiä, vaikka se onkin mopoauton korirakennetta vahvempi. Muuta liikennettä huomattavasti hitaammin liikkuvien ajoneuvojen runsas lisääntyminen Suomen maanteillä aiheuttaisi liikenteen jonoutumista, vaarallisia ohitustilanteita ja lisäisi ruuhkia.

Kevytautojen käyttöönotto tulisi varsinkin nuorten keskuudessa vähentämään merkittävästi sekä pyöräilyä että joukkoliikenteen käyttöä. Liikenteeseen tulevien uusien kevytautojen lukumäärän arvioidaan kasvavan moninkertaiseksi verrattuna nykyiseen mopoautojen määrään. Viime vuonna (2018) Suomessa oli 7097 rekisteröityä mopoautoa. Uusien kevytautojen lukumääräksi arvioidaan noin 25 000-41 000, joten sekä liikennesuoritteen että päästöjen määrä tulisi kasvamaan merkittävästi.

Liikkumisessa tulee Suomen ympäristötavoitteiden mukaan suosia joukkoliikennettä, jalankulkua ja pyöräilyä. Liikenne- ja viestintäministeriön liikenteen ilmastopolitiikan työryhmän loppuraportin mukaan henkilöautoilla ajettavat kilometrit eivät saa kasvaa vuoden 2025 jälkeen, jos haluamme, että Suomi on hiilineutraali vuonna 2045. Henkilöautojen ajosuoritetta ei näin ollen voida ryhtyä kasvattamaan kymmenillä tuhansilla uusilla fossiilisia polttoaineita käyttävillä kevytautoilla.

Kaikissa erilaisissa skenaarioissa todetaan, että nopeudeltaan rajoitetun henkilöauton eli niin sanotun kevytauton/hidasauton käyttöönotto kasvattaisi nuorten liikennesuoritetta, aiheuttaisi haittaa liikenteen suju- 
vuudelle, heikentäisi kaikkien tienkäyttäjäryhmien liikenneturvallisuutta, lisäisi yksityisautoilua ja kasvattaisi liikenteen aiheuttamien ympäristöhaittojen määrää. Siksi tässä kansalaisaloitteessa vaaditaan kaikkien jo aikaisemmin hyväksyttyjen kevytautolakien kumoamista ja kyseisen lainsäädäntöprosessin lopettamista.

\subsubsection{7-vuotiaiden poikkeusluvat}

Heinäkuun alusta 2018 lainmuutoksella helpotettiin alaikäisten mahdollisuuksia saada B-ajokortti hakemuksesta poikkeusluvalla. Aikaisemmin vaadittiin erityisen painavia syitä, nyt riittävät erityiset syyt. Lupa myönnetään kokonaisharkinnan perusteella arvioiden nuoren omaa kulkemis- tai ajokorttitarvetta. Erityisiä syitä ovat esimerkiksi työhön, työharjoitteluun, kouluun tai säännölliseen ja tavoitteelliseen harrastukseen pääsemistä hankaloittavat olosuhteet:

- pitkät etäisyydet kodin ja työ-, työharjoittelu-, opiskelu- tai harrastuspaikan välillä

- puuttuvat joukkoliikenneyhteydet

- harvoin kulkevista joukkoliikenneyhteyksistä johtuva vähintään tunnin kestävät kokonaismatka-ajat per suunta tai yli tunnin kestävät julkisen liikenteen odotusajat useimpina päivinä viikossa.

Lisäksi arvioinnissa voidaan ottaa huomioon:

- ennalta arvaamattomat muutokset samassa taloudessa asuvan perheen tilanteessa (esim. vanhemman tai muun ajokortillisen perheenjäsenen sairastuminen tai kuolema)

- samassa taloudessa asuvan perheen toimentulon turvaamiseen ja välttämättömien asioiden hoitamiseen liittyvät kulkemis- tai kuljettamistarpeet.

Hakemuslomakkeen liitteenä on oltava poikkeusluvan hakemisen tarkoituksesta riippuen jokin seuraavista liitteistä:

- opiskelutodistus, kun poikkeuslupaa haetaan koulumatkojen kulkemiseen etäisyyden tai puuttuvien joukkoliikenneyhteyksien takia, sisältäen tiedon opiskelupaikan sijainnista (toimipiste ja/tai osoite) 
- oppilaitoksen todistus liikkumistarpeesta, kun poikkeuslupaa haetaan opintoihin kuuluvaa työharjoittelua tai työpaikalla oppimista varten

- työnantajan todistus työpaikasta tai työharjoittelusta, kun poikkeuslupaa haetaan työmatkojen kulkemiseen etäisyyden tai puuttuvien joukkoliikenneyhteyksien takia

- työnantajan todistus liikkumistarpeesta, kun poikkeuslupaa haetaan työssäkäyntiä tai työharjoittelua varten ja ajokorttitarve liittyy työn suorittamiseen

- seuran, valmentajan, yhdistyksen, opiston tai muun vastaavan tahon antama todistus säännöllisestä ja tavoitteellisesta urheilutai muusta harrastustoiminnasta

- lääkärinlausunto tai muun terveydenhuollon ammattihenkilön laatima todistus, josta ilmenevät hakijan tai hänen läheisensä terveydentilan aiheuttamat rajoitteet liikkumiseen ja välttämättömien asioiden hoitamiseen, kun poikkeuslupaa haetaan välttämättömien matkojen tekemiseksi johtuen hakijan tai hänen läheisensä terveydentilasta

- muu selvitys (esim. huoltajan vapaamuotoinen selvitys) välttämättömästä kulkemistarpeesta.

Poikkeuslupahakemuksia on jo tehty erittäin paljon, ja lähes kaikki hakemukset on hyväksytty. Henkilöauton ajokortin myöntämisen vähimmäisikä olisikin mielestäni turhan byrokratian välttämiseksi syytä Suomessakin alentaa 17 vuoteen ilman tarveharkintaa, nopeusrajoitinta tai nopeusrajoituslätkää. Ajokorttidirektiivikin sallii tämän. 


\section{3 \\ Perintöverokarhun \\ peijaiset?}

\subsection{Varhaisimmat perintöverotukset}

Eufratin ja Tigrisin varteen virisi vuoden 3200 eaa. tienoilla sumerilainen kulttuuri, jossa kirjoitustaidon lisäksi kunnostauduttiin verokeksinnöillä. Vastaava yhteisö syntyi sen jälkeen Niilin vaikutuspiiriin Egyptiin. Roomassa perintövero otettiin käyttöön keisari Augustuksen aikana (31 eaa.-14 jaa.).

Augustuksen perintövero oli $5 \%$ perintöosuuden arvosta, ja siitä oli vapautettu lähiomaisten saamat perinnöt ja pienet perinnöt. Veroa arvosteltiin ankarasti ja kapinallakin uhattiin, mutta vero tuli hyväksytyksi, kun vaihtoehtona olisi ollut vieläkin vastenmielisempi, provinsseissa jo kannettu maavero.

Samoihin aikoihin perintöverotuksen kanssa alkoi Roomassa yleistyä tapa testamentata omaisuutta keisarille. Augustus saikin huomattavia omaisuuksia myös sitä kautta. Roomaa vuosina 37-41 hallinnut keisari Caligula, joka piti itseään jumalana, pakotti senaattoreita itsemurhiin, kidutti uhrejaan hengiltä ja myös teloitutti rikkaita, jos nämä eivät suostuneet testamenttaamaan omaisuuttaan hänelle.

Vuonna 212 Rooman perintövero nostettiin 10 \%:iin ja verovapaudet poistettiin. Jatkossa perintövero kuitenkin osoittautui väestön keskuudessa niin epäsuosituksi, että saman vuosisadan kuluessa siitä luovuttiin kokonaan. 


\subsection{Perintöverotus keskiajalta Suomen itsenäistymiseen}

\subsubsection{Keskiaika ja kirkon vaatimukset}

Kirkko opetti, että varmin keino ikuisen autuuden saamiseksi oli käyttää omaisuutensa kirkon hyväksi. Kanonisen oikeuden mukaan oikeutta testamentata kirkolle oli rajoitettu ainoastaan sikäli, että lapsia ei saanut tehdä täysin perinnöttömiksi vaan heille oli varattava lakiosa. Tämä sääntö lausuttiin seuraavasti: Se, jolla on yksi poika, tehköön Kristuksesta toisen, ja se, jolla on kaksi poikaa, tehköön Kristuksesta kolmannen. Ellei vainajalla ollut lapsia, hän sai testamentata koko omaisuutensa kirkolle.

Ruotsissa vapaalla miehellä oli alkuaan valta vapaasti määrätä omaisuudestaan. Mutta kun lahjoitukset kirkon hyväksi olivat saaneet huomattavan merkityksen, kirkon säännöt kohtasivat vastarintaa kansan taholta. Esimerkiksi Uplannin lain mukaan saattoi sielun autuudeksi kirkolle antaa perimysmaasta kymmenennen osan ilman lähimmän perillisen suostumusta, mutta perillisen suostumuksella sai tähän tarkoitukseen antaa miten paljon tahansa. Ansiomaata ja irtaimistoa sai antaa kirkolle täysin vapaasti. Testamentista käytettiinkin nimitystä sialagift, sielun autuudeksi annettu lahja.

Keskiajalla kannetun pääkymmenyksen eli pääomakymmenyksen ( hufwudtionde) voitiin katsoa sisältävän tietynlaisen ajatuksen perinnön verottamisesta. Tuolla kymmenyksellä tarkoitettiin kirkon vaatimusta, että jokaisen hyvän kristityn tuli ainakin kerran elämänsä aikana suorittaa kymmenesosa varallisuudestaan kirkolle.

\subsubsection{0-luvulta Ruotsin vallan loppuun}

Varsinainen perinnön verotusta koskeva lainsäädäntö Ruotsissa alkoi kehittyä pääasiassa leimaverosäännösten pohjalta. Ensimmäisessä leimaveroasetuksessa vuonna 1660 säädettiin, että yhteisen ja köyhän kansan testamentit oli laadittava 16 äyrin ja arvohenkilöiden testamentit 2 hopeataalerin leimapaperille, ja että pesäluettelot ja perinnönjakokirjat oli kirjoitettava 8 tai 16 äyrin tahi 1 tai 2 hopeataalerin 
leimapaperille sen mukaan, kenelle omaisuus oli tuleva. Viimeisessä leimaveroasetuksessa, joka annettiin Suomen ollessa Ruotsin yhteydessä (v. 1803), pesäluetteloiden ja perinnönjakokirjojen leimaverokin oli jo säädetty riippuvaksi pesän säästöstä.

Toisesta jäämistöä kohtaavasta tietynlaisesta perintöverosta oli säännöksiä vuonna 1698 annetussa asetuksessa kerjäläisistä, köyhistä, kulkureista ym. Siinä säädettiin, että kun jäämistö joko perittiin tai käytettiin velkojen maksuun, niin pesän varoista oli annettava $1 / 8 \%$ köyhille. Lisäksi märätttiin, että kaikkien testamentinsaajien tuli testamentatusta määrästä tai sen arvosta antaa köyhille 0,5 \%. Säännökset olivat meillä osittain voimassa peräti vuoden 1980 loppuun.

Edellistä lähellä oli kuolinpesäkalustoprosentti eli oikeusviraston prosentti. Sitä kannettiin valtiolle vuodesta 1752 lähtien 0,25 \% ritaristoon, aateliin tai pappis- tai porvarissäätyyn kuuluneen henkilön pesän säästöstä.

Myös suostuntaveroasetuksissa oli säännöksiä perinnön ja testamentin verottamisesta. Ensimmäinen tällainen säännös annettiin vuonna 1789. Sen mukaan kaikista rahamääristä, jotka testamentilla annettiin muille henkilöille kuin puolisolle ja rintaperillisille, oli suostuntaveroa maksettava $1 \%$. Vuoden 1800 suostuntaveroasetuksessa verovelvollisuus ulotettiin muuhunkin testamentilla saatuun omaisuuteen kuin rahaan. Samalla nostettiin suostuntaveron määrä 6 \%:iin. Lisäksi kaikista kuolinpesistä, joissa pesänosakkaina ei ollut puoliso, rintaperilliset, vanhemmat tai sisarukset, tuli omaisuuden säästöstä maksaa suostuntaveroa $2 \%$.

\subsubsection{Suomen autonomian aika}

Suomen ollessa Venäjän yhteydessä kannettiin yhä edellä mainittua vuonna 1698 säädettyä vaivaisprosenttia. Samoin oli suoritettava edellä mainittua kuolinpesäkalustoprosenttia eli oikeusviraston prosenttia. Suostuntaverot sen sijaan lakkautettiin vuonna 1808, mutta ne otettiin muuttuneina jälleen käyttöön vuonna 1865 . Vuosina 1810-1917 voimassa olleissa leimaveroasetuksissa säädettiin perukirjasta edelleenkin otettavaksi leimaveroa pesän säästön perusteella. Testamentilla saadusta omaisuudesta perittiin yhä leimaveroa testamenttia valvottaessa. 
Perukirjasta kannettava leimavero oli pesän säs̈stön perusteella maksettavaksi pantua jäämistöveroa, eikä se kohdistunut perinnönsaajalle perintöosuutena tulleeseen omaisuuden lisäykseen. Testamentista menevä leimavero sitä vastoin koski testamentilla saadun omaisuuden lisäystä, joka lisäksi oli perukirjasta suoritettavan jäämistöveron alainen. Perintöverotus rakentui pääosiltaan sille pohjalle, joka oli syntynyt jo Ruotsin vallan aikana. Vaikka Suomi oli 1900-luvun alussa hyvin maatalousvaltainen, leimaverona kannetun perintöveron tuotosta yli $70 \%$ kertyi kaupungeista.

Kunnallisverotus järjestettiin Suomessa 1800-luvun lopulla. Silloin kunnallisveron alaisiksi säädettiin myös sivuperinnöt ja sivulahjat.

\subsection{Kehitys itsenäisessä Suomessa}

\subsubsection{0- ja 1930-luvut}

Vuoden 1918 valtiopäiville annetun hallituksen esityksen mukaisesti säädettiin laki perintö- ja lahjaverosta, joka oli voimassa 1.7.1919 lukien vuoden 1921 loppuun. Tällä lailla kumottiin aikaisemmat säännökset, jotka koskivat perukirjojen, testamenttien ja lahjakirjojen varustamista leimamerkeillä, sekä kuolinpesäkalustoprosenttia eli oikeusviraston prosenttia koskevat säännökset. Lain mukaan perintövero oli suoritettava perinnön- tai testamentinsaajalle tulevasta osuudesta (perintöosuusvero) eikä siis koko pesään kohdistuvana jäämistöverona. Veron määrämisen toimittivat maalla kruununvoudit ja kaupungissa maistraatti.

Seuraava perintö- ja lahjaverolaki tuli voimaan jo 1.1.1922. Perintöveron määrääminen toimitettiin perintöosuusverona perukirjan taikka poikkeustapauksessa perinnönjakokirjan tai veroilmoituksen perusteella. Perintöveron märääminen siirrettiin perintöverolautakunnille.

Vuoden 1919 perintö- ja lahjaverolaissa veronmaksajat jaettiin neljään veroluokkaan. Keveimpään eli I veroluokkaan kuuluivat rintaperilliset, isä ja äiti, aviopuoliso ja rintaperillisen jälkeläiset. II veroluokassa olivat veli ja sisar sekä veli- ja sisarpuoli. III veroluokassa olivat isän ja äidin vanhemmat sekä veljen, sisaren ja veli- ja sisarpuo- 
len jälkeläiset. IV veroluokkaan kuuluivat kaukaisempaa sukua olevat ja vieraat. Veroluokkajako säilyi samanlaisena vuoden 1921 laissa.

Vuoden 1919 laissa verokanta riippui perintöosuuden suuruudesta ja sukulaisuussuhteesta. I veroluokassa marginaalivero oli enintään $5,5 \%$. Vero kannettiin kolminkertaisena II veroluokassa (korkein marginaalivero siis 16,5\%), III veroluokassa viisinkertaisena (korkein marginaalivero siis $27,5 \%$ ) ja IV veroluokassa seitsenkertaisena (korkein marginaalivero siis 38,5\%).

Vuonna 1921 säädetyn perintö- ja lahjaverolain ylin marginaalivero oli I veroluokassa $11 \%$. II veroluokassa vero oli kolminkertainen, jolloin korkein marginaalivero ylsi $33 \%$ :iin. III veroluokan vero oli nelinkertainen ja ylin marginaalivero siis $44 \%$. IV veroluokassa veroa maksettiin viisinkertaisesti, jolloin ylin marginaalivero oli $55 \%$. Kiinnostavaa oli, että marginaalivero ei ollut korkeimmillaan kaikkein isoimmissa perinnöissä vaan sitä kooltaan edeltäneessä omaisuusryhmässä. Tämä erikoisuus säilyi vuosikymmeniä.

Lisäksi sivuperinnöistä ja sivulahjoista oli maksettava kunnallisveroa.

Perintö- ja lahjaveron osuus valtion verotuloista oli 1920- ja 1930 -luvuilla erittäin pieni $(0,15-0,21 \%)$. Märään saattoivat vaikuttaa varallisuuden vähäinen määrä ja varallisuuden hyvin varovainen arvostus.

\subsubsection{0-luvun alusta 1970-luvun lopulle}

Seuraava, osittain vieläkin voimassa oleva perintö- ja lahjaverolaki säädettiin 1940. Sen alkuperäisissä säännöksissä verovelvolliset jaettiin veroluokkiin seuraavasti:

I: aviopuoliso, lapsi, ottolapsi, isä, äiti, ottovanhemmat ja lapsen tai ottolapsen rintaperillinen

II: veli, sisar ja veli- tai sisarpuoli sekä henkilö, joka vähintään viimeiset 10 vuotta perinnönjättäjän kuolinhetkeen asti oli ollut hänen palveluksessaan ja häntä hoitanut

III: isän ja äidin vanhemmat sekä veljen, sisaren ja veli- tai sisarpuolen jälkeläinen

IV: muut sukulaiset ja vieraat. 
Vuoden 1940 perintö- ja lahjaverolaissa vero oli II veroluokassa kaksinkertainen, III veroluokassa kolminkertainen ja IV veroluokassa viisinkertainen. Ylin marginaalivero oli 1940-luvun alussa I veroluokassa $13 \%$, II veroluokassa $26 \%$, III veroluokassa $39 \%$ ja IV veroluokassa peräti $65 \%$. Vuonna 1942 tuli voimaan suuria perintöjä koskeva lisävero, jonka marginaalivero oli ylimmillään $30 \%$. Näin vero saattoi periaatteessa nousta jopa yli $90 \%$ :n. Kun sivuperinnöistä piti maksaa myös kunnallisvero, vero saattoi periaatteessa nousta noin $100 \%$ :iin, vaikka kunnallisveroäyri tuolloin ei ollutkaan nykyistä tasoa. Oltiin varmaankin lähellä konfiskatorista verotusta, mikä voi herättää pohtimaan perustuslaissa turvattua omaisuudensuojaa. Tosin varojen arvostus oli tuohon aikaan käytännössä varovaista.

Lisäveroa ei määrätty, jos perinnönjättäjä maan ollessa sodassa tai sitä vastaavassa tilanteessa oli saanut surmansa taikka myöhemmin kahden vuoden sisällä oli kuollut sotilaallisen toiminnan johdosta saamaansa vammaan tai tautiin. Lisäveroa ei määrätty enää 31.12.1947 jälkeen.

Perintöveroasteikon ankarin marginaalivero esimerkiksi 1950luvun alussa oli I veroluokassa $13 \%$. II veroluokassa prosenttimäärä oli kaksinkertainen, III veroluokassa kolminkertainen ja IV veroluokassa viisinkertainen. Sivuperinnöillä ja sivulahjoilla oli lisäksi kunnallisvero, joten kokonaisvero saattoi nousta vaikkapa $70 \%$ :iin.

Kun asteikkoja ei muutettu rahanarvon heikentyessä, verotus tiukentui asiallisesti melkoisesti mutta perintö- ja lahjaveron osuus valtion verotuloista säilyi silti hyvin vaatimattomana. Vuonna 1940 se oli $0,22 \%$, vuonna 1945 se oli $0,58 \%$ ja viisi vuotta myöhemmin 0,31\%. Vuodesta 1955 vuoteen 1978 se oli noin $0,4 \%$ :n tasoa.

Vuonna 1978 perintö- ja lahjaveron tuotto oli 137,7 miljoonaa markkaa ja kunnallisveron tuotto sivuperintöjen osalta 48,4 miljoonaa markkaa.

\subsubsection{0-luvun lopulta 2000-luvulle}

Edellä kuvatut neljä veroluokkaa säilyivät vuoden 1979 lainmuutokseen asti. Tuolloin siirryttiin kolmeen veroluokkaan siten, että aikaisemmin III veroluokkaan kuuluneet siirrettiin II veroluokkaan, jolloin III veroluokka tuli koskemaan muita sukulaisia ja vieraita. 
Vuonna 1979 lakiin myös lisättiin huojennussäännökset maatilojen ja yritysten sukupolvenvaihdoksista. Perintö- ja lahjaveron osuus valtion verotuloista oli esimerkiksi vuonna 1988 noin $0,5 \%$ ja vuonna 1992 noin $0,9 \%$.

Lakia muutettiin vuonna 1995 niin, että I veroluokkaan kuului myös sellainen avopuoliso, johon tuloverotuksessa sovellettiin puolisosäännöstä, mikä yleensä edellytti yhteistä lasta. Samalla poistettiin II veroluokasta uskollinen palvelija eli perittävää vähintään 10 vuotta hoitanut henkilö. Luovuttiin myös kunnallisverottamasta sivuperintöjä ja -lahjoja; niitä oli siihen saakka kohdeltu ansiotuloina.

Laki muutettiin vuoden 2007 lopulla niin, että III veroluokasta luovuttiin ja siihen kuuluneet sijoitettiin II veroluokkaan, johon tämän jälkeen kuuluivat myös muut sukulaiset ja vieraat.

Samaa sukupuolta olevat rekisteröidyssä parisuhteessa asuvat on 2000-luvun alusta lukien rinnastettu puolisoihin, ja he kuuluvat siten I veroluokkaan.

Perintö- ja lahjaveron määräksi vuonna 2019 arvioidaan 720 miljoonaa euroa, joka on noin 1,6\% valtion verotuloista. Vaikka perintöja lahjaveromme osuus verotuloista ei ole tätä isompi, se on kansainvälisesti verrattuna erittäin suuri.

\subsection{Kansainvälistä vertailua}

\subsubsection{Tilanne 1800- ja 1900-lukujen vaihteessa}

Englannissa perintöverokanta säädettiin 1,0-8,0 \%:ksi vuonna 1894 ja 7,0-15,0 \%:ksi vuonna 1907. Perintöverotus oli tärkeä myös Ranskassa, jossa verokannaksi säädettiin 1,0-20,5 \% vuonna 1901. Italian perintöveroksi säädettiin $0,1-22,0 \%$ vuonna 1901 . Norjan verokanta vuonna 1905 oli $1,0-10,0 \%$.

Saksassa perintövero oli ensin alueellinen, ja vuoteen 1906 asti se vaihtelikin suuresti. Bremenissä se oli huomattavan korkea, esimerkiksi Preussissa hyvin vaatimaton. Vuonna 1906 Saksaan säädettiin valtakunnallinen perintövero, jonka verokanta oli 4,0-25,0 \%. Vero oli progressiivinen, ja se oli lievin I veroluokassa ja ankarin IV veroluokassa. 


\subsubsection{Tilanne 2000-luvun alun Euroopassa}

\subsubsection{Ruotsi ja muut Pohjoismaat}

Sosiaalidemokraattisen puolueen, ympäristöpuolueen ja vasemmistopuolueen neuvotteluissa vuoden 2005 talousarvioksi sovittiin, että perintö- ja lahjaverosta luovutaan kokonaan, ja hallitus antoi asiasta esityksen, jonka valtiopäivät hyväksyivät.

Perintöveron poistamisen taustalla oli keskustelu, jossa kritiikkiä kohdistettiin siihen, että vero vaikeutti sukupolvenvaihdoksia perheyrityksissä. Lisäksi oli tuotu esiin, että kasvualueilla asuntojen verotusarvot olivat nousseet korkeiksi ja ankaroittaneet verotusta. Myös varojen arvostuksen epäyhtenäisyyteen kiinnitettiin huomiota.

Ruotsi oli vauras maa, ruotsalaisetkin olivat kuolevaisia, Ruotsin veroprosentit olivat korkeita ja maan verotusorganisaatio toimi hyvin. Silti perintöveron tuotto oli Ruotsissa hyvin pieni verrattuna vaikkapa Suomeen. Ilmeisesti Ruotsissa perintöverosuunnittelu oli yleistä, pitkälle kehittynyttä ja aggressiivistakin. Hallituksen mielestä vero oli myös kallis hallinnoida.

Tätä taustaa vasten ja sukupolvenvaihdosten helpottamiseksi noteeraamattomissa yrityksissä perintövero poistettiin kokonaan. Fiskaalinen näkökohta oli merkittävä, kun pohdittiin perintöveron ja varallisuusveron asemaa. Ruotsissa varallisuusveron tuotto oli noin kaksinkertainen perintö- ja lahjaveron tuottoon verrattuna. Sittemmin Ruotsissa on kyllä poistettu myös varallisuusvero.

Norjassa perintöverotus on ollut lievää ja sen tuottokin valtion verotuloista perin vaatimaton, esimerkiksi vuonna 2008 vain $0,18 \%$. Vuonna 2014 Norja poisti perintöveron kokonaan. Tanskan perintöverotus on jäämistöveron ja perintöosuusveron yhdistelmä, ja sen tuotto on kansainvälisessä vertailussa varsin korkea.

\subsubsection{Viro ja Venäjä}

Virossa ei nykyisin ole perintöverotusta. Perityn omaisuuden hankintamenoksi tuloverotuksessa katsotaan siellä nolla, eli koko saatu myyntihinta on veronalaista tuloa. Joitakin poikkeuksia tästä ankarasta säännöstä kuitenkin on, esimerkiksi leskellä hankintamenoksi katsotaan $50 \%$. 
Myös Venäjällä perintöverotus on poistettu. Pidettiin oikeana poistaa vero omaisuudesta, joka luovutetaan perintönä, koska miljardeja dollareita oli piilossa offshore-alueilla ja ne varat eivät periytyneet Venäjällä.

\subsubsection{Muu Eurooppa}

Itä-Euroopassa on muitakin valtioita, jotka ovat vailla perintöverotusta. Sellaisia ovat esimerkiksi Latvia ja Slovakia. Siellä on myös maita, joissa perintöveron osuus valtion verotuloista on suurempi kuin Suomessa, esimerkiksi Serbia (2,8 \%), ja maita, joissa perintöveron osuus verotuloista on jonkin verran pienempi kuin Suomessa (esim. Unkari $0,9 \%$ ) tai hyvin vaatimaton (Puola 0,2 \%) taikka lähes olematon (Kroatia 0,013 \%, Tšekki 0,02 \%). Myös Sloveniassa ja Ukrainassa on perintöverotus, samoin Romaniassa, mutta viimeksi mainitussa ei ole lahjaverotusta.

Itävallassa perustuslakituomioistuin katsoi epäyhtenäisten arvostussäännösten johtavan kansalaisten eriarvoiseen kohteluun ja olevan perustuslain vastaisia. Perintöverotus siellä loppui vuonna 2008. Luopumista helpotti veron vaatimaton tuotto, noin $0,2 \%$ valtion verotuloista.

Myös Saksan perintöverotuksessa on koettu valtiosääntöoikeudellisia ongelmia ja sen vuoksi jouduttu perusteellisesti muuttamaan arvostussäännöksiä. Saksassa perintövero voi nousta korkeaksikin, mutta toisaalta vapaamäärät ovat todella suuria. Veron osuus valtion verotuloista on noin $0,85 \%$ - siis pienempi kuin Suomessa mutta ei aivan mitätön.

Isoa-Britanniaa on pidetty ankarana perintöverottajana, mutta nykyisin veron tuotto valtion verotuloista on vain noin $0,5 \%$. Irlannissa verovapaa alaraja on hyvin korkea.

Belgiassa ja Sveitsissä perintöveron osuus verotuloista vaihtelee alueittain, mutta se on keskimäärin melko korkea. Ranskassa veron suhteellinen osuus valtion verotuloista on suurempi kuin Suomessa, ja Alankomaissa se on Suomen luokkaa. Luxemburgissa perintöveron suhteellinen osuus on selvästi pienempi kuin Suomessa. Ranskassa, Alankomaissa ja Belgiassa ylimmät marginaaliverot ovat olleet hyvin korkeita, alimmassa veroluokassa 30-40 \%:n tasoa ja ylimmässä 60-80\%:n tasoa. 
Portugalissa ei ole varsinaista perintöveroa, mutta siellä kannetaan myös vastikkeettomista luovutuksista varainsiirtoveroa. Näin valtiolle kertyy perinnöistä huomattavat tulot (n. $4 \%$ verotuloista).

Italiassa perintövero on kertaalleen poistettu ja sitten taas palautettu, mutta sen tuotto on ollut miltei olematon. Perintövero on tuottanut valtiolle erittäin vähän myös Kreikassa ja Espanjassa. Kyproksella ei ole perintöverotusta. Maltalla puolestaan on perintöverotus mutta ei lahjaverotusta.

\subsection{Perintöveron puoltajat ja vastustajat}

Olen menettänyt uskoni perintöveron autuuteen ja ikuisuuteen. Jo vuonna 2008 esitin, että asetetaan kaksi toimikuntaa: elvytystoimikunta ja hautajaistoimikunta. Elvytystoimikuntaan pääsisivät perintöverouskossa vahvat, ja tämän toimikunnan tehtävänä olisi esittää keinot perintöverotuksen loistavaksi tulevaisuudeksi. Hautajaistoimikunta, jonka jäsenet valittaisiin uskonsa menettäneistä, ei rajoittuisi arvokkaiden hautajaisten järjestämiseen perintöverolle vaan selvittäisi, miten perintöverotus korvattaisiin muuta pääomaverotusta kehittämällä. Olisin halunnut hautajaistoimikuntaan, mutta sellaista ei asetettu. Hetemäen työryhmä (Verotuksen kehittämisryhmän loppuraportti 2010) suhtautui perintöverotuksen säilyttämiseen suopeasti ja teki vain pieniä kehittämisehdotuksia.

Useimmat verotutkijamme näkevät perintöverossa enemmän hyvää kuin pahaa eivätkä vaadi perintöveron hautaamista. Kielteisemmin perintöveroon taitavat suhtautua perhe- ja jäämistöoikeuden asiantuntijat. Urpo Kangas esimerkiksi toteaa: "Jännite suomalaisen ja eurooppalaisen perintöverojärjestelmän tason välillä alkaa käydä kivulloiseksi. Pitkällä aikavälillä tähän liittyy negatiivisia haittavaikutuksia, mm. harmaata jäämistötaloutta ja varojen siirtämistä ulkomaille." ${ }^{28}$

28 Urpo Kangas, Perhe- ja jäämistöoikeuden alkeet (2012) s. 364. 


\subsection{Perintöveron puolesta ja sitä vastaan esitetyt väitteet}

\subsubsection{Tutkimuskirjallisuudesta}

Perintöverotusta on tutkittu sekä taloustieteissä että oikeustieteessä tavattoman paljon. Sitä on käsitelty laajasti useissa vero-oikeudellisissa väitöskirjoissammekin. Useimmat tutkijat suhtautuvat perintöverotukseen ymmärtäväisesti ja esittävät lähinnä rakentavaa kritiikkiä sen yksityiskohdista.

Monipuolisin analyysi on Juhani Henttulan vuoden 2005 lopulla julkaistussa väitöskirjassa. Siinä esitellään ja arvioidaan kymmenen väitettä perintöveroa vastaan ja kymmenen sen puolesta. ${ }^{29}$ Seuraavassa tarkastelussa on hyödynnetty Henttulan kokoamia näkökohtia, mutta niihin on lisätty kaksi perintöveron puolesta esitettyä näkökohtaa (valtion yliomistusoikeus ja varainsiirtoveron täydentäminen) ja jätetty pois yksi sitä vastaan esitetty lainmuutoksen vuoksi ajankohtaisuutensa suureksi osaksi menettänyt peruste (puoliso- ja alaikäisyysvähennyksen minimaalinen määrä). Lisäksi kaksi toisiaan lähellä olevaa perustetta perintöveron puolesta (pääomatulon verotuksen täydentäminen ja ansiotulon verotuksen täydentäminen) on tässä yhdistetty. Perustelut myös esitetään tässä erilaisessa järjestyksessä ja osittain erilaisin painotuksin kuin Henttulan tutkimuksessa.

\subsubsection{Perintöveron puolesta}

\subsubsection{Pitkä historia - hieno perine}

Juhani Henttula esittelee yhtenä perintöveroa puoltavana näkökohtana perintöverotuksen historiallisen taustan ja sen suhteen tähän päivään. Hän toteaa, että perintöverotus on vanha veromuoto, jolla on hienot perinteet. Perintöverotuksen taustat ovat todella kaukana historiassa. Perintöverotuksen poikkeuksellisen pitkän historian tarkastelu osoittaa Henttulan mukaan, että tämän veromuodon teoreettiset perusteet eivät ole hävinneet tänäkään päivänä; kuten Rooman

29 Juhani Henttula (2005) s. 172-189. 
valtakunnassa tehdyt ratkaisut osoittavat, ongelmat ja veroasteikot ovat olleet ainakin osittain vastaavia jo noin 2000 vuotta sitten.

Kaikki tuskin pitävät perintöverotuksen historiaa erityisen hienona. Vanha vero ei myöskään yleensä ole tosiasiassa parempi kuin uusi, vaikka tuttuus antaa turvaa $\mathrm{mm}$. verosuunnittelussa. Totta kuitenkin on, että järjestelmän säilyessä pääosin ennallaan vältytään siirtymäkauden ongelmilta, jotka voivat olla vaikeita erityisesti joitakin veroja korotettaessa, esimerkiksi tiukennettaessa luovutusvoittoverotusta vastineena perintöverotuksen poistolle.

\subsubsection{Valtion yliomistusoikeus}

Vuoteen 1894 saakka Englannissa oli viisikin erillistä perintöveroa. Järjestelmä oli mutkikas ja sekava. Tuona vuonna ajoi rahaministeri Sir William Harcourt läpi lain, jolla perintövero järjestettiin uudestaan. Silloin säädettiin kolme varsinaista perintöveroa, joista tärkein, estate duty, oli jäämistövero, ja muut kaksi veroa kohdistuivat perintöosuuksiin.

Harcourt oli sitä mieltä, että valtion oikeus ottaa osa perinnöstä on muiden perijäin oikeuksien edellä, sillä luonto ei ole antanut ihmiselle mitään oikeutta ja valtaa määrätä maallisesta tavarasta elämänsä jälkeen. Tämä oikeus riippuu valtion säätämästä laista. Perintöoikeus kuuluu siis periaatteessa valtiolle. Ja vasta sitten kun valtio oikeuttaan käyttänyt, on muilla perillisillä tilaisuus käyttää perintöä valtion säätämissä muodoissa ja rajoissa.

Tällainen perintöverotuksen oikeutuksen perustelu on nykyisessä suomalaisessa yhteiskunnassa niin vieras, ettei sitä esimerkiksi Henttulan laajassa analyysissä esitellä lainkaan. Suomalaisessa verokeskustelussa ainakin Raimo Ilaskivi on kutsunut perintöverotusta salasosialisoinniksi ja vaatinut sen lopettamista (Helsingin Sanomat 6.10.2004).

\subsubsection{Valtion varaintarpeen tyydyttäminen}

Perintöveronkin ensisijainen tavoite on fiskaalinen eli valtion varaintarpeen tyydyttäminen. Nykyisessä hyvinvointiyhteiskunnassamme verovarojen tarve on paljon suurempi kuin perintö- ja lahjaverotusta käyttöön otettaessa. 
Vuonna 2020 perintö- ja lahjaveroa arvioidaan kertyvän 733 miljoonaa euroa, joka on noin 1,5\% valtion verotuloista. Määrä on suhteellisen vähäinen mutta ei mitättömän pieni; itse asiassa prosenttiluku on maailman korkeimpia. Mm. Ruotsin kokemuksiin viitaten katsotaan yleisesti, ettei perintö- ja lahjaveroa voida olennaisesti ankaroittaa, koska se johtaisi yhä aggressiivisempaan verosuunnitteluun, josta taas voisi seurata verotulojen vähentyminen.

\subsubsection{Maksukyvyn verottaminen}

Veronmaksukyky on tärkeimpiä perintöverotuksen perusteluja. Perintövero liittyy kuitenkin osittain myös sellaisiin tilanteisiin, joissa veronmaksukykyä on vaikea havaita. Tyypilliset tällaiset tapaukset kohdistuvat puolisoihin ja alaikäisiin lapsiin, osittain myös maatilojen ja yritysten sukupolvenvaihdostilanteisiin ja erilaisiin hallintaoikeusjärjestelyihin.

Perintö on taloudellinen etuus, jonka perinnönsaaja saa itselleen ilman vastasuoritusta, ja useimmiten saanto lisää edun vastaanottajan veronmaksukykyä. Periaatteessa veronmaksukykyä lisäävä vaikutus voitaisiin ottaa huomioon tuloverotuksessa. Niin meillä osittain tehtiinkin 1990-luvun puoliväliin eli sivuperinnön ja -lahjan kunnallisverotusta koskevien säännösten kumoamiseen asti.

On esitetty, että perintöjen sijasta verotettaisiin vain luovutusvoittoja, jolloin perintönä saadusta omaisuudesta maksettaisiin veroa vasta, kun sen vaihtaa rahaksi. Koska peritty omaisuus on saatu ilmaiseksi, hankintamenona ei saisi vähentää mitään. Kun luovutushinnasta ei voitaisi vähentää hankintamenoa ollenkaan, se usein merkitsisi verotuksen kiristymistä, ja toisaalta verotusta ei tapahtuisi, jos omaisuus siirtyisi aina perintönä eteenpäin.

\subsubsection{Oikeudenmukaisuus}

Verotuksen keskeinen ongelma on, miten verorasitus jakaantuu kansalaisten kesken. Verotuksen tulisi olla järjestetty siten, että jakaantumisnormi voidaan kokea oikeudenmukaiseksi. Ei kuitenkaan ole yhtä ainoaa oikeudenmukaista verotusta, vaan oikeudenmukaisuuskäsitykset ovat pitkälti aikaan, paikkaan ja henkilöön sidottuja. Juhani Henttula pitää väitöskirjassaan perintöverotusta yleisellä tasolla 
vähintään yhtä oikeudenmukaisena kuin kaikkia muitakin keskeisiä veromuotoja.

Oikeudenmukaisuus on lähellä edellä käsiteltyä maksukykyisyysperiaatetta. Oikeudenmukaisuus voidaan liittää myös etuperiaatteeseen eli verovelvollisen valtiolta saamaan etuun, mutta on vaikea nähdä, mitä erityistä etua perillinen yhteiskunnalta tässä saa, ellei pidetä valtiota jonkinlaisena yliomistajana tai omaisuuden suojelijana. Oikeudenmukaisuus voidaan nähdä myös seuraavaksi käsiteltävän jakopolitiikan sukulaisena.

\subsubsection{Varallisuuden uusjako}

Näkökohta, jolla perintöverotusta on yleisesti perusteltu, on jakopoliittinen tavoite. Jakopoliittisilla tavoitteilla on ymmärretty tulojen ja varallisuuden keskittymisen estämistä tai jo keskittyneiden tulojen ja varojen uusjakoa.

Perintöverotuksella voidaan myös tasoittaa eri sukupolvien jäsenten keskinäistä taloudellista lähtökohtatilannetta. Tätä tavoitetta voidaan perustella yhdenvertaisuuden näkökulmasta: yhteiskunnan jäsenillä pitäisi olla elämänkaarensa alkuvaiheissa keskenään samanlaiset mahdollisuudet taloudellisen toiminnan aloittamiseen. Perittyjen varojen epätasainen jakaantuminen on ristiriidassa samanlaisten mahdollisuuksien periaatteen kanssa.

\subsubsection{Tuloveron täydentäminen}

Perintöverotusta on pidetty oikeutettuna myös sillä perusteella, että se soveltuu käytettäväksi tuloverotuksen täydennyksenä varsinkin silloin, kun ns. vakautetun tulon eli pääomatulon verotusta ei ole järjestetty tyydyttävästi. Kysymys siitä, onko vakautetun tulon verotus järjestetty tyydyttävästi vai ei, on sidoksissa yhteiskunnan arvopohjaan. Suomessa esimerkiksi aikoinaan yleisesti katsottiin, että pääomatuloja tulisi verottaa ankarammin kuin ansiotuloja, mutta tämä kanta ei toteutunut käytännössä. Vuoden 1989 verouudistuksessa kaikki tulot pantiin lähtökohtaisesti samalle viivalle. Vuoden 1993 verouudistuksessa siirryttiin eriytettyyn tuloverojärjestelmään, jossa suuria pääomatuloja verotetaan lievemmin kuin ansiotuloja mutta alemmissa tuloluokissa tilanne on päinvastainen. Ansiotulojen verotusta ei mielellään lisä- 
tä eikä veron progressiota kiristetä; juuri progression kiristämiseen perintöverotuksen poistaminen loisi paineita.

Perintöveron voidaan katsoa täydentävän tuloverotusta myös siten, että sen avulla saadaan verotetuksi pimeitä tuloja. Silloin perintöverotusta voidaan pitää verotusmenettelylain 30 \$:ssä säädetyn selvittämättömän omaisuudenlisäyksen verotuksen sukulaisena.

\subsubsection{Varallisuusveron täydentäminen}

Itsenäisen Suomen verojärjestelmään tuli vuonna 1918 yleinen varallisuusvero. Sitä pidettiin erityisesti tuloveron täydentäjänä. Verokanta oli progressiivinen. Tämä vero oli alkuaikoina valtiontaloudellisestikin merkittävä. Esimerkiksi 1920- ja 1930-luvuilla varallisuusveron osuus valtion tulo- ja omaisuusveron yhteistuotosta oli 20-30 \% ja omaisuusveron tuotosta kertyi 2/3 osakeyhtiöiltä.

Varallisuusverotuksemme uudistettiin perusteellisesti 1960-luvun lopulla, ja siitä voidaan sanoa sen alamäen alkaneen. Vähitellen veroa lievennettiin niin, että vuonna 2005 epäyhtenäinen ja vuotava varallisuusvero tuotti enää alle 100 miljoonaa euroa. Se oli siis rapautettu ja kuihdutettu veropohjaan nähden lähes merkityksettömäksi. Vero kumottiin vuodesta 2006 alkaen.

Perintöveroa voidaan luonnehtia myös jälkikäteen perityksi varallisuusveroksi. Klassisen liberalismin käsityksen mukaan piti täydellisesti kunnioittaa yksityisen omistusoikeutta ansaitsemaansa omaisuuteen, mutta siitä ei seurannut, että saman oikeussuojan olisi tultava myös perillisen hyväksi. Niin kauan kuin omaisuus oli ansaitsijansa hallussa, verotusta ei tullut kohdistaa tähän ansaitsijaan, vaan verotus siis toteutettiin vasta hänen kuollessaan ja kohdistettiin hänen varallisuutensa saajaan.

Kun varallisuusvero meillä poistui, olisiko myös jälkikäteinen varallisuusvero eli perintövero tullut poistaa? Juhani Henttulan mukaan klassinen liberalismi lähti siitä, että vero tuli kohdistaa omaisuuden saajaan eikä perinnön saaja nauttinut samaa omaisuuden suojaa kuin omaisuuden ansaitsija, ja kun ansaitsijan varallisuusvero poistui, olisi voitu perustella sitäkin, että perintöveroa olisi korotettu vastaavalla määrällä, jolla varallisuusveroa alennettiin. 


\subsubsection{Varainsiirtoveron täydentäminen}

Perintöverotuksen voidaan sanoa alkaneen meillä leimaverotyyppisenä varainsiirtoverona. Leimapaperista ja leimamerkeistä on luovuttu, mutta kiinteistöjen ja arvopaperien varainsiirtoverotus on säilytetty lukuun ottamatta pörssiosakkeita. Asunto-osakkeiden varainsiirtovero on vuonna 2013 nostettu $2 \%$ :iin, ja myös varainsiirtoveron veropohja on laajentunut, kun asuntoyhteisöjen velkaosuudestakin joudutaan nykyisin tämä vero maksamaan. On mietitty myös finanssitransaktioveroa, joka sekin on leimaverotuksen perillinen.

Kun vastikkeettomista saannoista ei makseta varainsiirtoveroa, perintö- ja lahjaveron voidaan sanoa täydentävän sitä. Portugalissa perintöjen verotus tapahtuukin leimaverotyyppisellä varainsiirtoverolla.

\subsubsection{Psykologinen tekijä}

Esimerkiksi Juhani Henttulan väitöskirjassa esitetään yhtenä tärkeänä argumenttina perintöverotuksen puolesta veronmaksuun liittyvä psykologinen tekijä. Kun veroja tarvitaan ja kun niitä joudutaan suorittamaan, sanotaan olevan miellyttävämpää maksaa perintöveroa kuin tuloveroa. Perinnössä on useimmiten kyse ylimääräisestä lisästä saajan käyttövaroihin ilman omaa työpanosta ja ilman että saaja aina on täysin varmaksi voinut laskea toimeentuloaan sen varaan. Jos perinnönjättäjä ei ole läheinen, perintötapahtumaan ei liity kovin voimakkaita tunnekysymyksiä, jolloin korkeakaan veroaste ei tunnu niin pahalta.

Tuollainen psykologinen tekijä saattaa liittyä arpajaisveron hyväksyttävyyteen, mutta se tuntuu jotenkin vieraalta perintöverotuksen yhteydessä. Jos joku kokee perintöveron maksamisen miellyttävämmäksi kuin tuloveron maksamisen, se voi johtua enemmän perintöveron ja tuloveron välisestä tasoerosta kuin näiden verojen luonne-eroista. Jos taas perintöveroa pitää mukavana sellainen tuloverovelvollinen, joka ei itse perintöveroa maksa, saattaa kysymys olla siitäkin, että toisten veronmaksu tuntuu yleensä miellyttävämmältä kuin oma veronmaksu. 


\subsubsection{Perunkirjoituksen varmistaminen}

Oikeuskirjallisuudessa on korostettu perintöverotuksen roolia perunkirjoituksen varmistajana. Perintöverotus tapahtuu pääasiallisesti perukirjojen pohjalta, ja nykyisin veroviranomaiset huolehtivat perunkirjoitusten pitämisen kontrollista.

Jos perintöverotus lakkautettaisiin, perukirjojen tarkastaminen olisi järjestettävä muulla tavoin. Perukirja on perusta perinnönjaolle ja monille muille jäämistöoikeuden toimille. Esimerkiksi rekisteröityä omaisuutta ja pankkitalletuksia ei voida käytännössä siirtää perillisille (tai luovuttaa edelleen), ellei niitä ole mainittu perukirjassa. Tällä on merkityksensä myös harmaan talouden torjunnan näkökulmasta.

Vaikka perunkirjoitus on käytännössä tärkeä toimi, perintöverotuksen puolustaminen yksin sillä ei vakuuta. Ongelmaan löytyy varmasti tarvittaessa muukin ratkaisu, vaikkapa perukirjojen tallettaminen maistraattiin.

\subsubsection{Perintöveroa vastaan}

\subsubsection{Kaksinkertainen verotus tuloveron kanssa}

Yleisin perintöverotusta vastaan esitetty maallikon perustelu on väite kaksinkertaisesta verotuksesta. Perintöveron sanotaan johtavan kaksinkertaiseen verotukseen, koska varat on hankittu tuloilla, joista perinnönjättäjä on jo maksanut tuloverot.

Perinnönsaaja on kuitenkin eri verovelvollinen, ja perintöveron kohteena on hänen varallisuutensa lisääntyminen. Näin kyseessä ei varsinaisesti ole kaksinkertainen verotus. Lisäksi suuret varallisuudet ovat monissa tapauksissa peräisin perinnönjättäjän varallisuuden realisoitumattomasta tai verottamatta jääneestä arvonnoususta. Perinnönjättäjän varallisuus on voinut osaltaan syntyä myös verovapaista tuloista.

\subsubsection{Pääoman muodostumisen estäminen kansantaloudessa}

On sanottu, että perintö ei edusta mitään uutta varallisuutta ja että perintövero on omiaan estämään kansantaloudellisesti tärkeää pää- 
oman muodostumista. Perintövero vähentää perinnön arvoa verrattuna siihen tilanteeseen, että perintöveroa ei tarvitsisi ollenkaan suorittaa. Tämä näkökohta saattaa vaikuttaa perinnönjättäjän käyttäytymiseen. Perinnönjättäjä haluaa ehkä itse elinaikanaan saada jälkeensä jäävän perinnön pienemmäksi ja käyttää itsekkäästi enemmän varoja omaan kulutukseensa. Tätä kuitenkaan kaikki eivät pidä suurena veropoliittisena haittana ainakaan veronsaajien kannalta, koska silloin vastaavasti arvonlisävero ja muut kulutusverot lisääntyvät. Koko yhteiskunnankaan kannalta taloudellisen toiminnan lisääntymistä ei välttämättä katsota olevan syytä vastustaa.

\subsubsection{Omaisuus ei todellisuudessa lisäänny}

Erityisesti rintaperillisten ja puolison perintöverottamista on vastustettu siksi, että perintö ei useinkaan tuota heille todellista omaisuuden lisäystä, vaan he perinnönjättäjän kuoltua edelleen hallitsevat sellaista omaisuutta, jota he jo perinnönjättäjän eläessä yhdessä tämän kanssa hallitsivat.

Jos perinnönjättäjä on perheensä pääasiallinen elättäjä, hänen kuolemansa on omiaan vain vaikeuttamaan perinnönsaajan taloudellista asemaa. Sellaisissa muutoinkin sekä henkisesti että taloudellisesti vaikeissa olosuhteissa joudutaan ottamaan lainaa tai jopa myymään asunto tai muuta varallisuutta perintöveron maksamiseksi. Käytännössä on yleistä, että leski saa varallisuuteen elinikäisen hallintaoikeuden omistusoikeuden siirtyessä lapsille. Tällöinkin perintövero pannaan maksuun perillisille, vaikka he eivät vielä saa periaatteessa mitään kuolinpesästä. Käytännössä on kuitenkin varsin tavallista, että perintöverot tällöinkin maksetaan pesän varoista, vaikka kysymyksessä ei muodollisjuridisesti ole pesän meno tai velka.

Lesken ja alaikäisen rintaperillisen erityisasema perintöverotuksessa on huomioitu PerVL 12 \$:ssä. Vuodesta 2008 alkaen leski on saanut vähentää puolisovähennyksenä 60000 euroa (aikaisemmin vain 6800 euroa) ja alaikäinen rintaperillinen alaikäisyysvähennyksenä 40000 euroa (aikaisemmin vain 3400 euroa). 


\subsubsection{Yritysten sukupolvenvaihdosten vaikeutuminen}

Keskeinen perintöverotuksen kritiikki kohdistuu yritysten ja maatilojen sukupolvenvaihdoksiin. On ensinnäkin huomautettu, että silloin kun maanviljelijän tai yrittäjän lapset työskentelevät vanhempiensa tilalla tai yrityksessä, he voivat joutua suorittamaan veroa sellaisestakin omaisuudesta, jota he ovat olleet hankkimassa yhdessä perinnönjättäjän kanssa. Tämä näkökohta on merkittävä. Yritysten ja maatilojen sukupolvenvaihdokset muodostavat muutoinkin monitahoisen veroja elinkeinopoliittisen ongelman. Verotus saattaa kohtuuttomasti vaikeuttaa yritystoiminnan jatkajan asemaa tai johtaa jopa yritystoiminnan päättymiseen.

Sukupolvenvaihdosproblematiikkaan on meillä kiinnitetty perintö- ja lahjaverotuksessa erityistä huomiota vuodesta 1979 lukien. Tuolloin säädetystä sukupolvenvaihdoshuojennuksesta on kehittynyt merkittävä veromeno eli verotuki.

\subsubsection{Laajat välttämismahdollisuudet}

Perintöverojärjestelmämme vuotaa. Sellainen järjestelmä, jossa veroa saatetaan joutua maksamaan enemmän tietämättömyydestä kuin varallisuudesta, ei ole veronmaksukykyperiaatteen mukainen eikä tyydytä oikeudenmukaisuuden vaatimuksia.

Esimerkkeinä laillisista ja laittomista veron torjuntakeinoista, joissa tarvitaan usein juristien apua, voidaan mainita seuraavat: ${ }^{30}$

- luovutusten hajauttamisen eri antajille ja eri saajille

- luovutusten vaiheistamiset

- perinnöistä luopumiset

- sukupolvien yli hyppäykset

- omistajattoman tilan testamentit

- hallintaoikeusjärjestelyt

30 Perintöverosuunnittelulla voi rajatapauksissa olla vaikutusta myös kuoleman ajankohtaan. Olen nähnyt myös hoitotahdon, jossa sallitaan elämän keinotekoinen pitkittäminen vain, jos eduskunnan käsittelyssä on hallituksen esitys perintöveron kumoamiseksi. 
- korottomat lainat ja velkojen anteeksiannot

- yritysten sukupolvenvaihdosten hyödyntämiset

- omaisuuden piilottamiset sekä laiminlyödyt ja virheelliset veroilmoitukset.

Perintö- ja lahjaverolaissa oleva veronkiertämissäännös on melko tehoton, ja se onkin tarkoitettu lähinnä ennalta ehkäiseväksi moraalin kohottajaksi. Lainsäätäjä on ollut pidättyväinen perintö- ja lahjaveron vuotokohtien tilkitsemisessä. Vuoden 2013 alussa on kuitenkin tullut pieni tiukennus lahjaverotukseen vakuutusjärjestelyissä. Valvontavaikeudet ovat lisääntyneet varallisuusverotuksen kumoamisen jälkeen, ja kansainvälistymisen ansiosta ne lisääntyvät yhä.

Verosuunnittelun ja verokonsulttien suurta merkitystä perintö- ja lahjaverotuksessa kuvaa sekin, että verokirjallisuudessamme perintö- ja lahjaverotus on selvästi ylikorostunutta verrattuna veron kertymään. Verosuunnittelu voi herättää moraalisiakin kysymyksiä. Verohallinnossa pitkään työskennellyt Pertti Puronen totesi vuoden 2009 lopussa ilmestyneen kirjansa "Näin onnistut perintöverosuunnittelussa" alkusanoissa (s. 5) seuraavaa:

"Kysymys perintöverosuunnittelukirjan kirjoittamisesta on ollut aika ajoin esillä. En ole kuitenkaan ollut halukas ryhtymään siihen, koska pidin sitä jollain tavalla moraalittomana aiemman virka-asemani takia. Tilanne on nyt toinen, kun olen jättämässä Verohallinnon.”

\subsubsection{Kansainvälinen kilpailu ja veropako}

Perintöverotus voi joskus ohjata sijoittamaan varoja maihin, joissa perintöverotusta ei ole. Valtioiden perintöveroerot saattavat vaikuttaa jopa asuinvaltion valintaan. Vuoden 1996 lainmuutoksen jälkeen perintö- ja lahjaverolain alueellinen ulottuvuus on Suomessa niin laaja, että sijoitusten pako perintö- ja lahjaveron vuoksi lienee jäänyt vähäiseksi. Perintöveroa joudutaan maksamaan yleensä kaikesta omaisuudesta, mikäli perinnönjättäjän tai perinnönsaajan asuinvaltio kuolinhetkellä oli Suomi. On huomattava, että perintö- ja lahjaverolaissamme ei ole veropaon estämiseksi samanlaista kolmen vuoden sääntöä kuin tuloverotuksessa. Ruotsin luovuttua perintöverosta asuinvaltion valinta Tornionjokilaaksossa on saanut lisäelementin. 
Varsinkin pääkaupunkiseudulla taas perintöveroton Viro voi kiinnostaa elämänsä ehtoopuolella olevia.

\subsubsection{Yhdenvertaisuuspuutteet}

Perintö- ja lahjaverotuksemme on epäyhtenäinen, ja siihen sisältyy myös perustuslain kannalta ongelmallisuutta, kuten epäneutraalisuutta ja arvostamisen epäyhtenäisyyttä. Tämä tuli selvästi ilmi vuonna 2008 eduskunnassa käsiteltäessä sukupolvenvaihdoshuojennusta koskevaa hallituksen esitystä. Esityksen osumatarkkuus oli heikko, ja lopulta esitys peruutettiin sen saatua perustuslakivaliokunnassa voimakasta kritiikkiä lähes kaikilta siellä kuulluilta oikeustieteen asiantuntijoilta.

\subsubsection{Vähäinen tuotto}

Perintöveron osuus verojemme kokonaistuotosta ei ole ollut Suomessa koskaan kovin merkittävä, mutta se ei ole ollut myöskään mitättömän pieni. 2010-luvun alussa tuottoa pyrittiin kasvattamaankin. Suuret korotukset kuitenkaan eivät liene mahdollisia, koska ankara perintöverotus kiihdyttää verosuunnittelua tavalla, joka voi johtaa verojen vähentymiseen. Ruotsin kokemukset ennen perintöverotuksen kumoamista pelottavat myös Suomessa.

\subsubsection{Verotuskustannukset}

Perintöverotuksen arvostelijat viittaavat verotuskustannuksiin. Eräiden selvitysten ja arvioiden mukaan perintö- ja lahjaverotukseen käytetään noin 150 henkilötyövuotta ja kustannukset ovat viisi miljoonaa euroa. Kustannukset koostuvat ensisijaisesti palkkakuluista, koska tietotekniikan kustannukset ovat tämän verolajin osalta suhteellisen vähäiset. Näin lasketut kustannukset eivät olennaisesti alenna veron nettotuottoa.

Kustannuksista puhuttaessa olisi kuitenkin kiinnitettävä valtiolle syntyvien verotuskustannuksien lisäksi huomio verovelvollisille verotuksesta ja sen välttämisestä aiheutuviin menoihin. Voidaan jopa sanoa, että monessa varakkaassa kuolinpesässä lakimiehet ja muut verokonsultit ovat tärkeitä "pesänosakkaita". 


\subsubsection{Pisteet, korvauspalikat ja vaihtoehtoiset mallit}

Kilpailu perintöveron puolesta ja sitä vastaan näyttäisi edellä esitetyn perusteella päättyvän perintöveron voitoksi 11-9. Voitossa tärkeitä olisivat näin laskien perintöveron saamat kolme pistettä verojärjestelmän täydentämisestä (tulovero, varallisuusvero, varainsiirtovero).

Tulosta vastaan voidaan kuitenkin protestoida. Valtion pitäminen omistajana tai perillisenä voidaan kiistää, samoin perintöveroa puoltavaksi väitetty psykologinen tekijä. Myös perintöveron historian hienous voidaan riitauttaa. Jos kaksi näistä kolmesta protestiperusteesta menee läpi, päädytään tasatulokseen 9-9. Jos toisiaan lähellä olevat perusteet maksukyky ja oikeudenmukaisuus yhdistetään yhdeksi argumentiksi, voitto kallistuu jo niukasti vastustajien hyväksi. Lopputulos ei muutu, jos argumenteista jätetään pois esimerkiksi toisaalta perunkirjoituksen varmistaminen ja toisaalta suuriksi väitetyt verotuskustannukset taikka toisaalta veron fiskaalinen merkittävyys ja toisaalta veron vähäisyys.

Ulkomaiset esimerkit Suomea muistuttavissa maissa osoittavat, että nyky-yhteiskunta voi toimia myös ilman perintöveroa ja sitä täydentävää lahjaveroa. Perintö- ja lahjaveron poistaminen ei hyvinvointiamme romahduttaisi.

Perintöveroa vastaan esitetty kritiikki meillä on viime vuosien aikana suureksi osaksi laimentunut. Tähän ovat vaikuttaneet verotettavan varallisuusmäärän alarajan nostaminen sekä puoliso- ja alaikäisyysvähennysten merkittävä kasvattaminen. Näiden muutosten jälkeen aivan vaatimattomista perinnöistä ei enää veroa makseta.

Vaikka perintöverotus Suomessakin on jo ylitutkittu sen valtiontaloudelliseen merkitykseen nähden, kirjoituksissa on ollut yksi puute. On lähdetty siitä, että perintöveron kumoaminen johtaa valtion verotulojen vähentymiseen tai siihen, että vain jotakin tiettyä veroa nostetaan. Esillä ei näy olleen vaihtoehto, että kompensaatio muodostuisi monesta palikasta. Löytyisikö tästä keino perintöveron siirtämiseksi veromuseoon - toisten ihailtavaksi ja toisten pilkattavaksi?

Yksi palikka saataisiin siitä, että perintöjen verottamisesta vapautuva virkamiehistö siirrettäisiin tehostamaan muiden verojen valvontaa. Toinen palikka olisi luovutusvoittoverotuksen tiukentaminen vastik- 
keettomien saantojen vähennyskelpoista hankintamenoa pienentämällä. Tätä tiukennusta mitoitettaessa olisi kuitenkin huolehdittava, ettei synny myyntejä lukkiuttavaa vaikutusta. Kolmantena palikkana voitaisiin ajatella osinko- ja muiden pääomatulojen veroprosenttien nostamista.

Neljäs palikka olisi jonkinlaisen varallisuusveron palauttaminen. Viides palikka olisi kiinteistöjen ja arvopapereiden vastikkeettomienkin luovutusten saattaminen varainsiirtoveron piiriiin käyvästä arvosta (Portugalin malli). Varallisuusverosta ja varainsiirtoverosta on tässä kirjassa omat lukunsa (luvut 4 ja 5).

Perinnöt voitaisiin myös säätää pääomatuloina vuotuisen tuloverotuksen yhteydessä verotettaviksi myöntämällä niistä ennen veronalaiseksi tuloksi katsomista euromääräisiä ja/tai prosentuaalisia vähennyksiä sukulaisuuden ja perityn määrän yms. perusteella, jolloin veron määrä ei välttämättä paljonkaan poikkeaisi nykyisin maksettavan perintöveron määrästä. Tässä mallissa muutos olisi pitkälti vain lakitekninen ja organisatorinen. Radikaalimpi vaihtoehtoinen malli olisi kuoleman ja lahjan pitäminen perittävän/lahjanantajan tuloverotuksessa arvonnousuvoiton realisoivana luovutuksena (Kanadan malli).

Perintö- ja lahjaveron tuoton korvaamiseksi toki olisi ainakin periaatteessa monia muitakin keinoja, esimerkiksi finanssitransaktiovero. Vastaava määrä veroja saataisiin kasaan myös ihan toisenlaisilla veromuutoksilla, vaikkapa pienentämällä monia verotukia.

\subsection{USA:n perintöverouudistus ${ }^{31}$}

\subsubsection{USA:n perintöverotuksen kehitys}

Vuoden 1797 leimaverotusta voidaan pitää Yhdysvaltain ensimmäisenä perintöverona, mutta moderni perintöverotus USA:ssa alkoi vasta vuonna 1916. Vero on ollut senkin jälkeen ajoittain kumottuna. Yhdysvaltain liittovaltion perintövero on tyypiltään kuolinpesän

31 Ks. kirjoitukseni USA:n perintöverotus ja Suomi, Verotus 2018 s. 224 ss. 
jäämistövero (federal estate tax), kun taas Suomessa kyseessä on perillisten perintöosuusvero.

George W. Bushin presidenttikauden (2001-2009) alussa säädettiin laki, joka alensi perintöveroa vähitellen siten, että se poistui kokonaan vuonna 2010. Vero kuitenkin palasi Barack Obaman presidenttikaudella vuodesta 2011 lähtien. Donald Trumpin vaaliohjelmaan sisältyi liittovaltion perintöveron poistaminen. Perintövero säilyi, mutta verotettavaa alarajaa korotettiin merkittävästi vuosiksi 2018-2025.

Yhdysvalloissa perintöveroa joudutaan maksamaan vain tosi suurista varoista. USA:n liittovaltion perintöverotuksessa vapaaosa eli veronalaisen varallisuuden alaraja ja enimmäisverokanta ovat kehittyneet 2000-luvulla seuraavasti:

\begin{tabular}{|c|c|c|}
\hline Vuosi & Vapaaosa USD & Enimmäisvero \\
\hline 2001 & 675000 & $55 \%$ \\
\hline 2002 & 1000000 & $50 \%$ \\
\hline 2003 & 1000000 & $49 \%$ \\
\hline 2004 & 1500000 & $48 \%$ \\
\hline 2005 & 1500000 & $47 \%$ \\
\hline 2006 & 2000000 & $46 \%$ \\
\hline 2007 & 2000000 & $45 \%$ \\
\hline 2008 & 2000000 & $45 \%$ \\
\hline 2009 & 3500000 & $45 \%$ \\
\hline 2010 & - & ei veroa \\
\hline 2011 & 5000000 & $35 \%$ \\
\hline 2012 & 5120000 & $35 \%$ \\
\hline 2013 & 5250000 & $40 \%$ \\
\hline 2014 & 5340000 & $40 \%$ \\
\hline 2015 & 5430000 & $40 \%$ \\
\hline 2016 & 5450000 & $40 \%$ \\
\hline 2017 & 5490000 & $40 \%$ \\
\hline 2018- & 11200000 & $40 \%$ \\
\hline
\end{tabular}


Vuodesta 2011 alkaen puolisoiden vapaaosa on ollut kaksinkertainen mainittuihin määriin verrattuna, esimerkiksi vuonna 2018 se on jo 22400000 dollaria. Yleisen vapaaosan lisäksi perheyrityksiä varten on erityinen yritysvarallisuusvapaaosa.

Korkeiden vapaaosien ansiosta hyvin harvat joutuvat maksamaan liittovaltion perintöveroa. Vuonna 2000 veroa maksettiin vielä 52 000:sta jäämistöstä, vuonna 2017 enää 5 000:sta. Vuonna 2018 maksajia arvioidaan olevan vain 1800 , joka on alle $0,1 \%$ jäämistöistä.

Liittovaltion ohella perintöveroa USA:ssa kantavat nykyisin Columbian liittopiiri (pääkaupunki Washington D.C.) ja 17 osavaltiota. Jäämistöverotyyppistä veroa (state estate tax) perivät seuraavat osavaltiot: Delaware, Rhode Island, Connecticut, Pohjois-Carolina, Illinois, Havaiji, Vermont, Maine, Washington, Minnesota, New York ja Massachusetts. Näiden osavaltioiden perintöverotuksessa ankarimmat verokannat ovat olleet tyypillisesti $16 \%$. Verotettava alaraja on osavaltioidenkin verotuksessa korkea; usein verotettava alaraja on säädetty samaksi kuin liittovaltion perintöverotuksessa. Perintöosuusverotyyppinen osavaltion perintöverotus (state inheritance tax) on käytössä seuraavissa osavaltioissa: Iowa, Kentucky, Nebraska ja Pennsylvania. Marylandissa käytössä on sekä jäämistö- että perintöosuusvero, mutta ne on synkronoitu toisiinsa niin, ettei täyttä tuplaverotusta synny.

\subsubsection{Lahjaverotus USA:ssa}

Lahjaveron keskeinen tehtävä Yhdysvalloissakin on pyrkiä estämään perintöveron välttäminen elinaikaisilla lahjoilla. Liittovaltion perintövero on kuolinpesän jäämistövero eikä perillisten perintöosuusvero. Kuolinpesän jäämistöveron kanssa johdonmukaista on, että lahjaverossakin verovelvollisena on lahjan antaja, ei saaja. Lahjaverotus ei koske liittovaltiolle, osavaltiolle, sotaveteraanien organisaatioille, uskonnollisille yhdyskunnille eikä monille muillekaan yleishyödyllisille yhteisöille annettuja lahjoituksia. Lahjaveroa ei suoriteta yleensä myöskään puolisolle annetuista lahjoista.

Lahjaverotus ei koske määrältään pieniä lahjoja. Vuodesta 2018 alkaen veronalaisen lahja alaraja on 15000 dollaria vuodessa lahjan- 
saajaa kohden (esim. v. 2017 alaraja oli 14000 dollaria). Suuremmista lahjoista laskettava vero, joka on enintään $40 \%$, voidaan tiettyyn rajaan asti jättää määräämättä ja ottaa huomioon myöhempien vuosien lahjaverotuksessa tai perintöverotuksessa hyvitysmenetelmällä (applicable credit), joka tavallaan kuluttaa silloin verottoman vapaaosan määrää.

Lahjojen kumulointi ja yhdistäminen perintöverotukseen koskee USA:ssa lähtökohtaisesti miten kauan tahansa aikaisemmin annettuja lahjoja. Järjestelmä on suomalaisin silmin tavattoman monimutkainen, mutta lahjaveroa tulee käytännössä harvoin maksettavaksi edellä mainitun hyvityssysteemin vuoksi.

\subsubsection{Perintö- ja lahjasaannot USA:n tuloverotuksessa}

Lahjan tai perinnön arvo ei ole saajan veronalaista tuloa, eikä lahjoittaminen tai perinnön jättäminen realisoi arvonnousun verotusta lahjoittajalla tai perinnönjättäjällä. Jos lahjansaaja myy saamansa omaisuuden, yleisenä sääntönä USA:ssa on, että hänen hankintamenonsa on sama kuin lahjoittajalla; sovelletaan siis jatkuvuusperiaatetta. Sääntely on erilainen, jos myyty omaisuus on saatu perintönä - tällöin sovelletaan kuolinhetken käypää arvoa.

\subsubsection{Esikuvaksi Suomeen?}

Meillä perintö- ja lahjaveroa aletaan maksaa paljon pienemmistä varoista kuin Yhdysvalloissa. Verotettavan perinnön alaraja on Suomessa nykyisin 20000 euroa. Meillä verokanta on lähiomaisilla nykyisin yleensä melko kohtuullinen, enimmillään $19 \%$. Sivuperillisillä enimmäisvero voi nousta 33 \%:iin. Vielä 1990-luvun alussa, jolloin perintöverokannat olivat korkeammat ja sivuperinnöistä maksettiin lisäksi kunnallisveroa, sivullisen saaman perinnön arvosta saattoi mennä veroa jopa reilusti yli puolet. Verotettavan lahjan alaraja on nykyisin 5000 euroa ja lahjojen kumulointiaika kolme vuotta; lahjaveron enimmäismäärä on I veroluokassa $17 \%$ ja II veroluokassa $33 \%$. 
Jos perintöverotus olisi poistettu USA:ssa, vaatimukset perintöveron hautaamiseksi meilläkin olisivat varmaan kiihtyneet. Koska vero USA:ssa jäi vielä henkiin, suomalaiset perintöverokriitikot saattavat tyytyä vaatimaan verotettavan määrän alarajan korottamista amerikkalaisen mallin mukaisesti 20000 eurosta esimerkiksi 10 tai 20 miljoonaan euroon.

Voidaan kysyä, miksi Suomessa ei äänekkäämmin ole vaadittu perintöveron kumoamista. Siihen vaikuttaa ainakin pelko, että tilalle saattaisi tulla varakkaiden kannalta ikävämpää ja vaikeammin vältettävää. Pelätään karhunpalvelusta. Tilanne vaikuttaa samankaltaiselta kuin Augustuksen tuodessa perintöveron Rooman keisarikuntaan; vielä pahemmalla verolla uhkaamalla keisari sai perintöveron hyväksytyksi.

Jos perintöverotus kumotaan, luovutusvoittoverotusta voidaan tiukentaa jopa niin, että kuolinhetkellä kiinteistöt ja arvopaperit katsotaan myydyksi käypään hintaan. Tällaiseenkin järjestelmään on kyllä mahdollista yhdistää oman asunnon luovutusten verovapaus ja yritysten sukupolvenvaihdosten verohelpotukset. Perintövero on mahdollista korvata monia muitakin veroja kehittämällä.

Kuulun niihin, jotka ovat menettäneet uskonsa perintöveron ikuiseen elämään, enkä aio kuolla ennen kuin näen perintöverokarhun peijaiset. Ainakaan nykyisen hallituksen aikana en voi kuolla, koska SDP päättäväisesti vastustaa perintöveron poistamista. Saatan elää yli 100-vuotiaaksi; kollegat ovat toivottaneet minulle ja perintöverokarhullekin pitkää ikää. ${ }^{32}$

Perintöveron poistaminen lisäisi paineita varallisuusveroon, jota käsitellään seuraavaksi (luku 4).

32 Ks. myös jäljempänä kansalaisaloiteluku 7.4.3.6. 


\section{4 \\ Varallisuusveron reinkarnaatio? ${ }^{33}$}

\subsection{Varallisuusveron synty, kehitys, hiipuminen ja kuolema}

Todelliseen tuloon perustuvan yleisen tuloveron rinnalle kehitettiin 1800- ja 1900-lukujen taitteessa Saksassa koko nettovarallisuuden omaisuus- eli varallisuusvero. Pian tuollainen vero otettiin käyttöön monessa muussakin valtioissa, Suomessakin vuonna 1918. Varallisuusvero oli meillä alkuaikoina valtiontaloudellisesti merkittävä. Sen osuus 1920- ja 1930-luvuilla valtion tulo- ja omaisuusveron yhteistuotosta oli $20-30 \%$, ja omaisuusveron tuotosta kaksi kolmasosaa kertyi osakeyhtiöiltä. Kansalaisten varallisuus kasvoi, mutta varallisuusveron tuotolle kävi päinvastoin. Se alkoi voimakkaasti hiipua 1960-luvulla, kun se poistettiin osakeyhtiöiltä. Vähitellen varallisuusverotusta lievennettiin niin, että 2000-luvulle tultaessa sen tuotto oli jo erittäin vaatimaton. Varallisuusveron heikkoon tilaan vaikuttivat verokannan alentamisen lisäksi mm. laajat verovapaudet ja omaisuu-

33 Tämä luku pohjautuu suureksi osaksi teoksiin Esko Linnakangas - Leila Juanto, Verojen historia. Synty, kehitys, kuolema, ylösnousemus, reinkarnaatio (2016) s. 60 ss. sekä Esko Linnakangas, Suomen kulutusverotuksen historia ja veneveron haaksirikko (2017) s. 167 ss. 
den varovainen arvostus. Vuodelta 2003 varallisuusveroa määrättiin vain noin 120 miljoonaa euroa. Verovelvollisten verotettavasta bruttovarallisuudesta $77 \%$ muodostui kiinteistöistä, asunto-osakkeista sekä maa- ja metsätalouden varallisuudesta. Loppuosa muodostui lähinnä arvopapereista, joista pääosa oli osakkeita. Useat maat olivat tuolloin jo luopuneet varallisuusverosta.

Yritys- ja pääomaverouudistuksen myötä osakeomistuksen verotus kiristyi, kun yhtiöveron hyvitysjärjestelmästä luovuttiin ja siirryttiin osinkona jaetun voiton osittaiseen kahdenkertaiseen verotukseen. Osinkoverotuksen muutos antoi aiheen tarkistaa osakeomistukseen kohdistuvan verotuksen kokonaisuutta. Omistuksen verottamisen sijasta pidettiin tarkoituksenmukaisempana kohdistaa osakeomistuksen verotus tuoton eli osinkojen verotukseen. Siksi osakevarallisuuden varallisuusverotuksesta ehdotettiin luovuttavaksi.

Pelkkä osakkeiden varallisuusverotuksesta luopuminen olisi merkinnyt sitä, että varallisuusveroa olisi kertynyt enää lähinnä kiinteistövarallisuudesta, joka oli ja on yhä kiinteistöverotuksen piirissä. Kiinteistöverotuksen taustanäkökohdat olivat osin toiset kuin varallisuusverotuksessa, mutta yhteistä näille veromuodoille oli se, että vero kohdistui varallisuuteen sen todellisesta tuotosta riippumatta. Osakkeiden varallisuusverotuksesta luopumisen jälkeen ei ollut myös varallisuusverotuksen hallinnolliset kustannukset huomioon ottaen - syytä ylläpitää kiinteistöjen verotuksessa kahta päällekkäistä veromuotoa.

Hallitus esitti varallisuusverotuksesta luopumista vuoden 2006 alusta, ja eduskunnassa esitys hyväksyttiin äänestyksen jälkeen.

\subsection{Varallisuuden verottamistavoista}

Verotuksen perustehtävä on varojen saaminen valtiolle ja muille julkisyhteisöille niiden tehtävien suorittamiseksi. Varoja on saatavissa niiltä veronmaksajilta, joilla varoja on. Varallisuus onkin luonnollisimpia ja vanhimpia verotuskohteita. Joskus on myös sanottu, että veroja on perittävä varallisuudesta siksi, että valtio turvaa varallisuutta. Kysymys siis olisi tavallaan vakuutusmaksuista tai suojelurahoista. 
Varallisuuden veroja voidaan luokitella monella tavalla, esimerkiksi seuraavasti:

Yleiset ja osittaiset varallisuusverot. Yleisillä varallisuusveroilla pyritään verottamaan koko varallisuutta, kun taas osittaiset varallisuusverot kohdistuvat vain tiettyyn varallisuuden osaan, kuten kiinteistöomaisuuteen tai elinkeino-omaisuuteen.

Nimelliset ja todelliset varallisuusverot. Nimellisissä eli epäaidoissa varallisuusveroissa veron kohteena on omaisuuden tuotto. Nimelliset varallisuusverot ovat pääasiassa tuloveron täydennysveroja eli vakautetun tulon (pääomatulo) lisäveroja. Todellista eli aitoa varallisuusveroa taas kannetaan kantavarallisuudesta, ei sen tuotosta.

Luonnollisten henkilöiden ja yhteisöjen varallisuusverot. Luonnollisten henkilöiden varallisuusverot kohdistuvat fyysisten henkilöiden eli ihmisten varoihin, kun taas yhteisöjen varallisuusvero kohdistuu juridisten henkilöiden varoihin.

Objektiiviset ja subjektiiviset varallisuusverot. Objektiiviset varallisuusverot eivät ota huomioon luonnollisten henkilöiden henkilökohtaisia olosuhteita, kun taas subjektiivisissa varallisuusveroissa on esimerkiksi verovapaa minimi ja huomiota saavat myös perhesuhteet.

Bruttovarallisuuden ja nettovarallisuuden varallisuusverot. Nettovarallisuusveroissa, toisin kuin bruttovarallisuusveroissa, varallisuudesta vähennetään velat.

Kulutusvarallisuusverot ja elinkeinovarallisuusverot. Kulutusvarallisuusverot kohdistuvat yksityisessä kulutuksessa olevaan varallisuuteen, elinkeinovarallisuusveroja kannetaan liike- ja ammattivarallisuudesta.

Kauppa-arvoon ja tuottoarvoon perustuvat varallisuusverot. Edellisten pohjana on omaisuuden vaihtoarvo, jälkimmäiset määräytyvät omaisuuden tuottokyvyn mukaan.

Yleinen verovelvollisen kaikkien varojen ja velkojen erotukseen kohdistuva varallisuusvero ei siis ole ainoa tapa järjestää varojen verottaminen. 


\subsection{Varallisuusveron paluusta}

Vaikka yleisen varallisuusverotuksen henkiin herääminen Suomessa ei nyt vaikuta käytännössä mahdolliselta, varallisuusvero voi kuitenkin joskus vielä jossakin muodossa palata verojärjestelmäämme. ${ }^{34}$ Juha Sipilän hallitus jo yritti säätää veneveron. Venevero olisi ollut osittainen objektiivinen bruttovarojen mukaan määräytyvä kulutusvarallisuusvero.

Jonkinlainen varallisuusvero voi vielä joskus palata, jos pääomaverotusta halutaan lisätä, jotta olisi varaa vastaavasti alentaa ansiotulojen verotusta. Silloin kysymys ei olisi varallisuusveromme ylösnousemuksesta eli jälleensyntymisestä entisenlaisena, vaan pikemminkin reinkarnaatiosta eli uudelleen syntymisestä toisenlaisessa olomuodossa.

Varallisuusveroa, kuten myös pääomatulojen verotuksen tiukentamista, puolletaan voimakkaasti professori Thomas Pikettyn laajassa ja paljon huomiota saaneessa tutkimuksessa Pääoma 2000-luvulla. Kirja ilmestyi alun perin ranskaksi vuonna 2013, ja suomennos ilmestyi vuonna 2016.

Meillä SAK ehdotti keväällä 2019 ennen eduskuntavaaleja laajapohjaisen varallisuusveron luomista. ${ }^{35}$ Fiskaalisten syiden lisäksi tätä perusteltiin varallisuuserojen kasvun hillinnällä. Laajapohjainen varallisuusvero koskisi esimerkiksi pankkitalletuksia, osakkeita, rahastosijoituksia, yritysvarallisuutta, metsiä ja peltoja. Yli 100000 euron sijoitusvarallisuuksiin kohdistettu $0,1 \%$ :n vero tuottaisi SAK:n mukaan yli 100 miljoonaa euroa verotuloja. Asunnot, kesämökit ja autot olisivat vapautettuja uudesta varallisuusverosta, koska ne ovat jo valmiiksi arvoon tai omistukseen kytkeytyvän verotuksen piirissä.

34 Jan Hurri, Taloussanomat 13.11.2019: Kun tuloerot ylittävät poliittisen kipukynnyksen, kasvaa paine kiristää rikkaimpien verotusta. Yksi mahdollinen keino on varallisuusverotuksen paluu. Keskustelu varallisuusveron paluusta jatkuu meilläkin, mutta Suomi tuskin tekee omin päin suuria aloitteita. Mutta jos ja kun varallisuusvero palaa ensin Suomea suurempiin maihin, tilanne muuttuu meilläkin.

35 SAK:n esitystä on sosiaalisessa mediassa vastustettu $\mathrm{mm}$. viittaamalla työmarkkinajärjestöjen jäsenmaksujen vähennyskelpoisuuteen verotuksessa. Jäsenmaksujen vähentämisestä ja perusteista vähennysoikeuden puolittamiseen ks. esim. kirjoitukseni Verotus-lehdessä 2015 s. 550-551 ja kristillisdemokraattien ehdotus vuodelta 2016. Ks. myös jäljempänä luku 7.4.3.2.1.2. 
Kiinteistövero koskee vain asuntoja, mökkejä ja muita kiinteistöjä. Sen sijaan osakkeet, talletukset, sijoitusrahastot, metsät ja pellot on vapautettu tällaisesta verosta. SAK haluaa ulottaa myös nämä omaisuuslajit varallisuusveron piiriin.

Kahdeksantoista USA:n superrikasta, mm. George Soros, vaati kesäkuussa 2019 Yhdysvaltoihin uutta varallisuusveroa. Esityksessä todettiin, että Amerikalla on moraalinen, eettinen ja taloudellinen velvollisuus verottaa rikkaimpia enemmän. Varallisuusverolla voitaisiin ryhtyä toimiin ilmastonmuutosta vastaan, kohentaa taloutta, parantaa terveyttä ja vahvistaa demokraattisia vapauksia. Varallisuusveron käyttöönotto olisi kansallinen etu. Ehdotuksen mukaan olisi asetettava 2 sentin vero jokaista dollaria kohden 50 miljoonaa dollaria ylittävälle varallisuudelle; lisäksi olisi suoritettava 1 sentin vero dollaria kohden varallisuudesta, joka ylittää miljardi dollaria. Alle 50 miljoonan dollarin varallisuudesta tätä veroa ei siis joutuisi maksamaan.

Uutinen sai huomiota Suomessakin (Talouselämä 25.6.2019 ja 26.6.2019). SAK:n pääekonomisti Ilkka Kaukoranta painotti, että SAK kannattaa maltillista varallisuusveroa, jossa veroa maksaisi meillä lähinnä varakkain kymmenys.

Mielestäni on hyvä idea tuoda varallisuusvero keskusteluun, varallisuusverolla voitaisiin korvata myös perintö- ja lahjavero. Ideaa ei kyllä jokuseen aikaan toteuteta, koska sille ei ole riittävästi poliittista tahtoa.

Ylioppilaslehdessä 13.9.2019 julkaistiin Mia Haglundin huomiota herättänyt kolumni köyhistä ja rikkaista. Haglund totesi: "Maailmanlaajuinen omistuskatto voisi näin alkajaisiksi olla vaikka kohtuulliset 10 miljoonaa. Ylimenevä osuus kerättäisiin rikkailta saman tien ja kohdistettaisiin muun muassa ilmastonmuutoksen torjuntaan ja nälänhädän lopettamiseen."36 Tuollainen uudistus Suomen lainsäädäntöön kuitenkin edellyttäisi, vaikka se tehtäisiin varallisuusveron

36 Haglund on saanut ymmärtämystä vasemmistoliiton kansanedustajalta Anna Kontulalta, joka totesi Ylen Sannikka \& Ukkola -ohjelmassa 27.9.2019, että ei omistuskatosta ainakaan mitään haittaa olisi, mutta hän ei usko, että se yksin ratkaisisi. Kapitalismista seuraa Kontulan mukaan eriarvoistumista, pääomien keskittymistä ja ilmastonmuutos; keskeinen ilmastonmuutoksen syy on se, että kapitalismi pakottaa jatkuvaan kasvuun, vaikka ekologiset rajat ovat tulleet vastaan jo ajat sitten. Uusi Suomi 28.9.2019. 
4 Varallisuusveron reinkarnaatio?

muodossa, omaisuudensuojan vuoksi perustuslainsäätämisjärjestystä. Se taas vaatisi kansanedustajissa niin vahvan enemmistön, ettei sellaisen saavuttaminen ole mahdollista nykyisen eduskunnan aikana, tuskin myöhemminkään. 


\section{5 \\ Varainsiirtoveron menneisyys ja tulevaisuus $^{37}$}

\subsection{Varainsiirtoveron tarkoitus ja fiskaalinen merkitys}

Kun varhaisnuorena kuulin isältäni lainhuutoleimaverosta, nykyisestä varainsiirtoverosta, luulin kysymyksessä olevan maksu, jolla korvataan valtiolle omistajanvaihdoksen tarkastamisesta ja rekisteröinnistä aiheutuvat kustannukset. Iän karttuessa selvisi, että olin erehtynyt.

Varainsiirtoveron tarkoitus on puhtaasti fiskaalinen. Sillä pyritään vain tuottamaan valtiolle verotuloja. Varainsiirtoveroa on viime vuosina kertynyt Suomessa vuosittain runsaat 800 miljoonaa euroa. Pääosa siitä tulee kiinteistöjen ja kiinteistöosakkeiden luovutuksista. Varainsiirtoveron osuus valtion arvioiduista verotuloista on noin 1,8\%. Se on suhteellisen vähäinen mutta ei merkityksetön määrä - suurempi kuin perintö- ja lahjaveron tuotto.

37 Tämä luku perustuu pitkälti kirjoitukseeni Varainsiirtovero kuolemassa sukupuuttoon? Verotus 4/2018 s. 498-503. 


\subsection{Varainsiirtoveron kielteiset vaikutukset asumiseen ja työllisyyteen}

Varainsiirtoveroa on arvosteltu viime aikoina erityisesti siitä, että se vaikeuttaa ja vähentää ihmisten muuttamista. Osana valtioneuvoston selvitys- ja tutkimussuunnitelman toimeenpanoa on toteutettu tutkimus, jonka ovat tehneet VATT ja Helsingin kaupunginkanslia. ${ }^{38}$ Tutkimuksessa selvitettiin muuttohalukkuutta ennen vuonna 2013 toteutettua verouudistusta ja sen jälkeen. Tuossa verouudistuksessa asunto-osakkeiden varainsiirtovero nousi 1,6 \%:sta 2,0 \%:iin.

Tutkimuksessa saatiin näyttöä siitä, että varainsiirtovero vähentää muuttamista. Muuttamisen väheneminen johtaa siihen, että monet kotitaloudet asuvat tilanteeseensa nähden kooltaan tai sijainniltaan väränlaisissa asunnoissa. Varainsiirtovero vähentää myös maakuntien välisiä muuttoja, mikä viittaa siihen, että se haittaa työvoiman liikkuvuutta. Vuonna 2013 tehdyn osakehuoneistoja koskevan varainsiirtoveron korotuksen hyvinvointitappio on noin $20 \%$ verotulojen lisäyksestä. Hyvinvointitappio kasvaa nopeasti veroasteen noustessa, joten se on todennäköisesti selvästi korkeampi kiinteistömuotoisten omakotitalojen osalta, joissa varainsiirtovero on $4 \%$.

\subsection{Leimaverotuksen keksiminen}

Varainsiirtovero on hyvin vanha vero, ja se sai alkunsa leimaverona. Leimaverotus taas sai alkunsa 1600-luvun alkupuoliskolla Hollannissa. ${ }^{39}$ Pitkällisten sotien köyhdyttämä maa oli käyttänyt loppuun tavalliset verotusmenettelyt. Keksittiin leimapaperivero, joka kerättiin

38 Valtioneuvoston selvitys- ja tutkimustoiminta Policy Brief 8/2018. Ks. myös Christian A. L. Hilber - Teemu Lyytikäinen, Housing transfer taxes and household mobility: Distortion on the housing or labor market? VATT Working Papers 47 (2013).

39 Leimaverotuksen synnystä ja kehityksestä ks. esim. Markku O. Tunturi, Lainhuutoleimaverosta (1982) s. 28 ss. sekä Esko Linnakangas - Leila Juanto, Verojen historia. Synty, kehitys, kuolema, ylösnousemus, reinkarnaatio (2016) s. 111 ss. 
siten, että oikeudellisesti tärkeät asiakirjat oli kirjoitettava määrätystä maksusta saatavalle leimatulle paperille. Tämä verotusmuoto otettiin käyttöön eräissä Hollannin maakunnissa vuonna 1624 ja koko maassa vuonna 1635. Kerrotaan, että leimaveron keksi vuonna 1623 yksityishenkilö Johannes van den Broeck (synt. 1597) ja että hänelle luvattiin keksinnöstä 3000 guldenin vuotuinen maksu, jos vero otettaisiin käyttöön. Palkkiota ei ilmeisesti kuitenkaan ollut maksettu, ja hänen perillisensä yrittivät vielä vuonna 1728 periä sitä.

Uusi verotusmuoto osoittautui näppäräksi. Se oli tasaisesti tuottava, ja sen veroluonne oli hyvin kätketty. Niinpä se otettiin käyttöön 1600-luvulla useissa Euroopan maissa. Leimaverotuksen piiriin kuuluvat asiakirjat vaihtelivat maittain.

\subsection{Leimaverotus Ruotsin vallan aikana}

Kiinteä omaisuus on jo varhain ollut keskeisessä asemassa yhteiskunnassa. Tähän perustuvat kiinteistöjen omistussuhteiden saattaminen julkisiksi ja luovutukselle vaaditut määrämuodot. Ruotsissa nämä vaatimukset täytettiin keskiajalla sillä, että kiinteistönkauppa oli tehtävä käräjillä vahvistajien myötävaikutuksella.

Kirjoitustaidon yleistyessä keskiajan lopulla alettiin käyttää luovutuskirjoja. Koska kyse oli jälkeenpäin tapahtuvasta tuomioistuimen toimenpiteestä, siirtyi lainhuudatukseksi kutsuttu julkistamisvelvollisuus myyjältä ostajalle.

Ruotsissa leimapaperimaksu otettiin käyttöön joulukuussa 1660 annetulla leimapaperiasetuksella neljäksi vuodeksi. Seuraava asetus annettiin joulukuussa 1686, eikä välivuosia enää tullut. Pääsäännöksi tuli, että kaikki yksityisten väliset oikeustoimet oli tehtävä leimatulle paperille. Tämä koski ensinnäkin kiinteistön kauppa- ja vaihtokirjaa. Myös kiinnekirja, jonka tuomari antoi kaupan syntymisestä, oli kirjoitettava charta sigillata -paperille. Yksityisten välisistä sopimuksista koski leimapaperin käyttöpakko myös testamentteja, perukirjoja ja perinnönjakokirjoja. Leimapaperimaksu meni näin samasta saannosta moneen kertaan. 
Aluksi kyse oli enemmänkin leimamaksusta, koska se kannettiin käytettyjen arkkien märän perusteella. Vuoden 1732 leimapaperiasetuksessa siirryttiin jo lähemmäksi leimaveroa, kun testamentista säädettiin perittäväksi määrä, joka perustui omaisuuden arvoon.

Leimapaperin käyttö oli oikeustoimen pätevyyden edellytys. Oli lähdetty siitä, että oikeustoimeen ryhtyvällä oli käytössään leimapaperia. Tämä teki järjestelmästä tavattoman hankalan, ja leimapaperin käyttöpakosta luovuttiinkin asetuksella 30.12.1732. Leima säädettiin maksettavaksi rahassa virkamiehelle, joka vastaanotti asiakirjan. Leimaverotuksessa palattiin 14.1.1748 annetulla asetuksella periaatteessa leimapaperin käyttöpakkoon. Poikkeuksena kuitenkin säädettiin, että tavallista paperia sai käyttää, mikäli leimapaperia ei ollut saatavissa. Kyseinen asiakirja tuli myöhemmin kirjoittaa leimatulle paperille.

\subsection{Leimaverotus Suomen autonomian aikana}

Leimapaperimaksusta 4.4.1810 annetussa suomalaisessa asetuksessa oli edelleen pääsääntönä, että yksityisten välinen sopimus oli kirjoitettava leimatulle paperille. Sama menettely jatkui 8.9.1848 annetussa asetuksessa. Suomessa leimapaperin käyttöpakosta luovuttiin säädöstasolla vasta 24.11.1864 annetulla leimapaperiasetuksella. Saantokirjojen varustaminen "karttapaperilla, kun ne lainhuudatusta varten oikeuden eteen tuodaan" säädettiin ainoaksi menettelytavaksi karttasuostuntaveroasetuksella 21.12.1891. Leimasuostunta-asetuksella 8.1.1910 uudistettiin leimaverotusta tuntuvasti.

\subsection{Kiinteistöjen leimavero/ varainsiirtovero itsenäisessä Suomessa}

Vuoden 1921 lopussa säädettyyn leimaverolakiin otettiin säännös, jonka perusteella leimavero palautettiin hakemuksesta, jos samasta omistusoikeuden siirrosta oli jo maksettu perintö- tai lahjaveroa. 
Myös vuonna 1940 säädettyyn perintö- ja lahjaverolakiin otettiin säännös, jonka tarkoituksena oli estää päällekkäisyys leimaverotuksen kanssa. Vuonna 1943 säädetyssä uudessa leimaverolaissa ei lainhuudatusleimaveroon tullut muutoksia.

Lainhuudatusleimaveron määrä oli vuoden 1943 laissa alun perin 3-5 \% kiinteistön arvosta. Vero oli pienempi, jos luovutuskirja oli tehty lähisukulaisten kesken. Sittemmin vero korotettiin 4-6\%:ksi; sukulaisuusalennus säilytettiin. Vuoden 1991 alussa tuli voimaan verovapaus 18-39-vuotiaille ensiasunnon hankkijoille.

Kiinteistöjen luovutuksesta suoritettavaa leimaveroa koskevat säännökset kumottiin vuoden 1997 alusta varainsiirtoverolailla. Veromääräksi säädettiin nyt $4 \%$ kauppahinnasta tai muun vastikkeen arvosta. Samalla luovuttiin edellä mainitusta sukulaisalennuksesta.

\subsection{Osakeantileimavero}

Osakeantileimaveroa alettiin periä Suomessa 1.1.1916 lukien pörssin ylikuumentumisen vuoksi. Tuota veroa oli maksettava, kun osakekirja annettiin yhtiötä perustettaessa. Vero oli esimerkiksi vuoden 1943 leimaverolain 5 luvun alkuperäisissä säännöksissä 2 \% osakkeen nimellisarvosta. Kun osakekirja annettiin osakepääomaa korotettaessa, vero oli $2 \%$ osakkeesta yhtiölle suoritetusta määrästä ja $6 \%$ siitä osasta osakkeen nimellisarvoa, joka annettiin yhtiön omilla varoilla. Jos osakepääoman lisäksi päätettiin muodostaa osakeyhtiölle rahastoja tai näitä kartuttaa siten, että osakkaat suorittivat yhtiölle varoja osakekirjoja niistä saamatta, oli sen yhtiökokouksen pöytäkirja, jossa sellainen päätös oli tehty, tai asiaa koskeva sopimuskirja leimattava määrän, joka vastasi yhtä prosenttia suoritettavaksi päätettyjen erien summasta. Vuonna 1948 tämäkin vero korotettiin $2 \%$ :ksi. Osakeantileimaverotus kumottiin 1960-luvun lopulla.

\subsection{Obligaatioiden leimavero}

Vuoden 1865 alusta leimaveroa ei ilmeisesti kannettu silloin, kun yrityksen obligaatio emittoitiin, vaan ainoastaan silloin, kun se esitettiin 
viranomaiselle. Tähän tuli muutos vuoden 1921 alussa, josta lähtien obligaation antajan oli varustettava obligaatiokirja $0,5 \%$ :n leimalla. $\mathrm{Mm}$. valtion, kunnan ja suomalaisen kiinteistöluottolaitoksen obligaatiot kuitenkin olivat verottomia.

Vero alennettiin vuoden 1930 alussa 0,3 \%:ksi ja korotettiin 0,6 \%:ksi vuonna 1957. Ulkomailla annettu obligaatio, jonka antajana oli ulkomaalainen, oli, ennen kuin se tälllä lainoitettiin, myytiin tai muulla tavalla siirrettiin, varustettava kaksinkertaisella leimalla. Obligaatioiden leimavero kumottiin vuonna 1968 samalla kertaa kuin osakeantileimavero.

\subsection{Arvopaperien siirtovero}

Arvopapereiden siirtoleimaveroa koskevat säännökset olivat vuoden 1943 leimaverolain 8 luvussa. Arvopaperilla tarkoitettiin osakkeita ynnä niiden väliaikaistodistuksia ja muita osuustodistuksia taloudellisissa yhteisöissä sekä sellaisia osakeyhtiön antamia velka- tai muita saamistodisteita, joissa korko oli märä̈tty riippuvaksi yhtiön vuosivoiton tai osingon suuruudesta taikka jotka oikeuttivat osallisuuteen vuosivoitosta. Arvopapereiksi katsottiin myös osakkeiden ja mainitunlaisten saamistodisteiden merkintäoikeudesta annetut todistukset ja sanottua oikeutta koskevat luovutuskirjat.

Myytäessä tai vaihdettaessa arvopapereita oli leimaveroa maksettava $1 \%$, kun myynti tapahtui arvopaperipörssin välityksellä, ja 1,2 \%, kun luovutus tapahtui ilman arvopaperipörssin välitystä. Valtioneuvostolla oli kuitenkin oikeus korottaa vero peräti kymmenkertaiseksi mutta asunto-osakeyhtiön osakkeiden kohdalla "vain" $5 \%$ :ksi. Tämä korotusmahdollisuus kumottiin vasta 1980-luvulla.

Arvopapereiden siirtoleimavero korotettiin 1980-luvun puolivälissä pörssikauppojen osalta 1,4\%:ksi kauppahinnasta ja muiden luovutusten osalta 1,6\%:ksi. Pari vuotta sen jälkeen vero alennettiin pörssikauppojen osalta $1 \%: k s i$.

Perinnäisten arvopaperimarkkinoiden rinnalle kehittyivät organisoidut optio- ja termiinimarkkinat. Näillä markkinoilla käytiin kauppaa johdannaissopimuksilla, joiden arvo perustui jonkin toisen hyödykkeen, ns. perushyödykkeen, arvoon. Tällainen toiminta aloi- 
tettiin Suomessa keväällä 1988. Leimaverolakiin lisättiin 8. päivänä huhtikuuta 1988 annetulla lailla (305/1988) säännökset, joilla leimavero ulotettiin koskemaan myös johdannaissopimuksia, jotka pohjasivat arvonsa leimaverolaissa tarkoitettuihin arvopapereihin.

Johdannaissopimuksiin ei sovellettu arvopapereiden siirtoleimaveroa koskevia säännöksiä. Arvopapereiden luovutuksiin, jotka perustuivat vakioituihin johdannaissopimuksiin ja tapahtuivat vakioitujen johdannaissopimusten kaupan selvittelytoiminnan välityksellä, sovellettiin leimaverolain 9 luvussa olevia säännöksiä (9 luku oli vapaana, kun siinä aiemmin säädetty pelikorttileimavero oli kumottu). Leimaveroa oli suoritettava $1 \%$ preemiosta, lunastushinnasta, arvopaperin myyntihinnasta tai hyvitetystä nettoarvosta, joihin ei luettu selvittelytoiminnan harjoittajan kantamia maksuja ja välityspalkkioita.

Vuonna 1992 laman aikana leimaverolakiin tehtiin suuri muutos. Pääomaliikkeiden vapautuessa katsottiin, että lainsäädännön oli oltava kilpailukykyinen, jotta pääomat eivät siirtyisi ulkomaille. Yritysten oman pääoman hankkimisen helpottamiseksi ja osakemarkkinoiden elvyttämiseksi arvopaperipörssin välityksellä tapahtuneista arvopapereiden siirroista poistettiin leimaverovelvollisuus. Koska optioiden ja termiinien arvo perustui leimaveronalaisiin arvopapereihin, luovuttiin myös johdannaissopimuksista suoritettavasta leimaverosta.

Julkisesti listatun arvopaperin varainsiirtoverovapaus on merkittävä verotuki. Tämän verotuen vuotuiseksi määräksi arvioidaan valtion talousarviossa peräti kaksi miljardia euroa. Tällainen staattinen tarkastelu on kuitenkin harhaa, koska jos pörssiosakkeiden myynnistä perittäisiin $2 \%$ :n siirtovero, pörssivaihto pienenisi olennaisesti. ${ }^{40}$

Arvopapereiden siirtoleimaveroa koskevat säännökset korvattiin vastaavilla varainsiirtoverosäännöksillä vuoden 1997 alusta voimaan tulleessa varainsiirtoverolaissa. Arvopaperin luovutuksessa varainsiirtovero oli 1,6\% kauppahinnasta tai muun vastikkeen arvosta $(20 \$)$. Julkisen kaupankäynnin kohteena olevan arvopaperin luovutuksesta ei veroa suoritettu eikä nykyisinkään suoriteta (ks. tarkemmin 15a \$).

Vuodesta 2013 alkaen varainsiirtovero on 2,0 \%, jos luovutuksen kohteena on asunto-osakeyhtiön tai keskinäisen kiinteistöosakeyhtiön osake tai asunto-osuuskunnan tai kiinteistöosuuskunnan osuus taikka

40 Ks. kirjani Historiallinen verokirja (2014) s. 45. 
muun osakeyhtiön osake, jos yhtiön toiminta tosiasiallisesti käsittää pääasiallisesti kiinteistöjen omistusta tai hallintaa tai jos luovutetaan sellaisen osakeyhtiön osake, jonka toiminta tosiasiallisesti käsittää pääasiallisesti edellä tarkoitettujen osakkeiden tai osuuksien tai niiden ja Suomessa sijaitsevien kiinteistöjen suoraa tai välillistä omistamista tai hallintaa (ks. tarkemmin VSVL 20.3 \$). Vastikkeeseen luetaan myös osakkeisiin kohdistuva yhtiölainaosuus (ks. tarkemmin VSVL $20.4-5 \$)^{41}$

\subsection{Finanssitransaktioverot}

Nykyinen varainsiirtoveromme ei enää vastaa niitä ajatuksia, joilla leimaverotus 1600-luvulla synnytettiin. Veropohja on aivan liian kapea ja veroprosentti liian korkea, jotta vero voisi olla vaikuttamatta verovelvollisten käyttäytymiseen.

Varainsiirtoveron saattohoito alkoi 1990-luvun alussa, kun arvopaperipörssin välityksellä tapahtuneista arvopapereiden siirroista luovuttiin suorittamasta leimaveroa. Kuten edellä olevasta historiallisesta tarkastelusta ilmenee, varainsiirtoveron sukulaiset ovat jo menehtyneet, ja koko suku on sammumassa, jos kiinteistöjen ja asunto-osakkeiden varainsiirtovero haudataan.

Jos varainsiirtovero poistetaan verojärjestelmästämme, on mietittävä, miten valtion verotuloihin syntyvä aukko täytetään. Mikäli varainsiirtoveron poistuminen kompensoidaan kiristämällä luovutusvoittoverotusta esimerkiksi luopumalla oman asunnon myyntivoiton verovapaudesta, kotitalouksien asunnonvaihto ei helpotu - päinvastoin.

Vielä 2010-luvun alkupuolella pidettiin mahdollisena, että varainsiirtovero saa perillisekseen Tobinin veron, pörssiveron, rahoitusveron tai jonkin muun finanssitransaktioveron. Tällä hetkellä pelastajan löytymisestä ei ole hyviä toiveita ja varainsiirtoverokarhuamme saattaa uhata sukupuutto.

41 Vertailun vuoksi mainittakoon, että velkakirjojen ja muiden saamistodisteiden leimaverotuksesta luovuttiin 1990-luvulla. Ks. kirjani Historiallinen verokirja (2014) s. 117 ss. 


\subsection{Kiinteistöveron korottaminen tai asuntotuloveron palauttaminen varainsiirtoveron tilalle}

Ainakin kokoomuksessa on ollut jonkinlaista kannatusta sille, että varainsiirtovero kumotaan ja toisaalta kiinteistöveroa korotetaan.

Kiinteistövero ei perustu nettotuloon vaan omaisuuden bruttoarvoon ja tuottokykyyn. Kiinteistövero on tiettyyn omaisuuteen (kiinteistöön) kohdistuva objektiivinen varallisuusvero ${ }^{42}$, jossa ei vähennetä velkoja eikä muutenkaan oteta huomioon omistajan henkilöön liittyviä olosuhteita.

Kiinteistövero eri muodoissaan on maailman vanhimpia veroja. Suomen nykymuotoinen kiinteistövero on kuitenkin kunnalle maksettava vero; se ei ole valtiolle maksettava vero, jollainen on varainsiirtoveromme. Jos varainsiirtovero haluttaisiin korvata kiinteistöverolla, lakia olisi siis muutettava siten, että kiinteistöveroa maksettaisiin myös valtiolle. Tämä merkitsisi samalla eräänlaista paluuta asuntotuloveroon, jollainen Suomessakin oli vielä 1990-luvun alussa ennen kiinteistöverolain säätämistä. Asuntotulon verotuksella tarkoitetaan sen laskennallisen edun tuloverottamista, jonka henkilö saa asuessaan omistamassaan asunnossa. Taloustieteilijöiltä (fiktiivisen) asuntotulon verottaminen saa paljon enemmän ymmärtämystä kuin veronmaksajilta.

Omassa omistusasunnossa eläminen $\mathrm{mm}$. rajoittaa halua muuttaa työn perässä toiselle paikkakunnalle. Työvoiman liikkuvuuden kannalta vuokralla asumista saatetaankin pitää parempana. Elinkeinoelämän tutkimuslaitoksen tutkimusjohtaja Mika Maliranta totesi tammikuussa 2015 kirjansa "Luovan tuhon tie kilpailukykyyn - miten innovointi vaikuttaa yrityksiin, kansantalouteen ja kansalaisiin" julkistamistilaisuudessa, että vuokra-asuminen edistää muuttoa työn perässä, joten asuntokauppojen varainsiirtovero on talouskasvun kannalta yksi huonoimmista veroista (Taloussanomat 14.1.2015). Hyödyllisempää olisi hänen mukaansa verottaa asuntotuloa eli sitä etua, jonka saa, jos asuu omassa asunnossaan. Asuntotulovero olisi

42 Erilaisista varallisuusveroista ks. edellä luku 4.2. 
hänen mielestään sosiaalisesti ja sukupolvien välisesti oikeudenmukainen. Koska Maliranta ei halunnut henkeensä kohdistuvia uhkauksia, hänkään ei tunnustanut käytännössä kannattavansa tuollaista veroa.

Mikrotaloustieteen professori Marko Terviö on Akateemisessa talousblogissa 10.7.2012 tehnyt ehdotuksen muuttoveroksi kutsumansa varainsiirtoveron tasaamiseksi. Muuttoveron voisi hänen mielestään korjata budjettineutraalilla muutoksella. Ehdotuksen mukaan veron määrä riippuisi vain asunnon hinnasta, ei siitä kuinka usein joutuu muuttamaan. Jos omistusasujat nykyisin muuttavat keskimäärin kerran 10 vuodessa, niin perittäköön muuton jälkeen joka vuosi 1/10 nykyisestä varainsiirtoverosta riippumatta siitä, kuinka kauan muutosta on kulunut. Tällaista veroa olisi mahdollista pitää kiinteistöveron etäsukulaisena.

Terviön esitys on saanut jonkinlaista ymmärtämystä esimerkiksi kokoomuslaiselta Juhana Vartiaiselta (Talouselämä 23.5.2018). Malliin liittyy kuitenkin niin paljon ongelmia erityisesti aikaisemmin hankitun asunnon huomioimisen osalta, ettei ehdotuksen mukaisen lain säätäminen vaikuta realistiselta.

\subsection{Muita vaihtoehtoja}

Varovaiset voivat suositella kompromissimallia, jossa menetettävä varainsiirtoverotuotto kerättäisiin korottamalla useita veroja eikä vain yhtä veroa. Silloin yksittäisen veron korotukset olisivat hyvin pieniä eivätkä juuri vaikuttaisi verovelvollisten käyttäytymiseen. Nimellisten verokantojen korotuksia voidaan myös välttää tiivistämällä veropohjia (esim. luopumalla kokonaan oman asunnon korkovähennyksestä).

Varainsiirtoveron poistamisen siunauksellisuuteen vahvasti uskovien mielestä tuosta verosta luopumista ei tarvitsisi kompensoida muuta verotusta korottamalla, koska valtio saisi menettämänsä verotulot takaisin työllisyyttä ja talouselämää edistävän dynaamisen vaikutuksen ansiosta lisääntyneinä tulo- ja arvonlisäverotuottoina.

On tietysti niitäkin, jotka nyt mieluummin lisäisivät valtionvelkaa kuin maksaisivat enemmän veroja, ja myös sellaisia, jotka kannattavat verojen vähentämistä niin, että valtion tehtäviä ja menoja supistetaan vaikkapa julkista sosiaaliturvaa leikkaamalla. 
Realistinen lainsäädäntövaihtoehto voisi olla malli, jossa varainsiirtoveroa ei kokonaan poisteta vaan se alennetaan esimerkiksi $1 \%$ :ksi ja samalla luovutaan ensiasunnon varainsiirtoverovapaudesta. Jonkinlaisen varainsiirtoveron säilyttämistä voidaan puoltaa fiskaalisesti myös viittaamalla siihen, että se vähentää verojen minimoimiseksi tehtäviä luovutuksia läheisten kesken. ${ }^{43}$

Varainsiirtoveron muutos onnistuisi poliittisesti helpommin kuin esimerkiksi joidenkin haaveilema yleisen varallisuusveron palauttaminen verojärjestelmäämme. ${ }^{44}$ Hyvin pienellä verokannalla on vain hyvin pieni vaikutus verovelvollisten käyttäytymiseen. Juuri se olikin perusideoita 1600-luvulla verokeksintökilpailun voittaneessa leimaverossa, jonka perillinen varainsiirtoveromme on.

43 Ristivaikutuksista verotuksessa ks. Kalle Isotalon väitöskirja (2019).

44 Varallisuusveron palauttamisesta ks. edellä luku 4. 


\section{6 \\ Verokarhun rooli naamiaisissa}

\subsection{Verosuunnittelun, veron kiertämisen ja verovilpin käsitteistä ${ }^{45}$}

Tarkasteltaessa veron kiertämistä joudutaan tekemään rajaa verosuunnitteluun ja verovilppiin. Verosuunnittelu luonnehditaan lain mukaiseksi toiminnaksi vero-oikeudellisen normiston asettamien kehysten sisällä. Veron kiertäminen ei ole vero-oikeudellisesti hyväksyttävää veron minimointia. Verovilpissä taas kysymys on suorastaan rikollisesta toiminnasta, jossa verovelvollinen esimerkiksi tahallaan antaa väärän veroilmoituksen.

\subsection{Yleiset veronkiertämissäännökset}

Suomessa lähes kaikissa verolaeissa on yleislauseke, joka antaa verottajalle normaalia lain soveltamista pidemmälle menevät mahdollisuudet

45 Ks. tarkemmin esim. Matti Myrsky - Timo Räbinä, Verotusmenettely ja muutoksenhaku (2015) s. 339 ss. ja Timo Räbinä - Matti Myrsky - Janne Myllymäki, Verotusmenettelyn perusteet (2017) s. 82 ss. 
puuttua veron kiertämiseen. Tuloverotusta koskee verotusmenettelylain $28 \$$, joka kuuluu seuraavasti:

Jos jollekin olosuhteelle tai toimenpiteelle on annettu sellainen oikeudellinen muoto, joka ei vastaa asian varsinaista luonnetta tai tarkoitusta, on verotusta toimitettaessa meneteltävä niin kuin asiassa olisi käytetty oikeaa muotoa. Jos kauppahinta, muu vastike tai suoritusaika on kauppa- tai muussa sopimuksessa märätty taikka muuhun toimenpiteeseen on ryhdytty ilmeisesti siinä tarkoituksessa, että suoritettavasta verosta vapauduttaisiin, voidaan verotettava tulo ja omaisuus arvioida.

Jos on ilmeistä, että verotusta toimitettaessa olisi meneteltävä 1 momentissa tarkoitetulla tavalla, on verotusta toimitettaessa huolellisesti tutkittava kaikki ne seikat, jotka voivat vaikuttaa asian arvostelemiseen, sekä annettava verovelvolliselle tilaisuus esittää selvitys havaituista seikoista. Mikäli verovelvollinen ei tällöin esitä selvitystä siitä, että olosuhteelle tai toimenpiteelle annettu oikeudellinen muoto vastaa asian varsinaista luonnetta tai tarkoitusta taikka ettei toimenpiteeseen ole ryhdytty ilmeisesti siinä tarkoituksessa, että suoritettavasta verosta vapauduttaisiin, verotusta toimitettaessa on meneteltävä 1 momentissa tarkoitetulla tavalla.

Esimerkiksi vastaava säännös perintö- ja lahjaverotuksessa (PerVL $33 \mathrm{a} \$$ ) kuuluu seuraavasti:

Jos perinnönjakosopimukselle, luovutustoimelle tai muulle perintö- tai lahjaverotukseen vaikuttavalle oikeustoimelle on annettu sellainen oikeudellinen sisältö tai muoto, joka ei vastaa asian varsinaista luonnetta tai tarkoitusta, tai jos on ryhdytty muuhun toimenpiteeseen ilmeisesti siinä tarkoituksessa, että perintö- tai lahjaverosta vapauduttaisiin, on perintötai lahjaverotuksessa meneteltävä asian varsinaisen luonteen tai tarkoituksenmukaisesti.

Jos on ilmeistä, että perintö- tai lahjaverotusta toimitettaessa olisi meneteltävä 1 momentissa tarkoitetulla tavalla, on perintö- tai lahjaverotusta toimitettaessa huolellisesti tutkittava kaikki ne seikat, jotka voivat vaikuttaa asian arvostelemiseen, sekä annettava verovelvolliselle tilaisuus esittää selvitys havaituista seikoista. Ellei verovelvollinen tällöin esitä selvitystä siitä, että perintö- tai lahjaverotukseen vaikuttavalle oikeustoimelle annettu oikeudellinen sisältö tai muoto vastaa asian varsinaista luonnetta tai tarkoitusta taikka ettei muuhun toimenpiteeseen ole ryhdytty ilmeisesti siinä tarkoituksessa, että suoritettavasta verosta vapauduttaisiin, perintö- tai lahjaverotusta toimitettaessa on meneteltävä 1 momentissa tarkoitetulla tavalla. 
EU:ssa on vuonna 2016 hyväksytty direktiivi 2016/1164, joka koskee yleisen veronkiertosäännöksen kansallista täytäntöönpanoa. ${ }^{46}$ Suomessa on katsottu, että VML 28 \$:ää ei direktiivin vuoksi tarvitse muuttaa, koska muutos aiheuttaisi oikeudellista epävarmuutta, kun vakiintunutta oikeustilaa jouduttaisiin tulkitsemaan suhteessa uuteen sanamuotoon. ${ }^{47}$

\subsection{Veronkiertämissäännöksen tyyppitilanteet ja soveltaminen verovelvollisen eduksi}

Tuloverotuksessa VML 28 \$:n tyypillisiä soveltamistilanteita ovat olleet seuraavat:

1. Oikeudellisen muodon ja taloudellisen sisällön ristiriidat. Näissä tapauksissa kysymys on yksityisoikeudellisen muodon väärinkäytöstä veroedun saavuttamiseksi. Käytetty oikeudellinen muoto ei vastaa asian taloudellista sisältöä tai asiassa on käytetty tiettyä

46 Ks. esim. Siru Lönnblad, Veron kiertämisen estäminen muuttuvassa toimintaympäristössä, Verotus 2018 s. 62 ss.

47 Vuoden 2020 alussa Suomessa on tullut voimaan kansainväliseen veronkiertämiseen liittyvää uutta verolainsäädäntöä, joka perustuu EU:n säädöksiin. On säädetty eräiden rajat ylittävien hybridijärjestelyjen verotuksesta. Säännökset koskevat menoja ja tuloja, joiden verokohtelu ei ole rajat ylittävässä tilanteessa yhdenmukainen sen vuoksi, että kyse on hybridijärjestelystä, jossa eri lainkäyttöalueiden verotuksessa kohdellaan eri tavalla suorituksen perusteena olevaa rahoitusvälinettä tai siihen perustuvaa suoritusta, suorituksen maksajaa tai suorituksensaajaa. Säännökset koskevat myös tilannetta, jossa kahdella lainkäyttöalueella asuva verovelvollinen vähentää samoja menoja kahteen kertaan, mutta eri tulopohjista. Lisäksi säädetään tilanteista, joissa verokohtelun eroavuuksia syntyy tulon ja menon kohdentamisessa pääliikkeen ja kiinteän toimipaikan välillä. Hybridijärjestelyjen johdosta rajat ylittävässä tilanteessa verokohtelun eroavuudesta syntyy kaksinkertaisia vähennyksiä ja tuloa jää verottamatta. Uusien säännösten tarkoituksena on ehkäistä näitä vaikutuksia.

Lisäksi on säädetty laki raportoitavista järjestelyistä verotuksen alalla. Veroalan palveluja tarjoaville välittäjille sekä verovelvollisille on tullut velvollisuus ilmoittaa Verohallinnolle tietoja tietyistä rajat ylittävistä järjestelyistä, joissa voi olla kyse veron välttämisestä. Tarkoituksena on parantaa EU:n jäsenvaltioiden veroviranomaisten tiedonsaantia rajat ylittävistä verosuunnittelujärjestelyistä, joissa voi olla veron kiertämisen tai välttämisen elementtejä. 
oikeudellista muotoa yksinomaan sen vuoksi, että saavutettaisiin veroetu.

2. Peräkkäiset tai edestakaiset oikeustoimet eli sarjatoimet. Tällöin verovelvollinen jakaa oikeusoikeustoimet keinotekoisesti useaan osaan, jotta osien perusteella erikseen määrättävät veroseuraamukset olisivat hänelle edullisemmat kuin mihin päädyttäisiin, jos arvioinnin kohteena olisi järjestely kokonaisuutena. Tähän kuuluvat myös edestakaiset toimet, jotka kumoavat toistensa taloudellisen vaikutuksen ja palvelevat vain veroedun saamista.

3. Intressinpuute- ja intressiyhteystilanteet. Intressinpuutetilanteissa vain toisella sopijapuolella on intressiä tiettyihin ehtoihin. Intressiyhteistilanteissa sopijapuolet ovat etuyhteydessä keskenään eikä toimi ole taloudellisesti perusteltu. Tällaisia oikeustoimia voidaan tehdä esimerkiksi vanhempien ja lasten, yhtiön ja osakkaan sekä samaan konserniin kuuluvien yhtiöiden välillä.

Perintö- ja lahjaverolain vero-objektien käsitteet (perintö, lahja, luovutus) perustuvat vahvasti yksityisoikeudellisiin käsitteisiin. Siksi veron kiertämistä koskevan säännöksen soveltamisen sanotaan olevan perintö- ja lahjaverotuksessa rajoitetumpaa kuin tuloverotuksessa, jossa vero-objektin muodostaa laaja tulon käsite ja jossa erilaisia suorituksia voidaan tarkastella niiden taloudellisen sisällön mukaan.

Sellaisen kannan tueksi, ettei veronkiertämissäännöstä voida soveltaa verovelvollisen eduksi, on viitattu seuraaviin oikeustapauksiin: ${ }^{48}$

KHO 1973 II 563. R. oli 5.12.1970 myynyt kahden muun henkilön kanssa erään tontin 85000 markan kauppahinnasta, mistä R:n osuus oli hänen omistusoikeutensa perusteella 3/5 eli 51000 markkaa. Verolautakunta totesi, että R:n ja hänen sisarensa N:n välillä 26.7.1962 tehdyn kauppakirjan mukaan R oli saanut sanotun kiinteistönosan omistukseensa ostamalla sen N:Ita 10500 markan kauppahinnasta, ja lisäsi R:n tuloon satunnaisena myyntivoittona 40 625,65 markkaa. $R$ valittaessaan verotuksesta selitti, että hänen isänsä jälkeen 25.7.1962 toimitetussa perinnönjaossa oli ennen pesänositus- ja perinnönjakokirjan allekirjoittamista sovittu, että $\mathrm{R}$ ja $\mathrm{N}$ vaihtavat perintöosuutensa. Vaikka edellä mainitun

48 Esim. Matti Myrsky - Timo Räbinä, Verotusmenettely ja muutoksenhaku (2015) s. 351-352. 
suullisen sopimuksen mukaiset korjaukset jäivätkin asiantuntemattomuudesta johtuen tekemättä perinnönjakokirjaan ja tontinosa oli sisällytetty 26.7.1962 tehtyyn kauppaan, jolla $\mathrm{N}$ oli myynyt myös aikaisemmin omistamansa $1 / 5$ osan tontista R:lle, $\mathrm{R}$ katsoi, että hän oli saanut $2 / 5$ tontista perintönä ja että verotuksessa oli muodollisista virheistä huolimatta meneteltävä sen mukaisesti. KHO katsoi, että R oli saanut koko puheena olevan 3/5 osaa tontista omistukseensa ostamalla. Verovuosi 1970. Eri mieltä ollut jäsen, ottaen huomioon verotuslain 56 \$:n (nyk. VML 28 \$), katsoi R:n saaneen 2/5 tontista perintönä ja ettei $R$ siten ollut saanut veronalaista myyntivoittoa. Äänestys 3-1.

KHO 29.5.1992 T 2059. Verovelvollinen oli 28.11.1988 myynyt 50 kappaletta osakkeita yhtiölle 4211500 markalla, jotka osakkeet hän oli 16.1.1987 allekirjoitetun leimaverolaskelman ja yhtiön osakeluetteloon tehtyjen merkintöjen mukaan ostanut 14.1.1987. Vastoin virallisiin asiakirjoihin tehtyjä merkintöjä verovelvollisen ei voitu katsoa olleen osakkeiden omistaja aikaisemmin kuin 14.1.1987 lukien siitä huolimatta, että esitettyjen todistajanlausuntojen mukaan toinen henkilö oli ollut vain muodollisesti kysymyksessä olevien osakkeiden omistaja vuodesta 1978 lukien. Kun osakkeet näin ollen eivät olleet olleet verovelvollisen omistuksessa vähintään 5 vuotta, niiden myynnistä saatu voitto oli satunnaisena myyntivoittona verovelvollisen veronalaista tuloa.

KHO 2.3.2005 T 422. A oli omistanut Kiinteistö Oy C:n koko osakekannan. Kiinteistöyhtiö omisti paitsi Lapissa lomakiinteistön myös rakennusalalla toimineen B Oy:n osakekannan. B Oy oli jatkanut vuonna 1998 konkurssiin asetetun yhtiön rakennusalan liiketoimintaa. Näissä kummassakin yhtiössä käytännön toiminnan, kuten urakkatarjouskirjeenvaihdon ja rahaliikenteen, oli hoitanut A:n isä. Tytär A oli isänsä ehdotuksesta ryhtynyt vuonna 1998 B Oy:n hallituksen varsinaiseksi jäseneksi. B Oy:llä ei ollut asiassa esitetyn selvityksen mukaan toimitusjohtajaa. A oli muualla päätoimessa.

B Oy:n Kiinteistö Oy C:lle lomakiinteistön käytöstä vuonna 1999 suorittama vuokra jälkiverotettiin A:n B Oy:ltä Kiinteistö Oy C:n osakkuusaseman perusteella saamana peiteltynä osinkona. A vaati, että VML 28 \$:ää oli sovellettava hänen hyväkseen sillä perusteella, että hän oli ollut vain muodollinen osakas ja isänsä bulvaani eikä perustetta VML 29 §:n soveltamiselle näin ollen ollut.

KHO katsoi, että rahanarvoinen etuus oli tullut B Oy:n osakkaan Kiinteistö Oy C:n omistajalle A:lle hänen osakkuusasemansa perusteella. Tällaisesta etuudesta oli verotettava VML 29 \$:n 1 ja 3 momentti huomioon ottaen A:ta, siitä riippumatta, että puheena oleva etuus olisi tosiasiassa kanavoitunut hänen isälleen, joka todellisuudessa oli yhtiön 
toiminnassa keskeisessä asemassa. B Oy:n osakasyhtiön täysi-ikäinen omistaja A ei voinut myöskään vapautua perhepiirissä sovitun ja tehdyn omistusjärjestelyn johdosta hänelle näin aiheutuvasta verotuksesta VML 28 \$:n nojalla. Perustetta jälkiverotuksen kumoamiseen ei siten ollut.

Verovelvolliselle näin kielteistä kantaa voidaan arvostella, eikä se varmaan sovellu kaikkiin tapauksiin. On otettava huomioon myös verotuksessa noudatettavat yleiset periaatteet, erityisesti tasapuolisuusvaatimukset. VML 26.1 \$:n mukaan verotusmenettelyssä ja muissa verotukseen liittyvissä toimissa veronsaajien ja verovelvollisen edut tulee ottaa huomioon tasapuolisesti. Samantapainen vaatimus on nykyisin PerVL 33 \$:ssä, jonka mukaan verotus toimitetaan perukirjan, veroilmoituksen, lahjaveroilmoituksen, sivulliselta tiedonantovelvolliselta saatujen tietojen ja asiassa saadun muun selvityksen perusteella ottaen huomioon tasapuolisesti valtion ja verovelvollisen etu.

\subsection{Verosuunnitteluksi naamioidut tasa-arvon loukkaukset}

Edellä on perintöverotusta koskevassa osassa mainittu ongelmana yritysten ja maatilojen sukupolvenvaihdosten verokohtelu. Huojennuksissa on perustuslain yhdenvertaisuusperiaatteen kannalta kyseenalaisia piirteitä. Huojennukset voivat myös yllyttää toimiin, jotka loukkaavat esimerkiksi lasten välistä tasa-arvoa ja rikkovat suhteita. Tähän liittyy seuraavakin tapaus.

Olipa kerran isäntä ja emäntä, joilla oli lähes velaton suuri maatila sekä tytär ja poika. Vanhemmat luovuttivat maatilan pojalleen nimellisellä kauppahinnalla. Huomattavilta veroilta välttymisen sanottiin vaativan tällaista menettelyä. Verot vältettiinkin, koska sovellettiin sukupolvenvaihdoshuojennussäännöstä.

Isäntä ja emäntä kuolivat pari vuosikymmentä maatilan luovutuksen jälkeen. He olivat perukirjojen mukaan varattomia, olihan heidän omaisuutensa siirtynyt pojalle lahjanluonteisella kaupalla. Tyttären mielestä sisarusten välistä tasa-arvoa oli loukattu $\mathrm{mm}$. sukupuolen perusteella. Hänen tuli mielestään saada edes osa lakiosastaan. 
Kun tytär vaati osaansa, sisarusten välit katkesivat täysin. Ulkopuolisten avustuksella saatiin molemmilta allekirjoitus lahjakirjaksi otsikoituun sopimukseen, jolla poika siirsi sisarelleen kotitilasta pienen maapalan. Sisar joutui maksamaan tästä luovutuksesta huomattavan lahjaveron.

Lahjan käsitteeseen kuuluvia lahjoitustahtoa, yksipuolisuutta ja vapaaehtoisuutta ei tässä veljen ja sisaren välisessä luovutuksessa ollut, vaan kysymys oli sisarusten välisestä sopimuksesta, jolla ratkaistiin perintöriidat. Tosiasiallisesti tytär sai näin vanhemmiltaan perinnön, joka oli naamioitu veljeltä saaduksi lahjaksi. Perintövero vanhempien jälkeen olisi ollut hyvin paljon pienempi kuin nyt maksuunpantu lahjavero. Muutoksen saamista toimitettuun verotukseen vaikeuttaa kuitenkin edellä selostettu oppi, jonka mukaan veronkiertämissäännöstä ei voitaisi soveltaa verovelvollisen eduksi. 


\section{7 \\ Kansalaisaloitteinen \\ verotus - vilhdettä vai demokratiaa?}

\subsection{Veroista säätämisestä ja kansalaisvaikuttamisesta}

\subsubsection{Säätyvaltiopäivien aika ${ }^{49}$}

Ruotsin, jonka osa Suomikin oli, valtiopäivillä oli neljä säätyä: aatelisto, papisto, porvaristo ja talonpojat. Kun Suomi vuonna 1809 irrotettiin sodalla Ruotsista ja liitettiin autonomisena osana Venäjään, Venäjän keisarin asema Suomen suuriruhtinaana perustettiin Ruotsin vallan aikaiseen Kustaa III:n valtiosääntöön vuodelta 1772 sekä yhdistys- ja vakuuskirjaan vuodelta 1789.

Vuonna 1809 järjestettiin Porvoon valtiopäivät, mutta seuraavan kerran valtiopäivät kutsuttiin koolle vasta 1860 -luvulla. Noin pitkää kokoontumistaukoa helpotti se, että valtiopäivien suostumus tarvittiin vain uusiin veroihin - ei tulleihin, jotka todellisuudessa olivat valtiontalouden selkäranka.

49 Valtiopäivien historiaa on selvitetty perusteellisesti $\mathrm{mm}$. kirjasarjassa Suomen kansanedustuslaitoksen historia, esim. 2. osa (1981). 
Suomen säätyvaltiopäivillä aatelia edustivat sukujen päämiehet, joita oli noin 200. Pappissäädyssä oli noin 40, porvaristossa runsaat 50 ja talonpoikaissäädyssä 70 edustajaa. Heidät valittiin vuoden 1869 valtiopäiväjärjestyksen mukaan seuraavasti:

$10 \$$. Ritaristo ja Aateli tulee valtiopäiville Ritarihuonejärjestyksen jälkeen, jonka pitää oleman perustuslakien mukaisesti tehtynä.

11 \. Papissäätynä ovat: Arkkipispa ja Pispat, jotka tulevat kokoon Keisarin ja Suuriruhtinaan kutsumuksesta, sekä kunkin hippakunnan puolesta vähintäänkin seuraava määrä vakinaisessa virassa tahi palveluksessa olevain hippakunnan papismiesten valitsemia edusmiehiä, nimittäin: Turun hippakunnan puolesta 12, Porvoon hippakunnan puolesta 10 ja Kuopion hippakunnan puolesta 6 .

Maan Yliopiston opettajain ja vakinaisten virkamiesten tulee valita yksi valtiopäivämies Papissäätyyn, kuitenkin sillä oikeudella että saavat, jos tahtovat, panna kaksi. Samoin tulee alkeisoppilaitosten kaikkien vakinaisten opettajain valita valtiopäivämiehiä Papissäätyyn, yksi kunkin hippakunnan puolesta, mutta saattavat, jos niin haluavat, määrätä kaksi.

Vaalien tavasta ja järjestyksestä eri hippakunnissa sopikoot valitsiat keskenänsä.

$12 \S$. Porvarissäätynä ovat Suomenmaan kaupunkien edusmiehet sillä tapaa: että jokaisen kaupungin puolesta valitaan yksi valtiopäivämies, mutta jos väkiluku henkikirjan mukaan nousee kuuteentuhanteen henkeen, valitaan kaksi ja siitä pällle, yksi kultakin täydeltä 6,000 hengen luvulta; kuitenkin saakoon kaupunki, jossa on vähemmän kuin 1,500 asukasta, joko panna erinäisen edusmiehen puolestansa taikka suostua yhteisestä valtiopäivämiehestä jonkun toisen kaupungin kanssa, joka, sen mukaan kuin tässä on sanottu, saattaa valtiopäiville lähettää yhden edusmiehen.

Oikeutetut vaalissa osallisina olemaan ovat: porvarit, laivan-omistajat, vapriikinhaltiat, elinkeinojen harjoittajat erinäisillä eri-oikeuksilla, ja talon-omistajat, jos ovat kaupungissa verollekirjoitetut, niin myös kaupunkien vakinaiset pormestarit ja raatimiehet.

Vaali-oikeutta eivät nauti:

- vaimo-ihminen, naitu tahi naimaton;

- se talon-omistaja, joka on vapasukuinen taikka kuuluu Papissäätyyn;

- kauppamerimiehet, alhainen sotaväestö, sekä yleisten ja yksityisten laitosten ja yhteyskuntain vahtipalveliat; 
- ne, jotka toisen palveluksessa tahi alituisessa työssä ovat, päiväpalkkalaiset ja muut senkaltaiset, jotka elättävät itseänsä satunnaisella työnteolla; samoin myös ne, jotka vaan omaksi elatuksekseen saavat jotakin elinkeinoa harjoittaa.

Vaali toimitetaan Maistraatin edessä siksi kuulutettuna päivänä lipuilla kaupungissa tavallisen vaalitavan mukaan. Äänet luetaan vero-äyrejä tahi niitä muita perustuksia myöten, joita noudatetaan määrättäissä mitä minkin valitsijan tulee maksaa kaupungin kassaan yleisiä tarpeita varten. Jos kaupungin vaali-oikeutetut asukkaat tahtovat saada muutosta vaalin tavassa ja järjestyksessä, ovat äänet siitä päätettäessä luettavat samain perustusten mukaan ja asia lykättävä Keisarin ja Suuriruhtinaan tutkittavaksi ja vahvistettavaksi. Kaupungissa, jossa on tapana valita valitsijamiesten kautta, olkoon kullakin valitsijamiehellä valtiopäivämiehen vaalissa yksi ääni.

$13 \$$. Talonpojansäätynä ovat edusmiehet, valitut yksi maan kunkin tuomarikunnan puolesta. Vaali toimitetaan valitsiamiesten kautta, jotka ovat valitut jokaisesta tuomarikuntaan kuuluvasta kunnasta tahi kunnan osasta, ja pidetään tuomarin edessä hänen siihen määräämänä päivänä. Valitsiamiesten vaali pidetään asianomaisesti kuulutetussa kuntakokouksessa tahi, missä sitä ei ole, pitäjänkokouksessa, viimeistäänkin kahdeksan päivää ennen valtiopäivämiehen vaalia. Valitsiamiehen vaalissa on osallisena jokainen kunnassa asuva mies, jolla on manttaaliin pantua relssi- tahi perintömaata, taikka joka vakaalla asukas-oikeudella hallitsee kruununtilaa tahi arennilla pitää kruununpuustellia, kuninkaankartanoa tahi kuninkaan-latokartanoa ja ei kuulu muuhun säätyyn tahi ole maan palveluksessa. Jokaisen kunnan tulee silloin valita yksi sen piirissä asuva valitsiamies vaali-oikeutettujen seasta ja siitä päälle, henkikirjan osoittamaa asukaslukua myöten, yksi kultakin täydeltä 2,000 hengen luvulta; ja luetaan äänet tilain uusien eli tasattujen manttaalien mukaan. Valitsiamiesten pitää, varustettuina tätä vaalia koskevan pöytäkirjan otteella, kokoutuman määrättynä päivänä ja määrättyyn paikkaan, ja tulee heillä valtiopäivämiehen vaalissa kullakin olla yksi ääni.

$14 \$$. Oikeutettu olemaan osallisena valitsiamiehen tahi valtiopäivämiehen vaalissa aatelittomaan säätyyn on, noudattamalla 11,12 ja 13 \$\$:ssä säättyjä perustuksia, jokainen säätyyn kuuluva ja vaalipiirissä asuva täysivaltaisen ikään tullut Suomen mies, vaikka olisi muutakin kuin kristinuskoa; älköön kuitenkaan vaalioikeutettuna pidettäkö sitä:

- joka ei kolmena viimeksikuluneena vuotena ole ollut maassa verollekirjoitettuna; 
- joka on holhun alla;

- joka on luovuttanut omaisuutensa velkojainsa tyydyttämiseksi ja ei voi näyttää olevansa vapautettu heidän vaatimuksista;

- joka mainetta pahentavasta rikoksesta on edesvastaukseen tuomittu taikka jätetty tulevaan aikaan;

- joka on julistettu kansalaistensa luottamuksen menettäneeksi tahi kelvottomaksi toisen puolesta puhumaan;

- joka todistetaan syypääksi koettaneensa valitsiamiehen tahi valtiopäivämiehen vaalissa rahalla tahi lahjoilla hankkia ääniä, taikka väkivallalla tahi uhkauksilla häirinneen vaalivapautta;

- joka siihen on syypääksi näytetty, että hän valitsiamiehen tahi valtiopäivämiehen vaalissa on äänensä palkintoa vastaan antanut;

- joka jo on ollut valitsiamiestä tahi edusmiestä valitsemassa muun säädyn puolesta kuin sen, jossa hän sittemmin itsensä valitsevaksi ilmoittaa.

Vaali-oikeutta älköön missään tapauksessa asiamiehen kautta käytettäkö. Valitsiamiehen vaaliin käypä on jokainen vaalipiirissä asuva, jolla itsellään on oikeus sen vaalissa osallisena olla.

Valtiopäivämiehen vaaliin käypä aatelittomassa säädyssä on, alempana luetelluilla poikkeuksilla, jokainen joko vaalipiirissä taikka siitä ulkona asuva säädynjäsen, jolla itsellään on oikeus olla osallisena saman säädyn valitsiamiehen tahi edusmiehen vaalissa; älköön kuitenkaan velvollisuutta, joka koskee kolmena viimeksikuluneena vuotena maassa verolle-kirjoitettuna olemista, käytettäkö sitä kohtaan, joka on Keisarin palveluksessa, vaikka ei Suomen virkamiehenä.

Valtiopäivämieheksi ei saa hyväksyä sitä:

- joka ei ole kristin-uskoa;

- joka ei vielä ole 25 vuoden ikäinen;

- joka on ollut valitsemassa valitsiamiestä tahi edusmiestä muuhun säätyyn kuin siihen, jossa hän ilmoittaa itsensä valtiopäivämiehen tointa käyttämään.

Kaikki mitä tässä ylempänä sanotaan aatelittomassa säädyssä estävän vaalissa osallisena-olemisen, vaaliinkelpaavaisuuden ja valtiopäivämieheksi hyväksymisen oikeutta, olkoon myös esteenä Ritariston ja Aatelin edusmiehen hyväksymiseen.

Valtiopäivillä kaikki neljä säätyä kokoontuivat ja käsittelivät esityksiä erikseen. Yleensä lain hyväksymiseen riitti hyväksyminen kolmessa 
säädyssä, mutta uusien verojen asettamiseen vaadittiin kaikkien säätyjen hyväksyminen. Suostuntavaliokunnan tuli "valmistaa kaikki säädyistä sinne lykätyt asiat, jotka koskevat muutosta suostuntaveron maksamisen säännöistä” (37 \$).

\subsubsection{Eduskuntauudistus 1906 ja Suomen itsenäistyminen 1917}

Suomelle avautui tie valtiopäivätoiminnan uudistamiseen syksyllä 1905, kun Venäjä ajautui yhteiskunnalliseen kriisiin Japanille sodassa kärsityn tappion jälkeen. Säätyvaltiopäivät tuki yhtenäisenä ehdotusta yksikamarisen ja yleisellä äänioikeudella valittavan eduskunnan perustamisesta Suomelle. Venäjän keisari vahvisti esityksen, ja eduskunta perustettiin 1906.

Eduskunnan perustaminen merkitsi suurta hyppyä keskiaikaisesta säätyedustuksesta parlamentaariseen järjestelmään. ${ }^{50}$ Uuden valtiopäiväjärjestyksen mukaan äänioikeus oli yleinen ja yhtäläinen kaikille 24 vuotta täyttäneille suomalaisille, mikä merkitsi äänioikeutettujen määrän kasvua lähes kymmenkertaiseksi säätyvaltiopäivien aikaan verrattuna. Maailmanlaajuisesti erittäin poikkeuksellista oli se, että myös naiset saivat täydelliset valtiolliset oikeudet eli oikeuden äänestää ja asettua vaaleissa ehdolle. Eduskuntapaikat jakautuvat vuoden 1906 vaaleissa seuraavasti:

$\begin{array}{lr}\text { Sosialidemokraattinen puolue } & 80 \\ \text { Suomalainen puolue } & 59 \\ \text { Nuorsuomalainen puolue } & 26 \\ \text { Svenska folkpartiet } & 24 \\ \text { Maalaisliitto } & 9 \\ \text { Kristillinen työväenliitto } & 2\end{array}$

50 Eduskunnan päätösvallalle asetetut pidäkkeet yhdessä hallitsijalle jääneen vallan kanssa rajoittivat kuitenkin kansan enemmistön tahdon mukaisia ratkaisuja vielä pitkään, jopa 1990-luvun lopulle saakka. Esko Riepula - Jukka Kultalahti - Teuvo Pohjolainen, Kenellä valta valtiossa - Kuninkaiden ja säätyjen vallasta kansan valtaan. Perustuslakiemme pitkä kaari (2019). 
Autonomian ajan eduskunnan ensimmäiset vuodet olivat poliittisesti epävakaita, ja päätöksenteossa törmättiin moniin ongelmiin. Eduskunta hajotettiin useaan otteeseen, ja uudet vaalit jouduttiin järjestämään miltei vuosittain. Maailmansota ja Venäjän vallankumoukset kiihdyttivät Suomen erkaantumista keisarikunnasta niin, että eduskunta julistautui korkeimman vallan käyttäjäksi Suomessa marraskuussa 1917 ja Suomi itsenäiseksi muutamaa viikkoa myöhemmin. Itsenäisen Suomen eduskunnan ensimmäistä toimintavuotta leimasi sisällissodan lisäksi kiista valtiomuodosta. Lopulta päädyttiin tasavaltaiseen demokraattiseen järjestelmään, mutta presidentille myönnettiin laajat valtaoikeudet.

Vuoden 1919 hallitusmuodon 61 \$:ssä todettiin, että "verosta, myöskin tulliverotuksesta, säädetään lailla". Nykyisin tullitulot ja niiden sääntely kuuluu kuitenkin Euroopan unionille. Valtiopäiväjärjestyksessä meillä oli pitkään määräenemmistö- yms. vaatimuksia, joilla vaikeutettiin pysyvien uusien verojen säätämistä. Nykyisin sellaisia vaatimuksia ei enää ole, vaan verolakien sovelletaan samanlaista menettelyä kuin muidenkin lakien säätämiseen.

\subsubsection{Vaatimuksia kansalaisaloitejärjestelmäksi Suomessa 1900-luvulla}

Kansanvalta on Suomessa vanhastaan ollut erityisesti vasemmiston tavoitteena. Suomen Työväenpuolueen, sittemmin Suomen Sosialidemokraattisen Puolueen, Forssan kokouksen 1903 tärkeimpiä vaatimuksia olivatkin nämä:

1. Yleinen, yhtäläinen ja välitön vaali- ja äänioikeus kaikille 21 vuoden ikäisille Suomen kansalaisille sukupuoleen katsomatta kaikissa vaaleissa ja äänestyksissä sekä kunnallisella että valtiollisella alalla. Suhteellinen edustus ja yksikamarijärjestelmä. Salainen äänestys. Vaalien ja äänestysten toimittaminen lain määräämänä vapaapäivänä. Palkkio valituille edusmiehille kaikilla aloilla.

2. Välitön lainsäädäntöoikeus kansalle lakien esittämis- ja hylkäämisoikeuden kautta. 
Kansanvaltuuskunnan perustuslaissa 1918 oli kansalaisaloitetta kehitetty varsin pitkälle. Siinä todettiin:

"Kun vähintään kymmenentuhatta kansalaista, joilla on valtiollinen äänioikeus, allekirjoittamansa asiakirjan kautta esittää Kansaneduskunnalle ehdotuksen haluamansa lain säätämisestä, on tämä kansan alote valtiopäivillä kiireellisenä asiana käsiteltävä.

Jos sama kansan alote sisältää useampia asioita, jotka eivät yhteen sovellu, eroittakoon Kansaneduskunta ne toisistaan ja käsiteltäköön kutakin erikseen niinkuin siitä olisi tehty eri alote. Ellei kansan alote jo sisällä lain muotoon valmistettua ehdotusta, antakoon asianomainen Kansaneduskunnan valiokunta erityisen komitean tehtäväksi kiireellisesti valmistaa sen mukainen lakiehdotus.

Kansan alotteen kautta esille tullut lakiehdotus on valtiopäivillä käsiteltävä samassa järjestyksessä kuin muista lainsäädäntöesityksistä on voimassa, mutta älköön sitä lepäämään jätettäkö.

Ellei Kansaneduskunnan päätös asiasta tule kansan alotteen mukainen ja vähintään kolmasosa Kansaneduskunnan jäsenistä vaatii kansanäänestystä, on kansan alotteessa tarkoitetun ehdotuksen hyväksymisestä toimitettava kansanäänestys. Kansanäänestys on myös toimitettava, jos sitä kirjallisesti vaatii sellainen määrä kansalaisia, joka vastaa vähintään viittä sadasosaa viimeksi toimitettuihin kansanedustajain vaaleihin osaaottaneiden luvusta.

Jos Kansaneduskunta on, kansan alotteen johdosta hyväksynyt toisellaisen ehdotuksen, olkoon se kansanäänestyksessä vastaehdotuksena.

Jos kansanäänestyksessä enemmistö hyväksyy kansan alotteessa tarkoitetun ehdotuksen tahi vastaehdotuksen, on Kansaneduskunnan viivyttelemättä säädettävä kansan päätöksen mukainen laki."

Kansalaisaloite oli mukana myös paljon myöhemmin Demokraattisen Vaihtoehdon perustamisjulistuksessa 1986, jossa esitettiin, että uusi eduskunta säätäisi ensi töikseen lain kansalaisaloitteesta. Esimerkiksi 5 000:lla kansalaisella olisi sen mukaan tullut olla oikeus saada määräajassa aloitteensa eduskunnan käsittelyyn. 


\subsection{Ulkomaisia kansalaisaloite- järjestelmiä}

\subsubsection{Yleistä}

Kansalaisaloitteella voidaan tarkoittaa sekä kansalaisten aloitetta kansanäänestyksen järjestämiseksi jostakin asiasta että sellaista aloitetta, jolla kansalaiset voivat saada haluamansa asian edustuksellisen toimielimen käsiteltäväksi. Käsillä olevassa esityksessä keskitytään erityisesti jälkimmäiseen, ns. sisällölliseen kansalaisaloitteeseen, jossa aloitteen kohteena oleva asia saatetaan parlamentin käsiteltäväksi ja päätettäväksi eikä menettelyyn kytkeydy kansanäänestyksen järjestämistä asiasta. Tarkastelu perustuu hallituksen esityksessä 46/2011 olevaan selvitykseen ja Annika Korpelan vuonna 2016 tekemään tutkielmaan $^{51}$ ja kohdistuu eurooppalaisiin aloitejärjestelmiin valtiollisella (kansallisella) tasolla. Useissa maissa, Suomi mukaan lukien, on myös kunnallisen tai alueellisen tason kansalaisaloitejärjestelmiä.

Läntisen Euroopan maista mukaan on tässä otettu ne valtiot, joissa on sisällöllinen kansalaisaloite valtiollisella tasolla. Esimerkiksi Ruotsissa, Norjassa, Tanskassa ja Saksassa sellaista järjestelmää ei ole. ${ }^{52}$

Aloitteiden muodot ja menettelyt Euroopan maiden välillä vaihtelevat paljon. Eräissä valtioissa, esimerkiksi Itävallassa, kansalaisaloitejärjestelmä on ollut valtiollisella tasolla käytössä jo pitkään. Euroopassa on myös melko uusia kansalaisaloitejärjestelmiä. Tällaisia ovat Alankomaiden ja ns. uusien demokratioiden järjestelmät. Kansalaisaloitejärjestelmän yleistyminen liittyy pyrkimykseen lisätä kansalaisten suoran vaikuttamisen mahdollisuuksia.

\subsubsection{Sveitsi}

Suoralla demokratialla on Sveitsissä pitkät ja vahvat perinteet, vaikkakin Sveitsin valaliitto perustettiin alun perin edustukselliseksi jär-

\footnotetext{
51 Annika Korpela, Kansalaisaloitteelle säädetyt rajoitukset erityisesti perustuslain osallistumisoikeuksien näkökulmasta, pro gradu -tutkielma, Tampereen yliopisto 2016.

52 Osavaltiotasolla sellainen tunnetaan esim. Saksassa.
} 
jestelmäksi. Kansalaisaloite otettiin siellä käyttöön jo vuonna 1891 . Seuraavassa käsitellään Sveitsin nykyistä, kansanäänestyksen järjestämiseen kytkeytyvää kansalaisaloitemenettelyä, joka ei sinällään rinnastu edellä tarkasteltuihin sisällöllisiin kansalaisaloitteisiin. Sveitsissä on ollut aikaisemmin käytössä myös puhtaasti sisällöllinen kansalaisaloite, mutta siitä on luovuttu.

Kansalaisaloitteen tekemiseen vaaditaan 100000 allekirjoitusta, jotka on kerättävä 18 kuukauden aikana. Kansallisen kansalaisaloitteen pitää koskea perustuslain tai sen osan muuttamista. Tätä vaatimusta tulkitaan käytännössä melko väljästi. Aloite voi sisältää ehdotetun uuden perustuslain säännöksen tai muutosvaatimuksen ilman säädösehdotusta. Kunta- ja kantonitasolla kansalaisaloite on käytettävissä myös muuntasoisten lainsäädäntömuutosten ehdottamiseen.

Parlamentti voi todeta aloitteen pätemättömäksi ainoastaan silloin, jos sen muoto on virheellinen tai jos se loukkaa kansainvälisen oikeuden velvoittavia normeja. Toistaiseksi vain neljä aloitetta on todettu pätemättömiksi. Parlamentti voi myös muotoilla aloitteelle vastaehdotuksen, jolloin kansanäänestys järjestetään sekä kansalaisaloitteesta että parlamentin vastaehdotuksesta.

Kansalaisaloitteen käsittelyn käynnistää aloitekomitea, johon tulee kuulua vähintään 7 ja enintään 27 äänioikeutettua Sveitsin kansalaista. Komitea saattaa aloitteen liittokanslerinvirastoon, jossa tarkastetaan, että se täyttää muodolliset edellytykset. Samoin esitarkastuksessa tarkastetaan allekirjoituslistojen vaatimustenmukaisuus. Tämän jälkeen allekirjoitusten keräämisen alkamisajankohta julkaistaan maan virallisessa lehdessä, ja siitä alkaa kulua laissa määritelty 18 kuukauden määräaika. Kerätyt nimilistat toimitetaan kunkin kunnan viranomaisille, jotka tarkastavat allekirjoitukset. Tarkastetut listat toimitetaan jälleen liittokanslerinvirastoon, jossa todetaan virallinen keräystulos. Jos allekirjoituksia on riittävä määrä, aloite tulee muodollisesti vireille.

Hallituksen on lausuttava kantansa aloitteesta vuoden kuluessa sen vireilletulosta, ja parlamentin on otettava aloite käsittelyynsä kahden ja puolen vuoden kuluessa.

Suoran demokratian mekanismeilla on tärkeä asema Sveitsin poliittisessa järjestelmässä. Edellä kuvattu kansalaisaloitemenettely on ollut myös puolueille keskeinen politiikkaväline. Vuosien 1891-2010 
aikana on käynnistetty 378 kansalaisaloitetta, ja niistä on järjestetty 174 kansanäänestystä. Vaikka toistaiseksi vain 18 aloitetta on lopulta hyväksytty äänestyksessä, on aloitemenettelyllä ollut tärkeä rooli uusien asioiden tuomisessa päätöksenteon ja poliittisen keskustelun kohteeksi. Toisaalta kansalaisaloitetta on kritisoitu siitä, että se voi kohdistua ainoastaan perustuslain säännöksiin.

\subsubsection{Itävalta}

Kansalaisaloitteella on myös Itävallassa pitkät perinteet: se sisällytettiin perustuslakiin vuonna 1920. Ensimmäiset parlamenttikäsittelyyn edenneet aloitteet tehtiin kuitenkin vasta 1960-luvulla.

Kansalaisaloitteen saa vireille 0,1 \% Itävallan äänioikeutetuista kansalaisista eli noin 8000 henkilöä. Aloitteen saamiseksi parlamentin käsittelyyn vaaditaan kuitenkin 100000 tuenilmausta (n. 1,2\% äänioikeutetuista).

Aloitteen aiheen tulee kuulua liittovaltion säädösvaltaan. Se voi koskea uuden lain säätämistä taikka voimassa olevan lain muuttamista tai kumoamista. Aloite voi koskea perustuslakia, eikä sen tarvitse olla sisällöltään yhdenmukainen EU:n oikeusjärjestyksen tai Itävallan kansainvälisten velvoitteiden kanssa, sillä aloitteen sisältö arvioidaan näiltäkin osin vasta myöhemmin parlamenttikäsittelyssä. Vuonna 1947 säädetyn, kansallissosialismin nousun estämiseksi tarkoitetun lain noudattamista aloite kuitenkaan ei saa vaarantaa. Aloite voidaan esittää lakiehdotuksen muodossa tai yleisemmässä, toimenpidealoitteeseen rinnastuvassa muodossa.

Allekirjoituskelpoisia ovat ne 16 vuotta täyttäneet parlamenttivaaleissa äänioikeutetut Itävallan kansalaiset, joiden pääasiallinen asuinpaikka on Itävallassa.

Liittoparlamentilla on velvoite ottaa aloite käsiteltäväksi, mutta sen ei tarvitse tehdä aloitteesta nimenomaista päätöstä. Parlamentin työjärjestyksen mukaan kansalaisaloitteella on parlamenttikäsittelyssä etusija verrattuna hallituksen esityksiin ja parlamentin jäsenten aloitteisiin.

Ensimmäiset kolme aloitetta 1960-luvulla toteutuivat myöhemmissä lainsäädäntömuutoksissa (Itävallan yleisradioyhtiö 1964, 40-tuntinen työviikko 1969, 13:nnen kouluvuoden poistaminen 
1969). Sisällöltään aloitteet ovat kohdistuneet mm. sosiaalipolitiikkaan, koulujärjestelmään ja muihin julkisiin palveluihin, ympäristön- ja terveydensuojeluun, ydinvoimaan ja EU-kysymyksiin sekä maanpuolustukseen.

Nykyisin kansalaisaloitteiden taustayhteisöinä toimivat yleensä poliittiset puolueet. Aloiteinstituutio on Itävallassa muotoutunut voimakkaasti oppositiopolitiikan välineeksi.

\subsubsection{Alankomaat}

Kansalaisaloitejärjestelmä on ollut Alankomaissa käytössä vuodesta 2006 alkaen. Aloitteen tekemisestä säädetään parlamentin työjärjestyksessä. Kansalaisaloitteelle vaaditaan 40000 allekirjoitusta, hiukan yli 0,2 \% äänioikeutetuista. Aloiteoikeus kuuluu parlamenttivaaleissa äänioikeutetuille Alankomaiden kansalaisille. Aloitteeseen osallistuvien on allekirjoitettava aloite ja ilmoitettava nimensä ja syntymäaikansa sekä vakuutettava olevansa Alankomaiden kansalaisia. Allekirjoitusten keräämiselle ei ole määräaikaa.

Aloite voi olla muodoltaan lakiehdotus tai toimenpidealoite, kunhan sen tavoite on ilmaistu selkeästi ja esityksellä on riittävät perustelut. Aiheen on kuuluttava parlamentin päätösvaltaan. Aloite ei saa koskea asiaa, josta parlamentti on tehnyt päätöksen edellisen kahden vuoden sisällä, elleivät olosuhteet ole olennaisesti muuttuneet.

\subsubsection{Espanja}

Espanjassa kansalaisaloitteesta säädetään perustuslaissa ja sitä täydentävässä laissa vuodelta 1984. Aloitteen voivat tehdä vaaliluetteloon merkityt täysi-ikäiset Espanjan kansalaiset. Aloitteen saaminen parlamentin käsiteltäväksi edellyttää 500000 allekirjoitusta (n.1,5\% äänioikeutetuista). Aloitteen täytyy sisältää jäsennelty lakiehdotus perusteluineen sekä aloitteen vireillepanijoiden täydelliset nimet ja henkilötiedot.

Aloitteen on oltava sopusoinnussa perustuslain säännösten kanssa, eikä se siten voi kohdistua perustuslain muuttamiseen. Aloitetta ei voi myöskään tehdä verotusta koskevista tai kansainvälisiin asioihin liittyvistä laeista. 
Aloitemenettely käynnistetään antamalla aloite parlamentin puhemiehistölle, joka 15 päivän kuluessa ratkaisee, voidaanko aloite ottaa käsiteltäväksi. Hylkäämiseen voi johtaa edellä mainittu kielletty aihe tai aloitteen puutteellisuus. Samoin hylkääminen voi seurata siitä, että asia on edustajainhuoneessa tai senaatissa parhaillaan käsiteltävänä tai että aiemmin samoilla valtiopäivillä on käsitelty samansisältöinen aloite. Kielteisestä päätöksestä voi valittaa perustuslakituomioistuimeen.

Kun vaadittava määrä nimiä on kerätty, aloitetaan menettely asian saamiseksi parlamenttikäsittelyyn. Kun vähintään 500000 allekirjoittajan nimet on varmistettu, parlamentin puheenjohtajisto julkistaa aloitteen ja lisää sen kuuden kuukauden kuluessa täysistunnon esityslistalle. Jos aloite tulee parlamentissa käsiteltäväksi, voivat aloitteen tekijät vaatia valtiolta korvausta nimien keräämisestä aiheutuneista kustannuksista, kuitenkin enintään 300000 euroa.

Espanjassa on pantu vireille kaikkiaan puolisensataa kansalaisaloitetta, joista suurin osa on kaatunut sisällöllisiin rajoituksiin tai ei ole saanut riittävästi allekirjoituksia. Hyvin monet aloitteista ovat koskeneet työelämän sääntelyä tai sosiaaliturvaa. Lainsäädäntömuutoksiin on johtanut ainoastaan yksi aloite.

\subsubsection{Italia}

Italian perustuslain mukaan vähintään 50000 äänioikeutettua Italian kansalaista voi tehdä lakiehdotuksen jommallekummalle parlamentin kamareista: edustajainhuoneelle tai senaatille. Kyse on luonteeltaan sisällöllisestä kansalaisaloitteesta. Vaadittujen allekirjoitusten määrä vastaa noin $0,08 \%$ äänioikeutetuista. Aloite tulee laatia lakiehdotuksen muotoon, ja aloite pitää perustella.

Aikaa allekirjoitusten keräämiseen on kuusi kuukautta ennen aloitteen luovuttamista parlamentille. Aloitteesta ei seuraa mitään velvoitteita parlamentille: parlamentti ei ole velvollinen keskustelemaan tai äänestämään aloitteesta.

Aloitteita on runsaan 60 vuoden aikana tehty noin 250 . Niiden vuosittainen määrä on ollut kasvussa erityisesti 1990-luvulla, mutta vain pieni osuus aloitteista on johtanut lainsäädäntötoimiin. Yleisin aloitteen kohde on ollut jonkin pienen ryhmän taloudellisia etuja kos- 
keva, yleiseltä merkitykseltään melko vähäinen asia. Usein taustalla on järjestäytynyt väestöryhmä, kuten poliittinen puolue, ammattiyhdistys tai uskonnollinen järjestö.

\subsubsection{Portugali}

Portugalissa oikeudesta tehdä kansalaisaloite säädetään perustuslaissa ja sitä täydentävässä kansalaisten lakialoitteita koskevassa laissa vuodelta 2003. Aloiteoikeus on äänioikeutetuilla ja vaalirekisterissä olevilla Portugalissa tai ulkomailla asuvilla Portugalin kansalaisilla, ja aloitteen tekemiseen vaaditaan 35000 allekirjoittajaa.

Aiheen tulee kuulua parlamentin lainsäädäntövaltaan, ja aloitteen tulee sisältää selkeästi määritelty lainsäädäntöesitys. Aloite ei saa kuitenkaan koskea perustuslain muuttamista, perustuslain mukaan hallituksen toimivaltaan tai Madeiran ja Azorien alueellisille parlamenteille kuuluvia kysymyksiä, parlamentin ehdottomaan toimivaltaan kuuluvia kysymyksiä eikä budjettikysymyksiä. Aloite ei saa myöskään loukata perustuslakia tai sen henkeä, ja hylättyä aloitetta ei voi tuoda uuteen käsittelyyn saman istuntokauden aikana.

\subsubsection{Puola}

Puolassa oikeus kansalaisaloitteen tekemiseen perustuu vuoden 1997 perustuslakiin sekä kansalaisaloitelakiin vuodelta 1999. Parlamentille tehtävä aloite vaatii 100000 äänioikeutetun (0,3\% äänioikeutetuista) kansalaisen kannatuksen.

Prosessi on kaksivaiheinen. Aloite saadaan vireille 1000 allekirjoituksella, mutta sen saaminen parlamentin käsittelyyn edellyttää vielä vähintään 99000 allekirjoitusta lisää.

Aloiteoikeus on äänioikeutetuilla Puolan kansalaisilla. Se koskee kaikkia lakeja lukuun ottamatta perustuslakia, valtion talousarviota ja valtion velanottoon tai valtion vakuuksiin liittyviä lakeja. Näissä asioissa aloiteoikeus on ainoastaan maan hallituksella.

Kansalaisaloitetta koskevat samat muotovaatimukset kuin muitakin lakialoitteita: sen tulee sisältää lakiehdotus perusteluineen, arviointi lain vaikutuksista sekä ehdotus lain rahoituksen järjestämisestä. Lisäksi tulee osoittaa aloitteen yhdenmukaisuus EU:n lainsäädännön 
kanssa. Valtaosa kansalaisaloitteista ei menettelyn alkuvaiheessa täytä näitä vaatimuksia, ja ennakkohyväksynnän saaminen edellyttääkin usein aloitteen jatkovalmistelua.

Kansalaisaloitteen tekemistä varten on muodostettava ns. lakialoitekomitea, jonka jäseninä tulee olla vähintään 15 äänioikeutetuksi rekisteröityä Puolan kansalaista. Komitean on valittava keskuudestaan itselleen edustaja. Komitea voi edistää ainoastaan yhtä aloitetta kerrallaan. Aloitekomitean on myös annettava valtiovarainministeriölle julkinen selvitys aloitteen rahoituksesta. Ulkomaisen rahoituksen hankkiminen aloitteen tekemistä varten on kielletty.

Vuosien 1999-2009 välisenä aikana ennakkohyväksynnän läpäisi 61 kansalaisaloitetta, joista 24:ssä onnistuttiin keräämään vaadittu määrä hyväksyttyjä allekirjoituksia. Näistä 24:stä parlamenttikäsittelyyn edenneestä aloitteesta seitsemän johti lainsäädännön muutoksiin, kolme hylättiin ja 14:n käsittely ei ollut päättynyt tai aloite oli rauennut. Kansalaisaloitteet ovat kohdistuneet mm. sosiaali- ja terveysalaan, työelämän sääntelyyn ja koulujärjestelmään. Muutamat aloitteet ovat koskeneet selkeästi alueellisia intressejä tai tiettyä ammattiryhmää.

\subsubsection{Unkari, Slovakia ja Liettua}

Unkarin uusi perustuslaki vuodelta 1989 sisältää useita suoran demokratian mekanismeja. Jo ennen sitä säädettiin laki kansanäänestyksistä ja kansalaisaloitteista, jota tarkistettiin vuonna 1997 perustuslain muutoksen yhteydessä menettelyllisten epäselvyyksien poistamiseksi.

Sisällöllisen kansalaisaloitteen tekemiseksi parlamentille vaaditaan 50000 allekirjoitusta (n. 0,6 \% äänioikeutetuista). Aloiteoikeutettuja ovat Unkarin äänioikeutetut kansalaiset, ja aikaa allekirjoitusten keräämiselle on kaksi kuukautta.

Aloitteen pitää kuulua parlamentin toimivaltaan sekä tarkasti ja yksiselitteisesti sisältää parlamentin keskusteluun saatettava kysymys. Lain mukainen kahden kuukauden nimienkeräysaika alkaa siitä kun kansallinen vaalilautakunta hyväksyy allekirjoituslomakkeen. Lomake voidaan hylätä, jos aloite ei kuulu parlamentin toimivaltaan, jos kysymyksen muotoilu ei ole lain säännösten mukainen tai jos lomake ei muutoin vastaa vaatimuksia. Tämä aloitteen ennakkotarkastusme- 
nettely otettiin käyttöön vuoden 1997 lainmuutoksella. Sillä haluttiin estää allekirjoitusten kerääminen sellaisille aloitteille, jotka eivät täytä lain vaatimuksia ja joita ei voida ottaa parlamentin käsiteltäväksi.

Unkarissa parlamentin on otettava aloite esityslistalleen ja päätettävä asiasta kolmen kuukauden kuluessa aloitteen ilmoittamisesta täysistunnolle. Parlamentin käsittelyyn on edennyt kaikkiaan 11 aloitetta, joista useimmat ovat olleet erilaisten kansalaisjärjestöjen alulle panemia. Vain kaksi kansalaisaloitetta (aiheina eläintensuojelu ja julkisen sektorin palkat) on parlamentissa hyväksytty.

Slovakiassa 100000 äänioikeutettua on vuodesta 1992 lähtien voinut tehdä kansalaisaloitteen.

Liettuassa kansalaisaloite otettiin käyttöön vuonna 1998, ja sellaiseen vaaditaan 50000 kannatusilmoitusta. Aloitteiden käsittelyyn liittyy monivaiheinen tarkastusmenettely.

\subsection{Kansalaisaloite Suomen perustuslakiin ja kansalaisaloitelain säätäminen 2010-luvulla}

\subsubsection{Perustuslain muutos}

Suomen perustuslaki ei alun perin sisältänyt mahdollisuutta valtiolliseen kansalaisaloitteeseen. ${ }^{53}$ Hallituksen esityksessä 60/2010 esitettiin perustuslakiin lisättäväksi säännökset sellaisesta. Esityksen mukaan kansanäänestyksen kehittämistä koskevien vaihtoehtojen sijasta suomalaista poliittista järjestelmää ja suoraa demokratiaa oli luontevampaa täydentää valtiollisella kansalaisaloitteella, jossa tietty määrä äänestäjiä voi saada asian eduskunnan käsiteltäväksi. Kyse on ns. sisällöllisestä kansalaisaloitteesta. Eduskunnan hyväksymä kansalaisaloitetta koskeva perustuslain $53.3 \$(4.11 .2011 / 1112)$ kuuluu seuraavasti: "Vähintään viidelläkymmenellätuhannella äänioikeute-

53 Kuntalaisen aloiteoikeudesta säädetään kuntalain (410/2015) 23 §:ssä. Ks. siitä Heikki Harjula - Kari Prättälä, Kuntalaki (2019) s. 260 ss. Vrt. kuntalaisen kansanäänestysaloite $(25 \$)$. 
tulla Suomen kansalaisella on oikeus tehdä eduskunnalle aloite lain säätämiseksi sen mukaan kuin lailla säädetään.” Allekirjoituspäivä ratkaisee täysi-ikäisyyden, joten kannatusilmoituksen allekirjoittajan tulee olla 18 vuotta täyttänyt ilmoituksen allekirjoittaessaan; aloitteen päiväys ei siis ratkaise.

\subsubsection{Kansalaisaloitelaki}

Perustuslain muutoksen jälkeen hallitus antoi esityksen kansalaisaloitelaista (HE 46/2011), ja kansalaisaloitelaki (13.1.2012/12) säädettiin vuoden 2012 alussa. Hallituksen esityksen (HE 251/2018) mukaisesti kansalaisaloitelakiin tehtiin muutoksia, jotka tulivat voimaan 1.6.2019. Nykyisessä muodossaan kansalaisaloitelaki kuuluu seuraavasti:

\section{$1 \mathbb{S}$ Lain tarkoitus ja soveltamisala}

Tässä laissa säädetään menettelystä, jota noudatetaan perustuslaissa säädetyn kansalaisaloitteen tekemisessä.

Euroopan unionin kansalaisaloitteen tekemisestä säädetään kansalaisaloitteesta annetussa Euroopan parlamentin ja neuvoston asetuksessa (EU) N:o 211/2011. Unionin kansalaisaloitteen tekemiseen sovelletaan lisäksi tämän lain 10 ja 15 §:ää.

\section{$2 \lessgtr$ Aloiteoikeus}

Oikeudesta tehdä eduskunnalle kansalaisaloite säädetään perustuslaissa.

\section{$3 \mathbb{S}$ Kansalaisaloitteen vastuuhenkilö}

Kansalaisaloitteen voi panna vireille vähintään viisi äänioikeutettua Suomen kansalaista.

Aloitteen vireillepanijoita kutsutaan aloitteen vastuuhenkilöiksi.

Aloitteen vastuuhenkilöiden yhteystiedot on ilmoitettava asioinnin yhteydessä Väestörekisterikeskukselle, oikeusministeriölle ja eduskunnalle aloitetta koskevaa yhteydenpitoa varten.

\section{$4 \$$ Kansalaisaloitteen muoto}

Kansalaisaloite sisältää lakiehdotuksen tai ehdotuksen lainvalmisteluun ryhtymisestä sekä ehdotuksen perustelut. Aloitteella on oltava sen sisältöä kuvaava otsikko. Aloite on päivättävä.

Samaan aloitteeseen ei saa sisällyttää erilaisia asioita.

Aloite laaditaan suomen tai ruotsin kielellä taikka molemmilla kielillä. 


\section{S Kannatusilmoitusten kerääminen}

Kansalaisaloitetta tukevat allekirjoitukset (kannatusilmoitukset) kerätään paperimuodossa tai sähköisesti tietoverkossa. Paperimuotoisissa kannatusilmoituksissa käytettävästä lomakekaavasta säädetään oikeusministeriön asetuksella.

Kannatusilmoitukset on kerättävä kuuden kuukauden kuluessa aloitteen päiväyksestä.

Kannatusilmoituksia kerättäessä on aloite, tieto sen vastuuhenkilöistä ja heidän yhteystietonsa oltava aloitteen allekirjoittajien nähtävissä. Aloitetta ei saa muuttaa kannatusilmoitusten keräyksen alkamisen jälkeen.

\section{$6 \int$ Kannatusilmoituksen sisältö}

Kannatusilmoituksessa tulee olla:

1) kansalaisaloitteen otsikko ja päiväys;

2) aloitteen allekirjoittajan täydellinen nimi, syntymäaika ja kotikunta;

3) aloitteen allekirjoittajan vakuutus siitä, että hän on äänioikeutettu Suomen kansalainen ja että hän on tehnyt kannatusilmoituksen samaan aloitteeseen vain kerran;

4) kannatusilmoituksen päiväys.

\section{S Sähköisen menettelyn tekniset vaatimukset}

Kerättäessä kannatusilmoituksia sähköisesti tietoverkossa on käytettävä Liikenne- ja viestintäviraston hyväksymää tietojärjestelmää. Hyväksynnän edellytyksenä on, että:

1) kannatusilmoitusten keräyksessä käytetään vahvasta sähköisestä tunnistamisesta ja sähköisistä luottamuspalveluista annetussa laissa (617/2009) tarkoitettua vahvaa sähköistä tunnistamista;

2) järjestelmän sisältämien tietojen luvaton muuttaminen ja muu luvaton tai asiaton käsittely estetään käyttöoikeushallinnan, käytön valvonnan sekä tietoverkkojen, tietojärjestelmien ja tietopalvelujen asianmukaisilla ja riittävillä turvallisuusjärjestelyillä ja muilla toimenpiteillä;

3) järjestelmä on 2 momentissa tarkoitettujen Väestörekisterikeskuksen antamien määräysten mukainen.

Väestörekisterikeskus antaa määräykset tietojärjestelmässä kerättyjen tietojen vakiomuodosta, jossa ne ovat sähköisesti yhdistettävissä väestötietojärjestelmän tietoihin $9 \$$ :ssä säädettyä tarkastusta varten.

Tietojärjestelmän hyväksynnästä ei peritä maksua.

Tieto Liikenne- ja viestintäviraston hyväksynnästä on oltava kansalaisaloitteen allekirjoittajien nähtävissä verkkosivustolla, jossa kannatusilmoitukset kerätään. 


\section{$8 \int$ Oikeusministeriön verkkopalvelu}

Kannatusilmoituksia voidaan kerätä myös oikeusministeriön ylläpitämässä verkkopalvelussa. Tämän edellytyksenä on, että aloite täyttää tässä laissa säädetyt vaatimukset. Oikeusministeriö toimii verkkopalvelussaan kerättyjen henkilötietojen rekisterinpitäjänä.

Verkkopalvelun on täytettävä 7 §:ssä säädetyt tekniset vaatimukset.

Verkkopalvelun käytöstä ei peritä maksua.

\section{S Kannatusilmoitusten tarkastaminen}

Vastuuhenkilö toimittaa kannatusilmoitukset vuoden kuluessa kannatusilmoitusten keräämisen päättymisestä Väestörekisterikeskukselle, joka tarkastaa niiden oikeellisuuden ja kelpoisuuden.

Oikeusministeriö toimittaa ylläpitämässään verkkopalvelussa kerätyt kannatusilmoitukset vastuuhenkilön pyynnöstä Väestörekisterikeskuksen tarkastettaviksi.

Väestörekisterikeskus vahvistaa, onko hyväksyttyjä kannatusilmoituksia perustuslaissa säädetty vähimmäismäärä.

Kannatusilmoitusten tarkastamisesta ja sen vahvistamisesta, että niitä on säädetty vähimmäismäärä, ei peritä maksua.

\section{Suroopan unionin kansalaisaloitteeseen liittyvät viranomaistehtävät} Kansalaisaloitteesta annetun Euroopan parlamentin ja neuvoston asetuksen (EU) N:o 211/2011 15 artiklan 1 kohdassa tarkoitettu toimivaltainen viranomainen Suomessa on Liikenne- ja viestintävirasto. Mainitun artiklan 2 kohdassa tarkoitettu toimivaltainen viranomainen Suomessa on Väestörekisterikeskus.

\section{IS Kansalaisaloitteen toimittaminen eduskunnalle}

Vastuuhenkilö toimittaa kansalaisaloitteen ja 9 \$:n nojalla annetun Väestörekisterikeskuksen päätöksen eduskunnalle, jos perustuslaissa ja tässä laissa säädetyt aloiteoikeuden edellytykset täyttyvät.

Aloite raukeaa, jollei sitä ole toimitettu eduskunnalle viimeistään vuoden kuluttua 9 \$:n nojalla annetusta Väestörekisterikeskuksen päätöksestä.

\section{$12 \int$ Henkilötiedot}

Kannatusilmoituksissa kerättyjä henkilötietoja voidaan käyttää vain tässä laissa säädetyllä tavalla. Vastuuhenkilöt saavat luovuttaa tietoja vain Väestörekisterikeskukselle. Viranomaisen hallussa olevat tiedot ovat julkisia, kun perustuslaissa säädetty kannatusilmoitusten vähimmäismäärä on täyttynyt.

Aloitteen vastuuhenkilöiden ja oikeusministeriön on huolehdittava hallussaan olevien kannatusilmoitusten hävittämisestä viimeistään kuu- 
den kuukauden kuluttua 9 \$:n nojalla annetusta Väestörekisterikeskuksen päätöksestä. Jos kannatusilmoituksia ei toimiteta Väestörekisterikeskuksen tarkastettaviksi, ne on hävitettävä viimeistään vuoden kuluttua siitä, kun kannatusilmoitusten keräys on lopetettu.

Väestörekisterikeskuksen on hävitettävä hallussaan olevat kannatusilmoitukset viiden vuoden kuluttua 9 \$:n nojalla tekemästään päätöksestä.

\section{S Taloudellisen tuen ilmoittaminen}

Kansalaisaloitteen vastuuhenkilön on huolehdittava siitä, että aloitteen tekemistä varten saatu taloudellinen tuki ja sen antaja ilmoitetaan kannatusilmoituksia kerättäessä, jos yksittäisen tuen tai useista samalta tukijalta saaduista suorituksista koostuvan tuen arvo on vähintään 1500 euroa. Yksityishenkilön nimeä ei saa ilmoittaa ilman hänen suostumustaan, jos hänen antamansa tuen arvo on pienempi kuin 1500 euroa.

Tueksi luetaan rahana, tavarana, palveluna tai muulla vastaavalla tavalla saadut suoritukset. Tukena ei kuitenkaan pidetä tavanomaista talkootyötä eikä tavanomaisia ilmaispalveluja. Tuki, jota ei ole saatu rahana, arvioidaan ja ilmoitetaan rahamääräisenä.

Tueksi luetaan suoritukset, jotka on saatu aikaisintaan kaksi kuukautta ennen kannatusilmoitusten keräyksen alkamista ja viimeistään kolmen kuukauden kuluttua aloitteen toimittamisesta eduskunnalle.

Tukea, jonka antajaa ei voida selvittää, ei saa vastaanottaa. Tämä ei kuitenkaan koske tavanomaisesta keräystoiminnasta saatua tukea.

\section{$14 \int$ Menettely tuen ilmoittamisessa}

Tuki on ilmoitettava tietoverkossa siten, että tiedot ovat yleisön nähtävissä viimeistään tuen vastaanottamista seuraavan kalenterikuukauden päättyessä, kuitenkin aikaisintaan kannatusilmoitusten keräyksen alkaessa.

Kannatusilmoituksia kerättäessä on tieto verkko-osoitteesta, jossa tuki ilmoitetaan, oltava kansalaisaloitteen allekirjoittajien nähtävissä.

Tukea koskevat tiedot on poistettava tietoverkosta aloitteen eduskuntakäsittelyn päätyttyä. Jos aloitetta ei toimiteta eduskuntaan, tiedot on poistettava kannatusilmoitusten keräyksen päätyttyä tai aloitteen rauettua 11 §:n 2 momentin mukaisesti.

\section{S Muutoksenhaku}

Liikenne- ja viestintäviraston, oikeusministeriön ja Väestörekisterikeskuksen tekemään päätökseen saa hakea valittamalla muutosta siten kuin hallintolainkäyttölaissa (586/1996) säädetään. 


\section{$16 \int$ Rangaistussäännökset}

Rangaistus väärän henkilötiedon antamisesta ja väärän todistuksen antamisesta viranomaiselle sekä salassapitorikoksesta ja salassapitorikkomuksesta samoin kuin tietosuojarikoksesta säädetään rikoslaissa (39/1889).

\section{(17 S Voimaantulo)}

\subsection{Verotusta koskevat kansalaisaloitteet}

\subsubsection{Määrä ja verolajeittainen jakautuminen}

Kansalaisaloitteita on Suomessa pantu vireille järjestelmän voimassaoloaikana 30.11.2019 mennessä 1 066, ja ne löytyvät netistä (kansalaisaloite.fi), josta ne voidaan hakea aikajärjestyksessä ja myös kannattajamäärien mukaan järjestettyinä mutta ei teemoittain ryhmiteltyinä. ${ }^{54}$ Erikoisia uusimpia aloitteita ovat 27.5.2019 vireille pantu esitys jääkiekon MM-finaalin jälkeisen päivän säätämisestä kansalliseksi pyhäpäiväksi ${ }^{55}$ ja 30.5.2019 vireille pantu esitys Mörköpäivä juhlapäiväksi 26.5.56 Nuo esitykset eivät koskeneet verotusta.

54 Myös Euroopan unionissa on kansalaisaloitejärjestelmä: vähintään miljoona EU-kansalaista voi ehdottaa Euroopan komissiolle uutta lakialoitetta. Unionissa on tätä kirjoitettaessa vireillä yksi verotusta koskeva kansalaisaloite. Se on tehty 10.5.2019; keräysaika kansalaisten EU-aloitteissa on yksi vuosi. Aloite koskee lentopolttoaineen verovapautuksen lopettamista Euroopassa. Aloitteessa pyydetään Euroopan komissiota ehdottamaan jäsenvaltioille lentopolttoaineen (kerosiinin) verotuksen käyttöönottoa. Aloitteessa todetaan ilmailualalle myönnettävän veroetuja huolimatta siitä, että se on yksi nopeimmin kasvavista kasvihuonekaasupäästöjen lähteistä. Aloitteessa todetaan myös, että liikennemuodot, jotka kuormittavat ympäristöä vähemmän kuin ilmailu, joutuvat maksamaan korkeita veroja samaan aikaan kun ilmailuala hyötyy monista epäoikeudenmukaisista verovapautuksista. Lentopolttoainetta ei veroteta EU:ssa, eikä jäsenvaltioissa kanneta arvonlisäveroa lentolipuista, mikä tekee ilmailusta entistä houkuttelevampaa, vaikka se on liikennemuodoista hiili-intensiivisin. Kerosiinin verottaminen antaisi EU:lle mahdollisuuden lisätä ympäristöystävällisemmän liikkuvuuden rahoitusta merkittävästi, koska liikenne on nopeimmin kasvava kasvihuonekaasupäästöjen ala.

55 Aloite sai 1017 kannattajaa.

56 Aloite sai 126 kannattajaa. 
Verotusta koskevien joulukuun alkuun 2019 mennessä tehtyjen kansalaisaloitteiden määrä on jakautunut seuraavasti:

\begin{tabular}{|c|c|c|c|c|c|c|c|c|c|}
\hline & 2012 & 2013 & 2014 & 2015 & 2016 & 2017 & 2018 & 2019 & Yhteensä \\
\hline 1 Verotus yleensä & - & 3 & 3 & 1 & 1 & - & - & - & 8 \\
\hline 2 Tuloverotus & - & 4 & 3 & 3 & 3 & 4 & 8 & 10 & 35 \\
\hline 3 Yleisradiovero & - & - & 1 & - & 1 & - & - & 2 & 4 \\
\hline 4 Kirkollisvero & - & 1 & 1 & - & - & - & - & - & 2 \\
\hline 5 Kunnallisvero & - & 1 & - & - & - & - & 1 & - & 2 \\
\hline $6 \begin{array}{l}\text { Perintö- ja } \\
\text { lahjavero }\end{array}$ & - & - & - & 1 & - & 1 & - & - & 2 \\
\hline 7 Varainsiirtovero & - & - & - & - & - & - & - & 1 & 1 \\
\hline 8 Kiinteistövero & - & - & 1 & - & - & - & 2 & - & 3 \\
\hline 9 Kaivosvero & - & 1 & - & 1 & - & - & - & - & 2 \\
\hline 10 Alkoholivero & - & - & 2 & 1 & - & - & 1 & - & 4 \\
\hline $\begin{array}{l}11 \text { Elintarvike- } \\
\text { verotus }\end{array}$ & 1 & - & - & 1 & - & - & 3 & - & 5 \\
\hline 12 Arvonlisäverotus & - & 2 & 2 & 1 & 3 & 4 & 2 & - & 14 \\
\hline $\begin{array}{l}13 \text { Tieliikenteen } \\
\text { verot }\end{array}$ & 2 & 5 & 2 & 3 & 1 & - & 4 & 5 & 22 \\
\hline $\begin{array}{l}14 \text { Vene- ja traktori- } \\
\text { verot }\end{array}$ & - & - & - & 1 & 1 & - & - & - & 2 \\
\hline 15 Lentovero & - & - & - & - & - & - & - & 1 & 1 \\
\hline $\begin{array}{l}16 \text { Lämmitysöljyn } \\
\text { vero }\end{array}$ & - & - & - & - & - & - & - & 1 & 1 \\
\hline 17 Tekstiilivero & - & - & - & - & - & - & - & 1 & 1 \\
\hline Yhteensä & 3 & 17 & 15 & 13 & 10 & 9 & 21 & 21 & 109 \\
\hline
\end{tabular}

Verotuksen kansalaisaloitteet ovat koskeneet erityisesti tuloverotusta, tieliikenneveroja ja arvonlisäveroa mutta myös lähes kaikkia pienempiä veroja. 


\subsubsection{Vireillepanijoista, kannattajista ja kommenteista}

109:stä kansalaisaloitteesta 88 on yhden henkilön vireillepanemia, 21:ssä vireillepanijoita on kaksi tai enemmän. ${ }^{57}$ Useimmat ovat panneet vireille vain yhden aloitteen; vähintään kaksi aloitetta ovat panneet vireille seuraavat seitsemän kansalaista:

$\begin{array}{ll}\text { Jukka Niemi } & \text { (4 aloitetta) } \\ \text { Jarno Siivola } & \text { (3 aloitetta) } \\ \text { Aleksi Hernesniemi } & \text { (2 aloitetta) } \\ \text { Ari Käkelä } & \text { (2 aloitetta) } \\ \text { Juha Porkka } & \text { (2 aloitetta) } \\ \text { Sulo Ranne } & \text { (2 aloitetta) } \\ \text { Petri Rautiainen } & \text { (2 aloitetta) }\end{array}$

Verotusta koskevista kansalaisaloitteista on kerännyt määräajassa eduskuntakäsittelyyn vaadittavat 50000 kannattajaa vain kolme: aloite perintö- ja lahjaverosta luopumiseksi (6.11.2017), aloite dieselautojen käyttövoimaveron poistamiseksi (12.11.2018) ja aloite lentoverosta (2.5.2019).

Kun jäljempänä selostetaan aloitteiden sisältöä, mainitaan vireillepanijoiden lisäksi myös kunkin aloitteen kannattajamäärä. Paikoin on aloitteiden kieltä varovasti muokattu, ja useita aloitteita on myös lyhennetty. Aloitteen tai aloitejoukon jälkeen on kommenttejani erityisesti verohistorian kannalta. ${ }^{58}$ Kommenteissa käsitellään myös ehdotusten suhdetta kesäkuun alussa 2019 muodostetun pääministeri Antti Rinteen hallituksen ohjelmaan ("Osallistuva ja osaava Suomi"). Tässä hallituksessa ovat mukana SDP, keskusta, vihreät, vasemmistoliitto ja RKP.

\footnotetext{
57 1.6.2019 voimaan tulleen lainmuutoksen jälkeen kansalaisaloite on vaatinut vähintään viisi äänioikeutettua Suomen kansalaista.

58 Tässä on hyödynnetty erityisesti teosta Esko Linnakangas - Leila Juanto, Verojen historia (2016).
} 


\subsubsection{Verotusaiheisten aloitteiden teemat ja sisällöt}

\subsubsection{Verotus yleensä}

\subsection{Verot vapaaehtoisiksi}

Matti Pörin 19.2.2016 vireille panemassa aloitteessa (10 kannattajaa) esitettiin, että verotus on lopetettava välittömästi, koska valtiolla ei ole oikeutta väkivallan uhalla ryöstää kansalaisilta heidän omaisuuttaan. Jos kansalainen haluaa veroilla rahoitettuja palveluita, hän voi maksaa siitä vapaaehtoisesti. Tämä halu ei tuo hänelle tai muille oikeutta pakottaa muita samaan. Verotus myös vääristää markkinoiden toimintaa tehden liiketoiminnasta kalliimpaa ja jopa kannattamatonta. Jokainen verovaroin ylläpidetty palvelu voidaan toteuttaa vapaaehtoisesti vapailla markkinoilla, mikäli todellista halua löytyy.

\section{Kommentteja}

Nykyisin verot määritellään pakkosuorituksiksi, mutta aina ei ole ollut näin. Esimerkiksi muinaiset ateenalaiset eivät pääsääntöisesti kantaneet kansalaisiltaan välittömiä veroja, koska heidän ajatusmaailmansa mukaan sellaiset sotivat vapaan miehen ideaa vastaan ja olivat osoitus jonkinasteisesta orjuudesta. Muukalaisilta henkilöveroa sitä vastoin kannettiin, ja jos muukalaiset eivät tätä veroa maksaneet, heidät alennettiin orjiksi. Vaikka ateenalaiset suhtautuivat vapaisiin kansalaisiin kohdistuviin välittömiin veroihin kielteisesti, he jopa ylpeilivät sillä, kuinka kukin tuki valtiontaloutta ns. liturgioilla. Tämän instituution juuret ovat sellaisessa ajassa, jossa valtiolla ei vielä ollut kykyä pakottaa ketään veronmaksuun vaan sen talous rakentui kansalaisten kunniantunnon ja hyväntahtoisuuden varaan. Alun perin kansalaiset tukivat liturgioilla uskonnollisten tapahtumien järjestämistä, mutta ajan oloon liturgiat otettiin maalliseen käyttöön. Tällöin niiden suorittaminen muuttui käytännössä enemmän tai vähemmän pakolliseksi.

Vanhat ruotsalaiset sadut kertovat verolahjoista ja henkiverosta. Historiallisessa asiakirjassa vuodelta 1285 henkivero mainitaan Vestmanlannissa maksettuna säännöllisenä verona, mutta todennäköisesti sekin on alkuaan kuulunut vapaaehtoisiin tai puolipakollisiin verolahjoihin.

Verovelvollisen kokonaistuloon kohdistuva tuloverotus säädettiin meillä ensimmäisen kerran vuonna 1865, mutta siitä luovuttiin vuon- 
na 1885. Tuloverotuksen silloiseen epäonnistumiseen vaikutti myös liberalistisen politiikan mukainen torjuva asenne tulojen ilmoittamiseen.

Norjassa on kesäkuusta 2017 lähtien voinut halutessaan maksaa ylimääräistä veroa. Tällainen mahdollisuus kuitenkaan ei ole norjalaisia ainakaan heti suuresti innostanut. Ensimmäisen kuukauden aikana tuota vapaaehtoista veroa kertyi vain 11000 Norjan kruunua (vajaat 1176 euroa), eikä maan valtiovarainministeri jatkossakaan odota valtavia summia.

Veronmaksun säätäminen vapaaehtoiseksi ei vaikuta realistiselta vaihtoehdolta Suomessa.

\subsection{Valintamahdollisuus veron käyttötarkoitukseen}

Juha Starckin 13.10.2014 vireille panemassa aloitteessa (12 kannattajaa) esitettiin Suomen kansalaisille oikeutta kohdentaa ansiotulosta perittävästä verostaan $50 \%$ johonkin tiettyyn tarkoitukseen. Valintamahdollisuuksia olisi useita, ja valintamahdollisuutta voisi muuttaa kulloisenkin yhteiskunnallisen, poliittisen tai paikallisen tilanteen mukaan. Neljänneksen perittävästä verosta saisi valita asuttavan kaupungin/kunnan käytettäväksi, toinen neljännes menisi koko Suomen hyväksi kohdentamisvalintojen mukaan. Puolet perittäisiin nykyiseen tapaan valtiolle.

Demokratiassa valta kuuluu kansalle eli meille kaikille. Vallan voi ulottaa koskemaan myös verovarojaan jossain määrin. Tämä olisi verodemokratiaa. Olemmehan valinneet äänestyksellä edustajat, jotka ovat muodostaneet monenmoiset verot maahamme.

Muutos lisäisi äänestysaktiivisuutta voidessamme konkreettisesti vaikuttaa äänestämämme puolueen tahi edustajan ajamiin asioihin. Heidän ei ensimmäisenä tarvitsisi lähteä keräämään rahaa vaalilupauksilleen, vaan se tulisi suoraan äänestäjien ohjaamasta verorahasta. Omien verotulojensa kohdentamisoikeuden voisi valitessaan jättää myös valtiolle.

Verovelvollinen maksaa koko elämänsä aikana satojatuhansia euroja ansiotulosta perittävää veroa, mutta hän ei ole koskaan voinut kohdentaa tätä summaa haluamilleen tahoille. Muutamissa maissa tällainen valintamahdollisuus on käytössä, eri mittakaavassa vain. Uudistus voi vaikuttaa myös työllistymishalukkuuteen, koska pääsisi vaikuttamaan enemmän. Veroista valittamisen sijaan syntyisi uudenlainen keskustelukulttuuri vaikuttamisesta. Isänmaallisuushan on vaikuttamista.

\section{Kommentteja}

Korvamerkityksi kutsutaan sellaista talousarvion erää, joka on säädetty käytettäväksi joidenkin määrättyjen menojen maksamiseen ja jota 
ei saa käyttää muihin tarkoituksiin. Korvamerkkiverot ovat maksujen etäsukulaisia, mutta maksuina niitä ei voida pitää välittömän vastikkeen puuttumisen takia. ${ }^{59}$

Vanhempina aikoina korvamerkkiverot olivat erittäin yleisiä; kutakin veroa kerättiin määrättyyn tarkoitukseen. Julkinen talous perustui vielä 1800 -luvulla pitkälti rahastotalouteen tai muuten erityisiin tarkoituksiin kannettuihin suorituksiin. Vasta vuoden 1919 hallitusmuotomme lakkautti erillisten rahastojen järjestelmän, jolloin budjetista tuli yhtenäinen valtiontaloutta koskeva asiakirja ja rahastotalous muodostui poikkeukselliseksi järjestelmäksi.

Voitaisiinko verovelvollisen valinnanvapautta lisätä esimerkiksi niin, että hän saisi rastittaa veroilleen haluamansa käyttötarkoitukset vaikkapa hallinnonaloittain? Jos verovelvollisille annettaisiin mahdollisuus vaikuttaa verojensa käyttökohteeseen, he varmaankin pitäisivät riittämättömänä pelkkää ministeriöiden välillä valitsemista ja haluaisivat yksilöidympiä kohteita. Verojärjestelmämme muuttaminen sellaiseksi, että verovelvollinen voisi suoraan määrätä verojensa käyttötarkoituksen, tuskin on odotettavissa.

\subsubsection{3 Äänioikeus veronmaksun mukaan}

Sulo Ranne pani 1.7.2013 ja 7.10.2013 vireille identtiset aloitteet (2 kannattajaa), joissa vaadittiin demokratian vääristymän korjaamista antamalla vaaleissa lisä-ääniä enemmän veroa maksaville. Ehdotuksen mukaan perustuslakia ja äänioikeuslakeja olisi muutettava seuraavanlaisiksi:

a. Kaikilla äänioikeutetuilla on yksi ääni riippumatta maksetuista veroista.

b. Henkilö, joka maksaa veroja vähintään 10000 euroa vuodessa, saa yhden äänen lisää; hänellä on siis 2 ääntä.

c. Henkilö, joka maksaa veroja vähintään 100000 euroa vuodessa, saa kaksi ääntä lisää; hänellä on siis 3 ääntä.

d. Henkilö, joka maksaa veroja vähintään 1000000 euroa vuodessa, saa kolme ääntä lisää; hänellä on siis 4 ääntä.

Lisä-äänien perustana oleviksi maksetuiksi veroiksi lasketaan viimeisessä vahvistetussa verotuksessa määrätyt henkilökohtaiset verot, tuloverot, eläkkeestä maksetut verot, pääomatuloverot sekä maatalouden yrittäjinä

59 Tarkemmin kirjoitukseni Korvamerkkiverot, vapaaehtoiset verot ja veron kirnuaminen, Defensor Legis 4/2018 s. 656 ss. 
maksetut henkilötuloverot vähennettynä maatalouden tukiaisilla. Näihin veroihin ei lasketa arvonlisäveroja eikä korvamerkittyjä veroja, kuten TV-veroa, autoveroa yms. Yritysten maksamia veroja ei lasketa mukaan. Kunkin henkilön äänimäärä ilmoitetaan henkilölle postitse toimitetussa äänioikeusilmoituksessa. Ehdotus koskisi kaikkia Suomessa toimitettavia henkilövaaleja, ei kansanäänestyksiä.

Nykyisessä Suomen kansantalouden tilanteessa joudumme elämään osittain velkarahalla. Jotain on tehtävä, että eläisimme ns. suu säkkiä myöten. Ei ole kuitenkaan nähtävissä, että tilanne paranisi ainakaan lyhyellä tähtäyksellä. Toisaalta kaikissa vaalikeskusteluissa on havaittavissa keskustelun painopisteen olevan kakun jakamisen puolella. Tämä tarkoittaa sitä, että puolueet pyrkivät kalastelemaan ääniä sieltä, mistä niitä on helpoimmin saatavissa etuja lupaamalla. Kaikki luvatut edut täytyy kuitenkin maksaa. Ne joudutaan suurelta osin maksamaan velkarahalla. Puolueet siis ostavat ääniä valtiolle otettavalla velkarahalla. Tämä ei voi olla kestävää kehitystä eikä reilua tulevia sukupolvia kohtaan.

Tuo kehitys ei koske ainoastaan Suomea, vaan on havaittavissa melko yleisesti muissakin valtioissa. Suomi on kuitenkin ainoa valtio, jonka asioihin me voimme itse vaikuttaa. Länsimaisen demokratian heikkous on juuri se, että kun kakun jakajien määrä ylittää kakun kasvattajien määrän, koko systeemi muuttuu tasapainottomaksi ja voi pahimmillaan johtaa hallitsemattomaan syöksykierteeseen. Joitakin esimerkkejä on havaittavissa Euroopassakin. Ehdotuksen mukaan äänioikeutta muuttamalla siirretään painopistettä enemmän kakun kasvattajien kannustuksen suuntaan.

Ehdotus kannustaisi verojen maksuun, koska jo melko pienellä panoksella saa yhden äänen lisää. Suurin osa kakkua kasvattavasta keskiluokasta osuu 10000 ja 100000 euron veropanoksen väliin. Näin ollen puolueiden on huomioitava tämän ryhmän edut paremmin. Myös yli 100000 euron veropotin maksajille on enemmän kannustinta. Tämä kannustaa myös yhden äänen kansalaisia äänestämään, koska on tärkeää saada kaikki äänet käyttöön. Ehdotus puuttuu syvällisesti kansalaisten äänioikeuteen, mutta ohjaa kaikkia parempaan taloudenhoitoon.

\section{Kommentteja}

Vuonna 1865 säädettiin Suomessa ensi kertaa yleinen kokonaistuloon perustuva valtion tuloverotus. Se tapahtui samaan aikaan kuntauudistuksen ja tuloon perustuvan kunnallisverotuksen säätämisen kanssa. Äänioikeus nähtiin tuolloin veronmaksuun liittyvänä oikeutena: yksi veroäyri vastasi yhtä ääntä, mutta kaupungeissa korkein yhden verovelvollisen äänimäärä oli 25 . Äänioikeuden sitominen verovelvollisuuteen ei poikennut valtiopäivävaaleissa noudatetusta käytännöstä; 
porvarissäädyn vaaleissa ja talonpoikaissäädyn valitsijamiesvaaleissa noudatettiin samantapaista periaatetta.

Suomessa on jo pitkään ollut perustuslaissa turvattu yleinen ja yhtäläinen äänioikeus. Lapuan liike esitti 1930-luvulla vaatimuksen äänioikeuden kytkemisestä uudelleen veronmaksuun, mutta vaatimus ei menestynyt. Vielä vaikeampaa meillä on nykypäivänä hyväksyä tuollaista ajattelua.

\subsection{Verolotto ja nollaverokorttiarpajaiset}

Anssi Puruskaisen 4.4.2013 vireille panemassa aloitteessa (263 kannattajaa) esitettiin lakia kansalaisarpajaisista. Kerran viikossa lauantaisin loton yhteydessä arvottaisiin suorassa televisiolähetyksessä sosiaaliturvatunnuksen perusteella yhdelle Suomen kansalaiselle iästä riippumatta elinikäinen verovapaus Suomen valtiollisesta ja kunnallisesta tuloverosta, ei kuitenkaan pääomatuloverosta. Jokainen Suomen kansalainen olisi automaattisesti mukana arvonnassa. Verovapaus tulisi voimaan arvontahetkestä, eikä se olisi voimassa takautuvasti. Verovapaus lakkaisi ihmisen kuoltua, eikä se periytyisi. Sitä ei voisi myöskään siirtää toiselle henkilölle. Vuodessa tulisi 52 onnekasta. Jos voittaja olisi keskimäärin 35-vuotias ja jatkaisi työuraa 63-vuotiaaksi, tulisi verottomia työvuosia 28 . Nuorella lapsella tai eläkeläisellä olisi voiton arvo täysin erilainen, mutta kaikille voittajille verottomuus toisi hyvän mielen. Verottomuusarvonta ei vaikuttaisi merkittävästi valtion tai kuntien verokertymään. Hyvä puoli voitossa olisi se, että se kannustaisi työntekoon; ei tuloa ilman työtä. Osa voittajan lisäansioista palaisi erinäisten muiden verojen, esimerkiksi arvonlisäveron, lahjaveron tai perintöveron kautta valtiolle.

Osmo Anttalaisen 16.2.2015 vireille panemassa aloitteessa (13 kannattajaa) esitettiin nollaverokorttiarpajaisia, joilla tavoitellaan yritteliäisyyden, kekseliäisyyden ja taloudellisen toimeliaisuuden lisäämistä ilman valtiolle tai kunnille aiheutuvia lisäkuluja. Kekseliäisyys, yritteliäisyys ja niihin liittyvä taloudellinen toimeliaisuus ovat toimivan ja hyvinvoivan yhteiskunnan peruskiviä. Niitä olisi mahdollista lisätä käynnistämällä vapaaehtoisuuteen perustuva vuosittainen nollaverokorttiarvonta, joka toimisi seuraavasti:

Arvontaan voi osallistua jokainen tuloveroa maksava verovelvollinen ilmoittamalla osallistumishalukkuudestaan verottajalle ja sitoutumalla samalla oman tuloveroprosenttinsa korottamiseen yhdellä prosenttiyksiköllä kyseisen arvontavuoden aikana. Verottajan tekemässä arvonnassa nollatuloverokortti jaetaan joka sadannelle osallistujalle. Nollatuloverokortti on voimassa yhden verovuoden ja sen voi käyttää yhden kerran seuraavan kolmen vuoden kuluessa osallistujan valitsemana verovuonna. 
Nollaverokorttiarpajaisjärjestelmä synnyttää lukuisia voittajia:

- Verottaja voittaa, koska keskimääräinen tuloveroprosentti on pienempi kuin arvonnan palautussuhde: jos keskimääräinen tuloveroprosentti on P, tarvitaan noin P osallistujaa kattamaan yhden voittajan aiheuttama suora verojen menetys. Kun palautussuhde on 1:100 ja $\mathrm{P}<100$, verottajalle jää voittoa 100-P osallistujasta.

- Koska palautussuhde on hyvä, osallistujien määrä on suuri, jolloin myös voittajien määrä on suuri. Voittajat käyttävät kaiken kekseliäisyytensä maksimoidakseen nollatuloverokortin tuoman hyödyn kehittämällä lisätuloja, käyttämällä veronmaksusta säästyvät rahat omaksi ilokseen ja hyödykseen, sijoittamalla tai muulla tavalla, joka synnyttää suoraan tai sivuvaikutuksena taloudellista toimeliaisuutta. Osa rahasta palautuu välillisinä veroina takaisin verottajalle. Riippumatta tuloluokasta, yksilön kannalta nollaverokortti on aina merkittävä mahdollisuus.

- Arvontaan osallistumattomille järjestelmä ei maksa mitään. Arpajaisissa ylimääräisen tuloveroprosentin maksaneille epäonnisille kyse on hallitun riskin toteutumisesta. Välillisten vaikutusten kautta kaikki hyötyvät järjestelmän tuloksista.

\section{Kommentteja}

Veikkaus Oy:tä on arvosteltu mm. siitä, että sen toiminta vie rahat köyhiltä peliriippuvaisilta. 22.10.2019 tehty kansalaisaloite, jossa vaaditaan rahapeliautomaattien poistamista kaupoista, kioskeilta, ravintoloista ja huoltoasemilta, on kerännyt lyhyessä ajassa jo niin paljon kannattajia (marraskuun loppuun mennessä n. 16000 ), että aloite voi hyvin saavuttaa 50000 kannattajan rajan ja edetä eduskuntakäsittelyyn. Voisi olla hyödyllistä selvittää myös, olisiko veikkaustoiminnan sijalle mahdollista kehittää jonkinlainen verolotto.

Veroetujen arpominen kansalaisten kesken herättää kuitenkin perustuslaillisia kysymyksiä erityisesti yhdenvertaisuudesta. Lähimpänä vertailukohtana lienee vuosina 2017 ja 2018 toteutettu perustulokokeilu, jossa 2000 verovapaan perustulon (560€/kk) saajaa valittiin satunnaisotannalla eli arpomalla tietyistä kansalaisryhmistä. Perustuslakivaliokunnan lausunnossa (51/2016) todettiin perustulokokeilusta mm. seuraavaa:

Perustuslain 6 \$:n 1 momentin mukaan ihmiset ovat yhdenvertaisia lain edessä. Säännös ilmaisee paitsi vaatimuksen oikeudellisesta yhdenvertaisuudesta myös ajatuksen tosiasiallisesta tasa-arvosta. Siihen sisäl- 
tyy mielivallan kielto ja vaatimus samanlaisesta kohtelusta samanlaisissa tapauksissa. Yhdenvertaisuussäännös kohdistuu myös lainsäätäjään. Lailla ei voida mielivaltaisesti asettaa ihmisiä tai ihmisryhmiä toisia edullisempaan tai epäedullisempaan asemaan. Yhdenvertaisuussäännös ei kuitenkaan edellytä kaikkien ihmisten kaikissa suhteissa samanlaista kohtelua, elleivät asiaan vaikuttavat olosuhteet ole samanlaisia. Yhdenvertaisuusnäkökohdilla on merkitystä sekä myönnettäessä lailla etuja ja oikeuksia ihmisille että asetettaessa heille velvollisuuksia. Toisaalta lainsäädännölle on ominaista, että se kohtelee tietyn hyväksyttävän yhteiskunnallisen intressin vuoksi ihmisiä eri tavoin edistääkseen $\mathrm{mm}$. tosiasiallista tasa-arvoa.

Yleistä yhdenvertaisuussäännöstä täydentää perustuslain 6 \$:n 2 momentin sisältämä syrjintäkielto, jonka mukaan ketään ei saa asettaa eri asemaan sukupuolen, iän, alkuperän, kielen, uskonnon, vakaumuksen, mielipiteen, terveydentilan, vammaisuuden tai muun henkilöön liittyvän syyn perusteella. Säännöksessä lueteltuja erotteluperusteita voidaan pitää syrjintäkiellon ydinalueena. Luetteloa ei ole kuitenkaan tarkoitettu tyhjentäväksi, vaan eri asemaan asettaminen on kielletty myös muun henkilöön liittyvän syyn perusteella. Tällainen syy voi olla esimerkiksi yhteiskunnallinen asema, varallisuus, yhdistystoimintaan osallistuminen, perhesuhteet, raskaus, aviollinen syntyperä, seksuaalinen suuntautuminen ja asuinpaikka.

Perustuslakivaliokunta on kuitenkin pitänyt jonkinasteiseen erilaisuuteen johtavaa kokeilulainsäädäntöä sinänsä hyväksyttävänä yhdenvertaisuuden kannalta, mikäli kokeilulle on osoitettavissa hyväksyttävä tavoite. Valiokunta on tällöin korostanut, ettei yhdenvertaisuusperiaatteesta johdu tiukkoja rajoja lainsäätäjän harkinnalle pyrittäessä kulloisenkin yhteiskuntakehityksen vaatimaan sääntelyyn ja että kokeilu saattaa ainakin joissakin rajoissa muodostaa sellaisen hyväksyttävän perusteen, jonka nojalla muodollisesta yhdenvertaisuudesta voidaan tinkiä alueellisessa suhteessa. Valiokunta on kytkenyt kokeilun hyväksyttävyyden myös nimenomaisesti tietojen ja kokemuksien hankkimiseen tiettyjen suunnitteilla olevien uudistusten vaikutuksista. Valiokunnan mielestä myös henkilölliseen satunnaisotantaan perustuvaa perustulokokeilua voidaan arvioida samanlaisista lähtökohdista.

Nyt arvioitavan lakiehdotuksen mukaiset kokeiluryhmät muodostetaan laissa säädettyjen yhdenmukaisten kriteerien perusteella. Henkilön sijoittuminen kokeiluryhmään perustuu satunnaisotantaan. Kysymys ei tältä osin ole erilaisesta kohtelusta henkilöön liittyvän syyn perusteella, minkä vuoksi asiaa tulee kokeiluun kuuluvien ryhmien osalta arvioida perustuslain $6 \$$ :n 1 momentin yleisen yhdenvertaisuussäännöksen valossa.

Perustuslakivaliokunta on kokeilulainsäädännön arvioinnin yhteydessä kiinnittänyt huomiota myös sääntelyn oikeasuhtaisuuteen. Lakiehdotuk- 
sen mukaisessa kokeilussa perustuloa saavat henkilöt asetetaan perustulon suuruus ottaen huomioon merkittävästi parempaan asemaan kuin muut henkilöt. Toisaalta kyse on määräaikaisesta kokeilusta, jolle on edellä osoitettu perusoikeusjärjestelmän kannalta hyväksyttäviä perusteita. Valiokunnan mielestä kokeilun sääntely ei ole oikeasuhtaisuusvaatimuksen vastaista.

$[--]$

Perustuslakivaliokunta kiinnittää lailla säätämisen vaatimuksen johdosta huomiota myös otantamenettelyyn ja sen läpinäkyvyyteen. Hallituksen esityksen mukaan Kansaneläkelaitos poimii satunnaisotannalla 2000 henkilöä, joille maksetaan perustuloa. Säätämisjärjestysperusteluissa viitataan siihen, että satunnaistaminen tarjoaa jokaiselle kohdejoukon henkilölle yhtäläisen mahdollisuuden päästä perustulon piiriin, minkä johdosta menetelmä kohtelee kaikkia laissa täsmällisesti säädetyn kohdejoukon henkilöitä tasapuolisesti. Satunnaistamisen ohjelmistokoodi julkaistaisiin ennen poiminnan suorittamista. Valiokunnan käsityksen mukaan esitettyjä perusteluja voidaan pitää sinänsä asianmukaisina. Valiokunnan mielestä kokeiluryhmää ei voi jättää pelkästään ohjelmakoodilla määriteltäväksi, vaan sekä lailla säätämisen vaatimus että tarkkarajaisuuden ja täsmällisyyden vaatimukset edellyttävät, että otannan perusteista säädetään laissa esimerkiksi säätämisjärjestysperusteluissa selostettuja luonnehdintoja vastaavin vaatimuksin. Sääntelyä on tältä osin täydennettävä. Laissa on syytä säätää nimenomaisesti myös ohjelmistokoodin julkaisemisesta ja julkisuudesta.

Tuosta lausunnosta huolimatta veroloton perustuslainmukaisuus on niin kyseenalainen, että jos kyseiset lakiehdotukset olisivat edenneet eduskuntaan, niistä olisi ollut syytä hankkia perustuslakivaliokunnan lausunto. Jos säädettäisiin kansalaisaloitteiden kuvaamia verovapausarpajaisia, olisi myös syytä selvittää, olisiko tuollaiset verovapausvoitot verotettava arpajaisverolla.

\subsection{Veronpalautukselle ulosmittauskielto}

Mika Kärkkäisen 10.12.2014 tekemä aloite (7 kannattajaa) koski veronpalautusten ulosmittausta. Lakia olisi aloitteen mukaan muutettava niin, että jos verovelvollinen on ollut palkkatyössä ja hänen palkastaan on suoritettu verojen lisäksi ulosmittaus, kyseisen vuoden veronpalautusta ei voisi enää ulosmitata. Aloitteessa todetaan, että ihmiseltä on jo ulosmitattu kyseisestä palkasta kerran, ja on riistoa, että vielä veronpalautus ulosmitataan. Moni velallinen varmaan jo tämänkin takia tekisi mieluummin töitä. Ei rangaista ihmistä toista kertaa siitä, että hän tekee työtä. 


\section{Kommentteja}

Aloitteessa viitattaneen kaksoisrangaistuskieltoon (ne bis in idem). Tuolla kiellolla tuskin kuitenkaan voidaan perustella lain muuttamista aloitteen mukaiseksi eli sellaiseksi, että jos verovelvollisen palkasta on verovuonna toimitettu ennakonpidätys ja ulosmittaus, niin hänen veronpalautuksensa ulosmittaaminen ei olisi mahdollista.

\subsection{Kansanäänestys veronkorotuksista ja säästöistä}

Tanja Hietasen 26.3.2014 vireille paneman aloitteen mukaan (kannattajia 33) valtion velkaa koskevista säästöistä ja tulevista veronkorotuksista tulisi järjestää kansanäänestys. Päätöksissä tulee huomioida myös kansalaisten mielipide. Jokaiselle äänioikeutetulle suomalaiselle on annettava mahdollisuus tuoda oma kantansa ja ehdotuksensa julki niin leikkausten kuin veronkorotustenkin osalta. Kuntien ja kaupunkien tulisi olla velvollisia toteuttamaan äänestys samalla tavoin kuin eduskuntavaalitkin. Vaihtoehtoisesti äänestys voitaisiin toteuttaa sähköisesti.

Suomi ei voi maksaa velkojaan ainoastaan eduskunnan päätösten perusteella, vaan tässä tulisi huomioida kaikki kansalaiset. Suurin osa valtion veloista jää tavallisten suomalaisten maksettavaksi, ja nykyisen taloustilanteen valossa se ajaa liian monta perhettä ja taloutta kestämättömyyden partaalle. Palkat eivät nouse, mutta työmatka-, ruoka-, sähkö- ja autonkäyttökulut nousevat. Kiinteistöveroa on korotettu ja sitä korotetaan lisää. Erilaiset tukimuodot, jotka ovat monelle se viimeinen oljenkorsi, ovat leikkausten kohteena. Jos esimerkiksi nettopalkka on 1500 euroa/kk, se ei enää riitä normaaliin asumiseen ja elämiseen niin, ettei tarvitsisi jatkuvasti stressata ja laskea pennejä. Normaalin kolmihenkisen perheen ruokakulut ovat helposti jo 500 euroa/kk, vuokra vähintään toiset 500 euroa/kk. Miten jäljelle jäävällä 500 eurolla/kk sitten katetaan kolmen ihmisen vaatekulut, puhelinlaskut, harrastukset, kodin hygieniatarvikkeet, mahdollinen lemmikki ja vaikkapa autolaina? Aletaan olla tilanteessa, jossa mukaan tarvittaisiin myös kaikki eduskunnan jäsenet ja ylipäänsä päättäjät. Suurimman osan säästöistä kursivat kasaan tavalliset kansalaiset, eivät he, jotka asioista päättävät. Annetaan suomalaisille oikeus vaikuttaa siihen, mistä ollaan valmiita maksamaan.

Kunnallis- ja eduskuntavaalit ovat osaltaan juuri tätä varten, mutta valitettavan moni kansanedustaja on jo vaalilupauksensa syönyt. Toteuttamalla aktiivisemmin kansanäänestystä ja täsmentämällä aihealueita saataisiin todennäköisesti myös useampi ihminen äänestämään ja juuri niistä asioista, jotka häntä henkilökohtaisesti koskettavat. Sellainen tulisi tasa-arvoisen ja hyvinvoivan Suomen olla. 
7 Kansalaisaloitteinen verotus - viihdettä vai demokratiaa?

\section{Kommentteja}

Suomen valtiosääntö mahdollistaa neuvoa-antavien kansanäänestysten järjestämisen, mikäli niistä päätetään erikseen lailla (perustuslain 53 §). Sitovaa kansanäänestystä lainsäädäntömme ei tunne. Neuvoaantava kansanäänestys on meillä järjestetty vain kahdesti: joulukuussa 1931 kieltolain lakkauttamisesta ja lokakuussa 1994 Euroopan unioniin liittymisestä. Valtiontalouden säästöt ja tulevaisuuden veronkorotukset sopisivat huonosti kansanäänestykseen. Mielipidekyselyillä voidaan kartoittaa kansalaisten suhtautumista tällaisiin kysymyksiin.

\subsubsection{Tuloverotus}

\subsection{Perheverotus}

\section{a) Yhteisverotus perheenjäsenille}

Heikki Mustaniemen 14.1.2019 vireille panemassa aloitteessa (1 kannattaja) ehdotettiin yhteisverotusta, jossa perheen tulot lasketaan yhteen ja jaetaan elätettävien määrällä. Elätettäviin voitaisiin laskea myös perheen tulojen varassa elävät vanhemmat. Tällä tavalla saatu vuositulo märittäisi veroprosentin. Kun tuloverojen kokonaiskertymä pidetään samana, perheiden veroprosentti laskisi. Mitä isompi perhe, sen pienempi olisi progressio. Yhden ja kahden lapsettoman tulonsaajan verotus sen sijaan kiristyisi. Hyviä malleja löytyy useista Euroopan maista, vaikkapa Ranskasta.

Periaate, että progressio perustuu tulojen lisäksi elätettävien määrään, on oikeudenmukaisempi. Se myös kannustaisi lastentekoon, mikä on välttämätöntä kestävyysvajeen paikkaamiseen. Järjestelmä mahdollistaisi myös joissakin tapauksissa äidin kotiin jäämisen lasten hoitoa varten. Yrittäjyyskin lisääntyisi, koska hyviltä palkkatuloilta siirtyminen matalatuloiseksi yrittäjäksi olisi vähemmän riskialtista. Suurin vaikutus olisi pienituloisissa lapsiperheissä, joissa tulot menevät päivittäiseen selviämiseen. Tällä hetkellä yhden hyvin tienaavan lapsiperheellä on todella tiukkaa, koska perheen tuloista verotetaan suhteettomasti verrattuna perheisiin, joissa on kaksi palkansaajaa.

\section{Kommentteja}

Aviopuolisoihin sovellettiin meillä 1970-luvun puoliväliin saakka valtionverotuksessa yhteisverotusta: tulot laskettiin yhteen ja vero määrättiin yhteenlasketun määrän perusteella. Kun verotus on progressiivinen ja molemmilla puolisoilla on tuloja, yhteisverotus muodostuu ankarammaksi kuin kummankin puolison erillinen verottaminen. 
Tämän välttämiseksi puolisoita verotettiin erityisen, yksineläjiin sovellettavaa asteikkoa lievemmän asteikon mukaan. Lisäksi vähemmän ansainnut puoliso sai tietyin edellytyksin tehdä vähennyksen. Tällä tavalla puolisoiden yhteisverotus voitiin rakentaa sellaiseksi, että avioliiton solmiminen usein pikemminkin alensi kuin lisäsi verorasitusta.

Yhteisverotusta perusteltiin mm. avioliittolaista johdettavin argumentein. Sanottiin myös, että kun puolisoilla on yhteinen talous, heillä on yhteinen veronmaksukyky, joten heidän verotuksensakin on toimitettava yhteisesti. Pidettiin myös perusteltuna, ettei puolisoiden veromäärään vaikuttanut se sattumanvarainen seikka, miten puolisoiden tulot jakautuivat heidän keskensä.

Puolisoiden yhteisverotusta alettiin 1960-luvulla vastustaa sanomalla, että se ei ole nykyajan hengen mukaista ja ettei ole perusteltua sitoa aviopuolisoita verotuksellisesti niin läheisesti toisiinsa kuin yhteisverotus edellyttää. Huomautettiin myös yhteisverotuksen eräissä tapauksissa veroa korottavasta vaikutuksesta. Tärkeänä näkökohtana viitattiin siihen, että yhteisverotus saattoi pitää aviovaimot poissa työelämästä, koska heidän ansiotuloonsa sovellettiin aviomiehen korkeaa marginaaliveroprosenttia. Ennakkoperintäjärjestelmäkin toimi yhteisverotuksessa epätyydyttävästi.

Puolisoiden tulojen yhteisverotuksesta luovuttiin 1970-luvun puolivälissä, yhteisestä varallisuusverotuksesta vähän myöhemmin. Kunnallisverotuksessa ei yhteisverotusta ollut ennenkään. Vaikka yhteisverotuksesta on luovuttu, joitakin sen piirteitä on vielä jäljellä alijäämähyvitysjärjestelmässä ja kotitalousvähennyksessä.

Yhteisverotuksen puoltajat ovat meillä nykyisin harvassa. Kyseisellä kansalaisaloitteellakin oli vain yksi kannattaja.

\section{b) Lapsettomille naisille lisävero}

Kimmo Kemppaisen 7.6.2013 vireille panemassa aloitteessa (26 kannattajaa) ehdotettiin lisäveroa lapsettomille naisille kannustamaan nuoria naisia perheen perustamiseen.

Eduskunnan työasiainvaliokunta korosti hallituksen esityksen (HE 131/1994) johdosta antamassaan lausunnossa naisten asepalvelun vapaaehtoisuutta. Valiokunnan mukaan vain muutamassa maassa pakollinen asepalvelu koskee molempia sukupuolia. Valiokunta totesi, että äitiys, synnyttäminen ja lapsista huolehtiminen ovat tärkeitä perusteita sille, miksi naisten pakollista asepalvelusta ei voida puoltaa vain kapea-alaisesti tasa-arvon näkökulmasta. 
Mikäli nainen jättäytyy lapsettomaksi, tuollainen perustelu ei päde. Tällöin on aiheellista luoda lasten hankintaan kannustin ottamalla käyttöön lisävero, joka tulee maksuun verotuksessa, mikäli naisella ei ole vielä hankittuna lapsia. Perheen perustamisen jälkeen lisävero poistuu. Lisäverosta nainen voi halutessaan vapautua myös suorittamalla asepalveluksen ennen 28. ikävuotta. Lisäveron toisena tarkoituksena on parantaa miesten ja naisten välistä tasa-arvoa, jolloin syntyy kummallekin sukupuolelle kannustin sellaiseen toimintaan, joka on Suomen kansan kokonaisuudelle parhaaksi. Eli nuorilla miehillä on kannustin käydä armeija, nuorilla naisilla on kannustin hankkia lapsia. Perheiden perustaminen lisääntyy ja tapahtuu nykyistä nuorempana, jolloin Suomen kansa kokonaisuudessaan nuorentuu, millä on myönteisiä kansantaloudellisia vaikutuksia.

\section{Kommentteja}

Vuosina 1643-1712 elänyt Preussin pääministeri Johan Kasimir von Wartenberg sai mainetta neitsytverosta, jota 20-40-vuotiaiden naimattomien naisten piti maksaa kuukausittain. Jonkinlaisena tuon veron sukulaisena voidaan pitää Suomessa 1970-luvun puoliväliin asti voimassa ollutta vanhanpiian/vanhanpojan veroksi kutsuttua järjestelmää. Sillä tarkoitettiin säännöstä, jonka mukaan tuloverotuksessa ankarimpaan veroluokkaan joutui 24 vuotta täyttänyt lapseton naimaton henkilö. Tuohon aikaan veroluokkia oli kolme ja veroluokka määräytyi aviosäädyn ja elätettävänä olevien lasten mukaan. ${ }^{60}$ Lapsettomien naisten lisävero ei vaikuta tämän päivän Suomessa realistiselta. ${ }^{61}$

\section{c) Sinkuille tasavertainen asema verovähennyksissä}

Pia Pelkosen 5.5.2018 vireille panemassa aloitteessa (17 kannattajaa) ehdotettiin sinkkujen verovähennysoikeuden tasapuolistamista työnteon mahdollistamiseksi.

Nykyinen verotus puoltaa perheellisiä ja avoliitossa eläviä, mutta syrjii yksineläjiä. Modernissa yhteiskunnassa ei voida syrjiä työnteon mahdollistamisessa niitä, jotka asuvat yksin omasta tahdostaan tai olosuhteista johtuen. Yksineläjillä tulee olla samat oikeudet ja mahdollisuudet tasapuolisiin verovähennyksiin kuin muillakin Suomen kansalaisilla. Tämänhetkinen työelämä Suomessa perustuu pätkätöiden teettämiseen työntekijöillä, ja nyt vain perheelliset hyötyvät systeemistä. Yksinelävät,

\footnotetext{
60 Ks. myös Helsingin Sanomien Kuukausiliite 11/2019, jossa käsitellään vanhanpiianveroa ja rapujuhlapakkoa ratkaisuna vauvapulaan.

${ }^{61}$ Vrt. kuitenkin edempänä tässä kirjassa luku 2.2.
} 
ahkerat työntekijät eivät voi hyödyntää kaikkia tulonhankkimiskuluja verotuksessa tasapuolisesti muihin nähden. Tarvitaan muutos, jotta freelance-työntekijöiden lyhyiden työsopimusten ottaminen vastaan mahdollistuisi.

\section{Kommentteja}

Aloite on hieman arvoituksellinen. Koska aloitteessa käsitellään työelämää, kritiikki kohdistunee yksin elävien oikeuksiin saada matka- ja työasuntovähennyksiä; ne nimittäin ovat heikommat kuin perheellisillä.

Aikoinaan asunnon ja työpaikan väliset matkakulut eivät olleet vähennyskelpoisia, vaan ne katsottiin elantokustannuksiksi. Ajatuksena oli, että verovelvollinen säästi asumiskuluja asumalla kauempana. Enää tämä ajattelutapa ei päde, ja matkakulut onkin tehty tietyissä rajoissa vähennyskelpoisiksi (tuloverolain $93 \$$ ). Yksinäinen henkilö, jolla on vakituinen työpaikka ja asunto työskentelypaikkakunnalla, ei oikeuskäytännön mukaan yleensä saa vähentää toisella paikkakunnalla olevalla asunnosta käynneistä aiheutuneita kuluja.

Tuloverolaissamme on vuodesta 2008 alkaen ollut työasuntovähennys $(95 \mathrm{a} \$)$. Jos verovelvollinen on varsinaisen työpaikkansa sijainnin vuoksi vuokrannut käyttöönsä asunnon (työasunto) ja hänellä on myös toinen asunto, jossa hän puolisonsa tai alaikäisen lapsensa kanssa asuu (vakituinen asunto), vähennetään verovelvollisen tulonhankkimiskuluina 450 euroa jokaista sellaista täyttä kalenterikuukautta kohti, jona hänellä on ollut kaksi asuntoa (työasuntovähennys). Vähennyksenä myönnetään kuitenkin enintään verovelvollisen työasunnosta maksamaa vuokraa vastaava määrä. Vähennyksen myöntäminen edellyttää, että vakituinen asunto sijaitsee yli 100 kilometrin etäisyydellä työasunnosta ja siitä varsinaisesta työpaikasta, jonka sijainnin vuoksi työasunto on hankittu. Työasuntovähennystä ei saa, jos työn vuoksi hankittu asunto on omistusasunto, mutta vakituinen asunto voi olla omistusasunto.

Vähennystä ei myönnetä, jos verovelvollinen on saanut toisella paikkakunnalla asumiseen liittyvää verovapaata korvausta tai etuutta, eikä siltä osin kuin hän on muun säännöksen nojalla vähentänyt asunnon käyttöön liittyviä kustannuksia verovuodelta toimitetussa verotuksessaan. Kotitalousvähennys ei kuitenkaan estä työasuntovähennyksen myöntämistä. 
Jos vähennyksen edellytykset täyttyvät molempien puolisoiden osalta ja molemmat puolisot ovat vaatineet vähennystä, vähennys myönnetään sille puolisolle, jonka puhdas ansiotulo on suurempi.

Verovelvolliselle myönnetään työasuntovähennys myös silloin, kun hänellä on työasunnon lisäksi vakituinen asunto toisen varsinaisen työpaikan sijainnin vuoksi, vaikka hän asuisi vakituisessa asunnossaan yksin. Jos siis työntekijä on yksinäinen henkilö, hänellä tulee vähennyksen saadakseen olla samanaikaisesti kaksi varsinaista työpaikkaa ja samanaikaisesti käytössään vakituinen asunto ja työasunto.

Aloitteessa esitetty ongelma on vielä ratkaisematta. Kansanedustaja Joona Könttä on 29.8.2019 tehnyt seuraavan kirjallisen kysymyksen työasuntovähennyksen laajentamisesta (93/2019):

Suomalainen yhteiskunta muuttuu ja moninaistuu, mikä heijastuu vahvasti myös työelämään. Yhä useampi suomalainen siirtää varsinaista perheen perustamista myöhäisempään ajankohtaan. Käsitys perheestä on myös muuttunut ja avoliitot ovat yleistyneet. Samalla työelämän vaatimukset ovat lisääntyneet. Kodilla ja kotipaikalla on iso rooli ihmisen elämässä. Kotipaikka on ennen kaikkea se paikka, johon ihminen on kotiutunut. Se on alue tai yhteisö, jossa ihminen tuntee olevansa kotona ja jossa ystävät ja turvaverkko ovat läsnä. Kotipaikka on osa ihmisen identiteettiä ja luo perustan tasapainoiselle, hyvinvoivalle elämälle.

Valtiovarainministeriön vero-osasto teki selvityksen (17.8.2018) työasuntoa ja viikonloppumatkoja koskevan verovähennyksen ulottamisesta niihin ryhmiin (esim. yksinelävät), jotka eivät ole tällä hetkellä oikeutettuja vähennykseen. Tällä haluttiin selvittää taloudellisia sekä työllisyysja yhteiskunnallisia vaikutuksia. Lisäksi selvitettiin, missä määrin näiden ryhmien lisääminen mahdollistaisi vähennyksen käyttämisen muissakin tapauksissa kuin vähennyksen tarkoituksen täyttämisessä. Selvityksessä keskityttiin luettelemaan esteitä työasuntoa ja viikonloppumatkoja koskevan verovähennyksen ulottamisessa myös yksineläville. Selvitys nojasi myös valtiovarainvaliokunnan mietintöön (VaVM 15/2007 vp), jonka mukaan yksin asuva voi muuttaa perhettä helpommin uudelle paikkakunnalle eikä ole yhtä lailla sidottu asuinpaikkaansa. Mietintöä voi monella tapaa pitää vanhentuneena, kun huomioidaan kotipaikan merkitys, nykyisen työelämän muutosherkkyys ja perheen käsityksen muuttuminen.

Työasuntovähennyksen ulottamisessa myös yksinasuville on kysymys paitsi tasa-arvosta myös merkittävästä työllistymisen esteen poistamisesta. On selvää, että vähennystä laajennettaessa tulee luoda uusia kriteerejä, joilla pyritään määrittelemään tosiasiallisten olosuhteiden olemassaoloa. Ulotettaessa työasuntovähennys myös yksinasuville koskisi se tosiasiallisesti myös avoliittoja. Edellä olevan perusteella ja eduskunnan työjär- 
jestyksen 27 \$:ään viitaten esitän asianomaisenministerin vastattavaksi seuraavan kysymyksen: Aikooko hallitus selvittää työasuntovähennyksen ulottamista myös niihin ryhmiin (esim. yksinelävät), jotka eivät ole tällä hetkellä oikeutettuja vähennykseen?

\section{d) Lasten päivähoitomaksut vähennyskelpoisiksi}

Paavo Tannin 28.2.2017 vireille panemassa aloitteessa (7 kannattajaa) ehdotettiin töihinpaluun jouduttamista säätämällä päivähoitomaksut verovähennyskelpoisiksi. Ehdotus muuttaisi sosiaali- ja terveydenhuollon asiakasmaksuista annettuun lakiin ja asetukseen perustuvat kunnalliset päivähoitomaksut ansioverotuksessa vähennyskelpoiseksi rahamääräksi sekä valtionverotuksessa että kunnallisverotuksessa. Perheen sisäisesti voitaisiin joustavasti sopia, jaetaanko vähennys molemmille vanhemmille vai osoitetaanko se vain toiselle vanhemmista.

Keskimääräiset tulot vuonna 2015 olivat miehillä 33193 euroa ja naisilla 24545 euroa. Noilla tuloilla päivähoidon piirissä olevan kaksilapsisen perheen taloudessa päivähoitomaksut olivat vuoden ajalta noin 4800 euroa, joka oli noin $20 \%$ perheen pienempituloisen ansiotulosta ennen verotusta. Kuukausitasolla esimerkin naisen tulot olivat noin 2000 euroa ja verojen jälkeen käytettäväksi jäi noin 1600 euroa, josta kahden lapsen hoitomaksuihin kului keskimäärin 400 euroa, jolloin muihin kuluihin (esim. auton ylläpitoon työssä käymisen mahdollistamiseksi) jäi vain 1200 euroa. Mikäli pienempituloinen pysyi kotona, kunnes nuorimmainen lapsista täytti kolme vuotta, ja hoiti lapsia kotona, sai hän noin 700 euroa/kk (hoitoraha ja -lisä sekä kuntalisä); mikäli ansiot olivat tuota keskimääräistä heikommat, niin ero kaventui huomattavasti. Esimerkiksi 1500 euron kk-ansioilla ei hoitomaksujen ja verojen jälkeen jäänyt enää kuin 800 euroa/kk. Näin oli selvää, että varsinkin pienipalkkaisiin tehtäviin palaaminen ei houkuttele, kun "saman rahan saa kotiin".

Töihinpaluun nopeuttamiseksi olisi säädettävä verovähennysoikeus, jolloin kunnallisiin päivähoitomaksuihin käytetty rahamäärä voitaisiin vähentää ansiotuloverotuksessa. Esimerkin perheellä vaikutus olisi vuositasolla pelkästään valtionverotuksen osalta noin 900 euroa perheen kohdentaessa vähennykset täysimääräisesti parempituloisen verovähennykseksi. Kansantaloudelle hyödyllisenä perheen molemmat henkilöt alkavat nopeammin saada ansioita ja maksaa veroja, ja perheelle ei enää makseta hoitorahaa ja hoitolisää.

\section{Kommentteja}

Lastenhoitokustannukset ovat tyypillisiä verotuksessa vähennyskelvottomia elantomenoja, mutta lapsesta suoritettavat elatusapumaksut ovat - tosin vähäiseltä osin - vähennyskelpoisia. 
Lasten kotihoidon tuki on saajalleen veronalaista ansiotuloa. Lasten kaitseminen verovelvollisen kotona on tavanomaista hoiva- ja hoitotyötä, joten tällaisesta työstä lastenhoitajalle maksetusta palkasta voi saada kotitalousvähennyksen - ei kuitenkaan, jos se maksetaan palvelusetelillä tai muulla vastaavalla maksusitoumuksella. Kunnalle maksetuista palveluista ei voi saada kotitalousvähennystä.

Tässä kansalaisaloitteessa, joka sai hyvin vähän kannattajia, ehdotettiin verotuksessa vähennyskelpoisiksi kunnallisessa päivähoidossa olevista lapsista suorittavia päivähoitomaksuja. Ehdotusta olisi vaikea sovittaa verojärjestelmämme johdonmukaiseksi osaksi.

\subsection{Harrastusmenot vähennyskelpoisiksi}

Asko Veteläisen 22.5.2014 vireille panemassa aloitteessa (29 kannattajaa) esitettiin ostettujen liikuntapalveluiden verovähennysmahdollisuutta yksityishenkilöille. Verovähennyskelpoisiksi liikuntapalveluiksi luettaisiin terveyttä ja hyvinvointia edistävän liikunnan muodot, poislukien huippuurheilu.

Tämän päivän yhteiskunnassa ongelmana on ihmisten liikkumattomuus. Yhteiskuntamme on istuva. Lähestulkoon kaikki työ tehdään istuen, ja vapaa-aikana istumista jatketaan television tai erilaisten näyttöpäätteiden äärellä. Jos valtion ja yhteiskunnan yhteisenä tavoitteena on jatkaa ihmisten työurien pituutta, tulisi sitä myös tukea voimakkaasti. Liikunnalla on tutkitusti ihmisen elämän laatuun positiivisia vaikutuksia. Tällä hetkellä kotitalousvähennyksien kautta ihmiset voivat vähentää kiinteistöihin kohdistuvia kunnostustöitä. Miksi ihmisten itsensä kunnostusta valtio ei voisi tukea verovähennysten muodossa? Onhan ihminen itsessään aikamoinen "arvokiinteistö"!

Ketään ei voi pakottaa liikkumaan, mutta yksilön liikkumista voimakkaasti tukien voidaan tällä hetkellä passiivisetkin yksilöt muuttaa aktiivisiksi. Työssä käyvillä on mahdollista tällä hetkellä, työpaikasta riippuen, lunastaa liikuntaseteleitä, mutta työttömillä ei ole vastaavanlaista tukea saatavilla. Liikuntapalveluiden verovähennyskelpoisuus yksityisille henkilöille olisi tasa-arvoinen menettely tulotasoihin katsomatta. Lisäksi verovähennyskelpoisuudella voitaisiin edistää liikunta-alan osaajien työllistymistä yrittäjiksi tai työntekijöiksi liikunta-alan yrityksiin lisääntyvän palvelukysynnän kautta.

Tuomas Tiaisen 24.9.2017 vireille panemassa aloitteessa (18 kannattajaa) esitettiin alaikäisten lasten harrastusmaksujen säätämistä verovähennyskelpoisiksi. Lasten harrastusmaksut olisivat verovähennyskelpoisia aina kunnes lapsi täyttää 18 vuotta. Perheillä kuluu kymmenistä euroista aina tuhansiin euroihin vuodessa lasten harrastusmaksuihin. Monien harras- 
tusmaksut nousevat lapsen iän noustessa, ja tämä voi estää monien lahjakkaiden lasten harrastamisen aikuisikään saakka. Samalla harrastuksiin lähtemisen kynnys alenisi ja lapset saataisiin liikkumaan ja harrastamaan.

Myös Juho Tolppolan 21.2.2019 vireille panemassa aloitteessa (2 kannattajaa) ehdotettiin harrastuskuluja verovähennysten piiriin. Aloitteessa ehdotettiin samanlaista mallia kuin remonttien kotitalousvähennykset 3000 euroon asti, josta $50 \%$ olisi mahdollisuus vähentää verotuksessa omavastuuosuuden ollessa 200 euroa. Huolestuttava muutos on näkynyt terveysmenojen kasvussa ja liikkumattomuudessa. Kysymys on parhaasta ennaltaehkäisevästä mielenterveys- ja päihdetyöstä. Tulevaisuudessa suurimman ryhmän liikkuminen näkyy myös suomalaisen urheilun huipulla.

Antti Hietakankaan, Jani Raution, Eva Joutsen-Rinteen, Janne Rinteen, Anu Hietakankaan ja Anu Raution 9.9.2019 vireille panemassa aloitteessa (684 kannattajaa 30.11.2019 mennessä) ehdotetaan valmisteltavaksi laki alaikäisen liikuntavähennyksestä. Vähennys olisi kotitalousvähennyksen kaltainen vähennys. Verovelvollinen saisi osittain vähentää veroista alaikäisen liikuntaan kohdistuvia kuluja. Alaikäisen liikuntavähennys olisi henkilökohtainen vähennys. Siten esimerkiksi puolisoista vähennyksen voi saada kumpikin erikseen, jos heillä on riittävästi vähennyskelpoisia kustannuksia. Liikuntavähennyksenä voi vähentää esimerkiksi 500-1000 € vuodessa. Liikuntavähennyksen edellytyksenä vähennettävän osuuden tulee liittyä liikuntaan.

Vähennyskelpoisesta osuudesta tulee olla selkeä kuitti ennakkoperintärekisteriin merkityltä yritykseltä tai yrittäjältä tai urheiluliittoon kuuluvalta liikunta- / urheiluseuralta tahi yleishyödylliseltä yhteisöltä. Vähentää voisi osan (esim. $75 \%$ ) laskussa olevasta korvauksesta. Vähennettävän osuuden ei tarvitsisi välttämättä kohdistua oman lapsen liikuntaharrastukseen. Alaikäisten liikunnan merkitys terveyteen sekä kehitykseen on kiistaton. Nykyajan liikuntaharrastukset kasvavat kustannuksiltaan jatkuvasti, jolloin kaikilla alaikäisillä ei ole tasapuolista mahdollisuutta harrastaa liikuntaa. Aloitteella pyritään mahdollistamaan alaikäisten liikkumista riippumatta perheen tulotasosta. Innostamalla alaikäiset eri harrastusten pariin, olisi paremmat mahdollisuudet, että alaikäiset liikkuvat liikuntasuositusten mukaisesti. Lisäksi tämä yleistä terveyttä edistävä aloite on ensiarvoisen tärkeä investointi tulevaisuuden sosiaali- ja terveyskustannusten nousun taltuttamiseksi.

\section{Kommentteja}

Hyvin voimakas lähtökohta tuloverotuksessa on, että verovelvollisen ja hänen perheensä elantomenot eivät ole vähennyskelpoisia. Erilainen veronmaksukyky pyritään ottamaan huomioon veroasteikkoja 
laadittaessa. Merkittävä poikkeus tästä periaatteesta on seuraavaksi käsiteltävä kotitalousvähennys.

\subsection{Kotitalousvähennys suuremmaksi ja laaja-alaisemmaksi}

Heikki Ahosen 1.4.2013 vireille panemassa aloitteessa (516 kannattajaa) ehdotettiin kotitalousvähennyksen palauttamista ennalleen tai sen määrän kasvattamista, koska veroleikkausten jälkeen kotipalvelualan yksityiset työmahdollisuudet olivat vähentyneet jyrkästi.

Sirpa Hirvikallion 23.4.2019 vireille panemassa aloitteessa (811 kannattajaa) ehdotettiin huonekalujen verhoilun ja entisöinnin liittämistä kotitalousvähennykseen oikeuttaviin töihin siten, että vähennystä voisi saada maksimissaan 2400 euroa vuodessa. Vähennyksen omavastuu olisi 100 euroa henkilöltä vuodessa. Tämä parantaisi usein pienyrittäjinä toimivien verhoilijoiden/entisöijien tilannetta, lisäisi käsityöammattien arvostusta sekä kierrättämistä ja helpottaisi erityisesti alalle kouluttautuneiden ja kouluttautuvien nuorten työllistymistä. Tällä hetkellähän uusien huonekalujen kokoaminen kuuluu kotitalousvähennykseen oikeuttaviin töihin.

\section{Kommentteja}

Kotitalousvähennystä, joka otettiin käyttöön 1990-luvun lopulla, perustellaan sillä, että työllisyyspoliittisesti on tarkoituksenmukaista edistää kotityöpalvelujen käyttöä, jonka uskotaan luovan uusia työpaikkoja näitä palveluja tuottavalle pienyrityssektorille. Sosiaalipoliittisista syistä pyritään myös aktivoimaan koteja omaehtoisiin hoivajärjestelyihin. Yhteiskunnan ja osapuolten kannalta on pidetty tärkeänä, ettei kotityöhön liittyviä maksuvelvoitteita laiminlyödä.

Kotitalousvähennyksenä (tuloverolain $127 \mathrm{a}-\mathrm{c} \$$ ) verovelvollinen saa vähentää verosta osan käyttämässään asunnossa tai vapaa-ajan asunnossa tehdystä työstä maksamistaan summista. Vähennykseen oikeuttavat tavanomainen kotitalous-, hoiva- tai hoitotyö sekä asunnon tai vapaa-ajan asunnon kunnossapito- tai perusparannustyö. Vähennys oli vuonna 2018 enintään 2400 euroa vuodessa, ja se myönnettiin vain siltä osin kuin vähennettävä osa kustannuksista ylitti 100 euroa.

Asunnon kunnossapitotyönä ei pidetä kodin koneiden ja laitteiden korjaus- tai asennustyötä. Tieto- ja viestintätekniikan laitteiden, 
ohjelmistojen, tietoturvan ja tietoliikenneyhteyksien asennus-, kunnossapito- ja opastustyöhön sovelletaan kuitenkin, mitä asunnon kunnossapito- ja perusparannustyöstä säädetään. Työllisyysperusteilla saattaisi olla perusteltua tarkistaa niiden töiden piiriä, jotka oikeuttavat kotitalousvähennykseen.

Pääministeri Antti Rinteen hallituksen ohjelmassa (s. 22) kotitalousvähennystä ehdotettiin supistettavaksi veropohjan tiivistämiseksi: "Kotitalousvähennyksen osuutta työkorvauksista lasketaan 40 prosenttiin ja palkoista 15 prosenttiin. Lisäksi kotitalousvähennyksen enimmäismäärää alennetaan 2250 euroon. Muutos lisää verotuottoja vuositasolla noin 95 miljoonaa euroa." Hallitus on antanut tällaista tiukennusta tarkoittavan esityksen (HE 24/2019). Vähennykseen oikeuttavan toiminnan alaan ei ole tulossa muutoksia. ${ }^{62}$

\subsection{Omaishoidon tuki kokonaan tai osaksi verovapaaksi}

Juha Pätsin 7.4.2017 vireille panemassa aloitteessa (20 kannattajaa) ehdotettiin omaishoidon tuen muuttamista verovapaaksi, koska omaishoitajat tekevät arvokasta työtä eikä tuki useinkaan nosta omaishoitajan tulotasoa vaan ainoastaan peittää aiheutuneita kuluja. Sitä paitsi omaishoidon tuen muuttaminen verovapaaksi vähentäisi kuluja muualla vanhusten huollossa mm. huomattavasti kalliimman laitoshoidon vähentymisenä. Omaishoitajat ovat yhteiskunnalle erittäin edullista työvoimaa, ja heidän tukensa muuttaminen verottomaksi kannattaa vaikka pelkästään syntyvän säästön takia.

Päivi Lämsä, Markku Koponen, Merja Salminen, Sanna-Mari Seppälä ja Mika Salminen ovat 8.11.2019 panneet vireille aloitteen (5 580 kannattajaa 30.11.2019 mennessä) omaishoitajien aseman parantamiseksi. Siinä ehdotetaan monia toimenpiteitä, joista yksi on verotuksellinen. Omaishoidon erityisluonne tulisi ottaa verotuksessa huomioon ja omaishoidon tuki tulisi muuttaa osittain verovapaaksi ansiotuloksi, jollaista esimerkiksi opintotuki on.

\section{Kommentteja}

Myös Omaishoitajaliitto on vaatinut verokevennyksiä omaishoitajille. Se on mm. tehnyt esityksiä omaishoitopalkkion verottomuudesta.

62 Oppositiopuolue Kokoomus on varjobudjetissaan marraskuussa 2019 esittänyt kotitalousvähennyksen suurentamista ja laajentamista erityisesti 75-vuotiaiden ja sitä vanhempien kohdalla. 
Liiton mielestä palkkiosta olisi kuitenkin maksettava sosiaaliturvamaksut, jolloin perusteet ansiosidonnaiseen sosiaaliturvaan sekä eläke- ja tapaturmavakuutusetuuksiin säilyisivät. Liiton mukaan omaishoitajien verotusta voitaisiin keventää myös ottamalla mallia eläketulovähennyksestä. Valtiovarainministeriö on torjunut verokevennysehdotukset, koska yksi ryhmä ei voi saada erioikeuksia. Työperäisen palkkion veronalaisuus onkin lähes poikkeukseton pääsääntö.

\subsection{Eläkkeiden verotusta kevennettävä}

Viidessä kansalaisaloitteessa on ehdotettu muutoksia eläkkeiden verotukseen. Näistä ajallisesti ensimmäinen oli Mervi Jankon 19.3.2015 vireille panema aloite (2 069 kannattajaa). Siinä vaadittiin eläkeläisten verotuksen muuttamista tasa-arvoiseksi muiden tulonsaajaryhmien verotuksen kanssa. Esityksessä viitattiin perustuslakiin. Eläkkeiden verotus ei saisi olla millään tulotasolla korkeampi kuin vastaavien palkkatulojen verotus. Aloitteessa todettiin, että eläkeläispolitiikka ja siitä päättäminen on osa sosiaalipolitiikkaa. Sen takia eläkkeiden kehityksen seuraamisen ja päätösten valmistelun tulisi olla poliittisen arvioinnin ja valmistelun alaista toimintaa. Nyt arviointi ja päätösten valmistelu tapahtuu ns. kolmikannan toimesta. Eläkeläisten "raippavero" on perustuslain hengen vastainen, koska tulonsaajia kohdellaan eriarvoisesti. Eläkeläisten raippavero ei säästä valtion menoja vaan lisää työttömyyttä eläkeläisten kulutuksen vähentyessä. Raippavero pitää poistaa tai ainakin säätää samoilla ehdoilla kuin muidenkin tulonsaajien kohdalla. Työntekijä- ja työnantajajärjestöt ja eläkeyhtiöt valmistelevat eläkeasioita, joissa niillä on ajettavanaan eläkkeensaajien etujen vastaiset omat etunsa. Tätä ei ole pidettävä demokraattisena eikä yleisen oikeuskäsityksen mukaisena. Valmistelu ei ole tosiasiallisesti eduskunnan ohjauksessa. Lisäksi eläkkeensaajilla ei ole ollut mahdollisuutta vaikuttaa päätöksiin.

Vappu Säynätkarin aloitteessa 29.1.2018 (8 091 kannattajaa) vaadittiin raippaveron poistamista eläkeläisiltä. Esityksessä todettiin, että palkansaajilta on raippavero poistettu mutta eläkkeistä ei. Eläkkeestä maksettava vero on prosentiltaan korkeampi kuin palkkavero. Eläke on kaikilla pienempi kuin palkka, miksi siis siitä pitää maksaa korkeampaa veroa kuin palkasta? Tehdään asialle jotakin ja helpotetaan eläkeläisten verotusta. Samalla nousee ostovoima. Moni eläkeläinen pystyisi sitten myös ostamaan parempaa ruokaa.

Lasse Helskyahon 6.3.2018 vireille panemassa aloitteessa (41 kannattajaa) ehdotettiin lakia muutettavaksi sitten, että 2000 euron ja sitä pienempää eläketuloa ei lasketa verotettavaksi tuloksi. Progressiota olisi jyrkennettävä 
enemmän isoihin tuloihin vaikuttavaksi. Palkkatulosta, joista eläkekertymä on koostunut, on jo kertaalleen maksettu tulovero. 2000 euron ja sen alle jäävän eläketulon kanssa ei pysty elämään inhimillisesti verotuksen jälkeen.

Mirja Hirvijärven ja Irma Hirvijärven 8.3.2018 vireille panemassa aloitteessa (16 kannattajaa) vaadittiin eläkeläisille tasavertaista kohtelua verotuksessa muihin tulonsaajiin nähden. Eläkeläisiä kohdellaan Suomessa muihin kansalaisiin nähden syrjivästi. Suomen perustuslaissa säädetään kansalaisten yhdenvertaisesta kohtelusta. Tämä ei toteudu eläkeläisten verotusasioissa, vaan eläkkeistä maksetaan prosentuaalisesti huomattavasti enemmän veroa samansuuruiseen muuhun verotettavaan ansioon nähden. Raippavero olisi poistettava ja eläkeläisiä kohdeltava tasavertaisesti muiden tulonsaajien kanssa.

Myös Heikki Haaslahden 22.3.2018 vireille panemassa aloitteessa (2 461 kannattajaa) vaadittiin eläkeläisten verotusta samalle tasolle kuin työssä käyvien kansalaisten. Eläkeläiset maksavat huomattavasti korkeampaa veroa verrattuna työstä saatuun ansioon. Jos henkilö ansaitsee työansionaan 18000 euroa vuodessa, maksaa hän veroa 6,5\% eli 1 150,59 euroa. Jos henkilö saa saman 18000 euroa vuodessa eläkettä, maksaa hän veroa 16,5 \% eli 2903,51 euroa. Jos työansio on 48000 euroa vuodessa, maksaa työssä käyvä henkilö veroa $25,5 \%$ eli 12 014,34 euroa. Jos henkilö saa saman 48000 euroa eläkettä vuodessa, maksaa hän veroa 33,0 \% eli 15744,65 euroa. Verojen määrissä on siis kohtuuton ero. Epätasapainoa pahentavat eläkeläisten tappioksi vielä mahdolliset työntekoon liittyvät lisävähennykset, kuten työmatkavähennys ja koulutusvähennykset.

Eläkettä saa aiempaa huomattavasti suurempi määrä ihmisiä, ja heidän eläkkeensä ovat suurempia. Yhä useampi on myös turvautunut ns. vapaaehtoisiin lisäeläkkeisiin hyvän toimeentulon takaamiseksi lakisääteisen eläkkeen jäädessä riittämättömäksi. Eläkeläisten merkitys talouden rattaiden pyörittämisessä on olennaisesti lisääntynyt viimeisten kymmenien vuosien aikana, sillä he käyttävät enenevässä määrin erilaisten yritysten tuottamia palveluja. Esimerkkinä mainittakoon ravintola- ja matkailupalvelut - myös kotimaassa -, terveyteen ja kuntoiluun liittyvät palvelut, kuntoutuspalvelut, sairaanhoidon palvelut ym. vastaavat palvelut. Pksektorin yritysten palveluiden käyttäjinä eläkeläiset ovat myös kasvava kuluttajaryhmä esimerkiksi oman kodin kunnostus- ja korjauspalvelujen muodossa.

Eläkeläiset ovat pitkien työuriensa aikana kantaneet jo kortensa kekoon yhteisen hyvän eteen. Ei ole oikeudenmukaista periä heiltä enempää veroja kuin mitä työtulosta peritään. Erot euromäärissä ovat räikeät varsinkin alemmalla eläketulotasolla, johon kuuluville henkilöille tämä on erityisen merkittävä toimeentuloa vaikeuttava tekijä. 


\section{Kommentteja}

Eläketulon perusteella ei saa ansiotulovähennystä eikä työtulovähennystä, vaan eläketuloja varten on eläketulovähennykset. Aikoinaan monet eläkkeet kyllä olivat verovapaita. Kansaneläkeuudistukseen ja siihen liittyvään kansaneläkkeiden säätämiseen veronalaiseksi tuloksi perustui eläketulovähennysten käyttöönotto vuodesta 1983 alkaen. Eläketulovähennysten tarkoituksena on varmistaa, ettei pienituloinen eläkeläinen joudu maksamaan valtion- eikä kunnallisveroa. Nämä vähennykset sisältyvät TVL 100 \$:ään (valtionverotuksen eläketulovähennys) ja TVL 101 §:ään (kunnallisverotuksen eläketulovähennys), ja ne tehdään verovelvollisen puhtaasta ansiotulosta.

Eläketulovähennyksiä säädettäessä käytiin melkoinen poliittinen taistelu. Erimielisyyttä oli erityisesti siitä, voitiinko ja oliko syytä kytkeä nämä vähennykset indeksiin, vaikka muita TVL:n vähennyksiä ei indeksiin kytketty. Kytkennän puoltajat katsoivat, että vain kytkennällä voitiin välttää kansaneläkkeiden joutuminen uudistuksen periaatteiden vastaisesti tulevina vuosina verotuksen kohteeksi sen vuoksi, ettei vähennyksiä koroteta indeksin nousua vastaavasti. Kiistan ratkaisuksi muodostui se, että vähennyksen määrä kytkettiin täyden kansaneläkkeen märään. Koska tämä puolestaan on sidottu elinkustannusindeksiin, voidaan sanoa, että eläketulovähennyksetkin tulivat välillisesti sidotuiksi indeksiin. ${ }^{63}$

Eläketulon lisäveroa (ns. raippavero) on kannettu vuoden 2013 alusta alkaen suurista eläkkeistä. Vuosina 2013-2016 lisäveron määrä oli $6 \%$ siltä osin kuin eläketulo verovuonna ylitti 45000 euroa. Vuodesta 2017 alkaen lisävero on 5,85 \% siltä osin kuin eläketulo ylittää 47000 euroa.

Hallituksen esityksen perustelujen mukaan eläketulon lisäverolla on tarkoitus ensinnäkin kerätä verotuloja niiltä, joiden veronmaksukyky on korkealla tasolla. Hallitus katsoi eläkkeitä verotettavan liian kevyesti verrattuna palkkatuloon. Hallituksen mielestä lakisääteiset työntekijämaksut piti veronluonteisina maksuina ottaa tässä vertailussa huomioon, koska ne vähentävät verovelvolliselle verojen ja maksujen jälkeen jäävää tuloa.

63 Edward Andersson - Esko Linnakangas - Joakim Frände, Tuloverotus (2016) s. 413 ss. 
Hallitus totesi, että eläketulon lisäveroa maksetaan kaikkien eläketulojen perusteella eikä pelkästään esimerkiksi vanhuuseläkkeen perusteella ja että säännöksen soveltaminen perustuu siihen, minkä tyyppisestä ansiotulosta on kyse - eläketulon saajan henkilöön liittyvillä ominaisuuksilla ei ole merkitystä säännöksen soveltumiseen.

Eläketulon lisäveron suhteesta perustuslakiin saatiin 15.11.2016 korkeimman hallinto-oikeuden päätös (2016:180), jossa katsottiin, että eläketulon lisävero perustui vähintäänkin välillisesti henkilön ikään. KHO totesi, että lainsäätäjän oli katsottava ensisijaisesti kohdentaneen verorasituksen veronmaksukyvyn perusteella suurituloisiin eläkkeensaajiin veropoliittisten tavoitteiden saavuttamiseksi. Eläketulon lisäveron ensisijaiseksi tarkoitukseksi esitetty veronmaksukykyä koskeva peruste vastasi niitä tavoitteita, joita Suomen tuloverojärjestelmään on yleisesti liitetty, ja kuului sellaisenaan lainsäätäjän yhteiskuntapoliittisen harkintavallan piiriin. Kyseisen verovelvollisen voitiin KHO:n mukaan katsoa kuuluvan sellaisten eläkkeensaajien joukkoon, joiden maksukyky oli lain esitöissä tarkoitetulla tavalla korkealla tasolla. Veroaste oli hänen eläketulostaan kannettavan lisäveron myötä muodostunut palkansaajan veroastetta korkeammaksi riippumatta siitä, luettiinko palkansaajien veroasteeseen palkansaajamaksut. Lain esitöissä mainittua työelämässä jatkamista koskevaa tavoitetta ei voitu enää pitää ajankohtaisena kyseisen verovuonna 65 vuotta täyttäneen verovelvollisen tilanteessa. Kaikesta huolimatta eläketulon lisäveroa koskevan sääntelyn soveltaminen ei ollut KHO:n mielestä verovelvollisen veronmaksukyky ja sääntelyn kannalta hyväksyttävät tavoitteet huomioon ottaen perustuslain $6 \$$ :n mukaisen yhdenvertaisuussääntelyn kannalta arvioiden tai muutoinkaan perustuslain 106 §:ssä tarkoitetulla tavalla ilmeisessä ristiriidassa perustuslain kanssa.

Jotta tuomioistuin voisi jättää eduskuntalain säännöksen soveltamatta, vaaditaan, että laki on ilmeisesti, siis ilmiselvästi, ristiriidassa perustuslain kanssa. Kysymys ei ollut selvästä perustuslain loukkaamisesta vaan rajatapauksesta, josta ei ollut perustuslakivaliokunnan kannanottoa ja jossa asiantuntijoidenkin käsitykset poikkesivat toisistaan.

Eläketulon lisäveron perustuslainmukaisuutta käsiteltiin perustuslakivaliokunnassa ensi kerran syksyllä 2016, kun eduskuntaan annettiin hallituksen esitys (HE 135/2016) eläketulon lisäveron alentamisesta. 
Valiokunnan kuulemien asiantuntijoiden mielipiteet jakaantuivat. Enemmistö piti eläketulon lisäveroa perustuslain mukaisena. Perustuslakivaliokunnan kannanotto saatiin kohta KHO:n päätöksen jälkeen 18.11.2016. Valiokunta (PeVL 53/2016) totesi verotuksessa olevan tyypillistä, että eri tulolajeja (pääomatuloja ja ansiotuloja) ja tulolähteitä (elinkeinotoiminta, maatilatalous ja muu toiminta) sekä eri omaisuuslajeja kohdellaan eri tavoin, ja että menojen vähennyskelpoisuus on säännelty erikseen ja se vaihtelee eri tilanteissa. Vaikka verotuksen ensisijainen tehtävä on tuottaa julkiselle sektorille tuloja niin paljon, että ne riittävät kattamaan julkisen sektorin menot, verotusta on perinteisesti käytetty myös muiden yhteiskunnallisten tavoitteiden toteuttamisen välineenä. Perustuslakivaliokunnan mielestä hallituksen esityksessä mainittuja ihmisten välisten keskinäisten tuloerojen tasaamista ja heidän kannustamistaan työnteon jatkamiseen eläkkeelle jäämisen sijasta voidaan sinänsä pitää hyväksyttävinä verolainsäädännön tavoitteina.

Oikeasuhtaisuusvaatimuksen kannalta perustuslakivaliokunta totesi, että tietyn veron kohdistaminen yksinomaan eläketuloon voisi merkitä yhdenvertaisuuden loukkausta vain, jos se samalla saattaisi eläkkeen saajat merkittävästi heikompaan asemaan. Hallituksen esityksessä tehdyt vertailut palkansaajien ja eläkkeensaajien kokonaisverorasituksen osalta osoittavat valiokunnan mielestä sen, etteivät eläkkeensaajat ole verotuksen kokonaisuuden kannalta yleisesti palkansaajia heikommassa asemassa. Esitettyjen laskelmien perusteella eläketulojen veroaste on vastaavaa palkkatulon veroasetetta korkeampi vasta hyvin suurien, yli 118000 euron eläketulojen kohdalla. Tällöinkään veroaste ei ole merkittävässä epäsuhteessa vastaavan suuruisten palkkatulojen veroasteen kanssa, eikä sen voi katsoa olevan verovelvollisten kannalta kohtuuton, kun otetaan huomioon myös heidän veronmaksukykynsä.

Perustuslakivaliokunta katsoi, että lakiehdotukselle oli esitetty hyväksyttävä peruste, eikä ehdotus johtanut tietyn ryhmän asettamiseen merkittävästi muita heikompaan asemaan. Säännös eläketulon lisäverosta ei siten valiokunnan mielestä muodostunut perustuslain 6 \$:ssä säädetyn yleisen yhdenvertaisuuden taikka syrjinnän kiellon vastaiseksi (ks. myös edellä luku 1.12). 
7 Kansalaisaloitteinen verotus - viihdettä vai demokratiaa?

\subsection{Lääkekaton vuosiomavastuuosuus verovähennyskelpoiseksi osittain tai kokonaan}

Tommi Kvistin, Nina-Katariina Kettusen, Marja-Leena Kvistin, Henri Kvistin ja Riitta-Liisa Mustikkamäen 20.10.2019 vireille panemassa aloitteessa (846 kannattajaa 30.11.2019 mennessä) vaaditaan lääkekaton vuosiomavastuuosuutta verovähennyskelpoiseksi osittain tai kokonaan. On kohtuutonta että esimerkiksi pienituloinen vanhus/sairas/vammainen ihminen joutuu maksamaan 572 euron omavastuun vuoden alussa (2019), mikä vastaa hänelle noin 2-3 viikon palkkaa/tuloa. Esimerkiksi moni vanhus ajautuu tilanteeseen, että ostaako lääkkeitä vai ruokaa. Jos lääkekaton omavastuuosuus olisi verovähennyskelpoista, tämä kohtuullistaisi hänen elämäänsä. Henkilön lääkekattotiedot menevät Kelalta suoraan verottajalle.

\section{Kommentteja}

Tuloverotuksessamme oli verovuoteen 1991 asti säännös, joka salli verovelvollisen vähentää verotettavasta tulostaan tietyissä rajoissa oman ja perheenjäsenten lääke- ja muita sairauskuluja. Tämän jälkeen sairaudesta johtuvat kustannukset on otettu tuloverotuksessa huomioon vain harkittaessa mahdollisuutta myöntää verovelvolliselle veronmaksukyvyn alentumisvähennys (TVL 98 \$).

Verotukea yksinkertaisempi keino sairaudesta aiheutuneiden kustannusten vähentämiseen olisi Kelan suora tuki eli lääkekaton omavastuuosuuden poistaminen tai pienentäminen.

\subsection{Polkupyörävähennys kilometriperusteiseksi}

Teemu Lindelän 8.1.2016 vireille panemassa aloitteessa (1 938 kannattajaa) esitettiin, että polkupyörän, muun moottorittoman ajoneuvon, kevyiden sähköajoneuvojen ja sähköavusteisten polkupyörien käytöstä asunnon ja työpaikan välillä maksettava korvaus muutetaan nykyisestä kiinteästä korvauksesta kilometriperustaiseksi. Sopiva korvaus polkupyörän käytöstä olisi 0,15 euroa/km. Liikuntarajoitteinen saisi invaliditeettiasteensa mukaisen korotuksen (invalidiprosentin ollessa $60 \%$ olisi korvaus 0,15 euroa $/ \mathrm{km}$ x 1,60 = 0,24 euroa), kuitenkin enintään moottoriajoneuvolla ajetun työmatkan korvauksen verran ( 0,25 euroa). Käytettäessä pyörää työmatka-ajoneuvona ei myöskään otettaisi huomioon julkisen liikenteen käyttömahdollisuutta, vaan kilometrikorvaus maksettaisiin aina polkupyörän ollessa ensisijainen kulkuneuvo asunnon ja työpaikan välillä. 
Esimerkki 1: A:n työmatka on $15 \mathrm{~km}$ yhteen suuntaan. Kodin ja työpaikan välillä ei ole julkista liikennettä, jota A voisi hyödyntää. Tämän vuoksi hän ajaa työmatkan omalla autollaan. Päiväkohtaiseksi matkaksi tulee tällöin $30 \mathrm{~km}$. A voi vähentää kodin ja työpaikan väliset matkakulut oman auton mukaan. Hän on vuoden aikana normaalisti lomalla yhden kuukauden, joten vähennys lasketaan 11 kuukauden ajalta. Lisäksi A tekee kaksi päivää kuukaudessa etätöitä kotoa käsin. Kuukaudessa on keskimäärin 22 työpäivää, mutta etätyöpäivien vuoksi A laskee matkakulut 20 päivältä. A:n matkakulut ovat vuodessa $11 \mathrm{kk}$ x 20 pv x $30 \mathrm{~km}$ x 0,25 euroa/ $/ \mathrm{km}=1650$ euroa. Tästä summasta vähennetään omavastuu 600 euroa. Näin A saa verovähennyksiä 1050 euroa.

Esimerkki 2: B:n työmatka on $15 \mathrm{~km}$ yhteen suuntaan. Kodin ja työpaikan välillä ei ole julkista liikennettä, jota B voisi hyödyntää. Tämän vuoksi hän ajaa työmatkan polkupyörällä. Päiväkohtaiseksi matkaksi tulee tällöin $30 \mathrm{~km}$. B voi vähentää kodin ja työpaikan väliset matkakulut polkupyörän mukaan. Hän on vuoden aikana normaalisti lomalla yhden kuukauden, joten vähennys lasketaan 11 kuukauden ajalta. Lisäksi B tekee kaksi päivää kuukaudessa etätöitä kotoa käsin. Kuukaudessa on keskimäärin 22 työpäivää, mutta etätyöpäivien vuoksi B laskee matkakulut 20 päivältä. B:n matkakulut ovat vuodessa $11 \mathrm{kk}$ x 20 pv x $30 \mathrm{~km}$ x 0,15 euroa $/ \mathrm{km}$ = 990 euroa. Tästä summasta vähennetään omavastuu 600 euroa. Näin B saa verovähennyksiä 390 euroa. Nykymuodossaan pyöräilijä saisi verovähennystä 85 euroa riippumatta matkan pituudesta.

Käytännössä siis valtio säästää B:n kohdalla 660 euroa verovähennyksiä. Jos tuhat esimerkin 1 mukaista henkilöä siirtyy työmatkapyöräilyyn, säästöä valtiolle tulee 660000 euroa. Lisäksi voidaan tehdä oletus siitä, että valtio säästää terveydenhuoltokuluissa, koska kansalaisten yleiskunto kohoaa. Tämän vuoksi voidaan myös tehdä linjaus, jossa polkupyörää voitaisiin julkisen liikenteen rinnalla pitää aina ensimmäisenä vaihtoehtona asunnon ja työpaikan väliseen liikenteeseen. Näin lakimuutos kannustaisi myös taajama-alueella asuvat liikkumaan töihin pyörää käyttäen.

Ehkä rahaakin tärkeämpi peruste lakimuutokselle olisi asenteiden muuttaminen. Yksityisautoilusta maksettavan korvauksen pienentäminen toki säästää valtion menoja, mutta yksityiskansalaisesta se tuntuu lähinnä kiusaamiselta. Kaikkien käytössä ei ole julkista liikennettä, joten oman kulkuneuvon käyttäminen on välttämätöntä. Tämän lakialoitteen tarkoitus onkin kiusaamisen ja rajoittamisen sijaan vähentää yksityisautoilua positiivisin kannustamisen keinoin. Tarkoitus ei siis ole rajoittaa ja hankaloittaa yksityisautoilua, vaan tehdä pyöräilystä kannattavaa. 
Työmatkapyöräilyyn panostaminen osoittaisi Suomelta vastuunkantoa omien kansalaisten terveydestä, ilmastosta ja yhteisestä ympäristöstä. Pyöräily on myös helpompaa ja vaivattomampaa, kun pyörä on hyvin huollettu. Kuitenkin esimerkiksi polkupyörän ulkorenkaat maksavat helposti 85 euroa parilta, puhumattakaan muista osista. Kaikki eivät myöskään pysty tekemään huoltoja pyörälleen itse, mikä lisää pyöräilyn kustannuksia. Jos pyöräilyä tuettaisiin verovähennyksin, olisi nuo rahat myös helpompi ohjata esimerkiksi pyöräliikkeiden asiantuntevaan huoltopalveluun.

\section{Kommentteja}

Verohallinnon päätöksen mukainen vähennys oman polkupyörän käytöstä asunnon ja työpaikan välillä on 85 euroa vuodessa. Kun omavastuuosuus on nykyisin 750 euroa vuodessa, polkupyörävähennyksen merkitys on käytännössä hyvin vähäinen.

Kansalaisaloitteessa ei mainita, millaiseen kustannuslaskelmaan perustuu ehdotettu 15 penniä kilometriltä, joka on lähes yhtä suuri kuin moottoripyörälle ja mopoautolle vahvistettu 19 penniä kilometriltä ja selvästi suurempi kuin mopon 9 penniä kilometriltä. Ilmeisesti tarkoituksena olisi antaa verotukea polkupyörää käyttäville.

Pääministeri Antti Rinteen hallituksen ohjelmassa (s. 114-115) oli maininta työsuhdepyöräilyn edistämisestä. Sama tavoite on nykyisellä pääministeri Sanna Marinin hallituksella.

\subsection{Ilmastonmuutoksen torjuntaan lahjoitusvähennys}

Pentti Koutin 19.10.2018 vireille panemassa aloitteessa (31 kannattajaa) esitettiin ilmastonmuutoksen torjuntaan tehdyille lahjoituksille verovähennysoikeutta. Teknisesti tämä toteutettaisiin lisäämällä TVL 57 §:ään uudeksi kohteeksi "ilmastonmuutoksen torjunta" ja poistamalla 850 euron alaraja näiden rahalahjoitusten osalta.

Ilmastonmuutosta tulee torjua kaikin tavoin ja nopealla aikataululla. Yksi keino on käyttää siihen halukkaiden yritysten ja muiden yhteisöjen vapaaehtoista rahaa. Nykyisellään jos yritys tai muu yhteisö haluaa lahjoittaa rahaa ilmastonmuutoksen torjuntaan, esimerkiksi kompensoidakseen hiilipäästöjään, se ei voi vähentää tätä lahjoitusta verotuksessaan. Verovähennyksen saa jo nykyisinkin tehdä, jos kohteena on tiede, taide tai suomalainen kulttuuriperintö. Verovähennyksen ulottaminen ilmastonmuutoksen torjuntaan luonnollisesti lisäisi lahjoituksia tähän tarkoitukseen. Alaraja 850 euroa ei soveltuisi ilmastonmuutoksen torjunnan lahjoituksiin. Jos lahjoituksia tehdään vaikkapa yrityksen hankkimien lentolippujen päästökompensaation vuoksi, summat ovat yleensä muutamia kymppejä. 


\section{Kommentteja}

Lahjoitusvähennys tuli verojärjestelmäämme 1930-luvun lopulla, kun sodan vaara kasvoi. Vuonna 1938 Suomessa säädettiin valtionverotuksessa vähennyskelpoiseksi rahamäärä, jonka verovelvollinen luovutti valtiolle käytettäväksi valtiovarainministeriön hyväksymään tarkoitukseen. Hallitus viittasi esityksessään siihen, että eräät teollisuudenharjoittajat ilmoittivat halunsa tehdä huomattavia lahjoituksia valtiolle ilmatorjunnan ja kaasusuojelun järjestämiseksi teollisuusalueillaan yhteistoiminnassa puolustuslaitoksen kanssa, joka puolestaan piti tällaista järjestelyä erittäin suotavana. Teollisuudenharjoittajat toivoivat, että ne, jotka tekivät lahjoituksia maanpuolustuksen hyväksi, vapautuisivat valtiolle menevän tuloveron suorittamisesta tältä osin. Hallitus otaksui, että erinäiset yhtymät ja yksityishenkilötkin, jos niille myönnettäisiin verovapaus lahjoituksia vastaavalta osalta, tekisivät lahjoituksia muihinkin valtion tarkoituksiin, esimerkiksi sellaisten sairaaloiden ja koulujen rakentamiseen, jotka muutoin valtion olisi rakennettava.

Laajimmillaan vähennyskelpoisten vähennysten piiri Suomessa oli 1980-luvun loppupuolella, jolloin vähennyskelpoisia lahjoituksia voitiin tehdä seuraaviin tarkoituksiin:

- maanpuolustus,

- kehitysyhteistyö,

- humanitaarinen avustustoiminta,

- sodasta kärsimään joutuneiden avustaminen,

- suomalainen kulttuuriperinne,

- tiede ja

- taide.

Kokonaisverouudistuksen yhteydessä 1980-luvun lopussa vähennyskelpoisten lahjoitusten piiriä supistettiin voimakkaasti. Siitä karsittiin maanpuolustus, kehitysyhteistyö ja humanitaarinen avustustoiminta.

Nykyisin yhteisöjen lahjoitusvähennyksestä säädetään tuloverolain 57 \$:ssä. Yhteisön tuloverotuksessa vähennyskelpoisia ovat vähintään 850 ja enintään 250000 euron rahalahjoitukset tiedettä tai taidetta varten taikka suomalaisen kulttuuriperinteen säilyttämiseksi. Luon- 
nollisen henkilön lahjoitusvähennyksestä säädetään tuloverolain 98a §:ssä. Luonnollisella henkilöllä ja kuolinpesällä on oikeus vähentää ansiotulostaan yliopistolle tai korkeakoululle tekemänsä vähintään 850 ja enintään 500000 euron rahalahjoitus.

Muihin tarkoituksiin tekemiään lahjoituksia luonnollinen henkilö ei saa tuloverotuksessa nykyisin vähentää. Monissa muissa maissa lahjoitukset ovat paljon laajemmin verovähennyskelpoisia.

\subsection{Talkoiden ja vaihtotyön esteet poistettava}

Heikki Wariksen 19.12.2014 vireille panemassa aloitteessa (14 kannattajaa) ehdotettiin kanssaihmisten auttamista estävän vero- ja muun lainsäädännön korjaamista siten, että talkoo-, vaihto- ja vapaaehtoistyötä, naapuriapua ja vastaavaa auttamistyötä koskevia lakeja tarkennetaan tai muutetaan seuraavien periaatteiden mukaisesti:

1. Auttamistyön on oltava työtä, jota luonnollinen henkilö tekee toiselle luonnolliselle henkilölle tai luonnollinen henkilö tekee voittoa tavoittelemattomalle yhteisölle.

2. Auttamistyöksi lasketaan työ, josta tekijän saamat korvaukset ovat auttamistyöstä aiheutuvien kustannusten vähentämisen jälkeen yhteensä korkeintaan 2000 euroa vuodessa.

3. Tekijän auttamistyöstä saamat korvaukset ja auttamistyöstä aiheutuvien kustannusten korvaukset ovat verovapaita eivätkä vaikuta sosiaalitai työttömyysetuuksiin.

4. Auttamistyöhön sovelletaan lakeja ja säädöksiä samalla tavalla kuin jos henkilö tekisi vastaavaa työtä itselleen, poikkeuksena toiminta, jonka luvanvaraisuus perustuu vakavaan terveyteen kohdistuvaan riskiin (esim. sähkötyöt) tai merkittävän taloudellisen vahingon riskiin (esim. sijoitusneuvonta).

5. Auttamistyötä koskevat muut ehdot ovat vapaasti sovittavissa avun saajan ja tekijän välillä, kunhan ne ovat kohtuullisia ja hyvän tavan mukaisia.

Monella on silloin tällöin tarvetta avulle, joskus pienissäkin arkisissa asioissa. Julkisia tai yksityisiä palveluita on kuitenkin vaikea saada silloin, kun apua tarvitsee, tai hinnalla, johon on varaa. Apua tarvitseva puree siis hammasta, sinnittelee omillaan, ja väsyy. Toisaalta on myös paljon auttamishalua, mutta lainsäädäntö estää auttamasta kanssaihmisiä. Kaikki tekeminen lasketaan palkkatyöksi tai yritystoiminnaksi, ellei se täytä tiettyjä kapeita ehtoja.

Auttaja ei halua aiheuttaa itselleen ongelmia viranomaisten kanssa, joten apu jää antamatta. Häviäjä ei ole vain avun tarvitsija, vaan koko 
yhteiskunta. Lainsäädännölliset esteet, jotka haittaavat ihmisten keskinäistä auttamista, on poistettava.

Ongelman ytimessä on avusta tarjottava korvaus, jonka pelätään lisäävän harmaata taloutta tai vääristävän kilpailua. Avunsaajan auttajalleen antama korvaus, sikäli kuin siihen on varaa, on kuitenkin ensisijaisesti osoitus siitä, että auttajan vaivannäköä arvostetaan. Avustustyöllä ei ole tarkoituskaan ansaita, mutta auttajallekin voi olla tärkeää, että hänen aikaansa ei pidetä arvottomana.

Ongelmia on kaikissa auttamisen muodoissa:

1. Vapaaehtoistyön tekijä tarjoaa ilmaiseksi omaa aikaansa, mutta voi joutua lisäksi maksamaan itse matkansa ja ateriansa. Lisäksi vapaaehtoistyö voi johtaa työttömyys- ja muiden etuuksien menetykseen.

2. Talkootyön tekijää, kuten muutossa auttajaa, voi palkita vaikkapa järjestämällä saunaillan. Mutta jos kavereita ei ole ja haluaisi ottaa vastaan talkooapua tuntemattomilta, tällaisen tarjoilun sijaan ei voi tarjota vastaavan suuruista rahamääräistä korvausta.

3. Naapuriapu on talkootyön luonteista satunnaista apua, mutta siitäkään ei saa ottaa vastaan muuta korvausta kuin ruokaa, juomaa tai arvoltaan vähäisiä tavaroita. Sekä auttajan että autettavan kannalta vastaava, vaikka pienikin, rahamäärä olisi huomattavasti kätevämpi.

4. Vaihtotyön tekijä auttaa toisia ihmisiä asiassa, jonka itse osaa, ja saa vastapalveluksena apua jossakin toisessa asiassa (aikapankin kautta tai muuten vaan). Verolainsäädäntö estää kuitenkin vaihtotyön ammatin tai koulutuksen mukaisissa tehtävissä ja arvioi eri ihmisten ajan eri arvoiseksi. Viranomainen määrittelee, mikä osa ihmisten kotitöistä on tavanomaista ja arvoltaan vähäistä. Muu on verotettavaa toimintaa.

5. Kimppakyydit ovat oman reitin varrella tarjottuja kuljetuksia, joskus tuntemattomille mutta usein myös työkavereille tai samoihin harrastuksiin menijöille. Autoton naapuri tai tuntematon kyyditettävä ei voi vastavuoroisesti tarjota kimppakyytiä vuorollaan, eikä saa antaa korvausta kuljettajan vaivannäöstä. Toisten tavaroita ei saa kuljettaa korvausta vastaan suurella henkilöautolla tai pakettiautolla.

Aloitteella tavoiteltiin seuraavia hyötyjä:

1. Vähennetään kansalaisten eriarvoisuutta.

Apua tarjotaan enemmän, ja sitä on mahdollista saada helpommin silloin, kun sitä tarvitsee. Apua voi saada myös henkilö, jonka omat lähisukulaiset, tuttavat tai naapurit eivät sitä tarjoa. Apua voi saada myös henkilö, jolle julkinen sektori ei myönnä siihen oikeuttavaa etuutta. Apua voi saada myös henkilö, joka haluaa noudattaa lakia ja joutuu nyt kieltäytymään tarjoamasta auttajalle mitään korvausta. 
2. Vähennetään harmaata taloutta.

Tavallisella kansalaisella ei ole enää syytä kiertää veroja ja säädöksiä, kun auttaminen ja pienet korvaukset voi tehdä avoimesti. Toiminnallaan rahallista hyötyä tavoittelevat toimijat erottuvat helpommin. Kansalaiset voivat tukea viranomaisia näiden valvontatehtävissä, kun laki on linjassa heidän oikeustajunsa kanssa.

3. Edistetään taloudellisesti, ekologisesti ja sosiaalisesti kestävää kehitystä ja tehokkuutta.

Kansalaisten on helpompi käyttää aikaansa tekemiseen eikä kuluttamiseen. Paikallisessa yhteisössä on helpompi vaihtaa palveluksia, jolloin ei tarvitse matkata pitkiä matkoja palveluiden perässä. On helpompi auttaa muita oman toimen ohessa kimppakyydeillä, jolloin pienellä lisävaivalla vapauttaa autettavan paljon suuremmalta vaivannäöltä ja kustannuksilta.

4. Edistetään työllistymistä, yrittäjyyttä ja uuden elinkeinotoiminnan kehittymistä.

Kansalaisten on helpompi pyytää apua muilta. Vastaavasti apua tarjoava voi tunnistaa tai kehittää taitoja ja kykyjä, joiden pohjalle voi rakentaa uutta toimeentuloa. Aktiivinen toiminta yhteisössä ehkäisee syrjäytymistä ja luo verkostoa, joka voi auttaa työllistymisessä.

\section{Kommentteja}

Verohallinto on 4.7.2018 antanut ohjeen talkoo-, naapuriapu- ja vaihtotyön verotuksesta esimerkkeineen. Ohje on jäsennelty seuraavasti:

1 Johdanto

1.1 Yleistä

1.2 Talkootyö

1.3 Naapuriapu

1.4 Kahdenkeskinen vaihtotyö

1.5 Monenkeskinen vaihtotyö

2 Veronalainen tulo ja kustannusten vähentäminen verotuksessa

2.1 Korvausta vastaan tehtävä työ on veronalaista

2.2 Ilman korvausta tehtävä työ on verovapaata

2.3 Kustannusten vähentäminen

3 Talkootyö verotuksessa

4 Naapuriapu verotuksessa

5 Vaihtotyö verotuksessa

5.1 Kahdenkeskisen vaihtotyön verotus

5.1.1 Korvaukseksi saatu vaihtotyö on lähtökohtaisesti veronalaista ansiotuloa

5.1.2 Verovapaa tavanomaisen ja vähäisen naapuriavun luonteinen vaihtotyö 
5.1.3 Muu kuin tavanomaisen ja vähäisen naapuriavun luonteinen vaihtotyö

5.2 Monenkeskisen vaihtotyön verotus

5.2.1 Monenkeskinen vaihtotyö on lähtökohtaisesti veronalaista ansiotuloa

5.2.2 Naapuriavun luonteinen vaihtotyö on myös vaihtopiirissä verovapaata

5.2.3 Muu kuin verovapaan naapuriavun luonteinen vaihtotyö vaihtopiirissä

5.3 Veronalainen vaihtotyö ja kotitalousvähennys

6 Veronalaisen vaihtotyön ennakonpidätys ja ilmoittaminen

6.1 Palkka

6.2 Työkorvaus

6.3 Veronalaisen tulon ja menojen ilmoittaminen veroilmoituksella.

Ohje on hyvin yksityiskohtainen ja havainnollinen. On kyseenalaista, voitaisiinko lainsäädäntöä muuttamalla päästä onnistuneempaan tulokseen. Tämänkaltaisista ongelmista voidaan käytännössä usein selvitä myös panemalla silmät kiinni puolin ja toisin.

\subsection{Osinko- ja vuokratuloille verovapaa määrä}

Heikki Kärkkäisen 4.4.2013 vireille panemassa aloitteessa (639 kannattajaa) esitettiin osinkotuloille ja osuuspääoman koroille yhdenvertaista asemaa verotuksessa. Luonnollisella henkilöllä osuuspääoman korot olivat esityksen tekoaikaan verovapaita 1500 euroon asti, mutta osinkotulot olivat veronalaisia ensimmäisestä eurosta lukien. Kansalaiset olivat eriarvoisia saamiensa pääomatulojen suhteen. Kaikkia pääomatulolajeja tulisi kohdella tasa-arvoisesti. Ehdotuksen mukaan mainitut pääomatulolajit olisi säädettävä yhtäläisen verotuksen alaiseksi, jolloin myös osinkotulot olisivat verovapaita 1500 euroon asti.

Jani Ehron 13.6.2016 vireille panemassa aloitteessa (7 kannattajaa) ehdotettiin vuokra-asumisen turhan verorasitteen poistamista ja vuokra-asumisen tuomista tasa-arvoiseen asemaan omistusasumisen kanssa. Ihmisten ei enää tarvitsisi välttämättä asua omistamassaan asunnossa, vaan he voisivat vuokrata sen vapaasti eteenpäin ja vuokrata markkinoilta kulloisenkin elämäntilanteensa mukaan käyttöönsä paremmin soveltuvan asunnon ilman täysin turhaa verorasitetta. Ehdotuksen mukaan ensimmäisestä (yhdestä) omassa omistuksessa olevasta vuokralle annetusta asunnosta syntyvät pääomatulot olisivat verovapaita maksimissaan 900 euroon/kk asti (siis 1800 euroon/kk asti kahdella hengellä). Vuokranantaja olisi oikeutettu pääomatuloverovapauteen vain niiltä osin kuin vuokran 
maksajana ja vuokralle ottajana olisi luonnollinen henkilö/luonnollisia henkilöitä. Vuokranantaja ei voisi saada pääomatuloverovapautta, mikäli hän on vuokralaisen lähisukulainen. Esityksen perusteluiksi esitettiin seuraavaa:

1. Oman omistusasunnon vuokraaminen eteenpäin ja asunnon vuokraaminen markkinoilta omaan käyttöön ei ole järkevää verorasitteen takia. Tähän halutaan muutos. Vuokra-asuminen halutaan tuoda omistusasumisen kanssa samanarvoiseen asemaan.

2. Ajatus siitä, että ihmisen pitää omistaa juuri se asunto, jossa hän kulloinkin asuu, on vanhoillinen, eikä se tue nyky-yhteiskunnan tarpeita.

3. Ihmiset voisivat vapaammin ja ketterämmin valita, missä he kulloinkin ja missäkin elämäntilanteessa asuvat ilman että heidän ensin tarvitsisi hakea uutta lainaa ja tehdä kahdet asuntokaupat.

4. Keskimääräinen markkinointiaika omistusasuntomarkkinoilla on vaihdellut vuosien 2015-2016 aikana 100-130 päivän välillä, mikä on nopeassa elämäntilanteen muutoksessa aivan liian paljon.

5. Työmarkkinoilla lähes kuudesosa tekee töitä määräaikaisessa työsuhteessa. Työvoiman tulisi pystyä liikkumaan vapaammin työn perässä, eikä omistusasunnon sijainti saa rajoittaa työpaikan vastaanottamista. Lisäksi uuden työn vastaanottaneen osa-aikaisessa ja määräaikaisessa työsuhteessa olevan on vaikeampi saada asuntolainaa markkinoilta.

6. Ratkaisulla halutaan pienentää asumisloukkojen syntymisen riskiä, kun muuttaminen onnistuisi vuokramarkkinoiden puitteissa helpom$\min$.

7. Ihmisten olisi helpompi asettaa oma asuntonsa vuokralle ja muuttaa yhteen.

8. Ihmisillä olisi pienempi kynnys ryhtyä asunnon omistajiksi, eivätkä heidän asunnon hankintaansa rajoittaisi omat asumistarpeet, vaan he voisivat ostaa asunnon oman ostokykynsä mukaan ja vuokrata asumistarpeidensa mukaisen asunnon, kun ei olisi verotuksellisesti merkityksellistä, asuisiko asunnossa itse vai ei.

9. Ihmisillä on monesti asumiseen liittyviä tarpeita, jotka eivät välttämättä ole ratkaistavissa rahallisten resurssien takia omistusasuntomarkkinoilla mutta jotka olisivat ratkaistavissa vuokra-asuntomarkkinoilla.

10. Markkinoille saataisiin lisää pieniä vuokra-asuntoja, kun niiden omistajat voisivat elämäntilanteensa mukaan muuttaa itse vuokralle suurempaan asuntoon, mikä ei olisi välttämättä mahdollista omistusasuntomarkkinoilla.

11. Vuokra-asuntomarkkinat tulisivat dynaamisemmiksi ja vuokra-asunnot hajautetummin omistetuiksi. 
12. Helsingissä isomman perheasunnon ( $100 \mathrm{~m} 2$ tai suurempi) vuokra on 1 500-2 500 euroa/kk, joten ehdotuksessa on päädytty valitsemaan pääomatuloveroista vapaaksi summaksi 900 euroa/kk, eli yhteensä 1800 euroa/kk kahdelle hengelle.

13. Pääomatuloveroista vapaaksi saisi vain yhden asunnon vuokratuotot, jolloin lakia ei olisi suunniteltu ammattimaista asuntovuokrausta ajatellen, vaan lakimuutos tukisi kaikkia asuntomarkkinoilla yhdenvertaisesti ja tarvelähtöisesti.

14. Pääomaverovapauteen olisi oikeutus vain, mikäli asuntoa vuokrataan luonnolliselle henkilölle/henkilöille. Tällä estetään se, ettei asunnosta "vuokrata" esimerkiksi omalle yritykselle ylihintaan yksittäistä huonetta ja kierretä tällä tavoin muuta pääoma- tai tuloverotusta.

15. Pääomatuloverovapautta ei voi saada niiltä osin kuin maksajana on vuokranantajan lähisukulainen. Tällä estetään se, että esimerkiksi sukulaisten kesken siirrettäisiin omaisuuksia henkilöltä toiselle järjestelmää hyödyntäen.

16. Pääomatuloverovapauden voisi saada vain, mikäli asunto on kokonaan tai osittain henkilön omassa omistuksessa. Pääomaverovapautta ei haeta tässä jälleenvuokrattaviin asuntoihin.

\section{Kommentteja}

Meillä on aikoinaan ollut hieman aloitteessa esitettyä mallia muistuttava vähennys, jolla alun perin lievennettiin osinkotulojen ja osuuspääoman korkojen verotusta. Vuoden 1981 alusta vähennyksen soveltamispiiri laajennettiin sisältämään muutkin korot ja myös muuna kuin vapaa-ajan asuntona vuokratusta asunnosta saadut vuokratulot. Laajennuksella pyrittiin saattamaan erilaiset veronalaiset pääomatulot keskenään tasapuolisempaan asemaan. Asuntojen vuokratulojen osalta pidettiin silmällä vuokra-asuntojen määrän laskua, joka ainakin osaksi johtui verotuksesta. Viimeisenä soveltamisvuotenaan 1992 omaisuustulovähennyssäännös kuului seuraavasti:

\footnotetext{
"Luonnollinen henkilö tai erillisenä verovelvollisena verotettava kotimainen kuolinpesä saa vähentää kokonaistulostaan omaisuustulovähennyksenä kotimaasta saamiensa sijoitusrahaston voitto-osuuksien, muuna asuntona kuin vapaa-ajan asuntona käytettäväksi vuokratusta asunnosta saamiensa vuokratulojen ja muiden kuin yhtiöveron hyvitykseen oikeuttavien tai korkotulon lähdeverosta annetun lain mukaan verotettavien korkojen perusteella 2000 markkaa lisättynä 50 prosentilla siitä määrästä, jolla nämä tulot ylittävät 2000 markkaa. Omaisuustulovähennyksen
} 
määrä voi kuitenkin olla enintään sen perusteena olevien tulojen yhteismäärän suuruinen ja enintään 20000 markkaa.

Omaisuustulovähennyksen määrää laskettaessa ei oteta huomioon luonnollisia vähennyksiä.”

Tämä vähennys lakkautettiin, kun siirryttiin ansio- ja pääomatulojen eriytettyyn verotukseen. Pääomatulojen verokannaksi säädettiin aluksi $25 \%$, mutta nykyisin se on 30-34\%. Suurimpana esteenä aloitteiden mukaisen huojennuksen säätämiselle on pidettävä sitä, että huojennus vähentäisi verotuloja merkittävästi, koska osinko- ja vuokratulojen saajien määrä on hyvin suuri.

\subsection{Työmarkkinajärjestöjen tuloverotusta tiukennettava}

Juha Porkan 25.2.2018 vireille panemassa aloitteessa (585 kannattajaa) esitettiin, että ammattiyhdistysliikkeiltä poistetaan yleishyödyllisen yhdistyksen status tai että laissa asetetaan yleishyödyllisten yhdistysten sekä säätiöiden verovapaille tuloille euromääräinen yläraja.

Ammattiyhdistysliikkeiden edustajat ja heihin kytkeytyvät poliitikot esiintyvät mielellään julkisuudessa silloin, kun keskustelu veronkierron haitoista nousee pintaan. Paheksunnan määrällä ei silloin ole rajaa, kun varakkaat yksityishenkilöt tai yritykset harrastavat laillista verosuunnittelua. Ammattiyhdistysliikkeet ovat saaneet viimeisten vuosien aikana lähes 100 miljoonaa euroa VVO:n vuokraosinkoja. Ammattiliitot kuittaavat vuokratuotoista verovapaat osingot, koska ovat juridisesti yleishyödyllisiä yhdistyksiä. Vuokrien nousua maksetaan siis suuressa määrin pienituloisille maksetuilla asumistuilla. Tämän lisäksi järjestelmä toimii automaattisesti osinkojen korotusautomaattina eli vuokrien noustessa nousevat myös asumistuet. Ammattiyhdistysliikkeiden pelkästään VVO:sta vuosittain saamien miljoonaosinkojen perusteella voi perustellusti kysyä: Ovatko ne oikeutettuja nauttimaan yleishyödyllisyyden statusta viitaten laissa määritettyyn taloudellisen edun tavoitteluun?

\section{Kommentteja}

Työmarkkinajärjestöjen, poliittisten puolueiden ja muiden yleishyödyllisten yhteisöjen laajaa verovapautta erityisesti osinko- ja muista sijoitustuloista on jatkuvasti ja perustellustikin arvosteltu. Kritiikki ei kuitenkaan ole johtanut lainsäädännön tiukentamiseen. Pääministeri Antti Rinteen hallituksen ohjelmaan sisältyi kuitenkin maininta (s. 22), jonka mukaan hallitus selvittää, onko veropohjan tiivistämiseksi mahdollisuus ottaa käyttöön osinkoveroista vapautet- 
tujen yhteisöjen saamille osingoille 5 \%:n lähdevero. Sanna Marinin hallituksen ohjelma on samanlainen.

\subsection{Työmarkkinajärjestöjen jäsenmaksujen verovähennys poistettava}

Juha Tuomalan ja Juha Porkan 10.9.2015 vireille panemassa aloitteessa (4 626 kannattajaa) vaadittiin, että palkansaajien ja työnantajien liittojen jäsenmaksujen verovähennysoikeus poistetaan.

Liittojen jäsenmaksujen verovähennysoikeudesta aiheutuu valtiolle 200 miljoonan veromenetykset. Viime aikoina useita muitakin verovähennysoikeuksia on leikattu. Järkeviä säästöjä etsittäessä työmarkkinajärjestöjen jäsenmaksujen verovähennysoikeus ei voi muodostua pyhäksi.

Suomessa jokaista koskee yhdistymisvapaus ja järjestäytymisaste on verrattain suuri, noin $75 \%$. Kokoomusopiskelijat kannattavatkin järjestäytymistä, eikä tämä aloite vastusta itse toimintaa. Nykyisellään ei ole kuitenkaan enää perusteltua, että valtio kompensoi mihinkään yhdistykseen kuulumista verovähennysoikeuksin. Työmarkkinajärjestöiden jäsenmaksujen verovähennysoikeuden voidaan nähdä olevan historiallinen jäänne, jota on syytä tarkastella kriittisesti. Jälleen otsikoihin on noussut ammattiliittojen varojen käyttäminen yksittäisen SDP:n puheenjohtajaehdokkaan puolueensisäiseen vaalikampanjaan. Tämänkaltaisen varojenkäytön ei pitäisi olla soveliasta, ja se asettaa etenkin valtion kompensaation kyseenalaiseksi.

Voidaan myös perustellusti nähdä, että keskitetyt työehtosopimukset aiheuttavat työttömyyttä ja loukkaavat yksilön sopimisvapautta, ja kartellisoituneet työmarkkinat vähentävät kilpailua ja palkkojen ylihinnoittelua, joka ajaa elinkeinoa Suomen ulkopuolelle. Lisäksi valta kasautuu ulkoparlamentaarisille voimille. Ammattiyhdistysliike vaatii uudistumista, jota valtio voi myös omalla toiminnallaan jouduttaa.

Perusteltua on, että jokainen jäsen ottaa itse vastuunsa liittoon liittymisestä, myös jäsenmaksusta, jonka kautta maksun vastineesta pidetään myös tarkemmin huolta. Valtion tuki stabiloi ja estää ammattiyhdistysliikkeen uudistumisen. Tasapuolisuuden nimissä molempien työmarkkinaosapuolten jäsenmaksun verovähennysoikeus tulisi poistaa.

Janne Heikkisen 24.9.2018 vireille panemassa aloitteessa (8 587 kannattajaa) esitettiin luovuttavaksi työmarkkinajärjestöjen jäsenmaksujen ja työttömyyskassamaksujen verovähennyskelpoisuudesta. Työmarkkinajärjestöjen jäsenmaksut olivat ennen vuotta 1969 vähennyskelvottomia. Jäsenmaksujen nähtiin menevän järjestöille, jotka osallistuvat yhteiskunnalliseen taistelutoimintaan, kuten palkkataisteluihin. Työmarkkinajärjestön jäsenmaksu ei ole sellainen tulon hankkimisesta johtuva meno, jota olisi syytä oikeuttaa vähentämään ansiotulosta. 
Tuloverojärjestelmämme pohjaa on viime vuosina paikattu $\mathrm{mm}$. rajaamalla asuntolainan korkovähennysoikeutta sekä vähentämällä kilometrikorvausten verovapaata ylikompensaatiota. Työmarkkinajärjestöjen jäsenmaksujen verovähennyskelpoisuuden poistaminen olisi luontevaa jatkoa tuloverojärjestelmän yksinkertaisuuteen tähtäävälle politiikalle.

Työmarkkinajärjestöjen jäsenmaksujen vähentämisoikeuden on laskettu maksavan yhteiskunnalle 200 miljoonaa euroa vuosittain. Monet ammattiyhdistykset tukevat avokätisesti tiettyjä puolueita ja ehdokkaita, mistä aiheutuu merkittävää piilopuoluetukea. Jäsenmaksun verovähennyskelpoisuutta onkin perusteltua kritisoida, kun jäsenyydellä rahoitetaan toimintaa, joka ei muulla tavoin rahoitettuna oikeuttaisi verovähennyksiin. Poliittisten puolueiden jäsenmaksut eivät ole verovähennyskelpoisia.

Yhteiskunnallisen oikeudenmukaisuuden ja verotuksen kokonaisuuden näkökulmasta pitäisi työmarkkinajärjestöjen ja työttömyyskassamaksujen verovähennyskelpoisuudesta luopua ja palata ennen vuotta 1969 vallinneeseen tilanteeseen, jossa työmarkkinajärjestöjen ja työttömyyskassojen jäsenmaksut eivät olleet vähennyskelpoisia.

\section{Kommentteja}

Työmarkkinajärjestöjen jäsenmaksut olivat meillä pitkään vähennyskelvottomia sekä työntekijöiden että työnantajien verotuksessa. Tätä perusteltiin sillä, että järjestöt osallistuvat yhteiskunnalliseen taistelutoimintaan, kuten palkkataisteluihin. Työmarkkinajärjestöjen tukiessa tiettyjä puolueita jäsenmaksujen vähennyskelpoisuuden voidaan myös sanoa merkitsevän piilopuoluetukea.

Työmarkkinajärjestöjen jäsenmaksut on säädetty vähennyskelpoisiksi vuodesta 1969 alkaen. Verokohtelu on edullinen, koska jäsenmaksut ovat verovapaata tuloa yleishyödyllisinä pidettäville työmarkkinajärjestöille. Palkansaajien verotuksessa jäsenmaksut nauttivat erityiskohtelua sikäli, että verotuksen yksinkertaistamiseksi säädetty kaavamainen tulonhankkimisvähennys myönnetään palkansaajille työmarkkinajärjestöjen jäsenmaksujen vähentämisen lisäksi.

Nettotulolle rakentuva tuloverojärjestelmämme perustuu ajatukseen, jonka mukaan tulonhankkimismenoina ei saa vähentää elantokustannuksia ja muita vastaavia menoja. Jäsenmaksun täydellistä vähennysoikeutta voidaan tästä näkökulmasta kritisoida silloin, kun jäsenyydellä rahoitetaan toimintaa, jonka maksuja verovelvollinen ei voisi vähentää maksaessaan ne itse suoraan. Kuten aloitteessa todetaan, työmarkkinajärjestöjen jäsenmaksujen vähentämisen lasketaan 
merkitsevän parinsadan miljoonan euron vuotuista verotukea. Verotulojen lisäykseen pyrittäessä saatetaan kysyä, onko työmarkkinajärjestöjen jäsenmaksujen välttämättä oltava kokonaan vähennyskelpoisia. Verotuksessakaan "on-off" ei ole ainoa mahdollinen periaate.

Voitaisiin harkita mallia, jossa vähennyskelpoista olisi kaavamainen osuus, vaikkapa puolet jäsenmaksusta. ${ }^{64}$ Puolittaminen on jo todettu hyväksi ratkaisuksi edustusmenojen vähennysoikeudessa. Vähennysoikeuden osittaminen on tuttua myös asuntolainojen koroissa.

Kristillisdemokraatit ovat jo vuoden 2016 lopulla esittäneet ammattiliittojen jäsenmaksujen verovähennysoikeuden puolittamista ja työnantajaliittojen jäsenmaksujen verovähennysoikeuden poistamista kokonaan.

\subsection{Viron malli yhteisöverotukseen}

Tero Kalliokorven 15.5.2015 vireille paneman aloitteen (10 kannattajaa) tarkoituksena oli muokata Suomen yhteisöverotusta Viron mallin kaltaiseksi. Siinä yritys maksaa veroa vasta jakamaansa osinkoa ja muuta voitonjakoa koskien; yrityksen sisään jäävää rahaa ei siis veroteta enää erikseen. Myös uudistetun yhteisöveromallin suuruudeksi voitaisiin ottaa olemassa oleva $20 \%$. Viron yhteisöveromalli on viime aikoina noussut usein esille niin yrittäjien, kansanedustajien kuin talouden asiantuntijoidenkin toimesta.

Viron yhteisöveromalli on tehnyt maasta suositun kohteen liiketoiminnalle, ja myös Suomesta on moni varsinkin pääkaupunkiseudulla toimiva pk-yritys siirtänyt toimipaikkansa Viroon. Suomi pärjää melko hyvin yrittämisen aloittamista arvioivilla mittareilla, mutta Viron yhteisöveromalli toimii arkielämässä tehokkaammin; yritykseen jää suurempi märä rahaa esimerkiksi tuotekehitystä, markkinointia ja uusien toimipaikkojen perustamista varten, ja se tekee yrittämisen aloittamisesta houkuttelevampaa myös suurelle yleisölle - varsinkin, kun yrityksen perustaminen muutaman tunnin laivamatkan päähän käy nykyaikana niin vaivattomasti.

Uudistetusta yhteisöverotuksesta hyötyisivät erityisen paljon nopeasta kasvusta nauttivat pk-yritykset, ja laihan tilikauden tehneillä suuryrityksilläkin olisi tässä tilanteessa korkeampi kynnys yt-neuvotteluihin. Näihin liittyvistä suurista irtisanomisista on saatu enenevässä määrin kuulla ikäviä uutisia.

Lisääntyvät työpaikat kaventavat myös viime aikoina kasvaneita tuloeroja eri väestöryhmien kesken ja lisäävät tätä kautta myös ansio-

64 Perusteluista tarkemmin ks. kirjoitukseni Puolittaminen jäsenmaksujen verovähennykseen? Verotus 5/2015, s. 550-551. 
tuloista saatavia verotuloja. Korkeampi ostovoima edistää maan sisämarkkinoita, jonka myötä puolestaan lisääntyvät myös arvonlisäveroista, polttoaineveroista yms. saatavat tulot. Myös julkinen talous tulee siis hyötymään tästä parin vuoden sisällä merkittävästi.

\section{Kommentteja}

Tämä aloite on saanut yllättävän vähän kannattajia siihen nähden, miten paljon Viron mallia puolletaan yrittäjien mielipidekirjoituksissa. Viron yritysverotusjärjestelmä on kansainvälisesti hyvin erikoinen ja verotaso niin alhainen, että maata on kutsuttu jopa veroparatiisiksi. Tuollainen järjestelmä vähentää merkittävästi valtion verotuloja ${ }^{65}$ ja houkuttelee verokeinotteluun. Siihen siirtyminen ei vaikuta Suomessa todennäköiseltä ainakaan nykyisen hallituksen aikana.

\subsection{Työurien pidentäminen sekä yrittäjyyden ja työllisyyden edistäminen yhteisöverotusta muuttamalla}

Aki Käkelän 8.3.2013 vireille panemassa aloitteessa (32 kannattajaa) ehdotettiin valtionverotukseen työurien pidentämisvähennystä.

Verovelvollinen, joka on merkitty Verohallinnon työnantaja- ja ennakkoperintärekisteriin, voisi vähentää sen murtoluvun suuruisen osan valtionverosta, jossa osoittaja on niiden verovelvollisen palveluksessa olevien Suomessa verovelvollisten henkilöiden, joiden työllistymistä tällä lailla halutaan erityisesti tukea, tekemä työkuukausien lukumäärä verovuonna. Nimittäjänä on kaikkien verovelvollisen palveluksessa olevien Suomessa verovelvollisten työntekijöiden työkuukausien lukumäärä verovuonna. Vähennys valtiolle maksettavasta verosta voisi olla enintään 2/3:n suuruinen verovelvolliselle muuten määräytyvästä valtion verosta.

$\mathrm{Ne}$ henkilöt, joiden työllistymistä tällä lailla tuettaisiin, olisivat seuraavat:

- Alle 25-vuotiaat henkilöt sen vuoden loppuun, jona vuonna he täyttävät 25 vuotta.

- Yli 55-vuotiaat henkilöt sen vuoden alusta, jona vuonna he täyttävät 55 vuotta.

- Alle 30-vuotiaana oppilaitoksista valmistuvat sen vuoden loppuun, kun on kulunut 5 täyttä kalenterivuotta valmistumisesta. Asianomainen ministeriö säätäisi asetuksella ne oppilaitokset ja tutkinnot, joista valmistuminen antaa oikeuden vähennykseen.

65 Yhteisöveron tuotto on meillä vuosittain runsaat 4 miljardia euroa. 
- Maahanmuuttaja viiden täyden kalenterivuoden ajan työsuhteen alkamisesta, kuitenkin enintään 10 täyttä kalenterivuotta maahanmuuttajan rekisteröitymisestä suomalaiseen henkilötietojärjestelmään.

- Pitkäaikaistyötön 5 täyden kalenterivuoden ajan työsuhteen alkamisesta.

- Työrajoitteinen, invalidi, osatyökykyinen ja työkyvyttömyyseläkkeeltä työhön kuntoutuva henkilö viiden täyden kalenterivuoden ajan työsuhteen alkamisesta, ja sen jälkeen viiden vuoden jaksoissa, mikäli Verohallinto tapauskohtaisesti hyväksyy vähennyksen.

Verovähennykseen oikeuttavia työkuukausien veroisia kuukausia olisivat verovähennykseen oikeuttavien työntekijöiden vuosilomakuukaudet ja verovelvollisen palveluksessa olevien kaikkien työntekijöiden ne kuukaudet, jotka työntekijä on ollut sairauslomalla, äitiys-, isyys- tai vanhempainvapaalla, hoitovapaalla ja osittaisella hoitovapaalla.

Verovähennykseen oikeuttava työkuukausi olisi sellainen työkuukausi, josta työntekijälle vuosilomalain 6 \$:n mukaisesti kertyy vuosilomaa ja viikkotuntien määrä ylittää 30 viikkotyötuntia. Muussa tapauksessa työntekijän työkuukausi kerryttäisi puolet verovähennykseen oikeuttavasta työkuukaudesta, mikäli tehtyjen työtuntien yhteismäärä kuukaudessa olisi enemmän kuin 50 tuntia. Verovelvollinen ilmoittaisi Verohallinnolle verovähennykseen oikeuttavat kuukaudet/kaikki työkuukaudet kausiveroilmoituksessaan.

Lakiesityksen tavoitteena olisi pidentää työuria. Samalla esitys pyrkisi luomaan kestäviä polkuja työelämään henkilöille, joiden työn tuottavuus muuten ei ole kilpailukykyinen parhaassa työskentelyiässä oleviin verrattuna. Esityksen tavoitteena olisi työntekijöiden työurien pidentäminen niin että työntekijän pitkä työura on työnantajaa motivoiva ja palkitseva. Lisäksi lakiesitys pyrkisi tasaamaan perhevapaiden työnantajille aiheutuvia kustannuksia ja edistämään työelämän tasa-arvoa.

Esitys pyrkisi myös vastaamaan elinkeinoelämän esittämiin vaatimuksiin yhteisöverotuksen tuntuvaksi alentamiseksi. Esityksen voimaantulon jälkeen yhteisöveron suuruus verotettavasta tulosta tulisi vaihtelemaan yhteisön työvoimarakenteesta riippuen $11-33 \%$ :n välillä.

Aki Käkelän ja Lars Käkelän 7.4.2017 vireille panemassa aloitteessa (7 kannattajaa) ehdotettiin verovähennysoikeutta yrityksille pitkäaikaistyöttömien, nuorten alle 25 -vuotiaiden ja alle 30 -vuotiaiden vastavalmistuneiden sekä 55 vuotta täyttäneiden henkilöiden palkkaamiseksi. Ehdotuksen mukaan heidät palkkaava työnantaja vapautettaisiin heidän yrityksessä tekemänsä työn osalta yritykselle muuten määräytyvästä yhteisöverosta. Aloitteessa myös ehdotettiin, että perhevapailla olevien henkilöiden työstä 
poissaoloaika antaisi työnantajalle vastaavan vähennysoikeuden. Valtioneuvoston olisi ryhdyttävä tämän ehdotuksen mukaisiin toimenpiteisiin vaikeassa työllistymisasemassa olevien henkilöiden työllistymisen edistämiseksi. Tuloverolakiin olisi lisättävä säännös, jonka sisältö noudattaisi seuraavanlaista määritelmää:

Verovelvollinen, joka on merkitty Verohallinnon työnantaja- ja ennakkoperintärekisteriin ja jonka palveluksessa on vähintään 10 henkilöä, voi saada verovapaaksi muuten määräytyvästä valtionverosta sen murtoluvun suuruisen osan, jonka suuruus määräytyy seuraavasti:

Murtoluvun osoittajana on niiden yrityksen palveluksessa olevien Suomessa verovelvollisten henkilöiden, joiden työllistymistä tällä esityksellä halutaan tukea, tekemä työkuukausien lukumäärä verovuonna. Murtoluvun nimittäjänä on kaikkien yrityksen palveluksessa olevien Suomessa verovelvollisten työntekijöiden työkuukausien lukumäärä verovuonna. Ne henkilöt, joiden työllistymistä yhteisöveron vähennyksellä näin halutaan tukea ja joiden tekemä työkuukausien määrä vuodessa otetaan huomioon murtoluvun osoittajaa laskettaessa, olisivat seuraavat:

1. Alle 25-vuotiaat nuoret ja alle 30-vuotiaat vastavalmistuneet henkilöt, kolme vuotta työsuhteen alkamisesta.

2. Pitkäaikaistyöttömät, kolme vuotta työsuhteen alkamisesta.

3. Henkilöt, jotka ovat täyttäneet 55 vuotta.

4. Verovelvollisen palveluksessa olevat perhevapaalla olevat henkilöt.

Verovähennykseen oikeuttava työkuukausi olisi sellainen työssäolokuukausi, josta työntekijälle vuosilomalain $6 \$$ :n mukaisesti kertyy vuosilomaa ja jossa viikkotuntien määrä ylittää 30 viikkotyötuntia.

Verovelvollinen ilmoittaisi Verohallinnolle verovähennykseen oikeuttavat kuukaudet kausiveroilmoituksessaan.

Verovähennykseen oikeuttavia työkuukausien veroisia kuukausia olisivat myös vähennykseen oikeuttavien työntekijöiden vuosilomakuukaudet ja verovelvollisen palveluksessa olevien työntekijöiden ne kuukaudet, jotka työntekijä on perhevapaalla.

Jotta yhteisöveron tuotto valtion taloudessa ei alenisi liikaa ja vähennysoikeus kannustaisi voittoa tuottavien yrityksien omistajia ja ylintä johtoa huomioimaan yhteiskunnallisesti vastuullisen toiminnan uusia työntekijöitä palkatessaan, yhteisöveron veroprosentti ilman tätä vähennystä palautettaisiin vuonna 2010 olleelle tasolle eli $26 \%$ :iin.

Tarkoituksena olisi, että esityksessä määriteltyjen henkilöiden tekemän työn osuus yrityksen voitoista on valtionverosta vapaata tuloa yrityksen omistajille. Kun yritys tekee liiketoiminnallaan voittoa ja on palkkaamassa uusia työntekijöitä, yrityksen omistajat ja johtotehtävissä olevat henkilöt tulevat harkitsemaan kunkin työtehtävän kohdalla mahdollisuutta pal- 
kata nuoria, vastavalmistuneita, pitkäaikaistyöttömiä tai yli 55-vuotiaita henkilöitä yrityksen palvelukseen. Lisäksi ehdotuksen tavoitteena olisi:

1. Kannustaa ulkomaisia yrityksiä tehostamaan ja laajentamaan toimintaansa Suomessa. Erityisesti Isossa-Britanniassa pääkonttoriaan pitävät yritykset, jotka harkitsevat pääkonttoritoimintojen siirtämistä muualle EU:n alueelle, voivat harkita Suomea kilpailukykyisenä vaihtoehtona. Taitavalla henkilöstöhallinnolla voi Suomeen muuttavan yrityksen yhteisöveroprosentti olla ehdotuksen voimaantulon jälkeen $0 \%$.

2. Kannustaa yrityksiä palkkaamaan yli 55-vuotiaita henkilöitä työntekijöikseen ja kehittämään yrityksen työoloja siten, että varttuneemmat työntekijät viihtyvät työtehtävissään vielä silloinkin kun heillä ikänsä puolesta olisi oikeus vanhuusajan eläkkeeseen. Ehdotus myös kannustaa työnantajia pysyttämään niiden henkilöiden työsuhteet, jotka ovat lähestymässä 55 vuoden ikää.

3. Parantaa pitkäaikaistyöttömän mahdollisuutta työllistyä pitkäaikaisesti markkinaehtoisilla työpaikoilla, koska työnantajan saama verohuojennus kompensoi niitä kustannuksia, joita pitkän aikaa työttömänä olleen henkilön kouluttaminen tehtäviinsä edellyttää. Esityksen tarkoituksena on parantaa erityisesti koulutettujen pitkäaikaistyöttömien työllistymistä.

4. Mahdollistaa nuorille ja vastavalmistuneille henkilöille riittävän pitkä työsuhde, jolloin toimialan tavat ja vaatimukset ehtivät juurtua nuorelle työntekijälle. Lisäksi ehdotus kannustaa yrityksiä palkkaamaan nuoria kesätöihin opiskelun kesälomien aikana.

5. Kannustaa yrityksiä, jotka haluavat hyötyä verovähennyksestä täysimääräisesti, tarjoamaan koko henkilökunnalleen yli 30 viikkotyötuntia sisältävän työmäärän.

6. Antaa yritykselle mahdollisuuden yhteiskuntavastuuta osoittavan ja yleisesti hyväksyttävän tavan verosuunnitteluun, jonka avulla yritys voi pienentää voitosta muuten maksettavaksi määräytyvää yhteisöveroa.

7. Kannustaa pieniä yrityksiä kasvamaan niin suureksi, että ne ovat oikeutettuja yhteisöverovähennykseen. Siten työpaikkojen määrä kasvaa pienissä yrityksissä ja työttömyys vähenee.

Esityksen tarkoituksena on pyrkiä luomaan kestäviä polkuja työelämään henkilöille, joiden työn tuottavuus ei ole kilpailukykyinen parhaassa työskentelyiässä oleviin verrattuna työsuhteen alkuvaiheessa. Esityksen tavoitteena on myös työntekijöiden työsuhteiden pidentäminen niin että työntekijän pitkä työsuhde työnantajan palveluksessa on motivoiva ja omistajaa palkitseva. Lisäksi tämä lakiesitys pyrkii tasaamaan perhevapaista työnantajille aiheutuvia kustannuksia ja edistämään työelämän tasa-arvoa. 
Esitys pyrkii myös vastaamaan elinkeinoelämän vaatimuksiin yhteisöverotuksen tuntuvaksi alentamiseksi. Mikäli tämä lakiesitys tulee hyväksytyksi esityksen sisällön mukaisena, yhteisöveron suuruus yrityksen muuten verotettavasta tulosta tulee vaihtelemaan yrityksen työvoimarakenteesta riippuen välillä $0-26 \%$.

\section{Kommentteja}

Näiden aloitteiden mallit yhteisöveron muuttamiseksi vaikuttavat liian monimutkaisilta ja kansainvälisesti erikoisilta voidakseen toteutua. Aloitteet ovatkin saaneet vain muutamia kannattajia.

\subsection{Osinkotulojen verotus yhdenmukaistettava}

Jukka Niemen 6.2.2019 vireille paneman aloitteen (16 kannattajaa) mukaan olisi lakkautettava kaikkien verovapaiden osinkojen verovapaus ja saatettava kaikki osingot yhdenvertaisen verotuksen kohteeksi. Monimutkainen ja eriarvoinen osinkoverotusmenettely olisi korvattava sellaisilla verolaeilla, että riippumatta osingon saajasta tai antajasta osinkojen verotusmenettely on aina sama ja osinkojen verovapaudesta luovutaan kaikkien osinkojen osalta.

Nykyinen osinkojen verotus riippuu voimakkaasti mm. yhtiöstä, joka osingon jakaa. Seuraavassa esitetään esimerkkinä listaamattomien yhtiöiden osinkoverotusmenettely:

Jaetusta osingosta $25 \%$ on veronalaista pääomatuloa ja $75 \%$ verotonta tuloa 150000 euroon saakka, jos jaettu osinko on enintään $8 \%$ osakkeen matemaattisesta arvosta. 150000 euron ylittävästä osasta $85 \%$ on veronalaista päöomatuloa ja $15 \%$ verotonta tuloa. Tämä 150000 euron raja on osakaskohtainen, ja kaikki kyseisen henkilön samana vuonna saamat listaamattomien yhtiöiden osingot lasketaan yhteen. Listaamattomien yhtiöiden osalta osingon saaja saa siis merkittäviä osinko-osuuksia verovapaasti. Tämä kohtelu on epäoikeudenmukainen ja pienentää verokantaa merkittävästi aiheuttaen muulle palkka- ja osinkoverotukselle ylimääräistä verotaakkaa, koska merkittävä osa osingoista annetaan tässä verovapaasti. Perustuslain yhdenvertaisuusvaade ei toteudu osinkojen verotuksen suhteen. Epäyhtenäisyyttä syntyy myös siitä, että listaamattomien yhtiöiden osalta osinkojen verotus voidaan toteuttaa joko pääomatulona tai palkkatulona.

Osinkoverotuksen suhteen löytyy eri tilanteissa lukuisia erilaisia verotusmenettelyitä, joista tässä on siis tarkasteltu esimerkkinä listaamattomia yhtiöitä. On perusteltua ja yhdenvertaista, että osinkoverotuksessa siirrytään pois poliittisella harkinnalla tehdyistä erillisratkaisuista ja siirrytään poikkeuksettomaan yhtenäisverojärjestelmään kaikkien osinkotulolajien osalta. 


\section{Kommentteja}

Nykyistä osinkoverojärjestelmäämme voidaan pitää jopa perustuslain yhdenvertaisuusperiaatteen vastaisena. Olisi pyrittävä yksinkertaisuuteen, yhdenmukaisuuteen ja oikeudenmukaisuuteen. Listaamattomien ja listattujen yhtiöiden maksamien osinkojen verokohtelut eroavat liikaa toisistaan. Osinkoverotuksen kahdenkertaisen verotuksen ongelma olisi pyrittävä ratkaisemaan mahdollisimman samanlaisella mekanismilla, oli sitten kysymys listaamattomien tai listattujen yhtiöiden maksamista osingoista. Kahdenkertaisen verotuksen ongelman ratkaisemiseksi yhteisöverokannan olisi oltava melko matala ja osinkotuloista vain tiettyä prosentuaalista osaa olisi pidettävä luonnollisen henkilön veronalaisena tulona (pääomatulona). Osinkotuloa ei pitäisi katsoa osaksikaan ansiotuloksi, mutta suuria veronalaisia pääomatuloja voitaisiin verottaa jonkin verran korkeammalla verokannalla kuin pienempiä pääomatuloja. Suotavana ei voida pitää osinkojen verotuksen sitomista osakkeiden arvoon ja ns. normaalituottokorkoprosenttiin. Jonkinlaista eroa listattujen ja listaamattomien yhtiöiden verotuksessa voidaan puoltaa vaikkapa oman pääoman vahvistamiseksi ja riskinottoon kannustamiseksi, mutta välttämättömänä ei ole pidettävä nykyisenkaltaista rakenteellista eroa.

Periaatteessa on mahdollista saada hyvinkin laaja kannatus kyseisessä aloitteessa esitetylle yhdenmukaiselle mallille. Käytännössä esteitä kohdataan heti, kun siirrytään keskustelemaan verotasosta ja sen noususta varakkaiden listaamattomien yhtiöiden osinkojen kohdalla.

\subsection{Vakuutuskuorien veroedut poistettava}

Jukka Niemen 31.1.2019 vireille paneman aloitteen (14 kannattajaa) mukaan valtion tulee ryhtyä toimiin vakuutuskuoriin sisältyvän myöhennetyn verosaatavan perimiseksi mahdollisimman nopeasti valtion menojen katteeksi. Hallitus valittaa jatkuvasti valtion tulojen niukkuutta ja etsii kohteita, joista leikata; milloin eläkeläisiltä, milloin lapsiperheiltä, milloin koulutuksesta ja milloin mistäkin. Rahapulasta huolimatta valtio sallii eri yhteyksissä käytettävän ns. myöhennettyä verotusta, jolloin veroja ei makseta myynti- tai muun voiton syntyessä vaan verosumma jää toimijan käyttöön esimerkiksi sijoitustoimintaan tms. ja vero peritään vasta voittoja "kotiutettaessa". Aloitteessa ehdotettiin myöhennetyn verovelan menettelyn lakkauttamista vakuutuskuoriin liittyen. Aloite olisi analogisesti erikseen hyödynnettävissä myös vastaavissa muissa myöhennetyn verotuksen menettelyissä. Ei ole mitään ymmärrettävää perustetta antaa 
mm. yrityksille ja sijoittajille korotonta lainaa myöhennetyn verotuksen muodossa ja vieläpä rajaamattomaksi ajaksi. Samanaikaisesti valtio tai verottaja perii saatavistaan kulloinkin voimassa olevan viivästyskoron mukaisen koron, kun on kyseessä tavallisen kansalaisen saatava. Saatava johtaa normaalisti varsin nopeasti myös ulosottotoimiin. Vakuutuskuoriin liittyvän myöhennetyn verosaatavan summa on merkittävä.

\section{Kommentteja}

Aloite liittyy kapitalisaatiosopimuksiin, joiden verotuksesta on otettu tuloverolakiin nimenomaiset, vuodesta 2020 alkaen sovellettavat säännökset (ks. HE 275/2018). Uudetkaan säännökset eivät estä verotuksen myöhentämistä. Sijoittajien verotuksen myöhentäminen pikemminkin lisääntyy uusien osakesäästötilisäännösten vuoksi.

\subsection{Korkojen vähentämistä rajattava yritysverotuksessa ja Suomen verotusoikeus turvattava}

Jukka Niemen 5.2.2019 vireille panemassa aloitteessa (28 kannattajaa) ehdotettiin yritysten verotuksessa hyväksyttävää enimmäiskorkoa rajoitettavaksi lailla.

Kansalaisille tärkeitä ja välttämättömiä palveluita tuottaa nykyisin yrityksiä, jotka ovat hyväksyneet itselleen velvoitteen maksaa markkinakorkotasoon nähden merkittävästi korkeampia korkoja (julkisuudessa tällaisista ovat olleet esillä mm. Caruna Oy ja Esperi Care Oy). Yritykset tai niiden omistajat ovat saattaneet "laillisella tavalla" pyrkiä minimoimaan tai kokonaan välttämään Suomeen maksettavia veroja maksamalla lainoistaan niin korkeita korkoja, että verotettavaa voittoa ei enää merkittävästi voisi syntyä Suomessa tapahtuvassa verotuksessa. Esiintyneen toiminnan ja mahdollisten uusien vastaavien menettelyiden estämiseksi tulee Suomessa toimivien yritysten verotuksessa hyväksyttävää laina- ja rahoituskorkoa tai vastaavaa kulua rajoittaa vastaamaan enintään uutta yritysverotuksessa hyväksyttävää enimmäiskorkoa.

Eira Kantolan 29.1.2019 vireille panemassa aloitteessa (3 234 kannattajaa) vaadittiin, että kaikkien verovaroin tuotettavien julkisia palveluita (mm. sosiaali- ja terveyspalvelut) Suomessa tuottavien yritysten on maksettava kaikki veronsa Suomeen. Suuret hoivajätit yms. tuottavat Suomessa palveluja, jotka maksetaan pääasiassa julkisista varoista. Yritykset eivät maksa verojaan Suomeen, ja verovarat valuvat ulkomaille. Jos kyseiset verot maksettaisiin Suomeen, se olisi kaikkien etu. Varat voisi käyttää siihen, mistä ne tulevatkin, esimerkiksi heikommassa asemassa olevien huoltoon ja hoitoon. 


\section{Kommentteja}

Jukka Niemen aloite tarkoittanee sitä, että laissa säädettäisiin tietty korkoprosentti tms., jonka ylittävältä osalta korkoja ei voitaisi verotuksessa vähentää. Enimmäiskorkoprosentin säätäminen voisi hyvin olla perusteltua niiden monimutkaisten rajoitusten lisäksi, joita viime vuosina on säädetty.

Eira Kantolan aloitteesta ei tarkemmin ilmene, millaisia muutoksia lainsäädäntöömme olisi tehtävä. Mahdollisesti tässäkin aloitteessa halutaan esimerkiksi lisärajoituksia korkojen vähennysoikeuteen.

Pääministeri Antti Rinteen hallituksen ohjelmassa (s. 190) esitettiin lukuisia kansainvälisen veronkierron ja aggressiivisen verosuunnittelun vastaisia toimia. Tilanne on samanlainen pääministeri Sanna Marinin hallituksen ohjelmassa.

\subsection{Halpatyövoimalle maahantuontivero}

Risto Kosamon 1.1.2014 vireille panemassa aloitteessa (671 kannattajaa) ehdotettiin halpatyövoiman kitkemistä Suomesta verotusta hyödyntämällä sekä kotimaisen työvoiman saattamista kilpailukykyisemmäksi verrattuna ulkomaisen työntekijän tuntihinnoitteluun. Aloite koski kaikkia työaloja Suomessa.

Nykyisin saapuu Suomeen paljon halpatyövoimaa ulkomailta, joten asiaan voitaisiin vaikuttaa siten, että hallitus valmistelisi verolain, joka kohdistuu halpatyövoiman ulkomailta Suomeen välittäjiin. Esimerkiksi työvoimaa ulkomailta Suomeen välittävälle firmalle langetettaisiin maahantuontivero. Vero kohdentuisi halpatyövoiman välittäjiin siten, että he joutuisivat maksamaan työntekijästä maahantuontiveroa työskentelyluvan pituiselta ajalta jonkinasteisen veroprosentin mukaan. Kyseinen vero koskisi nimenomaan sitä aikaa, minkä pituisen työskentelyluvan maahan tuleva työntekijä tarvitsee, eikä verotuksen märärä vaikuttaisi mitenkään siihen, kuinka kauan työntekijä todellisuudessa olisi Suomessa töissä.

Jos maahantuontiveroa on esimerkiksi maksettu Suomeen tulevasta työntekiiästä 90 vrk:n työskentelyluvan mittaisesta ajasta, mutta työntekijä ei ammattitaidoltaan olekaan työnantajille sopiva ja joutuu ammattitaidottomuutensa vuoksi poistumaan maasta aikaisemmin, kärsijänä olisi kyseisen henkilön Suomeen tuonut välittäjä, joka ei tiedä mitään henkilön ammattitaidosta. Laista johtuen ulkomaalaiset työvoiman välittäjät joutuisivat pakostakin nostamaan Suomeen saapuvien työntekijöiden hinnoittelua, ja siitä johtuen suomalaisilla olisi huomattavasti paremmat mahdollisuudet työllistyä firmoihin, kun tuntihinnoitteluissa ei olisi juurikaan eroja. Tämä kasvattaisi valtion kassaan tuloja, ja suomalaiset työntekijät olisivat paremmin kilpailukykyisempiä työnantajien tuntihinnoitteluun suhteutettuna. 
7 Kansalaisaloitteinen verotus - viihdettä vai demokratiaa?

\section{Kommentteja}

Aloite tarkoittanee yritykselle määrättävää lisäveroa ulkomaisen työvoiman käytöstä ja välityksestä. Tällainen lisävero olisi varmaan EUsäädösten ja muidenkin kansainvälisten sopimustemme vastainen.

\subsection{Ylimääräinen verovähennys yhdistystoiminnan sponsoroimiseksi}

Sari Kaihon 1.10.2016 vireille panemassa aloitteessa (2 kannattajaa) esitettiin ylimääräistä verovähennysoikeutta yrityksille yhdistystoiminnan taloudelliseen tukemiseen. Sponsoroinnista myönnettäisiin yrityksille ylimääräinen verovähennysoikeus kotimaisen, rekisteröidyn ja voittoa tavoittelemattoman yhdistystoiminnan vastikkeelliseen tukemiseen. Ylimääräisen vähennysoikeuden perusteen enimmäismäärä olisi 10000 euroa vuodessa ja lisävähennys $50 \%$. Esimerkiksi yritys, joka tukisi harrastus- tai tukitoimintaa vuodessa 5000 eurolla, voisi vähentää verotuksessa kuluna 7500 euroa. Veroporkkana kannustaisi yrityksiä ja yhdistyksiä yhteistyöhön ja kehittämään näkyvyyspalveluita yhdessä. Yhteistyön tuloksena yritykset saisivat tuotteilleen ja palveluilleen markkinointikanavan ja yhdistykset nopean ja jatkuvan varainhankintakanavan.

Suomessa toimii yli 100000 voittoa tavoittelematonta yhdistystä. Yhdistykset vastaavat suurelta osin kulttuuri- ja liikuntapalveluiden, lapsi- ja nuorisotyön sekä sosiaali- ja terveysalan tukipalveluiden järjestämisestä. Yhdistystoiminta perustuu suurelta osin vapaaehtoistyöhön. Tästä syystä se on kustannustehokkain tapa tarjota "leipää ja sirkushuveja" ja siten ehkäistä erilaisia yksilöllisiä ja yhteiskunnallisia ongelmia, esimerkiksi syrïäytymistä.

Vallitseva taloustilanne on kiristänyt yhdistysten taloudellisia resursseja, vaikka täll̈ hetkellä yhdistysten tarjoamia palveluita tarvitaan ehkä enemmän kuin koskaan aiemmin. Yhdistysten eli ns. kolmannen sektorin liikevaihto on noin $5 \%$ Suomen bruttokansantuotteesta eli noin 10 miljardia euroa. Valtio rahoittaa kolmatta sektoria noin 3,5 miljardilla eurolla vuosittain. Pääosa valtion rahoituksesta koostuu veroista. Verorahoitus on jatkuvaa mutta hidasta ja kallista. Yhdistystukena maksettu yksittäinen veroeuro palaa markkinoille usein vasta kolmen vuoden jälkeen kierrettyään ensin yrityksen tilikauden, veronkannon ja tukien maksamisen ja niiden kulutuksen kautta. Veronkantoon, tukien kohdentamiseen ja niiden käyttöön liittyvä byrokratia laimentaa jokaista euroa merkittävästi. Suora yhdistystuki palaa takaisin markkinoille saman vuoden aikana ja siten lisää valuutan kiertonopeutta.

Yhä suurempi osuus kotimaisten yritysten markkinointieuroista kohdistuu digitaaliseen markkinointiin. Sosiaaliseen mediaan ja hakukonenäkyvyyteen kohdennetut eurot valuvat pysyvästi maamme rajojen 
ulkopuolelle. Suurten mediayhtiöiden aggressiivinen verosuunnittelu varmistaa, ettei kyseisistä tuotoista makseta juurikaan veroja kotimaahan.

Vastikkeellinen yhdistystuki eli sponsorointi edellyttää yrityksen näkyvyyttä yhdistystoiminnassa. Yhdistyksillä on käytössään lukuisia sähköisiä kanavia, esimerkiksi internetsivut sekä sähköposti- ja muut pikaviestiryhmät, joita hyödyntämällä paikalliset yritykset voivat löytää asiakkaansa. Kannustamalla kotimaisia toimijoita yhteistyöhön yli sektorirajojen voidaan lisätä yritysten elinkelpoisuutta ja yhdistysten taloudellisia resursseja. Markkinointiin käytetyt eurot voidaan pitää suuremmalta osin kotimaassa ja rahan kiertonopeutta lisätä. Valtio voi ehdotetun tukiperusteen enimmäismäärää tai lisävähennysprosenttia säätämällä tarvittaessa lisätä ja nopeuttaa kolmannen sektorin rahoitusta ja samalla lisätä erityisesti mikroyritysten toimintamahdollisuuksia ja yrittäjyyden kiinnostavuutta.

\section{Kommentteja}

Kun aloitteessa on kysymys vastikkeellisesta suorituksesta, esitys tarkoittanee, että sponsorointimenot vähennettäisiin ensin normaaleina tulonhankkimismenoina ja lisäksi niistä annettaisiin ylimääräinen vähennys. Järjestelmä muistuttaisi meillä aikoinaan mm. joissakin kehitysalueiden ja merenkulun veronhuojennuslaeissa olleita ylimääräisiä vähennyksiä, joista on verojärjestelmässämme luovuttu. ${ }^{66}$

\subsubsection{Yleisradiovero kumottava}

Yleisradioveron lopettaminen on ollut monen kansalaisaloitteen teemana ja saanut melko paljon kannattajia, mutta ei eduskuntakäsittelyyn vaadittavaa 50 000:ta.

Ensimmäiseksi asiasta pani vireille aloitteen Petri Rautiainen 21.7.2014 (2 098 kannattajaa). Vuoden 2013 alusta yleisradiovero korvasi siihen asti voimassa olleen televisiolupamaksun. Yleisradio ja hallitus perustelivat aikoinaan yleisradioveron käyttöönottoa sillä, että moni jätti televisiolupamaksun maksamatta ja Yleisradion tarjoaman ohjelman taso oli maksamattomien lupamaksujen myötä selvästi laskenut. Moni kokee asian epäoikeudenmukaisena, koska samassa perheessä saattaa olla kolme, neljä henkeä ja jokainen joutuu maksamaan saman lupamaksun. Tämä koskee myös perheitä, jotka eivät omista televisiota ja joilla ei ole mahdollisuutta seurata ohjelmia. Toiseksi ne ohjelmat, joita väki eniten seuraa, siirrettiin

${ }_{66}$ Korotetut eli nopeutetut poistot (esim. HE 85/2019) ovat eri asia. Niissä on kysymys vain poistojen nopeuttamisesta eli veronmaksun lykkäämisestä. 
maksullisille kanaville. Jos haluat katsoa näitä ohjelmia, joudut maksamaan kyseisestä TV-kanavasta toisen maksun. Kolmanneksi kansalla ei ole mitään takuita siitä, mihin menevät yleisradioveroon kerätyt varat. Ohjelman laadun parantumisesta ei ainakaan voi puhua, kun koko ajan tulee jotakin uusintanäytöksiä.

Yleisradio kohtelee eri asiakasryhmiä eri tavoilla. Toisia on syrjitty sillä, ettei niille myönnetä TV-näkyvyyttä, kun taas toisille myönnetään. Yleisradio on rikkonut toistamiseen puoluelakia, joka määrää sitä kohtelemaan kaikkia puolueita tasapuolisesti. Syrjinnän, moninkertaisen verotuksen, ohjelmien seuraamisen mahdollisuuden ja Yleisradion ohjelmien laadun heikkenemisen johdosta olisi palattava vanhaan televisiolupakäytäntöön.

Seuraavan aloitteen yleisradioveron lakkauttamiseksi pani vireille Aleksi Hernesniemi 15.2.2016 (22 670 kannattajaa). ${ }^{67}$ Aloitteen mukaan Yleisradio voisi jatkossa hankkia rahoituksensa esimerkiksi maksukortilla ja/ tai mainoksilla. Lähtökohta on, että jos ei halua katsoa Yleisradion ohjelmia, ei tarvitse maksaa. Kun yleisradiovero lopetetaan, suomalaisille jää enemmän rahaa käteen. Yleisradiovero on epäoikeudenmukainen mm. seuraavista syistä:

1) Yleisradion palveluiden ylläpito tulee kalliiksi suomalaisille. Yleisradiovero voi olla yksityishenkilölle 143 euroa ja yhteisölle jopa 3000 euroa. Tämä on täysin kohtuuton maksu ottaen vielä huomioon ohjelmiston tason.

2) Kun Yle lähettää heikkoa ohjelmistoa, ihmiset eivät voi äänestää lompakollaan ja vaihtaa parempaan palveluntarjoajaan. Vaikka koko kansa ryhtyisi täydelliseen Yle-boikottiin, sekään ei auttaisi, koska rahat otetaan veroista. Koska Yleisradio ei toimi markkinaehtoisesti, sillä ei ole taloudellista pakkoa muuttaa ohjelmistoa vastaamaan paremmin katselijoiden toiveita.

3) Ylen vuoksi kaupalliset maakunta- ja paikallismediat joutuvat kamppailemaan yhä kovemmin selviytymisestään. Monet makuntamediat ovat jo ilmaisseet huolensa Yleisradion huolestuttavasta asemasta. Näillä toimialoilla on jo muutenkin tarpeeksi haastavaa, joten Yleisradiolle on pakko laittaa jotain rajaa. Miksi tilata maksullista paikallislehteä, jos

67 Perussuomalaisten ryhmänjohtajan Ville Tavion 18.10.2019 tekemässä lakialoitteessa 21/2019 ehdotetaan valtion Ylen rahoituksen määrärahaa pienennettäväksi. Lakialoitteessa viitataan $\mathrm{mm}$. siihen, että yleisradioveron lakkauttamista vaatinut 15.5.2016 vireille pantu kansalaisaloite keräsi 22670 kannatusilmoitusta, ja siihen, ettei Yle ole poliittisesti sitoutumaton ja että Yleisradion ohjelmistoa on pidetty epätyydyttävänä. Tavion mielestä Ylen tulee tehostaa ja uudelleen organisoida toimintaansa. 
samat uutiset saa "ilmaiseksi" Ylen nettisivuilta? Miksi maksaa digilehdestä, jos samat asiat voi kuunnella "ilmaiseksi" Yleisradion maakuntaradiosta?

4) Yleisradio ei ole poliittisesti sitoutumaton. Yleisradiota johtaa poliittisesti valittu hallintoneuvosto. Lisäksi Yleisradion lakisääteisiin tehtäviin kuuluu monikulttuurisuuden tukeminen, mikä on ristiriidassa uutisoinnin puolueettomuusvelvoitteen kanssa. On kohtuutonta, että ihmiset joutuvat maksamaan veroa siitä hyvästä, että Yleisradio julkaisee poliittisesti väritettyjä uutisia. Lisäksi erityisesti vaalien alla pienpuolueet eivät saa samanlaista kohtelua kuin eduskuntapuolueet, vaikka pienpuolueiden kannattajat maksavat muiden kansalaisten lailla yleisradioveroa.

5) Verorahoilla ylläpidettävä Yleisradio on nykyaikana yksinkertaisesti tarpeeton, koska internet, TV ja radio tarjoavat valtavat määrät maksutonta ohjelmistoa ja palvelua. Suomalainen kulttuuri ei ole riippuvainen verorahoin ylläpidetystä Yleisradiosta.

6) Suomessa ei ole myöskään valtiollista sanomalehtitaloa. Hyvin on pärjätty ilman sitäkin, sillä yksityiset yritykset hoitavat niitä tehtäviä. Mihin siis tarvitaan valtiollista radio- ja televisioyhtiötä? Kuluttaja tietää itse parhaiten, millaista ohjelmistoa hän haluaa televisiosta katsoa.

Kolmannen aloitteen pani vireille jälleen Petri Rautiainen 17.1.2019 (4 002) edellisten aloitteiden kaltaisilla perusteilla. Hän toteaa, että Ahvenanmaalla asuvilta ei peritä yleisradioveroa, vaan siellä kotitalouksilta peritään 220 euron suuruinen tv-maksu, jolla rahoitetaan Ahvenanmaan maakuntahallinnon omistaman Ålands Radio och TV -yhtiön toiminta. Ahvenanmaan TV-maksu perustuu siihen, omistaako asukas television.

Yleisradiovero koskee myös yrityksiä, jotka harjoittavat taloudellista toimintaa. Yhteisöjä, joilla on jäsenmaksuja, korkotuloja, osinkotuloja, vuokrahuonetuloja, lahjoituksia ja avustuksia, ei yleensä veroteta. Veron suuruus määräytyy verovuoden verotettavan tulon mukaan. Alle 50000 euron tulosta ei yhteisön tarvitse tätä veroa maksaa. 50000 euroa ylittävältä osalta yleisradiovero on $0,35 \%$. Veron vähimmäissumma on 140 euroa, ja enimmillään vero on 3000 euroa.

Yrittäjiltä yleisradiovero peritään sekä henkilöverotuksessa että yrityksen verotuksessa. Yrittäjän henkilökohtainen yleisradiovero määräytyy puhtaiden ansio- ja pääomatulojen yhteissumman sekä yrittäjän eläkevakuutuksen (YEL, MyEL) palkkasumman perusteella sen mukaan, kumpi näistä on suurempi. Mainitusta syystä johtuen yrittäjä voi joutua maksamaan yleisradioveroa myös tappiollisesta yritystoiminnasta. Aloitteessa vaaditaan yleisradioveron maksamisen lopettamista Suomessa. Vero ei vastaa alkuperäistä tarkoitusta. Varoille löytyy muutakin käyttöä. 
Uusimman aloitteet asiasta panivat vireille 5.4.2019 Mauri Peltokangas, Aleksi Hernesniemi, Miika Tynkkynen, Antti-Matti Salminen, Juha Karjalainen ja Ano Turtiainen (13 663 kannattajaa). Aloitteessa esitettiin yleisradioveron lakkauttamista samantapaisilla perusteilla kuin aikaisemmissa aloitteissa. Jatkossa Yleisradio voisi hankkia rahoituksensa esimerkiksi maksukortilla ja/tai mainoksilla. Kun yleisradiovero lopetetaan, veroaste laskee ja suomalaisille jää palkasta enemmän rahaa käteen.

\section{Kommentteja}

Hallitus antoi 5.4.2012 esityksen laiksi yleisradioverosta (HE 28/2012). Esitys oli osa laajempaa kokonaisuutta, jonka tarkoituksena on uudistaa Yleisradio Oy:n julkisen palvelun rahoitusjärjestelmä. Kokonaisuuteen kuului myös ehdotus Yleisradio Oy:stä annetun lain sekä valtion televisio- ja radiorahastosta annetun lain muuttamiseksi (HE 29/2012). Tavoitteena oli luoda rahoitus- ja hallintomalli, joka turvaa pitkäjänteisesti Yleisradion julkisen palvelun kehittämisen ja riippumattomuuden silloisen kaltaisessa laajuudessa. Huomiota kiinnitettiin rahoitusmallin vakauteen, järjestelmän oikeudenmukaisuuteen ja laajaan maksupohjaan. Näin uskottiin turvattavan Yleisradion asema suomalaisen kulttuurin tuottajana, moniarvoisena ja riippumattomana tiedonvälittäjänä sekä sananvapauden ylläpitäjänä.

Kaikki kokonaisuuteen kuuluvat lakiehdotukset perustuivat eduskuntaryhmien puheenjohtajien ja asunto- ja viestintäministerin 16.12.2011 hyväksymään julkilausumaan sekä valtioneuvoston sen pohjalta 21.12.2011 hyväksymään periaatepäätökseen. Nämä sisälsivät uudistuksen keskeiset linjaukset julkisen palvelun rahoituksesta, ohjauksesta ja valvonnasta sekä julkisen palvelun määrittelystä. Päätösten taustalla olivat eduskuntaryhmien jo maaliskuussa 2010 hyväksymä yhteinen kannanotto ja sitä vastaava pääministeri Jyrki Kataisen hallitusohjelman kirjaus. Yleisradiotoiminnan rahoitukseen oli etsitty vaihtoehtoja useissa virallistyöryhmissä. Päävaihtoehdoista päädyttiin laajapohjaiseen veromalliin.

Yleisradioveroa peritään vuosittain noin 500 miljoonaa euroa eli suunnilleen yhtä paljon kuin olisi kannettu televisiomaksuja. Yleisradioverolla ei ole mitään konkreettista yhteyttä vastasuoritukseen, esimerkiksi radion kuunteluun tai TV-lähetysten seuraamiseen. Valtiosääntöoikeudellisesti kysymyksessä on selvästi vero eikä maksu. 
Tässä yleisradiovero eroaa ratkaisevasti aikaisemmista radiolupa- ja televisiomaksuista.

Kun ottaa huomioon, että yleisradioveron säätäminen lopulta perustui eduskuntapuolueiden yksimieliseen tahtoon, yleisradioverosta tuskin ainakaan lähiaikoina luovutaan.

\subsubsection{Kirkollisvero}

\subsection{Kirkollisvero poistettava yhteisöiltä}

Sami Malmin 31.7.2013 vireille panemassa aloitteessa (3 235 kannattajaa) ehdotettiin kirkollisveron poistamista yrityksiltä ja yhteisöiltä. Aloitteessa todettiin, että yritykset ja yhteisöt maksavat tuloistaan veroa kirkolle, vaikka eivät mitenkään pääse käyttämään kirkon palveluja.

Kirkollisvero on vanhentunut maksuautomaatti evankelisluterilaiselle kirkolle, josta täysi-ikäinen yksityishenkilö voi irtaantua. Miksi yritykset/ yhteisöt eivät voi irtaantua kirkollisverosta vaikka yrityksessä/yhteisössä ei muuten olisi yhtään evankelisluterilaisen kirkon jäsentä missään toimessa/tehtävässä? Eivät muutkaan uskontokunnat saa automaattista veronkantoa samassa muodossa, joten kirkollisvero on jo tasa-arvolainkin vastainen.

\section{Kommentteja}

Yhteisöveroa koskeva lainsäädäntö on aloitteen tekemisen jälkeen muuttunut. Vuodesta 2016 alkaen kirkko ei ole enää saanut osuutta yhteisöverosta. Evankelisluterilaisten ja ortodoksisten seurakuntien entinen yhteisövero-osuus on korvattu indeksiin sidotulla määrärahalla, jonka valtio maksaa seurakunnille.

\subsection{Kirkollisvero korvattava henkisen hyvinvoinnin verolla}

Sami Mäkisen 7.12.2014 vireille panemassa aloitteessa (3 kannattajaa) ehdotettiin kirkollisveron korvaamista kaikkia verovelvollisia koskevalla vuotuisella henkisen hyvinvoinnin verolla, jota luonnollisen henkilön ja yhteisön olisi suoritettava valtiolle. Lakia ei sovellettaisi luonnolliseen henkilöön tai yhteisöön, jonka kotikunta on Ahvenanmaan maakunnassa.

Suomessa yleisesti verovelvollisen, joka viimeistään verovuoden aikana on täyttänyt 18 vuotta, olisi suoritettava henkisen hyvinvoinnin veroa $1,0 \%$ tuloverolaissa tarkoitetun verovuoden puhtaan ansiotulon ja puhtaan pääomatulon yhteismäärästä tai sitä korkeammasta hänelle yrittäään eläkelain tai maatalousyrittäjän eläkelain mukaan vahvistetun työtulon 
yhteismäärästä. Jos vero olisi vähemmän kuin 50 euroa, sitä ei maksuunpantaisi. Verovuoden aikana kuolleen henkilön henkisen hyvinvoinnin vero määrättäisiin kuolinpesälle.

Liike- tai ammattitoimintaa tai maataloutta Suomessa harjoittavan yhteisön, jonka verovuoden verotettava tulo olisi vähintään 50000 euroa, olisi suoritettava henkisen hyvinvoinnin veroa 250 euroa lisättynä 0,35 \%:lla verotettavan tulon 50000 euroa ylittävältä osalta. Veron määrä olisi kuitenkin enintään 5000 euroa.

Valtion ja sen laitosten, kunnan, kuntayhtymän, seurakunnan, uskonnollisen yhdyskunnan, asunto-osakeyhtiön, tuloverosta vapaan yhteisön ja ulkomaisen kuolinpesän ei olisi suoritettava henkisen hyvinvoinnin veroa. Henkisen hyvinvoinnin vero määrättäisiin ja maksuunpantaisiin tuloverotuksen toimittamisen yhteydessä siten kuin verotusmenettelystä annetussa laissa säädetään.

Laki pohjautuisi yhteisvastuuseen, jossa heikoimpien palvelut on turvattava kaikkien edun vuoksi. Laki mahdollistaisi ihmisten henkisen hyvinvoinnin kehittämisen materialistisen hyvinvoinnin edelle ja ihmisen onnellisuuden saavuttamisen yhteiskunnan tukemana. Kerätyillä verovaroilla luotaisiin henkisen hyvinvoinnin infrastruktuuri, jolla turvataan henkisen hyvinvoinnin palveluiden saatavuus kaikille, erityisesti nuorille ja syrjääntyville sekä yllättävissä kriisitilanteissa yhteisöille ja sen jäsenille. Verovaroin ehkäistäisiin henkistä pahoinvointia valistuksen ja koulutuksen turvin.

Laki antaisi kaikille tasa-arvoisen mahdollisuuden valita henkisen hyvinvoinnin palvelut riippumatta kulttuurista, uskonnollisesta vakaumuksesta tai muusta aatteellisesta, ideologisesta tai periaatteellisesta syystä yksilölle sopivimmalta taholta. Laki antaisi yksilölle vapauden valita omien periaatteidensa mukaisesti henkisen hyvinvoinnin palvelut myös ilman kristillistä sanomaa. Palveluiden tuottajille tuloutettaisiin verotuloista palveluiden arvioidun kysynnän mukaisesti osa verotuloista.

Evankelisluterilaisten ja ortodoksisten seurakuntien tarjoamien henkisen hyvinvoinnin palveluiden saatavuus turvattaisiin ohjaamalla osa verotuloista seurakunnille niiden tarjoamien palveluiden arvioidun kysynnän perusteella samalla periaatteella kuin muille palvelutuottajille. Lailla myös ehkäistäisiin evankelisluterilaisista ja ortodoksisista seurakunnista eroamista taloudellisin perustein.

Henkinen hyvinvointi on laaja ja vaikeaselkoinen käsite. Lakialoite ei määrittelisi mahdollisia palvelutuottajia. Vastuu lain toteutukseen tarvittavan infrastruktuurin luomisessa jäisi sosiaali- ja terveysviranomaisille, joiden tehtävänä olisi huolehtia verotuloista vastuullisesti ja henkistä hyvinvointia edistävästi. 


\section{Kommentteja}

Kirkollisveroa, joka on alkuperäisimpiä veroja, jotkut pitävät anekauppana tai muuten tuomittavana. ${ }^{68}$ Jatkuvasti keskustellaan siitä, pitäisikö se korvata kirkon jäsenmaksuilla tai vastaavilla suorituksilla. Keskustelun määrään nähden tämä kansalaisaloite on saanut yllättävän vähän kannattajia. Kirkollisveron poistaminen ei ole hallituksen ohjelmassa. Sen sijaan Antti Rinne pääministeriaikanaan julkaisemassaan elämäkertakirjassa esitti, että myös islamilaiset seurakunnat voisivat luterilaisten ja ortodoksisten seurakuntien tavoin kerätä veroa (ks. esim. Iltalehti 24.10.2019).

\subsubsection{Kunnallisvero}

\subsection{Työssäkäyntikunnalle verosta osa}

Harry Mäkysen 3.9.2013 vireille panemassa aloitteessa (269 kannattajaa) ehdotettiin verotulosta osa siirrettäväksi työssäkäyntikuntaan.

Työntekijä käyttää jatkuvasti työssäkäyntikunnan infrastruktuuria ja vie taloudellista hyötyä kotikuntaansa työssäkäyntikunnan kustannuksella. Työssäkäyntikunta joutuu kohtuuttomasti maksumieheksi monessa asiassa. Työssäkäyntikunnalle taloudellisesti raskaan epäkohdan poistamiseksi olisi sädettävä laki, jossa työntekijän kotipaikkakunnan verotoimisto tilittäisi erikseen sovittavalla tavalla $10 \%$ työntekijän maksamasta verotulosta työssäkäyntikuntaan.

\section{Kommentteja}

Luonnollinen henkilö ja erillisenä verovelvollisena verotettava kotimainen kuolinpesä suorittavat kunnallisveron kotikunnalle (VML 4 \$). Verovelvollisen luonnollisen henkilön kotikuntana pidetään VML 5 \$:n mukaan kuntaa, jossa hänellä on verovuotta edeltäneen vuoden lopussa katsottava olleen kotikuntalaissa tarkoitettu asuinpaikka. Sellainen järjestelmä, jossa osa veroista menisi henkilön työskentelykunnalle, on vaikea toteuttaa käytännössä; ainakin se vaatisi perusteellisen valmistelun.

68 Kirkollisverosta ks. mm. väitöskirja Erä-Esko Ensio, Beskattningsrätt och skattskyldighet för kyrkan i Finland. Hanken 2009. 
7 Kansalaisaloitteinen verotus - viihdettä vai demokratiaa?

\subsection{Kunnan vähimmäisveroprosentiksi $22 \%$}

Pasi Heiskasen 17.9.2018 vireille panemassa aloitteessa (10 kannattajaa) ehdotettiin lakia, jonka mukaan kaikki kunnat olisivat velvoitettuja keräämään tuloveroa vähintään $22 \%$. Niille kunnille, joilla ei ole lainkaan konsernivelkaa, voisi eduskunta tai valtioneuvosto hakemuksesta myöntää poikkeuksen vuodeksi kerrallaan.

Kunnat velkaantuvat vauhdilla, koska ne keräävät liian vähän tuloja alimitoitetuilla tuloveroprosenteillaan. Veroprosenttia korotetaan yleensä liian myöhään, liian vähän ja vasta pakon edessä. Ongelman perussyy on se, että kunnanvaltuustojen jäsenet eivät uskalla kannatuksen menetyksen pelossa tehdä vaikeiksi ja kipeiksi koettuja mutta tarpeellisia ja tärkeitä veronkorotuspäätöksiä tarpeeksi ajoissa ja riittävän suurina. Näin kokonaisvelan määrä kasvaa kasvamistaan ja syö tosiasiallisesti tulevaisuuden hyvinvointia ja toimintamahdollisuuksia. Mikäli aloite hyväksyttäisiin ja siihen liittyvät tarpeelliset lait säädettäisiin, helpottaisi se kuntataloutta oleellisesti ja nopeasti. Lisäksi kunnanvaltuustojen jäsenet voivat huokaista helpotuksesta, kun tarpeellinen vaikea päätös on jonkun muun tekemä. Lisäksi kuntien tuloveroprosentit todennäköisesti vakioituisivat tuohon $22 \%:$ :iin, jolloin kuntien välinen sairas kilpailu veroprosenteilla loppuisi.

\section{Kommentteja}

Kunnallisveroprosentit ovat nykyisin 20 \%:n luokkaa, ja sosiaali- ja terveystoimen menot ovat kuntien menoista noin puolet. Suomessa on pitkään ollut vireillä suuri sosiaali- ja terveydenhuollon uudistus, sote-uudistus. Keväällä 2019 kariutuneessa ehdotuksessa sote-vastuu olisi siirtynyt maakunnille ja rahoitus olisi tullut valtion tuloverosta. Kunnat olisi vastaavasti pakotettu alentamaan kunnallisveroprosenttiaan.

Pääministeri Antti Rinteen hallituksen ohjelmassa (s. 152) oli maininta, jonka mukaan hallitus käynnistää valmistelun maakuntaveron käyttöönotosta niin, että verorakenteen muutokset eivät aiheuta verotuksen kiristymistä (makkuntaverosta ks. jäljempänä luku 9). Pääministeri Sanna Marinin hallitus pyrkii samaan.

\subsubsection{Perintö- ja lahjavero kumottava}

Jukka Vuorisen 3.2.2015 vireille panemassa aloitteessa (4 934 kannattajaa) ehdotettiin perintö- ja lahjaverolakia ja tuloverolakia muutettavaksi niin, että peritystä omaisuudesta ei makseta perintö- eikä lahjaveroa perinnön saamisen yhteydessä, vaan vasta sitten, kun peritty omaisuus myydään tai siirretään muuten vastikkeellisesti. 
Aloitteessa viitattiin siihen, että perintöveron maksu aiheuttaa suuria vaikeuksia niin yksityisomaisuuden kuin yritystenkin perijöille. Yksityisomaisuuden kohdalla perijällä pitäisi olla usein kymmeniä tuhansia euroja käteisvarallisuutta perintöveron maksamiseksi ennen kuin perintöä on edes haluttaessa voitu realisoida. Veron maksu asettaa kansalaiset kohtuuttomaan tilanteeseen ja omaisuuden pakkomyynteihin verotuskäytännön takia. Luovutusvoittoverotuksen kautta perijällä olisi varaa maksaa veroa, kun peritystä omaisuudesta on ollut myös tuloja. Nyt vero joudutaan maksamaan tilanteessa, jossa tuloja ei ole vielä tullut. Lisäksi vero voidaan joutua suorittamaan omaisuudesta, jonka arvo voi laskea merkittävästi perimishetken ja realisointihetken välillä, jolloin todellinen perintöveroprosentti on merkittävästi ajateltua suurempi.

Yritysomaisuuden perijöille tilanne on vielä kohtuuttomampi. Esimerkiksi hyväkuntoisen pienyrityksen matemaattinen arvo verottajan näkökannan mukaan voi olla esimerkiksi noin miljoona euroa, jolloin perijä joutuu maksamaan 160000 euroa veroa. Hyvinkin pienillä yritysomaisuuksilla veron määrä on kymmeniä tuhansia euroja. Vero on maksettava, vaikka yritys myytäisiin. Vero aiheuttaa kohtuuttomia seurauksia pienyrityksille, koska se huomioi ainoastaan menneisyydessä kertyneet tuotot mutta ei lainkaan yritystoimintaan oleellisesti liittyvää suurta riskiä varsinkaan yrittäjän vaihtuessa. Käytännön tilanteissa perijä maksaa kymmenien tuhansien perintöverot yrityksestä, jota hän ei pysty hoitamaan ammattitaidon tai koulutuksen puutteen tai muiden olosuhteiden nopeiden muutosten takia. Yrityksen arvo on usein vanhan yrittäjän osaamisessa, ja perijän hallussa yrityksen arvo voi laskea merkittävästi ja yritys mennä konkurssiin, mutta silti olisi maksettava kymmenien tuhansien eurojen verot.

Uusi yrittäjä ei voi myöskään käyttää yrityksen omaisuutta maksaakseen perintöverojaan, eikä yrityksen omaisuus käy vakuudeksi henkilökohtaiselle lainalle, joka joudutaan ottamaan perintöveron maksamiseksi. Uusi yrittäjä joutuu perinnön takia käytännössä panttaamaan koko siihen asti hankitun omaisuutensa, että voisi vastaanottaa perinnön ja jatkaa yritystoimintaa. Lopputulos estää suoraan kaiken järkevän toiminnan yrityksen jatkamiseksi omin voimin tai edes niin kauan, että löytyy ostaja, joka kykenee säilyttämään ja jatkamaan yritystoimintaa niin, että työpaikat säilyvät. Nykyisin jopa konkurssi voi olla parempi tapa hoitaa peritty yritysomaisuus mainittujen seikkojen takia.

Suuremmilla perheyrityksillä nykyinen menettely on johtanut suomalaisten yritysten myymiseen kansainvälisille pääomasijoittajille tai pääomistajien ja heidän perheidensä muuttoon ulkomaille. Kumpikaan edellisistä ei edesauta millään tavalla suomalaisten yritysten hyvinvointia, taloudellista vakautta, kestokykyä eikä kasvuhalua.

Perintöveron tuotto saadaan korvattua luovutusvoittoverotuksen kautta vähintään samantasoisena kuin nykyinen perintöveron tuotto on. 
Christian Pundarsin 6.11.2017 vireille panema aloite perintö- ja lahjaverosta luopumiseksi sai 57489 kannattajaa ja siis ylitti edustakuntakäsittelyyn vaaditun 50000 kannattajan rajan. ${ }^{69}$ Esityksessä todettiin, että lahja- ja perintöverosta luovuttiin Ruotsissa jo vuonna 2004 ja että Norja luopui verosta vuonna 2014. Lahjavero on yhteiskunnalle ongelmallinen. Se aiheuttaa ongelmatilanteita avio- tai avopuolison, rekisteröidyn parisuhteen osapuolen tai muun läheisen henkilön kuollessa. Perintövero on myös moraalisesti ongelmallinen; lähiomaisen kuoleman yhteydessä valtio rankaisee surijaa vaatimalla veroa yhteisestä omaisuudesta.

Perintöveron seurauksena moni siirtää omaisuuttaan ulkomaille välttääkseen veronkantoa. Lisäksi vero kohtelee kansalaisia epäoikeudenmukaisesti ja epätasaisesti. On tapauksia, joissa perijällä ei ole pääomaa veron maksamiseksi ja hän on näin pakotettu myymään yhdessä hankittua omaisuutta.

Vero vaikuttaa myös yrittäjyyteen; sillä estetään tai ainakin vaikeutetaan pitkäaikaista yritystoimintaa, kyseinen vero vaikeuttaa pk-yritysten sukupolvenvaihdoksia ja näin vaikuttaa suoranaisesti yritystoiminnan jatkuvuuteen. Sukupolvenvaihdokset pitkittyvät ja näin yrittäjien keskiikä nousee. Sukupolvenvaihdokset ovat jo ennestään vaativia ja vaikeasti toteutettavissa, perintövero vaikeuttaa ennestään hankalaa prosessia.

Perintövero sinällään on turhan kova, se kohdistuu jo ennestään verotettuun tuloon. Nämä verot edistävät eriarvoisuutta, eivät vähennä. Perintö- ja lahjavero on yksi Suomen talouden kehittymisen estokiviä. Veron poistaminen luo uusia mahdollisuuksia luomalla ja säilyttämällä työpaikkoja ja edistämällä kasvua, näin voidaan myös parantaa koulutuksen ja hoitoalan edellytyksiä - silloin verotus on järkevämpää ja veroihin käytetyt varat voidaan ohjata talouden kasvuun.

\section{Kommentteja}

Christian Pundarsin aloite perintö- ja lahjaverosta luopumiseksi siis ylitti edustakuntakäsittelyyn vaaditun 50000 kannattajan rajan. Aloite jätettiin eduskuntakäsittelyyn 28.9.2018, ilmoitettiin täysistunnossa 3.10.2018 ja lähetettiin valtiovarainvaliokuntaan.

Valtiovarainvaliokunnan verojaosto hankki aloitteesta lausunnot seuraavilta: OTT Pauli K. Mattila, lainsäädäntöneuvos Jukka Vanhanen (valtiovarainministeriö), emeritusprofessori Raimo Immonen, emeritusprofessori Heikki Niskakangas, lakiasiainjohtaja Vesa Korpela (Veronmaksajain Keskusliitto), veroasiantuntija Tero Honkavaara $(\mathrm{EK})$, vero-oikeuden dosentti Timo Räbinä, tutkimusjohtaja

$69 \quad 50$ 000:n kannattajan raja ylittyi 19.3.2018. 
Essi Eerola (VATT), pääekonomisti Ilkka Kaukoranta (SAK), ekonomisti Seppo Nevalainen (STTK), Simo Valtti (Perheyritysten Liitto), professori Juha Lindgren (Vaasan yliopisto) ja tutkimusjohtaja Mika Maliranta (ETLA). Lausunnonantajat vastustivat perintö- ja lahjaverosta luopumista ainakin lyhyellä aikavälillä. Yleisesti korostettiin sitä, että perintö- ja lahjavero on talouselämän kannalta vähemmän haitallinen kuin sille vaihtoehtoiset verot. Viitattiin myös siihen, että perintö- ja lahjaveron tuotto voi tulevaisuudessa nousta, kun perittävät jättävät entistä enemmän varallisuutta ja perillisten määrä vähenee.

Valtiovarainvaliokunta päätti 27.11.2018 hallituspuolueiden äänin 12-9 (enemmistössä keskustalaiset, kokoomuslaiset ja siniset), ettei tästä aloitteesta tehdä mietintöä. Näin kai tapahtui, koska perintöja lahjaveroa ei voida noin vain poistaa, vaan se vaatii laajemman veropoliittisen selvityksen; kysymyksessä on osa verojärjestelmää, ja asia vaikuttaa myyntivoittoverotukseen ja välillisesti tuloverotukseenkin. Päätökseen saattoi vaikuttaa eduskuntavaalien läheisyyskin. Jos valiokunta olisi todennut mietinnössään perintöveron tarpeelliseksi, kokoomuksen ja keskustan ehdokkaiden olisi ollut vaikea vaalitilaisuuksissa vaatia perintöveron poistamista. ${ }^{70}$ Pelättiin ehkä myös, että perintöverokeskustelu olisi jälleen nostanut esille epäilyn siitä, että perintö- ja lahjaverolain sukupolvenvaihdoshuojennuksissa on perustuslaillisia yhdenvertaisuusongelmia.

Valtiovarainvaliokunta ei kirjoittanut asiasta mietintöä, minkä vuoksi asian käsittely perustuslain 49.1 \$:n mukaisesti raukesi valtiopäivien päättyessä 16.4.2019. Vaikka perintö- ja lahjaveroa ei voida noin vain kumota, valiokunnan ratkaisua on syytä arvostella. ${ }^{71}$ Valiokunta olisi esimerkiksi voinut antaa mietinnön ja esittää asetettavaksi toimikunnan selvittämään, voitaisiinko ja miten perintö- ja lahjavero korvata muuta verotusta kehittämällä.

Uutissuomalaisen eduskuntaryhmille tekemän kyselyn mukaan (ks. esim. Yle Uutiset 30.10.2019) vain RKP luopuisi suoraan perin-

70 Simo Sipola, Verokirja (2019) s. 22, jossa viitataan Helsingin Sanomiin.

71 Nimimerkki "Pyyhitään hanuria" kirjoitti Kalevassa 15.12.2018: "Suomessa kansalaisaloitteet ja mielenosoitukset ovat lähinnä vitsi. Hallitus nimittäin pyyhkii sitä kuuluisaa hanuria HALLITUKSELLE epämieluisilla aloitteilla. [--] Päättäjät siis ovat sitä mieltä, että tyhmät suomalaiset mitään demokratiaa tarvitse.” 
töverosta. RKP korvaisi perintöveron luovutusvoittoverolla, joka maksetaan, jos perintö myydään eteenpäin. Kokoomus selvittäisi samaa asiaa. Muista puolueista osa huojentaisi ja osa kiristäisi veroa. Kristillisdemokraatit tekisi perintöveroon huojennuksia yritysten sukupolvenvaihdoksiin. Vihreät puolestaan kiristäisi perintöveron progressiota. Perintöverosta luopumisesta hyötyisivät SDP:n mukaan eniten rikkaat, ja vasemmistoliitto näkee veron poistamisen omistamisen suosimisena työnteon kustannuksella. Keskusta ei kannata korotuksia perintöveroon. Kyselyyn vastasivat muut paitsi perussuomalaiset ja Liike Nyt. Vaikuttaa siltä, että juuri kukaan ei tunne edellä luvussa 3.6.4 perintöveron poistamiseksi esittämääni yhdistelmämallia.

\subsubsection{Asunnon varainsiirtoveron poistaminen tai muuttaminen määräsuuruiseksi}

Pertti Savirannan, Anne Savirannan, Tapio Martikaisen, Linus Savirannan ja Rasmus Savirannan 13.10.2019 vireille panemassa aloitteessa (570 kannattajaa 30.11.2019 mennessä) ehdotetaan varainsiirtoverolain muuttamista verovapauden osalta niin, että lakiin lisätään pykälä tai muutetaan pykälää 11 ja 25 verovapaudesta siten, että verovapaus tulisi koskemaan laajemmin kaikkia yksityishenkilöitä ja yksityishenkilöä koskevaa asuntoosakeyhtiön osakkeen tai asuinkiinteistön luovutusta. Vaihtoehtoisesti lakiin olisi lisättävä pykälä tai muutetaan em. pykäliä siten, että varainsiirtovero on yksityishenkilönä tehtyjen asunto-osakeyhtiön osakkeen tai asuinkiinteistön luovutuksen osalta määräsuuruinen sitomatta sitä asunnon luovutushintaan.

Hallitus, kansanedustajat, yksityiset henkilöt sekä useat muut eri tahot ovat olleet huolissaan asumiskustannusten noususta sekä yksityishenkilöiden velkaantumisesta. Asumiskustannuksia lisää omistusasuntojen varainsiirtovero, joka on $2 \%$ osakeyhtiömuotoisen asunnon ja $4 \%$ asuinkiinteistön luovutushinnasta. Asuntojen hintojen nousun myötä, etenkin muuttovoittoisissa kunnissa, varainsiirtoveron osuus asunnon hankintamenoista on absoluuttisesti noussut johtuen prosenttiperustaisesta varainsiirtoverosta. Etenkin pääkaupunkiseudulla ja varsinkin Helsingissä muutos on merkittävä. Asumiskustannuksia nostavat myös muutokset asuntolainan verovähennysoikeuden poistumiseen vuonna 2020.

Työllisyyden näkökulmasta asuntomarkkinoiden jäykkyys, joka johtuu osittain korkeista asunnon myyntiin ja ostamiseen liittyvistä sivukuluista, mukaan lukien varainsiirtovero, rajoittaa osaltaan työvoiman siirtymistä työn perässä paikkakunnalta toiselle. Velkaantumisen näkökulmasta velkaantumista lisää se, että ensiasunnoksi ostetaan liian suuri asunto 
käyttötarpeeseen nähden. Ensiasunnossa halutaan asua mahdollisimman kauan, jolloin vältytään asunnon vaihdosta aihetuvasta varainsiirtoveron maksusta. Varainsiirtoveron poistaminen tai asettaminen määräsuuruiseksi vähentäisi asumiskustannuksia ja sitä kautta yksityishenkilöiden velkaantumista, lisäisi asunto- ja työmarkkinoiden dynamiikkaa sekä osaltaan välillisesti parantaisi työllisyyttä.

\section{Kommentteja}

Edellä tämän kirjan luvussa 5 on käsitelty varainsiirtoveron menneisyyttä ja tulevaisuuden kehittämisvaihtoehtoja. Realistinen lainsäädäntövaihtoehto voisi olla malli, jossa varainsiirtoveroa ei kokonaan poisteta vaan se alennetaan esimerkiksi $1 \%$ :ksi ja samalla luovutaan ensiasunnon varainsiirtoverovapaudesta. Hyvin pienellä verokannalla on vain hyvin pieni vaikutus verovelvollisten käyttäytymiseen. Juuri se olikin perusideoita 1600-luvulla verokeksintökilpailun voittaneessa leimaverossa, jonka perillinen varainsiirtoveromme on.

\subsubsection{Kiinteistöveron kohtuullistaminen, järkiperäistäminen tai poistaminen}

Alpo Kekkosen 22.10.2014 vireille panemassa aloitteessa (14 kannattajaa) ehdotettiin kiinteistöveron kohtuullistamista, koska nykyinen kuntien määrättävissä oleva kiinteistöverojärjestelmä on täysin kohtuuton ja eriarvoistava eri kunnissa.

Esimerkiksi Lappeenranta perii veroa mm. metsästysmajoista, tanssilavoista ym. talkoilla rakennetuista ja ylläpidettävistä kiinteistöistä; suuri osa metsästysseuran jäsenmaksusta menee kiinteistöveroon. Onko se oikein? Sen sijaan naapurikunta Luumäki ei peri veroa mainituista kiinteistöistä, koska se on aivan oikein katsonut olevan kohtuutonta verottaa talkootyötä. Laissa tulisi tarkemmin määritellä, mitä kiinteistöjä voidaan verottaa, jolloin yleishyödyllisten seurojen ja yhdistysten kiinteistöt rajattaisiin veron ulkopuolelle.

Urpo Mä̈̈tän 9.3.2018 vireille panemassa aloitteessa (14 kannattajaa) ehdotettiin kiinteistöverotuksen järkiperäistämistä ja kiinteistöverotuksen päivittämistä nykyisyyttä vastaavaksi. Kiinteistöveroa on määrättävä todellisen reaaliarvon mukaan. Maksettu kauppahinta kiinteistöistä on oltava arvostusperuste purkutuomittujen tai pakkohuutokaupattavien kiinteistöjen verotuksessa. Myös se, että kiinteistöverotus ei ota huomioon kiinteistöjen sijaintia Suomessa, on muutettava. Kiinteistöverotus perustuu arvoihin, jotka ovat kestämättömät nykyisiin olosuhteisiin ja käytäntöihin nähden. Kaikkialla Suomessa on tuhansittain jo tyhjillään 
olevia ja tyhjilleen jääviä rakennuksia ja maa-aloja, joiden reaalinen arvo on murto-osa kiinteistöverottajan arvostusperusteista.

Jukka Niemen 20.4.2018 vireille panemassa aloitteessa (kannattajia 1462) vaadittiin ensisijaisesti kiinteistöveron poistamista. Ellei kiinteistöveron poistamista nähdä mahdolliseksi, aloitteessa esitettiin toissijaisena toimenpiteenä kiinteistöverotuksen laajentamista koskemaan kaikkea maa-, metsä- ja kiinteistöomaisuutta yhdenvertaisesti. Tällöin kiinteistöverotuksen piiriin tulisi liittää mm. metsäkiinteistöt sekä kaavoitetut vapaa-ajan asuntojen rakennuspaikat siltä osin kuin ne ovat nykyään vapautettuja kiinteistöverosta.

Perustuslain tarkoituksena on tuottaa yhdenvertaisia ja syrjimättömiä menettelyjä ja turvata omaisuuden suojaa. Kiinteistöverotus on karkea poikkeus omaisuuden verokäsittelyssä. Omaisuuteen liittyvä verotus ei koske mm. pörssi- tai muitakaan osakkeita eikä talletuksia eikä metsäkiinteistöjä, ja myös monet vapaa-ajan rakennuspaikat ovat vapautettuja kiinteistöverosta. Tasapuolisena omaisuuden verottamisen lähtökohtana tulee olla, että mistään omistamisesta ei veroteta, vaan verotus kohdennetaan omaisuuden tuottamiin tuottoihin, kuten vuokratuloihin, osinkotuloihin, puunmyyntituloihin tai omaisuuden käytöstä syntyviin haittoihin määrittämällä näiden verojen tasot siten, että tarpeellinen verokertymä omistuksiin liittyen saavutetaan.

Perusteeksi edellä kuvatusta periaatteesta poikkeavalle kiinteistöverolle on monesti todettu, että kiinteistöjen verottaminen on helppoa ja mahdollista, koska kiinteistöjä ei voida siirtää ulkomaille verotuksen välttämiseksi. Jos kiinteistöveroa peritään, tulee perimisen koskea kaikkea maa-, metsä- ja kiinteistöomaisuutta tasapuolisesti perustuslain määräämää yhdenvertaisuusperiaatetta noudattaen.

Verottaja ja valtiovalta ovat ilmaisseet tavoitteeksi, että kiinteistöveron tulisi perustua yhä tarkemmin kiinteistön markkina-arvoon, mutta kiinteistöverotuksen eriarvoistavien piirteiden korjaamistarve on jäänyt vaille huomiota.

Kiinteistövero on ymmärrettävästi poliittisille päättäjille erinomaisen houkutteleva verotuksen ja verojen korotuksen kohde, sillä monikaan kansalaisista ei todennäköisesti tunnista sitä, että kaikissa asumismuodoissa asukkaat ovat lopulta kiinteistöverotuksen maksajina. Vaikka verottaja ei perikään veroa suoraan kaikista asunnoista vaan asuntoyhtiöiltä ja muilta kiinteistöjen omistajilta, siirtävät nämä veron luonnollisesti suoraan vuokriin ja yhtiövastikkeisiin. Pääkaupunkiseudulla verosta on kehittynyt jo merkittävä kuluerä asumiselle ja yhdessä muiden korkeiden asumiskustannusten kanssa se toimii esteenä tarvittavan työvoiman saannille pääkaupunkiseudulle. Samalla kun omaisuuden verotusarvoja nostetaan kohti ns. markkina-arvostusta, ongelma kärjistyy entisestään, jos epäkohtaa ei korjata pikaisesti. 
Viime vuosina kiinteistöjen omistusta on jo päädytty verottamaan yhä voimakkaammin. Kiinteistövero onkin noussut jo merkittävästi olemassaolonsa aikana. Esimerkkinä yhden samanlaisena pysyneen asumiskiinteistön vero on noussut nimellisarvoltaan jo noin seitsemänkertaiseksi vuodesta 1997 lukien.

Eräille poliittisille puolueille kiinteistövero on erityisen mieluinen, koska siirtämällä verotuksen painopistettä progressiivisesta tuloverotuksesta kiinteistöveroon saadaan verotaakan rakennetta ohjattua kohti tasaveroa. Kiinteistöverotuksen korotusten kautta saatavien verotuottojen avulla tämä on luonnollisesti poliittisesti helpompaa kuin tuloveroasteikkojen progression säätäminen suurituloisten veroja keventäen ja alempien ja keskituloisten tuloveroasteikkoja korottaen.

Kiinteistöveron jatkuva korottaminen ja pääkaupunkiseudulla käyttöön otettu rakentamattoman tontin verottaminen normaaliin kiinteistöverotasoon nähden jopa nelinkertaisesti saattaa pakottaa omakotitalon omistajan luopumaan kodistaan tai kodin rakentamiseksi hankitusta tontista.

Perintö- ja lahjaveroja on kritisoitu viime aikoina voimakkaasti. Niitä on vaadittu poistettaviksi mm. epäoikeudenmukaisina. Verrattaessa kiinteistöveron ja perintö- ja lahjaverojen olemuksia keskenään voidaan kuitenkin helposti todeta, että kiinteistövero on näistä selkeästi epäoikeudenmukaisin. Se tulisikin poistaa ennen kuin voidaan edes harkita vakavasti perintö- ja lahjaveron poistamista. Näin siksi, että kiinteistöverotuksessa verotus kohdentuu verotettavan omilla jo verotetuilla ansioilla ja omistuksilla hankittuun omaisuuteen, kun taas perintö- ja lahjaveron yhteydessä on kyse toisen omistuksessa olleen omaisuuden vastikkeettomasta siirrosta. Lisäksi kiinteistöveroa maksetaan joka vuosi ja siten kiinteistöverona maksettu kokonaisvero ylittää varsin nopeasti sen veromäärän, joka vastaavan suuruisesta perintöomaisuudesta maksetaan vain kertaverona perintöveroa. Perintö- ja lahjaveroa olisikin ehkä tarkoituksenmukaista jopa korottaa, mikäli verokertymään jäisi uusien haittaverojen toteuttamisen jälkeen vielä säätötarvetta kiinteistöverotulojen poistuessa; valtiohan joutuisi korvaamaan kunnilta saamatta jäävän kiinteistöveron muulla verotuksella.

Kiinteistöveron poistaminen lisää laaja-alaisesti ja merkittävästi kotimaista kysyntää, ja sillä puolestaan on merkittävä vaikutus työllisyyteen. Ehdotettu toimenpide tukisi siis toteutuessaan hallituksen tärkeimmän kehitystavoitteen toteutumista.

Kiinteistöverotus ei nykyisellään kosketa kaikkia kiinteistöjä yhdenvertaisesti vaan jättää mm. metsäkiinteistöt ja lukuisat kaavoitetut vapaa-ajan rakennuspaikat kokonaan verotuksen ulkopuolelle. Metsäkiinteistöjen pitämistä poissa kiinteistöverotuksen piiristä on perusteltu monesti sillä, että metsäkiinteistön tuotosta verotetaan puun myynnin yhteydessä. 
Tämä on toki totta, mutta vastaavasti maksetaan myös asuinkiinteistön vuokratuotosta erikseen veroa.

Metsäkiinteistöjen verotuksessa käytettävä markkina-arvo tulisi määrätä erikseen maapohjan ja sillä kulloinkin olevan puuston osalle vastaavasti kuin asuinkiinteistöjen osalta määritetään markkina-arvot sekä tontille että rakennuksille. Kiinteistöverossahan on kyse omistamisen verottamisesta, ja tämä kiinteistöomistamisen verottaminen tulisi tehdä yhdenvertaisin periaattein, jos sitä halutaan ylipäätään tehdä joidenkin kiinteistöomaisuuslajien osalta. Tärkeää on huomata, että puunmyynnin osalta tapahtuva verotus koskettaa tuottoa, ei omistamista. Jos tätä metsäomaisuuden verottamista ei voida pitää poliittisesti tai muutoin sopivana, tulee päätöksentekijöiden vakavasti harkita sitä, miksi taajama-alueella omistetusta omasta asunnosta ja siihen liittyvästä maapohjasta tulisi maksaa erittäin korkeaan markkina-arvostukseen perustuvaa omistusveroa, vaikka kiinteistöä ei olla aikeissakaan myydä vaan asunto on välttämätön perustarve ja myös perusoikeus.

Myös lukuisille kaavoitetuille vapaa-ajan asuntojen rakennuspaikoille säädetty vapautus kiinteistöverosta loukkaa verotuksen yhdenvertaisuutta. Lisäksi sillä ylläpidetään markkinoilla keinotekoista alitarjontaa vapaa-ajan rakennuspaikoista. Tämä puolestaan on osaltaan johtanut rakennuspaikkojen hintatason nousuun ja paikoittain selkeään vapaa-ajan rakennuspaikkojen pulaan.

Analogiseen tilanteeseen, pääkaupunkiseudun asuntopulaan, on sen sijaan luotu muusta verotuksesta radikaalisti poikkeava ja hyvin epätasa-arvoinen korotettu "sakko"-vero. Pääkaupunkiseudun kunnat on lakisääteisesti määrätty korottamaan rakentamattomien tonttien kiinteistöveroprosentteja jopa nelinkertaiseksi ns. normaaliin verotasoon nähden. Mikäli korotetun kiinteistöveron kohteena olevan rakentamattoman tontin omistaja ei halua tai voi rakentaa tontilleen tai halua myydä sitä, joutuu hän maksamaan kiinteistöverona suuruusluokaltaan koko omistamansa tontin arvon jokaista 25 vuoden omistusjaksoa kohden. Näinkö oikeusvaltiossa verotetaan jatkossakin?

Jos ensisijainen esitys kiinteistöverosta luopumisesta ei tulisi hyväksytyksi, on rakentamattomille vapaa-ajan rakennuspaikoille syytä harkita vastaava pakottava lainsäädäntö korotetun kiinteistöveron perimiseksi ainakin niille alueille, joilla on pulaa vapaa-ajan asuntojen rakennuspaikoista. Näin siis yhdenvertaisuusperiaatteen näkökulmasta tulisi menetellä.

Jos esitys kiinteistöveron luopumisesta ei tule hyväksytyksi, kiinteistöverotuksen laajentaminen kattamaan kaikki kiinteistöomaisuus parantaisi osaltaan merkittävästi kiinteistöverotuksen tasapuolisuutta ja ohjaisi samalla kiinteistöveron tason säätämistä nykyistä oikeudenmukaisemmin.

Verotason oikeudenmukaisuuden ja kohtuullisuuden paraneminen johtuisi siitä, että kiinteistövero kohdentuisi kaikkien suurten puoluei- 
den edunvalvontapiiriin nykyistä kattavammin ja oikeudenmukainen ja kohtuullinen verotaso määräytyisi todennäköisesti sen mukaan, kuinka suureksi maa- ja metsäpohjan verotus voitaisiin ylipäätään nostaa. Kiinteistöverotuksen kohtuullisuustaso on nyt ylitetty ilmeisesti sen vuoksi, että mikään puolue ei näytä olevan huolissaan nykyisen kiinteistöverotuksen tasosta. Melkeinpä päinvastoin, verotason kiristäminen nähdään useimmissa puolueohjelmissa perusteltuna tai jopa tavoiteltavana suuntana. Kiristykselle ei nykyisellään näytä olevan minkäänlaista poliittista rajaa, ja kun samojen puolueiden edustajat tulkitsevat perustuslakivaliokunnassa kiinteistöverotuksen perustuslainmukaisuutta, myöskään perustuslaillista ongelmaa ei kiinteistöverotukselle ja sen eriarvoistaville piirteille näyttäisi olevan näköpiirissä.

Laajempi kiinteistöveropohja pitäisi kiinteistöveroprosentit myös alhaisempina tavoiteltaessa samaa verokertymää koko kiinteistöverotuksen osalta.

\section{Kommentteja}

Nettotuloon perustuva yleinen tuloverotus on verohistoriassa varsin uusi keksintö. Suomessa sen voidaan katsoa alkaneen 1800-luvun lopulla ja silloinkin haparoiden. Sitä edelsivät kiinteistöjen ja elinkeinotoiminnan tuottoverot. Nykyinen kiinteistöverolakimme tuli voimaan vuoden 1993 alussa. Uudella kiinteistöverolla korvattiin neljä vanhaa veroinstituutiota: asuntotulon verotus, kiinteistöjen harkintaverotus, katumaksu ja manttaalimaksu.

Asuntotulon verotus perustui asuntotulon verottamisesta annettuun lakiin. Asuntotulolla oli 1970-luvun alussa korvattu vanha oman asunnon asuntoetuverotus. Perusteena oli omistusasunnosta saatava laskennallinen tuotto. Vaikka omasta asunnosta saatava etu oli pitkään ollut veronalaista tuloa, sen verotus ei ollut saavuttanut yleistä hyväksyntää. Omistusasunnosta saatavaa laskennallista hyötyä ei verovelvollisten ollut helppo mieltää tuloksi samalla tavalla kuin rahana saatuja tuloja.

Harkintaverotus oli ollut historiallisesti kunnallistalouden kannalta tärkeä instituutio, joka osaltaan oli turvannut kunnille vakaat verotulot. Harkintaverotuksen lainsäädännöllinen perusta ei kuitenkaan vastannut verolainsäädännön täsmällisyysvaatimuksia. Harkintaverotuksen hyväksyttävyyttä oli heikentänyt se, että vero ei kohdistunut todelliseen tuloon vaan oli tuottoverotyyppinen takuuvero. 
Katumaksun tarkoituksena oli ollut saattaa kiinteistöjen omistajat ja heihin verrattavat kiinteistöjen haltijat vastaamaan osasta heitä hyödyttäviä kadunpitomenoja. Kadunpitomenojen kustantamista ei voitu käytännössä toteuttaa pelkästään etuperiaatteen perusteella.

Manttaalimaksu oli liittynyt manttaalikuntien rahoitukseen. Tehtävissä ja toiminnassa tapahtuneet muutokset olivat olennaisesti heikentäneet manttaalikuntien verotusoikeuden perusteita. Verotusoikeuden pysyttämistä organisaatiolla, jonka päätöksenteossa äänivallan suuruus määräytyi maanomistuksen mukaan, voitiin myös pitää nykyistä oikeuskäsitystä vastaamattomana.

Kiinteistövero määräytyy kiinteistön arvon perusteella, ja kunta saa määrätä kiinteistöille veroprosentit lakisääteisissä rajoissa. Kiinteistövero ei perustu tuloveron tavoin suoraan verovelvollisen maksukykyyn, vaan kiinteistövero on kaavamainen veroesineen ulkoisiin tunnusmerkkeihin perustuva "objektivero". Kiinteistöverossa näkyy vahvemmin etuperiaate, joka nykyisin liitetään enemmän maksuna pidettävään suoritukseen kuin veroon.

Vaikka kiinteistöveroa voidaan arvostella mm. kansalaisten ostovoiman heikentämisestä, sille ennustetaan Suomessakin loistavaa tulevaisuutta, koska se ei anna mahdollisuutta kansainväliseen veropakoon. Kiinteistöthän eivät juuri voi siirtyä valtiosta toiseen muutoin kuin sotien seurauksena. Kiinteistöveron korostaminen merkitsee historiallista paluuta ajassa taaksepäin.

Pääministeri Antti Rinteen hallituksen ohjelmassa (s. 28) päämääränä oli uudistus, jossa kiinteistöverotusarvot kokonaisuutena heijastavat nykyistä paremmin käypiä arvoja mutta uudistus ei saa johtaa kohtuuttomiin muutoksiin kenenkään kiinteistöverossa. Sama tavoite on pääministeri Sanna Marinin hallituksella. Uudistuksen yhteydessä selvitetään, miten verovelvollisen alhainen maksukyky voidaan ottaa huomioon; kiinteistöverotusta ei laajenneta maa- ja metsätalousmaahan.

\subsubsection{Kaivosvero säädettävä}

Marko Järvelinin 16.2.2013 vireille panemassa aloitteessa (3 578 kannattajaa) esitettiin kaivosveron käyttöönottoa Suomessa.

On täysin järjetöntä, että kallioperästämme kaivetaan uusiutumattomat luonnonvarat ilman että me suomalaiset hyödymme siitä käytännössä 
millään tavalla. Kaivosteollisuuden tuomista työpaikoista saatavat edut ovat pientä sen rinnalla, mitä kaivosveron tuotto ja sen oikeaoppinen rahastoiminen antaisivat meille pitkäaikaisena hyötynä (esim. Norjan öljyrahasto). Verolla tulisi olemaan suuri kansantaloudellinen merkitys. Ympäristönäkökohtaakaan ei missään tapauksessa saa unohtaa. Ei voi olla oikein, että yksityisomistuksessa olevat kaivosyhtiöt vievät maaperämme rikkaudet ulkomaille ja jättävät siitä rahan sijasta korvaukseksi saastunutta maata.

Juha Hämäläisen 6.3.2015 vireille panemassa aloitteessa (1908 kannattajaa) esitettiin louhintaveron käyttöönottoa suomalaisessa kaivostoiminnassa.

Veron määrä sidottaisiin louhitun maa-aineksen määrään. Verolla korvattaisiin kunnille ja valtiolle kaivostoiminnan aiheuttamia kuluja.

Suomen kaivoslainsäädäntö on täysin retuperällä, vaikka jo kuudesosa maamme pinta-alasta on tavalla tai toisella varattu kaivosteollisuudelle. Osa varauksista kohdistuu myös Natura-alueelle. Kun lisäämme yhtälöön CETA- ja TTIP-sopimukset, jotka jatkossa investointisuojan turvin voivat aiheuttaa sen, ettei lainsäädäntöä enää voi muuttaa, niin nyt on korkea aika puuttua asiaan.

Talvivaaran tapaus oli katastrofi. Meillä ei ole varaa siihen, että vastaavia katastrofeja tapahtuisi kymmeniä lisää. Meillä ei ole myöskään varaa siihen, että ulkomaiset kaivosyhtiöt vievät rikkaudet ja jättävät siitä korvaukseksi saastuneen maaperän, joka pitää verovaroin puhdistaa. Siinä ei ole kyse pelkästään rahasta, vaan sellaisista arvoista, joita ei voi rahalla mitata.

Meillä ei ole myöskään varaa siihen, että jokin ulkomaisista toimijoista nostaa syytteen Suomen valtiota vastaan. Näistä välimiesoikeudenkäynneistä on maailmalla riittävästi esimerkkejä, kuinka useampikin valtio on saanut miljardien suuruiset maksuvaateet. Tämä on tietyntyyppisten monikansallisten yritysten uutta ansaintalogiikkaa, jonka vapaakauppasopimukset mahdollistavat. Meillä ei kerta kaikkiaan ole varaa sellaiseen.

Säilyttäkäämme Lappi matkailulle ja huolehtikaamme siitä, ettei Suomesta tule Ruhrin kaltaista kuolemanlaaksoa. Olemattomien kaivoslakien vuoksi tätä maata kutsutaan jo nyt Pohjolan Kongoksi. Älkäämme tehkö siitä oikeasti sellaista. Louhintavero ei vielä yksin takaa, etteivätkö pahimmat uhkakuvat toteutuisi, mutta ainakin se pienentää riskiä ja toivottavasti herättää kansanedustajat pohtimaan myös muuta asiaan liittyvää lainsäädäntöä.

\section{Kommentteja}

Kaivosveron säätämistarve on ajankohtainen keskustelunaihe. Esimerkiksi Finnwatch on vuonna 2016 julkaissut asiasta Lauri Finérin ja Matti Ylösen raportin "Kaivosverotuksen kehitysmaa. Selvitys 
metallimalmeja louhivien kaivosyhtiöiden veronmaksusta ja verosuunnittelusta Suomessa”.

Vuonna 2017 vihreät teki kaivoksiin kohdistuvasta louhintaverosta aloitteen, jonka mukaan kaivosyhtiöiltä perittäisiin veroa 40 senttiä jokaista louhittua maa-ainestonnia kohden. Kaivosvero myös mainittiin SDP:n toukokuussa 2018 julkistamassa ohjelmassa "Verotus tulevaisuuden hyvinvointivaltiossa". Vasemmistoliiton verouudistusesityksessä elokuussa 2018 ehdotettiin kaivostoimintaan veroa, joka määräytyisi joko louhitun maa-aineksen määrän tai malmin arvon taikka näiden molempien mukaan.

Kaivosveroa on vastustettu mm. siksi, että Suomessa kaivosyhtiöt maksavat korvauksia suoraan maanomistajille. Veron on myös katsottu vaarantavan kaivosyhtiöiden toiminnan kannattavuutta ja alan työllisyyttä.

Tämä vero ei olisi uusi keksintö. Kaivosveroja on kannettu meillä jo Ruotsin ja Venäjän vallan aikana, vaikka ei niitä silloin osattu kaupitella ympäristö-, haitta- tai windfall-verojen nimellä. Ennen kuin yleinen tuloverotus otettiin käyttöön, kaivosalalta perittiin monia tuottoverotyyppisiä elinkeinoveroja. Esimerkiksi rautakymmenyksessä veron perusteena olivat viime vaiheessa masuuniuunin työpäivät. Ruukin vasaraverossa vero oli yleensä $1 \%$ vuosituotannon arvosta. Kupari- ja tinaverossa vero pohjautui samoille periaatteille kuin rautakymmenysverossa. Vuoden 1883 kaivossäännöksissä määrättiin valtiolle suoritettavasta $5 \%$ :n suuruisesta kulta- ja hopeaverosta. Sellaisesta kullasta, jota ei saatu louhimalla vaan huuhtomalla, oli maksettava valtiolle vuotuinen maksu, jonka suuruuden senaatti päätti.

Sodan jälkeen 1940-luvun loppupuolella meillä säädettiin valmisteveroksi luokiteltu kultavero. Laki kotimaassa tuotetusta kullasta suoritettavasta verosta tuli voimaan 15.12.1945 ja laki kotimaassa tuotetusta hopeasta 1.7.1947. Näiden verojen säätämisen taustalla vaikuttivat sodan aiheuttamista poikkeuksellisista oloista johtuneet syyt, jotka eivät kuitenkaan olleet suoranaisesti valtiontaloudellisia vaan liittyivät kotimaassa tuotetun kullan ja hopean hintasäännöstelyyn ja keinottelun ehkäisemiseen. Veroilla pyrittiin vaikuttamaan kullan ja hopean hintakehitykseen. Kultaverosta ja hopeaverosta annettu lainsäädäntö kumottiin vuoden 1949 huhtikuun alusta, kun näille veroille asetetut tavoitteet oli saavutettu. 
Pääministeri Antti Rinteen hallituksen ohjelman mukaan, joka oli samanlainen kuin pääministeri Sanna Marinin hallituksen ohjelma, kaivokset siirrettäisiin sähköveroluokkaan I ja ne poistettaisiin energiaveroleikkurin piiristä. Samoin selvitetään mahdollisuutta ottaa käyttöön erillinen kaivosvero, jotta maaperän kaivannaisista saadaan yhteiskunnalle kohtuullinen korvaus. Selvitetään myös mahdollisuuksia verottaa kaivosoikeuksien myyntivoittoja Suomessa silloinkin kun kaivosoikeudet ovat ulkomaisten yhteisöjen omistuksessa.

22.1.2019 tehty kansalaisaloite kaivoslain muuttamisesta sai 58992 kannattajaa, ja se on edennyt eduskunnan käsiteltäväksi. Tuota kansalaisaloitetta koskeneessa lähetekeskustelussa lokakuussa 2019 myös kaivosvero sai kannatusta hallituspuolueiden lisäksi oppositioltakin. Esimerkiksi lappilaisen kokoomusedustajan Heikki Aution mielestä Suomeen pitäisi saada kaivosvero sellaisena, että se tuloutuu kaivoksen sijaintipaikkakunnalle. Järkevintä hänen mielestään olisi, että vero perustuisi louhitun malmin arvoon. ${ }^{72}$

\subsubsection{Alkoholiverotusta vähennettävä}

Jaakko Markkasen ja Onni Hytösen 28.4.2014 vireille panemassa aloitteessa (19 kannattajaa) esitettiin alkoholiveron poistamista anniskelumyynnissä.

Alkoholin anniskelumyynti vuonna 2013 oli vähentynyt 3,0 \% edellisestä vuodesta. Alkoholin anniskelumyynnillä on merkittävä taloudellinen vaikutus Suomen matkailu- ja ravintola-alalle. Alkoholiveron poistaminen anniskelumyynnistä alentaisi anniskelumyynnissä alkoholijuomien hintoja ja oletettavasti siirtäisi alkoholimyyntiä vähittäismyynnistä anniskelupaikoille. Vaikutukset alalle olisivat positiiviset, ja ne tukisivat suoraan suomalaista työllisyyttä ja yrittäjyyttä. Anniskelupaikkojen asiakkaiden määrän kasvua hyötyisivät ravintola-alan lisäksi myös mm. ravintoloissa esiintyvät taiteilijat, kuten muusikot, koomikot ja monet muut. Lisääntyneet ravintoloiden asiakasmäärät turvaisivat myös näiden alojen toimijoiden mahdollisuuden harjoittaa omaa elinkeinoaan kannattavasti myös jatkossa.

Alkoholin anniskelumyynnin rajoitukset tukevat ainoastaan virolaista alkoholin vähittäismyyntiä suomalaisen työn kustannuksella. Anniskelumyynnin vapauttaminen alkoholiverosta laskisi valtion alkoholiverosta saamaa tuottoa mutta vastaavasti kasvattaisi verotuloja muualla.

72 Ks. myös Uusi Suomi 17.10.2019. 
Koska anniskelumyynti kattaa alkoholin kokonaismyynnistä vain noin $14 \%$, tapahtuu suurin osa suomalaisten alkoholinkulutuksesta valvomattomissa ympäristöissä. Tällöin esimerkiksi järjestyshäiriöiden hoitaminen on huomattavasti vaikeampaa kuin valvotuissa ympäristöissä. Alkoholin kulutuksen siirtyminen valvottuihin ympäristöihin muuttaisi kuluttajien alkoholinkäytön tottumuksia. Se myös helpottaisi järjestyshäiriöiden hoitamiseen suunnattujen resurssien kohdentamista.

Aleksi Salinin 8.6.2014 vireille panemassa aloitteessa (33 kannattajaa) esitettiin Suomen alkoholiverotuksen laskemista Viron viinarallin hillitsemiseksi. Suomen alkoholiverotus on pudotettava sellaiselle tasolle, ettei alkoholijuomia olisi enää kannattavaa tuoda ulkomailta. Jos esimerkiksi olutlaatikon hinta jäisi alkoholiveron laskemisen jälkeen sellaiselle tasolle, että hintaero Viron hintoihin olisi noin 5 euron luokkaa, niin hyöty hinnanerossa olisi pienempi kuin matkakustannukset Viroon ja tällöin alkoholin maahantuonti laskisi rajusti. Nykyisen verotuksen ongelma on se, että kun alkoholijuomia tuodaan suuria määriä kerralla ulkomailta, niin sitä kulutetaankin enemmän, mikä johtaa alkoholinkäytön yleiseen lisääntymiseen ja näin suomalaisten kansanterveyden laskemiseen. Tämän aloitteen toteutuessa Alkon ja muiden alkoholin vähittäismyyjien myynti alkoholin osalta kasvaisi, mikä toisi Suomelle lisää verorahoja.

Aila Lahtisen 1.2.2015 vireille panemassa aloitteessa (4 697 kannattajaa) ehdotettiin alkoholiveron alentamista Viron ja Saksan tasolle. Suomi on verotuksella ajanut itsensä umpikujaan alkoholin tuotannossa ja myynnissä niin viinassa kuin viineissä. Suomalainen olutkin haetaan Virosta. Nyt tulee laskea alkoholivero samalle tasolle Viron ja Saksan kanssa. Meidän on oltava kilpailukykyisiä, jotta "viinarallia" jatkossa ei tarvitsisi tehdä. Viinan ja muiden alkoholijuomien valmistuskustannukset eivät ole korkeita, siksi tuotannon tulee tapahtua omassa maassa. Kotimaisten viinien ja viinojen pitää löytyä alkoholiliikkeen hyllyiltä kilpailukykyisinä ulkomailta tuotujen alkoholituotteiden kanssa. Ratkaiseva merkitys olisi alkoholijuomien valmistaminen kotimaassa kulutuksen tasolle. Tämä toisi Suomeen uusia työpaikkoja. Suomelle jäisi melkoinen euromäärä omaan kulutukseen, kun lisäksi otetaan huomioon menot laivamatkoissa, majoituskuluissa ja alkoholin tuomissa kustannuksissa.

Työllisyysvaikutus Suomelle olisi huomattava. Kotimaisen marjaviinin tuottajien kilpailuasema markkinoilla paranisi huomattavasti. Suomen valtio kantaa vastuun viinankäytön aiheuttamista kuluista ja haitoista, vaikka nyt käytännössä suurin osa myyntivoitoista ja veroista jää Suomen rajojen ulkopuolelle. Tämäkin ongelma ratkeaisi. Mitä enemmän haetaan ulkomailta alkoholia omiin nurkkiin säilytettäväksi, sitä runsaammin sitä kulutetaan. Seurauksena on perheongelmia, riitoja, avioeroja, lasten heit- 
teillejättöjä ym. seurannaishaittoja. Alkoholiliikkeistä tuskin haettaisiin näin suuria viinamääriä kuin nyt ulkomailta. Suomi tulisi jo hyväksymälleen EU-perustamissopimuksen artiklan 93 edellyttämälle valmisteverojen harmonisoinnin tasolle.

Timo Aallon ja Katja Salmelan 1.12.2018 vireille panemassa aloitteessa (32 kannattajaa) vaadittiin alkoholiveron alentamista eurooppalaiselle keskitasolle. Pienpanimoiden sekä viinitilojen myynti varmastikin hiukan kasvaisi, mikä omalla osallaan parantaisi työllisyyttä. Samalla maaseudun väestökato saattaisi hidastua, parhaassa tapauksessa jopa palveluiden saatavuus parantuisi. Suomen ja Baltian ns. viinaralli kääntyisi toiseen suuntaan, mikä auttaisi suurpanimoita ja Suomen vähittäiskauppaa sekä poistaisi maassamme olevan, maantieteestä johtuvan epätasa-arvon halvemman alkoholin suhteen.

\section{Kommentteja}

Raittiusliike voimistui 1800-luvun lopulla, ja vuonna 1919 Suomessa tuli voimaan kieltolaki, joka myös johti alkoholin valmisteverotuksen päättymiseen. Kieltolaille asetetut hyvät tavoitteet eivät toteutuneet, mutta salakuljetus ja muu rikollisuus lisääntyivät. Laman syveneminen 1930-luvun alussa lisäsi tarvetta myös uusiin verolähteisiin. Joulukuun lopussa 1931 meillä järjestettiin neuvoa antava kansanäänestys. Siihen osallistui 44,4 \% äänioikeutetuista, ja heistä yli $70 \%$ kannatti kieltolain kumoamista. Eduskunta kumosi kieltolain, Alko aloitti toimintansa ja alkoholijuomien verotus otettiin uudelleen käyttöön vuonna 1932.

Suomi on EU-maista ankarin oluen alkoholiverottaja, toiseksi ankarin väkevän alkoholin verottaja ja toiseksi ankarin viinin verottaja. Alkoholiveron valtiontaloudellinen merkitys on meillä suuri, esimerkiksi vuonna 2020 noin 1,5 miljardia euroa (yli $3 \%$ valtion verotuloista). Tästäkin syystä on ymmärrettävää, että Suomessa jatkuvasti esitetään vaatimuksia verotasomme alentamiseksi ja että veronalennusvaatimuksia toisaalta voimakkaasti vastustetaan.

Pääministeri Antti Rinteen hallituksen ohjelmassa (s. 27) jatketaan alkoholiveron maltillisia korotuksia ottaen huomioon toimintaympäristön muutokset niin, että vaikutuksia matkustajatuontiin seurataan. Pääministeri Sanna Marinin hallituksen ohjelma on samanlainen. 


\subsubsection{Elintarvikeverotusta muutettava ${ }^{73}$}

Heikki Häyrysen 15.9.2012 vireille panemassa aloitteessa (1 141 kannattajaa) esitettiin elintarvikkeiden arvonlisäverokannan alentamista EU:n painotetun keskiarvon mukaiselle 7 \%:n tasolle. Suomessa elintarvikkeiden alv-kanta on EU-maiden korkeimpia ja elintarvikkeiden hinta korkea, mihin vaikuttaa merkittävästi elintarvikkeiden arvonlisäkanta. Tilanne ei ole EU-kansalaisia tasapuolisesti kohteleva eikä oikeudenmukainen.

Tilastokeskuksen tilastojen mukaan Suomessa ruokakorin hinta on euroaikana vuoden 2011 loppuun mennessä noussut reaalisesti noin $6 \%$ ja vuoden 2013 budjettilakien johdosta jo noin $7 \%$ ja nimellisesti noin $48 \%$. Kun tähän lisätään vielä meneillään oleva yleinen elintarvikkeiden nopea hinnannousu, on tärkeimmän perushyödykkeen reaalihinta euroaikana nousemassa n. 8-9 \%. Tämä hinnannousu kohdistuu raskaimmin heikoimmassa taloudellisessa asemassa oleviin kansalaisiin. Ei ole yleisen poliittisen tilanteen ja poliitikkojen luottamusedun mukaista se, että korkeat poliittiset päättäjät ovat viemässä kehitystä heikompia eniten rasittavaan suuntaan.

Elintarvikkeisiin kohdistuva arvonlisävero on sillä tavoin ns. regressiivinen vero, että se rasittaa kansalaisia sitä raskaammin, mitä pienituloisemmasta kansalaisesta on kysymys. Tämä johtuu siitä, että mitä pienemmät tulot, sitä suurempi osuus niistä menee kansalaisen jokapäiväisiin pakollisiin elintarvikkeisiin ja samalla pienituloisten verorasitus suhteessa hyvätuloisiin verokantaa korotettaessa suhteellisesti kasvaa. Jos elintarvikkeiden arvonlisäveroa alennettaisiin tai vero poistettaisiin, alentaisi se merkittävästi vaikeuksissa oleville henkilöille maksettavia kuntien ja valtion sosiaali- ja toimeentulotukikustannuksia.

Elintarvikkeiden alv-kannan alentaminen nostaa työllisyysastetta. Elintarvikkeiden arvonlisäverokannan alentaminen $7 \%$ :ksi laskisi valtion elintarvikekaupasta saamia verotuloja noin 800 miljoonaa euroa. Tätä menetystä korvaisivat asiaan liittyvät monet vaikuttavat tekijät.

Olettamalla, että kansalaiset käyttäisivät elintarvikkeista verokannan alentumisesta säästyvät 800 miljoonaa muuhun kulutuskysyntään ja maksaisivat siinä $24 \%$ :n verokannan mukaista arvonlisäveroa, saisi valtio verotuloja noin 155 miljoonaa euroa.

Olettamalla, että noiden muiden kuin elintarvikkeiden kulutuskysynnän tyydyttämiseen tarvitaan tuotantopanoksia ja tuotteiden tekijöitä, voidaan laskea, että arvonlisäverojen jälkeinen 645 miljoonan euron kulutuskysyntä työllistäisi noin $8000-9000$ henkilöä. Nämä maksaisivat tuloveroa noin 50-55 miljoonaa euroa sekä arvonlisä- ja muita energia- ja valmisteveroja noin 45-50 miljoonaa euroa.

73 Ks. myös kirjani Verokarhun keitto- ja drinkkikirja - Terve elintarvikeverotus (2019). 
Laskelmaa jatkettaessa elintarvikkeiden verokannan alentamisella, huomioimatta sosiaali- ja terveyspuolen kulujen alentumista, päästään loppupeleissä tulokseen, että verokannan laskemisella EU-maiden painotetun $7 \%$ :n keskiarvon tasolle valtio ja kunnat menettäisivät verotuloja enimmillään noin 400 miljoonaa euroa. Tästä menetyksestä osa korvautuisi sosiaali- ja terveyspuolen kulujen alentumisella.

Elintarvikkeiden arvonlisäverokannan alentumisesta johtuva valtion em. noin 400 miljoonan budjettivaje voidaan ja tulee korvata siten, että osinkotuloista poistetaan $30 \%$ :n verovapaa osuus. Toimenpiteellä valtion verotulot kasvaisivat vuositasolla noin 600-700 miljoonaa euroa taholta, jolla ei olisi merkittävää vaikutusta työllistävään kulutuskysyntään. Nyt pörssiosakkeiden todellinen veroaste on noin 19 \% ja kaikkien osinkotulojen noin $14 \%$.

Elintarvikkeiden arvonlisäverokannan alentaminen elintarvikkeiden hinnanalentumisen johdosta mahdollistaisi monen kansalaisen ostokäyttäytymisen muuttumisen terveellisempiin ruokatottumuksiin ja täten vaikuttaisi pitkällä aikavälillä positiivisesti myös kansanterveyteen ja siitä johtuvaan terveys- ja sairaanhoitokulujen alentumiseen. Sama terveysvaikutus on sillä, että taloudellisesti ahtaimmalla olevien huoli huomisesta hieman kevenee.

Susan Virkkalan 24.2.2015 vireille paneman aloitteen (1 427 kannattajaa) mukaan luomutuottamisen houkuttelevuutta tulee lisätä tuotannon ja tuotteiden verohelpotuksilla, lisätuella ja byrokratian/myynnin helpottamisella. Luomutuotteet ovat tulevaisuuden vahvin ruokatrendi, ja ne ovat elintarvikkeista kaikkein turvallisin ja puhtain vaihtoehto. Luomutuotteiden turvallisuutta ei tarvitse erikseen todistaa silloin kun ovat kyseessä ykkösluokkaiset, suomalaiset luomutuotteet.

Luomutuotteet ovat myös vahva tulevaisuuden vientituote Suomelle, sillä mm. itänaapurissa suomalaisia laadukkaita ja puhtaita luomutuotteita osataan arvostaa, ja siellä GMO-merkinnät ovat jo pakollisia ja suhtautuminen GMO-valmisteisiin on hyvin kriittinen. Ruuanvienti Venäjälle onkin helppoa, kun pääsemme irti EU:n talouspakotteista, ja myös matkat Venäjälle ovat lyhyitä, joten kuljetus ei rasita ympäristöä niin kuin tuotteiden kauemmaksi vieminen.

Usein luomutuottajat/yritykset ovat pieniä ja heillä kuluu liikaa aikaa silmittömään paperityönmäärään. Myös suoraan tilalta tapahtuva tuotteiden myynti on tehty vaikeaksi, jos ei jopa mahdottomaksi. Turhaa byrokratiaa tulisi keventää, vaikkakin ruuan puhtaus tulee todistaa riittävin tutkimusmenetelmin. Luomutuotteiden suoramyyntiä tulee siis helpottaa ja eritoten tulee kannustaa sekä yrittäjiä että kauppaketjuja/kauppoja siihen, että luomutuotteet tulisivat mahdollisimman läheltä.

Luomutuotteiden lisääntyneet viljely ja tuotanto tulevat osaltaan auttamaan Suomen kansantalouden nousuun, ja se on myös yksi keinoista, 
joilla koheesioalueita voidaan asuttaa ja aktivoida. Luomutuotteet ovat lähitulevaisuuden vetonaula ja huippuvientituote $\mathrm{mm}$. itänaapuriin. Luomutuotanto on ympäristöystävällistä, se ei pilaa maaperää eikä rehevöitä vesistöjämme. Luomutuotteet ovat se kaikista puhtain ruuanmuoto, eikä se kuormita myöskään elimistöämme ylimääräisillä kasvintorjunta-aineilla tai muilla haitallisilla taikka vaillinaisesti tutkituilla ruuan ainesosilla. Luomuviljelijöiden- ja tuottajien toimintaa tulisikin tukea alv-helpotuksin sekä turhien säännösten ja paperisodan keventämisellä siten, että ruuan laatu silti voidaan vielä taata. Luomutuotantoon tulisi kannustaa myös suoralla luomutuotannon tukemisella.

Luomutuotantoon kannustaminen on tärkeää myös sen vuoksi, että suomalaiset luomutuotteet pärjäävät myös hintakilpailussa muiden tuotteiden rinnalla. Täten kaikilla suomalaisilla, varallisuuteen katsomatta, olisi mahdollisuus halutessaan syödä luomua sen sijaan, että joutuvat valitsemaan sen halvimman tuotteen. Tuotteiden hintataso myös osaltaan vääristää eri tuotteiden kysyntää ja tilastoja. Luomun ei tulisi olla pelkästään hyvin toimeentulevien ylellisyystuote. Lähiluomulla on myös ympäristövaikutus, sillä kuljetusmatkat ovat lyhyempiä. Luomun suoramyynti tiloilta sekä myynti suoraan (ilman tukkuliikkeitä) lähimmille kaupoille, kauppaketjusta riippumatta, tulisi olla itsestäänselvyys, eikä sitä saa vaikeuttaa millään tavalla. Myös tässä kontrollointi pitäisi olla eritoten tuotteiden laatuun ja puhtauteen keskittyvää eikä turhaa yritystoiminnan vaikeuttamista.

Sonja Tigosen 23.11.2018 vireille panemassa aloitteessa (2 790 kannattajaa) esitettiin liha-ja maitotuotteiden veron nostamista ilmastonmuutoksen hillitsemiseksi. Hiilijälkiään voi pienentää usealla tavalla. Yksilön kannalta yksi tärkeimmistä tavoista hillitä ilmastonmuutosta on oman ruokavalion muuttaminen.

25 \% maan kamarasta on karjantuotannon käytössä hiilidioksidia nielevien kasvien sijaan. Karja tuottaa myös paljon metaania, yhtä merkittävimmistä kasvihuonekaasuista. Ajamalla autolla 10 kilometriä tuotetaan saman verran kasvihuonekaasuja kuin yhden hampurilaisen lihatuotannossa. Maapallon kannalta parasta olisikin siirtyä kokonaan lihattomaan ruokavalioon. Välimeren ruokavalioon siirtymällä puolestaan olisi mahdollista vähentää kasvihuonekaasuja 15 \%:lla vuoteen 2050 mennessä.

Suomalaiset syövät enemmän lihaa kuin aikoihin. Luonnonvarakeskuksen mukaan suomalaiset kuluttivat henkeä kohti keskimäärin 174 kiloa nestemäisiä maitotuotteita ja noin 79 kiloa lihaa vuonna 2015 . Lihan kokonaiskulutus kasvoi vuodesta 2014 noin 3 \%. Eniten lisääntyi siipikarjanlihan kulutus, joka vuonna 2015 oli $7 \%$ edellisvuotista suurempi. Naudanlihan kulutus kasvoi vajaat $3 \%$ ja sianlihan kulutus vajaat 2 \%. Myös kananmunien kulutus kasvoi. Vuonna 2015 kananmunia syötiin henkeä kohden yli 11 kiloa, joka oli noin $6 \%$ edellisvuotta enemmän. 
Jos ilmaston lämpeneminen saadaan rajoitettua 1,5 asteeseen, puolet vähemmän ihmisiä kärsisi vedenpuutteesta verrattuna kahden asteen lämpötilannousuun. Alhaisempi lämpötilannousu suojelisi luontoa ja luonnon ekosysteemejä ja hillitsisi merenpinnan nousua. Lämpötilan nousun hillintätoimet on kuitenkin mitoitettava paikallisten olosuhteiden mukaan, ettei esimerkiksi maankäyttö vaaranna ruokaturvaa tai puhtaan veden saantia erityisesti kehittyvissä maissa.

Lainsäädännöllä liha- ja maitoveron nostamiseksi valtiovalta tukee ilmastonmuutoksen pysäyttämistä/hidastamista, vähentää eläinperäisten tuotteiden kulutusta ja ottaa täten vastuun antamastaan lupauksesta Pariisin ilmastosopimuksessa. Suomen hallituksen tulisikin pikaisesti ryhtyä toimiin ilmaston puolesta. Pariisin ilmastosopimuksen tavoitteena on pitää maapallon keskilämpötilan nousu selvästi alle kahdessa asteessa suhteessa esiteolliseen aikaan ja pyrkiä toimiin, joilla lämpeneminen saataisiin rajattua alle 1,5 asteen. Päästövähennystavoitteiden lisäksi sopimuksessa on asetettu pitkän aikavälin tavoite ilmastonmuutokseen sopeutumiselle sekä tavoite sovittaa rahoitusvirrat kohti vähähiilistä ja ilmastokestävää kehitystä.

Henri Aitakarin 19.10.2018 vireille panemassa aloitteessa (422 kannattajaa) ehdotettiin muutoksia seuraavien elintarvikkeiden arvonlisäverokantoibin.

1) Arvonlisävero tulisi kokonaan poistaa seuraavilta jalostamattomilta, tuoreilta elintarvikkeilta: kasvikset, juurekset, marjat, hedelmät, yrtit, maustekasvit, liha, kala sekä kananmunat. Varsinaiseksi tuotteen jalostamiseksi ei tässä katsottaisi tuoreen tuotteen leikkaamista, jauhamista tai pakkaamista.

2) Makeisten, makeiden leipomotuotteiden, jäätelöiden ja makeiden virvoitusjuomien arvonlisävero tulisi korottaa $24 \%$ :iin. Tämän tulee koskea myös keinotekoisilla makeutusaineilla makeutettuja tuotteita.

Lisäksi tulisi harkita, onko muita elintarvikkeita, joiden alv voitaisiin poistaa, tai muita, joiden alvia pitäisi korottaa. Suurimmalla osalla elintarvikkeista alv säilyisi muutosten jälkeenkin nykyisessä $14 \%$ :ssa.

Arvonlisäveron avulla olisi mahdollista ohjata kulutusta kansanterveyden näkökulmasta suotuisampaan suuntaan. Jo vuosikymmeniä ravintosuosituksissa on korostettu kasvisten merkitystä terveellisen ravinnon perustana. Niiden käyttö onkin lisääntynyt, mutta ei vielä riittävästi. Suomalaiset syövät tällä hetkellä kasviksia ja hedelmiä 300 g päivässä, kun suositusten mukaan niitä tulisi syödä $500 \mathrm{~g}$ päivässä. Arvonlisäveron muutoksilla voitaisiin ohjata kuluttajien valintoja entistä terveellisempiin elintarvikkeisiin. 
Myös liha- ja kalatuotteiden osalta tiedetään, että runsas jalostaminen ja prosessointi usein heikentävät tuotteiden ravintoarvoa. Jalosteissa on yleensä runsaasti suolaa, joka liiallisina määrinä mm. nostaa verenpainetta. Makkaroissa ja monissa muissa jalosteissa on terveydelle haitallisia nitriittejä. Liha, kala ja kananmunat ovat kuitenkin tärkeitä proteiininlähteitä ja kuuluvat ravintosuosituksiin. Jalostamattomina ne ovat osa terveellistä ravintoa.

Toisaalta suomalaiset syövät liikaa sokeria, jota saadaan erityisesti makeisista, makeista leipomotuotteista, jäätelöistä ja makeista virvoitusjuomista. Sokeri aiheuttaa suuria ongelmia väestön hampaille ja on merkittävä syy väestön liikalihavuuteen. Sokeri ei millään tavalla ole ihmiselle välttämätön ravintoaine, päinvastoin, se on merkittävä kansanterveydellinen haitta, jonka kustannuksia on kuitenkin paljon vaikeampi näyttää toteen kuin esimerkiksi alkoholin. Viimeisten 30 vuoden aikana makeisten kulutus henkeä kohti on kaksinkertaistunut $7 \mathrm{~kg}$ :sta vuodessa $14 \mathrm{~kg}$ :aan.

Myöskään keinotekoisesti makeutettuja tuotteita ei tule tässä yhteydessä suosia, koska niiden pitkäaikainen käyttö saattaa olla haitallista ja niiden oletettu apu painonhallinnassa on kiistanalainen. Lisäksi keinotekoisten makeutusaineiden käytön on todettu mahdollisesti lisäävän riskiä sairastua diabetekseen.

Makeiden ja keinotekoisesti makeutettujen tuotteiden arvonlisäveron nostaminen $24 \%$ :iin kompensoisi osaltaan myös terveellisten tuotteiden alv:n poistoa valtiontalouden näkökulmasta. Lisäksi toteutuisi edes jonkinlainen johdonmukaisuus haitallisten tuotteiden verotuksessa. Tällä hetkellä alkoholia, tupakkaa ja bensiiniä verotetaan niiden aiheuttamien haittojen ja kustannusten takia selvästi enemmän kuin makeisia. Tämäkään veronkorotus ei vielä nostaisi makeisten verotusta samalle tasolle, mutta ei olisi hyvä alku ja selkeä viesti siitä, että valtiovalta haluaa edesauttaa kansalaisten hyvinvointia.

Terveellisemmin syövä kansa pysyy terveempänä, mikä vaikuttaa myös kansantalouteen, koska sairauspoissaolot, sijaiskulut, lääkekustannukset, sairaalamaksut ja tulonmenetykset pienenevät.

Toteutuessaan aloite laskisi arvonlisäverottomiksi muuttuvien tuotteiden hintoja. Yleensä hintojen laskiessa kulutuskin lisääntyy, mikä tarkoittaa myös tuotannon lisääntymistä. Täten voitaisiin saada positiivisia vaikutuksia maataloustuotantoon.

Vastaavasti aloite nostaisi epäterveellistä sokeria sisältävien tuotteiden hintoja, mikä mahdollisesti vähentäisi niiden menekkiä. Aiempi makeisten valmistevero jouduttiin lopettamaan EU:n valtiontukisääntöjen vastaisena ja kilpailua vääristävänä. Valmistevero oli sisäisesti ristiriitainen eikä huomioinut kaikkia kilpailevia tuotteita. Siksi tämä aloite onkin syytä valmistella siten, että se ei törmää EU-säädöksiin. 
Mikko Kärnän 1.9.2018 vireille panemassa aloitteessa (765 kannattajaa) esitettiin reilun ruuan veroa. Aloitteessa ehdotettiin Suomen verotuslainsäädäntöä muutettavaksi niin, että kaikkien Suomessa myytävien elintarvikkeiden sekä ravintola- ja ateriapalveluiden hintaan lisätään yhden prosentin suuruinen reilun ruuan vero. Vero olisi tilapäinen, ja se säädettäisiin viiden vuoden määräajaksi. Reilun ruuan vero olisi arvonlisäveron kaltainen kulutusvero, joka tulee ostajan maksettavaksi kaikista edellä mainituista tuotteista. Valtion tulisi kohdentaa veron tuotto seuraavasti:

- $75 \%$ veron tuotosta ohjataan suoraan ja lyhentämättömänä neljännesvuoden välein Suomeen rekisteröityneille maatalousyrittäjille heidän tuotantomääriensä suhteessa. Tuotantomäärät on laskettava kuluneen kolmen vuoden keskiarvon mukaisesti. Vasta aloittaneille ja vasta toimintaansa investoineille tiloille on luotava oma laskentatapansa.

- 25 \% veron tuotosta rahastoidaan erilliseen maatalouden kriisirahastoon, josta sitä voidaan jakaa akuuteissa kriiseissä maataloustuottajien tukemiseen valtioneuvoston päätöksellä.

Vero on arvonlisäveron tapaan vähennyskelpoinen maatalousyrittäjille ja elintarvikkeiden jalostajille. Vero kohdentuisi täten kulutusketjussa niin tukkukaupan, päivittäistavarakaupan, ravintoloiden kuin kuluttajienkin maksettavaksi.

Suomalainen maatalous kamppailee ennennäkemättömän kannattavuuskriisin kourissa, ja maatalouden yrittäjätulo on Suomessa vaivaiset 300 miljoonaa euroa. Suomalaisten viljelijöiden tulot ovat romahtaneet ja pienentyneet viimeisen seitsemän vuoden aikana enemmän kuin missään muussa Euroopan unionin jäsenvaltiossa. Syitä on useita, mutta keskeisin ongelma kohdistuu alhaisiin tuottajahintoihin, joihin syypäänä pidetään yleisesti keskittynyttä vähittäiskauppaa. Suomalaisiin tiloihin kohdistuu myös valtavasti sääntelyä ja vaatimuksia, joiden johdosta ne tuottavat maailman eettisimpiä ja ekologisimpia elintarvikkeita. Valitettavasti suomalaiset elintarvikkeet joutuvat kuitenkin lopulta kilpailemaan hinnalla ulkomaisten elintarvikkeiden kanssa, jotka eivät täytä vastaavia laatukriteereitä.

Maatalouden heikkoa kannattavuutta on jouduttu vuodesta toiseen parsimaan erilaisilla kriisipaketeilla, jotka ovat lopulta hyvin riittämätön ja huonosti akuutteihin ongelmiin vastaava keino. Myös viljelijät suhtautuvat kriisipaketteihin kriittisesti. Erillinen, pääosiltaan suoraan maataloustuottajille jaettava reilun ruuan vero tasapainottaisi tuottajien tilannetta tasaisesti, parantaisi tilojen maksuvalmiutta sekä loisi osaltaan edellytyksiä sille, että erillisistä kriisipaketeista voitaisiin luopua. Mahdollinen kriisituki voitaisiin myös tulevaisuudessa maksaa veron kautta luotavan erillisen kriisirahaston kautta, jolloin se olisi valtion budjetista irrallista tukea. 
Vero ei kuormittaisi maatalousyrittäjiä ja elintarvikkeiden jalostajia, koska se olisi heille vähennyskelpoista. Vero kohdentuisi vain tukkukaupan, päivittäistavarakaupan, ravintoloiden sekä kuluttajien maksettavaksi.

Elintarvikkeiden kulutusmenot kotitalouksilla ovat Suomessa noin 12,5 miljardia euroa, ja ravitsemuspalveluita hankitaan noin 6,5 miljardilla eurolla. Kuluttajille kohdistuva verorasitus olisi karkeasti siis noin 190 miljoonaa euroa. Vuodessa tämä tarkoittaisi jokaista suomalaista kohden 34,5 euron verorasitusta. Päivää kohden tuo verorasitus olisi 9,5 senttiä.

Tukkukaupalle, päivittäistavarakaupalle ja ravintola-alalle aiheutuvaa verorasitusta ja sitä kautta veron tuottoa on haastavampaa arvioida. Mikäli arvioimme varovaisesti katteiden olevan keskimäärin $20 \%$, olisi tukkukaupalta kerättävä veron osuus 80 miljoonaa euroa, päivittäistavarakaupalta kerättävä veron osuus 100 miljoonaa euroa ja ravintola-alalta 52 miljoonaa euroa. Valtion ruoka-asiamiehen tulee veron säätämisen jälkeen valvoa, ettei kauppa- ja ravintola-ala kompensoi veron vaikutuksia itselleen ainoastaan korottamalla katteitaan.

Kokonaisuutena reilun ruuan veron tuotoksi voisi siis muodostua vuositasolla 422 miljoonaa euroa, josta 316,5 miljoonaa euroa jaettaisiin suoraan tuottajille ja 105,5 miljoonaa euroa rahastoitaisiin mahdollista myöhempää käyttöä varten. Veron palauttaminen tuottajille voisi tapahtua joko suorin tilityksin, arvonlisäveropalautuksen kautta tai näiden yhdistelmällä.

Reilun ruuan verosta säätäminen olisi poikkeuksellinen ja vahva toimenpide. Sen avulla voitaisiin kuitenkin varmistaa suomalaisen maatalouden jatkuvuus sekä maamme huoltovarmuus. Suomalaisen maatalouden kriisin ratkaisemisessa oleellisinta on keskittyä tilojen kannattavuuden parantamiseen, mutta tämä ei tapahdu nopeasti. Erillinen tuottajille ohjattava ruokavero helpottaisi tilannetta ja antaisi tiloille aikaa kehittää omaa toimintaansa. Samalla on tärkeää kehittää maataloustukijärjestelmää niin kansallisesti kuin EU:n sisälläkin ymmärtäen, että mikään elinkeino ei voi perustua pelkästään valtion subventioihin.

\section{Kommentteja}

Olennainen terveysveroihin liittyvä ongelma on se, että nämä verot kohdistuvat suhteellisesti enemmän matalatuloisiin kotitalouksiin kuin suurituloisiin kotitalouksiin. On kuitenkin korostettava, että tulo- ja varallisuuserojen tasoittamiseen sopivat progressiivinen tuloverotus ja varallisuusverotus sekä hyvä sosiaaliturva paljon paremmin kuin kulutusverolainsäädäntö.

Verotuksen perustehtävä on ollut ja on yhä fiskaalinen eli tulojen kerryttäminen valtiolle. Elintarvikeverotuksessa tuttuja ovat olleet myös maatalous- ja elinkeinopoliittiset pyrkimykset. Myöhemmin 
verotukseen on sisällytetty terveyspolitiikkaakin. Viime vuosikymmeninä verotukseen on alettu liittää myös ympäristöpoliittisia tavoitteita. Elintarvikkeiden kulutusverotuksessa luonnonsuojelu on näkynyt kuitenkin toistaiseksi lähinnä vain kehittämisideoina, joissa ankarampaa verotusta on vaadittu esimerkiksi lihatuotteille.

Verojärjestelmä pysyy kuitenkin terveempänä eli toimivampana, jos sille ei aseteta sellaisia tehtäviä, jotka soveltuvat paremmin muiden hoidettaviksi tai verovelvollisten omalle vastuulle. Tämä tarkoittaa neutraaliuden korostumista verotuksessa. Koska olemme jäsenenä EU:ssa, jossa tavarat ja ihmiset liikkuvat vapaasti, kansalliset mahdollisuutemme omintakeisiin terveys- ja ympäristöveroihin ovat oikeudellisesti ja tosiasiallisesti hyvin rajalliset.

Alkoholi ja tupakka soveltuvat hyvin terveyspoliittisen valmisteverotuksen kohteeksi jatkossakin, virvoitusjuomavero sen sijaan on kyseenalaisempi. Makeisten ja jäätelön valmisteveroa ei tulisi siihen liittyvien oikeudellisten ongelmien vuoksi palauttaa. Samoista syistä erityiset sokeri-, suola-, rasva-, liha- ja maitoverot eivät vaikuta realistisilta vaihtoehdoilta.

Elintarvikkeet sen sijaan voitaisiin ilman oikeudellisia ongelmia säätää arvonlisäverotuksessa yleisen verokannan piiriin. Näinhän on tapahtunutkin EU-maista Bulgariassa, Liettuassa, Tanskassa ja Virossa. Muutos voitaisiin toteuttaa kerralla tai vähitellen muutaman vuoden aikana. Jos elintarvikkeet säädettäisiin yleisen verokannan alaisiksi, myös makeisten, jäätelön, sokerin, suolan, lihan, maidon ja rasvojen verotus jonkin verran voimistuisi, mikä saattaisi hieman vähentää ylensyömisalttiutta.

Elintarvikkeiden ja rehujen alennettu arvonlisäverokanta on maamme suurimpia verotukia. Alennettujen verokantojen piirissä olevien tuotteiden karsiminen mahdollistaisi alennuksen yleiseen arvonlisäverokantaan tai ainakin vähentäisi paineita yleisen arvonlisäverokannan korottamiseen. Neutraalisuuden korostamisen kulutusverotuksessa voidaan olettaa myös palvelevan kokonaistaloudellista tehokkuutta, vaikka se heikentäisi joidenkin yritysten asemaa.

Jos ja kun kaikkia elintarvikkeita ei meillä ainakaan vielä säädetä yleisen verokannan piiriin, alemman verokannan hyödykkeiden piiriä voitaisiin ehkä yrittää olennaisesti supistaa. Terveys- ja ympäristösyistä elintarvikkeiden alempi verokanta saatettaisiin rajata koskemaan esi- 
merkiksi tuoreita ja jäähdytettyjä kasviksia sekä tuoreita ja kuivattuja hedelmiä.

Pääministeri Antti Rinteen hallituksen ohjelmassa (s. 27) tavoiteltiin terveyden edistämistä verotuksella. Pääministeri Sanna Marinin hallituksen ohjelma on samanlainen. Tarkoituksena on korottaa tupakkaveroa, alkoholiveroa ja virvoitusjuomaveroa. Hallitus myös selvittää mahdollisuuden ottaa käyttöön kansanterveyttä edistävä vero, joka kohdistuisi esimerkiksi sokeriin, ja vaikuttaa EU:ssa siihen, että uudenlaisia terveyttä edistäviä veroja voidaan ottaa käyttöön.

Rinteen hallitus toteaa ohjelmassaan (s. 25) myös, että elintarvikkeiden ja muiden kulutushyödykkeiden arviointia kehitetään kulutusverotuksen suuntaamiseksi ilmasto- ja ympäristövaikutukset huomioivaksi.

\subsubsection{Arvonlisäverotus}

\subsection{Arvonlisävero poistettava palveluilta ja alkutuotannolta}

Edvard Hannolaisen 13.3.2017 vireille panemassa aloitteessa (27 kannattajaa) vaadittiin poistettavaksi nykyiset arvonlisäverokäytännöt alkutuotannosta ja palvelumyynnistä.

Arvonlisävero haittaa työllistymistä ja yritystoiminnan kannattavuuden kasvua. Verottajalle maksetaan erotus ostojen ja myyntien arvonlisäveroista. Myynnin arvonlisäveron erotuksen osuus voi olla nollasta ylöspäin, riippuen katteesta. Palvelutyöstä maksetaan täysarvonlisävero, riippuen alasta se voi olla 10,14 tai $24 \%$. Tavaran myynnissä arvonlisävero on 0 tai $24 \%$. Palvelutyön myynnissä vähennettävää arvonlisäveroa ei ole vastaavalla tavalla kuin tavaramyynnissä, arvonlisävero lasketaan koko myynnistä. Tavaran välityksessä (myynnissä) arvonlisävero lasketaan arvonnoususta. Palvelutyöstä joutuu tilittämään verottajalle paljon enemmän arvonlisäveroa kuin tavaran myynnistä. Teoreettisesti palvelutyössä ei ole arvon lisäystä, se on arvon syntyä, ja siitä veloitetaan arvonlisäveroina täysmittaisesti. Arvonlisäveron maksajat ovat joutuneet eri asemaan.

Poistamalla arvonlisävero palvelutyön myynnistä ja alkutuotannosta päästään eron monimutkaisesta, eriarvoistavasta arvonlisäverojärjestelmästä, ja työnantajille muodostuvat resurssit työllistämiseen, edellytykset toiminnan kannattavuuden kasvuun. Saadaan alas työaikakulut, jotka menevät erilaisten arvonlisäverojen laskentaan ja raportointiin ja seurantaan. Työllistämisen kasvulla ja kansainvälisesti parannetulla tuotantotilanteella Suomen talous saa paljon enemmän hyötyä kuin nykyisessä jäykässä arvonlisäverojärjestelmässä. 


\section{Kommentteja}

Aloite tarkoittaa paluuta sellaiseen liikevaihtoverojärjestelmään, joka meillä oli voimassa 1990-luvun puoliväliin. EU:n jäsenenä Suomi on sitoutunut laajapohjaiseen arvonlisäverotukseen, joka kattaa myös palvelut ja alkutuotannon.

\subsection{Pienyrittäjien arvonlisäverovapautta laajennettava}

Christian Janssonin 10.6.2016 vireille panemassa aloitteessa (20 kannattajaa) ehdotettiin yrittäjyyden ja viennin lisäämiseksi 10000 euron alarajaa. Kun tuloja on 10000 euroa, tulisivat maksuun vain sen ylittävät arvonlisäverot, jos tätä ennen ei ole 10000 euroa ylittäviä vuosia. 10000 euroon laskettaisiin vain yrittäjän nostama "palkka", josta yrittäjä maksaa henkilökohtaisella verokortillaan verot eli ei liikevaihdosta niin kuin nykyään. Tarkoitus olisi, että tulevan yrittäjän ei tarvitse jarrutella menoaan, jos homma pyörii ja olisi mahdollisuus laittaa rahaa investointeihin. Suomeen tulee rahaa, joka tällaisessa nappikaupassa päätyy ruokakauppaan taikka pikku investointeihin. Annettaisiin ihmisille mahdollisuus kokeilla helpolla työtehtäviä pikku firmoissa. Vienti lisääntyisi, työttömyys vähenisi ja paljon muuta.

Harri Jyrkiäisen jo 24.6.2013 vireille panemassa aloitteessa (5 031 kannattajaa) ehdotettiin lainmuutosta, jonka mukaan myyjä olisi verovelvollinen tilikauden myynnistä 50000 euroa ylittävältä osalta, ellei häntä ole oman ilmoituksen perusteella merkitty verovelvolliseksi.

Arvonlisäverovelvollisuuden alhainen euroraja on yksi yritysten kasvun este. Huomioitavaa on myös, että verorajan ylityttyä yrittäjä joutuu maksamaan veron taannehtivasti. Kolmen vuoden aikana uusista alkavista yrityksistä lopettaa toimintansa noin puolet. Lisäksi Suomessa on noin 45000 yrittäjää ja ammatinharjoittajaa, joiden todelliset kuukausitulot alittavat virallisen köyhyysrajan. Suomen hallitus on hallitusohjelmassaan kiinnittänyt huomiota erityisesti yksinyrittäjien toimintaedellytysten kehittämiseen.

Hyödyt arvolisäverovelvollisuuden nostamisessa 50000 euroon ovat kiistattomat. Yrittäjälle jää rahaa elämiseen, ja kulutuksen kautta talouden pyörät pyörivät huomattavasti paremmin. Myös investointihalukkuus lisääntyy ja työllistämisen kynnys madaltuu. Yrityksille avautuu mahdollisuus kasvuun, joka on kansantaloudellisesti järkevää. Lisäksi uusien alkavien yritysten on mahdollista selviytyä alkuvaiheen haasteista. Pitkällä aikavälillä valtion verotulot voivat kasvaa arvioilta noin 700 miljoonaa euroa vuodessa.

Suomen Pienyrittäjät ry on toteuttanut kyselyn noin 500 suomalaiselle yrittäjille ja ammatinharjoittajalle aiheena arvolisäverorajan nostaminen 
50000 euroon ilman taannehtivuutta. Kyselyyn vastanneiden kanta oli sataprosenttisesti esityksen puolella.

Suomessa liikevaihtoraja on EU:n matalimpia, ja tutkimuksen mukaan se tulisi moninkertaistaa nykyisestään. Liikevaihtorajaan liittyy useita ongelmia, koska sen ylitettyään yritys joutuu maksamaan veroa koko myynnistään. Tämän vuoksi yritysten on kaksinkertaistettava myyntinsä päästäkseen samaan tulokseen kuin ennen verotusta. Osa yrityksistä ei tässä onnistu ja joutuu tinkimään voitostaan veronmaksun hyväksi. Yritysten sisäinen kasvu vaikeutuu, sillä yrityksen on usein kannattavampaa rajoittaa toimintaansa tai siirtää osa siitä harmaan talouden alueelle. Kannustin liiketoimintojen pilkkomiseen on myös olemassa. Poikkeuksellisen suuri joukko yrityksiä sijoittuu juuri liikevaihtorajan alapuolelle. Tämä koskee nimenomaan liikkeen- ja ammatinharjoittajia. Lisäksi VATT:n tutkimuksessa todetaan optimaalisen liikevaihdon rajan todetaan olevan 50000 euroa. Small Business Act -yrittäjyysjulistuksessa vuonna 2008 EU:n jäsenmaiden yritysten liikevaihtorajaksi suunniteltiin 100000 euroa.

Myös Heikki Hännisen ja Henri Hännisen 1.11.2017 vireille panemassa aloitteessa (18 661 kannattajaa) ehdotettiin vähäisen liiketoiminnan alv-velvollisuusrajan nostamista 50000 euroon. Suomessa on tuhansia pienyrittäjiä, jotka toiminnallaan elättävät perheensä ja lähipiirinsä. He tekevät pitkää päivää huonolla sosiaaliturvalla sekä suurella riskillä. Monella ammatinharjoittamiseen liittyvät ostot ja hankinnat ovat laskutukseen nähden pienet. Ostojen ja muiden kulujen alv-vähennyksellä ei ole merkittävää osaa toiminnan kannalta, joten arvonlisäveron maksaminen on kohtuutonta ja aiheuttaa suurta rasitetta. 50000 euron raja on riittävä toiminnalle, joka takaa riittävän toimeentulon itselle ja lähipiirille toimintaan liittyvien kulujen jälkeen. Lisäksi yrittäjä pystyy mahdollisesti palkkaamaan pienissä määrin kausiluonteista apua. Alv-raja on muissa EU-maissa suurempi kuin Suomessa. Virossa raja on 40000 euroa.

\section{Kommentteja}

Kaikissa EU-maissa Alankomaita ja Espanjaa lukuun ottamatta on järjestelmä, jonka mukaan pienyritykset voidaan vapauttaa arvonlisäverosta, jos myynti alittaa tietyn vuotuisen raja-arvon. Tuo arvonlisäverokynnys oli vuonna 2018 maittain seuraava:

\begin{tabular}{|l|l|}
\hline Belgia & 25000 euroa \\
\hline Bulgaria & 25565 euroa \\
\hline Irlanti & 75000 tai 37500 euroa \\
\hline
\end{tabular}


7 Kansalaisaloitteinen verotus - viihdettä vai demokratiaa?

\begin{tabular}{|l|l|}
\hline Italia & 65000 euroa \\
\hline Itävalta & 30000 euroa \\
\hline Kreikka & 10000 euroa \\
\hline Kroatia & 40324 euroa \\
\hline Kypros & 15600 euroa \\
\hline Latvia & 40000 euroa \\
\hline Liettua & 45000 euroa \\
\hline Luxemburg & 30000 euroa \\
\hline Malta & 35000 tai 24000 tai 14000 euroa \\
\hline Portugali & 10000 tai 12500 euroa \\
\hline Puola & 47180 euroa \\
\hline Ranska & 82800 tai 42 900 tai 33200 euroa \\
\hline Romania & 47180 euroa \\
\hline Ruotsi & 2943 euroa \\
\hline Saksa & 17500 euroa \\
\hline Slovakia & 49790 euroa \\
\hline Slovenia & 50000 euroa \\
\hline Suomi & 10000 euroa \\
\hline Tanska & 6713 euroa \\
\hline Tšekki & 25562 euroa \\
\hline Unkari & 40000 euroa \\
\hline Viro & 97838 euroa \\
\hline Yhdistynyt kuningaskunta \\
\hline & \\
\hline
\end{tabular}

Alaraja on Suomessa niin alhainen, että sen nostolle olisi hyvät perusteet. Pääministeri Antti Rinteen hallituksen ohjelmassa (s. 26) todettiin, että Suomi hakee EU:Ita poikkeuslupaa yritysten arvonlisäverovelvollisuuden alarajan nostamiseksi 15000 euroon. Pääministeri Sanna Marinin hallituksen ohjelma on samanlainen. 


\subsection{Kampaamo- ja parturipalvelujen arvonlisäverokantaa alennettava}

Jan Antinin 8.4.2013 vireille panemassa aloitteessa (2 011 kannattajaa) ehdotettiin, että arvonlisävero alennettaisiin parturi-kampaamoalan palveluissa 24 \%:sta 9 \%:iin. Tästä hyötyisivät kaikki: kuluttajat, parturikampaajat ja yrittäjät.

Vuonna 2011 arvonlisävero parturi-kampaajilla oli $9 \%$, ja vuonna 2012 se nousi rajusti 23:een, vuonna 2013 se nousi 24 :än. Tämä on nyt vaikuttanut siten, että palveluhinnat ovat parturi-kampaamoissa nousseet dramaattisesti. Suomessa tarvitsee 99 \% kuluttajista nämä palvelut, mutta hintojen nousun takia kuluttaja on joutunut vähentämään käyntejän. Kuukauden välein käynyt asiakas käy nyt jopa 3-4 kuukauden välein käyttämässä palvelut näiden kalliiden hintojen takia. Asiakashan on se, joka maksaa loppupeleissä nämä nousseet arvonlisäverot.

Pidemmän päälle tämä tulee antamaan työttömiä parturi-kampaajia, kun parturi-kampaajayrittäjät eivät enää voi palkata työntekijöitä, vähennetyn asiakasmäärän/tarpeen takia ja työntekijöille/yrittäjille itselleen ei riitä asiakkaita. Työttömille parturi-kampaajille valtio joutuu tulevaisuudessa maksamaan työttömyyskorvausta. Mikäli arvonlisävero olisi alempi, kuluttajalla olisi varaa käyttää palvelut ja tämä antaisi loppujen lopuksi valtiolle saman veromäärän. Nykyisellä verotuksella kärsivät kaikki: sekä parturi-kampaajat, yrittäjät että kuluttajat.

Myös Ronja Slotten 1.9. 2015 vireille panemassa aloitteessa (984 kannattajaa) vaadittiin, että kampaajien arvonlisävero laskettaisiin nykyisestä 24 \%:sta takaisin $9 \%:$ :iin. Syy siihen, miksi alv laskettiin $9 \%$ :ään oli se, että kampaajat palkkaisivat enemmän työntekijöitä ja laskisivat hintoja. Miksi haluttiin, että hintoja pitäisi laskea?

Pietarsaaressa hiustenleikkuu maksaa 30-40 euroa, muutamia poikkeuksia lukuun ottamatta. Leikkuu kestää 60 minuuttia ja maksaa 36 euroa sisältäen pesun. Hintaan sisältyy sampoo, hoitoaine, vesi, pyyhe, pesuaine, stailaustuotteet sekä työssä kuluva sähkö, vuokra, verot, sosiaaliset kustannukset ja viimeiseksi alv $24 \%$. Kampaajalle ylijäävä palkkio ei ole kummoinen. Yllä oleva kysymys on aiheellinen. Miksi hintoja pitäisi laskea?

Toinen esimerkki. Tunti hierojalla tai psykologilla Pietarsaaressa maksaa noin 50 euroa. Hierojan tai psykologin ei välttämättä tarvitse toimia keskustan tiloissa suurine näyteikkunoineen. Menot asiakasta kohden eivät ole kovin suuria. Heillä on silti mahdollisuus laskuttaa enemmän palveluistaan eikä kenelläkään ole ollut vaatimuksia hintojen laskemiseen.

Ellei kampaajien ala olisi niin naisvaltainen, olisi tilanne todennäköisesti täysin erilainen. 
Vaikuttaa siltä että moni juuri valmistunut kampaaja ryhtyy tekemään jotain muuta kuin sitä mihin ovat kouluttautuneet. Moni leikkaa ystävien ja tuttujen hiuksia kotona ilmaiseksi, ja moni jättää varmasti veroilmoituksen leikkuiden tuloista tekemättä. Jos alv laskettaisiin aiempaan $9 \%$ :iin, olisi vakiintuneimmilla kampaajilla mahdollisuus palkata uusia työntekijöitä ja uudet kampaajat uskaltaisivat avata omia liikkeitä. Mahdollisuus selvitä alalla ensimmäisten vaikeiden vuosien aikana nousee huomattavasti. Pimeä työ tuskin loppuu kokonaan, mutta se todennäköisesti vähenisi.

Alv:n laskua motivoi myös se, että kampaajilla ei ole mahdollisuutta saada starttirahaa. Se tarkoittaa, että ensimmäiset vuodet ovat hyvin vaikeita uusille yrittäjille.

Arvonlisäveroa ei kuulu alentaa, jotta saadaan halvempia hintoja vaan jotta annetaan kampaajille kohtuullinen palkka työstään ja että he voisivat ryhtyä palkkaamaan työntekijöitä. Moni vastavalmistunut kampaaja tekee töitä palkalla, joka ei ylitä köyhyysrajaa, ja huoli tulevaisuudesta on suuri. Kampaajana työskentely on käsityötä, ja sen kanssa työskentelevien kuuluu saada mahdollisuus selviytyä, kuten millä tahansa muullakin alalla.

\section{Kommentteja}

EU:n direktiiveillä on jäsenvaltioille annettu mahdollisuus kokeiluluonteisesti soveltaa alennettua arvonlisäverokantaa tiettyihin työvaltaisiin palveluihin. Kokeilun tarkoitus on ollut selvittää, minkälainen vaikutus kohdennetulla arvonlisäveron alennuksella on työllisyyteen ja harmaaseen talouteen. Suomessa kokeilu suoritettiin vuosina 2007-2011, ja se koski mm. parturi- ja kampaamopalveluja (ks. HE 119/2006). Viimeisenä kokeilun soveltamisvuotena 2011 näiden palvelujen arvonlisävero oli $9 \%$, kun yleinen verokanta oli $23 \%$.

VATT:ssa selvitettiin vuonna 2010 parturi-kampaamojen 14 prosenttiyksikön arvonlisäveroalennuksen vaikutuksia hintoihin ja pyrittiin samalla arvioimaan, voiko alennetuilla alv-kannoilla tukea kohdealojen kysyntää ja työllisyyttä. Tutkimuksen mukaan parturikampaamot alensivat hintojaan noin puolella veronalennuksen määrästä, mutta palveluiden kysyntään ei toimenpiteellä näyttänyt olevan vaikutusta. Kun parturi-kampaamojen kysyntä ei alv-alennuksen myötä muuttunut, ei alennuksella ollut vaikutusta myöskään alan työvoiman kysyntään. Tutkimuksen vertailuryhmänä olivat kauneushoitolat, joita alv-alennus ei koskenut. Kysyntä- ja työllisyysvaikutusten puuttuessa ei alv-alennuskokeilun alkuperäinen tavoite täyttynyt. 
Eriytetyt arvonlisäverokannat voivat olla perusteltuja, jos niillä saavutetaan jotain tehokkuusetua suhteessa muihin valtion käytettävissä oleviin ohjailukeinoihin. Tässä tapauksessa vaikutti kuitenkin siltä, että työvoimavaltaisten palvelualojen alv-kokeilu ei ollut tehokas talouden ohjailukeino. Siten tuon tutkimuksen johtopäätös oli, että kokeilu tuli lopettaa ja eri alojen yrityksille tuli suoda samanlainen toimintaympäristö. Asiaan saatetaan kuitenkin vielä palata.

\subsection{E-kirjojen arvonlisävero painettujen kirjojen veron tasolle}

Jaakko Kuosmasen ja Petri Kultarannan 10.10.2016 vireille panemassa aloitteessa (847 kannattajaa) esitettiin, että e-kirjojen ja paperikirjojen arvonlisäveroprosentteja muutetaan siten, että e-kirjojen arvonlisäveroprosentti ei ole korkeampi kuin paperikirjojen.

E-kirjat ja paperikirjat ovat erilaisia, mutta ne palvelevat samaa tarvetta. Nyt paperikirjojen arvonlisäveroprosentti on $10 \%$ ja e-kirjojen $24 \%$, mikä jarruttaa digitalisaatiota. Jotta digitalisaatiota ei jarrutettaisi verotuksella, tulee e-kirjojen ja paperikirjojen arvonlisäveroprosentteja muuttaa siten, että e-kirjojen arvonlisäveroprosentti ei ole korkeampi kuin paperikirjojen. Jos digitalisaatiota halutaan vauhdittaa, tulee e-kirjojen arvonlisäveroprosentin olla pienempi kuin paperikirjojen.

\section{Kommentteja}

EU:n neuvosto hyväksyi 6.11.2018 neuvoston direktiivin (EU) 2018/1713 direktiivin 2006/112/EY muuttamisesta kirjojen, sanomalehtien ja aikakauslehtien arvonlisäverokantojen osalta. Direktiivi mahdollistaa sen, että jäsenvaltiot voivat soveltaa alennettuja verokantoja sähköisiin julkaisuihin. Hallitus antoi tämän jälkeen esityksen (303/2018) arvonlisäverolakimme muuttamiseksi. Esitys hyväksyttiin, ja 1.7.2019 lukien sähköisiin kirjoihin ja sanoma- ja aikakauslehtiin sekä lehtien irtonumeromyyntiin sovellettava verokanta on $24 \%$ :n sijasta $10 \%$. Lainmuutos, jota kansalaisaloitteessakin esitettiin, on siis nyttemmin toteutettu.

\subsection{Tekstiilialan arvonlisäverokantaa alennettava}

Virva Klaasion 21.6.2017 vireille panemassa aloitteessa (1 970 kannattajaa) vaadittiin arvonlisäveron muutosta tekstiili/käsityöaloilla.

Koska maassamme on pitkään vallinnut tekstiili/käsityöalojen kehno kilpailukyky markkinoilla, tulisi arvonlisäveron määrä muuttaa $10 \%$ :ksi 
tai poistaa kokonaan. Tämänhetkinen $24 \%$ :n verokanta on kohtuuton näille aloille, joilla kaikki työ tapahtuu käsin. Muutos parantaisi merkittävästi ompelualojen työllisyyttä ja kilpailukykyä markkinoilla. On tärkeää saada muutettua kohtuuttoman suuri arvonlisävero tekstiilialojen säilyttämiseksi. Valtion Pukutehdas sekä Virke Oy ovat näistä suurimpia esimerkkejä; maassamme on ammattitaitoa, mikäli kilpailukyky saadaan asianmukaiselle tasolle.

\section{Kommentteja}

Eräät SDP:n ja vasemmistoliiton kansanedustajat tekivät lokakuussa 1999 kirjallisen kysymyksen (654/1999) vaatetusalan ottamisesta arvonlisäveron alentamiskokeiluun. Siinä todettiin:

Suomessa tekstiili- ja vaatetusalalla on edelleen muihin aloihin verrattuna maan huonoin työllisyystilanne: $23 \%$ alan jäsenistä on työttömänä. Pääomavaltaisella erikoistekstiilipuolella on vientiä ja palkanmaksukykyä, ompelupuoli on jäänyt varjoon alan keskusteluissa. Sen selviytymisongelmat ovat suuremmat ja vaativat enemmän työtä kuin tähän asti.

Ala on viime vuosina voimakkaasti pienyritysvaltaistunut. Tekstiilejä valmistaa 1400 toimipaikkaa, joista 1200 on alle viiden hengen työpaikkoja. Vaatteita valmistaa 1600 toimipaikkaa, joista 1400 on alle viiden hengen työpaikkoja. Mikroyrityksissä ei ole eroa palveluyrityksiin nähden. Ne ovat verrattavissa kahviloihin, partureihin, pieniin ruokaloihin, suutarinliikkeisiin tai ateljeeompelimoihin. Meille esimerkiksi tekstiili- ja vaatetusala on perinteisesti ollut tärkeä työllistäjä. Vaikka ala on kokenut rajun rakennemuutoksen, se työllistäisi edelleen tuhansia suomalaisia. Työvoimavaltaisen sekä avoimen ja kovan kilpailutilanteen puristuksessa oleva kotimainen teva-ala tarvitsisi juuri nyt avitusta valtiovallalta. Yksi vaihtoehto olisi ns. sotu-maksujen tehokkaampi porrastus tai alv:n verokannan alentaminen kokeilun ajaksi.

On perusteltua uskoa, että vaatetusalan ottaminen mukaan alv:n alentamiskokeiluun toisi alalle kauan kaivattuja työpaikkoja.

Valtiovarainministeri Suvi-Anne Siimeksen vastaus oli torjuva. Siinä todettiin:

Arvonlisävero on yleinen kulutusvero, jota kannetaan kaikesta liiketoiminnan muodossa Suomessa harjoitetusta hyödykkeiden myynnistä. Arvonlisäverolain mukaan tekstiili- ja vaatetusalalla myytyihin tavaroihin ja palveluihin sovelletaan yleistä $22 \%$ :n verokantaa.

Arvonlisäverolaissa sovellettava veropohja sekä verokantarakenne ja -taso on määritelty Suomea sitovasti arvonlisäverodirektiivissä. Suomella 
ei siten ole oikeutta kansallisilla päätöksillä soveltaa alennettua verokantaa muihin kuin direktiivin sallimiin hyödykkeisiin. Neuvosto hyväksyi 22. päivänä lokakuuta 1999 direktiivin 1999/85/EY kuudennen arvonlisäverodirektiivin muuttamisesta siten, että siihen sisällytetään mahdollisuus soveltaa kokeiluluontoisesti alennettua arvonlisäverokantaa erityisen työvaltaisiin palveluihin. Direktiivin mukaan neuvosto voi myöntää jäsenvaltiolle luvan soveltaa 1. päivänä tammikuuta 2000 alkavan kolmivuotiskauden aikana alennettuja verokantoja direktiivin liitteessä K lueteltuihin palveluihin. Jäsenvaltio voi pääsääntöisesti ottaa käyttöön alennetun verokannan enintään kahteen liitteessä mainittuun palveluryhmään kuuluviin palveluihin. Jäsenvaltion, joka haluaa osallistua kokeiluun, on ilmoitettava siitä komissiolle ennen 1. päivää marraskuuta 1999. Kokeilukauden lopulla kokeiluun osallistuvan jäsenvaltion on laadittava yksityiskohtainen kertomus, johon sisältyy yleisarvio toimenpiteiden vaikuttavuudesta erityisesti uusien työpaikkojen luomisen ja tehokkuuden kannalta.

Kirjallisessa kysymyksessä ehdotetaan, että tekstiili- ja vaatetusala otettaisiin mukaan työvaltaisten palvelujen alennettuja verokantoja koskevaan kokeiluun. Direktiivin mukaan jäsenvaltio ei voi ottaa alennettua verokantaa käyttöön tekstiili- ja vaatetusalalla siltä osin kuin kysymyksessä on uusien tekstiilien ja vaatteiden valmistaminen ja myynti. Työvaltaisia aloja koskevaa arvonlisäverokokeilua ei ole missään vaiheessa katsottu voitavan ottaa käyttöön tavaroiden myynnin osalta, koska tavarat voivat liikkua jäsenvaltioiden rajojen yli. Alennetun verokannan soveltaminen yhdessä jäsenvaltiossa aiheuttaisi siten todennäköisesti kilpailunvääristymiä yhteisön alueella. Kilpailuneutraalisuussyistä alennettua verokantaa ei ole myöskään katsottu voitavan ottaa käyttöön ostajan toimittamasta raaka-aineesta tapahtuvaan uusien tavaroiden valmistustyön myyntiin. Tästä syystä arvonlisäverokokeilun soveltamisala myös tekstiili- ja vaatetusalalla on rajoitettu direktiivin K liitteessä mainittuihin palveluihin.

Direktiivin liitteeseen $\mathrm{K}$ sisältyvät mm. pienet korjauspalvelut, jotka kohdistuvat kenkiin ja nahkatavaroihin sekä vaatteisiin ja liinavaatteisiin. Jotta jäsenvaltio voi saada luvan soveltaa alennettua verokantaa näihin palveluihin, niiden on lisäksi täytettävä kyseisessä jäsenvaltiossa direktiivissä säädetyt tarkemmat edellytykset: palvelujen on oltava työvaltaisia, niitä on tarjottava laajalti lopulliselle kuluttajalle ja niiden on oltava pääasiallisesti paikallisia, eivätkä ne saa todennäköisesti luoda kilpailunvääristymiä. Lisäksi verokannan alentamisesta aiheutuvan hinnanalennuksen sekä kysynnän ja tarjonnan välillä on oltava kiinteä yhteys.

Alennetun verokannan soveltamisella pieniin korjauspalveluihin ei olisi tehtyjen selvitysten perusteella merkittävää työllistävää vaikutusta Suomessa. Kenkien ja nahkatavaroiden sekä vaatteiden ja liinavaatteiden korjaus on taloudelliselta merkitykseltään vähäistä ja työllisyyden kannalta hyvin marginaalinen ala. Myös kokeilun seuranta direktiivin edel- 
lyttämällä tavalla olisi kyseisillä aloilla saattanut olla vaikeaa, koska nämä palvelut eivät muodosta yhtenäistä toimialaa.

Lisäksi on huomattava, että työllisyyden edistämiseksi on olemassa tehokkaampiakin keinoja kuin työvaltaisten palvelujen arvonlisäverokannan alentaminen. Muun muassa sosiaaliturvamaksujen ja tuloverotuksen alentaminen on eräiden selvitysten mukaan tehokkaampi verotuksellinen keino työllisyysvaikutusten aikaansaamiseksi kuin arvonlisäveron alentaminen.

Kokeilulla todennäköisesti saavutettavien työllisyysvaikutusten vähäisyyden takia talouspoliittinen ministerivaliokunta päätti 26. päivänä lokakuuta 1999, että Suomi ei osallistu työvaltaisten palvelualojen alennettuja verokantoja koskevaan kokeiluun direktiivin mahdollistamilla toimialoilla. Edellä esitetyillä perusteilla hallitus katsoo, että alennettuja verokantoja koskevan kokeilun käyttöönotto tekstiili -ja vaatetusalalla ei ole ollut perusteltua.

\subsection{Eläinlääkäripalvelujen arvonlisäverotusta kevennettävä}

Hanna Puhakan 25.2.2016 vireille panemassa aloitteessa (2 692 kannattajaa) esitettiin eläinlääkäripalveluja arvonlisäverottomiksi tai alennetun $10 \%$ :n arvonlisäverokannan piiriin.

Eläinlääkäripalvelut kuuluvat tällä hetkellä yleiseen arvonlisäverokantaan, joka on $24 \%$. Näin lähes neljännes eläinlääkärikäynnin hinnasta muodostuu arvonlisäverosta. Eläinten rehuissa alv on $14 \%$ ja lääkkeissä $10 \%$. Alennetussa $14 \%$ :n arvonlisäverokannassa ovat esimerkiksi elintarvikkeet ja ravintolapalvelut. Alennetussa $10 \%$ :n arvonlisäverokannassa ovat lääkkeiden lisäksi esimerkiksi kirjat, liikuntapalvelut, elokuvanäytökset ja majoituspalvelut. Arvonlisäverotuksen ulkopuolelle kuuluvat mm. terveyden- ja sairaanhoito sekä sosiaalihuolto, rahoitus- ja vakuutuspalvelut sekä kiinteistöjen ja osakehuoneistojen myynti ja vuokraus.

Eläimen pitämiseen liittyy olennaisesti taloudellinen vastuu. Tuotantoeläimet kuuluvat yritysverotukseen, joten yrittäjällä on oikeus alv-vähennyksiin toiminnassaan. Lemmikkieläinten osalta asia on toinen - omistaja maksaa 24 \%:n arvonlisäveron lemmikkinsä hoidosta eläinlääkärissä. Tämä muodostaa merkittävän osan kokonaishinnasta.

Voidaan ajatella, että lemmikkieläintä hankkivan täytyy tämä asia ymmärtää jo eläimen hankintavaiheessa ja varautua kuluihin. Kaikkeen ei aina kuitenkaan voi varautua eikä pysty varautumaan. Suomen yleisimmät lemmikkieläimet ovat koira ja kissa. Koiran keskimääräinen eläinikä on 10-15 vuotta ja kissan 15-20 vuotta. Pentuna hankitun lemmikin elinkaari on siis pitkä, ja omistajan elämässä saattaa tuona aikana tapahtua paljon muutoksia, jotka heikentävät taloudellista tilannetta ja maksukykyä. 
Lemmikkieläimille on saatavilla erilaisia vakuutuksia. Vakuutukset luovat turvaa, mutta eivät korvaa kaikkea. Useilla vakuutusyhtiöillä on lemmikkivakuutuksissa maksukatot, vakuutukset eivät lähtökohtaisesti kata kaikkea. Lisäksi usein vakuutus lakkaa lemmikin ikääntyessä eli juuri silloin, kun lemmikki tarvitsee lisääntyvästi eläinlääkärin palveluja. Lisäksi omistajan mahdolliset maksuhäiriömerkinnät estävät vakuutuksen saamisen sekä laskutussopimuksen tai erämaksun klinikalla.

Omistajan vastuulla on taata lemmikilleen hyvä terveydenhuolto, mutta nykyisellään moni ei voi vastata tähän eläinlääkärien palkkioiden ollessa korkeita. Iso osa asiaa on $24 \%$ :n arvonlisävero. Muuttamalla verokanta kokonaan $0 \%$ :n luokkaan tai alentamalla sitä edes liikuntapalveluiden $10 \%$ :n tasolle pystyttäisiin saavuttamaan tilanne, jossa lemmikkien omistajat voisivat helpommin hankkia eläimilleen eläinlääkärin apua. Nykyisellään eläimiä hoidetaan paljon vasta sitten, kun tilanne on akuutti. Tällöin omistaja saattaa joutua punnitsemaan vaihtoehtoja eläimen kalliiden kuntouttavien hoitojen tai elinkelpoisen eläimen lopetuksen välillä.

Suomessa eläinsuojelulaissa säädetään, että eläimiä tulee suojella parhaalla mahdollisella tavalla kärsimykseltä, kivulta ja tuskalta. Lain tarkoituksena on myös edistää eläinten hyvinvointia ja hyvää kohtelua. Arvonlisäveroluokan alentaminen eläinlääkäripalveluissa ihmisten terveyden- ja sairaanhoidon tasolle $0 \%$ :n luokkaan edistää eläinten hyvinvointia.

Sterilisaatiot ja kastraatiot ovat WHO:n mukaan paras tapa vähentää ei-toivottujen eläinten syntymistä. Suomessa ei kulkukoirapopulaatiota elä kuten monessa muussa Euroopan maassa, mutta meilläkin on ongelmana steriloimattomien eläinten lisääntyminen. Suomessa asia koskettaa erityisesti kissoja, jotka kulkevat vapaana lisääntyen. Suomessa eläinsuojelun haltuun päätyy vuosittain valtavia määriä kulkukissoja ja niiden villinä syntyneitä pentuja. Pelkästään eläinsuojelun haltuun päätyneistä kissoista joudutaan noin 20000 lopettamaan joka vuosi.

Jos eläinten sterilisaatioiden hinta olisi noin neljännes alhaisempi $0 \%$ :n arvonlisäkannalla, useammalla omistajalla olisi mahdollisuus leikkauttaa eläimensä. Tämä ehkäisisi paremmin eläinten hallitsematonta lisääntymistä.

Arvonlisäverokannan pudottamisessa $0 \%$-verokantaan tuo vain etuja. Se mahdollistaa parempaa lemmikkien hoitoa, vähentää kynnystä steriloida eläimiä sekä ennalta ehkäisee elinkelpoisten eläinten lopetusta tai hoitamatta jättämistä. Se takaa nykyistä paremmin eläimille hoidon, kun eläin sitä tarvitsee.

Lemmikit ovat osa yhteiskuntaa ja perhettä. Meidän tulee mahdollistaa eläimille paras mahdollinen hoito. Tätä voidaan edistää vapauttamalla eläinlääkäripalvelut $24 \%$ :n arvonlisäverokannasta. 


\section{Kommentteja}

Yleisen verokannan soveltaminen eläinlääkäripalveluihin johtuu EU:n arvonlisäverodirektiivistä. Sitä olisi muutettava, ennen kuin Suomi voisi vapauttaa eläinlääkintäpalvelut verosta tai säätää ne alennetun verokannan piiriin.

Suomen Eläinlääkäriliiton puheenjohtaja Päivi Lahti kirjoittaa Eläinlääkärilehdessä 1/2019 asiasta seuraavaa:

"Kun Euroopan arvonlisäverodirektiiviä alun perin tehtiin, ajateltiin lemmikkien olevan ylellisyyttä, jota on verotettava korkeimmassa arvonlisäveroluokassa. Ihmisten hyvinvointi-, liikunta- ja kulttuuripalvelut katsottiin niin tärkeiksi, että niiden sallitaan olevan alennetun arvonlisäveron piirissä. Ihmisten terveyspalvelut ovat arvonlisäverottomia. Eläinten myönteinen vaikutus ihmisten hyvinvointiin tiedostetaan yhä paremmin. Tämän pitää näkyä myös EU:n arvonlisäverolainsäädännössä. Olisi sekä eläinten että ihmisten etu, että eläimille välttämätön terveyden- ja sairaanhoito olisivat alennetun arvonlisäveron piirissä."

\subsection{Kuukautissuojien verokantaa alennettava}

Turkka Saarikosken 5.10.2018 vireille panemassa aloitteessa (6 885 kannattajaa) ehdotettiin kuukautissuojien verokannan alentamista $24 \%$ :sta $10 \%$ :iin. Kuukautissuojat ovat sukupuolisidonnainen välttämättömyys. Näiden tuotteiden arvonlisäverokantaa olisi laskettava apteekissa myytävien lääketuotteiden tasolle. On kohtuutonta, että tällaista naisille välttämätöntä tuoteryhmää verotetaan normaalien kulutushyödykkeiden tasolla. Kyse on terveydestä, hyvinvoinnista ja hygieniasta. Naisena eläminen aiheuttaa sukupuolisidonnaisen, jatkuvan kuluerän, jota olisi reilua kompensoida edes asiallisella farmakologisten tuotteiden verokannalla.

\section{Kommentteja}

EU-direktiivi mahdollistaa kuukautissuojien säätämisen alennetun verokannan piiriin, ja näin on tehtykin Espanjassa, Kreikassa, Itävallassa ja Ranskassa sekä vuodesta 2020 lähtien myös Saksassa. Irlannissa on näille tuotteille nollaverokanta, mikä on mahdollista ns. parking rate -poikkeuksen vuoksi, koska Irlannilla oli Euroopan unioniin liittyessään jo kyseinen nollaverokanta. Yhdistyneessä kuningaskunnassa kuukautissuojien nollaverokanta ei EU:n takia ole mahdollinen, mitä on käytetty jopa yhtenä perusteena brexitin puolesta. Kyseisten tuotteiden nollaverokanta on käytössä myös muutamissa EU:n ulkopuolisissa maissa. 
Kansalaisaloite kuukautissuojien arvonlisäverokannan alentamisesta sai niin vähän kannattajia, ettei se edennyt eduskunnan käsittelyyn. Samaa asiaa on eduskunnassa kuitenkin käsitelty kansanedustajan lakialoitteen ja kirjallisen kysymyksen pohjalta.

Kansanedustaja Hanna Sarkkinen (vas) teki 1.2.2017 lakialoitteen (2/2017), jossa ehdotettiin arvonlisäverolain 85a §:n muuttamista kuukautis- ja inkontinenssisuojien siirtämiseksi yleisestä $24 \%$ :n arvonlisäverokannasta alennettuun $10 \%$ :n arvonlisäverokantaan. Lakialoitetta perusteltiin seuraavasti:

Kuukautissuojat ja inkontinenssisuojat ovat välttämättömiä hygienia- ja terveystarvikkeita, joita voidaan perustellusti pitää alennettuun arvonlisäveroon kuuluvina farmakologisina tuotteina. Kuukautissuojien hankinnasta kertyy naisille vuosikymmenten aikana merkittäviä sukupuolisidonnaisia kustannuksia. Inkontinenssisuojat puolestaan ovat monille terveysongelmista kärsiville ja ikääntyneille terveydentilan heikentymisen johdosta välttämättömiä elämää helpottavia hygienia- ja terveystarvikkeita, joista kuitenkin muodostuu merkittäviä kuluja. Synnytykset lisäävät naisilla kuukautis- ja inkontinenssisuojien tarvetta.

Kuukautis- ja inkontinenssisuojat kuuluvat tällä hetkellä normaaliin $24 \%: n$ arvonlisäveron piiriin. Näitä tuotteita voi kuitenkin verrata apteekeissa myytäviin terveystuotteisiin, joiden arvonlisävero on $10 \%$. Kuukautis- ja inkontinenssisuojien arvonlisävero tulisikin alentaa kymmeneen prosenttiin. Tämä helpottaisi näiden välttämättömien tarvikkeiden hankintaa ja tasoittaisi kuukautissuojista nimenomaan naisille kohdistuvaa erityistä kulurasitetta.

On tärkeä̈, että alennettu verokanta koskisi kertakäyttöisten terveyssiteiden, tamponien ja pikkuhousunsuojien lisäksi myös pestävistä materiaaleista valmistettuja suojia ja kuukautiskuppeja. Pestävistä materiaaleista valmistetut suojat ovat ympäristöystävällisempiä kuin kertakäyttöiset, ja ne soveltuvat ominaisuuksiensa puolesta toisille paremmin kuin kertakäyttöiset tuotteet. Vaikka kestosuojien hankintahinta on korkeampi, tulee niiden elinkaarikustannus kuitenkin yleensä kertakäyttötuotteita halvemmaksi.

EU-direktiivi mahdollistaa kuukautis- ja inkontinenssisuojien verottamisen alennetussa farmakologisten tuotteiden kategoriassa. Suojat on siirretty alennettuun arvonlisäverokantaan ainakin Ranskassa ja IsossaBritanniassa. Keskustelu kuitenkin jatkuu, jotta kuukautissuojat voitaisiin vapauttaa EU:ssa kokonaan arvonlisäverosta. Yhdysvalloissa New Yorkin osavaltiossa kuukautissuojien arvonlisävero on poistettu kokonaan. Myös Australiassa ja Kanadassa käydään keskustelua kuukautissuojien verotuksesta. 
Kuukautissuojien ja inkontinenssisuojien siirto alennettuun arvonlisäverokantaan parantaisi sukupuolten välistä tasa-arvoa, kun kuukautissuojien hinnan laskiessa naisille ja tytöille kohdistuva kustannusrasite pienentyisi. Ikääntyvien ihmisten ja pidätysongelmia aiheuttavista sairauksista kärsivien henkilöiden taloudellista tilannetta helpottaisi inkontinenssisuojien hinnan alentuminen arvolisäveron laskun myötä.

Kuukautissuojien aiheuttamat kulut vaihtelevat suuresti, sillä jokaisen tarve suojille on henkilökohtainen ja vaihtelee elämän aikana. Keskimäärin kuukautissuojia tarvitaan aiempaa enemmän, sillä kuukautiset alkavat aiemmin ja jatkuvat pidempään ja raskauksia on vähemmän. Kuukautissuojien hinnan alentuminen helpottaisi naisten taloudellista asemaa. Kuukautissuojiin voi arvioida kuluvan naisen elämän aikana tuhansia euroja, ja inkontinenssisuojista yksilöille koituvat kustannukset voivat olla vielä merkittävämpiä. Inkontinenssisuojien hinnan alentuminen helpottaisi erityisesti ikääntyneiden taloutta. Veron alentamisen jälkeenkin suojista kertyvä kustannus yksilöille olisi edelleen suuri, mutta kuitenkin nykyistä alhaisempi. Verotuloihin kuukautis- ja inkontinenssisuojien siirto alennettuun arvonlisäveroluokkaan aiheuttaisi menetystä, veromenetyksen suuruus ei kuitenkaan valtiontalouden mittakaavassa olisi kovin suuri.

Helmikuussa 2019 eduskunta valtiovarainvaliokunnan mietinnön mukaisesti hylkäsi lakialoitteen.

Vihreiden Saara Hyrkkö teki 23.7.2019 seuraavan kirjallisen kysymyksen kuukautissuojien verotuksesta:

Kuukautissuojat - terveyssiteet, tamponit, pikkuhousunsuojat ja kuukautiskupit — ovat välttämättömiä hygienia- ja terveystarvikkeita. Niiden käyttötarve kestää usein kymmeniä vuosia, joiden aikana suojiin voi kulua merkittävä määrä rahaa. Tilastokeskuksen kotitalouksien kulutusta mittaavan tilaston mukaan yksittäinen kotitalous käytti terveyssiteisiin ja tamponeihin 12 euroa kuussa vuonna 2016. Kuukautissuojien hankinta aiheuttaa sukupuolittuneen, taloudellisen rasitteen erityisesti naisille.

Kuukautissuojien arvonlisävero on $24 \%$, joka on arvonlisäverokannoista yleisin ja korkein. Esimerkiksi terveyden kannalta välttämättömien lääkkeiden arvonlisävero on 10 prosenttia. Käyttötarkoituksensa perusteella kuukautissuojia voidaan pitää farmakologisina tuotteina lääkkeiden tapaan. Kuukautissuojien arvonlisäveroa on alennettu tai siitä on kokonaan luovuttu useissa maissa, kuten Irlannissa, Kanadassa, Intiassa ja Isossa-Britanniassa.

Tämän vuoden tammikuussa Euroopan parlamentti hyväksyi päätöslauselman sukupuolten tasa-arvosta ja EU:n veropolitiikasta, jossa se kehottaa EU:n jäsenmaita poistamaan "tamponiveron" eli kuukau- 
tissuojille kuuluvan käyttötarkoitustaan korkeamman verokannan ja soveltamaan hygieniatuotteisiin perustuotteiden verovapautusta tai nollaverokantoja. Parlamentti myös kehottaa jäsenvaltioita tekemään sukupuolivaikutusten arviointeja veropoliittisissa toimissa.

Kuukautissuojien hankinta aiheuttaa sukupuolisidonnaisia kustannuksia. Ottaen huomioon suojien hankinnan välttämättömyyden ja säännöllisyyden tulisi kuukautissuojat rinnastaa alemman verokannan hyödykkeisiin. Kuukautissuojien verokantaa laskemalla tai arvonlisävero kokonaan poistamalla edistetään tasa-arvoa, helpotetaan suojien hankintaa ja varmistetaan yhdenvertainen pääsy hygieniatuotteiden piiriin.

Edellä olevan perusteella ja eduskunnan työjärjestyksen 27 \$:ään viitaten esitän asianomaisen ministerin vastattavaksi seuraavan kysymyksen: Aikooko hallitus ryhtyä Euroopan parlamentin päätöslauselman mukaisiin toimenpiteisiin kuukautissuojien hankkimisesta aiheutuvien sukupuolisidonnaisten kustannusten vähentämiseksi?

\section{Valtiovarainministeri Mika Lintilä totesi vastauksessaan 14.8.2019:}

Tavarat ja palvelut, joihin jäsenvaltiot voivat soveltaa alennettua verokantaa, on lueteltu direktiivin liitteessä III. Liitteen 3 kohdan mukaan alennettuja verokantoja voidaan soveltaa farmakologisiin tuotteisiin, joita tavallisesti käytetään terveydenhoidossa, sairauksien ehkäisemisessä sekä lääketieteellisessä ja eläinlääketieteellisessä hoidossa, mukaan lukien ehkäisyyn ja naisten hygieniaan tarkoitetut tuotteet. Nollaverokantaa näihin ei voi soveltaa. Jäsenvaltiot voivat poikkeuksellisesti soveltaa nollaverokantoja, jos nämä verokannat ovat olleet voimassa jo 1 päivänä tammikuuta 1991. Tällaiseen poikkeukseen perustuu Irlannissa sovellettava kuukautissuojien verottomuus.

Arvonlisäverodirektiivi mahdollistaa kuukautissuojien verottamisen alennetulla verokannalla. Alennetun verokannan soveltamisalan laajentaminen kuukautissuojiin merkitsisi uuden tuoteryhmän lisäämistä alennettujen verokantojen piiriin kuuluviin tuotteisiin ja poikkeamaa niistä linjauksista, joihin terveyden- ja sairaanhoidon vapautus sekä lääkkeiden alennettu verokanta nykyisin Suomessa perustuvat. Vaikka sukupuolisidonnaisten kustannusten vähentäminen on sinänsä tärkeä tavoite, verokannan alentaminen ei kuulu nykyiseen hallitusohjelmaan. Alennetut arvonlisäverokannat kaventavat veropohjaa ja niiden käyttöalan laajentaminen vaikeuttaa pyrkimyksiä siirtää verotuksen painopistettä kulutuksen verottamiseen. Ne eivät myöskään yleensä ole tehokkaita välineitä yhteiskuntapoliittisten tavoitteiden saavuttamiseksi. Veron alentamisen siirtyminen hintoihin on myös epävarmaa. Lisäksi lukuisat verokannat lisäisivät arvonlisäverojärjestelmästä Verohallinnolle sekä yrityksille aiheutuvaa taakkaa ja hallinnollisia kustannuksia. 
Esitystä on saatettu myös vastustaa sukupuolten tasa-arvon nimissä viittaamalla siihen, että miehiltä peritään partaveroa, koska parranajotuotteet ovat arvonlisäverotuksen piirissä. ${ }^{74}$ Siitä huolimatta kuukautissuojien arvonlisäverokannan alentamista voidaan pitää perusteltuna. Se sopisi melko hyvin verojärjestelmäämme eikä romahduttaisi valtion verotuloja. Asiaan on syytä palata.

\subsection{Uusiutuviin luonnonvaroihin perustuvan energian arvonlisäverokantaa alennettava}

Markku Nivakosken, Veli-Pekka Heikkisen, Heikki Kanniaisen, Ismo Moilasen, Niina Huikurin, Sampo Jauhiaisen, Eero Piiraisen, Timo Roinisen, Pekka Välisen, Ilkka Kemppaisen ja Jorma Jurvan 15.12.2014 vireille panemassa aloitteessa (511 kannattajaa) esitettiin, että uusiutuvien luonnonvarojen käyttöön perustuvaan energian ja polttoaineiden sekä niitä hyödyntävien energiapalveluiden myyntiin sovellettaisiin alennettua verokantaa seuraavasti: Sähköenergian ja sen siirtopalvelun sekä verkon kautta toimitettavan lämpöenergian ja polttoaineina käytettävien kaasujen sekä nesteiden myynnin verokantaa alennetaan vaiheittain siten, että ensimmäisenä vuotena verokanta on $19 \%$, seuraavana vuotena $14 \%$ ja sen jälkeen $10 \%$. Polttoaineina käytettävien valmiiden polttopuiden "klapien", briketin ja pelletin myynnin sekä energiapalveluna (lämpöyrittäjä) tapahtuvan lämmön myynnin verokanta on $10 \%$. Kunnan toimiessa kilpailutilanteessa markkinoilla alennettua verokantaa sovelletaan, jos toiminta on järjestetty kuntalain $2 \mathrm{a} \$: n$ mukaisesti (yhtiöittämisvelvollisuus).

Suomen biotalousstrategian johtoajatuksena on luoda kilpailukykyisiä ja kestäviä biotalouden ratkaisuja maailmanlaajuisiin ongelmiin ja synnyttää sekä kotimaahan että kansainvälisille markkinoille uutta liiketoimintaa, joka tuo hyvinvointia koko Suomelle.

Energiamarkkinoiden rakennemuutos uusiutuvien luonnonvarojen käyttöön tapahtuu aluksi metsän biomassan osuutta lisäämällä. Siihen on hyvät mahdollisuudet, koska metsien käyttö on huomattavasti alle suurimman kestävän hakkuusuunnitteen ja käyttöön soveltuva sähkön- ja lämmöntuotannon teknologia on hyvin kehittynyttä ja laajalti käytössä. Nykyisissä voimalaitoksissa voidaan jo nyt lisätä puun osuutta. Samoin käyttö kasvaa, kun uusien ja saneerattavien voimalaitosten polttoainevalinnoissa huomioidaan uusiutuvia luonnonvaroja suosiva verotus.

74 Historia tuntee myös varsinaisia partaveroja. Esim. Venäjällä oli vuodesta 1698 vuoteen 1772 voimassa ukaasi, joka määräsi muut miehet kuin papit ajamaan partansa tai maksamaan partaveroa. 
Muiden käyttömuotojen ja erilaisten uusiutuvien luonnonvarojen hyödyntäminen kasvaa, kun niihin liittyvä teknologia ja tuotantomenetelmät kehittyvät riittävän pitkälle.

Uusiutuvan energian käyttö synnyttää yrittäjyyttä, työtä ja verotuloja tasaisesti kaikkialle kansantalouteen monin verroin enemmän kuin fossiiliset tuontipolttoaineet.

Suomen uusiutuvien luonnonvarojen hyödyntämisellä energiantuotannossa on merkittävät mahdollisuudet kansantalouden, työllisyyden ja ilmastotavoitteiden edistämisessä. Tämä on tuotu hyvin esille energiapolitiikka.fi-foorumin laatimassa julkaisussa "Kasvua ja työllisyyttä uudella energiapolitiikalla”. Energiaa tuodaan vuosittain 8,5 miljardin euron arvosta, vaikka siitä voitaisiin korvata merkittävä osa kotimaisilla uusiutuvilla luonnonvaroilla. Uusia työpaikkoja odotetaan syntyvän 50 000-100 000 vuoteen 2030 mennessä. Arvonlisäveron alentaminen esityksen mukaisesti käynnistää ostovoiman kasvun kautta markkinaehtoisen rakennemuutoksen, jossa kuluttajien etu ohjaa energiamarkkinoiden toimintaa ja tuotantorakennetta uusiutuvien luonnonvarojen käyttöön.

Verokannan alentaminen näkyy kuluttajilla välittömästi sähkö-, lämpö- ja polttoainelaskuissa hintojen alentumisena tuotannossa käytetyn uusiutuvan energian osuuden mukaan. Kiinteistöjen energiakustannukset ovat merkittävä osa elinkustannuksia. Alentamalla uusiutuviin luonnonvaroihin perustuvien energiatuotteiden arvonlisäverotusta voidaan vaikuttaa tehokkaasti ja nopeasti kuluttajien valintoihin - hinta ratkaisee.

Sähkön ja kaukolämmön verokannan alentaminen portaittain on perusteltua siksi, että kuluttajat ja energia-alan toimijat pystyvät reagoimaan hallitusti muutokseen ja estetään mahdolliset ylilyönnit markkinoilla. Sitoutuminen riittävään verokannan alentamiseen varmistaa kaikkien tuotantoketjun toimijoiden luottamuksen toiminnan jatkuvuuteen.

Verotus on tehokas keino ohjata yhteiskunnan kehitystä. Toistaiseksi sen käyttö kulutuksen ja tuotannon ohjauksessa on jäänyt vähälle huomiolle. Arvonlisävero kulutuksen verona vaikuttaa suoraan kuluttajien ostovoimaan ja kysyntään. Aleneva verotus lisää ostovoimaa, joka ohjautuu suurelta osin muuhun kulutukseen ja lisää siten osaltaan työllisyyttä sekä verotuloja. Ostovoiman lisäys ulottuu kaikkialle Suomeen, ja se kohdentuu kotitalouksiin, kyliin ja kaupunkeihin uusiutuvan energian käytön määrän mukaan. Lisäksi ostovoiman kasvu luo edellytyksiä maltilliseen palkkakehitykseen, mikä parantaa työn ja tuotteiden kilpailukykyä vientimarkkinoilla.

Sähkön ja lämmöntuotannon polttoaineiden käytön seuranta ja tilastointi on valmiina kaikilla nykyisillä energian tuottajilla. Arvonlisäveroja laskutusjärjestelmät pystyvät käsittelemään useita verokantoja, joten mahdolliset muutokset ja lisätyöt ovat hyvin vähäisiä. Fossiilisten ja 
uusiutuvien polttoaineiden yhteiskäytössä tuotettu energia eritellään eri verokannoille toimituskausittain käytettyjen polttoaineiden energiasisällön mukaisesti. Tuotteen tai palvelun myyjä vastaa energiaan sovellettavan verokannan kohdistamisesta tuotannon polttoaineiden käytön ja sisällön mukaan.

Alennetun verokannan soveltaminen polttopuun myyntiin parantaa rehellisten yrittäjien kilpailukykyä harmaata taloutta vastaan, koska siitä saatava etu pienenee. "Klapikaupan" ja lämpöyritysten verokannan voi laskea nopeasti, koska siten klapikauppa saadaan rehellisten yrittäjien haltuun. Metsänomistajien ja lämpöyrittäjien liiketoiminnan edellytykset paranevat, kun paikallisesti tuotetun energian kilpailukyky paranee. Potentiaalisia asiakkaita ovat nykyisin öljyä käyttävät, kaukolämpöverkon ulkopuolella olevat kiinteistöt ja kiinteistöryhmät. Jopa $0 \%$ :n verokannan soveltaminen klapikauppaan ja lämpöyrittäjien toimintaan olisi perusteltua harmaan talouden hävittämiseksi toiminnasta sekä siksi, että nykyisin keruutukea vaativa harvennuspuun käytön taloudellisuus paranisi. Tämä edistäisi hajautetun pien-CHP-tuotannon käyttöönottoa ja sen vaatiman kuivan hakkeen tuottamista materiaalin kuivauksella vähäarvoisesta paikallisesta puusta. Samoin edullinen ja hyvälaatuinen polttopuu voisi edistää energiatehokkaiden tulisijojen kehitystä ja nykyisten korvaamista niillä. Briketin ja pelletin alhainen verokanta edistää puunjalostuksen sivutuotteiden hyödyntämistä ja toiminnan kilpailukykyä.

Uusiutuva energia on pääosin paikallista ja kotimaista. Sen käyttö vähentää tuonnin tarvetta, parantaa huoltovarmuutta sekä tuo uusia pysyviä työpaikkoja maaseudulle ja siten hidastaa maaseudun autioitumista ja asutuskeskusten ruuhkautumista. Uusiutuva energia lisää maaseudun ja kaupunkien keskinäistä vuorovaikutusta ja vähentää vastakkainasettelua. Kunnan lakisääteisiin tehtäviin ei kuulu energiantuotanto. Siksi alennetun verokannan soveltaminen tulisi rajata kuntalain 2 a $\$$ :n yhtiöittämisvelvoitteen mukaisesti järjestettyyn toimintaan piiloverotuksen ja -tuen estämiseksi.

Energiateollisuuden tilastojen mukaan asumisessa ja maataloudessa metsäbiomassalla tuotetun sähkö- ja lämpöenergian määrien sekä verollisten keskihintojen mukaan laskettuna alv-kertymä on Suomessa n. 0,5 miljardia euroa/vuosi. Siirtymävaiheen lopussa kertymä puolittuisi nykykäytön mukaan. Yhteiskunta tukee energian käyttöä ja tuotantoa vuosittain yhteensä 2,7 miljardilla eurolla. Verotulojen alentuminen voidaan korvata leikkaamalla toimialan investointi- ja yritystukia, koska liiketoiminnan kannattavuus paranee kasvavan kysynnän myötä markkinaehtoisesti. Volyymien kasvaessa toiminta tehostuu, yksikkökustannukset alenevat ja tuotteiden hinnat kehittyvät kysynnän ja tarjonnan mukaan. Investointien tukeminen nykymuodossa tarkoittaa käytännössä sitä, että valtio käyttää rahaa etupainotteisesti ja ottaa vastuulleen osan toiminnan 
riskistä. Riskin toteutumisesta on todisteena tyhjillään olevia teollisuushalleja kautta Suomen. Yritysten perustaminen ja lähes kaikki investoinnit ovat olleet vuosikymmeniä riippuvaisia kulloinkin käytettävistä tuista. Osa yrityksistä on perustettu pelkästään tukien saamiseksi.

Muuttamalla toimintaa tässä esitetyllä tavalla valtio luo ennustettavat taloudelliset puitteet yritysten toiminnalle sekä vapautuu yritystoiminnan riskeistä ja investointien rahoituksesta.

Tuulivoiman määräaikaisen syöttötariffin ja metsäenergian haketustuen voisi korvata yksinkertaisemmin tällä tavalla. Muutos ei vaadi uutta byrokratiaa, ja tarpeettomaksi jäävää byrokratiaa voidaan purkaa. Työllisyyden kohentumisen kautta verotulot nousevat ja työttömyysmenot laskevat.

Arvonlisäverojärjestelmän kautta yhteiskunnalla on hyvä mahdollisuus ohjata kehitystä kansainvälisten ilmastotavoitteiden ja Suomen biotalousstrategian mukaisesti. Kilpailua vääristäviä yritys- ja elinkeinotukia sekä kallista ja tehotonta hallintoa voidaan korvata järkevällä verotuksella. Ja mikä tärkeintä - kannustaa kuluttajia sekä energiantuottajia tekemään valintoja paremman tulevaisuuden ja kestävän kehityksen edistämiseksi.

Arvonlisäverojärjestelmä on yhteinen kaikille EU-maille. Esitetyn uudistuksen myötä verojärjestelmä saa nimen lisäksi arvoja myös sisältöönsä ja keskeisen roolin kestävän kehityksen edistämisessä.

\section{Kommentteja}

Kuten aloitteen lopussa todetaan, EU:ssa on kaikkien jäsenmaiden yhteinen arvonlisäverojärjestelmä. Vaikuttaakin siltä, että aloitteen mukainen arvonlisäverotus edellyttäisi EU-direktiivin muutosta, joka taas vaatisi EU-mailta yksimielisyyttä.

\subsection{Aurinkosähkön arvonlisäveroa alennettava}

Sara Ahon 17.10.2014 vireille panemassa aloitteessa (35 kannattajaa) ehdotettiin aurinkosähkön verovapaaksi tekemistä tai verokevennystä aurinkosähkölle ja siihen liittyvälle yritystoiminnalle.

Aurinkoenergialla omavaraisesti tuotetun sähkön verotus vaatii tarkastelua, sillä vaikka aurinkopaneelien asennuksesta saakin kotitalousvähennystä, ei niillä tuotettu sähkö tule verotuksen kannalta edullisemmaksi. Aurinkosähkö on ympäristöystävällinen energiamuoto, sillä sen tuottamat päästöt liittyvät ainoastaan aurinkopaneelien valmistukseen, huoltoon ja jälkikäsittelyyn. Aurinkoenergian hyödyntäminen kannattaa, sillä aurinko säteilee maapallolle tunnissa enemmän energiaa kuin koko ihmiskunta tällä hetkellä käyttää vuodessa. Suomessa auringon säteilyenergian määrä vuosittain on keskimäärin $1000 \mathrm{kWh} / \mathrm{m} 2$. Sähkön verotus Suomessa on tällä hetkellä $1,90 \mathrm{snt} / \mathrm{kWh}$. 
Aurinkosähköä käyttävien kotitalouksien määrän kasvaminen edistäisi myös Suomen ilmasto- ja energiastrategian (2008) asettamaa tavoitetta siitä, että tuulivoimalla ja aurinkoenergialla tuotetun sähkön osuus nousisi 6 tWh vuoteen 2020 mennessä, vaikka aurinkosähkön laajamittainen käyttöönotto onkin suunniteltu vasta myöhempään ajankohtaan.

Viimeaikainen teknologian kehitys mahdollistaa aurinkoenergian joustavamman kulutuksen. Aurinkosähkön arvonlisävero tulee laskea 1-3 \%:iin, jolloin aurinkosähkön kysyntä kasvaa merkittävästi. Tällöin aurinkosähköä tai siihen liittyviä palveluita tarjoavien yritysten mahdollisuus työllistää paranee ja tuontienergian tarve pienenee.

\section{Kommentteja}

Tämänkin aloitteen mukainen arvonlisäverotus edellyttäisi EU-direktiivin muuttamista, joka taas vaatisi EU-mailta yksimielisyyttä.

\subsection{Verosta maksettava arvonlisävero poistettava}

Matti Hietasen 27.11.2017 vireille panemassa aloitteessa (35 kannattajaa) ehdotettiin, että arvonlisäveroa ei kerättäisi tuotteen tai palvelun verollisesta hinnasta vaan ainoastaan verottomasta hinnasta, eli arvonlisäveron periminen lopetetaan kaikissa tapauksissa, joissa maksetaan veroa verosta. Nykyään esimerkiksi sähkönsiirrossa ja polttoaineiden tuotteiden/ palvelujen verollisista hinnoista maksetaan $24 \%$ :n arvonlisävero, vaikka veron maksaminen ei ole mikään palvelu tai tuote vaan pelkkä lisärahastus valtiolle, joten arvonlisävero tulee periä ainoastaan verottomasta hinnasta. Nykyinen veron laskentatapa nostaa kohtuuttomasti esimerkiksi jo muutoinkin erittäin korkeita sähkönsiirtohintoja, jotka syntyivät, kun sähkönmyynti ja sähkönsiirto eriytettiin ja myytiin ulkomaille. Näistä jo korkeista hinnoista kärsivät varsinkin kaikki vähävaraiset (mm. vanhukset, eläkeläiset, opiskelijat), ja kun tähän lisätään nykyisellä tavalla laskutettava alv eli veroa verolle, hinta nousee edelleen ja on kestämätön. Lakia tulee muuttaa niin, että verosta ei tarvitse maksaa uudelleen veroa eli maalaisjärjen mukaiseksi.

Myös Veli-Matti Hietasen 6.12.2018 tekemässä aloitteessa (39 kannattajaa) ehdotettiin lakia muutettavaksi siten, että koskaan arvonlisäveroa ei saa verottaa jo muusta kannetusta verosta. Tällä hetkellä valmiste-, polttoaine-, sähköveron jne. päälle lisätään vielä arvonlisävero, siis verolle veroa. Suomessa rikotaan räikeästi verotuksen moraalista ja oikeudenmukaista verotapaa, että verosta ei saisi kantaa veroa. Tällainen toiminta ei ole kansalaisten näkökannalta reilua eikä näin ollen ole kohtuullista. Jo 450 vuotta vanhassa Tuomarin ohjeessa sanotaan: "Mikä ei ole oikeus ja kohtuus, se ei voi olla lakikaan.” 


\section{Kommentteja}

Arvonlisäverodirektiivin 78 artiklan a)-kohdan mukaan veron perusteeseen on sisällytettävä verot, tullit, tuontimaksut ja muut maksut, lukuun ottamatta itse arvonlisäveroa. Direktiivi sitoo myös Suomea, joten täällä ei voida säätää toisin. Autoveron ja arvonlisäveron keskinäisen suhteen osalta on nykyisin erityisjärjestely arvonlisäverolain 73.2 §:ssä. Sen mukaan autoverolain 39 \$:ssä tarkoitetun rekisteröidyn asiamiehen mainitun lain 4.2 \$:n nojalla liikenneasioiden rekisteriin merkityn ajoneuvon omistajan sijasta ajoneuvosta suorittama ja tältä veloittama autovero ei ole osa asiamiehen jälleenmyyjältä eikä jälleenmyyjän rekisteriin merkityltä ajoneuvon omistajalta ajoneuvon myynnistä veloittamaa vastiketta.

\subsubsection{Tieliikenteen verot ${ }^{75}$}

\subsection{Autovero on poistettava tai sitä on alennettava}

Ensimmäisen autoverolain kumoamista tarkoittavan kansalaisaloitteen pani vireille Jarno Siivola 5.12.2012 (2 206 kannattajaa). Autoverolaki otettiin käyttöön vuonna 1958 väliaikaisena, mutta tämä väliaikaisuus ei ole vieläkään päättynyt. On siis aika luopua tästä vanhanaikaisesta väliaikaisesta verosta viimein ja siirtyä nykyaikaan. Tämänkaltaiset lait, kuten autoverolaki, hidastavat nykyaikaisen yhteiskunnan kehitystä sekä heikentävät kansallista kilpailukykyä. Kansalaiset tarvitsevat ajoneuvoja päästäkseen töihin, ja kun ajoneuvon hinnassa on jopa puolet veroa, syntyy myös tarve palkankorotuksille sen takia, ettei ole varaa hankkia autoja, joilla kulkea töissä. Jotkut onnekkaat asuvat kaupunkien keskustoissa lähellä työpaikkaa tai suurimmissa kaupungeissa, joissa julkinen liikenne toimii, mutta hyvin moni kansalainen joutuu käyttämään omaa kulkuneuvoa päästäkseen töihin.

Suomen ajoneuvokanta on autoverosta johtuen Euroopan vanhimmasta päästä. Suomi on maa, jossa välimatkat ovat pitkiä, puolet vuodesta ajetaan pimeydessä, jään ja lumen keskellä, haastavissa ja vaarallisissa olosuhteissa. Vanhojen autojen turvarakenteet ja ajo-ominaisuudet eivät

75 Tieliikenneveroista ks. esim. kirjani Autoveron saattohoito ja tieliikenneverotuksen kehittäminen - Autovero 60 vuotta (2018). On syytä muistaa, että autovero ja ajoneuvovero ovat eri asioita. Edellinen liittyy ajoneuvon käyttöönottovaiheeseen ja jälkimmäinen käytettävissäolovaiheeseen. Käyttöönottovaiheesta eroaa hankintavaihe, jota verotetaan arvonlisäverolla. Käyttöönottovaiheesta puolestaan eroaa käyttövaihe, jota verotetaan polttoaineverolla. 
olleet uutenakaan sillä tasolla mitä nykyisissä autoissa on käytettyinä, tällä hetkellä vanhat autot kulutetaan ajamalla teknisesti loppuun, eivätkä ajo-ominaisuudet ja rakenteet ole enää vanhemmissa autoissa kovinkaan hyvässä kunnossa katsastuksesta huolimatta.

Jokainen liikenteessä menetetty henki näkyy myös kansantaloudessa. Lisäksi hyvin moni loukkaantuu vakavasti, jopa menettää työkykynsä pysyvästi. Uudet ajoneuvot ovat myös energiataloudellisempia sekä ympäristöystävällisempiä kehittyneemmän tekniikan myötä. Viranomaisille veron poistamisesta olisi hyötyä, esimerkiksi tullilla olisi enemmän aikaa käytettävissä muihin toimiin autoveropäätösten tekemisen sijaan. Poliisien määrärahat riittäisivät paremmin muuhun, kun hankittavista ajoneuvoista puuttuisi autoveron osuus, autovero tällä hetkellä peritään myös poliisiautoista ja -moottoripyöristä, säästetyllä rahamäärällä pystyttäisiin pitämään useampia poliisivirkoja nykyiseen verrattuna, se puolestaan toisi lisää työpaikkoja sekä turvallisuutta. Myös hallinto-oikeuksien työtaakka vähenisi, kun autoverovalituksia ei enää tulisi käsiteltäväksi. Kaiken lisäksi myös autokaupan huono tilanne parantuisi talouden taantuman aikana, kun ajoneuvoista perittäisiin verottoman hinnan lisäksi ainoastaan arvonlisävero, nykyisen arvonlisäveron sekä autoveron sijaan.

Kotimainen autokauppa on niin hiljaista autoverosta johtuen, ettei se juurikaan tuota verotuloja. Ilman autoveroa autokaupan tuottama arvonlisäveron määrä olisi jo hyvä tulonlähde valtion budjettiin, varsin helposti suurempana määränä mitä tällä hetkellä autokauppa tuottaa valtiolle autoveron muodossa. Autoverolaki pitäisi lakkauttaa. Tavoitteena on kehitystä hidastavan ja yksilöitä sekä yrityksiä ja yhteisöjä kohtaan vahingollisen autoveron lakkauttaminen.

Jarno Siivola pani vireille 2.9.2013 autoverotuksen poistamiseksi toisen aloitteen (2 593 kannattajaa). Se oli hyvin samanlainen kuin hänen 5.12.2012 tekemänsä aloite.

Kolmannen samantapaisen aloitteen autoveron poistamiseksi Jarno Siivola pani vireille 22.4.2015 yhdessä Nina Palomäen kanssa; kannattajia oli tällä kertaa 3774 .

Myös Ville Likitalon 6.12.2012 vireille panemassa aloitteessa (3 080 kannattajaa) vaadittiin autoverolain kumoamista. Autoveron fiskaalinen merkitys verokertymän kannalta on taantuman ja päästöihin perustuvan veron määräytymisen myötä oleellisesti vähentynyt. Lisäksi fiskaaliselta kannalta verokertymän maksimit osuvat talouden huippuvuosille ja minimit taantuma-aikoihin, jolloin päinvastaisesti valtion tarve verotuloille on korkeimmillaan.

Autoverolaki säädettiin alun perin tilapäisenä, ja lukuisten oikeudenkäyntien osoitettua autoveron olevan hyvin vaikeasti sovitettavissa 
nykyisiin olosuhteisiin on siitä aika luopua. Lisäksi autoveron kantaminen aiheuttaa sekä poliisille että tullille näiden pääsääntöisiin tehtäviin nähden ylimääräistä työtä mm. veronkierron valvonnan sekä veron määräytymisen osalta.

Lisäksi autoveron voidaan katsoa heikentävän liikenneturvallisuutta ajoneuvokannan uudistumista hidastavan vaikutuksen kautta sekä samalla myös hidastavan ajoneuvokannan kokonaispäästöjen vähenemistä. Hiilidioksipäästöjen vähentäminen on kirjattu myös autoverolain tavoitteisiin, tältä osin autovero vaikuttaa omien tavoitteidensakin kannalta ristiriitaisesti.

Verotettakoon liikennettä edelleen, mutta nykymaailmaan soveltuvin keinoin. Ja jääkööt tämän esityksen hyväksymisen myötä erilaiset piilopakettiautot, matkailuautorakennelmat ja kuorma-autoilla sekä naapurimaihin rekisteröidyillä autoilla jokapäiväinen ajaminen autoveron kiertäminen mielessä historian tuntemiksi kuriositeeteiksi.

Lasse Köngäksen 30.8.2013 vireille panema aloite (48 kannattajaa) oli maltillisempi. Siinä vaadittiin uusien autojen verotuksen puolittamista. Vuoden 2012 veronkorotus romahdutti Suomen autokaupan kuin myös aiheutti merkittävää tappiota valtion verotuloissa. Verotuksen puolittaminen nykyisestä toisi lisää työpaikkoja, lisää verotuloja valtiolle ja uudistaisi Suomen autokantaa.

Myöskään Lauri Heinosen 1.9.2014 vireille panemassa aloitteessa (22 kannattajaa) ei ehdotettu autoveron poistamista, vaan siinä vaadittiin veron korottamisen estämistä. Yksityiseen autoiluun on laitettava raja, jonka yli ei voi verotus mennä. Verotus on jo nyt todella korkea ja vielä nostetaan. Suomessa oma auto on pakollinen pitkien matkojen ja surkean joukkoliikenteen vuoksi varsinkin pohjoisessa autoilu on jo todella kallista. Lapsiperheiden ja vähäosaisten kukkaro on jo todella kovilla kalliin autoilun vuoksi ja vaaditaan nykyään, että työpaikka on otettava jopa 100 km:n päästä. Miten kohta ihmiset haluaa käydä töissä, kun enemmän jää rahaa käteen, kun elää kotona Kelan rahoilla? Nyt järki autoilijoiden verotukseen; autokantamme on tällä menolla kohta maailman vanhin. Poliitikkojen pitäisi nähdä että Kehä 3:n toisella puolellakin on ihmisiä.

Uusin kansalaisaloite autoveron poistamiseksi on Jukka Enäjärven 16.1.2019 vireille panema (79 kannattajaa). Autoveron poisto alentaa autojen hintoja ja uudistaa suomalaista autokantaa. Päästöt vähenevät ja liikenneturvallisuus paranee. Valtio saa menetetyt veroeurot muutamassa vuodessa takaisin korkojen kanssa virkistyneen kaupankäynnin arvonlisäveroina ja lisääntyneiden työpaikkojen kautta. 
Uuden auton hinta Suomessa muodostuu pääpiirteissään verottomasta hinnasta + arvonlisäverosta + autoverosta. Vuonna 2016 autojen keskihinta oli noin 32000 euroa ja autoveroon vaikuttava keskimääräinen CO2päästö $121 \mathrm{~g} / \mathrm{km}$. Tällaisen keskivertoauton veroton hinta on noin 21370 euroa, johon lisätään alv 5130 euroa, jolloin saadaan "autoveroton hinta" 26500 euroa. Siihen lisätään autovero 5500 euroa.

Valtion liikennemenot ovat viitenä viime vuonna olleet käytännössä jatkuvasti 1,85 miljardia, mutta vuosittaiset verotulot liikenteestä ovat samassa ajassa kasvaneet yli 600 miljoonaa ollen nyt yli 8,3 miljardia. Vuonna 2017 alv-verotuotto valtiolle uusista ajoneuvoista oli 884 miljoonaa ja autovero 977 miljoonaa.

Autoveron poiston olennaisimmat hyödyt:

a) erittäin todennäköisesti lisää valtion verotuloja muutaman vuoden perspektiivillä,

b) lisää työllisyyttä autojen maahantuonnissa ja myynnissä,

c) alentaa autojen hinnan samalle tasolle muun Euroopan kanssa ja vähentää tuontiautojen määrää,

d) vähentää päästöjä autokannan nuorentuessa ja muuttuessa pienipäästöisemmäksi,

e) parantaa turvallisuutta ja pienentää hoitokuluja autojen muuttuessa turvallisemmiksi,

f) lisää matkustusmukavuutta ja elämänlaatua.

Lähin vertailumaa Ruotsi poisti autoveron, ja siellä 9,5 miljoonaa ihmistä ostaa 372000 autoa vuodessa. Autokannan keski-ikä pysyttelee alle 10 vuodessa, kun taas suomalainen autokanta on keski-iältään lähes 12-vuotiasta - ja vanhenee.

Suomessa 5,6 miljoonaa ihmistä ostaa 120000 autoa vuodessa. Samalla väkiluvun ja myytyjen autojen suhdeluvulla kuin autoverottomassa Ruotsissa meillä myytäisiin vuosittain 224000 autoa, joiden arvonlisäverotuotto valtiolle olisi noin 1,66 miljardia (nykyinen autovero + alv tuottavat 1,86 miljardia).

Autoalan henkilöstöä on Suomessa noin 27 000. Autojen myyntimäärän kasvu 120 000:sta 224 000:een luo useita tuhansia uusia työpaikkoja ainakin maahantuontiin, myyntiin ja markkinointiin. 10000 työtöntä vähemmän alentaa pelkkiä työttömyyskuluja 100 miljoonalla, puhumattakaan verotulojen kasvusta. Myös käytettyjen kauppa virkistyy, ja paremmat uudemmat autot ovat hinnaltaan useampien ulottuvilla.

Suomeen tuotiin ulkomailta vuonna 2018 noin 40000 käytettyä autoa. Ilman autoveroa Suomessa hintataso alenee samalle tasolle muiden maiden kanssa ja nyt ulkomaille menevät eurot jäävät Suomeen. Arvonlisäverojen menetys vuonna 2018 oli noin 130 miljoonaa euroa. 40000 
Suomeen siirtyvää käytettyjen autojen myyntitapahtumaa luo myös työpaikkoja.

Parannus liikenteen päästöihin on merkittävä, kun 120 000:n sijaan yli 200000 vanhaa autoa ikäjakauman toisesta päästä vuodelta 1994 korvataan uusilla.

Vuoden 1994 autojen CO2-päästökeskiarvo on 194 g/km, uusien autojen keskiarvo on noin $121 \mathrm{~g} / \mathrm{km}$. Hiilidioksidipäästö on ainoastaan osa päästöistä; vielä merkittävämpää kehitystä on tapahtunut hiukkasym. päästöjen suodatuksessa. Nykymittapuulla vuoden 1994 autoissa on pahoja puutteita turvarakenteissa ja -varusteissa. Ei ole ajonvakautusta eikä välttämättä lukkiutumattomia jarruja. Olematon takamatkustajien suoja eikä juuri lainkaan jalankulkijoiden turvaa.

Trafi on tutkimuksessaan hinnoitellut liikennekuoleman maksavan yhteiskunnalle noin 2,77 miljoonaa euroa, vakavan loukkaantumisen on noin 790000 euroa ja lievän loukkaantumisen noin 34000 euroa. Kokonaiskustannus yhteiskunnalle liikenteessä loukkaantuneista ja kuolleista on suuruusluokkana noin 1,2 miljardia joka vuosi. Autovero suorastaan estää liikenneturvallisuuden parantumista, joka olisi aivan toisella tasolla autojen keski-iän alentuessa vaikkapa noin 10 vuoteen. Euromääräistä säästöä voi vain arvailla, mutta hyvällä syyllä voi olettaa sen olevan äkkiä joitain satoja miljoonia vuodessa.

Olisi viimein aika tarttua sanoista tekoihin ja poistaa autovero, jolle on vaikea keksiä yhtäkään järkiperustetta, olipa ajatusmaailma minkä tahansa puolueohjelman mukainen. Kärjistetysti autovero ei tuota mitään mutta lisää ilmansaasteita, loukkaantumisia ja liikennekuolemia. Autovero suorastaan estää liikenteen järkevän kehittymisen.

Autoilun muu nykyverotus pitää huolen, että ajokilometrit eivät pompsahda nykyisestä suuremmaksi, vaikka autovero poistetaan. Autoveron poistaminen kerralla alentaa käytössä olevien autojen arvoa, jolloin myös väliraha auton vaihdossa pienenee. Auton omistajille nykyisen auton arvon alenemisen pohtimista olennaisempaa on miettiä, haluaako maksaa seuraavasta autosta 5500 euroa enemmän vai vähemmän. Liikkeiden varastoissa olevien autojen arvonalenemista on helppo tehdä hyvitysmenettely.

Autovero on luonteeltaan sellainen, että sen voi poistaa ja kaikki hyötyvät. Tähän ei tarvita hienoja suuria liikenteen kokonaisuudistuksia.

\section{Kommentteja}

Suuressa osassa EU-maita ei ole autoveromme kaltaista veroa, vaan liikenneverotuksen painopiste on vuosittaisessa ajoneuvoveron tapaisessa verossa. Autoveroa ei ole lainkaan esimerkiksi Ruotsissa, Virossa ja Saksassa. Korkean autoveron maita ovat Suomen lisäksi Tanska, 
Irlanti, Portugali, Alankomaat ja Kreikka. ETA-maista Norjassa on suhteellisen korkea autovero.

Kun autoveromme säädettiin, eduskunta ilmoitti edellyttävänsä, että vero on vain tilapäinen ja valtion senhetkisestä poikkeuksellisen kireästä rahatilanteesta johtuva, ja että verosta pyritään luopumaan etenkin halvemman hintaluokan ajoneuvojen osalta heti, kun valtiontalous antaa siihen mahdollisuuden. ${ }^{76}$ Yli 60 vuotta on kulunut, eikä tuollaista mahdollisuutta ei ole tullut, vaan autoverolla kerätyt varat on tarvittu valtiontalouden hoitamiseen. Autoveroa tarvitaan jatkossakin, ellei valtion menoja supisteta tai valtion velkaa lisätä taikka autoveron tuottoa korvata muilla veroilla tai maksuilla.

Mikäli halutaan ylläpitää nykyisen kaltaista hyvinvointivaltiota, valtiontalouden supistaminen ei ole juuri mahdollista eikä valtion velkaakaan voi paljon lisätä. Jos autoverosta halutaan eroon, sen verotuotto on korvattava muilla veroilla tai maksuilla. Koska autovero on korkea, järjestelmän vaihdokseen liittyy siirtymäkautena erittäin suuria vaikeuksia verovelvollisten yhdenvertaisuuden ja muiden perusoikeuksien turvaamisessa.

Yksi syy, jolla autoveron poistamista on vastustettu, on pelko siitä, että hyöty ei menisi kuluttajille asti vaan jäisi valmistajille, maahantuojille ja autokauppiaille. Korkean autoveron takia henkilöautojen hinnat ovat Suomessa noin neljänneksen EU-maiden keskitasoa korkeammat ja autojen käyttöikä on meillä Euroopan korkeimpia.

Autoverosta luopumista on käsitelty tavattoman paljon. Keskustelua on liiaksi hallinnut joko-tai-kysymyksenasettelu, jossa autoveron tilalle on tarjottu vain yhtä korviketta. Vaikeiden siirtymäkausiongelmien kohtuullinen hallinta onnistuu kuitenkin paremmin yhdistelmämallissa, jossa yhdistellään useita palikoita. Tällaisessa mallissa voisi olla esimerkiksi seuraavanlaisia osia:

a) autoveron poiston voimaantulo takautuvasti pari kuukautta ennen uudistuksen voimaantuloa,

b) ajoneuvoveron lisävero autoveron kumoamisen jälkeen Suomessa ensi kertaa rekisteröitäville uusille ja käytetyille ajoneuvoille,

c) bensiinin ja dieselöljyn valmisteveron maltillinen korotus,

76 Autoveroa arvioidaan kertyvän vuonna 2020 noin 900 miljoonaa euroa. 
d) yleisen arvonlisäveroprosentin, joka koskee myös ajoneuvoja, pieni korotus,

e) ansio- ja pääomatuloveroprosenttien pieni korotus asteikkojen yläpäässä,

f) vanhojen autojen romutuspalkkio.

Mahdollisesti b-kohdan kuitenkin katsottaisiin syrjivän ulkomailta käytettyinä tuotavia vanhoja ajoneuvoja.

Pääministeri Antti Rinteen hallituksen ohjelmassa (s. 24-25) todettiin, että käynnistetään työ, joka tähtää liikenteen verotuksen fiskaalisen pohjan turvaamiseen hallituskautta pidemmällä aikavälillä. Fossiilisten polttoaineiden verotusta korotetaan. Nykyisen hallituksen ohjelma on samanlainen.

\subsection{Ajoneuvoveron perusvero on poistettava tai sitä on muutettava}

Liisa Kylänpä̈̈n 4.5.2015 vireille panemassa aloitteessa (10 kannattajaa) vaadittiin ajoneuvoveron poistamista. Aloitteen tekijä kertoi tarvitsevansa autoa, jotta pääsee osa-aikaiseen työhönsä (matkaa 2 x 20 km). Eläkettä hän kertoi saavansa 800 euroa/kk, josta ulosotto vie 288 euroa/kk. Hänen pitäisi maksaa (bensan ja auton muitten kulujen lisäksi) vielä ajoneuvoveroa yli 400 euroa vuodessa. On julmaa, että tällaisilla maksuilla vielä rasitetaan entuudestaankin huonossa taloudellisessa asemassa olevia, joita on paljon.

Kari Vuorentaustan ja Aarne Vuorentaustan 17.1.2016 vireille panemassa aloitteessa (4 193 kannattajaa) ehdotettiin, että yli 10 vuotta vanhoilta autoilta poistettaisiin ns. käyttövero. Autoilijoiden ei tarvitse maksaa siitä, että eduskunnassa eletään yli varojen.

Pertti Turusen 17.12.2018 vireille panemassa aloitteessa (19 kannattajaa) ehdotettiin auton käyttömaksun eli perusveron muuttamista joukkoliikennettä suosivaksi. Olisi varmistettava haja-asutusalueiden asukkaiden normaalin elämän vaatiman pakollisen auton käytön kohtuullinen verorasitus suuntaamalla suurempi veron osuus niihin auton käyttäjiin, joilla on todellinen mahdollisuus valita liikkumismuotonsa.

Auton vuosittainen käyttömaksu (ei siis ns. dieselvero) muutetaan määräytymään auton haltijan vakituisen asuinkunnan mukaan nykyisen standardimaksun sijaan. Maksun perusteena olisi asuinkunnan joukkoliikenteen taso. Nykyisin esimerkiksi Helsingin kaupungissa on 
monipuolinen ja toimiva joukkoliikenne. Valinnanvaraa on juna, metro, raitiovaunut ja bussit. Tilanne on hyvä myös useissa muissa suurissa kunnissa. Sen sijaan suurten kaupunkien ulkopuolella joukkoliikenne on rajoitettua tai sitä ei ole ollenkaan. Tämän seurauksena oman auton käyttö on käytännössä pakollista normaalin elämän vaatiman liikkumisen mahdollistamiseksi. Muutoksella varmistettaisiin haja-asutusalueiden asukkaiden pakollisen auton käytön kohtuullinen verorasitus suuntaamalla suurempi veron osuus niihin auton käyttäjiin, joilla on todellinen mahdollisuus valita liikkumismuotonsa.

Suomen kuntien joukkoliikenteen taso arvioitaisiin 5-portaisella asteikolla. Toimivan joukkoliikenteen määritelmänä voisi käyttää koulukuljetusten kilometrirajoja ja aikoja.

5 = Sujuva joukkoliikenne.

- Pääsy kunnan alueella kaikkialle mahdollista kaikkina vuorokaudenaikoina.

- Työmatkat mahdollista suorittaa kaikkialle kaikkina vuorokaudenaikoina.

4 = Tyydyttävä joukkoliikenne.

- Pääsy kunnan alueella kaikkialle mahdollista päiväsaikaan ja kunnan eri keskuksien välillä kaikkina vuorokauden aikoina.

- Työmatkojen suorittaminen mahdollista kaikkialle päiväsaikaan ja rajoitetusti yöaikaan.

3 = Välttävä joukkoliikenne.

- Pääsy kunnan alueella kaikkialle mahdollista päiväsaikaan.

- Työmatkojen suorittaminen mahdollista päiväsaikaan.

2 = Heikko joukkoliikenne.

- Päiväsaikaan yhteydet kunnan eri keskuksien välillä.

- Työmatkojen osittainen suorittaminen mahdollista päiväsaikaan.

1 = Ei järjestettyä joukkoliikennettä koulukyydityksen ulkopuolella.

- Työmatkojen suorittaminen ei mahdollista.

Nykyinen käyttömaksu on suuruusluokkaa 150-200 euroa/v, ja lisäksi tulee auton mahdollinen polttoaineperusteinen käyttömaksu.

Uutena maksuna olisi esimerkiksi (ainoastaan käyttömaksu):

Kuntaluokka 5: 2000 euroa/v

Kuntaluokka 4: 1500 euroa/v

Kuntaluokka 3: 1000 euroa/v

Kuntaluokka 2: 300 euroa/v

Kuntaluokka 1: 150 euroa/v 
Maksujen suuruuksissa pitää olla huomattava ero kuntaluokkien välillä, jotta maksu ohjaa käyttämään julkisia kulkuvälineitä. Samoin ylin maksuluokka pitää olla tarpeeksi iso, jotta se vastaa yhden talouden (2-3 henkilöä) noin vuoden julkisten kulkuvälineiden maksua. Auton vuosimalli ja käyttövoima eivät saa vaikuttaa tähän maksuun, koska tarkoituksena on ohjata julkisten yhteyksien käyttöön. Autoverotus ja polttoaineverotus ohjaavat ihmiset ostamaan vähäpäästöisiä autoja.

Tämä maksuluokitus ei koskisi yritysten käytössä olevia paketti-, linjaja kuorma-autoja, jolloin yritysten tuottamat palvelut eivät vaarantuisi. Yritysten omistamat henkilöautot (taksit, vuokra-autot yms. voivat vähentää kulut verotuksessa) jäisivät maksun piiriin, jotta yksityiset ihmiset eivät ryhtyisi kiertämään maksua perustamalla pöytälaatikkoyrityksiä.

Suurissa kaupungeissa yksityisessä käytössä olevien autojen määrä nousee koko ajan samalla kun Suomen autokanta vanhenee. Tämän seurauksena päästöjen määrä kasvaa ja ilmanlaatu huononee kaupungeissa. Suuri osa jalankulkijoista liikkuu juuri kaupunkialueella autojen joukossa altistuen päästöille. Kaupunkialueiden tiestö ruuhkautuu ja vajaakäytössä olevat autot seisovat jonoissa aiheuttaen turhaa ympäristökuormitusta. Parkkipaikkojen puute haittaa sujuvaa liikennettä, kun autot on pysäköity katujen varsille. Joukkoliikenne on toimivaa suurissa asutuskeskuksissa, mutta niiden ulkopuolella joukkoliikenteen taso ja käytettävyys putoaa nopeasti. Siellä missä joukkoliikenne toimii, oman auton käyttö ei ole välttämätöntä perusliikkumisen suorittamiseksi.

Käyttömaksun muuttamiseksi ja tilanteen tasaamiseksi on ehdotettu GPS-pohjaisia järjestelmiä autojen käyttömaksuksi. Näissä ehdotuksissa on ongelmana maksujen kerääntyminen juuri kuntaluokkien 1 ja 2 asukkaille, joiden on käytännössä pakko käyttää autoa työ- ja henkilökohtaisiin matkoihin. Lisäksi nykyisten tietomurtojen aikaan käyttäjien yksityisyys vaarantuu huomattavasti jatkuvalla GPS-seurannalla. GPS-järjestelmien vuosittaiset käyttökulut ovat huomattavat (julkisuudessa kerrottu useita kymmeniä prosentteja) verrattuna kerättyyn rahamäärään. Nykyään jo lähetetään maksulappu autojen haltijoille, joten vuosikustannukset eivät muutu. Kuntien joukkoliikenteen tason arviointi ja säännöllinen tarkistus aiheuttavat virkamiehille työtä ja kustannuksia.

Uuden maksuluokituksen vaikutuksen arviointi:

Kuntaluokissa 4 ja 5

- Yksityisauton käyttömaksu tulisi kalliiksi vastaten kustannuksiltaan vuoden julkisten kulkuneuvojen käyttöä.

- Tämän seurauksena asukkaat harkitsisivat tarkkaan oman auton hankkimista. Ainoastaan todella sitä tarvitsevat hankkisivat auton kyseisissä kunnissa. 
- Ns. kakkosauton hankkiminen vähentyisi huomattavasti. Lisäksi nämä autot ovat yleensä vanhempia ja suurikulutuksisia, jolloin niiden aiheuttamat ympäristöhaitat ovat suurempia.

Kuntaluokka 3

- Oman auton käyttömaksu nousee niillä ihmisillä, jotka liikkuvat iltaja yöaikaan.

- Julkisten yhteyksien käyttömäärä nousisi päiväsaikaan, koska yhteydet ovat jo olemassa.

- Lisääntyneen liikennemäärän ansiosta olisi mahdollista parantaa yhteyksiä myös ilta- ja yöaikaan.

- Ns. kakkosauton hankkiminen vähentyisi huomattavasti. Lisäksi nämä autot ovat yleensä vanhempia ja suurikulutuksisia, jolloin niiden aiheuttamat ympäristöhaitat ovat suurempia.

Kuntaluokat 1 ja 2

- Oman auton käyttö ja maksut eivät käytännössä muutu.

- Julkisten yhteyksien parantaminen vaatii lisää käyttäjiä alueelle, mikä on epätodennäköistä lyhyellä aikavälillä.

- Joidenkin isojen kuntien pienet naapurikunnat saattavat hyötyä muuttoliikkeestä marginaalisesti.

Yleisvaikutus:

Todennäköisesti yksityisautojen määrä vähenee muutaman vuoden viiveellä. Ensimmäiseksi hankkiudutaan eroon kakkosautoista, jolloin perheeseen jää ainoastaan yksi auto. Tämä on todennäköisesti uudempi ja parempi, koska maksu on sama riippumatta auton vuosimallista ja käyttövoimasta. Oman auton käytöstä luopuminen tuo automarkkinoille paljon käytettyjä autoja muutaman vuoden viiveellä. Näistä paljon ajetut ja huonokuntoiset autot todennäköisesti romutetaan ja uudet, vähän ajetut autot ostetaan muualle Suomeen. Autokannasta poistuu osa pahimmin saastuttavista yksilöistä.

Tämän jälkeen yhden auton taloudet miettivät hyvin tarkkaan, pitävätkö ne omaa autoa vai siirtyvätkö julkiseen liikenteeseen ja erilaisten kuljetuspalveluiden käyttöön. Auton hankkiminen on tämän jälkeen tietoinen tarpeeseen perustuva päätös.

Koska autojen määrä vähenee, ruuhkat ja pysäköinti helpottuvat jonkin verran. Talouksien säilyttäessä paremman auton, ympäristöön vapautuvat päästöt pienenevät koko Suomessa yleensä ja erityisesti kaupunkien keskustoissa. Autojen määrän vähentyessä myös verokertymä pienenee, mutta koska veroporras on suurempi kuin nykyinen verotus, niin lopullinen verokertymä jää suuremmaksi kuin nykyinen verokertymä. 
Käyttäjämäärien lisääntyessä joukkoliikenteen kannattavuus paranee, jolloin sitä pystytään kehittämään paremmaksi. Erityisesti kuntaluokkaan 3 kuuluvat kunnat ovat potentiaalinen kehittymiskohde.

Yksityisautojen vähentyessä suurissa kunnissa nousee tarve erilaisille kuljetuspalveluja tuottaville yrityksille, esimerkiksi taksit, tavarataksit ja autovuokraus. Näille uusille yrityksille on kyseisissä kunnissa voimakas asiakaspotentiaali, joten yritykset olisivat elinkelpoisia. Uusien yrityksien käyttöönsä hankkimat autot olisivat uusia ja vähäpäästöisiä sekä erityisesti käytössä hyvällä hyötysuhteella (ei ajeta vajaalla kuormalla).

Autojen määrän pienentyessä ja joukkoliikenteen lisääntyessä ei tarvitse rakentaa/laajentaa teitä, vaan voidaan keskittyä nykyisen tiestön tehokkaaseen ylläpitoon. Kaupungeissa voidaan rajallinen maa-alue käyttää muuhun käyttöön kuin teiden pohjiksi.

\section{Kommentteja}

Kiinteätyyppinen, hallintaperusteinen ajoneuvon vuotuinen verotus aloitettiin Suomessa vuonna 1922 leimaverolain nojalla kannettuna verona. Vero säädettiin progressiiviseksi moottoritehon suhteen. Tätä perusteltiin sillä, että tiestöä eniten vahingoittavissa autoissa (suuret autot) ja toisaalta arvokkaammissa autoissa oli yleensä voimakkaammat moottorit. Auton käyttämän polttoaineen laadulla ei ollut merkitystä veromäärään.

Verotuksen uudistaminen ja samalla saattaminen erillisen moottoriajoneuvoverolain perusteella määräytyväksi tuli 1920-luvun lopulla ajankohtaiseksi mm. siksi, että veron tuotto oli jäänyt vähäiseksi. Uudistuksessa korostettiin, että veron oli perustuttava ylellisyysnäkökohdan sijasta aikaisempaa enemmän tietaloudellisille näkökohdille. Todettiin, että tiestön kulumiseen vaikutti myös ajoneuvon nopeus. Kun Suomen teillä ei kuitenkaan yleensä voitu ajaa suuremmalla nopeudella kuin sellaisella, jonka melkein kaikki henkilöautot pystyivät saavuttamaan, otettiin moottorin teho huomioon aikaisempaa rajoitetummin. Koska tiestön kulumiseen vaikutti myös renkaiden laatu, vero määrättiin kannettavaksi korotettuna sellaisista ajoneuvoista, joiden pyörissä ei ollut kumisia ilmarenkaita. Vero oli korkeampi myös perävaunullisille ajoneuvoille.

Veron tuotto olisi hallituksen esityksen mukaan ollut tuolloin käytettävä yleisten teiden parantamiseen ja kunnossapitoon. Tämä velvoite kuitenkin poistettiin lopullisesta laista, koska katsottiin, että eduskunnan tuli saada vapaasti päättää tämänkin veron tuotosta. 
Moottoriajoneuvoverotuksessa siirryttiin uuteen vaiheeseen 1930-luvun lopulla. Veron uudistaminen tuli ajankohtaiseksi erityisesti siksi, että korkean tullin alaista bensiiniä käyttävien ajoneuvojen rinnalle olivat yleistyneet ajoneuvot, joiden polttoaineena käytettiin hyvin alhaisen tulliverotuksen piirissä olevaa dieselöljyä. Ruotsin esikuvan mukaisesti säädettiin vuodesta 1939 alkaen kannettavaksi tuossa vaiheessa lisäveroksi kutsuttua ajettujen kilometrien mukaan määräytyvää veroa ajoneuvoista, joita käytettiin muulla voimalla tai polttoaineella kuin bensiinillä. Suuremman oikeudenmukaisuuden ja tasapuolisemman verotuksen saavuttamiseksi moottoriajoneuvovero laskettiin ajoneuvon oman painon tai kokonaispainon perusteella.

Moottoriajoneuvoverotus uudistettiin vuodesta 1948 alkaen. Lisäveron (joka vastasi nykyistä käyttövoimaveroa) määräytymisperusteina luovuttiin käyttämästä ajettuja kilometrejä. Veron periminen ajettujen kilometrien mukaisesti olisi edellyttänyt täysin varmaa matkamittaria ja ehdottoman oikein pidettyä ajopäiväkirjaa. Niitten ei katsottu voivan toteutua, ja veron määrääminen olikin jäänyt käytännössä usein harkinnan varaan ja veron määräämisen perusteeksi otettiin keskimääräiset ajomatkat eri ajoneuvotyypeille. Tämän jälkeen tehdyt muutokset verotukseen olivat koko järjestelmän kannalta verraten vähäisiä.

Vuoden 1965 alusta toteutettiin erittäin merkittävä rakenteellinen uudistus: moottoriajoneuvovero poistettiin bensiinikäyttöisiltä ajoneuvoilta ja vastaavasti bensiinin valmisteveroa korotettiin. Tämän jälkeen varsinainen ajoneuvovero (joka vastasi nykyistä käyttövoimaveroa) tuli kannettavaksi vain muilta kuin bensiinikäyttöisiltä ajoneuvoilta, siis lähinnä dieselajoneuvoilta. Polttoöljyn käytön seurauksena oli lisävero (joka vastasi nykyistä polttoainemaksua). Laki oli aluksi voimassa yksivuotisena. Uudistuksen yhteydessä kumottiin myös autokumirenkaiden valmistevero. Vuonna 1966 säädettiin uusi, vuoden 1967 alusta voimaan tullut pysyvä moottoriajoneuvoverolaki, joka oli sisällöltään samanlainen kuin sitä edeltäneet yksivuotiset lait.

Järjestelmä säilyi tämän jälkeen pitkään rakenteellisesti lähes muuttumattomana. Vuosi 1976 oli kuitenkin mielenkiintoinen. Silloin Suomessa rekisteröidystä liikenteeseen käytetystä henkilöautosta kannettiin erityistä käyttömaksua. Maksun säätämisen perusteet olivat 
valtiontaloudellisia. Käyttömaksu määräytyi auton kokonaispainon perusteella. Maksu suoritettiin siten, että maksuvelvollinen oma-aloitteisesti lunasti postista tai tullista auton tuulilasiin kiinnitettäväksi maksun määrää vastaavan käyttömaksumerkin. Vuoden 1976 käyttömaksu oli tarkoitettu väliaikaiseksi yhtä vuotta koskevaksi fiskaaliseksi järjestelyksi, eikä se saanutkaan pitkään aikaan jatkoa.

Antaessaan keväällä 1993 auto- ja moottoripyöräverolain muutosesityksen hallitus sisällytti valtioneuvoston pöytäkirjaan lausuman, jonka mukaan tuosta lainmuutoksesta johtuva autoveron tuoton alentuminen oli korvattava ottamalla käyttöön kaikkia autoja koskeva vuotuinen vero. Autoveroa alennettiin noin viidennes. Verotulojen vähentymisen korvaamiseksi säädettiin laki eräistä ajoneuvoista suoritettavasta ajoneuvoverosta. Tuon lain mukaan ajoneuvovero kannettiin ajoneuvoon kiinnitettävällä veromerkillä. Veron suorittaminen järjestettiin siten, että ajoneuvon omistaja tai haltija oma-aloitteisesti hankki veromerkin ja kiinnitti sen ajoneuvonsa tuulilasiin. Vero muistutti vuoden 1976 käyttömaksua, mutta uusi vero oli tarkoitettu tieliikenteen verojärjestelmän pysyväksi ja olennaiseksi osaksi.

Eduskunta edellytti hallituksen ryhtyvän toimiin veron kantamiseksi vuotta lyhyemmiltä ajanjaksoilta sekä vammaisten käytössä olevien ajoneuvojen veronpalautuksen tai verovapauden toteuttamiseksi. Asiaa selvitettiin, ja lokakuussa 1996 hallitus antoi esityksen laiksi ajoneuvoverosta. Sen mukaisesti siirryttiinkin kantamaan vero vuodesta 1997 alkaen veromerkin sijasta verolipuilla. Keskeisenä tavoitteena oli hyödyntää atk:ta.

Vuoden 2004 alusta voimaan tulleen ja yhä rakenteeltaan voimassa olevan lainsäädännön keskeisenä tavoitteena oli lainsäädäntötekninen uudistus siten, että entiset ajoneuvoveron ja moottoriajoneuvoveron järjestelmät voitiin optimoida soveltuviksi uudistuviin tietotekniikkaratkaisuihin. Verojärjestelmän joustavuutta ja palvelukykyä erityisesti verovelvollisten näkökulmasta parannettiin. Kahden toisiaan lähellä olevan mutta kuitenkin useilta yksityiskohdiltaan toisistaan poikkeavan verojärjestelmän sijaan otettiin käyttöön yhdessä laissa säädelty verojärjestelmä. Ympäristö- ja liikennepoliittiset tavoitteet jätettiin tuossa uudistuksessa sivuun.

Uuden lain mukaisen veron nimenä on ajoneuvovero. Sen osatekijöinä ovat perusvero, joka vastaa entistä ajoneuvoveroa, sekä 
käyttövoimavero, joka on uudessa järjestelmässä entisen varsinaisen ajoneuvoveron eli dieselveroksi kutsutun veron vastine.

Hallitus antoi vuoden 2007 lopulla esityksen henkilöautoista kannettavan ajoneuvoveron perusveron muuttamisesta hiilidioksidipäästötasoihin perustuvaksi. Esitys annettiin samalla kertaa kun autoverotuksessa toteutettiin uudistus, jossa veromäärä porrastettiin auton päästötason mukaan. Uudistuksessa korostettiin ympäristönäkökohtia. Ajoneuvoveron perusvero, joka laskettiin päiväkohtaisesti, tuli olemaan vuodessa päästötasosta riippuen noin 20-600 euroa. Sillä pyrittiin keräämään valtiolle suunnilleen entinen veromäärä. Niistä ajoneuvoista, joista ei ollut päästötietoa, vero määräytyi kokonaismassan perusteella. Tietojärjestelmämuutosten vaatiman ajan takia muutos tuli voimaan vasta 2010 -luvun alussa. Veromääriä on sittemmin korotettu.

Ajoneuvoverolla on siis pitkä historia. Sillä on nykyisin myös suuri valtiontaloudellinen merkitys (vuosituotto n. 1,2 miljardia euroa). Jos nykyisenkaltainen ajoneuvoveron perusvero joskus poistetaan, se ehkä korvataan ajomäärään ja -paikkaan perustuvilla kilometriveroilla tai -maksuilla. Fossiilisten polttoaineiden verotuksen korottamisen varaan ei valtiontaloutta voida loputtomasti rakentaa, koska fossiiliset polttoaineet eivät ole loppumattomia.

\subsection{Käyttövoimavero poistettava dieselautoilta}

Jarmo Männikön 5.9.2013 vireille panemassa aloitteessa (2 680 kannattajaa) ehdotettiin dieselveron poistamista. Onko mitään järkeä maksaa veroa enää? Olisi tarpeellista poistaa vero. Nykypäivän autojen kulutus on aika tasoissa, oli kyseessä bensa tai diesel. Jos taas veroja ei poisteta, niin dieselin litrahintaa pitää pudottaa merkittävästi. Dieselin litrahinta on jo lähellä bensaa. Esimerkiksi logistiikka-alan kautta meidän jokapäiväisten tavaroittemme hinnat nousevat suhteessa veroon. Tälläkin hetkellä kuljetusala maksaa jo veroa pelkän kulutuksen myötä. Tämä on jatkuva oravanpyörä, joka täytyy saada pysähtymään.

Matti Erkkilän ja Jukka Paakin 10.9.2013 vireille panemassa aloitteessa (2 273 kannattajaa) vaadittiin käyttövoimaveron poistamista. Dieselautot ovat yleisimpiä maaseudulla, missä välimatkat ovat pitkät. Näin ollen on käyttövoimaveron periminen nykyolosuhteissa aluepoliittisesti epätasaarvoista. Suomi "dieselöitiin" 1990- ja 2000-luvuilla. Nyt on tapahtunut täyskäännös ja bensiini ja diesel ovat lähes samanhintaisia. Poukkoileva hintakehitys on aikanaan dieselauton ostoon kannustettujen pettämistä. 
Käyttövoimavero nostaa kuljetuskustannuksia pitkien etäisyyksien Suomessa. Yrittäjät maksavat valtiolle lukuisia muita veroja, ja korkea polttoaineen hinta ajaa kuljetustilaukset ulkomaisten, lähinnä venäläisten, yritysten käsiin.

Erittäin suuren kannatuksen (125 439 kannattajaa) ${ }^{77}$ on saanut Sisko Paavolan ja Heino Paavolan 12.11.2018 vireille panema aloite dieselautojen käyttövoimaveron poistosta. Käyttövoimaveron perusteena oleva käyttökustannusten tasaus ei enää toteudu bensiini- ja dieselpolttoainetta käyttävien autojen välillä. Esimerkiksi 95-oktaanisen bensiinin hinnan ollessa 1,55 euroa/l ja dieselpolttoaineen 1,57 euroa/l polttoaineisiin sisältyvien verojen määrä on bensiinillä 1,09 euroa/l ja dieselpolttoaineella 0,83 euroa/l. Käyttövoimavero on dieselautoilla huomattavasti suurempi kuin bensiiniä käyttävillä autoilla. Käyttökustannukset ovat dieselautoilla paljon suuremmat kuin bensiiniä käyttävillä autoilla johtuen dieselpolttoaineen hinnankorotuksista. Etenkään Pohjois-Suomessa ei tule toimeen ilman henkilöautoa, koska välimatkat ovat pitkiä ja työmatka-aikoihin joukkoliikenne ei useinkaan ole sopiva kohtuulliset matka-ajat huomioiden jos ollenkaan.

\section{Kommentteja}

Sisko Paavolan ja Heino Paavolan aloite dieselautojen käyttövoimaveron poistosta on saatettu syksyllä 2019 eduskunnan käsiteltäväksi. Valtiovarainministeri Mika Lintilä totesi tämän kansalaisaloitteen lähetekeskustelussa 26.9.2019, että aloite on hyvä isomman keskustelun avaus ja että valtiovarainministeriö on jo asettanut työryhmän suunnittelemaan liikenteen verotuksen pidemmän aikavälin tarpeita vastaavia uudistuksia. Käyttövoimaveron tarkastelu yksittäisenä ei riitä, vaan joudutaan katsomaan kokonaisuutta. ${ }^{78}$ Todennäköisesti valtio ei jatkossa kerää verotuloja samalla tavalla kuin tällä hetkellä. Autojen kulutus vähenee, koko ajan mennään enemmän sähköautoihin, hybridiin jne., totesi ministeri Lintilä.

Eduskunta tuskin nyt poistaa dieselautojen käyttövoimaveroa. Bensiinin ja dieselöljyn hintasuhde on aloitteen tekemisen jälkeen myös muuttunut siten, että dieselöljyn hinta on jälleen selvästi ben-

77 Näistä peräti 71621 kertyi jo ensimmäisenä päivänä 12.11.2018.

78 Tilanne on tässä samanlainen kuin oli eduskunnan käsitellessä kansalaisaloitetta, jossa vaadittiin perintöveron poistamista. Ei yhtä veroa voi poistaa kiinnittämättä huomiota verojärjestelmän kokonaisuuteen. 
siinin hintaa alhaisempi. Jos käyttövoimavero poistettaisiin dieselautoilta ja dieselöljyn polttoainevero vahvistettaisiin samalle tasolle kuin bensiinin polttoainevero, dieselöljyn hinta ja useimpien dieselautoja käyttävien kustannukset nousisivat entisestään, mikä ei olisi kansalaisaloitteiden tavoitteiden mukaista.

\subsection{Polttoaineveroa alennettava}

Jaska Ilvesluodon, Miika Sutisen, Harri Kuuselan, Sakari Peltolan ja Ossi Tiihosen 4.11.2019 vireille panemassa aloitteessa (4 615 kannattajaa 30.11.2019 mennessä) esitetään polttoaineveron alentamista. Polttoainevero on moottoribensiinistä, dieselöljystä sekä kevyestä ja raskaasta polttoöljystä kannettava valmistevero. Vuoden 2011 alusta polttoaineen valmistevero on koostunut kolmesta osasta, jotka ovat energiasisältövero, hiilidioksidivero ja huoltovarmuusmaksu. Hallituksen tulee lainsäädännöllisesti laskea polttoaineveroa huomattavasti.

Perustelut:

1. Tieliikenteestä otetaan jo eri veroina yli 8 miljardia vuodessa, joista palautuu tieliikenteelle vain vähän alle miljardi. Polttoaineveron osuus on lähes 2,7 miljardia.

2. Suurimmassa osassa Suomea henkilöauton käyttö on pakollista työ-, harraste- ja asiointimatkoille, koska julkisen kulkuvälineen käyttö ei ole mahdollista. Polttoaineveron suuruus aiheuttaa kohtuuttomia kustannuksia pieni- ja keskituloisille ihmisille näillä alueilla.

3. Polttoainevero ei ole oikeudenmukainen, koska kaupungin keskustassa asuvilla on mahdollista käyttää julkista liikennettä.

4. Polttoaineveron laskeminen lisää suoraan pienyrittäjien työn tuottavuutta.

5. Polttoaineverotuksen laskemisesta aiheutuva valtion tulojen tipahtaminen on helppo korvata EU:n ulkopuolelta tulevien halpatuotteiden tuontiverolla ja esimerkiksi muotituotteiden "luksusverolla".

\section{Kommentteja}

Polttoaineveron osuus valtion verotuloista on niin suuri, että polttoaineen verotasoa ei juuri koskaan ole alennettu; pikemminkin sitä on hallituspohjasta riippumatta jatkuvasti nostettu, mitä on perusteltu fiskaalisen tarpeen lisäksi ympäristösyillä ja verotuksen painopisteen siirtämisellä tuloverotuksesta kulutusverotukseen. Vaikka kansalaisaloite polttoaineveron alentamisesta etenisi eduskunnan käsiteltäväksi, siitä tuskin seuraisi veron alentaminen. Ympäristön kannalta 
hyödyllistä mutta valtiontaloudellisesti ongelmallista on se, että bensiini- ja dieselautojen polttoainekulutus laskee ja siirrytään yhä enemmän sähköautoihin.

Polttoaineen korkea hinta on viime vuosina ulkomailla (mm. Ranskassa, Ecuadorissa, Iranissa, Kiinassa, Zimbabwessa ja Indonesiassa) aiheuttanut suuria mielenosoituksia ja mellakoitakin. ${ }^{79}$ Sellaisten pelko saattaa meillä hillitä polttoaineveron korotuksia.

Polttoaineverotulojen vähentymisen korvaaminen säätämällä meille EU:n ulkopuolelta tuleville halpatuotteille tuontivero ja muotituotteille ylellisyysvero ei olisi helposti toteutettavissa, kun otetaan huomioon mm. se, että tulliverotus kuuluu EU:n eikä yksittäisen jäsenmaan päätösvaltaan.

\subsection{Uusiutuvan dieselin polttoaineveroa alennettava}

Tuomo Härkösen 26.11.2018 vireille panema aloite (10 kannattajaa) tavoitteli nykyisten dieselmoottoreiden kasvihuonepäästöjen alentamista $90 \%: 11$.

Vanhoista dieseleistä saadaan helposti erittäin ympäristöystävällisiä ilman rakenteellisia muutoksia tai vaikutusta auton omistajan autoilukustannuksiin. Auton arvo säilyy entisellään, myöskin dieselautojen kauppa palautuu normaaliksi.

Ympäristöystävällisyys voidaan toteuttaa pienellä polttoaineveron muutoksella. Leikataan uusiutuvan biodieselin hintaa polttoaineen verotusta alentamalla siten, että biodiesel on selvästi halvin vaihtoehto silloin, kun uusiutuvaa dieseliä on tarjolla. Hinnoittelun pitää myös kannustaa valitsemaan uusiutuvaa dieseliä tarjoava tankkausasema.

Nykyisin on tarjolla 100-prosenttista uusiutuvaa kotimaista biodieseliä, jonka avulla voidaan leikata $90 \%$ kasvihuonepäästöistä, jos niin halutaan. Keski-Euroopassa dieselautoilua rajoitetaan typpipäästöjen aiheuttamien paikallisten ilmanlaatuongelmien vuoksi. Suomessa typpipäästöt eivät ole ongelma, koska meillä ei ole suurkaupunkeja. Siirtymällä kotimaisen uusiutuvan biodieselin käyttöön tuetaan samalla kotimaista työllisyyttä ja lisätään merkittävästi valtion verotuloja, vaikka verotusta pumpulla kevennettäisiinkin merkittävästi.

79 Suomessa Autoliiton vuonna 2000 keräämä ja valtiovarainministeri Sauli Niinistölle luovuttama adressi polttoaineen litrahinnan alentamiseksi sai lähes puoli miljoonaa allekirjoittajaa. Polttoaineiden hinnat laskivat sen jälkeen, mikä ei kuitenkaan johtunut adressista vaan maailmanmarkkinahinnan laskemisesta. Ilta-Sanomat 21.11.2019. 
Myös Elias Hiltusen 28.1.2019 vireille panema aloite (110 kannattajaa) koskee dieselautojen verotusta. Dieselautojen verotus voitaisiin asettaa samalle tasolle bensiiniautojen kanssa, sillä esimerkiksi Neste on kehittänyt dieselpolttoaineen, joka vähentää $90 \%$ päästöjä. Myös ns. mittarihinta voisi olla samaa luokkaa esimerkiksi RE 85 -etanolibensiinin kanssa. Dieselautojen käyttö tulisi kannattavammaksi nykytilanteeseen verrattuna uuden jätteistä valmistetun biodieselin avulla, ja samalla Suomi ottaisi aimo harppauksen maailman polttoainemarkkinoilla, vienti alkaisi paremmin vetämään, työllisyys paranisi ja kansalaisen olisi taas mukava ajaa hymy huulilla kohti auringonlaskua.

Jussi Isoahon 3.4.2019 vireille panemassa aloitteessa (2 245 kannattajaa) ehdotetaan uusiutuvan dieselin (HVO-laatu) hinnanalennusta keventämällä polttoaineverotusta. Uusiutuvan dieselin veroa alennettaisiin siten, että uusiutuvan dieselin hinta laskee perinteisen fossiilisen dieselin tasolle tai sitä halvemmaksi. Autoilijalla tulisi olla kustannuksiltaan tasavertainen tai edullisempi vaihtoehto käyttää ilmastolle vähemmän haitallista polttoainetta.

Suomen tieliikenteen hiilidioksidipäästöt ovat yli 9,5 miljoonaa tonnia vuodessa, joka vastaa noin 17 \% koko Suomen kasvihuonekaasupäästöistä. Henkilöautoliikenne tuottaa näistä päästöistä noin viisi ja raskas liikenne 4,5 miljoonaa tonnia. Fossiilisella dieselillä kulkeva henkilöauto tuottaa noin 150 g:n hiilidioksidipäästöt kuljettua kilometriä kohti, uusiutuvan dieselin päästöjen ollessa vain noin $15 \mathrm{~g}$ samalla matkalla. Fossiilisella dieselillä kulkevan raskaan liikenteen keskipäästöt ovat noin $800 \mathrm{~g}$ hiilidioksidia/km, jolloin uusiutuvalla dieselillä kulkevan rekan päästöt voisivat pudota jopa fossiilisella dieselillä kulkevaa henkilöautoa alemmiksi. Huikea mahdollisuus!

Ilmastonmuutoksen torjunta on erittäin tärkeää tulevina vuosina, eikä liikenteen sähköistys etene riittävän nopeasti vastaamaan ilmastonmuutoksen asettamaa haastetta. Hiilineutraaliuden saavuttaminen pitäisi olla kuluttajalle ja yrityksille halvin tai vähintään samanhintainen mahdollisuus verrattuna fossiilisten polttoaineiden käyttöön, jolloin tähän mahdollisuuteen myös tartuttaisiin. Tähän muutokseen voimme vaikuttaa nopeimmin oikein suunnatulla polttoaineverolla, muiden keinojen ollessa huomattavasti hitaampia.

Voimme tehdä ilmastotekoja nykyisillä dieselautoillamme käyttämällä 100-prosenttista uusiutuvaa dieseliä. Maaliskuussa 2019 uusiutuvan dieselin hinta oli noin 19 senttiä litralta kalliimpaa verrattuna perinteiseen fossiiliseen dieseliin. Käyttämällä uusiutuvaa dieseliä (HVO-laatu) voimme pienentää liikenteen aiheuttamia hiilidioksidipäästöjä jopa $90 \%$ verrattuna perinteiseen fossiiliseen dieseliin (esimerkkinä Neste MY diesel). Pelkästään raskaassa ja ammattiliikenteessä, joissa myös päästöt ovat suurimpia, uusiutuva diesel olisi valtava mahdollisuus. 
Tällä hetkellä saatavilla olevaa korkealaatuista uusiutuvaa dieseliä voidaan käyttää kaikissa dieselmoottoreissa sellaisenaan, sekoittamatta joukkoon fossiilista dieseliä. HVO-laatuinen uusiutuva diesel tuottaa myös vähemmän partikkeli- sekä typenoksidipäästöjä, jolloin myös ilmanlaatu erityisesti kaupungeissa paranee. Näin voimme rajoittaa hiukkas- ja hiilidioksidipäästöjä merkittävästi uusimatta autokantaamme ja liikenteestä voidaan tehdä huomattavasti ympäristöystävällisempää nykyisellä autokannalla. Samalla saamme lisäaikaa vanhalle autokannallemme, kunnes sähköinen liikenne on realismia myös pidemmillä etäisyyksillä ja raskaassa liikenteessä.

Esimerkkilaskelma päästöistä ja kustannuksista (maaliskuun 2019 hinnoilla):

Tavanomainen dieselhenkilöauto, jolla ajetaan $20000 \mathrm{~km}$ vuodessa ja jonka päästöt ovat $150 \mathrm{~g} / \mathrm{Co} 2 / \mathrm{km}$ :

- Hiilidioksidipäästöt fossiilisella dieselillä: $20000 \mathrm{~km}$ x 0,15 kg Co2/ $\mathrm{km}=3000 \mathrm{~kg}$ Co2/vuosi.

- Polttoainekulut fossiilisella dieselillä: $20000 \mathrm{~km}$ x 0,06 litraa/km x 1,4 euroa litra = 1680 euroa/vuosi.

- Hiilidioksidipäästöt uusiutuvalla dieselillä: $20000 \mathrm{~km} \mathrm{x} \mathrm{0,015} \mathrm{kg}$ $\mathrm{Co} 2 / \mathrm{km}=300 \mathrm{~kg} \mathrm{Co} 2 /$ vuosi.

- Polttoainekulut uusiutuvalla dieselillä: $20000 \mathrm{~km}$ x 0,06 litraa/km x 1,6 euroa litra $=1920$ euroa/vuosi.

Laskelma ja esimerkit kertovat selvästi epäkohdan, jossa perinteisellä fossiilisella dieselillä tuotetaan 10-kertaiset hiilidioksidipäästöt 240 euroa alemmilla kustannuksilla. Tämä on epäkohta, joka pitää korjata veromuutoksella

\section{Kommentteja}

Vaatimattomasta kannattajamäärästä huolimatta nämä aloitteet ansaitsisivat päästä jatkoselvittelyyn. Nykyinen hallitus suunnittelee kuitenkin toisensuuntaista muutosta: parafiinisen dieselin polttoaineverolaissa olevan verotuen poistamista.

Polttoaineverolain mukaan dieselöljyllä tarkoitetaan tullitariffin nimikkeeseen 2710 kuuluvaa dieselöljyä. Parafiinisellä dieselöljyllä (dieselöljy para) tarkoitetaan tuotetta, jonka setaaniluku on vähintään 51, tiheys 765-810 grammaa litralta 15 celsiusasteessa, polyaromaattisten hiilivetyjen (PAH) pitoisuus enintään 1,1 painoprosenttia, rikkipitoisuus enintään viisi milligrammaa kilolta ja josta tislautuu vähintään 95 tilavuusprosenttia 360 celsiusasteessa. Parafiinista dieseliä on sekä fossiilista että uusiutuvaa. 
7 Kansalaisaloitteinen verotus - viihdettä vai demokratiaa?

\subsection{Käyttövoimavero poistettava kaasuautoilta}

Olavi Ojalan 2.1.2019 vireille panemassa aloitteessa (15 kannattajaa) ehdotettiin käyttövoimaveron poistamista kaasukäyttöisiltä henkilöautoilta. Käyttövoimavero kaasuautoille on kohtuuton ottaen huomioon ilmastomuutoksen hidastamiseen tähtäävät päästötavoitteet, joihin Suomikin on sitoutunut. Käyttövoimaveron poisto on yksi merkittävä tekijä nollapäästöisten autojen määrän kasvun edellytykselle. Autoilun päästötavoitteiden toteutuminen on vaikeaa, mikäli kaikkia mahdollisuuksia ei huomioida ja hiilineutraalia liikkumista rangaistaan käyttövoimaverolla, joka on noin 44-45\% dieselautojen käyttövoimaverosta; kaasuautostahan peritään perusveroa niin kuin myös polttoaineveroa aina kun sillä ajetaan bensiiniä käyttäen. Käyttövoimaveron poistolla olisi merkittävä vaikutus kaasutankkausasemien perustamisiin ja näin ollen siirtymiseen kohti hiilineutraalia autoilua ja biokaasun käyttöä.

\section{Kommentteja}

Vaatimattomasta kannattajamäärästä huolimatta tämäkin aloite olisi hyvin perusteltu jatkoselvittelyyn.

\subsection{Autojen käyttövoiman muuttamista tuettava}

Päivi Vahvaselkä-Valkosen 15.10.2018 vireille panema aloite (9 kannattajaa) tarkoitti vanhojen autojen käyttövoiman muuttamista ekologisemmaksi. Sähkö, kaasu ja bioetanoli ovat bensiiniä ekologisempia vaihtoehtoja autojen polttoaineeksi. Vanhojen autojen käyttövoiman muuttamista ympäristöystävällisemmäksi olisi tuettava valtion avustuksilla sekä verotuksellisin keinoin. Ilmastonmuutos ja sen ehkäisy tulee maksamaan meille kaikille. Autojen käyttövoiman muuttaminen olisi kohtuullinen ja käytännössä helppo sekä nopea toteuttaa. Tekniikka on valmiina. Kustannukset per ajoneuvo ovat arviolta 2 000-10 000 euroa. Ihmisiä kannustaisi teetättämään autoonsa tarvittavat muutostyöt, jos niihin saisi taloudellista tukea ja jos ympäristöystävällisiä ratkaisuja edistettäisiin verohelpotuksin. Autokannan uusiminen vie kauan aikaa, ja monille keski- ja pienituloisille ihmisille auton osto vaatii rahoitussuunnittelua. Töitäkin tämä toisi ammattitaitoisille automekaanikoille.

\section{Kommentteja}

Suomessa on voimassa laki, jolla vuosina 2018-2021 valtion varoista tuetaan henkilöautojen muuntamista kaasu- tai etanolikäyttöiseksi. Tuki on 1000 euroa henkilöauton muuntamiseen kaasukäyttöiseksi ja 200 euroa henkilöauton muuntamiseen etanolikäyttöiseksi. Tuen määrä on pienempi kuin sen kansalaisaloitteessa haluttiin olevan. 
Pääministeri Antti Rinteen hallituksen ohjelman mukaan (s. 25) olisi varmistettu, että auton käyttövoiman konversiot, jotka mahdollistavat vähäpäästöisemmän liikkumisen, otetaan huomioon auto-, ajoneuvo- ja käyttövoimaverotuksessa. Nykyisen hallituksen ohjelma on samanlainen.

\subsection{Sähköautoilun tukeminen kiellettävä}

Juha Kuismasen 22.2.2019 vireille panemassa aloitteessa (1 911 kannattajaa) ehdotetaan lakia, joka kieltää kaikenlaisen valtion tai kuntien tai niihin rinnastettavien yhteisöjen tai minkä tahansa yrityksen myöntämän tuen sähköautoihin ja niihin liittyviin sähkönjakeluverkostoihin tai latauspisteisiin. Tuki voi liittyä sähköauton hankintaan, käyttöön tai omistamiseen. Sähköautoiksi tässä luetaan kaikki kulkuneuvot, joissa käytetään voimanlähteenä sähköä ajoneuvon liikuttamiseen edes osittain. Polkupyöriä ei tässä yhteydessä lueta kulkuneuvoksi.

Tällä hetkellä pullonkaulana sähköautojen tuotannossa on akkujen saatavuus. Akkujen kysyntä ylittää reippaasti tarjonnan. Kun kysyntä ylittää tarjonnan, hinnat eivät pääse juurikaan laskemaan (n. 3 \% vuodessa) ja tukien syytäminen hankintoihin ei lisää akkuvalmistuskapasiteettia. Mitä enemmän tukia, sen hitaammin hinnat laskevat. Koska tarjonta on rajattua, Suomen tarjoamilla tukiaisilla ei valmisteta yhtään enempää akkuja tähän maailman kuin ilman tukiaisia.

Haasteemme on pelastaa maailman ilmasto, ei Suomen ilmasto, koska sellaista ei sinänsä ole. Jos ja toivottavasti kun Suomi luopuu sähköautoilun tuista, maailman ilmasto ei kärsi tai parane. Suomen ostamatta jääneet autojen akut menevät muille markkinoille käyttöön. Näin käy aina kun kysyntä ylittää tarjonnan.

On aivan vastuutonta tukea ilmaston pelastamisen nimissä sellaista, joka ei oikeasti paranna maapallon ilmastoa. Vaikka ohjaisimme miljardin sähköautoilun tukemiseen, se ei näy ilmastossa lainkaan. Mitä suuremmat tuet, sen edesvastuuttomampi on sen ehdottaja. Kaikki nämä tuet maksetaan verovaroista, mikä käytännössä on tulonsiirto kaikilta veronmaksajilta hyvätuloiselle - vähä- tai keskituloisilla kun ei mitenkään ole varaa sähköautoon tulevina vuosina.

Nykyakkuteknologiakin on kestämätön ympäristön kannalta ja erittäin tehoton sähkön varastoija, kun huomioidaan akkujen paino. Vielä on matkaa todelliseen akkujen vallankumoukseen, jossa nykyistä puolet pienemmillä (kevyemmillä) akuilla saavutetaan puolet suurempi varastointimäärä. Lisäksi kustannusten pitäisi puolittua. Tällöin sähköautoilla on mahdollisuus tulla koko kansan kulkupeleiksi.

Suomen maksamat tuet valuvat käytännössä suoraan auto- ja akkuvalmistajille, eikä niistä jää mitään tänne. Keskitytään mieluummin paikallisen teknologian tukemiseen ilmaston pelastamiseksi. 


\section{Kommentteja}

Aloitteessa esitetään lakia, joka kieltäisi kaikenlaisen valtion tai kuntien tai niihin rinnastettavien yhteisöjen tai minkä tahansa yrityksen myöntämän tuen sähköautoihin ja niihin liittyviin sähkönjakeluverkostoihin tai latauspisteisiin. Tämä aloite osoittaa, etteivät kaikki Suomen kansalaiset hyväksy sähköautoilun tukemista.

\subsection{Ulkomaisille ajoneuvoille tienkäyttömaksu}

Tienkäyttömaksua ulkomaisille ajoneuvoille on esitetty kolmessa kansalaisaloitteessa.

Ensimmäisen pani vireille Anne Pykälistö 25.2.2013 (1 887 kannattajaa). Sen mukaan muualla kuin Suomessa rekisterissä olevalla (eli sellaisella, josta ei makseta Suomeen ajoneuvoveroa) ajoneuvolla Suomessa liikennöivä velvoitettaisiin maksamaan Suomeen tienkäyttömaksua niin, etteivät koko ajan lisääntyvän ulkomaisten ajoneuvojen liikennöinnin aiheuttamat kustannukset jäisi kokonaan suomalaisen tienkäyttäjän maksettavaksi. Suomalainen tienkäyttäjä osallistuu tienpidon kustannuksiin maksamalla Suomeen ajoneuvoveroa. Tienpidon kustannuksia tulisi saada myös muualle rekisteröidyiltä ajoneuvoilta, jotka kustannuksia ovat aiheuttamassa. Esimerkiksi suomalaisen kuljetusliikkeen liikennöidessä Ruotsissa tulee olla maksettuna ajoneuvokohtainen tiemaksu, joka on noin 8 euroa vuorokautta kohti. Aiemmin tiemaksu maksettiin maahan saapuessa esimerkiksi huoltoasemalla. Nyt suuri osa käyttäjistä maksaa tiemaksun internetin kautta luottokortilla tai polttoaineyhtiön maksukortilla. Poliisi valvoo tiemaksun maksamista samaan tapaan kuin Suomessa ajoneuvoveron maksamista. Jos maksu on laiminlyöty, poliisi estää liikennöinnin kunnes maksut ja laiminlyönnistä aiheutuneet sanktiot on maksettu.

Samantapainen esitys oli Jussi Terhon aloitteessa 28.3.2014 (1 079 kannattajaa). Tienkäyttömaksu koskisi kokonaismassaltaan yli 12000 kg:n ajoneuvoja, jotka on rekisteröity ulkomaille. Esityksen tarkoituksena oli saada tienkäyttömaksu voimaan myös Suomen teillä koskien ulkomaista tavaraliikenteen kuljetuskalustoa. On kohtuutonta maksattaa suomalaisilla kaikki tiestön kuluminen, koska Suomen teillä liikkuu yhä enemmän ulkomaille rekisteröityä tavaraliikenteen kuljetuskalustoa. Tiestön kunto heikkenee nykyisellään koko ajan ja muuttuu kestämättömäksi korjausvelan koko ajan kasvaessa. Ruotsissa, Tanskassa, Luxemburgissa, Hollannissa ja Belgiassa on käytössä Eurovignette-järjestelmä, jonka tuottaa AGES Maut System GmbH \& Co. KG. Saksassa on käytössä HGV Toll -järjestelmä samalta yritykseltä. Myös Englanti on ottamassa käyttöön vastaavaa järjestelmää. 
Kolmas kansalaisaloite ulkomaisten ajoneuvojen tienkäyttömaksuksi oli Mira Katajamäen ja Tapio Saton 10.4.2015 vireille panema (2 229 kannattajaa). Aloitteessa todettiin, että Suomessa tieverkon rakentaminen ja ylläpito rahoitetaan pääosin verovaroin. Suomen taloudellinen tilanne on huono ja verovarojen kohdistaminen tiestön ylläpitoon on hyvin epätodennäköistä. Ulkomaiset kuljetusyritykset jyräävät maamme läpi tuhansien autojen voimalla vuosittain. Autot tankataan ennen Suomeen tuloa ja seuraava tankkaus suoritetaan, kun Suomen raja on jo takanapäin. Näin edes polttoaineveroja ei Suomeen kerry. Suomi onkin ulkomaisten kuljetusyritysten ilmainen kauttakulkumaa. Rapistuva tieverkkomme heikentää liikenneturvallisuutta ja aiheuttaa lisäkustannuksia kuljetusalalle. Suomen talouden sopeuttamistoimia ei tule kohdentaa jo huonokuntoiseen tieverkostoomme, ja tämän vuoksi tiestömme ylläpito vaatii valtion budjetin ulkopuolista rahoitusta. Tämä järjestyy, kun ulkomaisille kuljetusyrityksille asetetaan tienkäyttömaksut, jotka korvamerkitään tieverkoston ylläpitoon. Maksut eivät saa koskea suomalaisia kuljetusyrityksiä, koska nämä maksavat jo veroja monessa vaiheessa.

\section{Kommentteja}

Pääministeri Juha Sipilän hallituksen 19.12.2018 antamassa esityksessä (HE 314/2018) ehdotettiin säädettäväksi laki raskaiden kuorma-autojen tienkäyttöverosta. Esityksen mukaan käyttöön otettaisiin uusi valtiolle tuloutettava vuotuinen vero, joka kohdistuisi kuormaautojen ja ajoneuvoyhdistelmien käyttöön Suomen tieverkolla. Veronalaisia olisivat Suomessa ja ulkomailla rekisteröidyt kuormaautot ja ajoneuvoyhdistelmät, joiden kokonaismassa on yli 12000 kilogrammaa. Ajoneuvoverolakia olisi samalla muutettu siten, että raskaista kuorma-autoista kannettavaa ajoneuvoveron käyttövoimaveroa alennettaisiin ja veron rakennetta muutettaisiin. Käyttövoimavero määräytyisi kuorma-auton kokonaismassan, akselien lukumäärän ja jousitustyypin perusteella sekä sen mukaan, onko auto varustettu perävaunujen vetämiseen.

Hallituksen esityksessä nähtiin EU-oikeudellisia ongelmia, eikä esitystä ehditty käsitellä loppuun keväällä 2019 päättyneellä vaalikaudella, joten esitys raukesi.

Pääministeri Antti Rinteen hallituksen ohjelman (s. 114) mukaan oli valmisteltava raskaan liikenteen vinjettimaksu ottaen huomioon vaikutukset kuljetusalan kustannusrakenteeseen ja suhde EU-lainsäädännön valmisteluun. Nykyisen hallituksen ohjelma on samanlainen. 


\subsubsection{Vene-, traktori- yms. verot}

Matti Ahosen ja Heikki Heinon 31.5.2015 vireille panemassa aloitteessa (10 kannattajaa) todettiin, että veneveroksi suunnitellaan 50 euroa/vene. Aloitteen mukaan veroksi pitäisi säätää 0,75 euroa/hv/rekisteröity vene. Olisi kohtuullista, että verotusarvo olisi suhteessa moottorin hevosvoimiin ja tätä kautta myös päästöihin. Käyttömäärällä ei ole mitään merkitystä, koska autoveroissakaan ei tätä huomioida.

Mika Laakson 19.12.2016 vireille panemassa aloitteessa (8 kannattajaa) vaadittiin lainsäädännön muuttamista siten, että Suomessa rekisteröidyt maatalous-, liikenne- ja muut traktorit sekä moottorikäyttöiset maatalouslaitteet, kuten puimurit ja kaivinkoneet, laitetaan samanlaisen vuotuisen veron alaisiksi kuin veneet, moottoripyörät ja moottorikelkat. Aloitteessa ehdotettiin vuotuisen veron määräksi 150 euroa/laite, joka on saman suuruinen kuin hallituksen esitys moottoripyörien osalta. Liikenteen turvallisuusviraston tilastojen mukaan ko. moottorikäyttöisiä laitteita on Suomessa yli 500000 kappaletta, joten verokertymä olisi huomattavasti suurempi kuin veneiltä, moottoripyöriltä ja moottorikelkoilta kerättävä summa.

Hallituksen esityksen mukaan jatkossa myös lähes arvottomasta, rekisterissä olevasta veneestä, moottoripyörästä ja moottorikelkasta joutuu maksamaan vuosittaisen veron, joka perustuu ainoastaan omistamiseen. Ottamalla tässä aloitteessa mainitut laitteet samanlaisen omistukseen perustuvan vuosittaisen veron alaisiksi osoittaa valtio pyrkivänsä kohtelemaan kaikkia kansalaisiaan yhdenvertaisin perustein ilman että jokin tietty ryhmä saisi erityiskohtelua.

\section{Kommentteja}

Pääministeri Juha Sipilän hallituksen ohjelmassa vuonna 2015 oli kirjaus ottaa käyttöön venevero ja moottoripyörien ajoneuvovero valtion verotulojen lisäämiseksi 50 miljoonalla eurolla. Valtiovarainministeriö ryhtyi valmistelemaan asiasta hallituksen esitystä, ja joulukuussa 2016 ministeriö lähetti esitysluonnokset lausunnolle. Valtiovarainministeriö sai esityksestään miltei yksinomaan kielteistä palautetta. Myös hallituksen hanke säätää moottoripyörille yms. 150 euron vuotuinen ajoneuvovero sai ankaraa kritiikkiä. Hallitus päättikin 15.2.2017 luopua sekä veneverohankkeesta että moottoripyörien ajoneuvoverohankkeesta. ${ }^{80}$

80 Veneverosta tarkemmin kirjani Suomen kulutusverotuksen historia ja veneveron haaksirikko (2017). 


\subsubsection{Lentovero säädettävä}

Aloitteessa, jonka 2.5.2019 panivat vireille Silja Jääskeläinen, Arto Sivonen, Janne Kilpinen, Risto Isomäki, Puuah Auramo, Ina Rosberg, Emma Kurenlabti ja Otto Bruun, esitettiin matkustajakohtaisen lentoveron säätämistä Suomeen. Tämä esitys sai 55184 kannattajaa ja odottaa eduskunnan käsittelyä. ${ }^{81}$

Lentoveroa koskevan lain valmistelussa tulee selvittää, voidaanko matkustajakohtaisen lentoveron suuruudessa ottaa huomioon erityyppisten lentojen ilmastovaikutukset ja voidaanko verotuottoja ohjata ympäristöpoliittisesti. Matkustajakohtaisen lentoveron tulee määräytyä siten, että sillä saavutetaan mahdollisimman tehokas ympäristöpoliittinen ohjausvaikutus.

Lentäminen kiihdyttää ilmastonmuutosta, ja siksi tarvitaan myös taloudellisia ohjauskeinoja suomalaisten lentämisen vähentämiseksi. Lentoliikenne tuottaa hiilidioksidia erittäin paljon, koska yksikköpäästöt ovat suuret ja matkat pitkiä. Hiilidioksidin lisäksi vapautuu vesihöyryä ja muita päästöjä. Lentoliikenteen päästöt leviävät suoraan yläilmakehään, missä monien päästöjen ympäristövaikutukset voimistuvat. Kaiken kaikkiaan lentämisen lämpövaikutus on vähintään noin kaksinkertainen pelkkiin hiilidioksidipäästöihin verrattuna. Lentoliikenteen osuus ilmaston lämpenemisestä on noin $4 \%$. Lentämisen osuus yksittäisen suomalaisen hiilijalanjäljestä voi olla hyvinkin suuri.

Maapallon lämpötila on noussut jo noin asteella esiteollisesta ajasta, ja vaikutukset ovat jo tuntuvia. Hallitustenvälisen ilmastopaneelin IPCC:n 8.10.2018 julkaistussa raportissa varoitetaan, että mikäli lämpeneminen jatkuu nykyistä vauhtia, 1,5 asteen raja ylitetään vuosisadan puoleenväliin mennessä. Rajan ylittyminen aiheuttaisi katastrofaalisia seurauksia ihmiskunnalle ja luonnolle.

Huolimatta siitä, että ilmaston lämpenemisen mekanismi on jo pitkään ollut tiedossa, ovat hiilidioksidipäästöt jatkaneet kasvuaan. Globaalit päästöt ovat lisääntyneet 1980-luvun noin 17 gigatonnista vuodessa nykyiseen tasoon noin 33 gigatonniin vuodessa.

IPCC:n mukaan tarvitaan nopeita päästövähennyksiä, jotta ilmaston lämpeneminen voidaan rajoittaa 1,5 asteeseen. Globaalien ilmastopäästöjen on vähennyttävä noin puoleen vuoteen 2030 mennessä. Vuosisadan

81 Aloitteella oli syyskuun loppuun mennessä vain noin 5000 kannattajaa. Lokakuussa kannattajia tuli noin 45000 lisää. Pidettiin mm. mielenosoituksia lentoveron puolesta. Aloite sai näkyvää tukea myös monilta tutkijoilta ja taiteilijoilta. Esimerkiksi muusikko ja näyttelijä Olavi Uusivirta lupasi heittää kymmenen keikkaa vanhainkodeissa, sairaaloissa, vankiloissa ja hoitolaitoksissa, jos kansalaisaloite menee läpi. Onkohan ennen keikkojen alkamista lentovero saatava vielä eduskunnan hyväksymäksi? 
puoleenväliin mennessä tulee saavuttaa päästöjen ja uusien hiilinielujen tasapaino. 1,5 asteen tavoitteen saavuttamiseksi tarvittavan muutoksen mittakaava on ennennäkemätön: päästövähennyksiin tähtääviä toimia on tehtävä kaikkialla yhteiskunnassa ripeästi ja kauaskantoisesti.

Lentäminen on Suomessa, kuten suurimmassa osassa muutakin maailmaa, lähes verovapaata. Veroja ei peritä esimerkiksi polttoaineesta eikä kansainvälisestä matkustamisesta. Lentokentillä ja koneissa on laajat valikoimat tax-free-tuotteita. Lentomatkailu on verotuksen suhteen ollut vapaamatkustaja muihin matkustustapoihin verrattuna.

Verottomuus mahdollistaa erittäin halvat lennot. Tämä houkuttaa ihmisiä valitsemaan eri vaihtoehtojen joukosta lentämisen ja matkustamaan kauas. Suurituloiset on eniten lentävä tuloryhmä, joten heihin kohdistuu suoraan tai välillisesti verottomuudesta aiheutuva huomattava verohyöty. Suurin osa lennoista on vapaa-ajan lentoja, joita voidaan pitää ylellisyystuotteina. Lisäksi ne kuuluvat ympäristöä eniten kuormittaviin tuotteisiin, joita tulee verottaa suhteessa niiden aiheuttamaan hiilijalanjälkeen.

Verotuksen avulla tapahtuvan valtion taloudellisen ohjauksen tulee kannustaa ihmisiä tekemään ympäristön ja elinkelpoisen tulevaisuuden kannalta hyviä ratkaisuja, ei päinvastoin. Lentoliikenteen päästöihin tulee jatkossa kohdistaa haittaveroja. Lentoliikenteen verotuksen kokonaisvaltainen kehittäminen on otettava osaksi Suomen valtion aiempaa kunnianhimoisempaa ilmastopolitiikkaa sekä kansallisessa päätöksenteossa että kansainvälisissä neuvotteluissa.

Lentoliikenne on alana kovassa kasvussa. Viime vuonna maailmassa tehtiin yli 4 miljardia lentomatkaa. Kasvua oli 7 prosenttia edellisvuodesta, ja määrän arvioidaan 20 vuodessa kaksinkertaistuvan. Suomessa lentoliikenne on viime vuosina kasvanut lähes 10 prosentin vuositahdilla. Myös Helsinki-Vantaan lentokentällä varaudutaan nopeaan kasvuun.

Lentoveroa tarvitaan osana muita ilmastotoimia. Vaikka lentämisen päästöt kasvavat jatkuvasti, niitä ei säädellä riittävästi. Mm. näistä syistä perusteet lentoliikenteen tuomiseksi sääntelyn piiriin ovat nyt olemassa.

Jos lentoliikenteen päästöihin ei puututa, ne kasvavat niin suuriksi, että Pariisin sopimuksen ja Suomen ilmastolain mukaisiin ilmastotavoitteisiin ei päästä. Lentoliikenteen omat keinot eivät riitä. Ilmastotavoitteiden saavuttamiseksi tarvitaan lentämisen määrää hillitseviä keinoja.

Ruotsissa otettiin huhtikuussa 2018 käyttöön lentovero. Ruotsin mallissa lentovero kohdistuu matkustajaan, ja se vaihtelee matkan pituudesta riippuen. Euroiksi muutettuna vero on 6-40 euroa/lentomatkustaja. Lentoliikenteen kasvu on pysähtynyt veron käyttöönoton jälkeen, tosin syitä voi olla muitakin. Ruotsissa keskustellaan lentoveron kehittämisestä sellaiseksi, että se vähentäisi lentämisen ilmastovaikutuksia mahdollisimman tehokkaasti. Tällöin lentoveron määräytymisperusteissa voitaisiin ottaa paremmin huomioon eri lentomatkojen todelliset päästöt, joihin 
vaikuttavat mm. teknologiset innovaatiot, biopolttoaineen käyttö sekä lentoreittien ja muun logistiikan tehostaminen.

Ruotsin lisäksi erilaisia lentoveroja on käytössä esimerkiksi Norjassa, Isossa-Britanniassa, Saksassa ja Ranskassa. Suomen lentoveron valmistelussa on hyvä selvittää, mitä muiden maiden kokemuksista voidaan oppia.

\section{Kommentteja}

Vuosina 1968-1970 meillä oli voimassa laki matkustajaverosta. Sen säätämistä perusteltiin mm. tarpeella rajoittaa valuutan maastavientiä. Matkustajaveroa kannettiin Suomesta ulkomaille kauppa-aluksella meritse matkustavalta Suomessa asuvalta henkilöltä. Vero oli enintään 90 meripeninkulman matkasta 5 mk ja yli 90 meripeninkulman matkasta 10 mk. Vero jäi lyhytaikaiseksi: laki kumottiin vuoden 1970 lopussa, kun veron tuotto oli jäänyt arvioitua pienemmäksi.

Ulkomaanmatkailun erityisveron (tilauslentovero) käyttöönotto oli eduskunnassa esillä vuoden 1978 valtiopäivillä. Lakiesitys ehti toiseen käsittelyyn ennen kuin hallitus peruutti esityksensä sen eduskunnassa kohtaaman vastustuksen vuoksi. Tilauslentoveroa harkittiin valtiovarainministeriön selvityksissä myös 1980-luvulla, mutta konkreettisiksi hallituksen esityksiksi selvitykset eivät tuolloin muotoutuneet.

Seuraavan kerran matkustajaveron käyttöönotto tuli ajankohtaiseksi 1990-luvun alussa, kun taloudellinen lama synnytti tarpeen lisätä valtion verotuloja mm. uusia veroja sääämällä. Matkustajaveron ei katsottu kohtuuttomasti rasittavan kansantalouden kannalta keskeisiä toimintoja tai vaikeuttavan heikoimmassa asemassa olevien kansalaisten toimeentuloa. Toisaalta veron tavoitteena oli elvyttää kotimaanmatkailua ja turvata matkailualan työpaikkojen säilyminen tilanteessa, jossa matkustustaseen alijäämän kasvu oli jatkunut jo vuosia.

Matkustajaverolaki tuli voimaan 15.1.1992. Veroa suoritettiin jokaisesta matkustajasta, jolle Suomessa myytiin tai muutoin luovutettiin taikka välitettiin matkalippu, joka oikeutti Suomesta ulkomaille lähtevään tilauslentoon tai laivamatkaan. Tilauslennolla tarkoitettiin lentoa, jossa yksi tai useampi matkanjärjestäjä oli ostanut tai tilannut lentoyhtiöltä koko lennon ja yksi tai useampi matkanjärjestäjä kantoi riskin lentopaikkojen myynnistä. Alun perin matkustajaveroa suunniteltiin perittäväksi myös reittiliikenteen lentomatkoista, mutta tästä aikeesta luovuttiin, kun ulkomaanmatkojen hintoihin kohdistui muutoinkin nousupainetta. 


\section{Kansalaisaloitteinen verotus - viihdettä vai demokratiaa?}

Matkustajaverolaki oli määräaikainen; sitä ei sovellettu enää vuoden 1992 jälkeen alkaneisiin matkoihin. Vuonna 1993 tuli kuitenkin voimaan uusi ulkomaanmatkoihin kohdistunut verolaki, laki tilauslentoverosta. Tilauslentoveron keskeinen tavoite oli sama kuin matkustajaveron: matkustustaseen alijäämän supistaminen ja kotimaanmatkailun edellytysten parantaminen. Toisaalta valtio tarvitsi verotuloja taloudellisen laman jatkuessa. Tilauslennoksi katsottiin kaupallinen, matkustajia kuljettava lento, joka ei ollut säännöllistä liikennettä ja joka tapahtui vähintään 11 matkustajapaikkaa käsittävällä ilma-aluksella. Tilauslentoverolaki oli voimassa alun perin vuoden 1993 loppuun, mutta myöhemmin sen voimassaoloa jatkettiin vielä vuodella ja veroperusteet säilyivät ennallaan.

Lentoliikenne on erityisesti tieliikenteeseen verrattuna voimakkaasti aliverotettu. Nykyisessä tilanteessa lentoliikenteen ympäristöongelmien vähentämiseksi paras ja lähes ainoa käytännössä mahdollinen vero-ohjauskeino olisi juuri lentovero. Sen säätämisen tarkoituksena on vähentää matkustajalentoliikennettä tai ainakin hillitä sen kasvua. Lentoverolla ei pyritä varsinaisesti lisäämään valtion tuloja, mutta verotulot kyllä kasvavat, jos lentomatkustaminen ei veron vuoksi vähenny. ${ }^{82}$

Eduskuntapuolueista varsinkin vihreät ja vasemmistoliitto ovat olleet lentoveron säätämisen kannalla. Pääministeri Antti Rinteen hallituksen ohjelman mukaan (s. 25), joka oli samanlainen kuin nykyisen hallituksen ohjelma, Suomi tukee päästökaupan laajentamista kaikkiin ilmastoon vaikuttaviin lentoliikenteen päästöihin; vaihtoehtoisesti voidaan selvittää lentopolttoaineen veron tai lentomaksun käyttöönottaminen EU:n laajuisesti tai globaalisti.

Lentoveroa koskeva kansalaisaloite on saanut 2.11.2019 päättyneessä määräajassa yli 50000 kannattajaa ja odottaa eduskunnan käsittelyä. Teknisesti lentovero olisi helppo toteuttaa kääntämällä ja hiomalla Ruotsin lentoveron lakitekstiä, jolloin lentoverolakimme voisi olla seuraavan kaltainen:

82 Esko Linnakangas - Leila Juanto, Lentoveron ylösnousu? - Ilma- ja avaruusliikenteen verotus (2018). 
7 Kansalaisaloitteinen verotus - viihdettä vai demokratiaa?

\section{Lentoverolaki}

\section{Lain soveltamisala}

$1 \S$ Lentoveroa maksetaan valtiolle tämän lain mukaisesti kaupallisesta lentomatkustamisesta.

\section{Määritelmät}

$2 \$$ Lentoyhtiöllä tarkoitetaan tässä laissa luonnollista henkilöä ja oikeushenkilöä, jolla on voimassa oleva toimintalupa tai vastaava lupa kaupallisen lentoliikennetoiminnan harjoittamiseen.

Lentokentällä tarkoitetaan maa- tai vesialuetta, joka on kokonaan tai osittain perustettu ilma-alusten saapumis-, lähtemis- ja liikkumispaikaksi.

Lentohenkilöstöllä tarkoitetaan henkilöstöä, joka on lentokoneessa ja huolehtii ilma-aluksen lentämisestä, hoitaa teknistä valvontaa, huoltoa tai korjausta tai on vastuussa matkustajien turvallisuudesta matkustamossa taikka tarjoaa palveluja matkustajille.

\section{Verovelvollisuuden laajuus}

$3 \$$ Lentoveroa maksetaan matkustajista, jotka matkustavat Suomen lentokentältä yli kymmenelle matkustajalle hyväksytyllä ilma-aluksella.

\section{Vapautus verovelvollisundesta}

$4 \$$ Lentoveroa ei makseta

1. alle kahden vuoden ikäisestä lapsesta,

2. matkustajista, jotka eivät ole saavuttaneet kohdelentokenttää teknisen toimintahäiriön, sääolosuhteiden tai muun odottamattoman tapahtuman vuoksi, ja jos siitä seuraa uusi lähtö;

3. lennossa työskentelevästä lentohenkilökunnasta;

4. matkustajista, jotka saapuvat Suomen lentokentälle, josta lento jatkuu matkustusasiakirjojen mukaan samalla ilma-aluksella, eikä

5. matkustajista, jotka ovat saapuvat Suomen lentokentälle ja sieltä jatkavat toisella ilma-aluksella, jos seuraava matka matkustusasiakirjojen mukaan alkaa 24 tunnin sisällä.

\section{Verovelvollinen}

$5 \$$ Verovelvollinen on lennon suorittava lentoyhtiö.

\section{Verovelvollisuuden syntyminen}

$6 \$$ Verovelvollisuus syntyy, kun ilma-alus nousee Suomen lentokentältä. Tätä lakia sovelletaan lentoihin, jotka lähtevät tammikuun 1 päivänä 2021 tai sen jälkeen. 
7 Kansalaisaloitteinen verotus - viihdettä vai demokratiaa?

Veron suuruus

$7 \$$ Vero on

- 6 euroa matkustajaa kohti, kun matkan lopullinen määränpää on Suomi tai jokin seuraavista maista: Alankomaat, Albania, Andorra, Belgia, Bosnia ja Hertsegovina, Bulgaria, Espanja, Irlanti, Islanti, Iso-Britannia, Italia, Itävalta, Kosovo, Kreikka, Kroatia, Kypros, Latvia, Liechtenstein, Liettua, Luxemburg, Makedonia, Malta, Moldavia, Monaco, Montenegro, Norja, Portugali, Puola, Ranska, Romania, Ruotsi, Saksa, San Marino, Serbia, Slovakia, Slovenia, Sveitsi, Tanska, Tšekki, Turkki, Ukraina, Unkari, Valko-Venäjä, Vatikaani,Viro.

- 25 euroa matkustajaa kohti, kun lopullinen määränpää on Afganistan, Algeria, Armenia, Azerbaidžan, Bahrain, Burkina Faso, Djibouti, Egypti, Eritrea, Etiopia, Gambia, Georgia, Guinea, Guinea-Bissau, Irak, Iran, Israel, Jemen, Jordania, Kanada, Kap Verde, Kazakstan, Kirgisia, Kuwait, Libanon, Libya, Mali, Mauritania, Marokko, Niger, Norsunluurannikko, Oman, Pakistan, Palestiina, Qatar, Saudi-Arabia, Senegal, Sudan, Syyria, Tadžikistan, Tšad, Tunisia, Turkmenistan, USA, Uzbekistan, Venäjä, Yhdistyneet arabiemiirikunnat.

- 40 euroa matkustajaa kohti, kun matkan lopullinen määränpää on muualla kuin jossakin edellä mainitussa maassa.

Lopullinen määränpää tarkoittaa matkustusasiakirjojen mukaista määränpäätä.

\section{Verotusmenettely}

$9 \$$ Lentoverotus toimitetaan soveltaen lakia oma-aloitteisten verojen verotusmenettelystä (768/2016).

Merkittävä vaikeus lentoveron säätämiselle on se, että hallituspuolue keskustan johto on selvästi jo ennen kansalaisaloitteen eduskuntakäsittelyä ilmoittanut vastustavansa tätä veroa.

\subsubsection{Kiinteistöjen lämmitysöljyn veroa korotettava}

Veikko Peltosen 26.1.2019 vireille panemassa aloitteessa (11 kannattajaa) esitettiin kiinteistöjen lämmityksessä käytettävän lämmitysöljyn veroasteen merkittävää korottamista tavoitteena ohjata lämmitysjärjestelmien muuttamista vähemmän CO2-päästöjä tuottavaksi.

Kiinteistöjen lämmityksessä käytettävä lämmitysöljy on liikenteessä käytettävään dieselöljyyn nähden kevyesti verotettu. Kyseessä on pääosin fossiilinen polttoaine, ja tuote on kemiallisesti lähellä dieselöljyä tai 
samaa kuin dieselöljy. Lämmitysöljy tuottaa ilmastonmuutosta lisäävää hiilidioksidia samalla tavalla kuin dieselöljynkin polttaminen. Lämmitysöljylle löytyy monessa tapauksessa vaihtoehto paljon helpommin kuin dieselöljylle. Tulisikin verotuksellisin toimin edistää lämmitysöljyn käytön vähentämistä kiinteistöjen lämmityksessä. Lämmitysöljyn veroa tulisi merkittävissä määrin korottaa. Verotuotto voidaan ohjata lämmitysjärjestelmän muutoksien tukemiseen sekä voidaan tukea niitä tuottajia, joiden liiketoimintaa kyseinen veronkorotus mahdollisesti oleellisesti haittaa. Suomessa on noin 190000 öljylämmitteistä pientaloa, ja ne kuluttavat 460 miljoonaa litraa öljyä vuodessa. Lisäksi on paljon muuta öljylämmitteistä rakennuskantaa.

\section{Kommentteja}

Pääministeri Antti Rinteen hallituksen ohjelman mukaan (s. 34) fossiilisen öljyn käytöstä lämmityksessä oli luovuttava asteittain 2030-luvun alkuun mennessä ja kannustetaan öljylämmitteisiä kiinteistöjä siirtymään muihin lämmitysmuotoihin 2020-luvun aikana erillisellä toimenpideohjelmalla. Nykyisen hallituksen ohjelma on samanlainen.

\subsubsection{Tekstiiliveron säätäminen}

Laura Dammertin, Tapani Paalasen, Tiia Mension, Tinja Salmen, Seija Kankaan, Sonja Potenzin ja Aino Kiven 15.7.2019 vireille paneman aloitteen (892 kannattajaa 30.11.2019 mennessä) mukaan halpavaatetuontanto mm. Kiinassa ja Intiassa heikentää suomalaisen ja eurooppalaisen tekstiiliteollisuuden kysyntää, lisää tekstiilijätettä, pitää tasaisena Aasiasta virtaavaa postimyyntiä sekä ennen kaikkea lisää työttömyyttä kotimaisilla tekstiilialoilla. Suomessa syntyy tekstiilijätettä vuosittain noin 70 miljoonaa kiloa. Tämä tarkoittaa henkeä kohden noin kolmeatoista kiloa. Aloitteen tarkoituksena on varmistaa vaatekaappiin parempaa laatua, pienentää hiilijalanjälkeä tekstiilien osalta, tuottaa Suomeen lisää tekstiiliteollisuuden työpaikkoja ja osoittaa halpamuodille sen epämuodikkuus tässä maailman tilassa.

Tekstiilien verottaminen niiden valmistusmaanosan mukaan auttaisi pienentämään jätemäärää ja ostamaan kotimaista ja laadukasta sekä kierrätettyä. Ulkomaisen tekstiilin korkeampi vero antaisi suomalaiselle tekstiiliteollisuudelle elpymismahdollisuuden ja lisäisi alan työpaikkoja. Se myös jarruttaisi halpamuotiketjujen kasvattamaa kulutushysteeristä pikamuodin kulutusta ja näin ollen vähentäisi merkittävästi syntyvää tekstiilijätettä. Samalla se painostaisi Aasian tekstiiliteollisuutta tuottamaan laadukkaampaa, vähemmän ja ekologisemmin - toisin sanoen kilpaile- 
maan länsimaisen tekstiiliteollisuuden kanssa tervehenkisemmin. Tähän asti Aasiassa tuotettu on ohittanut länsimaisen tekstiilin lähinnä halpojen tuotantokustannustensa vuoksi. Tämän uudenlaisen tekstiiliveron ansiosta suomalainen tekstiiliteollisuus voisi nousta vielä tavoittelemaan kulta-aikaansa 50-80-lukuja, jolloin Suomi pukeutui vielä kotimaiseen vaatteeseen.

Kommentteja:

Tässä kansalaisaloitteessa hahmoteltu tekstiilivero vaikuttaa tuontitullilta, josta säätäminen kuuluu EU:n eikä Suomen toimivaltaan.

\subsubsection{Veroaloitteiden arviointia}

\subsubsection{Esitysten erilaisuus ja samanlaisuus}

Esitysten kirjo on suuri, mutta joukossa on myös parikymmentä teemaa, joista on tehty hyvin samanlaisia tai melko samankaltaisia esityksiä, jopa samojen henkilöiden tekeminä. Tällaisina voidaan pitää seuraavia esityksiä:

- eläkkeiden verotusta kevennettävä (5 aloitetta)

- autovero on poistettava tai sitä on alennettava ( 5 aloitetta)

- alkoholiverotusta vähennettävä (4 aloitetta)

- yleisradiovero kumottava (4 aloitetta)

- harrastusmenot vähennyskelpoisiksi (4 aloitetta)

- ajoneuvoveron perusvero on poistettava tai sitä on alennettava (3 aloitetta)

- käyttövoimavero poistettava dieselautoilta (3 aloitetta)

- uusiutuvan dieselin polttoaineveroa alennettava (3 aloitetta)

- ulkomaisille ajoneuvoille tienkäyttömaksu (3 aloitetta)

- pienyrittäjien arvonlisäverovapautta laajennettava (3 aloitetta)

- äänioikeus veronmaksun mukaan (2 aloitetta)

- verolotto ja nollaverokorttiarpajaiset (2 aloitetta)

- kotitalousvähennys suuremmaksi ja laaja-alaisemmaksi (2 aloitetta)

- omaishoidontuki kokonaan tai osaksi verovapaaksi (2 aloitetta)

- osinko- ja vuokratuloille verovapaa määrä (2 aloitetta)

- perintö- ja lahjavero kumottava (2 aloitetta)

- kiinteistöveron kohtuullistaminen (2 aloitetta) 
- kaivosvero säädettävä (2 aloitetta)

- kampaamo- ja parturipalvelujen arvonlisäverokantaa alennettava (2 aloitetta)

- verosta maksettava arvonlisävero poistettava (2 aloitetta).

\subsubsection{Verotuksen alentaminen vai lisääminen?}

Verotusta koskevista kansalaisaloitteista noin $75 \%$ :ssa on esitetty jonkin veron poistamista tai alentamista. Eniten kannatusta saivat perintö- ja lahjaveron sekä dieselautojen käyttövoimaveron poistamiseksi tehdyt aloitteet. Dieselveron poistamisaloitteessa ei kuitenkaan otettu huomioon sitä, että tuon veron poisto todennäköisesti aiheuttaisi polttoaineveron korottamisen. Yhdessä aloitteessa oli sekä verotusta alentavia että sitä lisääviä elementtejä; kahdeksan aloitteen verovaikutusta ei pysty arvioimaan.

Verojen lisäämistä joillekin tuloille, tavaroille tai palveluille on esitetty seuraavissa kansalaisaloitteissa:

- Lentovero säädettävä Silja Jääskeläinen, Arto Sivonen ym. 2.5.2019 (55 184 kannattajaa)

- Työmarkkinajärjestöjen jäsenmaksujen verovähennys poistettava Juha Tuomala ja Juha Porkka 10.9.2015 (4 626 kannattajaa) Janne Heikkinen 24.9.2018 (8587 kannattajaa)

- Kaivosvero säädettävä Marko Järvelin 16.2.2013 (3 578 kannattajaa) Juha Hämäläinen 6.3.2015 (1 908 kannattajaa)

- Korkojen vähentämistä rajattava yritysverotuksessa ja Suomen verotusoikeus turvattava Jukka Niemi 5.2.2019 (28 kannattajaa) Eira Kantola 29.1.2019 (3 234 kannattajaa)

- Lihan ja maidon veron nostaminen Sonja Tigonen 23.11.2018 (2 790 kannattajaa)

- Ulkomaisille ajoneuvoille tienkäyttömaksu Anne Pykälistö 25.2.2013 (1 887 kannattajaa) Jussi Terho 28.3.2014 (1 079 kannattajaa) Mira Katajamäki ja Tapio Sato 10.4.2015 (2 229 kannattajaa)

- Sähköautoilun tukeminen kiellettävä Juha Kuismanen 22.2.2019 (1911 kannattajaa) 
7 Kansalaisaloitteinen verotus - viihdettä vai demokratiaa?

- Reilun ruuan vero

Mikko Kärnä 1.9.2018 (765 kannattajaa)

- Halpatyövoimalle maahantuontivero

Risto Kosamo 1.1.2014 (671 kannattajaa)

- Työmarkkinajärjestöjen tuloverotusta tiukennettava Juha Porkka 25.2.2018 (585 kannattajaa)

- Tekstiilivero säädettävä Laura Dammert, Tapani Paalanen ym. 15.7.2019 (892 kannattajaa 30.11.2019 mennessä)

- Lapsettomille naisille lisävero Kimmo Kemppainen 7.6.2013 (26 kannattajaa)

- Osinkotulojen verotus yhdenmukaistettava Jukka Niemi 6.2.2019 (16 kannattajaa)

- Vakuutuskuorilla verotuksen myöhentäminen lopetettava Jukka Niemi 31.1.2019 (14 kannattajaa)

- Kiinteistöjen lämmitysöljyn veroa korotettava Veikko Peltonen 26.1.2019 (11 kannattajaa).

\subsubsection{Kellojen siirtäminen taaksepäin - taantumukselliset vai edistykselliset aloitteet?}

Kellojen siirtelystä eli talvi- tai kesäajan valinnasta on tehty useita kansalaisaloitteita, mutta tässä luvussa toimenpiteellä tarkoitetaan paluuta historiassa taaksepäin.

Edellä on kunkin aloitteen osalta selvitetty, millainen verosäännöstö on aikaisemmin ollut. Verotusta koskevista kansalaisaloitteista noin 2/5:ssa tosiasiassa haikaillaan vanhoihin aikoihin palaamista, vaikka osa aloitteen tekijöistä saattaa pitää ehdotustaan uutena keksintönä. Joissakin tapauksissa palattaisiin ajassa taaksepäin muutama vuosi, toisissa kymmeniä ja joissakin esityksissä jopa satoja vuosia. Vanhojen veromallien paluusta, usein tosin muuttuneessa muodossa, olisi kysymys seuraavissa aloitteissa:

- Verot vapaaehtoisiksi Matti Pöri 19.2.2016 (10 kannattajaa)

- Valintamahdollisuus veron käyttötarkoitukseen Juha Starck 13.10.2014 (12 kannattajaa) 
7 Kansalaisaloitteinen verotus - viihdettä vai demokratiaa?

- Äänioikeus veronmaksun mukaan

Sulo Ranne 1.7.2013 (2 kannattajaa)

Sulo Ranne 7.10.2013 (2 kannattajaa)

- Yhteisverotus perheenjäsenille

Heikki Mustaniemi 14.1.2019 (1 kannattaja)

- Lapsettomille naisille lisävero

Kimmo Kemppainen 7.6.2013 (26 kannattajaa)

- Eläkkeiden verotusta kevennettävä

Mervi Jankko 19.3.2015 (2 069 kannattajaa)

Vappu Säynätkari 29.1.2018 (8 091 kannattajaa)

Lasse Helskyaho 6.3.2018 (41 kannattajaa)

Mirja Hirvijärvi ja Irma Hirvijärvi 8.3.2018 (16 kannattajaa)

Heikki Haaslahti 22.3.2018 (2 461 kannattajaa)

- Lääkekaton vuosiomavastuuosuus verovähennyskelpoiseksi osittain tai kokonaan

Tommi Kvist, Nina-Katariina Kettunen ym. 20.10.2019 (846 kannattajaa 30.11.2019 mennessä)

- Osinko- ja vuokratuloille verovapaa määrä

Heikki Kärkkäinen 4.4.2013 (639 kannattajaa)

Jani Ehro 13.6.2016 (7 kannattajaa)

- Työmarkkinajärjestöjen jäsenmaksujen verovähennys poistettava

Juha Tuomala ja Juha Porkka 10.9.2015 (4 626 kannattajaa)

Janne Heikkinen 24.9.2018 (8587 kannattajaa)

- Osinkotulojen verotus yhdenmukaistettava

Jukka Niemi 6.2.2019 (16 kannattajaa)

- Yleisradiovero kumottava

Petri Rautiainen 21.7.2014 (2 098 kannattajaa)

Aleksi Hernesniemi 15.2.2016 (22 670 kannattajaa)

Petri Rautiainen 17.1.2019 (4002 kannattajaa)

Mauri Peltokangas, Aleksi Hernesniemi ym. 5.4.2019 (13 663 kannattajaa)

- Kaivosvero säädettävä

Marko Järvelin 16.2.2013 (3 578 kannattajaa)

Juha Hämäläinen 6.3.2015 (1 908 kannattajaa)

- Arvonlisävero poistettava palveluilta ja alkutuotannolta

Edvard Hannolainen 13.3.2017 (27 kannattajaa) 
7 Kansalaisaloitteinen verotus - viihdettä vai demokratiaa?

- Kampaamo- ja parturipalvelujen arvonlisäverokantaa alennettava Jan Antin 8.4.2013 (2011 kannattajaa) Ronja Slotte 1.9.2015 (984 kannattajaa)

- Autovero on poistettava tai sitä on alennettava Jarno Siivola 5.12.2012 (2 206 kannattajaa) Jarno Siivola 2.9.2013 (2 593 kannattajaa) Jarno Siivola ja Nina Palomäki 22.4.2015 (3 774 kannattajaa) Ville Likitalo 6.12.2012 (3080 kannattajaa) Lasse Köngäs 30.8.2013 (48 kannattajaa) Lauri Heinonen 1.9.2014 (22 kannattajaa) Jukka Enäjärvi 16.1.2019 (20 kannattajaa)

- Ajoneuvoveron perusvero poistettava Liisa Kylänpää 4.5.2015 (10 kannattajaa) Pertti Turunen 17.12.2018 (19 kannattajaa)

Kari Vuorentausta ja Antti Vuorentausta 17.1.2016 (4 193 kannattajaa)

- Käyttövoimavero poistettava dieselautoilta Jarmo Männikkö 5.9.2013 (2 680 kannattajaa) Matti Erkkilä ja Jukka Paakki 10.9.2013 (2 273 kannattajaa) Sisko Paavola ja Heino Paavola 12.11.2018 (125 439 kannattajaa)

- Lentovero säädettävä Silja Jääskeläinen, Arto Sivonen ym. 2.5.2019 (55 184 kannattajaa).

\subsubsection{Suhde perustuslakiin ja EU-oikeuteen}

Ainakin seuraavat kuusi kansalaisaloitetta ovat olleet ilmeisesti perustuslakimme yhdenvertaisuusperiaatteen vastaisia:

- Verot vapaaehtoisiksi

Matti Pöri 19.2.2016 (10 kannattajaa)

- Äänioikeus veronmaksun mukaan

Sulo Ranne 1.7.2013 (2 kannattajaa)

Sulo Ranne 7.10.2013 (2 kannattajaa)

- Verolotto ja nollaverokorttiarpajaiset

Anssi Puruskainen 4.4.2013 (263 kannattajaa)

Osmo Anttalainen 16.2.2015 (13 kannattajaa)

- Lapsettomille naisille lisävero

Kimmo Kemppainen 7.6.2013 (26 kannattajaa). 
Seuraavat aloitteet ovat olleet vähintäänkin kyseenalaisia EU-oikeuden kannalta:

- Halpatyövoimalle maahantuontivero Risto Kosamo 1.1.2014 (671 kannattajaa)

- Reilun ruuan vero Mikko Kärnä 1.9.2018 (765 kannattajaa)

- Lihan ja maidon veron lisääminen Sonja Tigonen 23.11.2018 (2 790 kannattajaa)

- Arvonlisävero poistettava palveluilta ja alkutuotannolta Edvard Hannolainen 13.3.2017 (27 kannattajaa)

- Tekstiilialan arvonlisäverokantaa alennettava Virva Klaasio 21.6.2017 (1 970 kannattajaa)

- Eläinlääkäripalvelujen arvonlisäverotusta kevennettävä Hanna Puhakka 25.2.2016 (2 692 kannattajaa)

- Verosta maksettava arvonlisävero poistettava Matti Hietanen 27.11.2017 (35 kannattajaa) Veli-Matti Hietanen 6.12.2018 (39 kannattajaa)

- Ulkomaisille ajoneuvoille tienkäyttömaksu Anne Pykälistö 25.2.2013 (1 887 kannattajaa) Jussi Terho 28.3.2014 (1 079 kannattajaa) Mira Katajamäki ja Tapio Sato 10.4.2015 (2 229 kannattajaa)

- Tekstiiliveron säätäminen Laura Dammert, Tapani Paalanen ym. 15.7.2019 (892 kannattajaa 30.11.2019 mennessä).

\subsubsection{Aloitteiden toteuttamiskelpoisuus}

Kansalaisaloitteessa esitetty idea on usein esitetty muuallakin, ja idea voinut tulla jo toteutetuksi. Näin on käynyt yhteisöjen asemaa kirkollisverotuksessa ja e-kirjojen verokantaa arvonlisäverotuksessa koskeneille kansalaisaloitteille. Pari kansalaisaloitetta (venevero ja moottoripyörien ajoneuvovero) on ollut ennenaikaisia hallituksen peruttua myöhemmin suunnitelmansa. 
Noin puolet verotusta koskevista kansalaisaloitteista ei kerännyt märäajassa vähintään 50:tä kannattajaa. ${ }^{83}$ Monet niistä edustavat niin harvojen ajattelua, että niiden ideoilla tuskin voi nähdä Suomessa mahdollisuuksia kehittyä verolainsäädännöksi. Melkoinen osa kansalaisaloitteista on myös perustuslakimme tai EU-säädösten vastaisia, eikä sellaisia esityksiä voi toteuttaa.

Muutaman paljon kannattajia saaneen idean, kuten autoveron ja dieselveron poiston, muuntumista lainsäädännöksi vaikeuttaa se, että niissä ei ole otettu huomioon esityksen heijastusvaikutuksia muuhun verolainsäädäntöön. Runsaasti kannatusta saaneista kansalaisaloitteista melkoinen osa koskee ideoita, joille ei ole riittävää kannatusta nykyisissä eduskuntapuolueissa eikä varsinkaan hallituspuolueissa (em. verojen lisäksi mm. yleisradioveron poistaminen ja suurten eläkkeiden veron alentaminen).

Useissa kansalaisaloitteissa on ideoita, jotka hallituksenkin olisi syytä pohtia vakavasti. Tällaisia aloitteita ovat lentoveron lisäksi esimerkiksi seuraavat, jotka eivät ole keränneet tarpeeksi kannattajia päästäkseen eduskuntakäsittelyyn.

- Sinkuille tasavertainen asema verovähennyksissä

Pia Pelkonen 5.5.2018 (17 kannattajaa)

- Omaishoidon tuki kokonaan tai osaksi verovapaaksi Juha Pätsi 7.4.2017 (20 kannattajaa)

Päivi Lämsä, Markku Koponen ym. 8.11.2019 (5 580 kannattajaa 30.11.2019 mennessä)

- Pienyrittäjien arvonlisäverovapautta laajennettava

Christian Jansson 10.6.2016 (20 kannattajaa)

Harri Jyrkiäinen 24.6.2013 (5031 kannattajaa)

Heikki Hänninen ja Henri Hänninen 1.11.2017 (18 661 kannattajaa)

- Kampaamo- ja parturipalvelujen arvonlisäverokantaa alennettava Jan Antin 8.4.2013 (2 011 kannattajaa)

Ronja Slotte 1.9.2015 (984 kannattajaa)

83 Veroaloitteista vähiten kannattajia - vain yhden - on saanut esitys yhteisverotukseen siirtymisestä (14.1.2019). Muissa kuin veroesityksissä on myös sellaisia esityksiä, joita ei kukaan ole kannattanut. 
- Kuukautissuojien verokantaa alennettava Turkka Saarikoski 5.10.2018 (6 885 kannattajaa)

- Uusiutuvan dieselin polttoaineveroa alennettava Tuomo Härkönen 26.11.2018 (10 kannattajaa) Elias Hiltunen 28.1.2019 (38 kannattajaa) Jussi Isoaho 3.4.2019 (2 245 kannattajaa)

- Käyttövoimavero poistettava kaasuautoilta Olavi Ojala 2.1.2019 (15 kannattajaa)

- Kaivosvero säädettävä Marko Järvelin 16.2.2013 (3 578 kannattajaa) Juha Hämäläinen 6.3.2015 (1908 kannattajaa).

\subsection{Kansalaisaloitejärjestelmän merkitys}

\subsubsection{Kansalaisaloitejärjestelmän tavoite, aloitteiden kannatus ja taloudellinen tuki}

Valtiollisen kansalaisaloitejärjestelmän tavoitteena on lisätä demokratiaa menettelyllä, jossa kansalaiset voivat saada haluamansa asian eduskunnan käsiteltäväksi ja päätettäväksi. Eduskuntakäsittelyyn pääseminen edellyttää 50000 kannattajan keräämistä puolen vuoden aikana. Kaikista kansalaisaloitteista tuon rajan ovat järjestelmän voimassa ollessa ylittäneet seuraavat aloitteet (verotusta koskevat aloitteet lihavoitu):

\begin{tabular}{|c|c|c|}
\hline Kannattajia & Aloitepäivä & \\
\hline 166851 & 19.3.2013 & Tasa-arvoinen avioliittolaki \\
\hline 140944 & 20.12.2017 & $\begin{array}{l}\text { HE 124/2017:n (työttömyysturvalain muutos) } \\
\text { kumoaminen }\end{array}$ \\
\hline 125439 & 12.11.2018 & Dieselautojen käyttövoimaveron poisto \\
\hline 118374 & 6.12 .2018 & Seksuaalirikoksesta tuomitun karkotus \\
\hline 106195 & 29.3.2015 & Sukupuolineutraalin avioliittolain kumoaminen \\
\hline 84820 & 24.9 .2015 & Työeläkeindeksin palauttaminen palkkatasoiseksi \\
\hline 76200 & 3.7.2019 & $\begin{array}{l}\text { Verkkokalastus kiellettävä saimaannorpan levin- } \\
\text { neisyysalueella }\end{array}$ \\
\hline
\end{tabular}


7 Kansalaisaloitteinen verotus - viihdettä vai demokratiaa?

\begin{tabular}{|c|c|c|}
\hline Kannattajia & Aloitepäivä & \\
\hline 72059 & 12.6.2017 & Vammaisten avun kilpailuttamisen lopettaminen \\
\hline 70393 & 10.10 .2016 & Kellojen kesäaikaan siirtämisen lopettaminen \\
\hline 70005 & 11.8.2017 & Kansanedustajien sopeutumiseläke poistettava \\
\hline 67547 & 23.5 .2014 & $\begin{array}{l}\text { Terveydenhoitohenkilökunnan oikeus kieltäytyä } \\
\text { suorittamasta aborttia }\end{array}$ \\
\hline 67422 & 24.1 .2017 & Terveydenhuoltolain $50.3 \S:$ muuttaminen \\
\hline 66797 & 10.4 .2014 & $\begin{array}{l}\text { Päivystysasetuksen muuttaminen synnytysten } \\
\text { osalta }\end{array}$ \\
\hline 65491 & 4.12 .2018 & $\begin{array}{l}\text { Pyroteknisten tuotteiden (ilotulitteiden) käytön } \\
\text { rajoittaminen }\end{array}$ \\
\hline 63078 & 14.2.2017 & Eutanasia hyvä kuolema \\
\hline 62835 & 17.8 .2013 & Rattijuoppojen rangaistuksia tiukennettava \\
\hline 62516 & 15.1 .2015 & Nollatuntisopimusten kieltäminen työsuhteissa \\
\hline 62211 & 11.4 .2013 & Energiatodistuslain muuttaminen \\
\hline 61438 & 17.5 .2018 & Avohakkuiden lopettaminen valtion mailla \\
\hline 61306 & 4.3 .2013 & Ruotsin kieli valinnaiseksi \\
\hline 61266 & 2.4.2018 & Tyttöjen sukuelinten silpomisen kieltäminen \\
\hline 59609 & 1.5 .2019 & Kannabiksen käytön rangaistavuuden poistaminen \\
\hline 59381 & 10.1 .2018 & Vakuutuslääkärien mielivalta poistettava \\
\hline 58992 & 22.1.2019 & Kaivoslain muuttaminen \\
\hline 58367 & 19.2.2018 & Mikromuovin kieltäminen kosmetiikassa \\
\hline 58013 & 6.5 .2014 & $\begin{array}{l}\text { Lapsiin kohdistuvien seksuaalirikosten rangais- } \\
\text { tukset }\end{array}$ \\
\hline 57489 & 6.11.2017 & Perintö- ja lahjaverosta luopuminen \\
\hline 56067 & 10.8 .2016 & Helsinki-Malmin lentopaikka \\
\hline 55723 & 5.6 .2018 & Raiskauksen määritelmä suostumusperusteiseksi \\
\hline 55707 & 28.11 .2015 & Äitiyslaki \\
\hline 55184 & 2.5.2019 & Lentovero säädettävä \\
\hline 54324 & 5.11 .2014 & $\begin{array}{l}\text { Rikokseen syyllistyneen ulkomaalaisen karkot- } \\
\text { taminen }\end{array}$ \\
\hline 53971 & 10.4.2019 & Kesäaika pysyväksi ajaksi \\
\hline 53425 & 16.7.2015 & $\begin{array}{l}\text { Kansanäänestys Suomen jäsenyydestä euroalu- } \\
\text { eessa }\end{array}$ \\
\hline 53098 & 18.9.2017 & Maksuton toisen asteen koulutus kaikille \\
\hline 53060 & 20.2.2019 & Terapiatakuu mielenterveyspalveluihin \\
\hline 52603 & 20.11.2018 & Lasten ja nuorten syrjäytyminen alakouluissa \\
\hline 51801 & 23.1 .2013 & Järkeä tekijänoikeuslakiin \\
\hline
\end{tabular}


Näistä 38:sta kansalaisaloitteesta toistaiseksi on kaksi hyväksytty kokonaan tai osaksi, nimittäin ensin tasa-arvoinen avioliittolaki ja sitten äitiyslaki, joka sallii naisparin lapselle kaksi äitiä jo ennen lapsen syntymää.

Ensimmäinen verotusta koskeva 50000 kannattajamäärän saavuttanut kansalaisaloite koski perintö- ja lahjaverotuksen lopettamista. Valtiovarainvaliokunnan enemmistö päätti olla antamatta siitä lausuntoa, joten esitys raukesi. Eduskuntakäsittelyssä on tätä kirjoitettaessa (joulukuussa 2019) aloite dieselautojen käyttövoimaveron poistamisesta, ja käsittelyyn on menossa aloite lentoverosta.

Kansalaisaloitelain 13 ja 14 \$:ssä säädetään aloitteen tekemistä varten saadun taloudellisen tuen ilmoittamisesta. Harvat kansalaisaloitteet ovat saaneet taloudellista tukea. Eduskuntakäsittelyyn vaadittavan 50000 kannattajan rajan ylittäneistä 38 kansalaisaloitteesta tukea ovat ilmoitusten mukaan saaneet seuraavat 10 aloitetta:

19.3.2013 Tasa-arvoinen avioliittolaki

29.3.2015 Sukupuolineutraalin avioliittolain kumoaminen

15.1.2015 Nollatuntisopimusten kieltäminen työsuhteissa

17.5.2018 Avohakkuiden lopettaminen valtion mailla

4.3.2013 Ruotsin kieli valinnaiseksi

1.5.2019 Kannabiksen käytön rangaistavuuden poistaminen

22.1.2019 Kaivoslain muuttaminen

10.8.2016 Helsinki-Malmin lentopaikka

2.5.2019 Lentovero säädettävä ${ }^{84}$

23.1.2013 Järkeä tekijänoikeuslakiin.

84 Lentoveroaloitteen taloudellisesta tuesta on ilmoituksessa linkki Maan ystävien sivuille. Maan ystävät on kansainvälinen ympäristöjärjestöjen verkosto, jonka tärkeitä teemoja ovat ympäristönsuojelu, demokratia, ihmisoikeudet ja tasa-arvo. Suomen Maan ystävät perustettiin vuonna 1996. Järjestö on osa kansainvälistä Friends of the Earth International -verkostoa, johon kuuluu ryhmiä noin 70 maasta kaikista maanosista. Kansainvälinen verkosto on toiminut vuodesta 1971. 
50 000:n kannattajan rajan alle jääneistä kansalaisten veroesityksistä suosituimmat ovat olleet seuraavat aloitteet (mikään niistä ei ole saanut taloudellista tukea):

Pienyrittäjien arvonlisäverovapautta laajennettava (1.11.2017) 18661 kannattajaa Yleisradiovero kumottava (5.4.2019) 13663 kannattajaa

Työmarkkinajärjestön jäsenmaksun verovähennys poistettava (24.9.2018)

Eläkeläisten raippavero poistettava (29.1.2018)

8587 kannattajaa 8091 kannattajaa

Kuukautissuojien arvonlisäveroa alennettava (5.10.2018)

6885 kannattajaa.

\subsubsection{Vertailua kansanedustajien aloitteisiin}

Yksi kansanedustaja tai joukko kansanedustajia voi tehdä eduskunnassa lakialoitteita. Vuosittain näitä aloitteita tehdään noin 100. Viime vuosina määrät ovat olleet seuraavat:

$\begin{array}{rr}2015 & 52 \text { aloitetta } \\ 2016 & 109 \text { aloitetta } \\ 2017 & 97 \text { aloitetta } \\ 2018 & 104 \text { aloitetta. }\end{array}$

Vuonna 2018 tehdyistä 104:stä lakialoitteesta 23 koski verotusta. Niistä oli 18 (78 \%) oppositiopuolueiden ja 5 (22\%) hallituspuolueiden kansanedustajien tekemiä. Puolueittain verolakialoitteet jakautuivat seuraavasti: perussuomalaiset $10, \operatorname{SDP} 5$, vihreät 1 , kristillisdemokraatit 1, RKP 1, keskustalaiset 4, kokoomuslaiset 1, siniset 0 . Aloitteet olivat seuraavat:

LA 94/2018 tuloverolain $10 \$: n$ muuttamisesta, 1. allekirjoittaja Harakka, Timo (sd)

LA 90/2018 tuloverolain 64 \$:n muuttamisesta, 1. allekirjoittaja Harakka, Timo (sd)

LA 87/2018 tuloverolain 116c \$:n muuttamisesta, 1. allekirjoittaja Skinnari, Ville (sd)

LA 81/2018 laiksi tuloverolain 88 \$:n muuttamisesta, 1. allekirjoittaja Ala-Nissilä, Olavi (kesk)

LA 79/2018 kiinteistöverolain muuttamisesta, 1. allekirjoittaja Meri, Leena ( $\mathrm{ps}$ ) 
LA 78/2018 yleisradioverosta annetun lain 2 \$:n muuttamisesta, 1. allekirjoittaja Meri, Leena (ps)

LA 75/2018 tuloverolain muuttamisesta, 1. allekirjoittaja Meri, Leena (ps)

LA 72/2018 arvonlisäverolain 3 ja 149a $\$: n$ muuttamisesta, 1. allekirjoittaja Meri, Leena (ps)

LA 71/2018 tuloverolain 101 \$:n muuttamisesta, 1. allekirjoittaja Meri, Leena (ps)

LA 69/2018 tuloverolain väliaikaisesta muuttamisesta, 1. allekirjoittaja Meri, Leena (ps)

LA 66/2018 nestemäisten polttoaineiden valmisteverosta annetun lain liitteen muuttamisesta, 1. allekirjoittaja Meri, Leena (ps)

LA 65/2018 sähkön ja eräiden polttoaineiden valmisteverosta annetun lain liitteen muuttamisesta, 1. allekirjoittaja Meri, Leena (ps)

LA 63/2018 raskaan liikenteen tienkäyttömaksuista ja ajoneuvoverolain 27 \$:n muuttamisesta, 1. allekirjoittaja Meri, Leena (ps)

LA 59/2018 perintö- ja lahjaverolain 7 ja 7 b $\$: n$ muuttamisesta, 1 . allekirjoittaja Meri, Leena (ps)

LA 53/2018 tuloverolain 48 \$:n muuttamisesta, 1. allekirjoittaja Harak$\mathrm{ka}$, Timo (sd)

LA 43/2018 tuloverolain 10 \$:n muuttamisesta, 1. allekirjoittaja Essayah, Sari $(\mathrm{kd})$

LA 37/2018 tuloverolain 95 \$:n ja elinkeinotulon verottamisesta annetun lain 8 \$:n muuttamisesta, 1. allekirjoittaja Wallin, Stefan (r)

LA 34/2018 tuloverolain muuttamisesta, 1. allekirjoittaja Savola, Mikko (kesk)

LA 32/2018 sähkön ja eräiden polttoaineiden valmisteverosta annetun lain 4 \$:n muuttamisesta, 1. allekirjoittaja Eestilä, Markku (kok)

LA 30/2018 arvonlisäverolain 59 \$:n muuttamisesta, 1. allekirjoittaja Maijala, Eeva-Maria (kesk)

LA 23/2018 tuloverolain väliaikaisesta muuttamisesta, 1. allekirjoittaja Kärnä, Mikko (kesk)

LA 8/2018 tuloverolain muuttamisesta, 1. allekirjoittaja Harakka, Timo (sd)

LA 5/2018 muovipakkausverosta, 1. allekirjoittaja Mikkonen, Krista (vihr).

Lakialoitteiden lisäksi kansanedustajat voivat tehdä toimenpidealoitteita, talousarvioaloitteita ja lisätalousarvioaloitteita. Kansanedustajienkin aloitteet tulevat erittäin harvoin hyväksytyiksi, kuten 
osoittavat seuraavat luvut keväällä 2019 päättyneeltä valtiopäiväkaudelta:

- Lakialoitteita 291, joista raukesi 223, hylättiin 62, peruutettiin 1 ja hyväksyttiin muutettuna 5 .

- Toimenpidealoitteita 216, joista raukesi 200, hylättiin 12, peruutettiin 2 ja hyväksyttiin muutettuna 2 .

- Talousarvioaloitteita 617, joista hylättiin 615, peruutettiin 1 ja hyväksyttiin 1.

- Lisätalousarvioaloitteita 54, jotka kaikki hylättiin.

Kaikista näistä yhteensä 1178 aloitteesta hyväksyttiin edes muutettuna yhteensä vain kahdeksan (0,68 \%).

\subsubsection{Hallituksen kokoonpanon tärkeys}

Edellä esitetyt luvut osoittavat, että kansalaisten ja kansanedustajien aloitteilla on tosiasiassa erittäin vaatimaton osa lakeja säädettäessä. Lähes kaikki lait ja niiden muutokset perustuvat hallituksen antamiin esityksiin, joita eduskuntakäsittelyssä hiotaan. Olennaisen tärkeää siis on, millainen on hallituksen kokoonpano ja millaiset ovat voimasuhteet puolueiden kesken. Kansalaiset voivat yrittää vaikuttaa puolueiden kannanottoihin kansanedustajien tai muiden vaikuttajien kautta taikka julkisilla esityksillä, joille voidaan saada julkisuutta mielenosoituksillakin. Kansalaisaloitteet ovat yksi tapa saada asialle julkisuutta ja hallituspuolueidenkin huomiota.

\subsubsection{Kansalaisaloitejärjestelmän muutostarve?}

Entinen oikeusministeri Tuija Brax (vihr) ei häpeä sitä, että hän oli ajamassa Suomen perustuslakiin mahdollisuuden kansalaisaloitteeseen, joka luotiin demokratian täydentäjäksi (Kaleva 15.12.2018): "Se on varaventtiili, jos tuntuu, että äänestäminen neljän vuoden välein ei auta."

Kansalaisaloitteilla on huomattava periaatteellinen merkitys demokraattisessa yhteiskunnassa, mutta meillä niiden käytännöllinen merkitys on ainakin toistaiseksi jäänyt järjestelmän periaatteellista 
merkitystä vähäisemmäksi. Edellä selostettuja tilastoja vasten voidaankin kysyä, pitäisikö järjestelmä tarpeettomana kumota vai pitäisikö sitä kehittää.

Kansalaisaloitejärjestelmämme kuitenkin on vielä melko uusi, ja systeemiä on hiljan uudistettukin, joten tarvetta kumoamiseen tai muuttamiseen tuskin nyt on. 50000 kannattajan rajaa ei voida pitää niin alhaisena, että se ruuhkauttaisi eduskunnan. 50000 kannattajan vaatimus, joka on muissakin maissa yleinen, ei ole myöskään kohtuuttoman suuri, kun aloitteiden kannattaminen erityisesti sähköisesti on tehty helpoksi. On myös huomattava, että samasta asiasta voidaan tehdä uusi kansalaisaloite, jos alkuperäinen ei saanut tarvittavaa kannattajamäärää. Näin on muutaman kerran tehtykin. Jos samanlaisesta asiasta on samaan aikaan vireillä useita kansalaisaloitteita, aloitteen kannattajan on syytä antaa kannatuksensa niille kaikille, jotteivät samansuuntaiset aloitteet vähennä toistensa kannattajia ja estä 50 000:n rajan saavuttamista.

Kun lentoveroaloite saavutti eduskuntakäsittelyyn vaadittavan kannattajamäärän, eduskunnan puhemies Matti Vanhanen totesi lehtihaastattelussa (Iltalehti 1.11.2019), että veroihin liittyvät kansalaisaloitteet ovat ongelmallisia. ${ }^{85}$

Verokysymykset kuuluvat eduskunnan vuosittaiseen budjettikäsittelyyn, eikä Vanhanen kannata sitä, että yksittäisiä veroja tai veronalennuksia alettaisiin säätää kansalaisaloitteiden kautta. Vaikka kyse on periaatteesta eikä niinkään verotuotoista, kohteena on valtion budjettitalous. Kansalaisaloitteiden tehtävä ei Vanhasen mielestä ole määritellä sitä, kuinka paljon valtio käyttää rahaa johonkin tarkoitukseen tai kuinka paljon veroja alennetaan tai nostetaan. Hän arvelee, että eduskunnan valiokunnat eivät tällaisia aloitteita kovin pitkälle käsittele; yksittäistä veroa tai veronalennusta ei voi erikseen päättää, vaan sitä joudutaan peilaamaan valtiontalouden tasapainoon.

Kansalaisaloitteesta käydään aina lähetekeskustelu ennen valiokuntakäsittelyä. Vanhasen mukaan puhemiesneuvosto joutuu sovittelemaan kansalaisaloitteiden lähetekeskustelujen aikatauluja, ja silloin hallituksen

85 Eduskunnan puhemiehet ovat aikaisemmin ottaneet kansalaisaloitteet vastaan juhlallisesti itse. Puhemies Matti Vanhasen väheksyvään asenteeseen kansalaisaloitteisiin voi viitata se, että hän teki kesäkuussa 2019 linjauksen, jonka mukaan hänen sijastaan kansalaisaloitteet ottaa vastaan eduskunnan lainsäädäntöjohtaja virkatyönä. 
esitykset ja eduskunnan omat toimet menevät aina edelle. Lopputulos on se, että kaikki kansalaisaloitteet eivät ehkä tekijöiden mielestä saa parasta aikaa keskustelulle. Valiokunnat joutuvat pohtimaan omaa ajankäyttöään ja kansalaisaloitteiden suhdetta siihen. Valiokunnilla on Vanhasen mukaan täysi valta päättää siitä, järjestävätkö ne asiantuntijakuulemisia ja tekevätkö mietintöjä aloitteiden pohjalta. Jos valiokunta katsoo, että sillä ei ole aikaa tarttua kansalaisaloitteeseen, aloite saattaa jäädä käsittelemättä. Tällöin harkitaan asiallisesti se, kuinka paljon aikaa koko eduskunnassa käytetään kunkin aloitteen valmisteluun.

Toisin kuin joissakin muissa valtioissa ${ }^{86}$ Suomen kansalaisaloitejärjestelmän ulkopuolelle ei ole perustuslaissa rajattu veroja eikä valtion budjettiin liittyviä lakeja, eikä tuota rajausta voi puhemies tai valiokunta tehdä. Totta on, että monet verotusta koskevat kansalaisaloitteet liittyvät kokonaisuuteen, josta ei voida erottaa yhtä osaa erikseen ratkaistavaksi. Esimerkiksi perintö- ja lahjaveron kumoaminen vaatisi muutoksia tuloverotukseen ja dieselautojen käyttövoimaveron kumoaminen vaatisi muutoksia polttoaineverotukseen. Esimerkiksi lentoveron säätäminen ei kuitenkaan edellyttäisi muutoksia muuhun verolainsäädäntöön. Valtion verotulojen kasvaminenkaan ei olisi ongelma.

${ }^{86}$ Vrt. Espanjan ja Portugalin kansalaisaloitejärjestelmät (edellä luvut 7.2.5 ja 7.2.7). 


\section{8 \\ Rahalla vaientamisen verokohtelu ja tuloverotietojen julkisuus}

\subsection{Johdanto}

Itseään erään suurvallan vaikutusvaltaisen johtomiehen seksikumppaneiksi väittäneet naiset ovat median mukaan vaatineet ja saaneet suuria korvauksia vaikenemisestaan. Suomessakin ihmisiä voidaan maksaa vaitonaisiksi. Toisaalta rahalla voidaan innostaa myös kertomaan omista ja toisten asioista viranomaisille ja tiedotusvälineille.

Sveitsiläisen UBS-pankin entisen pankkiirin, yhdysvaltalaisen Bradley Birkenfeldin, paljastukset johtivat maailman tähän mennessä suurimpaan veropetosvyyhdin paljastumiseen. Birkenfeldille annettiin sekä 104 miljoonan dollarin (verojen jälkeen 75816 958,40 USD) ilmiantopalkkio että vankeustuomio (Helsingin Sanomat 12.1.2019 s. B 11-12).

Seuraavassa selvitetään vaikenemiskorvausten ja vihjepalkkioiden verokohtelua Suomessa toisaalta saajalla ja toisaalta antajalla sekä tuloverotietojen yleisöjulkisuuden historiaa ja kehittämistarvetta. 


\subsection{Sananvapaus, yksityiselämän suoja ja seksuaalinen itsemääräämisoikeus}

\subsubsection{Sananvapaus}

Sananvapaudesta säädetään perustuslain 12 \$:ssä. Sen mukaan jokaisella on sananvapaus. Sananvapauteen sisältyy oikeus ilmaista, julkistaa ja vastaanottaa tietoja, mielipiteitä ja muita viestejä kenenkään ennakolta estämättä. Tarkempia säännöksiä sananvapauden käyttämisestä annetaan lailla.

Laissa sananvapauden käyttämisestä joukkoviestinnässä (13.6.2003/ 460) annetaan tarkempia säännöksiä perustuslaissa turvatun sananvapauden käyttämisestä joukkoviestinnässä. Laissa säädetään mm. julkaisijan velvollisuuksista, oikaisuista ja lähdesuojasta.

Euroopan ihmisoikeussopimuksen 10 artiklan mukaan jokaisella on sananvapaus. Tämä sisältää vapauden pitää mielipiteitä sekä vastaanottaa ja levittää tietoja ja ajatuksia alueellisista rajoista riippumatta ja viranomaisten siihen puuttumatta. Artikla ei estä valtioita tekemästä radio-, televisio- ja elokuvayhtiöitä luvanvaraisiksi. Koska näiden vapauksien käyttöön liittyy velvollisuuksia ja vastuuta, vapauksien käyttö voidaan asettaa sellaisten muodollisuuksien, ehtojen, rajoitusten ja rangaistusten alaiseksi, joista on säädetty laissa ja jotka ovat välttämättömiä demokraattisessa yhteiskunnassa kansallisen turvallisuuden, alueellisen koskemattomuuden tai yleisen turvallisuuden vuoksi, epäjärjestyksen tai rikollisuuden estämiseksi, terveyden tai moraalin suojaamiseksi, muiden henkilöiden maineen tai oikeuksien turvaamiseksi, luottamuksellisten tietojen paljastumisen estämiseksi tai tuomioistuinten arvovallan ja puolueettomuuden varmistamiseksi. $^{87}$

87 Sananvapaudesta Euroopan ihmisoikeustuomioistuimen käytännössä ks. esim. Matti Pellonpää - Monica Gullans - Pasi Pölönen - Antti Tapanila, Euroopan ihmisoikeussopimus (2018) s. 865 ss. 


\subsubsection{Kunnianloukkaus}

Kunnianloukkaus on rikos, josta säädetään nykyisin rikoslain 24 luvun 9 ja 10 \$:ssä. Joka esittää toisesta valheellisen tiedon tai vihjauksen siten, että teko on omiaan aiheuttamaan vahinkoa tai kärsimystä loukatulle taikka häneen kohdistuvaa halveksuntaa, on tuomittava kunnianloukkauksesta sakkoon.

Kunnianloukkauksesta on tuomittava myös henkilö, joka muulla tavalla halventaa toista. Tässä tarkoitettuna kunnianloukkauksena ei kuitenkaan pidetä arvostelua, joka kohdistuu toisen menettelyyn politiikassa, elinkeinoelämässä, julkisessa virassa tai tehtävässä, tieteessä, taiteessa taikka näihin rinnastettavassa julkisessa toiminnassa ja joka ei selvästi ylitä sitä, mitä voidaan pitää hyväksyttävänä.

Kunnianloukkauksena ei myöskään pidetä yleiseltä kannalta merkittävän asian käsittelemiseksi esitettyä ilmaisua, jos sen esittäminen, huomioon ottaen sen sisältö, toisten oikeudet ja muut olosuhteet, ei selvästi ylitä sitä, mitä voidaan pitää hyväksyttävänä.

Jos kunnianloukkauksessa aiheutetaan suurta kärsimystä tai erityisen suurta vahinkoa ja rikos on myös kokonaisuutena arvostellen törkeä, rikoksentekijä on tuomittava törkeästä kunnianloukkauksesta sakkoon tai vankeuteen enintään kahdeksi vuodeksi.

\subsubsection{Yksityiselämän suoja}

Perustuslain 10 \$:n mukaan jokaisen yksityiselämä, kunnia ja kotirauha on turvattu. Henkilötietojen suojasta säädetään tarkemmin lailla. Kirjeen, puhelun ja muun luottamuksellisen viestin salaisuus on loukkaamaton. Lailla voidaan säätää perusoikeuksien turvaamiseksi tai rikosten selvittämiseksi välttämättömistä kotirauhan piiriin ulottuvista toimenpiteistä. Lailla voidaan säätää lisäksi välttämättömistä rajoituksista viestin salaisuuteen yksilön tai yhteiskunnan turvallisuutta taikka kotirauhaa vaarantavien rikosten tutkinnassa, oikeudenkäynnissä ja turvallisuustarkastuksessa sekä vapaudenmenetyksen aikana.

Euroopan ihmisoikeussopimuksen 8 artiklan mukaan jokaisella on oikeus nauttia yksityis- ja perhe-elämäänsä, kotiinsa ja kirjeenvaihtoonsa kohdistuvaa kunnioitusta. Viranomaiset eivät saa puut- 
tua tämän oikeuden käyttämiseen, paitsi kun laki sen sallii ja se on välttämätöntä demokraattisessa yhteiskunnassa kansallisen ja yleisen turvallisuuden tai maan taloudellisen hyvinvoinnin vuoksi, tai epäjärjestyksen tai rikollisuuden estämiseksi, terveyden tai moraalin suojaamiseksi tai muiden henkilöiden oikeuksien ja vapauksien turvaamiseksi.

\subsubsection{Yksityiselämää loukkaava tiedon levittäminen}

Yksityiselämää loukkaava tiedon levittäminen on rikos, josta säädetään rikoslain 24 luvun 8 ja 8 a \$:ssä. Joka oikeudettomasti joukkotiedotusvälinettä käyttämällä tai muuten toimittamalla lukuisten ihmisten saataville esittää toisen yksityiselämästä tiedon, vihjauksen tai kuvan siten, että teko on omiaan aiheuttamaan vahinkoa tai kärsimystä loukatulle taikka häneen kohdistuvaa halveksuntaa, on tuomittava yksityiselämää loukkaavasta tiedon levittämisestä sakkoon.

Yksityiselämää loukkaavana tiedon levittämisenä ei pidetä sellaisen yksityiselämää koskevan tiedon, vihjauksen tai kuvan esittämistä politiikassa, elinkeinoelämässä tai julkisessa virassa tai tehtävässä taikka näihin rinnastettavassa tehtävässä toimivasta, joka voi vaikuttaa hänen toimintansa arviointiin mainitussa tehtävässä, jos esittäminen on tarpeen yhteiskunnallisesti merkittävän asian käsittelemiseksi.

Yksityiselämää loukkaavana tiedon levittämisenä ei myöskään pidetä yleiseltä kannalta merkittävän asian käsittelemiseksi esitettyä ilmaisua, jos sen esittäminen, huomioon ottaen sen sisältö, toisten oikeudet ja muut olosuhteet, ei selvästi ylitä sitä, mitä voidaan pitää hyväksyttävänä.

Jos yksityiselämää loukkaavassa tiedon levittämisessä aiheutetaan suurta kärsimystä tai erityisen suurta vahinkoa ja rikos on myös kokonaisuutena arvostellen törkeä, rikoksentekijä on tuomittava törkeästä yksityiselämää loukkaavasta tiedon levittämisestä sakkoon tai vankeuteen enintään kahdeksi vuodeksi.

Teon tunnusmerkistön täyttymisessä ei ole olennaista asianomistajan henkilökohtainen kokemus kärsimyksestä tai halveksunnasta. Lain valmisteluasiakirjojen mukaan rikoksen tunnusmerkistö täyttyy, kun teon yleisesti ajatellaan aiheuttavan kärsimystä suurelle osalle 
sellaisista ihmisistä, joihin se kohdistuu. Yksityiselämää loukkaava tiedon levittäminen on laitonta vain, jos teko on tahallinen. Tuottamuksellisesta teosta ei rangaista. Tietoa on pitänyt levittää ilman kohteen nimenomaista tai hiljaista suostumusta.

\subsubsection{Tiettyjen alojen lakisääteinen vaitiolovelvollisuus}

Tietyissä ammateissa toimiville on säädetty vaitiolovelvollisuus. Tällaisia säännöksiä on mm. laissa verotustietojen julkisuudesta ja salassapidosta, poliisilaissa, sosiaalihuoltolaeissa ja kirkkolaissa. Näistä vaitiolovelvollisuuksista on poikkeuksia erityisesti viranomaisten välisen tietojenvaihdon kohdalla.

Pappien rippisalaisuus on ehdottomampi. Kirkkolain 5 luvun 2 S:n mukaan yksityisessä ripissä tai muuten sielunhoidossa papille uskottua asiaa ei saa ilmaista, ei myöskään sitä henkilöä, joka papille on uskoutunut. Kun pappia kuulustellaan todistajana, hän ei saa ilmaista sitä, mitä yksityisessä ripissä tai sielunhoidossa on hänelle uskottu. Jos joku yksityisessä ripissä tai sielunhoidossa ilmaisee yleisen lain mukaan ilmiannettavan rikoksen olevan hankkeissa, papin on kehotettava häntä ilmoittamaan asiasta viranomaisille tai sille, jota vaara uhkaa. Jos ripittäytyjä ei suostu siihen, papin on kerrottava hyvissä ajoin ja varovasti asiasta viranomaisille, kuitenkin niin, ettei asianomainen suoraan tai välillisesti tule siitä ilmi.

Seksityöntekijöille ja heidän asiakkailleen ei ole meillä säädetty erityistä vaitiolovelvollisuutta, mutta yksityiselämää loukkaava tiedon levittäminen on heiltä kielletty niin kuin muiltakin. Sama koskee esimerkiksi hotellien, ravintoloiden, kampaamojen ja myymälöiden henkilökuntaa.

Heinäkuuhun 2018 saakka taksiliikennelain 17 \$:n 7 kohdassa oli laatuvaatimussäännös, jonka mukaan taksiliikennettä harjoitettaessa "kuljettaja noudattaa vaitiolovelvollisuutta asiakkaan yksityisyyden turvaamiseksi”. Ehkä säännöstä oli pidetty tarpeellisena siksi, että taksin asiakkaat ovat usein alkoholin vaikutuksen alaisina turhan avoimia jutuissaan.

Nykyisessä taksitoimintaa sääntelevässä laissa tuollaista erityissääntelyä ei enää ole pidetty tarpeellisena. Kukaan ei liene aikaisemmin- 
8 Rahalla vaientamisen verokohtelu ja tuloverotietojen julkisuus

kaan menettänyt taksilupaansa vaitiolovelvollisuuden rikkomisen vuoksi. Yksityiselämää loukkaava tiedon levittäminen on takseiltakin kielletty yleissäännösten perusteella, joten ihmisten ei tarvitse nytkään istua taksimatkoilla tuppisuuna.

\subsubsection{Vaitiolovelvollisuus sopimuksissa}

Työsopimuslain 3 luvun 4 \$:n mukaan työntekijä ei saa työsuhteen kestäessä käyttää hyödykseen tai ilmaista muille työnantajan ammatti- ja liikesalaisuuksia. Jos työntekijä on saanut tiedot oikeudettomasti, kielto jatkuu myös työsuhteen päättymisen jälkeen. Salaisuuden ilmaisseen työntekijän ohella työnantajalle syntyneen vahingon korvaamisesta on vastuussa myös se, jolle työntekijä ilmaisi tiedot, jos viimeksi mainittu tiesi tai hänen olisi pitänyt tietää työntekijän menetelleen oikeudettomasti.

Salassapitosopimuksessa voidaan tarkemmin määritellä salassa pidettävät tiedot, ja salassapitovelvoite voidaan ulottaa myös työsuhteen päättymisen jälkeiseen aikaan. Toisin kuin kilpailukieltosopimus salassapitosopimus voidaan periaatteessa tehdä työntekijän työtehtävistä ja asemasta riippumatta ja ilman työnantajan toimintaan liittyvää erityisen painavaa syytä.

Salassapitosopimuksessa voidaan sopia sopimussakosta. Käytännössä sopimussakon määrään soveltunevat kilpailukieltosopimusta koskevat rajoitukset, eli sopimussakko voi lähtökohtaisesti olla maksimissaan kuuden kuukauden palkkaa vastaava määrä. Salassapitosopimus ei saa olla työntekijän kannalta kohtuuton. Laajasti määritelty salassapitoehto voidaan toisinaan tulkita kilpailukieltosopimukseksi, jolloin siihen sovelletaan työsopimuslaissa säädettyjä rajoituksia.

\subsubsection{Kiristäminen ja lahjonta}

Ryöstöstä ja kiristyksestä säädetään rikoslain 31 luvussa. Ryöstössä on kysymys väkivallan käytöstä tai sillä uhkaamisesta. Kiristämisessä toinen pakotetaan muulla kuin väkivallalla uhkaamalla luopumaan taloudellisesta edusta, johon rikoksentekijällä tai sillä, jonka puolesta hän toimii, ei ole laillista oikeutta. Yrityskin on rangaistava teko. 
Lahjonta on korruptiota, jossa rahalla tai muulla perusteettomalla edulla pyritään vaikuttamaan lahjonnan kohteen käytökseen. Lahjontarikoksia on monenlaisia (ks. rikoslain 14, 16 ja 30 luvut). Lahjuksen antamiseen syyllistyy, jos pyrkii lahjomalla vaikuttamaan virkamiehen toimintaan palvelussuhteessa. Lahjomiseen elinkeinotoiminnassa voi syyllistyä, jos pyrkii saamaan elinkeinotoiminnassa toimivan suosimaan itseään tai jotakuta muuta.

\subsubsection{Seksuaalirikokset}

Seksuaalirikoksista säädetään rikoslain 20 luvussa. Raiskauksesta on tuomittava se, joka pakottaa toisen sukupuoliyhteyteen käyttämällä henkilöön kohdistuvaa väkivaltaa tai uhkaamalla sellaisella (ks. tarkemmin 1 ja 2 \$). Pakottamisesta seksuaaliseen tekoon on tuomittava se, joka väkivallalla tai uhkauksella pakottaa toisen ryhtymään muuhun seksuaaliseen tekoon tai alistumaan sellaisen teon kohteeksi ja se olennaisesti loukkaa toisen seksuaalista itsemääräämisoikeutta $(4 \$)$. Seksuaalisesta hyväksikäytöstä rankaisemisesta säädetään 5 §:ssä ja seksuaalisesta ahdistelusta 5 a §:ssä. Alle 16-vuotiaan lapsen seksuaalisesta hyväksikäytöstä on omat säännöksensä $(6,7$ ja 7a $\$)$.

Seksikaupan kohteena olevan henkilön hyväksikäytöstä säädetään 8 §:ssä. Tähän rikokseen syyllistyy se, joka lupaamalla tai antamalla välitöntä taloudellista arvoa edustavan korvauksen saa parituksen tai ihmiskaupan kohteena olevan henkilön ryhtymään sukupuoliyhteyteen tai siihen rinnastettavaan seksuaaliseen tekoon. Tästä rikoksesta tuomitaan myös se, joka tekee teon, vaikka hänellä ollut syytä epäillä henkilön olevan parituksen tai ihmiskaupan kohteena. Seksuaalipalvelujen ostamisesta alle 18-vuotiaalta säädetään 8a \$:ssä ja lapsen houkuttelemisesta seksuaalisiin tarkoituksiin 8b \$:ssä. Parituksesta ja törkeästä parituksesta säädetään 9 ja 9a §:ssä. Paritukseen syyllistyy se, joka hankkiakseen itselleen tai toiselle taloudellista hyötyä

- järjestää huoneen tai muun tilan korvausta vastaan tapahtuvaa sukupuoliyhteyttä tai siihen rinnastettavaa seksuaalista tekoa varten tai kahdeksaatoista vuotta nuoremman lapsen tekemää, ilmeisellä tavalla sukupuolisiveellisyyttä loukkaavaa tekoa varten, 
8 Rahalla vaientamisen verokohtelu ja tuloverotietojen julkisuus

- vakiintuneena osana liiketoimintaansa majoittaa sellaiseen tekoon ryhtyvää ja siten olennaisesti edistää tekoa,

- yhteystietoja välittämällä tai muuten markkinoi jonkun sellaiseen tekoon ryhtymistä tietäen, että hänen toimintansa olennaisesti edistää teon toteutumista,

- muuten käyttää hyväkseen jonkun ryhtymistä sellaiseen tekoon tai viettelee jonkun sellaiseen tekoon.

Ihmiskaupasta säädetään rikoslain 25 luvun 3 ja 3a \$:ssä. Ihmiskaupasta tuomitaan se, joka

- käyttämällä hyväksi toisen riippuvaista asemaa tai turvatonta tilaa taikka toista painostamalla,

- erehdyttämällä toista tai tämän erehdystä hyväksi käyttämällä,

- maksamalla korvauksen toista määräysvallassaan pitävälle henkilölle tai

- ottamalla vastaan sellaisen korvauksen

ottaa määräysvaltaansa, värvää toisen taikka luovuttaa, kuljettaa, vastaanottaa tai majoittaa toisen hänen saattamisekseen parituksen tai siihen rinnastettavan seksuaalisen hyväksikäytön kohteeksi, pakkotyöhön tai muihin ihmisarvoa loukkaaviin olosuhteisiin.

\subsection{Vaitiolokorvaukset verotuksessa}

\subsubsection{Laaja veronalaisuus lähtökohtana}

Tuloverolakiemme tulokäsitteet ovat laajat (esim. TVL 29 \$). Verovelvollisen kaikki tulot ja hänen saamansa rahanarvoiset edut ovat veronalaisia, ellei laissa nimenomaan toisin säädetä tai ellei kysymyksessä ole sen tyyppinen etuus, jonka voidaan katsoa vakiintuneen oikeusja verotuskäytännön perusteella jäävän kokonaan tulokäsitteen ulkopuolelle. Tulokäsitteen ulkopuolelle jäävät perinnöt ja lahjat, joista osaan kohdistetaan perintö- tai lahjaverotus.

Tulokäsitteen laajuutta osoittaa se, että veronalaiseksi tuloksi on katsottu prostituoidun tulot satunnaisten sukupuolisuhteiden tarjoamisesta maksua vastaan (KHO 1984 II 560). Yleensä kysymys lienee 
henkilökohtaiseen tulolähteeseen kuuluvasta TVL:n mukaan verotettavasta ansiotulosta. Jos toiminta on laajaa ja sitä harjoitetaan jatkuvasti esimerkiksi sitä varten ostetuissa erityisissä vastaanottotiloissa, kysymyksessä voinee olla myös elinkeinotulo, jolloin tulo jaetaan verotuksessa pääomatuloksi ja ansiotuloksi.

\subsubsection{Rikoksella saadun hyödyn verokohtelu}

Käsitystä, jonka mukaan rikollisesta toiminnasta ei kerry veronalaista tuloa, on puolustettu esimerkiksi sanomalla, ettei ole valtiovallan arvon mukaista ikään kuin osakkaana ottaa itselleen osuutta laittomasta saaliista. Toinen keskeinen näkökohta rikollisen toiminnan tulosten tuloverovapauden puolesta perustuu siihen, ettei kysymyksessä voi olla lopullinen tulo, koska rikoksen tuottama hyöty määrätään palautettavaksi asianomistajalle tai tuomitaan valtiolle menetettäväksi.

Kielletyn toiminnan tuloverotusongelmia koskevasta vanhemmasta suomalaisesta kirjallisuudesta voidaan mainita K. J. Ståhlbergin kannanotto 1920-luvulta: 88 "Jos mieli elinkeinoa verottaa, tulee sen olla luvallinen; ja sentähden esim. luvatonta välijuomain myyntiä tai siveettömyyden harjoittamista ei voida kunnallisverotuksessa taksoittaa."

Ongelmaa selvitti myös Aarne Rekola vuonna 1947 ilmestyneessä teoksessaan Tulo- ja omaisuusverolaki (s. 90). Hän totesi, että rikoksesta saatua hyötyä ei tavallisesti pidetty veronalaisena tulona. Hyöty oli Rekolan mielestä verovapaata kuitenkin vain sikäli kuin koko välitön tulonhankkiminen oli rikos, jossa sen tekijä anasti itselleen toiselle kuuluvaa tai sai muutoin yksistään rikoksesta etua, kuten varkaudessa. Jos tulon lähde ulkonaisilta muodoiltaan oli laillinen, vaikka erityiset olosuhteet tekivät toiminnan lainvastaiseksi, kuten sellaisenaan laillisessa liiketoiminnassa tapahtunut koronkiskonta, toiminnasta saatu hyöty oli veronalaista.

Lassi Kilven mukaan (Pääomanvähennys, 1952, s. 469) ei ollut tietenkään oikein, että valtio tulee osakkaaksi kiellettyyn toimintaan. Hän korosti kuitenkin sitä, ettei rikollisen toiminnan verottaminen vielä merkitse toiminnan myöntämistä lailliseksi. Kilven mukaan oli kohtuutonta, jos valtio jättäisi koskematta epärehellisesti hankitut

88 K. J. Ståhlberg, Lait ja asetukset maalaiskuntain hallinnosta, 1926, s. 432. 
tulot samalla kun se ottaa huomattavan osan kunniallisten ihmisten rehellisen työn tuloksista.

Jaakko Voipion vuonna 1968 ilmestyneen väitöskirjan (Verotuksen kiertämisestä, s. 258-259) mukaan ratkaisuun vaikutti erityisesti se, oliko rikos selvitetty ja sen taloudelliset seuraamukset oikaistu.

1980-luvulta mainittakoon Asko Lehtosen kannanotot, joiden mukaan rikoksen tuottama hyöty ei ole rikoksentekijälle jäävää lopullista varallisuuden lisäystä, eikä sitä voida pitää veronalaisena tulona tai omaisuutena, minkä vuoksi rikoksella saadun edun ilmoittamatta jättäminen ei voi tulla rangaistavaksi veropetoksena (Asko Lehtonen, Verorikoksista, 1984, s. 190 sekä Veropetoksesta, 1986, s. 202).

Uusimmasta vero-oikeuden peruskirjallisuudesta mainittakoon Edward Andersson - Esko Linnakangas - Joakim Frände, Tuloverotus (2016), s. 130-131:

”Jos on kysymys toiminnasta, joka sinänsä on normaalia verovelvollisen
toimintaa mutta johon liittyy kriminalisoituja piirteitä (esim. laittoman
ylihinnan ottaminen tai kuljetustulojen kasvattaminen ottamalla kuorma-
autoon ylikuorma), on näin saatu tulo ilmeisesti veronalaista. Jos tulo
konfiskoidaan sen jälkeen, kun siitä on jo verotettu, menetetyksi tuomittu
määrä saadaan kuitenkin vähentää joko konfiskaatiovuoden tulosta tai
valituksen perusteella. Jos verovelvollisen toiminta on jo sinänsä vahvasti
rikollista (hän elättää itseään esim. ryöstöillä, varkauksilla, koronkiskon-
nalla tai salakuljetuksella), siitä saadun tulon veronalaisuus on kyseenalai-
sempaa. Yleensä rikosprosessuaaliset toimet lienevätkin vero-oikeudellisia
toimia tehokkaampia. Kuitenkin erityisesti tapauksissa, joissa rikoksia ei
ole selvitetty, verottaja voi puuttua asiaan selvittämättömän omaisuuden-
lisäyksen verotuksella. (VML $30 \S$ ).”

\subsubsection{Saadun vahingonkorvauksen verovapaus ja vaitiolokorvauksen veronalaisuus}

Tuloverolain mukaan verotettavan henkilökohtaisen tulolähteen vahingonkorvausten veronalaisuutta koskeva perussäännös on ansiotulojen verotusta koskeva TVL $78 \$ .{ }^{89}$ Sen mukaan vahingonkorvaus tai muu siihen verrattava korvaus ei ole veronalaista tuloa, ellei sitä ole

89 Tarkemmin esim. kirjoitukseni Vahingonkorvausten veronalaisuus ja verovapaus henkilöverotuksessa, Verotus 2008 s. 240 ss. 
saatu veronalaisen tulon sijaan tai korvaukseksi elatuksen vähentymisestä. Verovapaita ovat siten esimerkiksi korvaukset kivusta ja särystä. Verottomaksi on katsottu myös tasa-arvolain mukainen hyvitys. Elinkeinotulon verotuksessa veronalaisuus on laajempi, koska vastikkeeksi katsotaan EVL 50 \$:n mukaan myös vahingonkorvaus ja muu sellainen korvaus.

Vaitiolokorvausta ei voida pitää vahingonkorvauksena, esimerkiksi hyvityksenä kivusta tai särystä, vaan se on yleensä lähinnä lisäpalkkioon rinnastettavaa veronalaista tuloa - yleensä TVL:n mukaan verotettavaa ansiotuloa.

\subsubsection{Sanktionluonteisten maksuseuraamusten vähentämiskielto verotuksessa}

Menojen vähennyskelpoisuus on varsinkin elinkeinotulon verotuksessa laaja. Muutamia poikkeuksia kuitenkin on säädetty. Tulon hankkimisesta tai säilyttämisestä johtuneita menoja eivät EVL 16 \$:n mukaan ole sen 5 kohdan sakot, seuraamusmaksut eivätkä muut sanktionluonteiset maksuseuraamukset.

Sanktiota koskeva vähennyskielto on kirjoitettu vain EVL:iin ja MVL:iin. Ilmeisesti lainlaatijoiden ajatus oli, että vähennyskielto koskisi ilman nimenomaista säännöstäkin myös TVL:n mukaan toimitettavaa verotusta, koska vähennysoikeuden katsottiin asettavan kansalaiset eriarvoiseen asemaan, kun vähennyskelpoisuus oli koskenut lähinnä vain elinkeinonharjoittajia.

Vähennyskieltosäännöksen kirjoittajat ovat varmaankin olettaneet, ettei sanktioiden vähentäminen voi olla EVL:a tai MVL:a sovellettaessa laajempaa kuin TVL:n mukaan verotettaessa. Verotuksessa on kuitenkin lähtökohtana nettotulon verottaminen ja verovelvollisen tavoitteita arvostava ns. subjektiivinen arviointi (ks. KHO 1987 II 518 ja KHO 2000:45). Tällä lähtökohdalla on TVL:nkin mukaan toimitettavassa verotuksessa merkitystä, vaikka ei ehkä yhtä vahvasti kuin elinkeinoa verotettaessa. Siksi oikeuskäytännössä ei ehkä hyväksytä TVL:n mukaisessa verotuksessa aivan niin laajaa sanktioiden vähennyskieltoa kuin nyt on EVL:ssa ja MVL:ssa. Sakot yms. selvät rangaistukset jäävät varmaankin hyväksymättä vähennettäviksi myös TVL:n mukaisessa verotuksessa. 


\subsubsection{Lahjusten vähentämiskielto}

Elinkeinoverolaissa on nykyisin nimenomainen säännös (16 \$:n 8 kohta), jonka mukaan tulon hankkimisesta tai säilyttämisestä johtuneita menoja eivät ole lahjukset eivätkä lahjusten luonteiset edut. ${ }^{90}$

Säännöksen sisällyttäminen EVL:iin vastaa aikaisempaa oikeustilaa, jossa mainitut menot on katsottu vähennyskelvottomiksi menon vähentämistä koskevan yleissääntelyn nojalla. Uudessa säännöksessä säädetään yksiselitteisesti, että lahjuksen antamisesta aiheutuneet menot eivät ole vähennyskelpoisia edes silloin, kun lahjuksen antaminen on antajan näkökulmasta välttämätöntä tulon hankkimiseksi. Tämä koskee myös kansainvälistä lahjontaa.

Säännöksen tavoitteiden toteuttaminen edellyttää hallituksen esityksen perustelujen mukaan, ettei vähennyskelpoisuuden epääminen rajoitu vain tilanteisiin, joissa lahjontarikoksesta on annettu tuomio tai vireillä on syyte rikosprosessissa. Verotuksessa on kysymys vähennysperusteiden itsenäisestä oikeudellisesta arvioinnista eikä rikoksen toteamisesta. Toisaalta näyttövelvollisuus jakautuu verotuksessa eri tavalla kuin rikosprosessissa.

Säännös kattaa kaikki tilanteet, joissa lahjuksen antajan tarkoituksena on vaikuttaa lahjottavan virkatoimiin tai tehtäviin. Lahjus voi olla vastikkeeton, mutta toisaalta se voi olla puettu näennäisen vastasuorituksen muotoon, esimerkiksi lahjottavalle tai hänen intressipiirilleen suoritetuksi konsulttipalkkioksi. Lahjus voidaan toteuttaa myös vaikkapa alihintaisena omaisuuden luovutuksena.

Vähennyskelvottomuussäännös on sisällytetty vain EVL:iin, jota sovelletaan elinkeinotoiminnassa kertyvään tuloon. Yleisten periaatteiden mukaisesti lahjukset eivät ole hallituksen esityksen perustelujen mukaan vähennyskelpoisia myöskään MVL:n mukaan verotettavasta maatalouden tulosta tai TVL:n mukaan verotettavasta tulosta.

90 Tarkemmin esim. kirjoitukseni Lahjonta verotuksessa, Verotus 2008 s. 460 ss. 


\subsubsection{Vahingonkorvaukset ja sopimussakot menoina verotuksessa}

Vahingonkorvausten vähennyskelpoisuus tuloverotuksessa ratkaistaan luonnollisia vähennyksiä koskevien yleissäännösten perusteella. Jos vahingonkorvaus siis johtuu tulon hankkimisesta tai säilyttämisestä, se on vähennyskelpoinen.

Kilpailukieltolausekkeen rikkomisesta aiheutuvasta korvauksesta on ollut kysymys seuraavassa ratkaisussa:

KHO 1984 II 572. Henkilöt olivat tehneet A Oy:n kanssa työsopimuksen, jonka mukaan he olivat sitoutuneet olemaan tietyn ajan sopimuksen päättymisestä lukien työskentelemättä $\mathrm{A} O \mathrm{O}: n$ päämiehenä olleen yrityksen hyväksi ja suorittamaan A Oy:lle korvauksen, jos he rikkoivat sitoumuksensa. Henkilöiden mentyä B Oy:n palvelukseen vastoin mainittua sopimusta heidät tuomittiin maksamaan A Oy:lle vahingonkorvausta, jonka B Oy puolestaan hyvitti heille. KVL:ssa katsottiin, että hyvitetty määrä oli henkilöiden veronalaista tuloa, mutta että vahingonkorvaus oli heidän tuloistaan vähennettävissä. Verohallinto valituksessaan vaati lausuttavaksi, ettei vahingonkorvausta saanut vähentää, mutta valitus hylättiin.

Vaitiolosta maksettua sopimukseen perustuvaa korvausta ei voitane rinnastaa esimerkiksi kilpailukieltolausekkeen rikkomiskorvaukseen.

\subsubsection{Seksipalvelun osto ja vaikenemiskorvaus}

Edellä on jo mainittu, että prostituoidun itse harjoittama vapaaehtoinen seksipalvelujen myynti ei ole rikollista toimintaa. Prostituoitua on myös verotettava tällaisesta toiminnasta jäävästä nettotulosta. ${ }^{91}$ Vaikenemiskorvausta voitaneen pitää hänen saamanaan veronalaisena lisäpalkkiona. Mutta jos kysymyksessä todetaan olevan kiristyksenä rangaistava teko, pitää maksun saaja tuomita menettämään etu valtiolle, jolloin häntä ei veroteta siitä.

91 Seksipalvelujen verokohtelusta tarkemmin esim. kirjoitukseni Väkivalta, seksi ja rikokset verotuksessa, Terttu Utriaisen 60-vuotisjuhlajulkaisu (2006) sekä Seksityöntekijöiden ja -asiakkaiden tuloverokohtelu, Oikeus 4/2005. 
Parittajan toiminta on rikollista, ja siitä saatavat tulot pitää tuomita valtiolle menetettäväksi. Rikokseen syyllistyy myös se, joka ostaa seksipalveluja parittajan tai ihmiskaupan uhrilta. Jos seksin ostaminen on ollut rikollista toimintaa, lisäpalkkion eli vaikenemiskorvauksen maksaminen saattaa olla rikoksen jatkamista.

Seksipalvelun ostajan maksamat suoritukset, myös vaikenemiskorvaukset, ovat yksityismenoja, joita ostaja ei voi vähentää verotuksessaan.

\subsection{Vihjepalkkioiden verokohtelu ${ }^{92}$}

Edellä on käsitelty henkilön vaientamista. Lopuksi tarkastellaan sitä, miten verotus koskee vastakkaista ilmiötä: tietojen antamisesta palkitsemista.

Ainakin muutama lehti on maksanut vihjepalkkioita "paparazzeille ja muille vasikoille". Tuollaiset palkkiot ovat saajilleen periaatteessa veronalaisia, mutta lehdet ovat vakuuttaneet, etteivät ne paljasta vihjeen antajan henkilöllisyyttä.

Myös julkisen vallan edustajat maksavat palkkioita rikollisten löytämisestä tai kiinniottamisesta, toisinaan jopa "dead or alive". Joskus palkkiota saatetaan myös pyytää. Tunnetuin tapaus lienee se, kun Juudas Iskariot sai ylipapeilta 30 hopearahaa Jeesuksen kavaltamisesta (Matteus 26:15). Sittemmin hän katui tekoaan ja palautti ennen itsemurhaansa rahat pyhäkköön; niillä ostettiin savenvalajan pelto muukalaisten hautausmaaksi (Matteus 27:3-10).

Poliisin esitettiin Suomessa pitkään vihjepalkkioiden säätämistä verovapaiksi. Vuonna 2005 tuloverolakiin lisättiinkin vihjepalkkioita koskeva 92b \$:n 2 kohta (528/2005). Sen mukaan veronalaista tuloa ei ole "viranomaisen maksama tai välittämä korvaus tai palkkio rikoksen estämistä, rikoksen selvittämistä, rikoksentekijän kiinni saamista tai rikoksella saadun hyödyn takaisin saamista edesauttaneesta tiedosta”. Rikoksen selvittämistä edesauttanut tieto voi olla myös epäillyn syyttömyyden todistava tieto.

92 Tämä jakso pohjautuu pitkälti artikkeliini Vihjepalkkioiden verokohtelu, Verotus 2005 s. $498-500$. 
Verovapaista vihjepalkkioista ei makseta myöskään työnantaja- ja eläkemaksuja. Se, että korvaus tai palkkio on saajalleen verovapaa, ei estä sen vähennyskelpoisuutta asianomistajayrityksen tuloverotuksessa.

Poliisi voi sopia tiedon antajan kertoman tiedon säilymisestä luottamuksellisena. Vaarallisimpien ja vakavimpien rikosten torjunnassa tiedon saaminen saattaa muutoin vaarantua. Tuloverovapautta pidetään tärkeänä, jottei tiedon antajan henkilöllisyys paljastu viranomaisille tehtävien ilmoitusten kautta (HE 266/2004 s. 40). Poliisin tiedossa on tapauksia, joissa kostonhimoiset rikolliset ovat koettaneet selvittää tiedon antajien olemassaoloa ja henkilöllisyyksiä. Tiedon paljastuminen voi uhata vihjeen antajan terveyttä tai jopa lyhentää hänen elinikäänsä.

Laissa tarkoitettu korvaus tai palkkio maksetaan päsaääntöisesti valtion varoista. Säännös mahdollistaa kuitenkin myös esimerkiksi asianomistajan tai vakuutusyhtiön maksaman palkkion verovapauden. On pidetty tarkoituksenmukaisena, että palkkion välittää poliisi, koska esitutkintaviranomaisella on parhaat edellytykset arvioida vihjeen merkitys. Tällöinkin poliisi hyväksyy välitettäväkseen vain selvitettävän rikoksen laatuun ja laajuuteen nähden kohtuulliset vihjepalkkiot. Näin todetaan ainakin hallituksen esityksen perusteluissa.

Kuten edellä on todettu, Suomessa seksipalvelujen osto on tietyin edellytyksin kriminalisoitu. Poliisimme tuskin on viranomaisena valmis ns. juorulehtien tai "Rysän päällä" (Cheaters) -tyyppisten TVohjelmien tuottajien kanssa sellaiseen yhteistyöhön, että nämä juttuja saadakseen poliisin välityksellä maksaisivat vaikkapa seksipalveluja ostavia paljastajille verovapaita palkkioita.

Entä yhteistyö seksipalvelusta maksun saaneen kanssa? Onko mahdollista, että hän (verottomia) lisäansioita saadakseen tulevaisuudessa ilmoittaa poliisille asiakkaansa (= rikolliset) ja näytön varmistamiseksi luovuttaa poliisille asiakasrekisterin tiedot tai salakuvaa seksiaktin ja äänittää keskustelunsa? 


\subsection{Tuloverotietojen julkisuus}

\subsubsection{Verotietojen julkisuuden kehitys Suomessa 1865-2019}

\subsubsection{Tuloverotuksen synty}

Nettotuloon perustuvan tuloverotuksen alkuna pidetään Isossa-Britanniassa vuonna 1799 säädettyä tilapäistä veroa Napoleonia vastaan käydyn sodan rahoittamiseksi. Jatkuvasti tuloverotus on ollut IsossaBritanniassa käytössä vuodesta 1842 . Ison-Britannian vero ei kuitenkaan perustunut kokonaistuloon vaan tulon lähteisiin.

Vuosi 1865 oli merkittävä Suomen verohistoriassa. Tuolloin annettiin Keisarillisen Majesteetin Armollinen Julistus siitä suostuntaverosta, jonka Suomenmaan säädyt olivat ottaneet maksaakseen. Valtion tuloveroa kutsuttiin nimellä "suostunta", kuten yleensä muitakin sellaisia veroja, joita hallitsija ei voinut määrätä ilman säätyjen suostumusta. Näin säädettiin Suomessa ensi kertaa yleinen kokonaistuloon perustuva tuloverotus. Se tapahtui samaan aikaan kuntauudistuksen ja tuloveroperusteisen kunnallisveron säätämisen kanssa. Äänioikeus vaaleissa nähtiin tuolloin veronmaksuun liittyvänä oikeutena: yksi veroäyri vastasi yhtä ääntä, mutta kaupungeissa korkein yhden verovelvollisen äänimäärä oli 25 . Äänioikeuden sitominen verovelvollisuuteen ei poikennut valtiopäivävaaleissa noudatetusta käytännöstä. Porvarissäädyn vaaleissa ja talonpoikaissäädyn valitsijamiesvaaleissa noudatettiin samantapaista periaatetta.

Valtion tuloverotuksen tuotot jäivät hyvin vähäisiksi, ja valtion tuloverosta luovuttiin vuoden 1885 valtiopäivillä. Valtiopäivillä korostettiin, että tuloverorasituksen kohdistuminen oli erittäin epätasaista, minkä vuoksi tuota veroa kannatti käyttää vain tilanteissa, joissa muut lähteet eivät riittäneet. Epäonnistumiseen vaikutti myös liberalistisen veropolitiikan mukainen varsin torjuva suhtautuminen ilmoittamisvelvollisuuteen. Pysyvä valtion tuloverotus Suomeen saatiin vasta vuodesta 1920 alkaen. 


\subsubsection{Julkisuus kunnallisverotuksessa ja valtionverotuksessa ${ }^{93}$}

Kunnallisverotuksessa taksoitusluetteloiden julkistamisesta säädettiin vuonna 1865 annetussa laissa. Sen mukaan kuulutuksella tuli ilmoittaa, missä luettelot ovat halukkaiden kunnan jäsenten tarkastettavana. Tuolloin jokainen verovelvollinen sai tiedon verotuksestaan lähinnä siten, että hänelle luettiin häntä itseään koskevat tiedot. Oli myös säädetty, että kappale takseerausluettelosta piti naulata pitäjäntupaan tai muuhun sopivaan paikkaan. Tämä selittyi myös sillä, että luettelo toimi samalla kunnan äänioikeutettujen luettelona.

1910-luvun lopussa säädetyn kunnallisilmoituslain 19 \$:n mukaan asianomaisen viranomaisen tuli pitää "mikäli mahdollista huolta siitä, ettei taksoitusluetteloita, niiden ollessa nähtävinä yleistä tarkastusta varten, väärinkäytetä taksoitettujen taloudellisen aseman ilmisaattamiseksi”. Käytännössä säännöstä tulkittiin monella tavalla, mutta 1920-luvulla KHO:n ennakkopäätösten mukaisesti vakiintui kanta, jonka mukaan taksoitusluettelot olivat yleisöjulkisia ja että niiden julkaiseminen myytäväksikin oli mahdollista.

Valtionverotuksen veroluettelojen yleisöjulkisuus aluksi pitkään epäselvä, mutta yleisimmin veroluettelojen katsottiin olevan yleisöjulkisuuden ulkopuolella. Kunnallisverotuksesta poikkeavaa kantaa tietojen julkisuuteen perusteltiin sillä, että valtionverotuksessa toisten henkilöiden verotuksella ei ole samanlaista merkitystä kuin kunnallisverotuksessa, jossa yksittäisen verovelvollisen veron suuruus riippuu kaikkien kunnan verovelvollisten äyrien kokonaismäärästä ja on siten sidoksissa muidenkin verotukseen.

Vuonna 1934 lainvalmistelussa asetuttiin sille kannalle, että veroluetteloiden julkisuus toimii erittäin tärkeänä takeena siitä, että veroilmoitukset ja verotus tulevat oikeiksi. Tämä uudistus toteutui vuonna 1943 säädetyssä tulo- ja omaisuusverolaissa ja säilyi, kun valtion- ja kunnallisverotusmenettely 1950- ja 1960-lukujen vaihteessa yhdistettiin.

93 Ks. tarkemmin Mirva Lohiniva-Kerkelän väitöskirja Verosalaisuus (2003) s. 54 ss. 


\subsubsection{Nykyinen sääntely ${ }^{94}$}

Nykyisin on voimassa laki verotustietojen julkisuudesta ja salassapidosta (30.12.1999/1346). Sen 5 §:ssä säädetään tuloverotuksen julkisista tiedoista. Vuosittain toimitetussa verotuksessa tuloverotuksen julkisia verotustietoja ovat verovelvollisen nimi, syntymävuosi ja se maakunta, jonka alueella verovelvollisen kotikunta sijaitsee. Lisäksi julkisia ovat tiedot

1) valtionverotuksessa verotettavasta ansiotulosta;

2) valtionverotuksessa verotettavasta pääomatulosta ${ }^{95}$;

3) kunnallisverotuksessa verotettavasta tulosta;

4) tuloverosta, kunnallisverosta sekä maksuunpantujen verojen ja maksujen yhteismäärästä;

5) ennakoiden yhteismäärästä;

6) veronkannossa maksettavasta ja palautettavasta määrästä.

Tuloverotuksen julkisten tietojen luettelo laaditaan maakunnittain.

94 Suomalainen verotietojen julkistamisen "kateuspäivä" on herättänyt kansainvälistäkin huomiota. Ks. HuffPost 2.11.2018 artikkeli "This Country Publishes Everyone's Income on 'National Jealousy Day'. Meanwhile in the U.S., President Trump won't publish his tax returns."

95 Vuoteen 2005 saakka meillä kannettiin myös varallisuusveroa, ja silloin tieto verovelvollisen varallisuudestakin oli julkinen. Tiedonjulkistamisen valtionpalkintojakin saanut Esko Seppänen on todennut varallisuustietojen julkistamisesta (sananvapauteen.fi): "Yleisradion toimittajina yhdessä Markku Lehtolan kanssa pyrimme saamaan verohallitukselta tietokoneajon Yleisradion rahoituksella suurimmista, yli miljoona markkaa omistavista suomalaisista. Verohallitus kieltäytyi antamasta sitä. Se kieltäytyi maksetusta tietokoneajosta, ja siitä valitettiin korkeimpaan hallinto-oikeuteen, joka piti voimassa verohallituksen päätöksen. Käsittelin omin käsin kaksi miljoonaa verotietoa - kahden miljoonan suomalaisen verotiedot - ympäri maata ja tein suhteellisen tarkat tiedot Suomen miljonääreistä. Se vei aikaa. Tein siitä Hannu Taanilan kirjan kanssa 'Ken on Maassa Rikkahin?' (1983), johon ne tiedot tulivat alustavassa muodossa, ja se oli loistava myyntimenestys. 'Liksaa ja luksusta' oli täydellisempi. Kirjaa myytiin 14000 kappaletta." 
Vuosittain toimitetussa verotuksessa yhteisöjen ja yhteisetuuksien verotustiedoista julkisia ovat verovelvollisen nimi, kotikunta sekä yritys- ja yhteisötunnus. Lisäksi julkisia ovat tiedot

1) verotettavasta tulosta;

2) maksuunpannun veron yhteismäärästä;

3) ennakoiden yhteismäärästä;

4) veronkannossa maksettavasta tai palautettavasta määrästä.

Tiedot ovat julkisia verotuksen päättymishetken mukaisina ja tulevat julkisiksi verovuotta seuraavan kalenterivuoden marraskuun alussa.

Verohallinto on korostanut, että henkilöasiakkaan tuloverotuksen julkiset tiedot ovat henkilötietoja. Jos Verohallinto veisi tiedot Internetiin, tarkoittaisi se koko julkisten tietojen luettelon luovuttamista kaikille Internetin käyttäjille. Laissa on rajoitettu henkilötietojen luovuttamista, eikä mainitun lainen luovuttaminen ole mahdollista. Tästä syystä tiedot ovat sähköisesti nähtävillä vain Verohallinnon toimipisteissä. Tuloverotuksen julkiset tiedot on säädetty laissa julkisiksi, eli Verohallinnolla on lakisääteinen velvoite asettaa kaikkien verovelvollisten julkiset verotustiedot nähtäville ja antaa niistä tietoa. Verohallinto ei siis voi poistaa yksittäisen verovelvollisen tietoja julkisista tiedoista.

Verohallinto luovuttaa vuosittain henkilöiden tuloverotuksen julkisia tietoja sähköisessä muodossa journalistiseen tarkoitukseen. Verohallinnon omaksuman kannan mukaan tiedotusvälineet voivat tilata tietoja niistä henkilöistä, jotka ovat saaneet yhteensä vähintään 100000 euroa valtionverotuksessa verotettavaa ansiotuloa ja pääomatuloa. Verohallinto on vuonna 2019 omaksunut kannan, jonka mukaan EU:n yleisen tietosuoja-asetuksen nojalla Verohallinnon asiakkaalla on oikeus henkilökohtaiseen erityiseen tilanteeseensa liittyvällä perusteella vastustaa tietojensa luovuttamista journalistiseen tarkoitukseen sähköisessä muodossa.

Verohallinto on hyväksynyt kaikki tehdyt 231 vastustamishakemusta, joten näiden henkilöiden tulot eivät sisälly tiedotusvälineille sähköisesti luovutettuun aineistoon. Heidänkin tietonsa ovat silti julkisia. Heistä monien verotiedot tiedotusvälineet hyvin nopeasti pystyivätkin kertomaan. 
Verohallinnon kantaa vastustamisoikeudesta on arvosteltu. ${ }^{96}$ Asiasta on myös kanneltu oikeuskanslerille, mutta oikeuskansleri ilmoitti 7.11.2019, että hän ei ryhdy tutkimaan kantelua, jos siinä tarkoitettuun asiaan on mahdollista hakea muutosta. Verohallinnolta voi pyytää valituskelpoisen päätöksen, jos journalistiseen tarkoitukseen toimitetut tiedot eivät ole riittäviä. Tämän jälkeen asiaan voi hakea muutosta hallinto-oikeudesta. Verohallinnon tietosuojavastaava Helena Hynynen on korostanut, että Verohallinto ei käsittele tietoja journalistisessa tarkoituksessa ja että siten sen on otettava huomioon tietosuoja-asetuksessa säädetty vastustamisoikeus (Helsingin Sanomat 10.11.2019).

\subsubsection{Julkisuuden rajaaminen suurituloisiin ilman vastustamisoikeutta?}

Verotustietojen yleisöjulkisuutta voidaan puoltaa verovelvollisten yhdenvertaisuutta lisäävällä kansalaiskontrollimahdollisuudella. Vielä tärkeämpää nykyisin on, että avoimuus tiedotusvälineiden kautta parantaa kansalaisten mahdollisuuksia verojärjestelmämme oikeudenmukaisuuden ja toimivuuden arviointiin sekä antaa lisävirikkeitä järjestelmän kehittämiseen.

Toisaalta laajaa julkisuutta saatetaan vastustaa viittaamalla kansalaisten yksityisyyden suojaamisen tarpeeseen. Julkisuudesta voi seurata yksittäiselle verovelvolliselle haittaa. Suomessa tosin ryöstäjät ja kiristäjät eivät juuri etsine kohteitaan veroluetteloista.

Osa hyvätuloisista kokee kiusallisena tulojensa julkistamisen ja kadehdituksi joutumisen. Laillisesti saatua suurta tuloa ja suuren veron maksamista ei voida kuitenkaan pitää häpeällisenä, vaan veronmaksu on syytä nähdä yhteiskunnallisesti arvokkaana tekona; vero ei ole rangaistus.

96 Ks. esim. professori Olli Mäenpää, Uusi Suomi 29.10.2019 ja oikeustieteen tohtori Riitta Ollila, Helsingin Sanomat 6.11.2019. Vrt. oikeustieteen tohtori, asianajaja Janne Juusela, jonka mukaan Verohallinnon tulisi kokonaan luopua verotietojen massaluovutuksesta, koska se loukkaa kansalaisten perusoikeuksia (Helsingin Sanomat 8.11.2019). Verotohtoreiden julkisista verotiedoista ks. jäljempänä luku 11.5. 
Helsingin Sanomissa 5.11.2019 julkaistussa mielipidekirjoituksessa Ritva Remes lausuikin: "Ehdotan verotietojen julkaisuun myönteisempää lähtökohtaa. Listan suurimmista veronmaksajista voisi otsikoida: Suomen hyvinvoinnin takaajat. Listassa olisi ensimmäisenä verosumma, sitten maksaja ja vasta lopuksi kaikki tulot. Lukijan mielikuva kääntyisi kateudesta ihailuun.” Tämän kirjan loppuluvussa onkin journalistisessa tarkoituksessa pantu paremmuusjärjestykseen Suomen verotohtorit heidän maksamiensa verojen perusteella.

Pienet tulot voivat viitata yksittäisen verovelvollisen taloudellisiin, terveydellisiin ja muihinkin vaikeuksiin. Helsingin Sanomissa 5.11.2019 olleessa mielipidekirjoituksessa Heikki Pohjola totesi: "Pienten tulojen julkitulo aiheuttaa tuskaa ja häpeää niille, joilla menee huonosti ja jotka kuitenkin yrittävät ylläpitää itsekunnioitustaan ja julkisuuskuvaansa yhteisössä. Koulussa lapset häpeävät vanhempiaan näiden pienten tulojen vuoksi ja saattavat joutua pilkan kohteeksi."

Pienituloisten verotietojen yleisöjulkisuudelle ei ole nykyaikaisessa pitkälle automatisoidussa tuloverotusmenettelyssä juuri yhteiskunnallista tarvetta. Pelkästään uteliaisuuden tyydyttämistä eli tuttavien ja julkkisten tulotietojen tirkistelyä ei voida pitää niin tärkeänä, että kaikkien henkilöiden verotietojen tulisi olla julkisia.

Verotietojen yleisöjulkisuus jakaa mielipiteitä. Kompromissina voisi olla lainmuutos, joka rajoittaisi julkisuuden vain suurituloisiin - esimerkiksi sellaisiin, joiden verotettavat ansio- ja pääomatulot ovat yhteensä vähintään 100000 euroa vuodessa.

Tietoteknisesti olisi mahdollista laajentaa julkisia tietoja niin, että tietoihin sisältyisi myös osinkotulojen verovapaa osuus. Lisäksi julkisuus voitaisiin ulottaa verovelvollisen vahingoksi tehtyihin verotuksen oikaisuihin. ${ }^{97}$

Mahdollisuus vastustaa tietojen sähköistä antamista tiedotusvälineille tuskin on välttämätön.

97 Pääministeri Antti Rinteen hallituksen ohjelman mukaan myös verotuksen päättymisen jälkeen tehdyt muutokset verotustietoihin tulisivat julkisiksi. Nykyisen hallituksen ohjelma on samanlainen. Ks. myös Lauri Finér, Verolistaukset voidaan pitää julkisina, Veropolitiikka-blogi 5.11.2019. 


\section{9 \\ Sotaveroista sote-veroihin}

\subsection{Sotaveroista}

Jo 1200-luvulla meillä alkoi säännöllinen veronmaksu kruunulle. Ahvenanmaa on muinoin suorittanut merisotavelvollisuutta (ledung). Siihen liittyvän sotalomaveron (ledungslama) järjestämisessä on samoja muotoja, joita muissa Skandinavian maissa käytettiin 1100-luvun lopulla ja 1200-luvun alkupuolella. Samantapaisia järjestelyjä oli myös Varsinais-Suomen ruotsalaisilla seuduilla. Sotalomavero on vanhin tunnettu kruununveromme. Se tarkoitti maksua siitä, ettei tarvinnut "asevelvollisena" soutaa sota- eli rosvolaivaa. ${ }^{98}$ Tähän ideologiaan liittyy myös ritariston ("ratsumiesten") rälssi (ruots. frälse) eli verovapaus.

Sotaveroista suppeassa merkityksessä on puhuttu tarkoittaen sodan aikana ilman valtiopäivien suostumusta säädettyjä veroja. Tällaisista mainittakoon I maailmansodan aikaiset kiistanalaiset telefoonivero, postimerkein kannettu huvivero ja junamatkustajilta peritty rautatievero.

98 Sveitsissä peritään nykyisinkin asevelvollisuuden korvausveroa (Wehrpflichtersatzabgabe) niiltä, jotka eivät suorita armeija- tai siviilipalvelusta. 
Vanhin historiallisten lähteiden mainitsema veronmaksun muoto on ollut työ yhteiskunnan ja hallitsijan hyväksi. Muinaisessa Egyptissä puhutussa kielessä työtä, työvoimaa ja raadantaa tarkoittava sana oli synonyymi sanalle vero. Byrokratian lisäksi merkittävimmät kohteet, joihin käytettiin kansan veroluonteista työvoimaa tai kansalta verona kannettuja luonnontuotteita ja rahaveroja, olivat maanpuolustus, kastelujärjestelmien rakentaminen ja ruokavarastojen kokoaminen katovuosien varalle, mutta veroja käytettiin myös eliitin enemmän tai vähemmän yksityisiin hankkeisiin, kuten palatsien ja hautamonumenttien rakentamiseen.

\subsection{Sosiaaliturvan kehitys ${ }^{99}$}

\subsubsection{Keskiajalta 1800-luvun puoliväliin}

Ennen kristinuskon leviämistä Suomeen köyhistä ja vaivaisista huolehtiminen täällä kuului perheelle ja suvulle. Katolisena aikana verovelvollisten talonpoikien kirkolle maksettavista ns. kymmenysveroista tuli tietty osa varata köyhien avustamiseen.

Suora almujen jakaminen yksityisiltä köyhille herätti arvostelua, ja siksi aloitettiin avustusten jako luostareiden ja kirkon kautta. Keskiajalla syntyi uskonnollisten yhteisöjen ylläpitämiä hoitolaitoksia. Protestanttisella kaudella valtio otti vastuun hospitaaleista, ja niistä muodostui vähitellen ennen muuta spitaalisten tai sellaisiksi epäiltyjen sekä väkivaltaisiksi osoittautuneiden mielenvikaisten sijoituspaikkoja.

Ruotsin suurvaltakaudella 1600-luvulla verotus oli jatkuvien sotien vuoksi ankaraa ja talonpoikien asema heikkeni. Verotuksen lisäksi kadot autioittivat valtakuntaa. Pahimmat katovuodet ajoittuivat vuosille 1696-1697, jolloin arviolta kolmannes suomalaisista menehtyi. Köyhien talonpoikien ja tilattomien märää lisääntyi voimakkaasti. Maatalouden vaikeudet aiheuttivat levottomuuksia ja hätää, joka ilmeni maaltamuuttona. Maalta pois pyrkivien nälkiintyneiden ihmisten pääsyä kaupunkeihin ryhdyttiin rajoittamaan.

99 Esko Linnakangas - Leila Juanto, Verojen historia (2016), s. 305 ss. ja siellä mainitut lähteet. 
1500-luvulta lähtien maaseudulla alkoi olla seurakuntien ylläpitämiä vaivaistupia, jotka saivat kruunun avustuksia. Irtolaissäädökset kiristyivät 1500-luvulta lähtien, ja kaupunkien irtolaisratsioissa kiinni saatuja työkuntoisia irtolaisia passitettiin kruunun pakkotöihin. 1600-luvulta lähtien perustettujen pakkotyölaitosten avulla työkykyiset köyhät (irtolaiset) pyrittiin erottamaan työkyvyttömistä köyhistä (vaivaisista). Näistä ryhmistä vain vaivaisille haluttiin antaa apua myöntämällä heille lupa kerjätä.

Köyhäinhoitopolitiikka jatkui 1740-luvulle saakka muuttumattomana. "Oikeita köyhiä" varten tuli seurakuntien köyhäinhoidon olla järjestyksessä, mutta "laiskureiden" (irtolaisten ja työkykyisten kerjäläisten) metsästämiseksi maaherrat ja kirkkoherrat määrättiin 1730-luvulla luetteloimaan kaikki läänien ja seurakuntien itselliset. Pakkotyölaitosverkostoa laajennettiin.

Vuonna 1763 annettiin hospitaali- ja lastenkotiasetus, joka korvasi aikaisemmat köyhäinhoitosäädökset. Sen mukaan vaivaishoitoon oikeutettuja olivat

1. vanhuudenheikot, kroonisesti sairaat ja vammaiset, jotka eivät itse kyenneet hankkimaan elatustaan ja joilla ei ollut heitä hoitamaan kykeneviä omaisia,

2. mielisairaat ja parantumattomia tarttuvia tauteja sairastavat, sekä 3. köyhät, hoitoa tarvitsevat lapset.

1700-luvun loppupuolella säätyläishyväntekeväisyys eli nousukautta. Leskien ja lasten tulevaisuuden turvaamiseksi luotiin kattavampi järjestelmä: leski- ja orpokassat. Kullakin säädyllä - papistolla, armeijalla ja virkamiehistöllä - oli omat kassansa. Kaupunkityöväen ja maaseudun kasvavan tilattoman väestön turvana ei ollut muuta virallista turvajärjestelmää kuin seurakunnan antama vaivaisapu.1700-luvun kuluessa seurakunnallinen vaivaishoito tehostui ja yhdenmukaistui. Vaivaishoidossa käytettiin kolmea tapaa: vaivaiset voitiin sijoittaa köyhäintupaan, heille voitiin antaa raha-avustuksia taikka heidän hoitovastuunsa voitiin jakaa maalla tilallisten tai kaupungeissa talonomistajien kesken.

1700-luvun puolivälissä väestönkasvu alkoi näkyä työkyvyttömien ja avun tarpeessa olevien määrän kasvuna. Kassa-avustusten täyden- 
nykseksi muodostui vaivaisruotujärjestelmä, jossa muutama talo vuoron perään huolehti hoidon tarpeessa olevasta. Kerjäläisten määrän yhä kasvaessa tuli 1700-luvun lopulla ruodutuksen täydentäjäksi paikallisten vaivaishoitoverojen kerääminen.

Väestönkasvu jatkui voimakkaana 1800-luvulla. Tilallisten määrä ei enää kasvanut, vaan kasvu kohdistui ennen muuta tilattomiin - niihin ryhmiin, joiden asema oli taloudellisesti epävarmin ja sosiaalisesti heikoin. Maaseudulle syntyi liikaväestö, eikä työvoimalle riittänyt täyttä kysyntää.

1840-luvulla alkoivat monet keski- ja yläluokkaiset naiset perustaa hyväntekeväisyysyhdistyksiä. Nämä rouvasväenyhdistykset suuntasivat sosiaalisen työnsä painopisteen erityisesti turvattomien lasten huoltoon ja köyhälistöperheiden vaimojen tukemiseen.

1830-luvulla Suomessa oli raivonnut koleraepidemia, jonka aikana kiertelevä kerjäläisyys yleistyi. Alkoi uuden lainsäädännön valmistelu, jonka tuloksena annettiin vuonna 1852 asetus vaivaisten holhouksesta. Samaan kokonaisuuteen liittyi myös irtolaisuutta ja laillista suojelua koskeva asetus, jolla laajennettiin palvelupakkoa ja rajoitettiin muutto-oikeutta. Näin pyrittiin köyhä väestö sitomaan sijoilleen.

Seurakunnallisen avun saaminen oli toissijainen keino, sillä yksityisoikeudellinen elatusvelvollisuus edellytti puolisoiden huolehtivan toisistaan ja vanhempien huolehtivan lapsistaan. Vaivaishoitoasetus määräsi apua tarvitsevat ennen seurakunnan apuun turvautumista kääntymään sukulaisten puoleen. Lisäksi palkollissääntö määräsi isännät huolehtimaan pitkäaikaisten, vanhuudenheikoiksi käyneiden palkollistensa elättämisestä. Seurakunnille tuli sitoviksi velvollisuuksiksi kerätä pakollisia köyhäinhoitoveroja ja toimia vaivaishoitohallitusten hallintoeliminä.

\subsubsection{0-luvulta 1930-luvun puoliväliin}

Vuosina 1865 ja 1873 annetuilla kunnallisasetuksilla vaivaishoito siirtyi seurakunnilta kunnille. Seurakuntahallinnon aikana avustustoiminta oli mielletty paljolti armeliaisuudeksi, jonka laajuus riippui vaivaiskassan tulonlähteiden riittävyydestä. Kunnallinen vaivaishoito sen sijaan oli budjettiperusteista taloushallintoa, joka rahoitettiin yhtenäisellä verolla. 
Vuoden 1879 vaivaishoitoasetuksen mukaan kunnilla oli velvollisuus avustaa vain työkyvyttömiä, sairaita, vanhuksia ja alaikäisiä. Työkykyisten henkilöiden avustaminen jäi kuntien omaan harkintaan: heille sai antaa apua vain työtä vastaan. Siksi jokaisen kunnan tuli perustaa joko yksin tai yhdessä muiden kuntien kanssa työlaitos. Työlaitostyyppisiä vaivaistaloja perustettiin hitaasti; 1880-luvun puolivälissä niitä oli toiminnassa vain kymmenkunta. Myöhemmin kunnat alkoivat saada valtionlainoja vaivaistalojen rakentamiseen ja avustuksia vaivaistalojen johtajien palkkaamiseen. Vaivaishoito siirtyi näin kunnilta valtiovetoiseksi.

1800-luvun lopulla luovuttiin ruotuhoidosta, joka oli ollut tyypillinen omavaraistalouteen kuulunut hoitomuoto. Kun vaivaishoidosta vastaavien pyrkimyksenä oli minimoida huoltokustannukset, siirryttiin 1800-luvun puolivälissä yleisesti huutokauppamenettelyyn, jossa hoitotehtävän sai sen vähimmällä maksulla ottamaan tarjoutunut. Vaivaishuutokaupat olivat laajimmillaan 1870- ja 1880-luvuilla. 1890-luvun alussa vaivaishuutokaupat kiellettiin, mutta niitä järjestettiin vielä 1910-luvulla.

Vuonna 1922 uusi köyhäinhoitolaki korvasi vaivaishoitoasetuksen. Se vahvisti sosiaalipoliittisen ajattelutavan muuttumista. Vaivaistalon nimikin muutettiin lain myötä kunnalliskodiksi. Kunnat pyrkivät minimoimaan sosiaalimenojaan antamalla apua vain pahimpaan tarpeeseen.

\subsubsection{0-luvun loppupuolelta 1950-luvun loppupuolelle}

Vuonna 1937 säädettiin kansaneläkelaki, jota toteuttamaan perustettiin Kansaneläkelaitos. Järjestelmä rakennettiin säästöperiaatteelle, ja vakuutusmaksut kertyivät jokaisen kansalaisen omalle tilille. Kansaneläkejärjestelmä muutti sosiaaliturvan painopistettä, joka oli aikaisemmin ollut köyhäinhoitokeskeinen.

Myös äitiysavustuslaki säädettiin vuonna 1937. Sen perusteella maksettiin avustuksia vähävaraisille synnyttäjille. Vuonna 1938 annettiin laki korvauksen suorittamisesta sotapalveluksessa aiheutuneen ruumiinvamman tai sairauden johdosta. Uusi sotatapaturmalaki annettiin vuoden 1941 alussa. 
Työmarkkinajärjestöjen välisissä suhteissa alkoi uusi aikakausi, kun SAK ja STK vuonna 1940 solmivat "tammikuun kihlauksen" ja loivat keskinäiset neuvottelusuhteet. Suomen ensimmäinen sodanjälkeinen suuri sosiaalipoliittinen reformi oli lapsilisäjärjestelmän luominen. Siitä päätettiin syksyllä 1947 SAK:n antaman yleislakkouhkauksen varjossa. Lapsilisä maksettiin äidille. Se oli verovapaata tuloa, ja sen saivat kaikki äidit tulo- ja omaisuusasemastaan riippumatta. Lapsilisät eivät olleet vähäinen asia, sillä vuonna 1949 niiden osuus valtion varsinaisista menoista oli $10 \%$.

Vuonna 1937 säädetty kansaneläkejärjestelmä osoittautui epäonnistuneeksi. Eläkkeet jäivät hyvin pieniksi, ja inflaatio vei pohjaa rahastointiin perustuvalta systeemiltä. Vuonna 1956 saatiin uusi kansaneläkelaki, jossa eläkemenot rahoitettiin pääosin vuotuisilla vakuutusmaksutuloilla.

\subsubsection{0- ja 1960-lukujen vaihteesta 2010-luvulle}

1950-luvun puolivälissä syntyi vaatimus virkamieseläkkeen tyyppisestä ansioeläkkeestä kaikille työntekijöille. Työntekijäjärjestöt asettivat työeläkeasian tutkimisen yhdeksi vuoden 1956 yleislakon lopettamisen ehdoksi. Lopulta keväällä 1960 saatiin valmiiksi sellainen pakollista työeläkevakuutusta koskeva lakiesitys, joka tyydytti työmarkkinaosapuolia. Toteutuneessa ratkaisussa työnantajapuolen kannalta myönteistä oli työeläkejärjestelmän rahastojen antaminen yksityisten vakuutuslaitosten, eläkesäätiöiden ja eläkekassojen hoitoon ilman valtion vahvaa kontrollia. Työntekijöiden eläkelaki ja lyhytaikaisessa työsuhteessa olevien eläkelaki tulivat voimaan vuonna 1962. Eläketurvaa täydennettiin 1970-luvun alussa maatalous- ja muiden yrittäjien eläkkeillä.

Sairausvakuutus on kolmas sotien jälkeinen merkittävä sosiaalireformi. Vuoden 1963 sairausvakuutuslaki saatiin aikaan monivaiheisen komiteatyön jälkeen. Kansaneläkelaitos sai sairausvakuutukset hoitoonsa, ja vakuutus ulotettiin koko väestöön, ei ainoastaan palkansaajaväestöön. Korvausjärjestelmän kustannukset sälytettiin valtion, työnantajien ja kunnallisverotuksessa verotettujen vakuutettujen maksettaviksi. 
Vuoden 1995 loppuun asti kansaneläke muodostui kaikille yhtä suuresta ja tuloista riippumattomasta pohjaosasta sekä muiden henkilölle maksettavien eläkkeiden määrästä riippuvasta lisäosasta. Vuoden 1997 alusta pohjaosa ja lisäosa yhdistettiin sellaiseksi kansaneläkkeeksi, jota muut eläkkeet yleensä pienentävät: kansaneläke on muihin eläketuloihin nähden toissijainen.

Vakuutetun kansaneläkevakuutusmaksun perimisestä luovuttiin vuoden 1996 alussa, minkä jälkeen vakuutetut eivät ole osallistuneet kansaneläkkeiden rahoituksen. Päättäessään työnantajan kansaneläkemaksun alentamisesta osana tammikuussa 2009 julkistettua talouden elvytyspakettia hallitus päätti samalla poistaa työnantajan kansaneläkemaksun kokonaan vuoden 2010 alusta, ja laki muutettiin tällaiseksi. Maksun poistamisen tavoitteena oli alentaa työnantajien työllistämiskustannuksia sekä siirtää verotuksen painopistettä työn verotuksesta ympäristö- ja energiaveroihin. Sittemmin valtio on yksin vastannut kansaneläkkeiden kustannuksista.

\subsection{Itsenäisen Suomen valtion menorakenteen kehitys}

Maamme itsenäistymisestä 1940-luvun puoliväliin Puolustusvoimien ja suojeluskuntajärjestön osuus valtion menoista oli erittäin merkittävä. Se oli 1910- ja 1920-lukujen vaihteessa vähän yli $20 \%$, 1920-luvulla yleensä noin $15 \%$ ja 1930-luvulla taas runsaat $20 \%$.

Sodan jälkeen tilanne muuttui ratkaisevasti. Esimerkiksi vuonna 1946 Puolustusvoimien osuus valtion talousarvion mukaisista varsinaisista menoista oli $7 \%$. Sen jälkeen puolustusministeriön osuus valtion talousarvion menoista on ollut 5-6\%:n tasolla (5,6 \% v. 2019). Puolustusvoimiemme kustannusten osuus bruttokansantuotteesta ja asukasmäärään nähden on kansainvälisesti vertaillen melko suuri. ${ }^{100}$

Sosiaali- ja terveysmenojen osuus valtion varsinaisista menoista oli pitkään hyvin vaatimaton. Vuonna 1922 se oli 2,3 \% ja vuosina 1939 ja 1946 noin $3 \%$, mutta vuonna 1956 se oli jo noussut yli $20 \%$ :iin.

100 Ks. Wikipedian luettelo valtioiden sotilaallisista menoista ja siellä mainitut lähteet. 
Vuoden 2009 valtion budjetista sosiaali- ja terveysministeriön menojen osuus oli 32,6\%, ja vuonna 2019 se oli $27,1 \%$.

Koulutusmenojen ja muiden opetusministeriön hallinnonalan menojen osuus valtion talousarvion mukaisista menoista oli vuonna 1922 noin $10 \%$ ja vuonna 1939 noin $17 \%$. Sodan jälkeen vuonna 1946 se oli vain runsaat $4 \%$, mutta vuonna 1956 taas jo noin $14 \%$. Vuonna 1966 se oli noin $16 \%$, vuonna 1975 noin 17,5\%, vuonna 1986 noin 16 \% ja vuonna 1996 noin 14 \%. Vuonna 2019 se oli $11,7 \%$.

Vuonna 2019 valtion budjetoidut menot 55,7 miljardia euroa jakautuivat ministeriöittäin seuraavasti:

\begin{tabular}{|l|c|}
\hline Valtiovarainministeriö & $17,5(31,4 \%)$ \\
\hline Sosiaali- ja terveysministeriö & $15,1(27,1 \%)$ \\
\hline Opetus- ja kulttuuriministeriö & $6,5(11,7 \%)$ \\
\hline Puolustusministeriö & $3,1(5,6 \%)$ \\
\hline Liikenne- ja viestintäministeriö & $3,0(5,4 \%)$ \\
\hline Maa- ja metsätalousministeriö & $2,6(4,7 \%)$ \\
\hline Työ- ja elinkeinoministeriö & $2,5(4,5 \%)$ \\
\hline Sisäministeriö & $1,5(2,7 \%)$ \\
\hline Ulkoministeriö & $1,1(2,0 \%)$ \\
\hline Oikeusministeriö & $1,0(1,8 \%)$ \\
\hline Ympäristöministeriö & $0,2(0,4 \%)$ \\
\hline
\end{tabular}

Valtiovarainministeriön 17,5 miljardin euron määrärahasta noin 8,5 miljardia euroa, siis noin puolet, oli valtionosuutta kunnille peruspalvelujen järjestämiseen ja noin 5 miljardia euroa oli eläkkeitä. Sosiaalija terveysministeriön 15,1 miljardin euron määrärahasta suurimmat erät olivat seuraavat:

\begin{tabular}{|l|l|}
\hline $\begin{array}{l}\text { Perhe- ja asumiskustannusten tasaus, } \\
\text { perustoimeentulotuki ja eräät palvelut }\end{array}$ & $4,4 \mathrm{mrd}$ \\
\hline Työttömyysturva & $2,4 \mathrm{mrd}$ \\
\hline Sairausvakuutus & $2,4 \mathrm{mrd}$ \\
\hline Eläkkeet & $4,7 \mathrm{mrd}$ \\
\hline
\end{tabular}


Sisäministeriön 1,5 miljardin euron määrärahasta Poliisin osuus oli 0,8 miljardia euroa ja Rajavartiolaitoksen runsaat 0,2 miljardia.

\subsection{Kokonaisveroaste}

Kokonaisveroaste on yleisimmin käytetty verotuksen tason mittari. Sillä tarkoitetaan julkisen sektorin keräämien pakollisten verojen ja veronluonteisten maksujen kertymää suhteessa saman ajanjakson bruttokansantuotteeseen. ${ }^{101}$

Suomen kokonaisveroaste oli vielä vuonna 1970 noin 32 \%, joka oli samaa luokkaa kuin Saksassa mutta selvästi vähemmän kuin esimerkiksi Ruotsissa, Itävallassa, Alankomaissa ja Isossa-Britanniassa. Vuonna 1980 Suomen kokonaisveroaste oli noin 35 \%, kuten Saksassa ja Isossa-Britanniassa, mutta selvästi vähemmän kuin esimerkiksi Itävallassa, Alankomaissa ja Ruotsissa. 1990-luvulla kokonaisveroasteemme vaihteli vuosittain 41,5 \%:sta 45,7 \%:iin, joka oli selvästi suurempi kuin mainituissa vertailumaissa. Ruotsissa kokonaisveroaste ylitti jo $50 \%$. Kokonaisveroasteemme nousu on pysähtynyt 2000-luvulla, kuten seuraavat luvut osoittavat:

\begin{tabular}{|l|l|}
\hline 2000 & $45,8 \%$ \\
\hline 2001 & $43,2 \%$ \\
\hline 2002 & $43,3 \%$ \\
\hline 2003 & $42,4 \%$ \\
\hline 2004 & $41,8 \%$ \\
\hline 2005 & $42,1 \%$ \\
\hline 2006 & $42,2 \%$ \\
\hline 2007 & $41,5 \%$ \\
\hline 2008 & $41,2 \%$ \\
\hline 2009 & $40,9 \%$ \\
\hline 2010 & $40,8 \%$ \\
\hline &
\end{tabular}

101 Tilastoista ks. Tilastokeskus, OECD ja Eurostat. 
9 Sotaveroista sote-veroihin

\begin{tabular}{|l|l|}
\hline 2011 & $42,0 \%$ \\
\hline 2012 & $42,7 \%$ \\
\hline 2013 & $43,6 \%$ \\
\hline 2014 & $43,8 \%$ \\
\hline 2015 & $43,8 \%$ \\
\hline 2016 & $44,0 \%$ \\
\hline 2017 & $43,3 \%$ \\
\hline 2018 & $42,7 \%$ \\
\hline
\end{tabular}

Suomen kokonaisveroaste on yhä EU-maiden vertailussa suurimpia. Vuonna 2017 kärkikymmenikkö oli seuraava:

\begin{tabular}{|l|l|}
\hline Ranska & $46,2 \%$ \\
\hline Tanska & $46,0 \%$ \\
\hline Belgia & $44,6 \%$ \\
\hline Ruotsi & $44,0 \%$ \\
\hline Suomi & $43,3 \%$ \\
\hline Italia & $42,4 \%$ \\
\hline Itävalta & $41,8 \%$ \\
\hline Kreikka & $39,4 \%$ \\
\hline Alankomaat & $38,8 \%$ \\
\hline Luxemburg & $38,7 \%$ \\
\hline
\end{tabular}

Irlannissa kokonaisveroaste oli tuolloin vain 22,8 \%. Virossa, Latviassa ja Liettuassa se oli noin $30 \%$. EU:n ulkopuolisista maista mainittakoon USA 27,1 \% ja Sveitsi 28,5 \%. Kaikkien OECD-maiden keskiarvo oli $34,2 \%$. 


\subsection{Aikaisempia maakuntahallintoehdotuksia}

Läänien rinnalla on meillä vanhastaan ollut maakunniksi kutsuttuja alueita, joilla ei kuitenkaan ole ollut organisoitua itsehallinnollista asemaa. Säädettäessä ensimmäisiä kunnallisasetuksia Suomessa vuosina 1865 ja 1873 ylemmänasteinen itsehallinto oli säätyvaltiopäivillä esillä useaan otteeseen, mutta siitä ei seurannut lainsäädäntötoimia. Uudelleen asiasta keskusteltiin valtiopäivillä ensin 1900-luvun taitteessa ja sitten vuonna 1917 käsiteltäessä kunnallishallinnon uudistamista. Suuret yhteiskunnalliset mullistukset - Suomen itsenäistyminen ja sisällissota - kuitenkin hautasivat uudistuksen, mutta vuoden 1919 hallitusmuotoon $(51.2 \$)$ kirjattiin kuitenkin ylemmänasteista itsehallintoa koskeva säännös.

Itsenäisyyden alkuvuosista lähtien ylemmänasteisen itsehallinnon toteuttamista valmisteltiin asiaa selvittäneessä komiteassa ja lainvalmistelukunnassa, joiden ehdotukset kohtasivat vastustusta. Uudistuksen kariutti vuonna 1932 uudistettu kuntien yhteistyötä koskeva lainsäädäntö, jossa kuntainliitto tuli kuntien pääasialliseksi yhteistoimintamuodoksi.

Kysymys ylemmänasteisesta itsehallinnosta nousi jälleen esille 1940-luvun lopussa ja oli siitä asti jatkuvan valmistelutyön - ja kiistojen - kohteena 1970-luvun alkupuolelle saakka. Vuonna 1972 käynnistettiin uusi yritys koko väliportaan hallinnon uudistamiseksi. Väliportaanhallintokomitean mietinnön pohjalta uudistuksia valmisteltiin aina 1980-luvun puoliväliin saakka, jolloin aluehallinnon kokonaisuudistuksen mahdottomuus kävi selväksi.

Aluehallintoa kehitettiin kokonaisuudistuksen hautauduttua siten, että koottiin alueellista kuntainliittojärjestelmää, erityisesti erikoissairaanhoidon kuntainliittohallintoa. Myöhemmin 1990-luvulla kuntainliittojen tilalle muodostettiin kunnallislain osittaisuudistuksella kuntayhtymät. Vuonna 1992 pääministeri Esko Ahon hallitus käynnisti hankkeen, jonka alkuperäisenä tarkoituksena oli kokeilla maakuntahallintoa. Kokeiluun suhtauduttiin kuitenkin varauksellisesti, minkä vuoksi asiaa valmistellut selvitysmies Kauko Sipponen laati lakiluonnoksen maakuntayhtymistä. Lainsäädäntötoimiin asiassa ei tälläkään kertaa ryhdytty. 
Konkreettisena uudistuksena 1990-luvun alkupuolella toteutettiin kuntayhtyminä toimivien makunnan liittojen perustaminen seutukaavaliittojen ja yksityisoikeudellisten maakuntaliittojen sijaan. Maakunnan liitosta tuli aluekehitysviranomainen, jolla on päävastuu alueen yleisestä kehittämisestä. Uudistus ei tarkoittanut ylemmänasteisen itsehallinnon luomista aluetasolle, jolla kunnallinen hallinto säilyi edelleen hajanaisena.

Vuoden 2000 perustuslaissa säädetään itsehallinnosta kuntaa suuremmalla hallintoalueella. Tällaista hallintoa ei toistaiseksi ole perustettu. Vuosina 2004-2012 toteutettiin Kainuun makunnassa kuitenkin erityislain nojalla hallintokokeilu, joka paljolti vastasi perustuslaissa säädettyä itsehallintoa kuntaa suuremmalla alueella.

Vuoden 2017 alussa annetussa pääministeri Juha Sipilän hallituksen esityksessä (HE 15/2017) ehdotettiin säädettäväksi mm. maakuntalaki sekä laki sosiaali- ja terveydenhuollon järjestämisestä. Esityksellä oli tavoitteena myös alueellisen tasa-arvon lisääminen.

Esityksen mukaan Suomeen olisi muodostettu 18 makuntaa. Maakunnat olisivat olleet julkisoikeudellisia yhteisöjä, joilla olisi ollut alueellaan itsehallinto. Uudet makunnat olisivat olleet alueeltaan nykyisiä maakuntia vastaavia eräin yksittäisiä kuntia koskevin poikkeuksin. Maakuntien ylin päättävä toimielin olisi ollut vaaleilla valittava maakuntavaltuusto. Maakunnat olisivat hoitaneet niille laissa säädettäviä tehtäviä, joista keskeisiä olisivat olleet sosiaali- ja terveydenhuolto sekä pelastustoimi. Lisäksi erikseen olisi valmisteltu eräiden elinkeino-, liikenne- ja ympäristökeskusten, työ- ja elinkeinotoimistojen ja aluehallintovirastojen sekä maakuntien liittojen ja ympäristöterveydenhuollon tehtävien siirtämistä maakuntien vastuulle.

Sosiaali- ja terveydenhuollon järjestämisestä annettavalla lailla olisi siirretty kunnallisen sosiaali- ja terveydenhuollon järjestämisvastuu perustettaville maakunnille. Lisäksi hyvinvoinnin ja terveyden edistäminen olisi jäänyt kuntien tehtäväksi, minkä lisäksi maakuntien olisi pitänyt myös omassa toiminnassaan huolehtia hyvinvoinnin ja terveyden edistämisestä.

Sosiaali- ja terveydenhuollon palvelutuotantoa olisi monipuolistettu siten, että maakunnan omilla sekä yksityisillä ja kolmannen sektorin palveluntuottajilla olisi ollut tasapuoliset toimintaedellytykset tuottaa kaikkia markkinoilla olevia palveluja. 
Maakuntien toiminta olisi rahoitettu pääosin valtion rahoituksella ja osaksi palvelujen käyttäjiltä perittävillä asiakasmaksuilla, mutta ei ainakaan alkuvaiheessa erillisellä maakuntaverolla. Rahoitus olisi määräytynyt laskennallisesti osin makunnan asukasluvun ja osin palvelujen tarpeen ja olosuhdetekijöiden perusteella. Valtion rahoitus olisi ollut maakunnille yleiskatteellista.

Rahoitusvastuun siirtyessä kunnilta valtiolle valtion tuloja olisi ollut lisättävä ja kuntien tuloja vastaavasti vähennettävä niiltä pois siirtyvän rahoitusvastuun verran. Tämän takia valtion verotuloja ehdotettiin kasvatettavaksi kiristämällä valtion ansiotuloverotusta. Jotta kokonaisveroaste ei olisi noussut, kunnat olisi velvoitettu alentamaan kunnallisveroa. Myös kuntien osuutta yhteisöveron tuotosta olisi alennettu ja valtion osuutta vastaavasti kasvatettu. Verotusta koskevat muutokset olisi toteutettu verovelvollisten kannalta mahdollisimman neutraalisti.

Uudistukseen liittyen valmisteltiin asiakkaan valinnanvapautta koskeva lainsäädäntö. Maakunta- sekä sosiaali- ja terveydenhuoltouudistuksen tavoitteena oli myös vähentää julkisen talouden kestävyysvajetta. Maaliskuussa 2019 todettiin hallituksen esityksessä yhä perustuslaillisia ongelmia siinä määrin, että asiaa ei ehditty saada täysistuntokuntoon ennen eduskuntavaaleja. Lainsäädäntöhanke keskeytyi.

\subsection{Nykyisen hallituksen sote-ohjelma}

Pääministeri Antti Rinteen hallitusohjelmassa 3.6.2019 (s. 152) todettiin sosiaali- ja terveyspalvelujen rakenneuudistuksesta seuraavaa:

Hallitus käynnistää sote-uudistuksen valmistelun. Valmistelussa otetaan huomioon edellisten vaalikausien valmistelu ja perustuslailliset reunaehdot. Uudistus tehdään hallitusti ja vaiheistaen.

Sosiaali- ja terveydenhuollon toiminnan painopistettä siirretään perustason palveluihin ja ennaltaehkäisevään toimintaan. Palvelut ovat yhteensovitettuja, hoitoketjut ovat sujuvia ja ihmiset saavat tarpeenmukaiset ja vaikuttavat palvelut oikea-aikaisesti.

Sosiaali- ja terveydenhuollon uudistuksessa kootaan sosiaali- ja terveyspalveluiden järjestäminen kuntaa suuremmille itsehallinnollisille alueille. 
Myös pelastustoimen järjestäminen siirretään maakuntien tehtäväksi. Itsehallinnollisia maakuntia on 18. Maakuntien toiminnasta, taloudesta ja hallinnosta säädetään erillisellä lailla. Alueiden päätöksenteosta vastaavat suorilla vaaleilla valitut valtuutetut. Asukkaiden osallisuutta ja käyttäjädemokratiaa vahvistetaan.

Mahdollisuus käyttää palveluita yli maakuntarajojen säilytetään. Maakunnat tekevät yhteistyötä keskenään. Erityistason palveluiden turvaamiseksi muodostetaan viisi yhteistoiminta-aluetta. Alueet pohjautuvat voimassaoleviin erityisvastuualueisiin (erva).

Maakunnat tuottavat palvelut pääosin julkisina palveluina. Yksityinen ja kolmas sektori toimivat täydentävinä palveluiden tuottajina. Kuntien osalta tämä ratkaistaan erillisen selvityksen pohjalta vuoden 2019 loppuun mennessä. Järjestöjen roolia hyvinvoinnin ja terveyden edistämisessä vahvistetaan ja järjestöjen mahdollisuus tuottaa palveluita turvataan.

Asiakkaiden yhdenvertaisten ja sujuvien palveluiden turvaamiseksi ja itsemääräämisoikeuden vahvistamiseksi valmistellaan palvelusetelilain uudistus ja tehdään linjaukset henkilökohtaisen budjetin käyttöönotosta sote-uudistuksessa.

Sosiaali- ja terveyspalveluiden vaikuttavuutta ja tuottavuutta parannetaan, palveluiden kustannusten nousua hillitään ja niiden läpinäkyvyyttä ja avoimuutta lisätään.

Maakuntien rahoitus perustuu pääosin valtion rahoitukseen. Soterahoitusjärjestelmä uudistetaan tarvevakioituihin kriteereihin perustuvaksi. Hallitus käynnistää välittömästi valmistelun maakuntaveron käyttöönotosta. Verorakenteen muutokset eivät saa voimaan astuessaan aiheuttaa verotuksen kiristymistä. ${ }^{102}$ Makunnat voivat periä lakiin perustuvia asiakasmaksuja.

Erillisinä asioina valmistellaan parlamentaarisessa komiteassa maakuntien verotusoikeus ja monikanavarahoituksen purkaminen vuoden 2020 loppuun mennessä.

Pääministeri Sanna Marinin hallituksen ohjelma on samanlainen.

102 Sosiaali- ja terveystoimen menot ovat nykyisin kuntien menoista noin puolet, joten kunnallisen tuloveron määrän pitäisi suunnilleen puolittua, jos sote-menot jäärät kunnilta pois. 


\subsection{Maakuntavero perustuslain kannalta}

Perustuslakimme $121 \S$ kuuluu seuraavasti:

Kunnallinen ja muu alueellinen itsehallinto

Suomi jakaantuu kuntiin, joiden hallinnon tulee perustua kunnan asukkaiden itsehallintoon.

Kuntien hallinnon yleisistä perusteista ja kunnille annettavista tehtävistä säädetään lailla.

Kunnilla on verotusoikeus. Lailla säädetään verovelvollisuuden ja veron määräytymisen perusteista sekä verovelvollisen oikeusturvasta.

Itsehallinnosta kuntia suuremmilla hallintoalueilla säädetään lailla. Saamelaisilla on saamelaisten kotiseutualueella kieltään ja kulttuuriaan koskeva itsehallinto sen mukaan kuin lailla säädetään.

Perustuslakivaliokunta on todennut (PeVL 67/2014, PeVL 26/2017): "Tehtävien siirtäminen kunnilta perustuslain 121 \$:n 4 momentissa tarkoitetuille kuntaa suuremmille itsehallintoalueille, joilla kansanvaltaisuus toteutuisi välittömien vaalien kautta ja joilla lisäksi olisi verotusoikeus, olisi perustuslain kannalta mahdollinen vaihtoehto." Mielestäni tämä tarkoittaa, että tehtävien ja verotusoikeuden siirto olisi mahdollista toteuttaa perustuslakia muuttamatta. ${ }^{103}$ Toisella kannalla on ainakin Janne Juusela, jonka mielestä jos maakunnille annetaan verotusoikeus, siitä pitää säätää perustuslaissa (Kauppalehti 28.5.2019).

Perustuslain mukaan perustuslakiehdotus hyväksytään lain toisessa käsittelyssä yksinkertaisella enemmistöllä. Tämän jälkeen lakiehdotus jätetään lepäämään seuraavaan vaalikauteen. Vaalien jälkeen kokoontuva eduskunta jatkaa lepäämään jätetyn lakiehdotuksen käsittelyä, ja sen tulee hyväksyä se asiasisällöltään muuttamattomana määräenemmistöllä (2/3:1la) annetuista äänistä. Perustuslakia koskevaa ehdotusta ei kuitenkaan jätetä lepäämään vaalien yli, mikäli se julistetaan kiireelliseksi vähintään 5/6:n kannatuksella. Lakiehdotus voidaan tämän jälkeen hyväksyä 2/3:n enemmistöllä.

103 Kirjoitukseni Maakunta- ja muista alueellisista veroista, Verotus 4/2019. 
Maakuntaveron säätäminen perustuslainsäätämisjärjestyksessä tuskin onnistuisi, koska siihen tarvittavaa märäenemmistöä ei eduskunnassa liene saatavissa ainakaan tällä vaalikaudella oppositiopuolueiden vastustuksen takia.

Vaikka maakuntaveron säätäminen vaikuttaa oikeudellisesti mahdolliselta, tämä rahoitusmalli ei ole välttämätön; voidaan viitata vaikkapa Tanskan kokemuksiin. Maakuntavero vaatisi joka tapauksessa rinnalleen maakuntien suurten kantokykyerojen vuoksi merkittävän kustannusten tasausjärjestelmän. Jos rahoitus perustuisi kokonaan valtion rahoitukseen, riskinä olisi, että se heikentäisi maakunnan kannustimia kustannusten hillintään. Voitaisiin säätää sellainenkin valtiolle perittävä sote-vero, joka korvamerkittäisiin maakuntien sosiaali- ja terveysmenoihin. ${ }^{104}$ Myös silloin olennaista olisi, miten soteveron tuotto jaettaisiin maakuntien kesken.

On viitattu siihen, että myös maakuntien verotusoikeuteen liittyy riski kokonaisveroasteen noususta jo siksi, että veroprosenteista päättävien tahojen määrä kasvaisi. Veroasteen tasoa arvioitaessa on kuitenkin hyvä muistaa, että nykyisin verotusta käytetään erityisesti Pohjoismaissa suurelta osin myös sosiaaliturvan rahoittamiseen, siis kansan hyväksi. Kuten edellä on selvitetty, aina näin ei ole ollut. Alun perin veroja perittiin yleensä lähinnä hallitsijoiden hyväksi - ne olivat "parabellumveroja", joilla rahoitettiin sotalaitosta ja muuta vallankäyttöä eikä kansalaisten sosiaaliturvaa.

104 Vrt. Martti Kekomäki, Etiikasta ekonomiaan - ja takaisin, 2019, s. 189 väläytetty hyvinvointivero. 


\section{0 \\ Robottivero ja digivero}

\subsection{Uusista veroista}

Oikeasti uusia veroja syntyy harvoin. Esimerkiksi kaivosvero ja lentovero, jos sellaiset meille säädettäisiin, olisivat vain kuolleiden verojemme reinkarnaatioita. Aidommin uusia veroja ovat seuraavassa käsiteltävät työ- ja elinkeinoelämän automatisointiin liittyvät robotti- ja digiverot.

\subsection{Robottivero}

\subsubsection{Robottiverokeskustelu Suomen eduskunnassa 1985-2014}

Verotus oli pitkään ihmisten käsityötä. Verohallinnon tilaisuudessa vuonna 1943 pitämässään esitelmässä totesi Paavo Viitanen:

"[-- ] olisi huomiota kiinnitettävä siihen, että ainakin kaikki suuremmat verotuslautakunnat saisivat käytettäväkseen lasku- ja kirjoituskoneen. [--] Nykyhetkellä on ehkä vaikea tätä toivomusta toteuttaa, joten verotuslautakuntien täytynee toistaiseksi tulla toimeen vuokraamillaan lasku- ja kirjoituskoneilla, sikäli kun he onnistuvat niitä vuokraamaan." 
Nykyisin verotuksemme on jo pitkälle automatisoitua. Eduskunnan apulaisoikeusasiamiehen 37-sivuisen kannanoton (20.11.2019) mukaan Verohallinnon automatisoitu verotus- ja päätöksentekomenettely ei nykyisin perustu asianmukaiseen ja täsmälliseen lainsääntelyyn, jossa olisi otettu huomioon hyvän hallinnon ja oikeusturvan sekä virkavastuun asianmukainen toteutuminen. Siksi apulaisoikeusasiamies pitää menettelyä lainvastaisena ja vaatii automatisoidun päätöksenteon sääntelytarpeen selvittämistä viipymättä.

Robottiverotuksella voidaan tarkoittaa sitä, että verotuksen toimittaa robotti eikä ihminen. Robottiverosta puhuttaessa tarkoitetaan kuitenkin nykyisin yleensä sellaista veroa, jonka kohteena välittömästi tai välillisesti olisivat robotit. Pitäisikö automaatiota hidastaa robottiverolla? Mieleen tulevat luddiitit, jotka 1700-luvun lopussa ja 1800-luvun alussa vastustivat teollista vallankumousta villa- ja puuvillatehtaita tuhoamalla. Koneiden verottamisesta on keskusteltu ainakin Saksassa ja Itävallassa 1970-luvulta alkaen.

Suomen eduskunnassa robottiveroa alettiin pohtia 1980-luvun puolivälissä. Seuraavassa on muutamia eri puolueiden edustajien asiasta eduskunnassa käyttämiä puheenvuoroja: ${ }^{105}$

30.10.1985 välikysymyskeskustelu Keski-Suomen Selluloosa Oy:n toiminnan turvaamisesta. Pentti Skön (smp): "SMP:n mielestä on välittömästi ryhdyttävä lainsäädäntötyöhön, jolla edes osittain turvataan suurteollisuudessa olevat työpaikat. Useissa maissa on voimassa ns. robottivero, joka tulisi säätää myös Suomessa. Robottiveron tuotto tulisi luovuttaa uusien työpaikkojen luomiseen. Jokainen teollisuuslaitos, joka maksaisi robottiveroa, voisi saada kertyneet verot takaisin, jos loisi ihmistyövoimalle soveltuvia uusia työpaikkoja."

26.11.1985 käsiteltäessä hallituksen esitystä tuotannollisia investointeja koskevista poikkeuksista liikevaihtoverolakiin annetun lain muuttamisesta. Matti Kautto (skdl): "Erityisen robotti- tai koneveron säätäminen vilahtelee aika ajoin maamme poliittisessa keskustelussa. Aivan äskettäin robottiveroa esitti Puutyöväen liiton toimestaan luopunut puheenjohtaja, sosialidemokraatti Esko Suikkanen. (Ed. Kortesalmi: "SMP:n ajatus!"). Tällainen ajatus on aivan erinomainen. Valtavan joukkotyöttömyyden

105 Tarkemmin kirjassani Autoveron saattohoito ja tieliikenneverotuksen kehittäminen (2018) s. 318 ss. 
ollessa tulisi verotusta suunnata työttömyyden aiheuttajaan, automaatioon ja rationalisointiin, eikä niinkään työpaikan luomiseen ja työvoimakustannuksiin. Syystä tai toisesta robottiveroa esittäneet eivät ole huomanneet, että meillä on jo robottiverolaki, tämä tuotannollisten investointien liikevaihtoverohuojennuslaki. Tällä lailla suhtaudutaan kuitenkin robottien verottamiseen täysin päinvastoin kuin ne, jotka robottiveroa nyt ovat esittäneet. [- - K Koneitten ja laitteiden sekä teollisuusrakennusten suosiminen liikevaihtoverotuksessa tulisi lopettaa kokonaan eikä laajentaa siten, niin kuin nyt esillä olevassa esityksessä esitetään.”

5.11.1986 käsiteltäessä lisämenoarviota. Arvo Kemppainen (vas): "Olemme valmiit hyväksymään myös työvoimaan sidottujen sosiaaliturvamaksujen alentamisen ja korvaamaan sen ns. robottiverolla."

11.12.1987 vuoden 1988 tulo- ja menoarvion yleiskeskustelussa. Erkki Pulliainen (vihr): "[- - ja kun ilmeisesti automatisoinnin edistymiselle ei paljon mahdeta, niin sen jälkeen pitää tehdä asiasta oikeat johtopäätökset. Tulee kaksi asiaa, työajan lyhentäminen ja työn uusjako yhteiskunnassa esiin [- - ] helposti syntyy ns. väliinputoajia, uhrataan heikoimmat [- -]. Jotta näin ei tapahtuisi, niin silloin tämä työn uusjako ja toisaalta kansalaispalkkajärjestelmä perustoimeentuloturvajärjestelmänä ovat se pelastus, mikä tässä [- - ' 'pakkotilanteessa' on edessä. Sen jälkeen me kysymme, millä tämä rahoitetaan, ja tämä on ehkä tähän se uusi lisä, se on robottivero. Jos automatisoidaan, jos roboteille siirretään töitä, niin verotetaan niitä robotteja ja rahoitetaan sillä tämä homma."

Martti Tiuri (kok): "Robottivero on siinä suhteessa hyvin huono, että se edelleen siten huonontaisi Suomen mahdollisuuksia myydä tuotteita ja meillä olisi vielä vähemmän varallisuutta sitten käytettäväksi tulevaisuudessa."

28.11.1989 käsiteltäessä sosiaaliturvamaksuja vuonna 1990. Lea Mäkipää (smp): "Olemme usein esittäneet, että pääomavaltaisille automatisoiduille yrityksille määrättäisiin ns. robottivero, jolla alennettaisiin ihmistyövoimaa käyttävien yritysten palkkaperusteisia sosiaaliturvamaksuja.”

6.5.1993 käsiteltäessä välikysymystä talous- ja työllisyyspolitiikasta. Raimo Vistbacka (smp): "SMP on toistuvasti esittänyt pk-yritysten nk. elatusmaksujen alentamista. Se tarkoittaa käytännössä sitä, että työntekijöiden työllistämisestä aiheutuvia maksuja supistetaan niillä yrityksillä, joiden toiminta perustuu pitkälti ihmisten työpanokseen. Nykyiset palkkoihin perustuvat maksut voitaisiin mielestämme nopealla aikataululla korvata liikevaihtoon tai muuhun yrityksen tuotannon arvoon perustuvalla maksujen määräytymisjärjestelmällä. Näin saataisiin yritysten sosiaaliturva- 
ym. maksurasite oikeudenmukaisemmaksi ja ennen kaikkea työllistämistä suosivammaksi. Käytännössä tämä merkitsee samaa kuin ns. robottivero, josta olemme esittäneet ajatuksen jo 1980-luvun puolivälissä. Tämän kaltainen verohan on joissakin maissa jo toteutettu, esimerkiksi Japanissa, jossa automaatio on varsin pitkälle kehittynyt."

Matti Korhonen (vas): " [- - s syntyy väistämättä kuva, että lamaa käytetään tietoisesti syynä siihen, että halutaan purkaa meidän sopimusjärjestelmämme suojaverkko työntekijöiltä. [- - t teollisuuden ongelmat eivät ole työvoimavaltaisuudessa eivätkä tuottavuuden heikossa tasossa. [- -] Kyllä nyt tarvitaan muita lääkkeitä, ja silloin se lääke on pelkästään työvoimavaltaisten alojen auttaminen, ja silloin voi keino olla vientivero, robottivero tai jokin muu vastaava."

Valtiovarainministeri Iiro Viinanen (kok): "Jos joku väittää vielä, että työmarkkinat eivät ole tässä suhteessa jäykät, niin erehtyy. Se on käytännön elämää tänä päivänä, puhumattakaan nyt robottiveroista. Minä en ymmärrä, mikä olisi se robotti. Ei robottia pystytä verottamaan. Mielestäni meidän pitää tuottavuutta saada yrityksiin lisää. Sitä saadaan monella muullakin tavalla kuin robotilla, jopa työyhteisöä, soluja kehittämällä. Emme me sellaisiakaan pysty verottamaan. Se on kestämätön tie.”

Pekka Leppänen (vas): "Olen hänen (Viinanen) kanssa täysin eri mieltä robottiverosta. Tuntuu tämän päivän Suomessa oudolta, kun pystytään robotti keksimään, että robotille ei pystytä keksimään veroa. Robotin työn arvo pystytään verottamaan.”

6.10.1993 käsiteltäessä välikysymystä kansantalouden rakenteiden muuttamisesta. Heidi Hautala (vihr): "Ei ihme, että kun työpaikkoja tällä tavalla rakenteellisesti katoaa maailmantaloudesta ja Suomen taloudesta, Euroopan taloudesta, Belgian talousministeri parkaisi viime keväänä, että tarvitaan kansainvälistä robottiveroa. Me tosin tutkittuamme tätä ehdotusta suositamme, että vähemmän työllistävät talouden sektorit otetaan mukaan rahoittamaan sosiaaliturvaa esimerkiksi sitomalla yritysten välillisiä sosiaalikuluja palkkasumman sijasta liikevaihtoon tai muuhun vastaavaan."

14.12.1993 käsiteltäessä valtion talousarviota vuodeksi 1994. Tellervo Renko (kesk): "On etsittävä uusia lisäkeinoja perusturvan rahoitukseen ja työpaikkojen lisäämiseen. Vakavaan neuvotteluun on nostettava pääomaverotuksen tilapäinen kiristäminen, vientivero tai vastaava vientiteollisuuteen kohdennettava tilapäinen teknovero. Ennen puhuttiin robottiverosta."

6.4.1994 käsiteltäessä välikysymystä työnteon verottamisesta. Sosiaali- ja terveysministeri Jorma Huuhtanen (kesk): "On esitetty, että periaatteessa ns. 
robottivero kuulostaa hyvältä, mutta omat rajoituksensa sen käytölle asettavat kansainväliset sopimuksemme. [- - (Ed. Stenius-Kaukonen: "Mitkä sopimukset estävät robottiverotuksen?") - Ne liittyvät Eta-käytäntöön. Tanska on kokeillut tätä ja joutui perääntymään. Meillä on nyt Eta-sopimus olemassa.” (Ed. Stenius-Kaukonen: ”Ei se kiellä mitään tällaista!”)

Juha Korkeaoja (kesk): ”En kuitenkaan itse kannata täälläkin esillä olleen robottiveron säätämistä."

Heidi Hautala (vihr): "Sitten hän (valtiovarainministeri Viinanen) sanoi, että niin kauan kuin automaatio etenee maailmalla, meillä ei voida mistään robottiveron tyyppisistä ratkaisuista ruveta puhumaan. [--] Viime talvena Belgian talousministeri, joka varmaankin on ministeri Viinasen kollega, parkaisi, että kyllä nyt tarvitaan jo kansainvälistä robottiveroa, että muuten työllisyydelle käy hullusti. Robottiverohan on jonkinlainen lempinimi. Sillä voidaan tarkoittaa hyvin erilaisia asioita. Joskus sanotaan, että koneille pitää antaa verokirjat, jotta nekin joutuvat kustantamaan sitä yhteistä hyvinvointia, joka on kaiken tuotantoelämän edellytys. Vihreässä eduskuntaryhmässä on tultu siihen tulokseen, että ns. robottivero pitäisi toteuttaa sitomalla yritysten väliset työvoimakulut yrityksen käyttökatteeseen eikä palkkasummaan, niin kuin nyt on käytäntö. Tällöin suosittaisiin työllistäviä aloja [--].”

2.2.1995 käsiteltäessä kysymyksiä valtioneuvostolle. Hannu Kemppainen (kesk): "Mihin aktiivisiin toimenpiteisiin hallitus ryhtyy, että nimenomaan työvoimavaltaista yritystoimintaa ja työn tekemistä rasittavat sosiaaliturvamaksut voitaisiin kohdentaa toisaalle esimerkiksi työnimellä robottivero?"

Valtiovarainministeri liro Viinanen (kok): "Mitä robottiveroon tulee, kauhistun sitä ajatustakin. Ensinnäkään kukaan ei pysty määrittelemään, mikä on robotti. Voihan sen koneen kylkeen pistää jonkin muunkin nimen kuin robotti. Rajanveto on sula mahdottomuus. Jos me haluamme tuottavuutta, automaatiota, supistaa tässä maassa, se on turmiolan tommin tie."

27.4.1995 käsiteltäessä tiedonantoa hallituksen ohjelmasta. Hannu Kemppainen (kesk): "Yksi mahdollisuus olisi siirtää painopistettä robottiveron suuntaan, tai ei se robottivero ole, vaan tarkoittaa kaikkea muutakin kuin robotteja, mutta että työvoimavaltainen yritystoiminta voisi selvitä vähemmällä. Edellisen hallituksen valtiovarainministeri oli täysin tämäntyyppistä vastaan. Toivoisi, että siinä edettäisiin, että painopiste siirtyisi.”

14.9.1995 käsiteltäessä valtion talousarviota vuodelle 1996. Markku Vuorensola (kesk): "Nyt pitäisi hoitaa työllisyyttä. En usko, että sanktioilla voidaan asia ratkaista. Tuskin ylityökielto tai robottivero ratkaisee asiaa, 
vaan ratkaisuksi kelvannee vain porkkana, siis toimenpiteet, joilla voidaan tehdä työvoiman käyttö vapaaehtoisesti kilpailukykyiseksi.”

20.2.-22.2.1996 käsiteltäessä välikysymystä työttömyyden vähentämisestä. Raimo Vistbacka (ps): "Edellä lueteltuja toimia on mahdollisuus rahoittaa $\mathrm{mm}$. korottamalla suurten pääomatulojen verotusta, lisäämällä koneiden ja automaation varassa toimivien yritysten verotusta tai säätämällä nk. robottivero, muuttamalla työnantajan sosiaaliturvamaksut ainakin osittain liikevaihdon mukaan määräytyviksi, säätämällä korkeille eläkkeille ja muille etuuksille katto sekä perimällä parhaiten menestyviltä suurilta vientiyrityksiltä erillistä veroa."

Esa Lahtela (sd): ”Toinen tekijä tässä on automaatiorobottivero, josta on puhuttu. Joka tapauksessa pakko on saada sillä tavalla, että pitkälle automatisoitunut teollisuus, mikä hyvänsä tuotanto, maksaa osan tästä meidän hyvinvoinnistamme."

Timo Ihamäki (kok): "Mistä sitten löytyy uusia työpaikkoja, mikä työllistää? Tiedämme, että suurteollisuus ja vientiteollisuus ei itse asiassa tuota lisää uusia työpaikkoja. Se robotisoi ja automatisoi. Jos laitetaan robottivero tai automatisaatiovero, siirtyvät teollisuuden laitteet ja yritykset naapurimaihin, Viroon ja muualle Eurooppaan.”

15.5.1997 Raimo Holopaisen (sd) kirjallinen kysymys: "Yksi syy työttömyyden paisumiseen on se, että yhteiskuntamme on teknistynyt ja koneellistunut. Työttömyyden poistamiseen ei ole yhtä patenttiratkaisua, vaan ratkaisua on etsittävä osasista. Kun 'ylikoneellistaminen' ja sen edullisuus vie ihmistyöpaikkoja, on syytä miettiä, löytyisikö osaratkaisu ns. kone- tai robottiverosta. Tällä tavalla kootuilla veroilla voitaisiin helpottaa työpaikkojen syntyä alentamalla esimerkiksi työvoimavaltaisten pk-yritysten välillisiä työvoimakustannuksia ja palvelualojen sekä käsityöläisten tuotteiden arvonlisäverokantaa. Ainahan voidaan nyt puheena oleva vero tyrmätä toteamalla, että sillä vaarannetaan kilpailukyky. Jos tällainen verouudistus on mahdotonta tehdä kansallisena, niin ryhdyttäköön pikaisesti toimiin eurooppalaisen veromallin etsimiseksi."

Valtiovarainministeri Arja Alhon (sd) vastaus 5.6.1997: "Koneellistamisen edullisuus suhteessa työvoiman käyttöön johtuu osaltaan yritysverotuksen nykyisestä poistojärjestelmästä. [- - Verotuksen ylipoistot vaikuttavat työn ja pääoman väliseen hintasuhteeseen alentaen pääoman laskennallista hintaa ja investointien tuottovaatimusta. Nykyinen poistojärjestelmä suosii näin ollen koneistamista ja vaikuttaa työn ja pääoman väliseen hintasuhteeseen työllisyyden kannalta epäedullisella tavalla. [- - ] Varsinaisesta kone- ja robottiverosta voitaneen puhua vasta silloin, kun investointia kohdellaan verotuksessa epäedullisemmin kuin sen taloudellinen luonne edellyttäisi. [- - ] verotuksen poistojen alentaminen vas- 
taamaan käyttöomaisuuden taloudellista käyttöikää ei olisi yhtä pitkälle menevä toimenpide kuin varsinainen robottivero, mutta muuttaisi kuitenkin selvästi työn ja koneiden välistä hintasuhdetta työn käyttöä suosivaan suuntaan. Sanktioluonteisella robottiverolla saattaisi olla haitallisia vaikutuksia yrityksen ja koko elinkeinoelämän kannalta. Ylimääräinen vero saattaisi ehkäistä yritykseen toiminnan kannalta tarpeellisten investointien toteuttamista, ja se saattaisi tällöin pikemminkin lisätä kuin vähentää työttömyyttä. [--] Paras tehokkuus investoinneissa saavutetaan, jos verotus ei ohjaa yritysten investointeja. [--] erillisen kone- tai robottiveron käyttöön ottaminen ei ole näin ollen perusteltua.”

2.12.-10.12.1997 käsiteltäessä arvonlisäverotusta. Sulo Aittoniemi (kesk): "Liikevaihtoon perustuva verotus tuodaan aina silloin tällöin uudelleen esille koskien sellaisia yrityksiä, joilla on suuri liikevaihto ja vähän työntekijöitä ja näin ollen tätä kautta vähän veronmaksajia. Yleensä tällaiset yritykset ovat juuri niitä, jotka käyttävät automaatiota hyväkseen, toisin sanoen robotteja, jotka tekevät ihmisen työn. Toisaalta jos lähdetään liikevaihdon perusteella erityisverotukseen, niin kysymyksessä on silloin oikeastaan sama kuin robottivero. Robottivero ei taas onnistu Suomessa, ellei sen tyyppistä verotusta tapahdu myös kilpailevissa maissa, joilla on samanlaista tuotantoa, teollisuutta, joka kilpailee kansainvälisillä markkinoilla. Esimerkiksi robottiveron, tai niin kuin tässä nyt puhutaan liikevaihdon perusteella tapahtuvan veron ottamisen käyttöön pitäisi tapahtua kansainvälisesti. Ei tämä ole niin yksinkertaista. Menee pitkä aika, ennen kuin liikevaihdon perusteella tapahtuvaa verotusta pystytään toteuttamaan. Se otetaan vain joskus puheeksi, ja onhan mukava sillä tavalla sanoa."

Veijo Puhjo (vasryhmä): "Meidän ryhmämme mm. vuosi sitten esitti yli 200000 tienaaville sellaista kohtelua, että he eivät saisi taulukkoalennuksia. Siitä olisi kertynyt yksi miljardi, puhumattakaan jos menisimme oikealla tavalla porrastettuun automatisoitujen yritysten uudenlaiseen kohteluun sosiaaliturvamaksuissa."

Sulo Aittoniemi (kesk): "Huomautan ed. Puhjolle samasta asiasta, josta salissa on keskusteltu aikaisemminkin. Automatiikkaa käyttävien yksityisten ns. robottivero on mahdoton yhden maan osalta. Siitä täytyy tulla kansainvälinen käytäntö. Muuten kilpailukyky heikkenee liian paljon niissä suomalaisissa yrityksissä, jotka tuotannossaan nojaavat ihmistyövoiman sijasta automaatioon; tämän vuoksi tämän verotus ei ole mahdollista. Tämä on kaunis ajatus mutta toteuttamiskelvoton yhdessä maassa. Tämän suuntauksen täytyy olla maailman ja mantereen laajuinen, ennen kuin siihen voidaan mennä.” 
25.2.1998 käsiteltäessä Suomen osallistumista euroalueeseen. Säde Tahvanainen (sd): "Meillä puhutaan paljon $\mathrm{mm}$. siitä, että suomalaisten pitäisi siirtyä työn verotuksesta siihen, että työvaltaisia aloja ei verotettaisi nykyisen kaltaisesti ja niin raskaasti kuin tällä hetkellä tehdään, vaan että pitäisi mennä pääomien verotukseen ja siihen, että koneita verotettaisiin yhä enemmän. Me tiedämme, että tällä hetkellä on mahdottomuus hallita tätä tilannetta ja Suomen tehdä yksipuolisesti päätöksiä mm. siitä, että loisimme robottiveron Suomeen ja että sitä kautta saisimme hyvinvointia maksamaan myös pääomavaltaisen teollisuuden. Sehän on tämän päivän ongelma."

9.6.1998 käsiteltäessä vuoden 1999 verotusta. Mikko Elo (sd): "Minä olisin valmis siihen, että keskusteltaisiin esimerkiksi yritysveron porrastamisesta. Monissa maissa tätä porrastusta käytetään sillä tavoin, että suuryritykset maksavat korkeampaa veroprosenttia kuin pienet yritykset. Esimerkiksi Ranskassa tämä otettiin käyttöön viime vuonna. Henkilökohtaisesti olen sitä mieltä, että suuryritykset voisivat hyvinkin maksaa eurooppalaiseen keskitason eli 36-38 \% yritysveroa eli yhteisöveroa ja pienille ja keskisuurille yrityksille voitaisiin säätää alempi verokanta. Minun mielestäni tähän olisi hyviä perusteluita. Kun me kaikki esimerkiksi tiedämme suomalaisten puheet ns. robottiverosta, niin tässäkin olisi tietyllä tavalla robottivero, koska suuryrityksethän ovat hyvin pitkälle automatisoituja. Ne eivät enää paljon työvoimaa käytä. Niiden verotusta voitaisiin jonkin verran kiristää."

24.11.1998 lakialoite yritysten automaatiomaksusta ja siitä käyty keskustelu. Allekirjoittajina seuraavat 43 kansanedustajaa: Raimo Holopainen (sd), Raimo Mähönen (sd), Erkki Partanen (sd), Helena Vartiainen (sd), Reijo Kallio (sd), Annikki Koistinen (kesk), Pekka Saarnio (vas), Veijo Puhjo (va-r), Pertti Virtanen (evir), Mikko Elo (sd), Tauno Pehkonen (skl), Matti Huutola (vas), Rauha-Maria Mertjärvi (vihr), Mikko Immonen (vas), Marjaana Koskinen (sd), Janina Andersson (vihr), Kalevi Olin (sd), Reino Ojala (sd), Säde Tahvanainen (sd), Marja-Liisa Tykkyläinen (sd), Reino Laine (vas), Esko-Juhani Tennilä (va-r), Eila Rimmi (vas), Pirkko Peltomo (sd), Marjatta Vehkaoja (sd), Pia Viitanen (sd), Jorma Vokkolainen (vas), Pekka Leppänen (vas), Hannu Takkula (kesk), Tapio Karjalainen (sd), Esa Lahtela (sd), Jorma Kukkonen (sd), Klaus Hellberg (sd), Valto Koski (sd), Matti Vähänäkki (sd), Mikko Kuoppa (va-r), Riitta Prusti (sd), Päivi Räsänen (skl), Tuija Pohjola (sd), Janne Viitamies (sd), Kimmo Kiljunen (sd), Annika Lapintie (vas), Marja-Leena Viljamaa (sd). "Lakialoitteessa esitetään säädettäväksi automaatiomaksu, joka on 11 prosenttia vuosittain tehtävistä poistoista. Automaatiomaksuna kertyneet varat kohdennetaan edelleen helpottamaan työvoiman sivukuluja, mistä 
hyötyisivät nimenomaan työvoimavaltaiset yritykset. Lakialoitteessa on kaikki poistot säädetty maksun piiriin riittävän veropohjan saamiseksi sekä tulkintaongelmien välttämiseksi.

[- - Yhteiskunnallisella tasolla on automatisointi saatu kannattavaksi sälyttämällä osa sen aiheuttamista kustannuksista toiselle sen kanssa vaihtoehtoiselle kustannustekijälle eli palkkoihin. Osa automatisoinnin aiheuttaman työttömyyden kustannuksista kerätään verotuksella ja maksetaan kansalaisille toimeentulotukina ja työttömyyskorvauksina. On korkea aika ruveta kohtelemaan tuotannontekijöitä tasapuolisemmin eli sälyttää automatisoinnin maksettavaksi ainakin pieni osa sen aiheuttamista kustannuksista. Työvoimavaltaisten yritysten kannattavuutta voidaan lisätä ja samalla edistää työllistämistä alentamalla työn sivukustannuksia. Tämä tapahtuu verottamalla poistoja samoin perustein kuin työtä.

[- - Pelko siitä, että teollisuus siirtyisi ulkomaille, jos automatisointiin kohdistetaan jokin maksu, on hätävarjelun liioittelemista. Pikemminkin teollisuus siirtyy ulkomaille korkeiden työvoimakustannusten ansiosta ja niitä tällä lakialoitteella juuri pienennetään. [- - ]

Lakialoitteessa korvataan työnantajan kansaneläkemaksu ja sairausvakuutusmaksu uudella automaatiomaksulla, joka on tietty prosentti tehdyistä poistoista. Vuonna 1996 tehtyjen poistojen yhteismäärä oli noin 87 miljardia markkaa. Lakialoitteessa esitetty 11 prosentin automaatiomaksu tuottaisi siis noin 9,5 miljardia markkaa. Nykyisen käytännön mukainen palkkoihin perustunut maksu tuotti vuonna 1997 noin 11,8 miljardia markkaa. Lakialoite tarkoittaa noin 2 miljardin markan kevennystä sosiaaliturvamaksuihin."

Erkki Partanen (sd): "[- - ] aloite on hyvä ja kannatettava. Automaatioverosta taikka robottiverosta on puhuttu vuosikymmenet, mutta se ei ole johtanut mihinkään [- - ].”

Sulo Aittoniemi (kesk): "[- - ] automaatio- eli robottivero on aina silloin tällöin noussut keskustelussa esille ja se on periaatteessa erinomaisen hyvä ja oikeudenmukainen asia mutta se vain, että se ei toimi teollistuneessa maailmassa yhdessä maassa, vaan silloin se täytyy ottaa käyttöön kaikissa maissa, joissa on kilpailevaa tuotantoa. [- - ]"

Toimi Kankaanniemi (krist): "[- - ] tavoite on todella hyvä, mutta on kyllä todettava, että kun rajat ovat auki ja vapaa kilpailu maailmassa ja maiden välillä, niin tällainen malli ei oikein istu siihen. Yritykset ja automaatio, jopa robotit, kävelevät maasta toiseen hyvin herkästi.”

12.2.2003 eläkelainsäädännön muuttaminen. Esa Lahtela (sd): "Nämä eläkemaksuthan kerätään työn sivukuluina. Minusta semmoinen uusi näkökulma tässä pitäisi ottaa koko tarkastelussa huomioon, ei pelkästään Suomessa vaan maailmanlaajuisesti, miten saada sitten se taho, joka omistaa ja jolle keskittyy jatkuvasti omistaminen, maksamaan jotakin muuta 
kuin työn sivukuluja, elikkä puhutaan robottiverosta, jonka osalta on epävarmaa, sopiiko se tähän päivään vai ei, mutta kuitenkin se on ajatus, että koneet maksaisivat enemmän meidän eläkemaksujamme, ei maksettaisi pelkästään työn sivukulujen muodossa.”

Martti Tiuri (kok): "Robottien verolle paneminenhan johtaa siihen, että hinnat nousevat. Televisiot, matkapuhelimet ja muut tehdään nykyään pääasiassa roboteilla. Jos niihin pannaan arvonlisäveron lisäksi vielä robottivero, niin eivät niitä sitten enää eläkeläiset pysty ostamaan.”

14.10.2004 sähköveron määräytymisperusteet. Janina Andersson (vihr): "Tämähän on myös työllisyyttä edistävää. Olen joskus kuvitellut kuulevani teidän [tarkoittanee Esa Lahtelaa] suunnaltanne tai jostakin sieltä päin, että robottivero olisi hyvä asia ja voitaisiin mieluummin työllistää ihmisiä eikä vain koneita. Tämä on vähän sama asia, eli mieluummin vähennetään työn kustannuksia ja otetaan ihmisiä töihin kuin tehdään kaikki vain suurella energiamäärällä ja raaka-aineen haaskaamisella.”

19.11.2014 keskustelu tuloveroasteikoista. Osmo Kokko (ps): "[- - palkan sivukulut ovat hyvin suuri kompastus ja este sille, että meille synnytettäisiin uusia työpaikkoja, ja se on asia, johonka on puututtava. Yksi vaihtoehto tässä olisi, kun mietitään, että entistä enemmän automatisoidaan ja muuta, esimerkiksi jonkinnäköinen robottivero. Tietysti siinäkin on ajateltava sillä tavalla, että tuote ei sitten tule kilpailemattomaksi, kun olemme viennistä riippuvaisia maita.”

\subsubsection{Robottiveroehdotukset 2010-luvun lopulla}

Suurta kansainvälistä huomiota robottiverokeskustelu sai 2010-luvun puolivälin jälkeen, kun Euroopan parlamentti käsitteli sitä tarkoittavaa esitystä. Helmikuussa 2017 Euroopan parlamentti torjui robottiveron. Huomiota lisäsi voimakkaasti se, että Microsoftin perustaja Bill Gates kannatti veroa. Robottiverokeskusteluun liittyvät olennaisesti kysymykset työllisyydestä, hyvinvoinnin turvaamisesta, tasa-arvosta ja perustulosta.

Vuonna 2015 Yhdysvalloissa ilmestyi teknologian asiantuntijan Martin Fordin paljon huomiota herättänyt teos "Rise of Robots", joka on julkaistu vuonna 2017 suomeksi nimellä "Robottien kukoistus - Teknologia ja massatyöttömyyden uhka". Kirjassa mm. todetaan (s. 76), että tulevaisuutta muovaavista voimista on tietotekniikan eksponentiaalinen kehitys omaa luokkaansa. Niissäkin maissa, joissa 
poliittinen ilmapiiri on myötämielisempi keskivertotyöntekijän hyvinvoinnille, tekniikan aiheuttamat muutokset ovat entistä tuntuvampia. Kehittyessään tekniikka valtaa yhä useampia työpaikkoja. Monet niistä aloista, joita nyt ei pidetä rutiininomaisina ja joiden ajatellaan siksi olevan turvassa automaatiolta, päätyvät lopulta rutiininomaisen ja ennalta-arvattavan työn kategoriaan. Kun robotit ja itsepalvelutekniikat kahmivat pienipalkkaisten töitä ja aiempaa älykkäämmät algoritmit uhkaavat korkean taitotason ammatteja, polarisoituneiden työmarkkinoiden ontoksi kovertunut keskusta todennäköisesti laajenee entisestään.

\subsection{Digivero ${ }^{106}$}

\subsubsection{Digitaalisen toiminnan kansainvälinen tuloverotus nykyisin}

Nykytilanteessa digitaalista toimintaa ei merkittävässä määrin veroteta eri tavalla kuin muuta toimintaa, vaan sen verotusoikeus jaetaan rajat ylittävissä tilanteissa valtioiden kesken verotuksen yleisten säännösten mukaan ja soveltaen asuin- ja lähdevaltioperiaatetta.

Asuinvaltiolla on maailmanlaajuinen oikeus verottaa tuloa. Lähdevaltio voi verottaa tuloa vain silloin, kun tulon lähde on kyseisessä valtiossa. Lähdevaltiona pidetään esimerkiksi kiinteän toimipaikan sijaintivaltiota.

Valtioiden välisten tuloverosopimusten märäykset lähde- ja asuinvaltion verotusoikeuden jaosta pohjautuvat 1920-luvun alussa silloisessa Kansainliitossa sovittuihin periaatteisiin, joiden kehittämistä on jatkettu OECD:ssä.

Verosopimusten kiinteän toimipaikan määritelmässä korostuu vahvasti se, että toimintaa on harjoitettava fyysisesti lähdevaltiossa, jotta tälle muodostuisi verotusoikeus. Koska digitaalinen toiminta ei välttämättä edellytä fyysistä toimintaa valtiossa, josta tuloa saadaan,

106 Ks. Marianne Malmgrén - Mika Nissinen, Digitaalisen toiminnan verotus, Edilex 14.6.2019 ja Marianne Malmgrén, Kansainvälisen verosääntelyn vaikutus kansalliseen tuloverojärjestelmään, Verotus 5/2019 s. 603 ss. 
ei lähdevaltiolle muodostu välttämättä verotusoikeutta nykyisten kiinteää toimipaikkaa koskevien määräysten mukaan. Tätä pidetään korjaamista vaativana epäkohtana.

\subsubsection{OECD:n hanke}

Ainakin vuodesta 2015 alkaen OECD:ssä on selvitelty digitaalisen toiminnan verotuskysymyksiä. OECD:n helmikuussa 2019 julkaisemassa keskustelupaperissa on pohdittu, miten digitaalisen toiminnan verotusoikeuden jakautuminen ja verotusoikeus olisi perusteltua märittää ja miten voitaisiin estää tulon siirtäminen matalan verotuksen tai nollaverotuksen valtioihin. OECD:n varajohtaja Grace Perez-Navarro selvitti Keskuskauppakamarin Suuressa Veropäivässä 9.10.2019 esitystä, jonka sisältö on muuttunut digiverosta suuryritysten koko kuluttajaliiketoiminnan verotukseksi. ${ }^{107}$ OECD:n tarkoituksena on julkaista loppuraportti vuonna 2020.

Ensisijaisena tavoitteena on saada monikansalliset yhtiöt maksamaan veroja voitoistaan niihin maihin, joissa voitot syntyvät. Toisena tavoitteena on sopia valtioiden kesken siitä, että yritykset maksaisivat tietyt maakohtaiset minimiverot. Hankkeen vaikutuksista Suomelle on esitetty erilaisia arvauksia. ${ }^{108}$

107 OECD: Public consultation document Secretariat Proposal for a "Unified Approach" Under Pillar One, 9 October 2019 - 12 November 2019. Esitetty malli kattaisi digitaaliset liiketoimintamallit mutta menisi laajemmalle keskittyen erityisesti kuluttajiin myyviin yrityksiin. Sääntelyn soveltamisalaan kuuluvien yritysten verotus ei riippuisi fyysisestä läsnäolosta, vaan se perustuisi suurelta osin myyntiin. Kynnysarvot, mukaan lukien maakohtaiset myyntikynnykset, voitaisiin ottaa huomioon sen varmistamiseksi, että myös pienemmän talouden lainkäyttöalueet voivat hyötyä. Uutta voitonjakosääntöä sovellettaisiin riippumatta jakelutavasta. Uudessa järjestelmässä säilyisivät pitkälti entiset siirtohinnoittelusäännöt, jotka perustuvat markkinaehtoisuusperiaatteeseen. Käyttöön otettaisiin myös kaavapohjainen hinnoittelu siltä osin kuin nykyiset siirtohinnoittelusäännökset eivät näytä ratkaisevan tulon kohdentamiskysymyksiä. Tarkemmin Marianne Malmgrén, Tax Services MSK Verouutiset 11.10.2019.

Esim. Helsingin Sanomat 10.10.2019 s. A 5 ja A 30. 


\subsubsection{EU:n direktiiviehdotukset}

Myös Euroopan unionissa on selvitetty digitaalisen talouden verotukseen liittyviä kysymyksiä. Euroopan komissio antoi 21.3.2018 digitaalisen toiminnan verotuksesta kaksi direktiiviehdotusta. Direktiiviehdotuksista ensimmäinen (147 final) koski digitaalista kiinteää toimipaikkaa. Tämä direktiiviehdotus sisälsi mm. seuraavat artiklat:

\section{1 artikla Kohde}

Tässä direktiivissä vahvistetaan säännöt, joilla ulotetaan jäsenvaltioissa yhteisöverotarkoituksissa sovellettava kiinteän toimipaikan määritelmä koskemaan merkittävää digitaalista läsnäoloa, jonka kautta liiketoimintaa harjoitetaan kokonaan tai osittain. Tässä direktiivissä vahvistetaan myös tietyt periaatteet, jotka koskevat merkittävään digitaaliseen läsnäoloon kohdennettavissa olevia tai siihen liittyviä voittoja yhteisöveron soveltamiseksi.

\section{2 artikla Soveltamisala}

Tätä direktiiviä sovelletaan yhteisöihin riippumatta siitä, onko niiden yhteisöverotuksellinen kotipaikka jäsenvaltiossa vai kolmannessa maassa.

Kuitenkin jos yhteisön yhteisöverotuksellinen kotipaikka on kolmannessa maassa, jonka kanssa asianomainen jäsenvaltio on tehnyt sopimuksen kaksinkertaisen verotuksen välttämiseksi, tätä direktiiviä sovelletaan ainoastaan, jos kyseiseen sopimukseen sisältyy kyseisen kolmannen maan osalta määräyksiä, jotka ovat samankaltaisia kuin tämän direktiivin 4 ja 5 artiklan säännökset, ja jos kyseiset määräykset ovat voimassa.

\section{3 artikla Määritelmät}

Tässä direktiivissä tarkoitetaan

1) 'yhteisöverolla' jotakin liitteessä I luetelluista yhteisöveroista tai myöhemmin käyttöön otettua samankaltaista veroa;

2) 'digitaalisella rajapinnalla' kaikkia käyttäjien saatavilla olevia ohjelmistoja, mukaan lukien verkkosivut sekä niiden osat ja sovellukset, myös mobiilisovellukset;

3) 'internetprotokollaosoitteella' verkkoon kytketyille laitteille annettua numerosarjaa, joka mahdollistaa laitteiden välisen kommunikoinnin internetissä;

4) 'käyttäjällä' luonnollista henkilöä tai yritystä;

5) 'digitaalisilla palveluilla' internetin tai sähköisen verkon välityksellä suoritettavia palveluita, jotka ovat luonteeltaan pääasiassa automatisoituja ja vain vähän ihmisen osallistumista vaativia ja joita ei voida 
suorittaa ilman tietotekniikkaa, mukaan lukien erityisesti seuraavat palvelut:

a) digitaalisten tuotteiden luovutukset yleensä, mukaan lukien ohjelmistojen ja niiden muutosten ja päivitysten luovutukset;

b) palvelut, joilla järjestetään yrityksille tai yksityishenkilöille läsnäolo sähköisessä verkossa (kuten verkkosivu tai -sivusto) tai tuetaan sitä;

c) palvelut, jotka tietokone tuottaa automaattisesti internetin tai muun sähköisen verkon välityksellä vastaanottajan syöttämän datan pohjalta;

d) oikeuden antaminen vastiketta vastaan asettaa tavara tai palvelu myytäväksi online-myyntipaikkana toimivalle internetsivustolle, jolla mahdolliset ostajat tekevät tarjouksensa automatisoidulla menettelyllä ja jolla osapuolet saavat tiedon myynnistä tietokoneen automaattisesti tuottamalla sähköposti-ilmoituksella;

e) internetpalvelupaketit, joissa televiestintäkomponenteilla on ainoastaan täydentävä ja toissijainen merkitys, eli paketit, jotka mahdollistavat muutakin kuin pelkän pääsyn internetiin ja kattavat myös muita elementtejä, kuten sisältösivuja, joista on pääsy uutisiin ja sää-tai matkailutietoihin, pelipaikkoja, verkkosivustojen isännöintiä, pääsyn online-keskusteluryhmiin tai muita samankaltaisia elementtejä;

f) liitteessä II luetellut palvelut.

Digitaaliset palvelut eivät kata liitteessä III lueteltuja palveluja eivätkä tavaroiden tai muiden palvelujen myyntiä internetin tai sähköisen verkon välityksellä.

6) 'tuloilla' myynnistä ja muista transaktioista saatavia monetaarisia tai eimonetaarisia tuottoja, joista on vähennetty valtion virastojen puolesta kannetut arvonlisäverot sekä muut verot ja tullit, mukaan lukien varojen ja oikeuksien luovutuksista saatavat tuotot, korot, osingot ja muut jaetut voitot, likvidaatioista saatavat tuotot, rojaltit, tuet ja avustukset, saadut lahjat, korvaukset ja vapaaehtoiset maksut. Tuloihin luetaan myös yhteisöverovelvollisen antamat ei-monetaariset lahjat. Tuloihin ei lueta yhteisöverovelvollisen hankkimaa omaa pääomaa eikä sille takaisin maksettua velkaa;

7) 'yhteisöllä' kaikkia oikeushenkilöitä ja oikeudellisia järjestelyjä, jotka harjoittavat liiketoimintaa joko yrityksen tai verotuksellisesti läpinäkyvän rakenteen kautta;

8) 'verokaudella' yhteisöverovuotta, kalenterivuotta tai mitä tahansa muuta yhteisöverotarkoituksiin soveltuvaa kautta; 
9) 'etuyhteydessä olevalla yrityksellä' yhteisöä, joka on etuyhteyssuhteessa tiettyyn asianomaiseen yhteisöön vähintään yhdellä seuraavista tavoista:

a) yksi niistä osallistuu toisen johtoon siten, että sillä on huomattavaa vaikutusvaltaa toiseen nähden;

b) yksi niistä osallistuu toisen määräysvaltaan siten, että sillä on suoraan tai välillisesti hallussaan yli 20 prosenttia äänivallasta;

c) yksi niistä osallistuu toisen pääomaan omistusoikeuden kautta suoraan tai välillisesti siten, että sillä on yli 20 prosenttia pääomasta.

Jos useampi kuin yksi yhteisö osallistuu saman yhteisön johtoon, määräysvaltaan tai pääomaan vähintään yhdellä a-c alakohdassa tarkoitetuista tavoista, kaikkien kyseisten yhteisöjen katsotaan olevan toisiinsa etuyhteydessä olevia yrityksiä.

Jos sama yhteisö osallistuu useamman kuin yhden yhteisön johtoon, määräysvaltaan tai pääomaan vähintään yhdellä a-c alakohdassa tarkoitetuista tavoista, kaikkien kyseisten yhteisöjen katsotaan olevan toisiinsa etuyhteydessä olevia yrityksiä.

Välillisen osallistumisen tapauksessa b ja c alakohdassa säädettyjen perusteiden täyttyminen määritetään kertomalla osallistumisen prosenttiosuudet omistusketjussa. Jos yhteisöllä on yli 50 prosenttia äänivallasta, sillä on katsottava olevan 100 prosenttia äänivallasta.

\section{4 artikla Merkittävä digitaalinen läsnäolo}

1. Yhteisöverotuksen soveltamiseksi kiinteän toimipaikan katsotaan olevan olemassa, jos liiketoimintaa harjoitetaan merkittävän digitaalisen läsnäolon kautta kokonaan tai osittain.

2. Edellä oleva 1 kohta täydentää mahdollista muuta unionin tai kansallisen lainsäädännön mukaista testiä, jolla määritetään kiinteän toimipaikan olemassaolo jäsenvaltiossa yhteisöveron soveltamiseksi, vaikuttamatta kuitenkaan tällaisen muun testin soveltamiseen ja rajoittamatta sitä sekä riippumatta siitä, onko kyse erityisesti digitaalisten palvelujen suorittamisesta.

3. Merkittävän digitaalisen läsnäolon katsotaan olevan olemassa jäsenvaltiossa verokautena, jos merkittävän digitaalisen läsnäolon kautta harjoitettava liiketoiminta kokonaan tai osittain koostuu digitaalisten palvelujen suorittamisesta digitaalisen rajapinnan välityksellä ja jos vähintään yksi seuraavista edellytyksistä täyttyy, kun otetaan huomioon kyseistä liiketoimintaa harjoittavan yhteisön tekemät kyseisten palvelujen suoritukset, jolloin mukaan lasketaan myös kaikki siihen etuyhteydessä olevien yritysten tekemät tällaisten palvelujen suoritukset digitaalisen rajapinnan välityksellä: 
a) osuus kokonaistuloista, jotka on saatu kyseisenä verokautena kyseisten digitaalisten palvelujen suorittamisesta käyttäjille, jotka sijaitsevat kyseisessä jäsenvaltiossa kyseisenä verokautena, on yli 7000000 euroa;

b) käyttäjiä, jotka käyttävät vähintään yhtä kyseisistä digitaalisista palveluista ja jotka sijaitsevat kyseisessä jäsenvaltiossa kyseisenä verokautena, on yli 100 000;

c) tällaisten digitaalisten palvelujen suorittamista koskevia liiketoimintasopimuksia, joita kyseisessä jäsenvaltiossa sijaitsevat käyttäjät ovat tehneet kyseisenä verokautena, on yli 3000.

4. Kun on kyse digitaalisten palvelujen käytöstä, käyttäjän katsotaan sijaitsevan jossakin jäsenvaltiossa verokautena, jos käyttäjä käyttää laitetta kyseisessä jäsenvaltiossa kyseisenä verokautena saadakseen pääsyn digitaaliseen rajapintaan, jonka välityksellä digitaalisia palveluja suoritetaan.

5. Kun on kyse sopimusten tekemisestä digitaalisten palvelujen suorittamiseksi,

a) sopimuksen katsotaan olevan liiketoimintasopimus, jos käyttäjä tekee sen liiketoiminnan harjoittamisen aikana;

b) käyttäjän katsotaan sijaitsevan jäsenvaltiossa verokautena, jos käyttäjällä on yhteisöverotuksellinen kotipaikka kyseisessä jäsenvaltiossa kyseisenä verokautena tai jos käyttäjällä on yhteisöverotuksellinen kotipaikka kolmannessa maassa mutta kiinteä toimipaikka kyseisessä jäsenvaltiossa kyseisenä verokautena.

6. Jäsenvaltio, jossa käyttäjän laitetta käytetään, määritetään laitteen internetprotokollaosoitteen perusteella tai tarkemmin jollakin muulla maantieteellisen paikantamisen menetelmällä.

7. Edellä olevassa 3 kohdan a alakohdassa tarkoitettu kokonaistulojen osuus määritetään suhteessa siihen, miten monta kertaa käyttäjät missä päin maailmaa tahansa käyttävät laitteita kyseisenä verokautena saadakseen pääsyn digitaaliseen rajapintaan, jonka välityksellä digitaalisia palveluja suoritetaan.

5 artikla Merkittävään digitaaliseen läsnäoloon kohdennettavissa olevat tai siihen liittyvät voitot

1. Merkittävään digitaaliseen läsnäoloon yksittäisessä jäsenvaltiossa kohdennettavissa olevat tai siihen liittyvät voitot ovat verotettavissa ainoastaan kyseisen jäsenvaltion yhteisöveropuitteiden mukaisesti.

2. Merkittävään digitaaliseen läsnäoloon kohdennettavissa olevat tai siihen liittyvät voitot ovat voittoja, jotka digitaalinen läsnäolo olisi saanut, jos se olisi ollut erillinen ja itsenäinen yritys, joka harjoittaa 
samaa tai samankaltaista toimintaa samoin tai samankaltaisin ehdoin digitaalisen rajapinnan välityksellä, varsinkin kanssakäymisessä yrityksen muiden osien kanssa ja ottaen huomioon suoritetut toiminnot, käytetyt varat ja otetut riskit.

3. Edellä olevan 2 kohdan soveltamiseksi merkittävään digitaaliseen läsnäoloon kohdennettavissa oleva tai siihen liittyvä voitto määritetään toiminnallisen analyysin perusteella. Jotta voitaisiin määrittää merkittävän digitaalisen läsnäolon toiminnot ja kohdentaa varojen taloudellinen omistajuus ja riskit merkittävään digitaaliseen läsnäoloon, on otettava huomioon tällaisen läsnäolon kautta digitaalisen rajapinnan välityksellä suoritettava taloudellisesti merkittävä toiminta. Tätä varten toimintaa, jota yritys harjoittaa digitaalisen rajapinnan välityksellä datan tai käyttäjien osalta, pidetään merkittävän digitaalisen läsnäolon taloudellisesti merkittävänä toimintana, joka kohdentaa riskit ja varojen taloudellisen omistajuuden tällaiseen läsnäoloon.

4. Määritettäessä 2 kohdan mukaisia kohdennettavissa olevia voittoja on otettava asianmukaisella tavalla huomioon taloudellisesti merkittävä toiminta, joka suoritetaan digitaalisen läsnäolon kautta ja joka on merkityksellistä yrityksen aineettomien hyödykkeiden kehittämisen, parantamisen, ylläpitämisen, suojaamisen ja käyttämisen kannalta.

5. Taloudellisesti merkittävään toimintaan, jota harjoitetaan merkittävän digitaalisen läsnäolon kautta digitaalisen rajapinnan välityksellä, kuuluvat muun muassa seuraavat toimet:

a) käyttäjätason datan kerääminen, varastoiminen, käsitteleminen, analysoiminen, käyttöön ottaminen ja myyminen;

b) käyttäjien tuottaman sisällön kerääminen, varastoiminen, käsitteleminen ja esittäminen;

c) verkkomainontatilan myyminen;

d) kolmannen osapuolen luoman sisällön asettaminen saataville digitaalisella markkinapaikalla;

e) minkä tahansa sellaisen digitaalisen palvelun suorittaminen, jota ei ole lueteltu a-d alakohdassa.

6. Määritettäessä 1-4 kohdan mukaisia kohdennettavissa olevia voittoja verovelvollisen on käytettävä voitonjakomenetelmää, ellei verovelvollinen osoita, että jokin kansainvälisesti hyväksyttyihin periaatteisiin perustuva muu menetelmä on tarkoituksenmukaisempi, kun otetaan huomioon toiminnallisen analyysin tulokset. Jakotekijöihin voivat kuulua muun muassa tutkimus-, kehittämis- ja markkinointimenot sekä käyttäjien ja kerätyn datan määrä jäsenvaltioittain. 
Väliaikaisratkaisuksi komissio ehdotti toista direktiiviä (148 final). Siinä oli kysymys uudesta verosta, digiverosta. Tässä direktiiviehdotuksessa olivat mm. seuraavat säännökset:

\section{1 artikla Kohde}

Tällä direktiivillä perustetaan digitaalisten palvelujen veroa, jäljempänä 'DPV', koskeva yhteinen järjestelmä tiettyjen digitaalisten palvelujen suorituksesta saataville tuloille.

\section{2 artikla Mä̈ritelmät}

Tässä direktiivissä tarkoitetaan

(1) 'yhteisöllä' kaikkia oikeushenkilöitä ja oikeudellisia järjestelyjä, jotka harjoittavat liiketoimintaa joko yrityksen tai verotuksellisesti läpinäkyvän rakenteen kautta;

(2) 'liikekirjanpidollisella konsernilla' kaikkia yksikköjä, jotka on täysimääräisesti sisällytetty kansainvälisten tilinpäätösstandardien tai kansallisen tilinpäätösjärjestelmän mukaisesti laadittuun konsernitilinpäätökseen;

(3) 'digitaalisella rajapinnalla' kaikkia käyttäjien saatavilla olevia ohjelmistoja, mukaan lukien verkkosivut sekä niiden osat, mobiilisovellukset ja muut sovellukset;

(4)'käyttäjällä' luonnollista henkilöä tai yritystä;

(5)'digitaalisella sisällöllä’ digitaalisessa muodossa toimitettua dataa, kuten tietokoneohjelmia, sovelluksia, musiikkia, videoita, tekstejä, pelejä ja muita ohjelmistoja, pois lukien digitaalisen rajapinnan itsensä edustama data;

(6) 'internetprotokollaosoitteella' verkkolaitteille annettua numerosarjaa, jota käyttäen viestintä suoritetaan internetissä;

(7) 'verokaudella' kalenterivuotta.

\section{3 artikla Verotettavat tulot}

1. Tulot, jotka yhteisö saa kunkin seuraavan palvelun tarjoamisesta, on katsottava tässä direktiivissä tarkoitetuiksi 'verotettaviksi tuloiksi':

(a) digitaalisen rajapinnan käyttäjille suunnatun mainonnan sijoittaminen kyseiselle rajapinnalle;

(b) sellaisen monisuuntaisen digitaalisen rajapinnan tarjoaminen käyttäjille, joka antaa käyttäjille mahdollisuuden löytää muut käyttäjät ja olla käyttäjien kanssa vuorovaikutuksessa ja joka voi mahdollistaa myös perustana olevan tavaroiden luovutuksen tai palvelujen suorituksen suoraan käyttäjien välillä;

(c) käyttäjistä ja käyttäjien toiminnoista digitaalisilla rajapinnoilla kerätyn datan siirto. 
2. Edellä 1 kohdassa tarkoitetut tulot käsittävät kokonaisbruttotulot ilman arvonlisäveroa ja muita vastaavia veroja.

3. Edellä olevan 1 kohdan a alakohtaa sovelletaan riippumatta siitä, omistaako digitaalisen rajapinnan se yhteisö, joka vastaa mainonnan sijoittamisesta sille. Jos yhteisö, joka sijoittaa mainonnan digitaaliselle rajapinnalle, ei ole kyseisen rajapinnan omistaja, on katsottava, että a alakohdassa tarkoitettua palvelua tarjoaa kyseinen yhteisö eikä rajapinnan omistaja.

4. Edellä olevaan 1 kohdan b alakohtaan eivät sisälly

(a) digitaalisen rajapinnan tarjoaminen, jonka ainoana tai pääasiallisena tarkoituksena on, että sen käyttöön tarjoava yhteisö toimittaa käyttäjille digitaalista sisältöä, viestintäpalveluja tai maksupalveluja;

(b) kauppapaikan tai kauppojen sisäisen toteuttajan suorittamat direktiivin 2014/65/EU liitteessä I olevan A osan 1-9 kohdassa tarkoitetut palvelut;

(c) säännellyn joukkorahoituspalvelun tarjoajan suorittamat direktiivin 2014/65/EU liitteessä I olevan A osan 1-9 kohdassa tarkoitetut palvelut tai säännellyn joukkorahoituspalvelun tarjoajan suorittama palvelu lainojen myöntämisen välittämiseksi.

5. Edellä olevaan 1 kohdan c alakohtaan ei sisälly kauppapaikan, kauppojen sisäisen toteuttajan tai säännellyn joukkorahoituspalvelun tarjoajan suorittama datansiirto.

6. Edellä 4 ja 5 kohdassa

(a) 'kauppapaikka' määritellään direktiivin 2014/65/EU 4 artiklan 1 kohdan 24alakohdassa ja 'kauppojen sisäinen toteuttaja' mainitun kohdan 20 alakohdassa;

(b) 'säännellyllä joukkorahoituspalvelun tarjoajalla' tarkoitetaan joukkorahoituspalvelujen tarjoajaa, joka on luvan ja valvonnan alainen joukkorahoituspalvelujen sääntelyä varten SEUT-sopimuksen 114 artiklan nojalla hyväksyttävän yhdenmukaistamistoimenpiteen mukaisesti.

7. Tuloja, jotka liikekirjanpidolliseen konserniin kuuluva yhteisö saa jonkin 1 kohdassa tarkoitetun palvelun tarjoamisesta samaan konserniin kuuluvalle toiselle yhteisölle, ei katsota verotettaviksi tuloiksi tätä direktiiviä sovellettaessa.

8. Jos liikekirjanpidolliseen konserniin kuuluva yhteisö tarjoaa jotakin 1 kohdassa tarkoitettua palvelua, jonka tarjoamisesta aiheutuvat tulot saa samaan ryhmään kuuluva toinen yhteisö, tämän direktiivin soveltamiseksi on katsottava, että kyseiset tulot on saanut palvelun tarjonnut yhteisö. 
9. Edellä 1 kohdassa tarkoitettuihin palveluihin viitataan 2 ja 3 luvussa 'verotettavina palveluina'.

\section{4 artikla Verovelvollinen}

1. 'Verovelvollisella' tarkoitetaan yhteisöä, joka täyttää verokaudella molemmat seuraavista edellytyksistä:

(a) yhteisön ilmoittama maailmanlaajuisten tulojen kokonaismäärä asianomaiselta tilivuodelta on yli 750000000 euroa;

(b) yhteisön asianomaiselta tilivuodelta unionissa saama verotettavien tulojen kokonaismäärä on yli 50000000 euroa.

2. Jos yhteisö ilmoittaa tai saa tuloja muussa valuutassa kuin euroina, tulot on 1 kohdan soveltamiseksi muunnettava euroiksi soveltamalla Euroopan unionin virallisessa lehdessä asianomaisen tilivuoden viimeisenä päivänä julkaistua valuuttakurssia tai, jos kyseisenä päivänä ei julkaista valuuttakurssia, edellisenä päivänä julkaistua valuuttakurssia.

3. Edellä 1 ja 2 kohdassa 'asianomaisella tilivuodella' tarkoitetaan tilivuotta, jolta on käytettävissä viimeisin yhteisön ennen kyseessä olevan verokauden päättymistä antamista tilinpäätöksistä.

4. Jäljempänä 5 artiklan 1 kohdassa vahvistettua sääntöä sovelletaan määritettäessä 1 kohdan $b$ alakohdan mukaisesti, onko verotettavat tulot saatu unionissa.

5. Verotettavat tulot on tätä direktiiviä sovellettaessa katsottava saaduiksi ajankohtana, jona ne erääntyvät, riippumatta siitä, onko kyseiset määrät tosiasiallisesti maksettu.

6. Jos 1 kohdassa tarkoitettu yhteisö kuuluu liikekirjanpidolliseen konserniin, kyseistä kohtaa sovelletaan koko konsernin osalta ilmoitettuihin maailmanlaajuisiin tuloihin ja unionissa saatuihin tuloihin.

\section{5 artikla Verotuspaikka}

1. Yhteisön verokautena saamia verotettavia tuloja on tämän direktiivin soveltamiseksi kohdeltava jäsenvaltiossa kyseisenä verokautena saatuina tuloina, jos käyttäjät sijaitsevat verotettavan palvelun osalta kyseisessä jäsenvaltiossa kyseisenä verokautena. Ensimmäistä alakohtaa sovelletaan riippumatta siitä, ovatko tällaiset käyttäjät osallistuneet rahallisesti kyseisten tulojen muodostukseen.

2. Verotettavan palvelun osalta käyttäjän katsotaan sijaitsevan jäsenvaltiossa verokautena, jos

(a) tapauksessa, jossa kyseessä on 3 artiklan 1 kohdan a alakohdassa tarkoitettu palvelu, asianomainen mainonta esiintyy käyttäjän laitteella silloin, kun laitetta käytetään kyseisessä jäsenvaltiossa kyseisenä verokautena digitaalisen rajapinnan käyttämiseksi; 
(b) tapauksessa, jossa kyseessä on 3 artiklan 1 kohdan b alakohdassa tarkoitettu palvelu:

i) jos palveluun liittyy monisuuntainen digitaalinen rajapinta, joka mahdollistaa perustana olevan tavaroiden luovutuksen tai palvelujen suorituksen suoraan käyttäjien välillä, käyttäjä käyttää laitetta kyseisessä jäsenvaltiossa kyseisenä verokautena käyttääkseen digitaalista rajapintaa ja suorittaa perustana olevan transaktion kyseisellä rajapinnalla kyseisenä verokautena;

ii) jos palveluun liittyy muuntyyppinen monisuuntainen digitaalinen rajapinta kuini alakohdassa tarkoitettu, käyttäjällä on kyseisen verokauden kokonaan tai osittain kattava tili, jonka avulla käyttäjä voi käyttää digitaalista rajapintaa ja joka avattiin käyttämällä laitetta kyseisessä jäsenvaltiossa;

(c) tapauksessa, jossa kyseessä on 3 artiklan 1 kohdan c alakohdassa tarkoitettu palvelu, sellaisesta käyttäjästä tuotettu data, joka on käyttänyt laitetta kyseisessä jäsenvaltiossa käyttääkseen digitaalista rajapintaa joko kyseisellä verokaudella tai jollain aikaisemmalla verokaudella, siirretään kyseisenä verokautena.

3. Se osuus yhteisön verotettavien tulojen kokonaismäärästä, jota kohdellaan 1 kohdan mukaisesti jäsenvaltiossa saatuina tuloina, määritetään kultakin verokaudelta seuraavasti:

(a) kun kyseessä ovat 3 artiklan 1 kohdan a alakohdassa tarkoitettujen palvelujen tarjoamisesta saadut verotettavat tulot, määräsuhteessa mainoksen esiintymiskertoihin käyttäjien laitteilla kyseisenä verokautena;

(b) kun kyseessä ovat 3 artiklan 1 kohdan b alakohdassa tarkoitettujen palvelujen tarjoamisesta saadut verotettavat tulot:

i) jos palveluun liittyy monisuuntainen digitaalinen rajapinta, joka mahdollistaa perustana olevan tavaroiden luovutuksen tai palvelujen suorituksen suoraan käyttäjien välillä, suhteessa niiden käyttäjien lukumäärään, jotka ovat suorittaneet perustana olevia transaktioita digitaalisella rajapinnalla kyseisenä verokautena;

ii) jos palveluun liittyy muuntyyppinen monisuuntainen digitaalinen rajapinta kuin i alakohdassa tarkoitettu, suhteessa niiden käyttäjien lukumäärään, joilla on kyseisen verokauden kokonaan tai osittain kattava tili, jonka avulla käyttäjät voivat käyttää digitaalista rajapintaa;

(c) kun kyseessä ovat 3 artiklan 1 kohdan c alakohdassa tarkoitettujen palvelujen tarjoamisesta saadut verotettavat tulot, suhteessa niiden käyttäjien lukumäärään, joista kyseisellä verokaudella siirrettyä dataa on tuotettu, kun käyttäjät ovat käyttäneet laitetta digitaalisen rajapinnan käyttämiseksi joko kyseisellä verokaudella tai jollain aikaisemmalla verokaudella. 
4. Määritettäessä verotuspaikkaa verotettaville tuloille, joihin sovelletaan DPV:tä, seuraavia tekijöitä ei oteta huomioon:

(a) jos kyseessä on 3 artiklan 1 kohdan b alakohdassa tarkoitettu perustana oleva tavaroiden luovutus tai palvelujen suoritus monisuuntaisen digitaalisen rajapinnan kautta suoraan käyttäjien välillä, paikka, jossa tällaiset perustana olevat luovutukset tai suoritukset tapahtuvat;

(b) paikka, josta mahdollinen verotettavan palvelun maksu suoritetaan.

5. Tätä artiklaa sovellettaessa jäsenvaltio, jossa käyttäjänlaitetta käytetään, määritetään laitteen internetprotokollaosoitteen perusteella tai sitä tarkemmin jollakin muulla maantieteellisen paikantamisen menetelmällä.

6. Tämän direktiivin soveltamiseksi käyttäjiltä saa kerätä ainoastaan dataa, josta ilmenee käyttäjän sijaintijäsenvaltio muttei henkilötietoja.

\section{6 artikla Verosaatavan syntyminen}

DPV kannetaan jäsenvaltiossa siitä verovelvollisen verokaudella saamien verotettavien tulojen osuudesta, joka 5 artiklan mukaisesti katsotaan saaduksi kyseisessä jäsenvaltiossa. DPV erääntyy maksettavaksi kyseisessä jäsenvaltiossa seuraavana työpäivänä kyseisen verokauden päättymisestä.

\section{7 artikla Veron laskeminen}

DPV on laskettava jäsenvaltiolle verokaudeksi soveltamalla DPV-kantaa 6 artiklassa tarkoitettuun verotettavien tulojen osuuteen.

\section{8 artikla Verokanta}

DPV-kanta on 3 prosenttia.

Direktiiviehdotusten ongelmana on pidetty mm. sitä, että EU ei esitä globaaleja ratkaisuja, kuten OECD. EU-valtioista mm. Ruotsi, Tanska, Suomi ja Irlanti ovat vastustaneet erityisesti jälkimmäistä direktiiviä. ${ }^{109}$ Ehdotusten hyväksyminen vaatii nykysäännösten mukaan EU:ssa yksimielisyyttä.

Asia oli esillä maaliskuun 2019 ECOFINissä, jossa ehdotusta ei hyväksytty, mutta valmistelua jatketaan. EU jäänee odottamaan OECD:n ehdotusta.

109 Voimakkaasta suomalaisesta kritiikistä ks. esim. Teknologiateollisuus ry:n 5.4.2018 päivätty lausunto valtiovarainministeriölle. 
Ranska ei jäänyt odottamaan; se sääti jo vuonna 2019 oman digiveron. Vero koskee sellaisia yrityksiä, joiden digitaalisten palveluiden liikevaihto on Ranskassa yli 25 miljoonaa euroa ja maailmanlaajuisesti yli 750 miljoonaa euroa. USA:n presidentti Donald Trump on uhannut ryhtyä vastatoimiin ja säätää ranskalaisille viineille korkeat tuontitullit.

\subsubsection{Vähimmäisverot}

Nykyisin pohditaan myös mahdollisuuksia vajaaverotuksen estämiseksi säätää kansainvälisille digi- ja muillekin yhtiöille vähimmäisveroja. Vähimmäisveroille voidaan löytää Suomestakin historiallisia vertailukohtia.

Ikääntyneet veroihmiset muistavat vielä kunnallisen harkintaverotuksen, joka oli meullä käytössä 1800-luvun lopulta 1990-luvun alkuun asti. Se oli takuu- eli vähimmäisvero, jota ei pidä sekoittaa epäluotettavuuteen perustuvaan arvioverotukseen. Harkintaverotus oli tuottoverotusta ${ }^{110}$, joka tuli kysymykseen, jos nettotuloa ei pidetty riittävänä kunnallisveron suorittamisen perusteeksi. Harkintaverotettava määrä vahvistettiin käytännössä liikkeiden osalta yleensä tietyksi prosentiksi liikevaihdosta.

Tuloveron vähimmäismäärä tunnettiin myös yhtiöveron hyvitysjärjestelmässä, jota meillä sovellettiin vuodesta 1990 vuoteen 2004. Osinkoa jakavan yhtiön oli suoritettava tuloveroa vähintään säädetty osa verovuodelta jaettavaksi päätetyn osingon määrästä. Vähimmäisverolla turvattiin jaettujen osinkojen yhdenvertainen verotus.

Nettotuloon perustuva tuloverotus on verohistoriallisesti suhteellisen nuori ilmiö, jonka ongelmat ovat lisääntyneet liiketoiminnan kansainvälistyessä. Pessimistit saattavatkin jo ehdotella yhtiöiden tuloverotuksesta luopumista - voitaisiinhan yhtiöiden tuloverotuksen ongelmat poistaa varmimmin poistamalla yhtiöiden tuloverotus. Ongelmat eivät kuitenkaan näin loppuisi, vaan tilalle saataisiin uusia rahoitus- ja muita ongelmia.

110 Elinkeinotoiminnan tuottoveroista tarkemmin kirjoitukseni Kauko Wikströmin juhlakirjassa (2013) s. 219 ss. 


\section{1}

\section{Suomen verotohtorit ${ }^{111}$}

\subsection{Vero-oikeudelliset väitöskirjat}

Väittelemistapa periytyy keskiaikaisista yliopistoista. Suomessa piti vielä 1800-luvulla julkaista väitöskirja myös maisterin arvoa varten. Vielä varhempina aikoina normaaliin käytäntöön kuului, että väitöskirjat olivat professorin laatimia ja opiskelijan tehtävänä oli osoittaa omaa oppineisuuttaan puolustamalla professorinsa työtä. ${ }^{12}$

Suomessa on 1900- ja 2000-luvuilla julkaistu seuraavat vero-oikeudellisiksi luokittelemani väitöskirjat:

1. Paasikivi, J. K., Lainkäytön kehittymisestä veronkanto- ja finanssikontrolliasioissa vanhemman ruotsalais-suomalaisen oikeuden mukaan: kompetenssikysymys. Helsingin yliopisto 1901

2. Kauppi, Aaro, Veron määrääminen I. Virheetön veron määrääminen ja sen oikeusvaikutukset. Helsingin yliopisto 1950

3. Kilpi, Lassi, Pääomanvähennys. Vero-oikeudellinen tutkimus pääomanvähennyksen suhteesta luonnollisiin vähennyksiin tulo- ja omaisuusverolaissa. Helsingin yliopisto 1952

111 Tämä luku sisältää osittain samoja tietoja kuin Verotus-lehdessä 1/2010 julkaistu artikkelini "Suomen verotohtorit - mitä, mistä, minne?” Jutussa esiintyvät vain väitelleet tohtorit, eivät h.c.- ja ei-väit.-tohtorit.

112 Ks. Jussi Nuorteva, Turun akatemian kirjapaino tieteen ja opetuksen palveluksessa $1642-1827$. 
4. Ikkala, Olli, Varasto ja sen arvostus tulo- ja omaisuusverotuksessa. Helsingin yliopisto 1955

5. Suviranta, Antti, Palkkatyön käsite vero-oikeudessa. Helsingin yliopisto 1961

6. Andersson, Edward, Resultatutjämning vid inkomstbeskattningen. Helsingin yliopisto 1962

7. Kotkansalo, Aleks., Verotusarvo liikevaihtoverotuksessa erityisesti Suomen voimassaolevaa oikeutta silmällä pitäen. Helsingin yliopisto 1967

8. Voipio, Jaakko, Verotuksen kiertämisestä. Luovutustoimien vero-oikeudellisista vaikutuksista erityisesti silmällä pitäen näennäisluovutuksia sekä verovelvollisen yrityksiä määrätä oikeusvaikutusten syntymisestä. Helsingin yliopisto 1968

9. Tikka, Kari S., Veron minimoinnista. Tutkimus tulo- tai omaisuusverosta vapautumisen tarkoituksessa tehdyistä toimista lainsoveltamisongelmana erityisesti silmällä pitäen verotuslain 56 §:ää. Helsingin yliopisto 1972

10. Sainio, Olli J., Verosopimusten vaikutus elinkeinotulon verotukseen. Helsingin yliopisto 1976

11. Niskakangas, Heikki, Rojaltit ja palvelumaksut kansainvälisessä verooikeudessa. Helsingin yliopisto 1983

12. Mattila, Pauli K., Varojen arvostaminen perintö- ja lahjaverotuksessa erityisesti silmällä pitäen kiinteää omaisuutta ja yritysvarallisuutta. Helsingin yliopisto 1984

13. Linnakangas, Esko, Urheilu ja verotus. Oikeustieteellinen tutkimus. Helsingin yliopisto 1984

14. Myrsky, Matti, Osakeyhtiön ja sen osakkeenomistajan kahdenkertaisesta verotuksesta. Oikeustieteellinen tutkimus jaetun voiton kahdenkertaisesta verotuksesta ja sen lieventämisestä. Helsingin yliopisto 1988

15. Aalto, Esa, Koron vähennysoikeus henkilöverotuksessa. Helsingin yliopisto 1988

16. Puronen, Pertti, Lahjaverotuksen ala. Helsingin yliopisto 1990

17. Viherkenttä, Timo, Tax Incentives in Developing Countries and International Taxation. Helsingin yliopisto 1991

18. Vest, Tage, Näringsverksamhet och självständigt företagande. Hanken 1991

19. Vapaavuori, Ahti, Suomeen suuntautuvien portfoliosijoitusten verokohtelu. Helsingin yliopisto 1991

20. Penttilä, Seppo, Osakkeen arvo verotuksessa. Helsingin yliopisto 1991

21. Immonen, Raimo, Fuusion verokohtelu. Turun yliopisto 1992

22. Lönnfors, Henry, Rörelseinkomst och kommunalbeskattning. Helsingin yliopisto 1992

23. Mannio, Lauri, Maatilan kaupan verotus. Helsingin yliopisto 1993

24. Kukkonen, Matti, Osakeyhtiön myynnin verotus. Tutkimus osakeyhtiön myynnin tuloverotuksesta erityisesti harvainomisteista yhtiötä silmällä pitäen. Helsingin yliopisto 1994 
25. Rehbinder, Maria, Personbolag i beskattningen. Inkomstbeskattningen av öppna bolag och kommanditbolag i spänningsfältet mellan beskattningen av enskilda näringsidkare och aktiebolag. Helsingin yliopisto 1995

26. Ryynänen, Olli, Förtäckt dividend i beskattningen. Helsingin yliopisto 1996

27. Määttä, Kalle, Environmental Taxes. From an Economic Idea to a Legal Institution. Helsingin yliopisto 1997

28. Juanto, Leila, Valmisteverotus. Oikeustieteellinen tutkimus valmisteverotuksen asemasta Suomen verojärjestelmässä. Lapin yliopisto 1998

29. Juusela, Janne, Kansainväliset sijoitukset ja verotuksen tehokkuus. Oikeustieteellinen tutkimus verotuksen tehokkuudesta ja verovalvonnan sääntelystä erityisesti kansainvälisiä portfoliosijoituksia silmällä pitäen. Helsingin yliopisto 1998

30. Ossa, Jaakko, Vapaaehtoisten eläkevakuutusten verokohtelu. Turun yliopisto 1999

31. Helminen, Marjaana, The Dividend Concept in International Tax Law. Dividend Payments between Corporate Entities. Helsingin yliopisto 1999

32. Lähteenoja, Pentti, Metsäpolitiikka ja verotus. Turun yliopisto 2000

33. Ryynänen, Olli, Bevisning i inkomstbeskattningen. Hanken 2000

34. Pikkujämsä, Mikko, Oikeusperiaatteet ja arvonlisäverotus kiinteistöalalla. Lapin yliopisto 2001

35. Haapaniemi, Matti, Virallisperiaate tuloverotuksessa ja tuloveroprosessissa. Tutkimus viranomaisaloitteisuutta osoittavien normien synnystä ja kehityksestä. Turun yliopisto 2001

36. Lindgren, Juha, Osakeyhtiön sukupolvenvaihdoksen verotus. Tampereen yliopisto 2001

37. Räbinä, Timo, Vastikkeeton saanto ja luovutusvoiton verotus. Tampereen yliopisto 2001

38. Kontkanen, Erkki, Pankin verotus. Tutkimus pankin verotuksesta erityisesti pankkitoiminnan sääntelyn ja verotuksen hallinnollisen ohjauksen näkökulmasta. Helsingin yliopisto 2002

39. Ranta-Lassila, Hannele, Konsernit ja verotuksen neutraalisuus. Helsingin yliopisto 2002

40. Lohiniva-Kerkelä, Mirva, Verosalaisuus. Lapin yliopisto 2003

41. Rother, Eila, Eurooppaoikeus ja arvonlisäverotus. Helsingin yliopisto 2003

42. Soikkeli, Lauri, Luottamuksensuoja verotuksessa. Helsingin yliopisto 2003

43. Viitala, Tomi, Tax Treatment of Investment Funds and their Investors within the European Union. Turun kauppakorkeakoulu 2004

44. Nykänen, Pekka, Julkisesti noteerattujen arvopapereiden luovutusvoitot henkilöverotuksessa. Tampereen yliopisto 2004 
45. Mehtonen, Pekka, Siirtohinnoittelu, tuloverotus ja konsernistrategiat. Joensuun yliopisto 2005

46. Saukko, Petri, Arvonlisäveroryhmät. Lapin yliopisto 2005

47. Henttula, Juhani, Varallisuuden arvostamisperusteesta perintöverotuksessa. Tampereen yliopisto 2005

48. Haapaniemi, Ossi, Osakeperusteisten kannustinjärjestelmien verokohtelu. Helsingin yliopisto 2006

49. Laukkanen, Antti, Taxation of Investment Derivatives. Hanken 2007

50. Malmgrén, Marianne, Oikeushenkilön asuinvaltio verotuksessa ja yrityksen kansainvälistyminen. Helsingin yliopisto 2008

51. Hakapää, Sari, Sähköinen verohallinto, automatisoiutu arvonlisäverotusmenettely. Vaasan yliopisto 2008

52. Erä-Esko, Ensio, Beskattningsrätt och skattskyldighet för kyrkan i Finland. Hanken 2009

53. Söderlund, Seppo, Oikeus ja kohtuus verotuksessa. Oikeustieteellinen tutkimus verovelvollisen oikeudesta saada ja viranomaisen velvollisuudesta myöntää harkinnanvaraisia veronhuojennuksia. Lapin yliopisto 2009

54. Äimä, Kristiina, Sisäiset korot lähiyhtiöiden kansainvälisessä verotuksessa. Helsingin yliopisto 2009

55. Knuutinen, Reijo, Muoto ja sisältö vero-oikeudessa - erityistarkastelussa rahoitus- ja sijoitusinstrumentit. Helsingin yliopisto 2009

56. Sainio, Nina, Yritysjärjestelyt arvonlisäverotuksessa. Tampereen yliopisto 2011

57. Iivonen, Seppo, Verohallinnon muuttuva norminanto. Vaasan yliopisto 2011

58. Torkkel, Timo, Tuloveron laskeminen. Vaasan yliopisto 2011

59. Urpilainen, Matti, Vapaa liikkuvuus ja verosuvereniteetti Euroopan unionin sisämarkkinoilla. Turun yliopisto 2012

60. Erä-Esko, Ensio, Rättelse av beskattning; implicit en komponent i god förvaltning och beskattningsprinciper. Turun yliopisto 2012

61. Nuotio, Vesa-Pekka, Tappiontasaus tuloverotuksessa. Helsingin yliopisto 2012

62. Sääski Keskitalo, Wisa M., Osakeyhtiön verovapaat osakeluovutukset. Lapin yliopisto 2012

63. Järvenoja, Markku, Henkilöyhtiön asema tuloverotuksessa. Helsingin yliopisto 2013

64. Frände, Joakim, Dubbelboende vid beskattning av fysiska personer. Helsingin yliopisto 2013

65. Hellberg, Nils, Konsernituki osana elinkeinotulon verotusta.Vaasan yliopisto 2013

66. Salo, Marjut, Vapaaehtoiset yksilölliset eläkejärjestelyt kansainvälisessä vero-oikeudessa. Aalto-yliopisto 2014

67. Nieminen, Martti, OECD Commentaries under the Vienna Rule. Tampereen yliopisto 2014 
68. Aittoniemi, Arja, Kiinteistöhallintapalvelujen oman käytön arvonlisäverotus. Itä-Suomen yliopisto 2015

69. Saarinen, Sirkka, Osakeyhtiön jakaminen tuloverotuksessa. Helsingin yliopisto 2016

70. Torkkeli, Anu, Structuring Corporate Capital Gains Tax System in the European Union. Hanken 2016.

71. Isomaa-Myllymäki, Anita, Konsernin sisäisen rahoituksen markkinaehtoisuus. Tampereen yliopisto 2016

72. Pankakoski, Katriina, Tavaran siirtohinnoittelu: etuyhteysliiketoimen markkinaehtoisen hinnoittelun rajat. Vaasan yliopisto 2018

73. Hanninen, Aleksei, Transfer Pricing of Business Restructurings of Russian, Finnish and U.S. Tax Law. Helsingin yliopisto 2018

74. Männistö, Eero, Takautuvan verolainsäädännön hyväksyttävyys - erityisesti EU-oikeuden ja perus- ja ihmisoikeuksien näkökulmasta tarkasteltuna. Helsingin yliopisto 2018

75. Hokkanen, Marja, Derivates and the European VAT System. Helsingin yliopisto 2019

76. Nissinen, Mika, Suomessa harjoitettavan yritystoiminnan kansallinen tuloverotusoikeus. Kontekstina nykytila ja hyvän verojärjestelmän kriteerit. Itä-Suomen yliopisto 2019

77. Isotalo, Kalle, Varainverotus - ristivaikutukset ja niiden hallinta. Lapin yliopisto 2019

Vuosikymmenkohtaisesti veroväitöksiä on ollut seuraavat määrät:

$\begin{array}{lr}1900-1909 & 1 \\ 1910-1919 & 0 \\ 1920-1929 & 0 \\ 1930-1939 & 0 \\ 1940-1949 & 0 \\ 1950-1959 & 3 \\ 1960-1969 & 4 \\ 1970-1979 & 2 \\ 1980-1989 & 5 \\ 1990-1999 & 16 \\ 2000-2009 & 24 \\ 2010-2019 & \underline{22} \\ \text { Yht. } & 77\end{array}$


Veroista väitteleminen on siis yleistynyt merkittävästi 1990-luvulta alkaen. Yliopistoittain veroväitökset ovat jakautuneet seuraavasti:

$\begin{array}{lr}\text { Helsingin yliopisto } & 42 \\ \text { Lapin yliopisto } & 7 \\ \text { Tampereen yliopisto } & 7 \\ \text { Turun yliopisto } & 6 \\ \text { Vaasan yliopisto } & 5 \\ \text { Hanken } & 5 \\ \text { Itä-Suomen (Joensuun) yliopisto } & 3 \\ \text { Turun kauppakorkeakoulu } & 1 \\ \text { Aalto-yliopisto } & 1 \\ \text { Yht. } & 77\end{array}$

Näistä on noin 3/4 kohdistunut varsinkin tuloverotukseen. Tuloveroväitöskirjoista pääosa on kohdistunut yritysten ja niiden omistajien verotukseen, viime vuosikymmeninä suurelta osin kansainväliseen verotukseen. Kulutusverotusväitöskirjat ovat lisääntyneet merkittävästi Suomen liityttyä Euroopan unioniin. Vuosina 1998-2019 tarkastetuista vero-oikeudellisista väitöskirjoistamme 1/5 kohdistui kulutusveroihin, pääasiassa arvonlisäveroon.

Verotusta on käsitelty myös sellaisissa oikeustieteellisten tiedekuntien väitöskirjoissa, jotka eivät ole varsinaisesti vero-oikeudellisia. Näistä mainittakoon Asko Lehtosen rikosoikeuteen painottunut tutkimus Veropetoksesta (1986) sekä Jorma Kuopuksen hallintooikeuteen ja oikeusinformatiikkaan painottunut tutkimus Hallinnon lainalaisuus ja automatisoitu verohallinto (1988). Verotus on lyhyesti esillä myös Esko Romppaisen finanssihallinto-oikeudelliseksi luokiteltavassa väitöskirjassa Sosiaali- ja terveysjärjestön oikeudellinen asema hyvinvointipalvelujen järjestämisessä (2007). Verotus on mukana lisäksi esimerkiksi Maurice N. Andemin vuonna 1978 Helsingin yliopistossa tarkastetussa väitöskirjassa International Economic Cooperation in Developing Countries with special reference to the legal protection of foreign investments in Africa, joka painottuu lähinnä oikeusvertailuun sekä kansainväliseen oikeuteen ja kansainväliseen yksityisoikeuteen.

Verotusta on sivuttu myös monissa sellaisissa väitöskirjoissa, jotka ovat olleet usein lähinnä yhtiöoikeudellisia. Vero-oikeudellisten väi- 
tösten joukkoon en ole ottanut finanssiopillisia väitöskirjoja, jotka ovat pikemminkin kansantaloustieteellisiä. Mukana ei siksi ole esimerkiksi Tuure Junnilan väitöskirja Omaisuusvero vakautetun tulon lisäveron toteuttajana (1945).

Pääosa veroväitelleistä on oikeustieteen tohtoreita, mutta joukossa on myös kauppatieteen, hallintotieteen ja filosofian tohtoreita. Suurella osalla veroväitelleistä on pari tutkintoa. Toistaiseksi eniten tutkintoja on OTT, KTT, YTM, VTM Matti Kukkosella.

\subsection{Väitöskirjan koko}

Veroväitöskirjat ovat paria artikkeliväitöstä lukuun ottamatta olleet monografioita. Niiden koko on vaihdellut noin 250 painosivusta noin 1000 sivuun. Keskiarvo on noin 450 sivua; suosituspituus on selvästi sitä alempi. Kun vuonna 2010 tutkin kaikkien veroväitöstemme koon, suurin sivumäärä (n. 750 sivua alkusivuineen) oli Matti Kukkosella. Raskain oli Marianne Malmgrénin väitöskirja (1 350 g), ja paksuin Kristiina Äimän teos (45 mm). Nykyisin kaikin puolin kookkain on vuonna 2012 julkaistu Wisa M. Sääski Keskitalon 1,6-kiloinen väitöskirja, jossa on noin 1000 sivua. ${ }^{113}$

\subsection{Väittelijän sukupuoli ja väitöskirjan kieli}

Veroväitöksistämme on ollut miesten tekemiä 60 (78 \%) ja naisten 17 (22\%). 2010-luvulla naisten osuus veroväitelleistä on $36 \%$.

Väitöskirjoista noin $4 / 5 \%$ on ollut suomenkielisiä ja loput englannin- tai ruotsinkielisiä.

Kun Lassi Kilpi väitteli vuonna 1952, hänen lähdeluettelossa mainituista lähteistään saksankielisiä oli 49,5 \%. Myös muilla 1950-luvun veroväittelijöillämme saksankielinen lähdeaineisto oli hyvin keskeinen. Vuonna 1967 julkaistussa Aleks. Kotkansalon väitöskirjassa

113 Muilla oikeudenaloilla on julkaistu paljon kookkaampiakin väitöskirjoja. 
saavutettiin veroväitösten lähteiden saksalaisuuden Suomen ennätys (54\%). Tämä voi tuntua yllättävältä, kun tutkimuksen nimenä oli "Verotusarvo liikevaihtoverotuksessa erityisesti Suomen voimassa olevaa oikeutta silmällä pitäen". Asian tekee kuitenkin helpommin ymmärrettäväksi se, että suomalainen oikeustieteellinen kulutusverokirjallisuus oli ennen Kotkansalon tutkimuksia lähes olematonta.

Saksan kielen osaaminen on meillä viime vuosikymmeninä voimakkaasti heikentynyt, ja 2000-luvulla monessa veroväitöskirjassa ei ole lainkaan saksalaista aineistoa. Sen sijaan englanninkielisen lähdeaineiston merkitys vero-oikeudellisessa tutkimuksessa on meillä nykyisin erittäin vahva.

\subsection{Ikä ja työ}

Veroväittelijän ikä väitöshetkenä on vaihdellut merkittävästi, 27 vuodesta 67 vuoteen; keskiarvo on ollut noin 40 vuotta. ${ }^{114}$

Veroväitelleiden miesten kuolinikä on vaihdellut 57 vuodesta 87 vuoteen; keskiarvo on ollut 75 vuotta. Pisimpään ovat eläneet hallintoneuvos Lassi Kilpi (87 v), tasavallan presidentti Juho Kusti Paasikivi (86 v), professori Jaakko Voipio (85 v) ja KHO:n presidentti Antti Suviranta $(85 \mathrm{v})$. Naispuoliset verotohtorimme ovat olleet toistaiseksi kuolemattomia.

Verotohtoreistamme oli vuoden 2019 lopussa elossa 61, joista eläkkeellä oli 18. Loput 43 työskentelivät seuraavilla sektoreilla:

$\begin{array}{lr}\text { Tilintarkastustoimistot yms. } & 15 \\ \text { Yliopistot } & 12 \\ \text { Hallintotuomioistuimet } & 6 \\ \text { Verohallinto } & 5 \\ \text { Muut } & 5\end{array}$

114 Aivan kaikkien syntymäaikoja en ole selvittänyt, koska ne puuttuvat matrikkeleista. 


\subsection{Verotohtorit veronmaksajina}

Tiedotusvälineille sähköisesti luovutettujen julkisten verotietojen perusteella monet verotohtorit maksavat paljon veroa. Suomen eniten tuloveroja vuonna 2018 maksaneet verotohtorit olivat paremmuusjärjestyksessä seuraavat: ${ }^{115}$

\begin{tabular}{|l|r|r|r|c|}
\hline & verot & ansiotulot & pääomatulot & yhteistulot \\
\hline 1. Penttilä, Seppo & 146447 & 276269 & 29028 & 305298 \\
\hline 2. Viherkenttä, Timo & 107222 & 245707 & 0 & 245707 \\
\hline 3. Torkkel, Timo & 103037 & 213836 & 19662 & 233499 \\
\hline 4. Ossa, Jaakko & 90140 & 185221 & 19668 & 204889 \\
\hline 5. Kontkanen, Erkki & 90099 & 182368 & 21642 & 204010 \\
\hline 6. Mattila, Pauli K. & 82294 & 165713 & 14904 & 180617 \\
\hline 7. Haapaniemi, Ossi & 77011 & 137992 & 58312 & 196304 \\
\hline 8. Kukkonen, Matti & 76281 & 112095 & 105786 & 217881 \\
\hline 9. Lindgren, Juha & 75213 & 163534 & 0 & 163534 \\
\hline 10. Juusela, Janne & 74774 & 144975 & 46350 & 191325 \\
\hline 11. Äimä, Kristiina & 72407 & 131672 & 50363 & 182035 \\
\hline 12. Pikkujämsä, Mikko & 62970 & 142534 & 2047 & 144581 \\
\hline 13. Immonen, Raimo & 61229 & 136769 & 0 & 136769 \\
\hline 14. Räbinä, Timo & 59811 & 136727 & 7992 & 144719 \\
\hline 15. Niskakangas, Heikki & 59159 & 140812 & 0 & 140812 \\
\hline 16. Soikkeli, Lauri & 58233 & 137230 & 0 & 137230 \\
\hline 17. Helminen, Marjaana & 55596 & 104281 & 41209 & 145490 \\
\hline 18. Järvenoja, Markku & 52086 & 117581 & 780 & 118361 \\
\hline 19. Saukko, Petri & 51743 & 124421 & 0 & 124421 \\
\hline 20. Knuutinen, Reijo & 49761 & 113797 & 32158 & 145955 \\
\hline 21. Nuotio, Vesa-Pekka & 45005 & 114938 & 0 & 114938 \\
\hline 22. Lähteenoja, Pentti & 44940 & 100401 & 42026 & 142427 \\
\hline 23. Isomaa-Myllymäki, Anita & 43263 & 111472 & 6694 & 118166 \\
\hline 24. Urpilainen, Matti & 40046 & 100474 & 1066 & 101540 \\
\hline
\end{tabular}

115 Ks. myös edellä verotietojen julkisuutta koskeva luku 8.5. 
Monen edellä mainitun tuloista osa on peräisin verokonsultoinnista. Verokonsulttina toimiminen lisää tohtorin asiantuntemusta mutta voi vähentää hänen kannanottojensa objektiivisuutta ja puolueettomuutta. ${ }^{116}$

116 Ks. Santtu Raitasuo, Verosuunnittelun tiede? Tapaustutkimus akateemisen verotutkimuksen sidonnaisuuksista, Lakimies 6/2019 s. 695 ss. sekä MTV uutiset 15.11.2019 Vero-oikeuden professorit ja tutkijat myyvät lausuntoja, joiden tavoitteena on yritysten verovälttely - "Palkkiot voivat olla kymmeniä tuhansia". Ks. myös Kauppalehti 15.11.2019 ja Uusi Suomi 16.11.2019. 


\section{Jälkipuhetta kirjan arvosta}

Eräs professori vieraili yliopiston kirjastossa ja ilahtui suuresti, kun näki teoksiaan olevan edustavasti esillä etuaulan pöydällä. Kun hän meni lähemmäksi, hän huomasi niiden keskellä kyltin, jossa luki isoilla kirjaimilla: "Ota tästä! FREE!"

Kirjoista, erityisesti kovakantisista tietoteoksista, on tullut melkein ongelmajätettä. Niistä on vaikea päästä eroon ilmaiseksikaan. Toisin oli vielä muutama vuosikymmen sitten. Hakuteossarjoja ja asiakirjallisuutta säilytettiin edustuspaikalla, ja mitä enemmän täysiä hyllymetrejä, sitä fiksumpi koti. Nyt kirjoja on vähemmän, nekin usein katseilta ja pölyltä suojassa kätevien ovien takana.

Käytäntö on opettanut, miten tärkeä markkinoinnissa ja myynnissä on kirjan nimi. Kun vuonna 1991 tein "Kulutusverotus"-nimisen kirjan, sille ei juuri löytynyt ostajia, sillä harva ymmärsi, että kirja käsitteli erityisesti uudistunutta liikevaihtoverotusta. Sitten vuonna 1995 kirjoitin Esko Tuomisen kanssa teoksen "Verosuunnittelu ja yritysverotus", ja sen ensimmäinen painos - joka oli suurempi kuin missään muissa kirjoissani - myytiin heti loppuun. Tästä opin, että jos veroalan kirjalle haluaa kaupallista menestystä, kirjan nimessä pitää esiintyä sana verosuunnittelu, koska veroista kiinnostuneet maksukykyiset asiakkaat yleensä haluavat vähentää verojaan.

Painatuskustannusten radikaalisti pienennyttyä ja saatuani oman kustannustoimittajan olen voinut siirtyä omakustanteisiin. Kun pyysin kaupalliselta kustantajalta lupaa saada hyödyntää sen julkaisemia aikaisempia juttujani verohistoriaa käsittelevässä omakustanteessa, 
hyväntahtoinen kustannuspäällikkö sanoi mielihyvin antavansa luvan ja ilmaisi erityisesti ilonsa siitä, etten tarjonnut kirjaa hänen edustamansa yhtiön kustannettavaksi.

Kaltaiselleni omakustantajalle kirjan painoarvo on tärkeä. Postituskustannusten säästämiseksi kirja lähetyskuorineen ei saa painaa yli 500 grammaa. A5-kokoisessa teoksessa saa silloin olla enintään 380 sivua $(80 \mathrm{~g} / \mathrm{m} 2)$ ja pehmeät kannet, ja mahdollisen saatekortin on oltava hyvin ohut.

Joku voi väittää kirjan arvon olevan siitä perityn hinnan suuruinen. Silloin lahjakirjat ja netistä ilmaiseksi saatavat kirjat olisivat nollan arvoisia. Kirjoittajalle itselleen tällaiset veroevankeliumit ovat arvokkaampia; toivottavasti ne levittävät hyvää sanomaa muillekin. 


\section{Asiahakemisto}

A

ajoneuvovero 233

alkoholivero 196

alkutuotannon arvonlisävero 207

ansiotulovähennys 28

arpominen 130

arvonlisävero 39, 207

aurinkosähkön arvonlisävero 225

automaatio 311

autovero 227

avainhenkilöiden verotus 30

D

dieselvero ks. käyttövoimavero

digivero 321

E

elintarvikeverot 199

eläinlääkäripalvelut 216

eläkkeiden verotus 31,148

energian arvonlisäverokanta 222

eurooppaoikeus 41, 262

H

halpatyövoiman maahantuontivero 174

harrastusmenot 144

henkilötietojen suoja ks. verotietojen julkisuus

henkisen hyvinvoinnin vero 180 hidasauto ks. kevytauto

hyvinvointivero 310

I

ikä 5, 31, 37

ilmastonmuutos 155

ilmiantopalkkio ks. vihjepalkkio

ilotulite 266

J

jäsenmaksu 164

K

kaasuauto 246

kaivosvero 193

kampaamo 211

kansalaisaloite 107

kansanedustajien aloitteet 268

kansanäänestys 113,121

kaupunkivero ks. sänkyvero

kevytauto 41

kiinteistöjen lämmitysöljy 256

kiinteistövero 95, 188

kiristäminen 278

kirkollisvero 180

koira 40

korkojen vähentäminen 173

kotitalousvähennys 146

kunnallisvero 182

kunnianloukkaus 275 
kuntalaisaloite 121

kuukautissuojien vero 218

käyttövoiman muuttaminen 246

käyttövoimavero 240, 246

L

lahjavero ks. perintövero

lahjoitusvähennys 155

lahjonta 278

lakialoitteet 268

lapsettomien naisten lisävero 139

lasten päivähoitomaksut 143

lentovero 40, 251

liikunta ks. harrastusmenot

lämmitysöljy 256

lääkekatto 153

M

maakuntavero 309

merimiesten verotus 29

metsälahjavähennys 25

mopoauto 41

N

naamiaiset 99

0

omaishoidontuki 147

omaisuustulovähennys 22

osinkoverotus 23, 160, 171

P

palvelujen arvonlisävero 207

parabellumvero 310

parturi 211

perheverotus 138

perintövero $38,53,183$

perustuslaki 121, 262, 309

perusvero 233

pienyrittäjien arvonlisävero 208

polkupyörävähennys 153

päivähoitomaksut 143
$\mathbf{R}$

rippisalaisuus 277

robottiverotus 311

S

sananvapaus 274

sinkkujen verovähennykset 140

sotavero 295

sote-vero 295

sähköauto 247

sähköiset julkaisut 213

sänkyvero 41

säätyvaltiopäivät 107

T

talkoot 157

tamponivero ks. kuukautissuojien vero

tekstiilialan arvonlisävero 213

tekstiilivero 257

tieliikenteen verot 227

tienkäyttömaksu 248

tuloverotus 66, 78, 288

turistivero ks. sänkyvero

työmarkkinajärjestöt 163

työtulovähennys 28

U

ulkomaiset ajoneuvot 248

uusiutuva diesel 243

uusiutuvat luonnonvarat 222

V

vahingonkorvaus 282, 285

vaientaminen 273

vaitiolokorvaukset verotuksessa 280

vakuutuskuoret 172

valintamahdollisuus veron käyttötarkoitukseen 130

valtion yliomistusoikeus 64

valtiopäivät 107 
vapaaehtoiset verot 129

varainsiirtovero $68,87,187$

varallisuusvero 67,81

venevero 84,250

verolotto 133

veron kiertäminen 72, 99

veronpalautus 136

verosta maksettava arvonlisävero

$$
226
$$

verosuunnittelu $65,99,104,344$, 345

verotietojen julkisuus 288

verotohtorit 335

verovilppi 99

veroväitökset 335

vetokoukku 43

vihjepalkkio 286

Viron yhteisöveromalli 166

vuokratulot 160

\section{$\mathbf{Y}$}

yhdenvertaisuus 73

yhdistystoiminnan sponsorointi 175

yhteisverotus 39, 138

yhteisövero 166, 167

yksityiselämän suoja 275

yleisradiovero 37,176

ylimääräinen vähennys 175

yrittäjävähennys 24

yritysten sukupolvenvaihdokset 71

Ä

äänioikeus 131 